UNIVERSIDADE DE SÃO PAULO

ESCOLA DE ENGENHARIA DE SÃO CARLOS

LUIZ FERNANDO DE LEMOS BARROSO

\title{
CONTRIBUIÇÕES AO PLANO DE RESÍDUOS SÓLIDOS DO ESTADO DE SÃO PAULO
}





\section{LUIZ FERNANDO DE LEMOS \\ BARROSO}

\section{CONTRIBUIÇÕES AO PLANO DE RESÍDUOS SÓLIDOS DO ESTADO DE SÃO PAULO}

Tese apresentada à Escola de Engenharia de São Carlos, da Universidade de São Paulo, como parte dos requisitos para obtenção do título de Doutor em Ciências: Engenharia Hidráulica e Saneamento.

Orientador: Prof. Assoc. Valdir Schalch

VERSÃO CORRIGIDA

São Carlos

2013 
AUTORIZO A REPRODUÇÃO TOTAL OU PARCIAL DESTE TRABALHO, POR QUALQUER MEIO CONVENCIONAL OU ELETRÔNICO, PARA FINS DE ESTUDO E PESQUISA, DESDE QUE CITADA A FONTE.

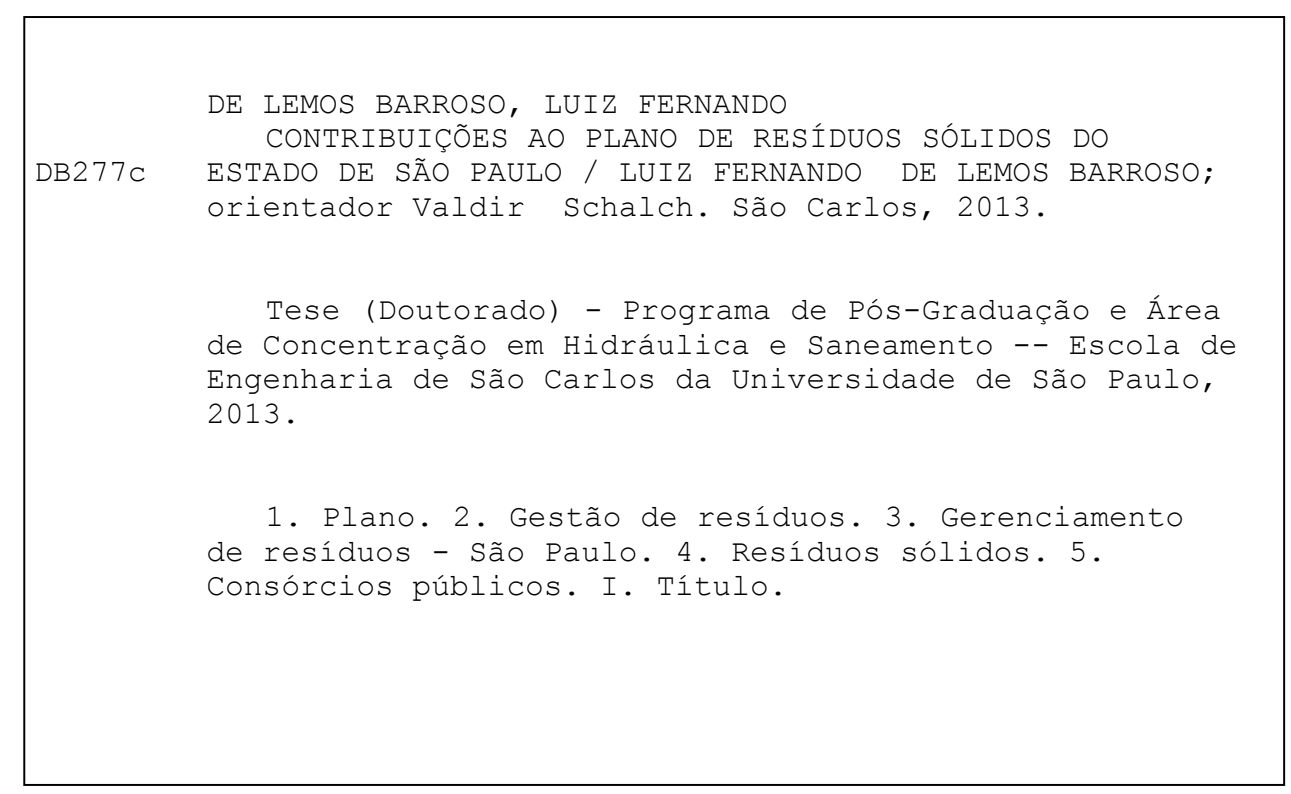


BARROSO, L. F. L. Contribuições ao Plano de Resíduos Sólidos do Estado de São Paulo. Tese apresentada à Escola de Engenharia de São Carlos da Universidade de São Paulo para a obtenção do título de Doutor em Ciências, Programa de Engenharia Hidráulica e Saneamento.

FOLHA DE JULGAMENTO

Candidato: Engenheiro LUIZ FERNANDO DE LEMOS BARROSO.

Título da tese: "Contribuições ao plano de resíduos sólidos do estado de São Paulo".

Data da defesa: 23/08/2013

Comissão Julgadora:

Prof. Associado Valdir Schalch (Orientador)

(Escola de Engenharia de São Carlos/EESC)

Prof. Dr. José Francisco

(Universidade Federal de São Carlos/UFSCar)

Prof. Dr. Wellington Cyro de Almeida Leite

(Universidade Estadual Paulista "Júlio de Mesquita Filho"/UNESP-Guaratinguetá)

Prof. Dr. Javier Mazariegos Pablos

(Instituto de Arquitetura e Urbanismo/USP)

Prof. Dr. João Sérgio Cordeiro

(Universidade Federal de São Carlos/UFSCar)
Resultado:

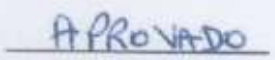

APNOVADO

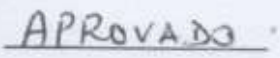

Iprovedo

Coordenador do Programa de Pós-Graduação em Engenharia Hidráulica e Saneamento:

Profa. Associada Maria Bernadete Amancio Varesche Silva

Presidente da Comissão de Pós-Graduação:

Prof. Titular Denis Vinicius Coury 
"O BICHO

Vi ontem um bicho

Na imundície do pátio

Catando comida entre os detritos.

Quando achava alguma coisa,

Não examinava nem cheirava:

Engolia com voracidade.

O bicho não era um cão, Não era um gato, Não era um rato.

O bicho, meu Deus, era um homem." Manuel Bandeira 
Dedico este trabalho de doutorado a minha esposa Ariane, aos meus filhos Alan e Tássio, que são a razão da minha alegria, e a Deus por tudo que me concede. 


\section{AGRADECIMENTOS}

Para elaboração desta pesquisa, contei com o inestimável auxílio, solidariedade e apoio de familiares, mestres, amigos, companheiros e colegas de curso. A todos os que me acompanharam, queria registrar aqui o meu agradecimento pela oportunidade que me deram de aprender com eles.

Sei que este espaço, não daria para identificar todos que me prestaram colaboração, mas mesmo com a certeza de que estou correndo o risco de esquecer alguns nomes, quero deixar registrado a enorme gratidão que sinto por todos, no entanto, torna-se imprescindível citar alguns.

Ao meu pai, José Rafael (in memorian) e à minha mãe, Maria Aparecida (in memorian), que me ensinaram os princípios mais importantes da vida, pelo amor e pela dedicação para que seus filhos tivessem um futuro melhor através da educação. Durante esta caminhada perdi meu maior HEROI e hoje, mais do que nunca, sua presença se faz sentir, pois percebo a continuidade do seu apoio irrestrito nas minhas escolhas.

Aos meus amores, Ariane, Alan e Tássio (por ordem de aparecimento em minha vida), minha gratidão e orgulho, por compreenderem minhas ausências, pelo apoio, amor, companheirismo e solidariedade que foram fundamentais para superar esta etapa.

Ao professor e orientador Prof. Dr. Valdir Schalch pela contribuição, paciência, amizade e dedicação, meu sincero agradecimento.

Ao CNPq, pelo suporte financeiro durante 0 período de concretização deste trabalho.

Ao amigo e professor Dr. José da Costa Marques Neto, por ter me dado a oportunidade de primeiramente ter contato com o curso de doutorado em Hidráulica e Saneamento e pela amizade sincera.

Sou grato a todos os professores do programa de Pós-Graduação em Hidráulica e Saneamento pelos ensinamentos recebidos. 
A Sá e demais funcionários da secretaria do programa, pela forma amável que sempre me receberam, pela gentileza e prontidão.

Aos colegas de doutorado que contribuíram diretamente para a realização do trabalho, cedendo artigos, emprestando livros e teses, assim, agradeço os ensinamentos recebidos e compartilhados, pelas sugestões e o prazer de conviver com vocês.

Ao Engenheiro Adriano Gentil da Agencia Ambiental de Embu das Artes pelas informações prestadas.

A Analista Rosângela Silva da Agencia Ambiental de Piracicaba pelas informações prestadas.

Ao Biólogo Alcides Arroyo Filho da Agencia Ambiental de Votuporanga pelas informações prestadas.

Ao Sr. Guilherme Xavier de Barros, Gerente da Agencia Ambiental de Votuporanga, pelas informações prestadas.

Ao Engenheiro Fernando Antonio Wolmer da CETESB São Paulo pelas informações prestadas e pelo modo carinhoso que sempre nos recebeu.

A Engenheira Ambiental Rosa Veloso, do Serviço Intermunicipalizado de Gestão de Resíduos do Grande Porto em Portugal, pelo acompanhamento e informações prestadas durante a visita técnica.

Ao Engenheiro Ambiental José Daniel Lamas, da Empresa Intermunicipal de Tratamento e Gestão de Resíduos Sólidos - Ambisousa em Portugal, pelo acompanhamento e informações prestadas durante a visita técnica.

Ao Engenheiro Industrial Carlos Genique Martín, Técnico do Consórcio Provincial de Meio Ambiente de Segóvia na Espanha, pelo acompanhamento e informações prestadas durante a visita técnica.

A Senhora Christelle Courcol-Lejeune, Técnica da Lille Métropole Communauté Urbaine do Setor de Resíduos Urbanos da Região Metropolitana de Lille na França, pelo acompanhamento e informações prestadas durante a visita técnica. 
A Senhor Jean Paul Minne, responsável pelo Setor de Comunicação e Visitas da Bruxelles Propeté de Bruxelas na Bélgica, pelo acompanhamento e informações prestadas durante a visita técnica.

A Deus, por nunca ter deixado de me socorrer em momentos difíceis e, por ter sempre me dado ânimo durante o caminho.

A TODOS, meu agradecimento por ter conseguido encerrar mais uma etapa de trabalho, olho para trás e sinto saudade. 


\section{RESUMO}

BARROSO, L. F. L. Contribuições ao Plano de Resíduos Sólidos do Estado de São Paulo. 2013. ...f. Tese (Doutorado) - Escola de Engenharia de São Carlos, Universidade de São Paulo, São Carlos, 2013.

Os problemas gerados ao meio ambiente decorrentes da produção de resíduos se apresentam hoje como grande desafio, pois podem produzir prejuízos econômicos a curto e médio prazo, pela perda da qualidade de vida e pelo comprometimento da sustentabilidade ambiental. Neste contexto, o poder público tem um papel fundamental na sua gestão e gerenciamento, e assim, depois de décadas tramitando no Congresso Nacional Brasileiro foi sancionada e regulamentada a Política Nacional de Resíduos Sólidos (PNRS), disciplinando um novo modelo de gestão destes resíduos e abordando um conjunto de princípios, objetivos, ações, metas, diretrizes e instrumentos para a implantação de políticas públicas que busquem a não geração, a redução, a reutilização, a reciclagem, o tratamento dos resíduos sólidos e a disposição final ambientalmente adequada dos rejeitos, bem como estabelecendo a responsabilidade compartilhada pelo ciclo de vida dos produtos, entre governo, empresas e sociedade. A Lei caracteriza os planos de resíduos e estabelece que todos os entes federativos e geradores de resíduos devem elaborar seus planos. Assim, foi desenvolvida uma versão preliminar para discussão do Plano Nacional de Resíduos Sólidos em 2011 e os estados procuraram atender o disposto na PNRS, estabelecendo priorização no acesso aos recursos financeiros para os municípios que optarem por soluções consorciadas e a formação de arranjos regionais para a gestão de resíduos sólidos. Insere-se neste estudo o Estado de São Paulo como objeto de pesquisa para elaboração de contribuições ao seu plano estadual. 0 presente trabalho procura gerar informações que possam constituir-se em instrumento de planejamento, informação e auxílio, contribuindo com a elaboração do Plano Estadual de Resíduos Sólidos do Estado de São Paulo e ao desenvolvimento da gestão dos resíduos sólidos. A metodologia empregada foi feita a partir de levantamentos de dados de fontes primárias e secundárias disponíveis em sítios oficiais na internet e publicações nacionais. Os resultados mostram que pouco se avançou no Plano e na Política Nacional, e apontam cenários de soluções para regionalização da gestão compartilhada dos resíduos sólidos.

Palavras-Chave: plano, gestão de resíduos, gerenciamento de resíduos - São Paulo, resíduos sólidos, consórcios públicos 


\begin{abstract}
BARROSO, L. F. L. Contributions to the Solid Waste Plan of São Paulo State. 2013. ;f. Thesis (Ph.D.) - School of Engineering of Sao Carlos, University of São Paulo, São Carlos, 2013.
\end{abstract}

The problems caused to the environment from the production of waste is present today as challenging as it can produce economic losses in the short and medium term, the loss of quality of life and commitment of environmental sustainability. In this context, the government has a key role in the administration and management, and so, after decades moving through the Brazilian National Congress was sanctioned and regulated the National Policy on Solid Waste (PNRS), disciplining a new model of management of waste and addressing a set of principles, objectives, actions, goals, guidelines and instruments for the implementation of public policies that seek no generation, reduction, reuse, recycling, solid waste treatment and environmentally sound disposal of waste, as well as establishing a shared responsibility for the lifecycle of products, from government, business and society. Law characterizes waste plans and provides that all federal entities and waste generators must prepare their plans. Thus, we developed a draft for discussion of the National Solid Waste in 2011 and states sought to meet the provisions of PNRS, establishing prioritization of access to financial resources for municipalities that choose solutions consortium and the formation of regional arrangements for the management solid waste. Inserts in this study the state of São Paulo as object of research for development contributions to state plan. This paper seeks to generate information that may constitute an instrument of planning, information and assistance, helping with the preparation of the Solid Waste Plan of São Paulo State and the development of solid waste management. The methodology used was made from survey data of primary and secondary sources available on the official sites on the Internet and national publications. The results show that little progress has been made in the Plan and National Policy, and point solution scenarios for regionalization of shared management of solid waste.

Keywords: plan, waste management, waste management - São Paulo, solid waste, public consortium. 


\section{LISTA DE TABELAS}

Tabela 1. UGRHIs segundo classificação numérica ............................ 168

Tabela 2. Lista de aterros particulares e quantidade recebida/dia ............. 175

Tabela 3. Aterros particulares - quantidade e município que dispõe ............ 177

Tabela 4. Maiores geradores de resíduos industriais classe I no Estado de São Paulo

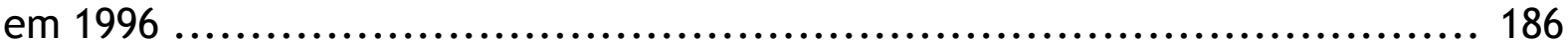

Tabela 5. Unidades de empresas privadas receptoras de resíduos industriais no Estado de São Paulo ................................................... 187

Tabela 6. Respostas da agência ambientais sobre aterros de resíduos industrial no Estado de São Paulo ..................................................... 188

Tabela 7. Consórcios intermunicipais com gestão ou serviços de manejo de resíduos sólidos existentes no Estado de São Paulo ...................................... 199

Tabela 8. Proposta de regionalização do Estado de São Paulo - Cenário ......... 211

Tabela 9. Municípios e produção diária de resíduos domiciliares da Região 1 - Raio

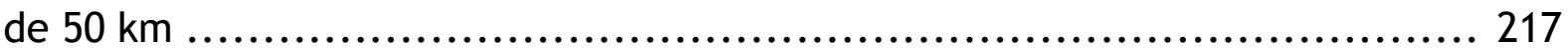

Tabela 10. Municípios e produção diária de resíduos domiciliares da Região 2 - Raio

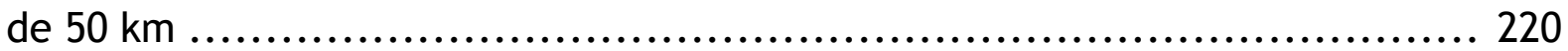

Tabela 11. Municípios e produção diária de resíduos domiciliares da Região 3 - Raio

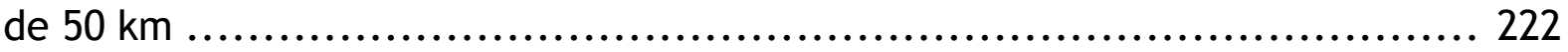

Tabela 12. Municípios e produção diária de resíduos domiciliares da Região 4 - Raio

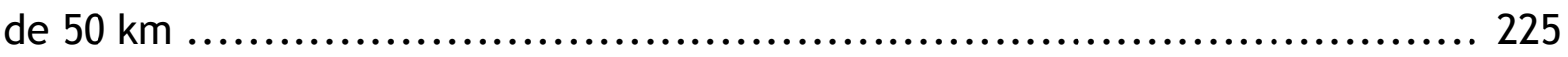

Tabela 13. Municípios e produção diária de resíduos domiciliares da Região 5 - Raio

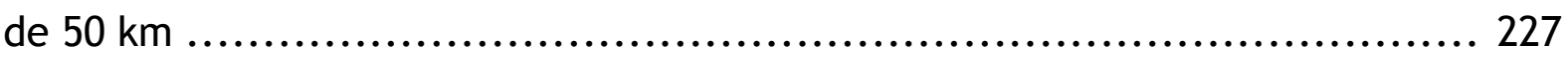

Tabela 14. Municípios e produção diária de resíduos domiciliares da Região 6 - Raio de $50 \mathrm{~km}$ 229 
Tabela 15. Municípios e produção diária de resíduos domiciliares da Região 7 - Raio de $50 \mathrm{~km}$ 232

Tabela 16. Municípios e produção diária de resíduos domiciliares da Região 8 - Raio de $50 \mathrm{~km}$ 234

Tabela 17. Municípios e produção diária de resíduos domiciliares da Região 9 - Raio de $50 \mathrm{~km}$ 236

Tabela 18. Municípios e produção diária de resíduos domiciliares da Região 10 Raio de $50 \mathrm{~km}$ 228

Tabela 19. Municípios e produção diária de resíduos domiciliares da Região 11 Raio de $50 \mathrm{~km}$ 240

Tabela 20. Municípios e produção diária de resíduos domiciliares da Região 12 Raio de $50 \mathrm{~km}$ 242

Tabela 21. Municípios e produção diária de resíduos domiciliares da Região 13 Raio de $50 \mathrm{~km}$ 244

Tabela 22. Municípios e produção diária de resíduos domiciliares da Região 14 Raio de $50 \mathrm{~km}$ 246

Tabela 23. Municípios e produção diária de resíduos domiciliares da Região 15 Raio de $50 \mathrm{~km}$ 248

Tabela 24. Municípios e produção diária de resíduos domiciliares da Região 16 Raio de $50 \mathrm{~km}$ 250

Tabela 25. Municípios e produção diária de resíduos domiciliares da Região 17 Raio de $50 \mathrm{~km}$ 252

Tabela 26. Municípios e produção diária de resíduos domiciliares da Região 18 Raio de $50 \mathrm{~km}$ 254

Tabela 27. Municípios e produção diária de resíduos domiciliares da Região 19 Raio de $50 \mathrm{~km}$ 256 
Tabela 28. Municípios e produção diária de resíduos domiciliares da Região 20 Raio de $50 \mathrm{~km}$

Tabela 29. Municípios e produção diária de resíduos domiciliares da Região 21 Raio de $50 \mathrm{~km}$

Tabela 30. Municípios e produção diária de resíduos domiciliares da Região 22 Raio de $50 \mathrm{~km}$ 263

Tabela 31. Municípios e produção diária de resíduos domiciliares da Região 23 Raio de $50 \mathrm{~km}$ 265

Tabela 32. Municípios e produção diária de resíduos domiciliares da Região 24 Raio de $50 \mathrm{~km}$ 267

Tabela 33. Municípios e produção diária de resíduos domiciliares da Região 25 Raio de $50 \mathrm{~km}$ 269

Tabela 34. Municípios e produção diária de resíduos domiciliares da Região 26 Raio de $50 \mathrm{~km}$ 271

Tabela 35. Municípios e produção diária de resíduos domiciliares da Região 27 Raio de $50 \mathrm{~km}$ 273

Tabela 36. Municípios e produção diária de resíduos domiciliares da Região 28 Raio de $50 \mathrm{~km}$ 275

Tabela 37. Municípios e produção diária de resíduos domiciliares da Região 29 Raio de $50 \mathrm{~km}$ 278

Tabela 38. Municípios e produção diária de resíduos domiciliares da Região 30 Raio de $50 \mathrm{~km}$ 280

Tabela 39. Municípios e produção diária de resíduos domiciliares da Região 31 Raio de $50 \mathrm{~km}$ 282

Tabela 40. Municípios e produção diária de resíduos domiciliares da Região 32 Raio de 50 km 284 
Tabela 41. Municípios e produção diária de resíduos domiciliares da Região 33 -

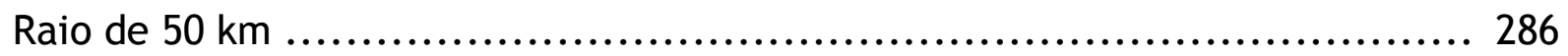

Tabela 42. Proposta de regionalização do Estado de São Paulo - Cenário 1 ...... 288

Tabela 43. Municípios e produção diária de resíduos domiciliares da Região 1 - Raio

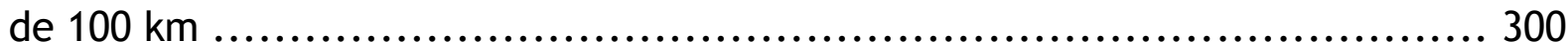

Tabela 44. Municípios e produção diária de resíduos domiciliares da Região 2 - Raio

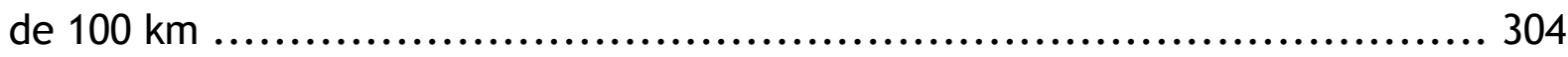

Tabela 45. Municípios e produção diária de resíduos domiciliares da Região 3 - Raio

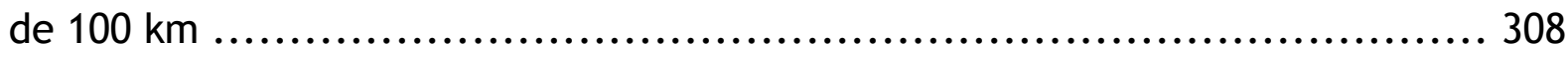

Tabela 46. Municípios e produção diária de resíduos domiciliares da Região 4 - Raio

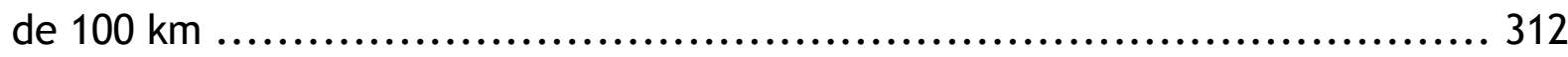

Tabela 47. Municípios e produção diária de resíduos domiciliares da Região 5 - Raio

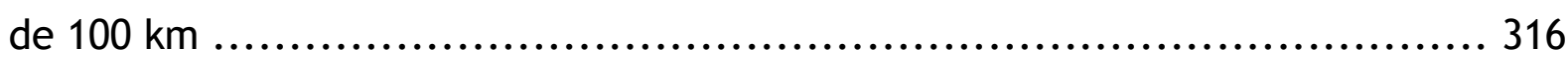

Tabela 48. Municípios e produção diária de resíduos domiciliares da Região 6 - Raio

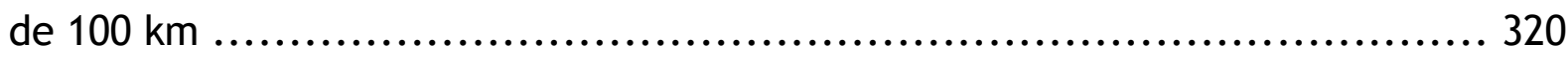

Tabela 49. Municípios e produção diária de resíduos domiciliares da Região 7 - Raio de $100 \mathrm{~km}$........................................................................ 325

Tabela 50. Municípios e produção diária de resíduos domiciliares da Região 8 - Raio

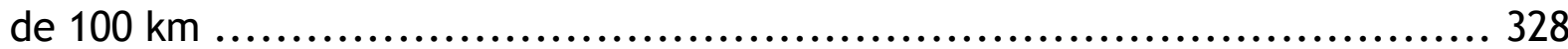

Tabela 51. Municípios e produção diária de resíduos domiciliares da Região 9 - Raio

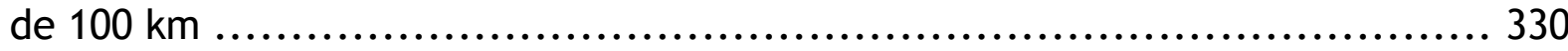

Tabela 52. Municípios e produção diária de resíduos domiciliares da Região 10 -

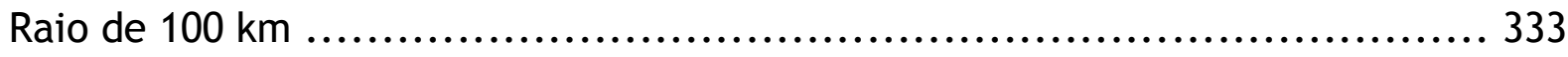

Tabela 53. Proposta de regionalização do Estado de São Paulo - Cenário 2 ...... 336

Tabela 54. Geração média per capita de RSU por faixas de população, segundo o Ministério das Cidades 347 
Tabela 55. Enquadramento da regionalização 


\section{LISTA DE QUADOS}

Quadro 1: Linhas de financiamento para gerenciamento de resíduos sólidos 86

Quadro 2. Evolução do PIB per capita e da população do Est. De São Paulo - 19952010 166

Quadro 3 - Premissas de engenharia para aterros típicos 295

Quadro 4 - Estimativa de custos para aterros típicos 296

Quadro 5 - Resumo de custos e preços para aterros típicos 297 



\section{LISTA DE FIGURAS}

Figura 1. Dimensões da gestão de resíduos...................................... 65

Figura 2. Hierarquia de gestão de resíduos................................... 66

Figura 3. Formulação da gestão dos resíduos sólidos pela PNRS................... 79

Figura 4. Estados que já desenvolveram regionalizações em seus territórios....... 87

Figura 5. Países que participam do programa Green Dot........................ 119

Figura 6. Símbolo Ponto Verde (Geen Dot)................................. 119

Figura 7. Fluxos do Sistema Integrado de Gestão de Resíduos de Embalagens da Sociedade Ponto Verde.................................................... 120

Figura 8. Mapa com a localização dos Sistemas de Gestão de Resíduos - Portugal.....

Figura 9. Mapa das infraestruturas e equipamentos- Portugal ................... 122

Figura 10. Evolução do número de lixeiras (lixões) entre 1996 e 2003 ............ 123

Figura 11. Comparação das metas definidas no PERSU I para 2005 e a situação

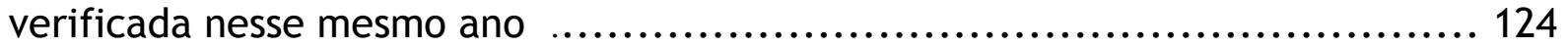

Figura 12. Localização dos municípios que formam a Lipor ..................... 125

Figura 13. Sistema integrado de gestão de resíduos da Lipor ................... 126

Figura 14. Sede administrativa da Lipor .................................. 127

Figura 15. Esquema de triagem de resíduos ................................ 128

Figura 16. Centro de Triagem da Lipor ................................... 128

Figura 17. Área de recepção de resíduos ..................................... 129 
Figura 18. Área de materiais enfardados e acondicionados 129

Figura 19. Plataforma de triagem de resíduos............................... 130

Figura 20. Centro de Valorização Orgânica .................................... 131

Figura 21. Cobertura dos tuneis com lâmina d'àgua para resfriamento........... 132

Figura 22. Esquema do Centro de Valorização Energética ......................... 132

Figura 23. Sala de controle do Centro de Valorização Energética ................. 132

Figura 24. Fossa de recepção do Centro de Valorização Energética............... 133

Figura 25. Equipamento de coleta de resíduos .............................. 134

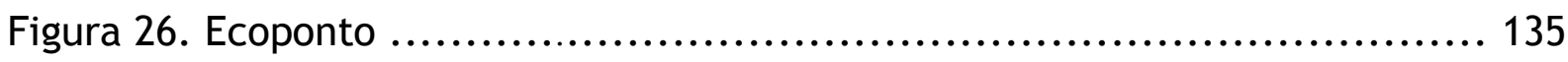

Figura 27. Ecocentro ................................................... 136

Figura 28. Veículo utilizado no Projeto Ecofone .............................. 136

Figura 29. Centro de educação ambiental .................................. 138

Figura 30. Centro de educação Horta da Formiga ............................... 138

Figura 31. Municípios que integram a Ambisousa .............................. 139

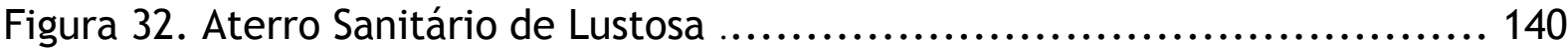

Figura 33. Central de Valorização Energética de Lustosa ........................ 141

Figura 34. Aterro Sanitário de Penafiel ..................................... 142

Figura 35. Central de Triagem de Lustosa.................................... 143

Figura 36. Organograma do ciclo de resíduos recicláveis na Ambisousa ........... 144

Figura 37. Estação de Triagem de Penafiel.................................... 144

Figura 38. Central de Valorização Energética de Penafiel ......................... 145

Figura 39. Centro de Tratamento de Resíduos - Segovia ........................ 146

Figura 40. Fossa para depósito de resíduos .................................. 146 
Figura 41. Esteira de triagem de resíduos - Segovia 147

Figura 42. Resíduos compactados e enfardados - Segovia 148

Figura 43. Centro de triagem de resíduos - Bruxelas 148

Figura 44. Plataforma de triagem de resíduos - Bruxelas 148

Figura 45. Caminhão coletor de resíduos químicos - Bruxelas 149

Figura 46. Usina de compostagem - Bruxelas 151

Figura 47. Unidade de recuperação de energia - Bruxelas 152

Figura 48. Infraestruturas de Gestão de RSU - Lille 153

Figura 49. Identificação de contêiners 154

Figura 50. Caminhão para coleta de resíduos - Lille 155

Figura 51. Ecocentro - Lille 156

Figura 52. Vista interna de um ecocentro - Lille 157

Figura 53. Centro de Triagem - Lille 157

Figura 54. Pátio de descarga de materiais CT - Lille 157

Figura 55. Esteira do Centro de Triagem - Lille 158

Figura 56. Depósito de materiais enfardados CT - Lille 158

Figura 57. Centro de Valorização Orgânica - Lille 159

Figura 58. Armazenamento do biogás - Lille 159

Figura 59. Ônibus abastecendo com biometano - Lille 160

Figura 60. Automóvel movido a biometano - Lille 160

Figura 61. Túneis de produção de composto orgânico - Lille 161

Figura 62. Cais de embarque - Lille 162

Figura 63. Ciclo dos resíduos no CVO - Lille 163 
Figura 64. Centro de Valorização Energética - Lille

Figura 65. Localização do Estado de São Paulo 165

Figura 66. Localização das Regiões Metropolitanas do Est. de São Paulo 167

Figura 67. Bacias Hidrográficas do Estado de São Paulo 169

Figura 68. Agências Ambientais do Estado de São Paulo 171

Figura 69. IQR-Índice de Qualidade de Aterro de Resíduos no Est. De São Paulo 172

Figura 70. Produção por município do Estado de São Paulo 174

Figura 71. Aterros particulares licenciados no Estado de São Paulo 176

Figura 72. Localização dos aterros Classe I do Estado de São Paulo 190

Figura 73. Aterros Classe II-A do Estado de São Paulo 191

Figura 74. Unidades incineradoras licenciadas no Estado de São Paulo 192

Figura 75. Unidades de tratamento biológico licenciadas no Estado de São Paulo 193

Figura 76. Unidades de dessorção licenciadas no Estado de São Paulo 194

Figura 77. Unidades cimenteiras com co-processamento licenciadas no Estado de São Paulo 195

Figura 78. Unidades de blindagem licenciadas do Estado de São Paulo 196

Figura 79. Destinadores de equipamentos eletro eletrônicos 198

Figura 80. Consórcios intermunicipais com gestão ou serviços de manejo de resíduos sólidos existentes no Estado de São Paulo 201

Figura 81. Consórcio Intermunicipal de Saneamento do Circuito das Águas 202 
Figura 82. Consórcio Intermunicipal de Saneamento Ambiental - CONSAB

Figura 83. CIVAP - Consórcio Intermunicipal do Vale do Paranapanema 204

Figura 84. Consórcio Intermunicipal para Tratamento e Disposição Final de Lixo COTRALIX 205

Figura 85. Consórcio Intermunicipal de Manejo de Resíduos Sólidos da RMC CONSIMARES 206

Figura 86. Consórcio Intermunicipal do Grande $A B C$ 207

Figura 87. Consórcio Intermunicipal para Gestão de Resíduos Sólidos

Figura 88. CIGA - Consórcio Intermunicipal para Gestão Ambiental e de Resíduos Sólidos Integrada 209

Figura 89. Consórcio Intermunicipal para Gestão Integrada de Resíduos Sólidos SIGEINRES 210

Figura 90. Mapa identificando raio de $50 \mathrm{~km}$ das cidades polo do Estado de São Paulo. 215

Figura 91. Proposta de regionalização - raio de $50 \mathrm{~km}$ das cidades polo do Estado de São Paulo 216

Figura 92. Regionalização Rio 50 km - Região 1 219

Figura 93. Regionalização Rio 50 km - Região 2 221

Figura 94. Regionalização Rio 50 km - Região 3 224

Figura 95. Regionalização Rio 50 km - Região 4 226

Figura 96. Regionalização Rio 50 km - Região 5 
Figura 97. Regionalização Rio 50 km - Região 6

Figura 98. Mapa de regionalização Rio 50 km - Região 7 ...................... 233

Figura 99. Mapa de regionalização Rio 50 km - Região $8 \ldots \ldots \ldots \ldots \ldots \ldots \ldots \ldots \ldots . \ldots 235$

Figura 100. Mapa de regionalização Rio 50 km - Região 9 ....................... 237

Figura 101. Mapa de regionalização Rio 50 km - Região 10 ..................... 239

Figura 102. Mapa de regionalização Rio 50 km - Região 11 ...................... 241

Figura 103. Mapa de regionalização Rio 50 km - Região 12 ...................... 243

Figura 104. Mapa de regionalização Rio 50 km - Região 13 ...................... 245

Figura 105. Mapa de regionalização Rio 50 km - Região 14 ..................... 247

Figura 106. Mapa de regionalização Rio 50 km - Região 15 ..................... 249

Figura 107. Mapa de regionalização Rio 50 km - Região 16 ..................... 251

Figura 108. Mapa de regionalização Rio 50 km - Região 17 ...................... 253

Figura 109. Mapa de regionalização Rio 50 km - Região $18 \ldots \ldots \ldots \ldots \ldots \ldots \ldots \ldots . \ldots 255$

Figura 110. Mapa de regionalização Rio 50 km - Região 19 ..................... 257

Figura 111. Mapa de regionalização Rio 50 km - Região $20 \ldots \ldots \ldots \ldots \ldots \ldots \ldots \ldots . . .260$

Figura 112. Mapa de regionalização Rio 50 km - Região 21 ...................... 262

Figura 113. Mapa de regionalização Rio 50 km - Região 22 ...................... 264

Figura 114. Mapa de regionalização Rio 50 km - Região 23 ..................... 266

Figura 115. Mapa de regionalização Rio 50 km - Região $24 \ldots \ldots \ldots \ldots \ldots \ldots \ldots \ldots \ldots . . . \ldots 268$ 
Figura 116. Mapa de regionalização Rio 50 km - Região 25 ..................... 270

Figura 117. Mapa de regionalização Rio 50 km - Região 26 ..................... 272

Figura 118. Mapa de regionalização Rio 50 km - Região 27 ...................... 274

Figura 119. Mapa de regionalização Rio 50 km - Região 28 ..................... 227

Figura 120. Mapa de regionalização Rio 50 km - Região 29 ..................... 279

Figura 121. Mapa de regionalização Rio 50 km - Região 30 ..................... 281

Figura 122. Mapa de regionalização Rio 50 km - Região 31 ..................... 283

Figura 123. Mapa de regionalização Rio 50 km - Região 32 .................... 285

Figura 124. Mapa de regionalização Rio 50 km - Região 33 ...................... 287

Figura 125. Mapa identificando raio de $100 \mathrm{~km}$ das cidades polo do Estado de São

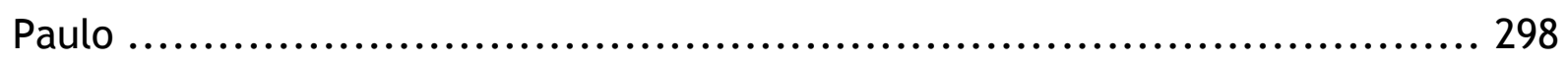

Figura 126. Mapa de proposta de regionalização - raio de $100 \mathrm{~km}$ das cidades polo do Estado de São Paulo ...................................................... 299

Figura 127. Mapa de regionalização Rio 100 km - Região 1 ..................... 303

Figura 128. Mapa de regionalização Rio 100 km - Região 2 ..................... 307

Figura 129. Mapa de regionalização Rio 100 km - Região 3 ..................... 311

Figura 130. Mapa de regionalização Rio 100 km - Região 4 .................... 315

Figura 131. Mapa de regionalização Rio 100 km - Região 5 .................... 319

Figura 132. Mapa de regionalização Rio 100 km - Região 6 ..................... 324

Figura 133. Mapa de regionalização Rio 100 km - Região 7 .................... 327

Figura 134. Mapa de regionalização Rio 100 km - Região 8 ..................... 329 
Figura 135. Mapa de regionalização Rio 100 km - Região 9

Figura 136. Mapa de regionalização Rio 100 km - Região 10 335 


\section{LISTA DE SIGLAS}

ABRELPE Associação Brasileira de Empresas de Limpeza Pública e Resíduos Especiais

ABNT Associação Brasileira de Normas Técnicas

APA Agência Portuguesa do Ambiente

ANVISA Agência Nacional de Vigilância Sanitária

CESP Companhia Energética do Estado de São Paulo

CF/88 Constituição Federal do Brasil 1988

CEPAM Centro de Estudos e Pesquisas de Administração Municipal

CETESB Companhia Ambiental do Estado de São Paulo

CIAS Consórcio Intermunicipal para Aterro Sanitário

CIGRS Consórcio Intermunicipal para Gerenciamento de Resíduos Sólidos

CIPAS Consórcio Intermunicipal para Aterros Sanitários

CNPq Conselho Nacional de Desenvolvimento Científico e Tecnológico

CODIVAP Consórcio de Desenvolvimento do Vale do Paraíba

CONAMA Conselho Nacional do Meio Ambiente

CONEP Comissão Nacional de Ética em Pesquisa

COTRALIX Consórcio Intermunicipal para Tratamento de lixo

DAESP Departamento Aeroviário do Estado de São Paulo

ECO 92 Conferência das Nações Unidas sobre o Meio Ambiente e o Desenvolvimento

EIA Estudo de Impacto Ambiental

FECOP Fundo Estadual de Prevenção e Controle da Poluição

FEHIDRO Fundo Estadual de Recursos Hídricos

FEPASA Ferrovia Paulista Sociedade Anônima

GADIS Gestão Ambiental e Dinâmica Sócio Espacial 
IBAMA Instituto Brasileiro do Meio Ambiente e dos Recursos Naturais Renováveis

IBGE Instituto Brasileiro de Geografia e Estatística

INFRAERO Empresa Brasileira de Infraestrutura Aeroportuária

IQR Índice de Qualidade de Aterro de Resíduos

ISWA International Solid Waste Association

MMA Ministério do Meio Ambiente

MNCR Movimento Nacional de Materiais Recicláveis

MS Ministério da Saúde

NBR Norma Brasileira de Referência

NR Norma de Referência

ONU Organização das Nações Unidas

PERSU Plano Estratégico de Resíduos Sólidos Urbanos

PIB Produto Interno Bruto

PGIRS Planos de Gestão Integrada de Resíduos Sólidos

PLANASA Plano Nacional de Saneamento

PNSB Pesquisa Nacional de Saneamento Básico

PNRS Política Nacional de Resíduos Sólidos

REBRAMAR Rede Brasileira de Manejo Ambiental de Resíduos

REPAMAR Rede Pan Americana de Manejo Ambiental de Resíduos

RIMA Relatório de Impacto Ambiental

SEADE Sistema Estadual de Análise de Dados

SIG Sistemas de Informação Geográfica

SISNAMA Sistema Nacional do Meio Ambiente

SINIMA Sistema Nacional de Informações sobre o Meio Ambiente

SINIR Sistema de Gestão dos Resíduos Sólidos

SINIS Sistema Nacional de Informações sobre Saneamento 
SISNAMA Sistema Nacional do Meio Ambiente

SMA Secretaria Estadual do Meio Ambiente

UE União Europeia

UGHRI Unidade de Gerenciamento de Recursos Hídricos

UNESP Universidade Estadual Paulista 


\section{SUMÁRIO}

1 INTRODUÇÃO .......................................................... 34

2 OBJETIVOS .......................................................... 40

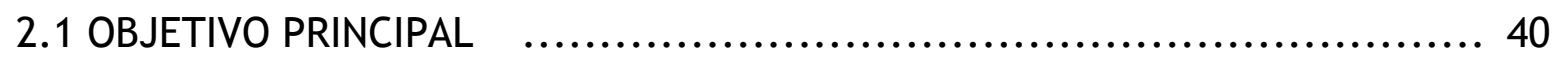

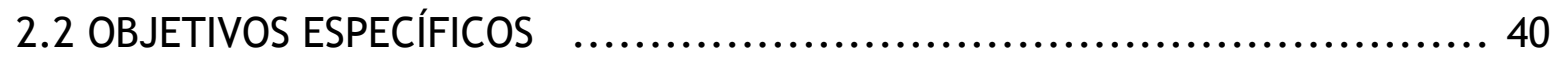

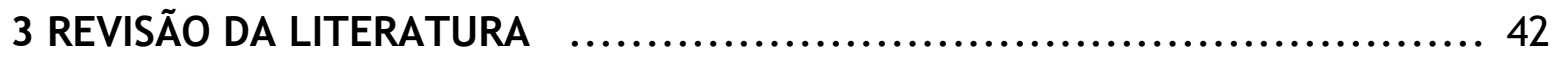

3.1 RESÍDUOS SÓLIDOS ..................................................... 42

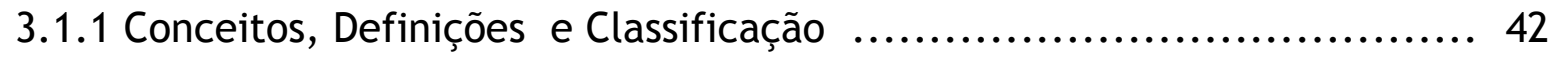

3.1.2 Legislação Federal e do Estado de São Paulo referente aos resíduos sólidos......................................................... 50

3.2 GESTÃO E GERENCIAMENTO DE RESÍDUOS SÓLIDOS $\ldots . \ldots \ldots \ldots \ldots \ldots \ldots \ldots . . . . . . . .64$

3.3 MARCOS REGULATÓRIOS APLICADOS AOS PLANOS DE RESÍDUOS

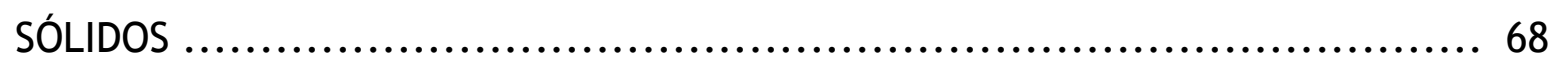

3.3.1 Política Nacional de Saneamento Básico ............................. 69

3.3.2 Política Nacional dos Resíduos Sólidos ............................. 71

3.3.3 Do Plano Nacional de Resíduos Sólidos............................. 81

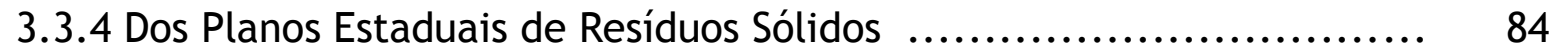

3.3.5 A Regionalização da Gestão dos Resíduos Sólidos ..................... 85

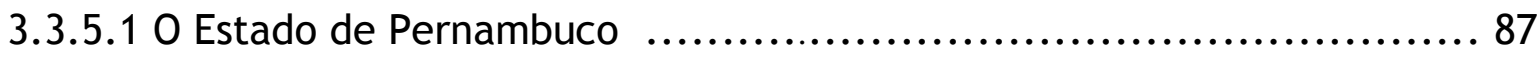

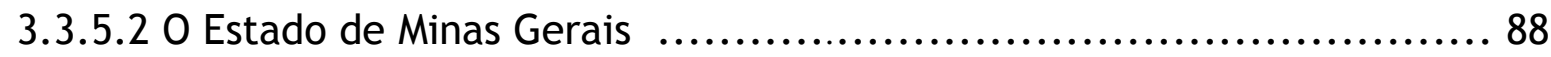

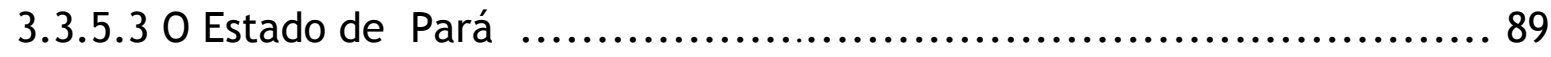

3.3.6 Dos Planos Municipais de Gestão Integrada de Resíduos Sólidos .......... 90

3.3.7 Política Estadual de Resíduos Sólidos ............................... 97 
3.3.8 Lei de Consórcios Públicos ............................................ 101

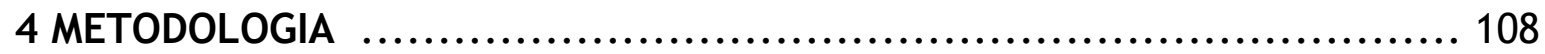

4.1 Considerações Gerais ................................................. 108

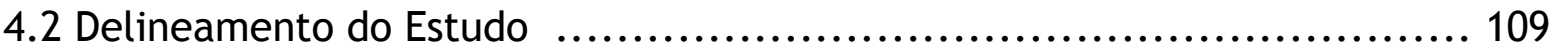

4.3 Universo de Estudo .................................................. 109

4.4 Período de Referência ................................................... 109

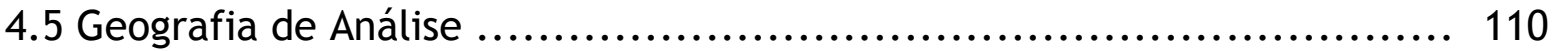

4.6 Pesquisa Bibliográfica ............................................ 110

4.7 Pesquisa de Campo................................................. 112

4.8 Estudo de Regionalização.......................................... 112

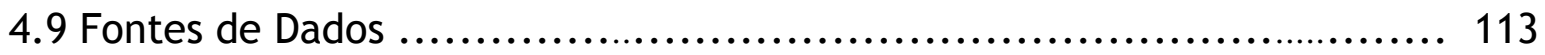

4.10 Softwares Utilizados no Estudo .................................... 113

4.11 Fluxograma da tese ................................................ 114

5 RESULTADOS E DISCUSSÕES ........................................... 116

5.1 A GESTÃO E GERENCIAMENTO DOS RESÍDUOS SÓLIDOS NO CONTEXTO

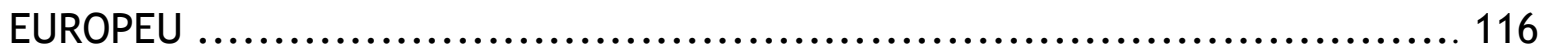

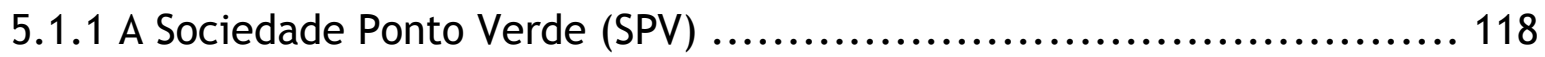

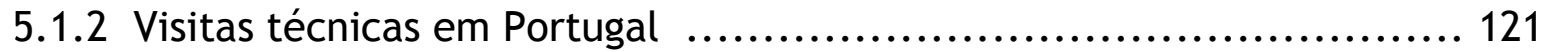

5.1.2.1 Visita técnica ao Lipor .......................................... 124

5.1.2.2 Visita Técnica ao Ambisousa ....................................... 139

5.1.3 Visita Técnica em Segóvia - Espanha ................................. 145

5.1.4 Visita Técnica em Bruxelas - Bélgica .................................... 148 
5.1.5 Visita Técnica em Lille - França ................................... 152

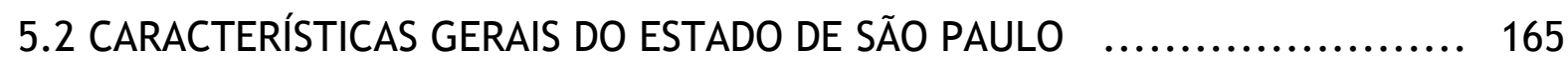

5.3 RESÍDUOS SÓLIDOS - ESTADO DE SÃO PAULO............................. 172

5.3.1 Resíduos domiciliares......................................... 172

5.3.2 Limpeza Pública.............................................. 182

5.3.2.1 Serviços de coleta ................................................ 183

5.3.2.2 Resíduos de Construção e Demolição ............................... 184

5.3.2.3 Resíduos Sólidos Industriais..................................... 184

5.4 ESTUDOS PARA PLANO DE REGIONALIZAÇÃO............................. 199

5.4.1 Consórcios Existentes............................................. 199

5.4.2 Regionalização.................................................. 213

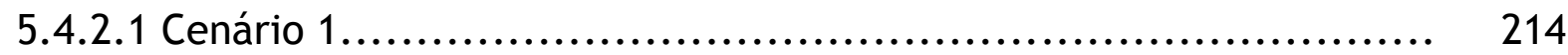

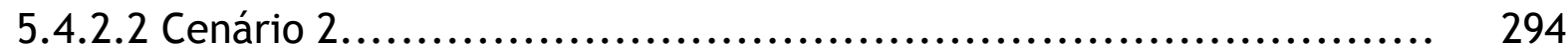

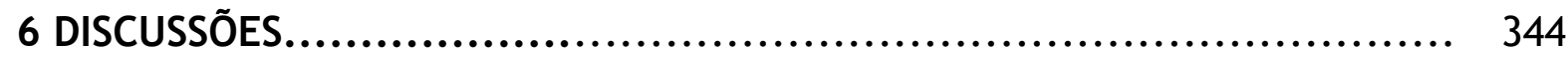

7 CONCLUSÕES E SUGESTÕES........................................ 350

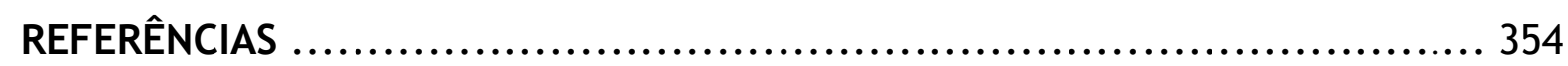

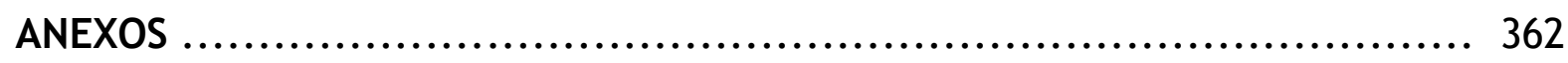

Anexo A - Questionário do diagnóstico de resíduos sólidos do Estado de Alagoas ...................................................................... 363

Anexo B - Regime jurídico do licenciamento da instalação e da exploração dos CIRVER - Portugal ...................................................... 374

Anexo C - Sínteses de Planos Internacionais ............................... 426 




\section{1 \\ INTRODUÇÃO}

Nosso planeta entra no século XXI com a maior população e configuração urbana de toda a sua história, as consequências desse processo se mostram pela acelerada degradação da biosfera com consequente detrimento da qualidade de vida. Esse contexto tem ocasionado uma maior ocupação territorial tanto para moradia como para a produção de bens de consumo e alimentos, necessitando de uma crescente utilização de matérias-primas para transformá-las em produtos acabados.

A ocupação do espaço na Terra, segundo Tucci (2002), para que seja de forma planejada e desenvolvida, necessita de uma visão mais ampla sobre os recursos terrestres e aquáticos disponíveis, assim como conhecer o comportamento dos processos naturais na bacia hidrográfica para que as necessidades crescentes do homem possam ser compatibilizadas racionalmente.

Um dos principais responsáveis pela degradação ambiental é a disposição no solo de resíduos sólidos urbanos sem qualquer forma de tratamento ou mesmo com tratamento inadequado, que sob a influência de agentes naturais como a chuva e microrganismos originam um processo de degradação dos 
compostos orgânicos e inorgânicos, iniciando o processo de formação de lixiviados e biogás.

A falta de interesse demonstrada pelas autoridades políticas dos países em desenvolvimento, seja em nível nacional, estadual ou local, em fazer investimentos na área do saneamento, procurar soluções adequadas e sustentáveis de gestão dos resíduos sólidos urbanos é um dos problemas apontados por Idris, Inanc e Hassan (2004).

Os governantes não levam em conta que com o desenvolvimento e o crescimento populacional há um aumento substancial de resíduos produzidos e, quase sempre se encontram despreparados para lidar com os problemas gerados por estes resíduos.

Assim, os impactos da geração de resíduos sólidos de várias naturezas, têm sido tratados com descaso pela esmagadora maioria dos administradores públicos brasileiros, pois são inadequadamente depositados comprometendo a qualidade de vida e a sustentabilidade ambiental, com contaminação de solos e recursos hídricos (Sissino \& Moreira 1996, Barbosa \& Otero 1999, Abu-Rukah \& AlKofahi 2001, Mazini 2003, Lopez et al 2007 entre outros).

Por muito tempo a questão dos resíduos sólidos ocupou uma condição terciária na discussão sobre saneamento básico, sendo que o debate principal sempre focou a distribuição de água potável, seguido pela coleta de esgoto.

O Plano Nacional de Saneamento (PLANASA), instituído no Brasil pelo extinto Banco Nacional da Habitação de maneira formal na década de 1970, conseguiu no prazo de quinze anos alcançar $80 \%$ da população abastecida de água potável e num resultado mais modesto, 35\% de esgoto coletado, enfatizando a ampliação destes serviços em claro prejuízo a investimentos na área dos resíduos sólidos.

A falta de investimentos na gestão de resíduos ocorrida nas décadas de 1970 e 1980 desencadeou no aparecimento de lixões espalhados na maioria dos municípios brasileiros. O IBGE realizou a Pesquisa Nacional de Saneamento Básico em 1989 e constatou que 75\% do lixo produzido no país era lançado a céu aberto. 
A proliferação dos lixões, com consequente agravamento dos problemas socioambientais, ocorridos com a destinação inadequada dos resíduos sólidos contribuiu para que a temática dos resíduos sólidos passasse a integrar as discussões sobre o saneamento básico no Brasil (DEMAJOROVIC et al., 2006).

Pela primeira vez no Brasil a questão dos resíduos sólidos passa a ser inserida em uma linha de financiamento com o surgimento em 1985 do Programa de Saneamento Básico para População de Baixa Renda, que ficou conhecido como Prosanear (SERRANO, 2001).

Este programa, financiado $50 \%$ pelo Banco Mundial, tinha como objetivo atender a população de baixa renda das cidades com os serviços de água, esgoto, drenagem e resíduos sólidos.

Após a promulgação da Constituição Federal em 1988, o tema resíduos sólidos ganha destaque nos anos de 1990 e assim, o país buscou a regulamentação sobre o tema e, por mais de duas décadas o Congresso Nacional debateu os Projetos de Lei 354/1989 e 203/1991, que originalmente estabeleceram discussões somente sobre os resíduos de serviços de saúde.

No final da década de 1990 com a criação das resoluções contendo o Princípio da Responsabilidade Pós-Consumo, editadas pelo Conselho Nacional do Meio Ambiente (CONAMA), o gerenciamento dos resíduos sólidos passou a ser discutido de forma mais emblemática no Congresso Nacional (CONFEDERAÇÃO NACIONAL DA INDÚSTRIA, 2008).

Neste contexto, o governo procurou adotar práticas de gestão eficientes dos serviços públicos de saneamento básico com vistas à proteção da qualidade ambiental, prevenção e controle da poluição e à promoção da saúde.

Atualmente o Brasil dispõe de um conjunto de políticas públicas, estabelecidas por novos marcos regulatórios de gestão dos resíduos sólidos. Dentre eles estão a Lei de Educação Ambiental (Lei Federal n 9.795/1999), o Estatuto da Cidade (Lei $n^{\circ}$ 10.257/2001), de Parceria Público-Privada (Lei $n^{\circ} 11.079 / 2004$ ), a Lei de Consórcios Públicos (Lei n 11.107/2005), a Política Nacional de Saneamento Básico (Lei n 11.445/2007), a Política Nacional de Resíduos Sólidos (Lei $\mathrm{n}^{\circ}$ 
12.305/2010) e no Estado de São Paulo a Política Estadual de Resíduos Sólidos do Estado de São Paulo (Lei Estadual n 12.300/2006).

A Política Nacional de Saneamento Básico define por saneamento básico o conjunto de serviços, infraestruturas e instalações operacionais do abastecimento de água potável, do esgotamento sanitário, da limpeza urbana, do manejo de resíduos sólidos e da drenagem e manejo das águas pluviais urbanas.

A Lei dos Consórcios Públicos disciplina as relações de cooperação federativa com a união entre dois ou mais entes da federação, sem fins lucrativos, para a prestação de serviços e desenvolver ações conjuntas, que visem o interesse coletivo e benefícios públicos.

A Política Nacional de Resíduos Sólidos (PNRS) institui diretrizes e instrumentos para a gestão dos resíduos sólidos, define termos, classifica os resíduos, estabelece responsabilidade compartilhada envolvendo governos, sociedade, empresas e cidadãos na gestão dos resíduos sólidos e determina que os entes federados terão que elaborar seus Planos de Gestão de Resíduos.

Essa Lei reúne vários dispositivos legais que estavam esparsos em uma série de instrumentos normativos e the dão força de lei federal, apesar de ser uma norma de eficácia contida, pois possibilita complementos e concorrência de leis estaduais e municipais para o seu funcionamento pleno.

Neste contexto, a PNRS articula-se com diversas políticas públicas estabelecidas por novos marcos regulatórios de gestão dos resíduos sólidos. Dentre eles estão a Lei de Educação Ambiental (Lei Federal no 9.795/1999), o Estatuto da Cidade (Lei $n^{\circ} 10.257 / 2001$ ), de Parceria Público-Privada (Lei $n^{\circ} 11.079 / 2004$ ), a Lei de Consórcios Públicos (Lei n 11.107/2005), a Política Nacional de Saneamento Básico (Lei $\mathrm{n}^{\circ} 11.445 / 2007$ ) e a Política Nacional de Resíduos Sólidos (Lei ${ }^{\circ}$ 12.305/2010).

A Política Estadual de Resíduos Sólidos aponta responsabilidades dos fabricantes, distribuidores ou importadores, consumidores e administradores públicos no consumo e pós-consumo de produtos que venham a gerar quaisquer resíduos de significativo impacto ambiental, bem como a gestão integrada e 
compartilhada dos resíduos sólidos, e ainda a mitigação dos efeitos nocivos que tais resíduos causem ao meio ambiente ou à saúde pública.

O Governo do Estado de São Paulo promulgou em 28 de fevereiro de 2012 o Decreto $n^{\circ}$ 57.817, instituindo o Programa Estadual de Implementação de Projetos de Resíduos Sólidos, que consiste em projetos de apoio a gestão municipal de resíduos sólidos e às atividades de reciclagem, coleta seletiva, melhoria na destinação final dos resíduos sólidos, educação ambiental e na elaboração do Plano Estadual de Resíduos Sólidos.

Nesse contexto, este estudo procura gerar informações que possam constituir-se em instrumento de planejamento, informação e auxílio, contribuindo com a elaboração do Plano Estadual de Resíduos Sólidos do Estado de São Paulo e ao desenvolvimento da gestão dos resíduos sólidos.

Após as discussões introdutórias deste capítulo, esta tese está estruturada e apresentada em seis capítulos subsequentes a saber:

- Capítulo 2: apresenta o objetivo principal e os objetivos específicos estabelecidos;

- Capítulo 3: contém a revisão bibliográfica, integrada por subseções, as quais encontram-se informações gerais sobre a área de pesquisa, conceitos voltados à gestão e ao gerenciamento de resíduos sólidos, modelos europeus de gestão, aspectos legais normativos, históricos e características de consórcios intermunicipais;

- $\quad$ Capítulo 4: descreve a metodologia da pesquisa e os parâmetros utilizados no estudo de regionalização para constituição de consórcios e para a gestão e manejo dos resíduos sólidos no Estado de São Paulo;

- $\quad$ Capítulo 5: apresenta os resultados e discussões da pesquisa às contribuições ao Plano Estadual de Resíduos Sólidos do Estado 
de São Paulo e o resultado do estudo da regionalização para constituição de consórcios;

- Capítulo 6: traz as conclusões do trabalho, bem como suas contribuições e limitações;

- $\quad$ Capítulo 7: indica sugestões para futuras pesquisas. 


\section{2 \\ OBJETIVOS}

\subsection{Objetivo principal}

0 presente trabalho tem como objetivo precípuo, elaborar contribuições ao Plano Estadual de Resíduos Sólidos do Estado de São Paulo, visando subsidiar o futuro plano paulista com diagnósticos e cenários do gerenciamento dos resíduos sólidos no Estado.

\subsection{Objetivos específicos}

Para realizar a proposta da pesquisa e complementar o objetivo precípuo, foram traçados os seguintes objetivos específicos:

> Identificar os locais de disposição dos resíduos sólidos no Estado;

$>$ Estudar modelos de gestão e gerenciamento de resíduos sólidos europeus;

> Executar o levantamento dos consórcios públicos para gestão de resíduos sólidos existentes no Estado; 
> Sugerir soluções consorciadas para manejo de resíduos sólidos, com base nas Leis Federais $n^{\circ}$. 11.445/2007 (Política Nacional de Saneamento Básico) e $n^{\circ}$. 11.107/2005 (Lei de Consórcios Públicos) e seu Decreto n. 6. 017/2007, Lei Federal $n^{\circ}$ 9.795/1999 (Lei de Educação Ambiental), Lei $n^{\circ}$ 10.257/2001 (Estatuto da Cidade), de Parceria Público-Privada (Lei $\left.n^{\circ} 11.079 / 2004\right)$, e Lei $n^{\circ}$ 12.305/2010 (Política Nacional de Resíduos Sólidos);

$>$ Realizar estudos de regionalização de gestão e manejo dos resíduos sólidos. 


\section{3 \\ REVISÃO DA LITERATURA}

\subsection{RESÍDUOS SÓLIDOS}

\subsubsection{Conceitos, Definições e Classificação}

Diversos conceitos são definidos para a palavra resíduo, o dicionário Michaelis (2012), em uma primeira menção define como "Aquilo que resta, que subsiste de coisa desaparecida". Segundo Annes (2012) resíduos é um sinal de produção ineficiente, referindo-se as ciências contábeis, e a Associação Brasileira 
de Normas Técnicas - ABNT, define como os "restos das atividades humanas, considerados pelos geradores como inúteis, indesejáveis ou descartáveis, podendo apresentar-se no estado sólido, semi-sólido ou líquido, desde que não seja passível de tratamento convencional" (ABNT, 2004).

A Associação Brasileira de Normas Técnicas (ABNT), por meio da NBR10004 (1987), define resíduos sólidos como os resíduos nos estados sólidos e semisólidos, que resultam de atividades da comunidade de origem: industrial, doméstica, hospitalar, comercial, agrícola, de serviços e de varrição. Consideramse também resíduos sólidos os lodos provenientes de sistemas de tratamento de água, aqueles gerados em equipamentos e instalações de controle de poluição, bem como determinados líquidos, cujas particularidades tornem inviável seu lançamento na rede pública de esgotos ou corpos d’água, ou exijam para isso soluções técnicas e economicamente inviáveis em face à melhor tecnologia disponível.

Conforme Schalch (2002), a definição da ABNT não contempla as palavras redução, reutilização e reciclagem, ressaltando ainda que, atualmente, os resíduos hospitalares são chamados de resíduos de serviços de saúde, conforme NBR-12807 (1993).

A Política Nacional de Resíduos Sólidos em seu art. $3^{\circ}$ diferencia rejeitos de resíduos sólidos como:

$\mathrm{XV}$ - rejeitos: resíduos sólidos que, depois de esgotadas todas as possibilidades de tratamento e recuperação por processos tecnológicos disponíveis e economicamente viáveis, não apresentem outra possibilidade que não a disposição final ambientalmente adequada;

XVI - resíduos sólidos: material, substância, objeto ou bem descartado resultante de atividades humanas em sociedade, a cuja destinação final se procede, se propõe proceder ou se está obrigado a proceder, nos estados sólido ou semissólido, bem como gases contidos em recipientes e líquidos cujas particularidades tornem inviável o seu lançamento na rede pública de esgotos ou em corpos d'água, ou exijam para isso soluções técnica ou economicamente inviáveis em face da melhor tecnologia disponível;

(Brasil, 2010) 
Podendo ser também aqueles que se encontram também nos estados líquido e gasoso, constituídos principalmente pelos efluentes de diversas atividades humanas.

A Norma NBR 10004:2004 da Associação Brasileira de Normas Técnicas (ABNT) classifica os diversos tipos de resíduos, segundo seus riscos potenciais à saúde e ao meio ambiente, porem a Lei Federal $n^{\circ} 12.305$ que instituiu a Política Nacional de Resíduos apresentou nova classificação dos resíduos sólidos quanto a origem e periculosidade, como:

I - quanto à origem:

a) resíduos domiciliares: os originários de atividades domésticas em residências urbanas;

b) resíduos de limpeza urbana: os originários da varrição, limpeza de logradouros e vias públicas e outros serviços de limpeza urbana;

c) resíduos sólidos urbanos: os englobados nas alíneas "a" e "b";

d) resíduos de estabelecimentos comerciais e prestadores de serviços: os gerados nessas atividades, excetuados os referidos nas alíneas "b”, “e”, "g”, “h” e "j”;

e) resíduos dos serviços públicos de saneamento básico: os gerados nessas atividades, excetuados os referidos na alínea "c";

f) resíduos industriais: os gerados nos processos produtivos e instalações industriais;

g) resíduos de serviços de saúde: os gerados nos serviços de saúde, conforme definido em regulamento ou em normas estabelecidas pelos órgãos do Sisnama e do SNVS;

h) resíduos da construção civil: os gerados nas construções, reformas, reparos e demolições de obras de construção civil, incluídos os resultantes da preparação e escavação de terrenos para obras civis;

i) resíduos agrossilvopastoris: os gerados nas atividades agropecuárias e silviculturais, incluídos os relacionados a insumos utilizados nessas atividades;

j) resíduos de serviços de transportes: os originários de portos, aeroportos, terminais alfandegários, rodoviários e ferroviários e passagens de fronteira;

k) resíduos de mineração: os gerados na atividade de pesquisa, extração ou beneficiamento de minérios;

II - quanto à periculosidade:

a) resíduos perigosos: aqueles que, em razão de suas características de inflamabilidade, corrosividade, reatividade, toxicidade, patogenicidade, carcinogenicidade, teratogenicidade e mutagenicidade, apresentam significativo risco à saúde pública ou à qualidade ambiental, de acordo com lei, regulamento ou norma técnica;

b) resíduos não perigosos: aqueles não enquadrados na alínea "a". 
Parágrafo único. Respeitado o disposto no art. 20, os resíduos referidos na alínea "d" do inciso I do caput, se caracterizados como não perigosos, podem, em razão de sua natureza, composição ou volume, ser equiparados aos resíduos domiciliares pelo poder público municipal.

Há diversas classificações aplicáveis aos resíduos sólidos, a Norma NBR 10004:2004 classifica os resíduos em dois grupos: perigosos e não-perigosos. Este último ainda pode ser subdividido em inertes e não-inertes:

a) Resíduos Classe I: denominados perigosos, são os resíduos sólidos que, devido às suas características, podem apresentar riscos à saúde pública. As características que conferem periculosidade a um resíduo são a inflamabilidade, corrosividade, reatividade, toxicidade e patogenicidade (ou contaminantes);

b) Resíduos Classe II: denominados não-perigosos, são os resíduos sólidos que não apresentam riscos ao ser humano e ao meio ambiente, sendo subdivididos em:

b1) Resíduos Classe II A: denominados não inertes, são os resíduos sólidos que, submetidos a testes de solubilização, não tenham nenhum de seus constituintes solubilizados em concentrações superiores aos padrões de potabilidade de águas, excetuando-se os padrões relativos ao aspecto, cor, turbidez e sabor; e

b2) Resíduos Classe II B: denominados inertes, são os resíduos que não se enquadram na Classe I ou na Classe II A, podendo ter propriedades, tais como, combustibilidade, biodegradabilidade, ou solubilidade em água.

A Norma NBR 12.808 que dispõe sobre os resíduos de serviços de saúde, separa os resíduos em infectantes, especiais e comuns e a Resolução Conama 358/2005 divide em cinco grupos os resíduos sendo: grupo A, resíduos com a possível presença de agentes biológicos, que por suas características de maior virulência ou concentração podem apresentar risco de infecção; grupo B, resíduos contendo substâncias químicas que podem apresentar risco à saúde pública ou ao meio ambiente, dependendo de suas características de inflamabilidade, corrosividade, reatividade e toxicidade; grupo $\mathrm{C}$, quaisquer materiais resultantes 
de atividades humanas que contenham radionuclídeos em quantidades superiores aos limites de eliminação 9 especificados nas normas da Comissão Nacional de Energia Nuclear (CNEN) e para os quais a reutilização é imprópria ou não prevista; grupo $D$, resíduos que não apresentem risco biológico, químico ou radiológico à saúde ou ao meio ambiente, podendo ser equiparados aos resíduos domiciliares e grupo $\mathrm{E}$, materiais perfurocortantes ou escarificantes.

A Política Nacional de Resíduos Sólidos apresenta também uma classificação a ser observada nacionalmente e fixou dois critérios para classificar os resíduos sólidos: quanto a origem e quanto a quanto a periculosidade.

\section{- QUANTO A ORIGEM:}

a) Resíduos domiciliares

Resíduos domiciliares são aqueles de originados de atividades domésticas realizadas em residência urbanas, sem importar as características intrínsecas a tais materiais descartados. Os resíduos gerados residências em áreas rurais, segundo o legislador, não são considerados resíduos domiciliares.

b) Resíduos de limpeza urbana

São os resíduos gerados na área urbana, não advindos de atividades domésticas realizadas no âmbito residencial, como resíduos oriundos de varrição e limpeza de vias.

c) Resíduos sólidos urbanos

São materiais sob a responsabilidade dos municípios e do Distrito Federal, unindo os resíduos domiciliares e resíduos de limpeza urbana.

d) Resíduos de estabelecimento comerciais prestadores de serviço

Pertencem a esta categoria os resíduos gerados em atividades comerciais ou de prestação de serviço, salvo quando por maior especificidade estes forem incluídos em outras categorias, como os resíduos de origem nos serviços de limpeza urbana, saneamento básico, saúde, construção civil ou transporte. Estes resíduos, se 
caracterizados como não perigosos, podem ser equiparados aos resíduos domiciliares pelo poder público municipal.

e) Resíduos de serviços públicos de saneamento básico

São resíduos gerados nas atividades destinadas ao abastecimento de água e ao tratamento de esgotos, salvo os resíduos com características de resíduos sólidos urbanos.

f) Resíduos industriais

Resíduos de origem das atividades de produção em indústrias.

g) Resíduos de serviços de saúde

O legislador delegou aos órgãos do Sisnama e do SNVS a competência para a definição dos termos que permitirão a classificação objetiva dos resíduos de serviços de saúde.

h) Resíduos da construção civil

São resíduos provenientes das obras de engenharia civil, incluindo as construções propriamente ditas, demolições, reparos, reformas, além de preparação e escavação de terrenos destinados ás atividades anteriormente listadas.

j) Resíduos agrossilvopastoris

Resíduos gerados nas atividades agropecuárias e silviculturais, incluindo os insumos utilizados nestas atividades.

k) Resíduos de mineração

Aqueles gerados nos processos de pesquisa, extração ou beneficiamento de minérios.

Quanto a periculosidade:

a) Inflamabilidade 
Substâncias que inflamam com facilidade e continuam mesmo após a retirada da fonte de inflamação.

b) Corrosividade

Substâncias que podem destruir tecidos vivos por contato.

c) Reatividade

Substancias que reagem de forma súbita com água e geram gases, vapores e fumos tóxicos em quantidades suficientes para provocar danos à saúde pública ou ao meio ambiente.

d) Toxidade

Substâncias que apresentam riscos graves a saúde quando inaladas, ingeridas ou em contato com a pele.

e) Patogenicidade

Substâncias que causam doenças nos seres humanos pois contem micro-organismos, toxinas ou outros elementos.

f) Carcinogenicidade

Substâncias que podem provocar ou aumentar a incidência de câncer quando inaladas, ingeridas ou em contato com a pele.

g) Teratogenicidade

Substâncias que induzem malformações congênitas não hereditárias em embrião ou feto quando inaladas, ingeridas ou em contato com a pele.

h) Mutagenicidade

Substâncias que induzem defeitos genéticos quando inaladas, ingeridas ou em contato com a pele.

A versão preliminar do Plano Nacional apresenta uma outra forma para agrupar tais resíduos, que considera o local ou atividade em que a geração ocorre: 
- Resíduos Sólidos Urbanos: divididos em materiais recicláveis (metais, aço, papel, plástico, vidro, etc.) e matéria orgânica.

- Resíduos da Construção Civil: gerados nas construções, reformas, reparos e demolições, bem como na preparação de terrenos para obras.

- Resíduos com Logística Reversa Obrigatória: pilhas e baterias; pneus; lâmpadas fluorescentes de vapor de sódio e mercúrio e de luz mista; óleos lubrificantes, seus resíduos e embalagens; produtos eletroeletrônicos e seus componentes; entre outros a serem incluídos.

- Resíduos Industriais: gerados nos processos produtivos e instalações industriais; normalmente, grande parte são resíduos de alta periculosidade.

- Resíduos Sólidos do Transporte Aéreo e Aquaviário: gerados pelos serviços de transportes, de naturezas diversas, como ferragens, resíduos de cozinha, material de escritório, lâmpadas, pilhas, etc.

- Resíduos Sólidos do Transporte Rodoviário e Ferroviário: gerados pelos serviços de transportes, acrescidos de resíduos sépticos que podem conter organismos patogênicos.

- Resíduos de Serviços de Saúde: gerados em qualquer serviço de saúde.

- Resíduos Sólidos de Mineração: gerados em qualquer atividade de mineração.

- Resíduos Sólidos Agrossilvopastoris (orgânicos e inorgânicos): dejetos da criação de animais; resíduos associados a culturas da agroindústria, bem como da silvicultura; embalagens de agrotóxicos, fertilizantes e insumos.

Todas estas classificações existem e devem ser observadas, pois cada tipo de resíduo sólido demanda procedimentos particulares em seu gerenciamento. 


\subsubsection{Legislação Federal e do Estado de São Paulo referente aos resíduos sólidos}

Considerando a hierarquia da legislação sobre resíduos sólidos, vale o princípio da supremacia da Constituição, segundo o qual as normas Constitucionais estão num nível de superioridade em relação às demais leis.

Em conjunto com as leis constitucionais, complementares, ordinárias e delegadas e os decretos legislativos, compõem o arcabouço legal federal e abaixo destas estão as constituições estaduais, seguidas das leis estaduais, municipais e normas subalternas - Decretos, Resoluções, Portarias, e as Instruções Normativas, entre outras, sendo:

\section{- CONSTITUIÇÃO FEDERAL}

- Artigo 23, inciso VI -“compete à União, aos Estados, ao Distrito Federal e aos Municípios proteger o meio ambiente e combater a poluição em qualquer das suas formas";

- Artigo 24 - estabelece a competência da União, dos Estados e do Distrito Federal em legislar concorrentemente sobre “(...) proteção do meio ambiente e controle da poluição" (inciso VI); e,

- Artigo 30, incisos I e II - estabelece que cabe ainda ao poder público municipal “legislar sobre os assuntos de interesse local e suplementar a legislação federal e a estadual no que couber".

\section{- GERAL - FEDERAL}

- Lei Federal $\mathrm{n}^{\circ} 11.455$ Estabelece as diretrizes nacionais para o setor de saneamento básico no Brasil.

- Conselho Nacional do Meio Ambiente - Resolução CONAMA nº 001/1986 Dispõe sobre critérios básicos e diretrizes gerais para o Estudo de Impacto Ambiental EIA e o Relatório de Impacto Ambiental - RIMA.

- Conselho Nacional do Meio Ambiente - Resolução CONAMA n 237/1997 Dispõe sobre o Licenciamento Ambiental. 
- Conselho Nacional do Meio Ambiente - Resolução CONAMA n 275/2001 Estabelece código de cores para os diferentes tipos de resíduos, a ser adotado na identificação de coletores e transportadores, bem como nas campanhas informativas para a coleta seletiva.

- Associação Brasileira de Normas Técnicas - ABNT.NBR 10.004 Classificação dos resíduos sólidos, 2004.

- Associação Brasileira de Normas Técnicas - ABNT.NBR 10.005 Procedimentos para obtenção de extrato lixiviado de resíduos sólidos, 2004.

- Associação Brasileira de Normas Técnicas - ABNT.NBR 10.006 Procedimentos para obtenção de extrato solubilizado de resíduos sólidos, 2004.

- Associação Brasileira de Normas Técnicas - ABNT.NBR 10.007 Amostragem de resíduos sólidos, 2004.

- Associação Brasileira de Normas Técnicas - ABNT.NBR 13.463 Coleta de resíduos sólidos, 1995.

- GERAL ESTADUAL

- Lei Estadual n 997/1976 Dispões sobre o controle da poluição do meio ambiente Lei Estadual $n^{\circ}$ 12.300/2006 Institui a Política Estadual de resíduos sólidos e define princípios e diretrizes, objetivos, instrumentos para a gestão integrada e compartilhada dos resíduos sólidos, com vistas à prevenção e ao controle da poluição, à proteção e a à recuperação da qualidade do meio ambiente, e à promoção da saúde pública, assegurando o uso adequado dos recursos ambientais no Estado de São Paulo (Revoga Lei 11.387, de 27.05.03).

- Decreto Estadual n 8.468/1976 Regulamenta a Lei 997/76 que dispões sobre a prevenção e o controle de poluição do meio ambiente.

- Decreto Estadual $n^{\circ}$ 47.397/2002 Dá nova redação ao Título V e ao Anexo 5 e acrescenta os Anexos 9 e 10, ao Regulamento da Lei n 997, de 31 de maio de 
1976, aprovado pelo Decreto $\mathrm{n}^{\circ} 8.468$, de 8 de setembro de 1976, que dispõe sobre a prevenção e o controle da poluição do meio ambiente.

- Decreto Estadual $\mathrm{n}^{\circ} 47.400 / 2002$ e 48.919/2004 Licenciamento ambiental Estabelece prazos de validade para cada modalidade de licenciamento ambiental e condições para sua renovação, estabelece prazo de análise dos requerimentos e licenciamento ambiental, institui procedimento obrigatório de notificação de suspensão ou encerramento de atividade, e o recolhimento de valor referente ao preço de análise.

- Resolução SMA 42/1994 Define os procedimentos para análise de Estudos de Impacto Ambiental (EIA/RIMA).

- Resolução SMA 54/2004 Dispões sobre procedimentos para o licenciamento ambiental no âmbito da Secretaria do Meio Ambiente.

- Resolução SMA 22/2007 Altera procedimentos para o licenciamento das atividades específicas, incluindo sistemas de armazenamento e transferência de resíduos da construção civil, desde que associadas a beneficiamento; sistemas de transbordo, tratamento e de resíduos sólidos domiciliares.

- Aterro Sanitário - Federal

- Conselho Nacional do Meio Ambiente - Resolução CONAMA n 316/2002 Dispõe sobre procedimentos e critérios para o funcionamento de sistemas de tratamento térmico de resíduos.

- Conselho Nacional do Meio Ambiente - Resolução CONAMA no 404/2008 Estabelece critérios e diretrizes para o licenciamento de aterro de pequeno porte de resíduos sólidos urbanos (Revoga.a 308/2002).

- Associação Brasileira de Normas Técnicas - ABNT.NBR 8.419 Apresentação de projetos de aterros sanitários de resíduos sólidos urbanos, 1992.

- Associação Brasileira de Normas Técnicas - ABNT.NBR 13.896 - Aterros de resíduos não perigosos - Critérios para projeto, implantação e operação Procedimento. 
- Aterro Sanitário - Estadual

- Resolução SMA 75/2008 Dispõe sobre licenciamento das unidades de armazenamento, transferência, triagem, reciclagem, tratamento e disposição final de resíduos sólidos de Classes, IIA e IIB.

- Norma CETESB p4.241 Apresentação de projetos para aterros sanitários de resíduos urbanos. Norma Brasileira ABNT NBR 15112/2004.

- Resíduos da Construção Civil - Federal

- Conselho Nacional do Meio Ambiente - Resolução CONAMA n 307/2002 Dispõe sobre a gestão dos resíduos da construção civil.

- Conselho Nacional do Meio Ambiente - Resolução CONAMA n 348/2004 Altera Resolução CONAMA n 307, de 5 de julho de 2002, incluindo o amianto na classe $D$, resíduos perigosos.

- Associação Brasileira de Normas Técnicas - ABNT.NBR 15.112 Resíduos sólidos da construção civil e resíduos volumosos - Áreas para transbordo e triagem Diretrizes para projeto implantação e operação, 2004.

- Associação Brasileira de Normas Técnicas - ABNT.NBR 15.113 Resíduos sólidos da construção civil e resíduos inertes - Aterros - Diretrizes para projeto, implantação e operação, 2004.

- Associação Brasileira de Normas Técnicas - ABNT.NBR 15.114 Resíduos sólidos da construção civil - Áreas de reciclagem - Diretrizes para projeto, implantação e operação, 2004.

- Associação Brasileira de Normas Técnicas - ABNT.NBR 15.115 Agregados reciclados da construção civil - Execução de camadas de pavimentação de Procedimentos, 2004. 
- Associação Brasileira de Normas Técnicas - ABNT.NBR 15.116 Agregados reciclados de resíduos sólidos da construção civil - Utilização em pavimentação e preparo de concreto sem função estrutural, 2004.

- Resíduos da Construção Civil - Estadual

- Resolução SMA no 41/2002 Procedimentos para licenciamento ambiental de aterros de resíduos inertes e da construção civil.

- Portos e Aeroportos - Federal

- Conselho Nacional do Meio Ambiente - Resolução CONAMA n 06/1991 Incineração de resíduos sólidos de serviços de saúde, portos, aeroportos.

- Conselho Nacional do Meio Ambiente - Resolução CONAMA n 05/1993 Gerenciamento de resíduos sólidos gerados nos portos, aeroportos, terminais ferroviários e rodoviários.

- Resolução RDC $n^{\circ}$ 342/2002 Dispõe sobre a elaboração do plano de gerenciamento de resíduos sólidos (PGRS), para instalações portuárias, aeroportuárias e terminais alfandegados de uso público.

- Resolução RDC no 217/2001 Retirada de resíduos sólidos de bordo de embarcações.

- Compostagem - Federal

- Lei Federal $n^{\circ}$ 6.894/1980 e Decreto Federal $n^{\circ}$ 4954/2004 Dispõe sobre a inspeção e fiscalização da produção e do comércio de fertilizantes, corretivos, inoculantes ou biofertilizantes destinados à agricultura, e dá outras providências. 
- Instrução Normativa $n^{\circ}$ 27/2006 Dispões sobre fertilizantes, corretivos, inoculantes e biofertilizantes, para serem produzidos, importados ou comercializados, deverão atender aos limites estabelecidos nos Anexos I,II, III,IV e $V$ desta Instrução Normativa no que se refere às concentrações máximas admitidas para agentes fitotóxicos, patogênicos ao homem, animais e plantas, metais pesados tóxicos, pragas e ervas daninhas.

\section{- Compostagem - Estadual}

- Resolução SMA 75/2008 Dispõe sobre licenciamento das unidades de armazenamento, transferência, triagem, tratamento e disposição final de resíduos sólidos de Classes IIA e IIB. (Revoga a 51/1997).

- Embalagens vazias de agrotóxicos - Federal

- Lei Federal $n^{\circ} 7.802 / 1989$ e Decreto $N^{\circ}$ 4074/2002 Dispõe sobre o destino final dos resíduos de embalagens e fiscalização de agrotóxicos, seus componentes e afins, e dá outras providências.

- Conselho Nacional do Meio Ambiente - Resolução CONAMA n 334/2003 Dispõe sobre os procedimentos de Licenciamento Ambiental de estabelecimentos destinados ao recebimento de embalagens vazias de agrotóxicos.

- Pilhas, baterias, lâmpadas fluorescentes e frascos aerossóis - Federal

- Conselho Nacional do Meio Ambiente - Resolução CONAMA no 401/2008 Estabelece os limites máximos de chumbo, cádmio e mercúrio para pilhas e baterias comercializadas no território nacional e os critérios e padrões para o seu gerenciamento ambientalmente adequado, e dá outras providências (Revoga.a n 275/1999 e 263/1999). 
- Pilhas, baterias, lâmpadas fluorescentes e frascos aerossóis - Estadual

- Lei Estadual $n^{\circ}$ 10.888/2001 Dispõe sobre o descarte final de produtos potencialmente perigosos de resíduos que contenham metais pesados (pilhas, baterias, lâmpadas fluorescentes e frascos de aerossóis em geral).

- Norma do IPT NEA n 76/2008 Requisitos mínimos de desempenho para avaliação de embalagens e acondicionamentos para o transporte de lâmpadas fluorescentes em todo ambiente de distribuição, inclusive pós uso.

- Pilhas, baterias, lâmpadas fluorescentes e frascos aerossóis - Municipal

- Lei Municipal $n^{\circ}$ 14.898/2009 Dispõe da obrigatoriedade da prefeitura de município de São Paulo, autarquias, órgãos municipais da administração direta e indireta e empresas municipais a coletar lâmpadas fluorescentes defeituosas ou que não mais acendem para reciclagem e reaproveitamento em todas dependências públicas da cidade de São Paulo.

- Lei Municipal $n^{\circ} 12.653 / 1998$ Fixa normas que estabelecem a maneira correta de descarte de lâmpadas fluorescentes e dá outras providências.

- Pneus - Federal

- Resolução Conjunta SMA/SS $\mathrm{n}^{\circ}$ 01/2002 Dispõe sobre a trituração ou retalhamento de pneus para fins de disposição em aterros sanitários.

- Óleo Lubrificante - Federal

- Conselho Nacional do Meio Ambiente - Resolução CONAMA n 362/2005 Estabelece diretrizes para o recolhimento e destinação de óleo lubrificante usado ou contaminado (Revoga. Resolução. 09/93). 
- Portaria ANP N. 125, DE 30.07.99 Regulamenta a atividade de recolhimento, coleta e destinação final do óleo lubrificante usado ou acabado, conforme diretrizes definidas na Portaria Interministerial MME-MMA n ${ }^{\circ}$ 1/99.

- Portaria ANP N. 71, DE 25.04.00 Regulamenta a atividade de coleta de óleo lubrificante usado ou contaminado (Altera Portaria ANP n. 164, de 28.09.99 e ANP n. 127, de 30.07.99).

- Portaria ANP N. 122, DE 29.07.99 Dispõe sobre o controle e descarte de óleos lubrificantes usados ou contaminados (Altera Portaria ANP nº 81, de 03.05.99).

- Óleo Lubrificante - Estadual

- Portaria CAT no 81, de 03/12/99 Disciplina o procedimento de coleta, transporte e recebimento de óleo lubrificante usado ou contaminado (Alteração incorporada: Portaria CAT n.60, de 04.08.00).

- Amianto - Federal

- Lei Federal no 9.055/1995 Disciplina a extração, industrialização, utilização, comercialização e transporte do asbesto/amianto e dos produtos que 0 contenham, bem como das fibras naturais e artificiais, de qualquer origem, utilizadas para o mesmo fim e dá outras providências.

- Decreto Federal $n^{\circ}$ 2.350/1997 Regulamenta a Lei 9055//95 e da outras providências.

- Decreto Federal $n^{\circ}$ 126/1911 Promulga a Convenção $n^{\circ} 162$, da Organização Internacional do Trabalho - OIT sobre a utilização do Abesto com Segurança.

- Conselho Nacional do Meio Ambiente - Resolução CONAMA nº 07/1987 Dispõe sobre a regulamentação do uso amianto/asbestos no Brasil.

- Conselho Nacional do Meio Ambiente - Resolução CONAMA n 09/1988 Dispõe sobre a regulamentação do uso de amianto/asbestos no Brasil (Altera a Resolução 07/87). 
- Conselho Nacional do Meio Ambiente - Resolução CONAMA n 19/1996 Complementa a Resolução 07/87.

- Conselho Nacional do Meio Ambiente - Resolução CONAMA n 23/1996 Dispõe sobre as definições e o tratamento a ser dado aos resíduos perigosos, conforme as normas adotadas pela Convenção de Basiléia sobre o controle de movimentos transfronteiriços de resíduos perigosos e seu depósito.

- Conselho Nacional do Meio Ambiente - Resolução CONAMA n 228/1997 Dispõe sobre a importação de desperdícios e resíduos de acumuladores elétricos de chumbo. Complementa a Resolução 23/06.

- Conselho Nacional do Meio Ambiente - Resolução CONAMA n 235/1998 Altera o anexo 10 da Resolução N ${ }^{\circ} 23 / 96$.

- Conselho Nacional do Meio Ambiente - Resolução CONAMA n 244/1998 Exclui item do anexo 10 da Resolução Nº 23/96.

- Conselho Nacional do Meio Ambiente - Resolução CONAMA n 307/2002 Estabelece diretrizes, critérios e procedimentos para a gestão dos resíduos da construção civil, disciplina as ações necessárias de forma a minimizar os impactos ambientais. Definições e classificações.

- Conselho Nacional do Meio Ambiente - Resolução CONAMA n 313/2002 Inventário Nacional de Resíduos Sólidos Industriais.

- Conselho Nacional do Meio Ambiente - Resolução CONAMA n 348/2002 Altera Resolução Conama 307 - Incluindo o amianto de resíduos perigosos.

- Norma Regulamentadora NR-15 Limites de tolerância para poeiras e minerais.

- Norma Regulamentadora PMA n 43 Dispõe sobre a vedação ao Ministério do Meio Ambiente e seus órgãos vinculados de utilização de qualquer tipo de asbesto/amianto e dá outras providências. 
- Amianto - Estadual

- Lei Estadual n 10.813/2001 Dispõe sobre a proibição de importação, extração, beneficiamento, comercialização, fabricação e a instalação, no Estado de São Paulo, de produtos ou materiais contendo qualquer tipo de amianto.

- Lei Estadual n 12.684/2007 Proíbe o uso, no Estado de São Paulo de produtos, materiais ou artefatos que contenham quaisquer tipos de amianto ou asbesto ou outros minerais que, acidentalmente, tenham fibras de amianto em sua composição.

- Resíduos de serviços de saúde - Federal

- Conselho Nacional do Meio Ambiente - Resolução CONAMA n 06/1991 Desobriga a incineração dos resíduos sólidos de serviços de saúde, portos e aeroportos.

- Conselho Nacional do Meio Ambiente - Resolução CONAMA n 358/2005 Dispõe sobre o tratamento e disposição final dos resíduos sólidos de serviços de saúde (Revoga. as Resoluções: $\mathrm{n}^{\circ}$ 05/1993, no que diz respeito a prestadores de serviços de saúde e a $n^{\circ} 283 / 01$.)

- Resolução RDC 306/2004 Dispõe sobre o regulamento técnico para o gerenciamento de resíduos de serviços de saúde (Revoga. a Resolução RDC $n^{\circ}$ $33 / 03)$.

- Portaria CVS n 16/1999 Institui norma técnica que estabelece procedimentos para descarte de resíduos quimioterápicos.

- Portaria MINTER n 53/1979 Incineração de resíduos sólidos ou semi-sólido.

- Associação Brasileira de Normas Técnicas - ABNT.NBR 9.191 Sacos Plásticos para acondicionamento de lixo - requisitos e métodos de ensaios.

- Associação Brasileira de Normas Técnicas - ABNT.NBR 12.807 Terminologia, 1993.

- Associação Brasileira de Normas Técnicas - ABNT.NBR 12.808 Classificação dos resíduos sólidos de serviços de saúde, 1993. 
- Associação Brasileira de Normas Técnicas - ABNT.NBR 12.809 Manuseio de resíduos sólidos de serviços de saúde, 1993.

- Associação Brasileira de Normas Técnicas - ABNT.NBR 12.810 Coleta de resíduos de serviços de saúde, 1993.

- Associação Brasileira de Normas Técnicas - ABNT.NBR 13.221 Transportes de resíduos - procedimentos, 2007.

- Associação Brasileira de Normas Técnicas - ABNT.NBR 13.853 Coletores de resíduos sólidos de serviços de saúde perfurantes ou cortantes - Requisitos e ensaios, 1997.

- Associação Brasileira de Normas Técnicas - ABNT.NBR 14.652 Coletor transportador rodoviário de resíduos sólidos de serviço de saúde.

- Resíduos de serviços de saúde - Estadual

- Resolução CETESB n 07/1997 Dispõe os sobre padrão de emissão para unidades de incineração de resíduos de serviço de saúde.

- Resolução SMA n 33/2005 Procedimento para gerenciamento e licenciamento de sistemas de tratamento e disposição final de resíduos sólidos de serviços de saúde.

- Resolução Conjunta SS-SMA/SJDC - SP-1/2004 Estabelece classificação, diretrizes básicas e regulamento técnico sobre resíduos de serviços de saúde animal RSSA.

- Resolução Conjunta SS-SMA/SJDC - SP-1/1998 Aprova diretrizes básicas e regulamento Técnico* para apresentação e aprovação do Plano de Gerenciamento de Resíduos Sólidos de Serviços de Saúde.

- Portaria CVS n 13, de 04.11.05 Aprova Norma Técnica que trata das condições de funcionamento dos Laboratórios de Análises e Pesquisas Clínicas, Patologia Clínica e Congêneres, dos Postos de Coleta Descentralizados ao mesmos 
vinculados, regulamenta os procedimentos de Coleta de material humano realizados nos domicílios dos cidadãos, disciplina o transporte de material humano (Revoga. a Portaria CVS n. 1, de 18.01.00).

- Portaria CVS $\mathrm{n}^{\circ} 16$, de 19.11.99 Institui norma técnica sobre resíduos quimioterápicos nos estabelecimentos prestadores de serviço de saúde.

- Norma CETESB E15.010 Sistema de tratamento térmico sem combustão de resíduos dos grupos $\mathrm{A}$ e $\mathrm{E}$.

- Norma CETESB E15.011 Sistema pra incineração de resíduos de serviços de saúde.

- Norma CETESB P4.262/2001 Dispõe sobre o gerenciamento de resíduos químicos provenientes de estabelecimentos de serviços de saúde.

- Decisão de Diretoria CETESB n 3/04/E, de 2004 Homologa a revisão da Norma Técnica P4.262 - Gerenciamento de Resíduos Químicos Provenientes de Estabelecimentos de Serviços de Saúde - Procedimento (dezembro/2003), em atendimento à Resolução Conjunta SS-SMA-SJDC n. 1/98.

- Diversos - Federal

- Decreto Federal $n^{\circ}$ 875/1993 Controle de movimentos transfronteiriços de resíduos perigosos e seu depósito.

- Decreto Federal $n^{\circ}$ 5.940/2006 Institui a separação dos resíduos recicláveis descartados pelos órgãos e entidades da administração pública federal direta e indireta, na fonte geradora, e a sua destinação às associações e cooperativas dos catadores de materiais recicláveis.

- Conselho Nacional do Meio Ambiente - Resolução CONAMA n 23/1996 Dispõe sobre o movimento transfronteiriço de resíduos.

- Conselho Nacional do Meio Ambiente - Resolução CONAMA n 344/2004 Estabelece diretrizes gerais e procedimentos mínimos para a avaliação do 
material a ser dragado em águas jurisdicionais brasileiras, e dá outras providências.

- Portaria IBAMA n 45/1995 Constitui a Rede Brasileira de Manejo Ambiental de Resíduos - REBRAMAR, integrada à Rede Pan Americana de Manejo Ambiental de Resíduos - REPAMAR, coordenada a nível de América Latina e Caribe pelo centro Pan Americano de Engenharia Sanitária e Ciências Ambientais - CEPIS.

- Portaria IPHAN n 230/2002 Dispõe sobre procedimentos para a obtenção das licenças ambientais em urgência ou não, referentes à apreciação e acompanhamento das pesquisas arqueológicas.

- Associação Brasileira de Normas Técnicas - ABNR.BR 7.500 Símbolos de risco e manuseio para transporte e armazenamento de materiais.

- Associação Brasileira de Normas Técnicas - ABNR.BR 11.682 Estabilidade de Taludes.

- Associação Brasileira de Normas Técnicas - ABNR.BR 15.495-1 Poços de monitoramento de águas subterrâneas em aquíferos granulares- Parte 1: Projeto e construção (Substitui a NBR 13.895).

- Associação Brasileira de Normas Técnicas - ABNR.BR 15.495-2 Poços de monitoramento de águas subterrâneas em aquíferos granulares - Parte 2: Desenvolvimento.

- Diversos - Estadual

- Lei Estadual $\mathrm{n}^{\circ}$ 4.435/1984 Veda a instalação de depósito de lixo, aterros sanitários e usinas de beneficiamento de lixo - Município de Embu.

- Lei Estadual $\mathrm{n}^{\circ} 10.888 / 2001$ Dispõe sobre o descarte final de produtos potencialmente perigosos de resíduos que contenham metais pesados.

- Lei Estadual n 11.575/2003 Dispõe sobre a doação e reutilização de gêneros alimentícios e sobras de alimentos. 
- Lei Estadual no 11.387/2003 Dispõe sobre a apresentação, pelo Poder Executivo, de um Plano Diretor de Resíduos Sólidos para o Estado de São Paulo e dá providências correlatas.

- Lei Estadual $n^{\circ} 12.047 / 2007$ Institui o Programa Estadual de Tratamento e Reciclagem de Óleos e Gorduras de Origem Vegetal ou Animal de Uso Culinário.

- Lei Estadual n 12.528/2007 Obriga os Shopping Centers, com número superior a cinquenta estabelecimentos comerciais, a implantarem processo de coleta seletiva de lixo.

- Decreto Estadual $n^{\circ}$ 44.760/2000 Autoriza a Secretaria do Meio Ambiente a, representando o Estado, celebrar convênios com Municípios Paulistas, integrantes do Vale do Ribeira, visando à implementação de aterros sanitários em valas para resíduos sólidos.

- Decreto Estadual $n^{\circ}$ 45.001/2000 Autoriza o Secretário do Meio Ambiente a celebrar convênios com Municípios Paulistas, relacionados no Anexo I deste decreto, visando à implantação de aterros sanitários em valas para resíduos sólidos.

- Resolução SS n 49/1999 Define procedimentos para utilização de restos alimentares provenientes dos estabelecimentos geradores desses resíduos para a alimentação de animais.

- Resolução SMA n 34/2003 Dispõe sobre as medidas necessárias à proteção do patrimônio arqueológico de pré-histórico quando do licenciamento ambiental de empreendimentos e atividades potencialmente causadores de significativo impacto ambiental, sujeitos a apresentação de EIA/RIMA, e dá providências correlatas.

- Resolução SMA no 38/2011Estabelece a relação de produtos geradores de resíduos de significativo impacto ambiental, para fins do disposto no artigo 19, do Decreto Estadual $n^{\circ} 54.645$, de 05.08.2009, que regulamenta a Lei Estadual $n^{\circ}$ 12.300, de 16.03.2006, e dá providências correlatas. 
- Resolução SMA n 39/2004 Estabelece as diretrizes gerais à caracterização do material a ser dragado para o gerenciamento de sua disposição em solo.

- Resolução SMA n 012/2009 Dispõe sobre a apresentação de certidões municipais de uso e ocupação do solo e sobre o exame e manifestação técnica pelas Prefeituras Municipais nos processos de licenciamento ambiental realizados no âmbito do SEAQUA e dá outras providências (Revoga. a Resolução SMA n 26, de 23.08.2005).

- Norma CETESB L1.022 Avaliação do uso de produtos biotécnológicos para tratamento de efluentes líquidos, resíduos sólidos e remediação de solos e águas.

- Decisão da Diretoria CETESB n 195/05 Dispõe sobre a aprovação dos valores orientadores para solos e águas subterrâneas no Estado de São Paulo.

- CONVENÇÕES INTERNACIONAIS

- CONVENÇÃO DE ESTOCOLMO - DECRETO LeGiSLativo N. ${ }^{\circ}$ 204, DE 7 DE MAIO DE $2004\left({ }^{*}\right)$ - Aprova o texto da Convenção de Estocolmo sobre Poluentes Orgânicos Persistentes, adotada, naquela cidade, em 22 de maio de 2001;

- CONVENÇÃO DA BASILÉIA - DECRETO FEDERAL Nº 4.581, DE 27 DE JANEIRO DE 2003. - Promulga a Emenda ao Anexo I e Adoção dos Anexos VIII e IX à Convenção de Basiléia sobre o Controle do Movimento Transfronteiriço de Resíduos Perigosos e seu Depósito.

\subsection{GESTÃO E GERENCIAMENTO DE RESÍDUOS SÓLIDOS}

Os conceitos de gerenciamento e de gestão tem sido confundidos ao longo do tempo mesmo por aqueles que atuam nestas áreas.

Buscando conceituar essas atividades, Schalch et al. (2002), afirmam que a gestão de resíduos sólidos referem-se as atividades como a tomada de decisões estratégicas e a estruturação do setor, abrangendo instituições, políticas, 
instrumentos e meios. Já o termo gerenciamento de resíduos sólidos envolve os aspectos tecnológicos e operacionais, incluindo fatores gerenciais, administrativos, econômicos, ambientais e de desempenho, como produtividade e qualidade.

A Diretiva $n^{\circ}$ 2006/12/CE da União Europeia definiu Gestão de Resíduos como as atividades que compreendem recolha, transporte, armazenagem, triagem, tratamento, valorização e eliminação de resíduos, bem como às operações de descontaminação de solos, incluindo a supervisão dessas operações e o acompanhamento dos locais de eliminação após encerramento.

Também são partes da gestão a prevenção da produção dos resíduos e as políticas ambientais que regulam as atividades do setor, como ilustra a figura 01 e a figura 02 que demonstra a hierarquia de gestão dos resíduos.

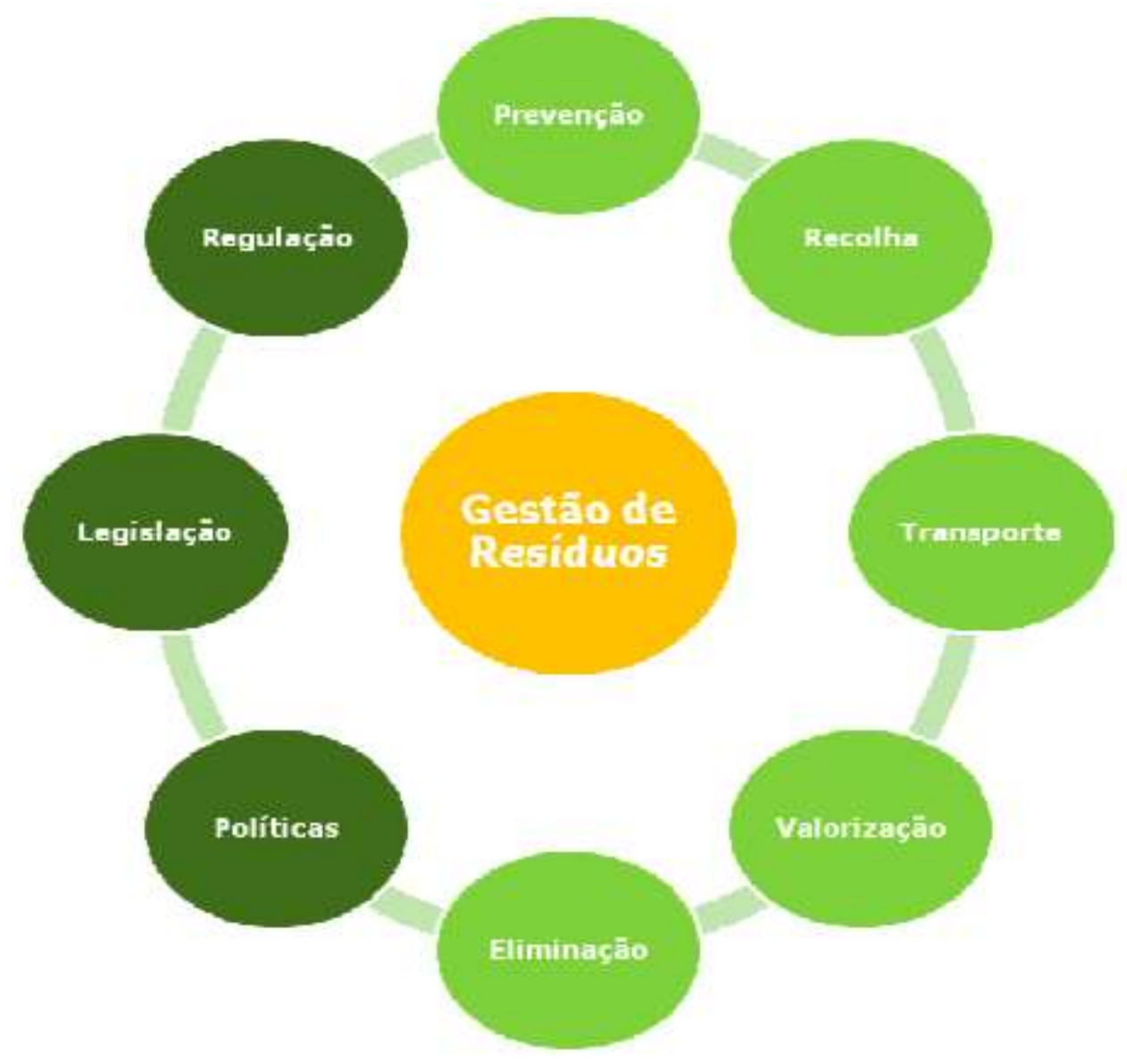

Figura 01. Dimensões da gestão de resíduos Fonte: APA (2011) 


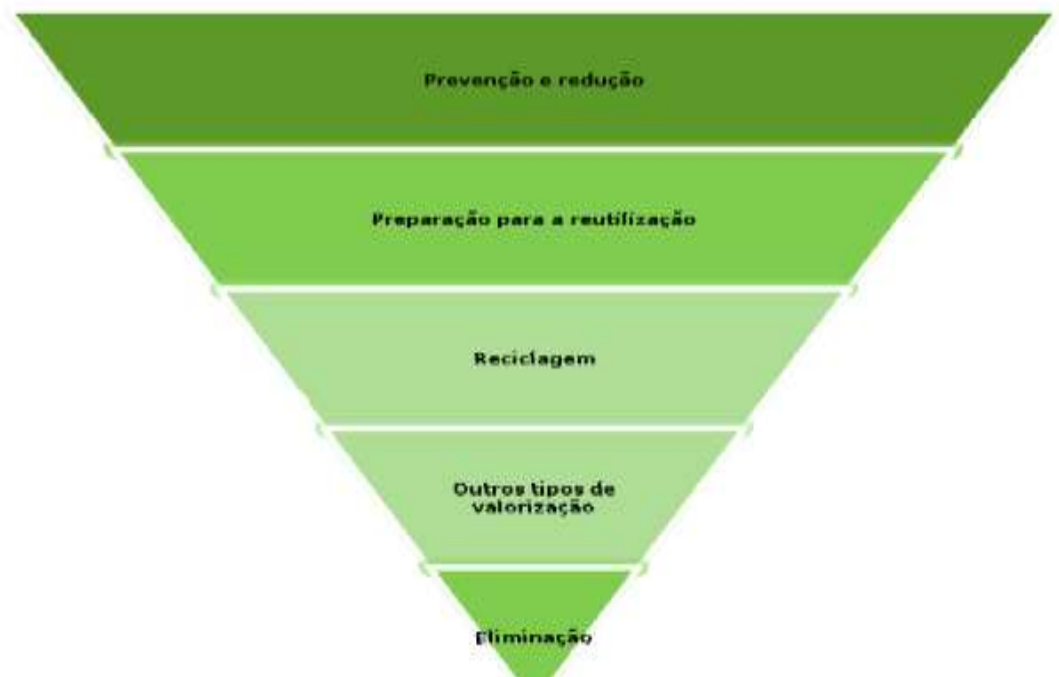

Figura 02. Hierarquia de gestão de resíduos

Fonte: APA (2011)

Para Schneider et al (2001), o gerenciamento é tido como um instrumento capaz de minimizar ou até mesmo impedir os efeitos adversos causados pelos resíduos sólidos, do ponto de vista sanitário, ambiental e ocupacional, sempre que realizado de forma racional e adequada.

No Brasil a gestão e gerenciamento dos resíduos sólidos sempre foi precária não somente pela dificuldade em discernir sobre estes conceitos, como também nas ações desenvolvidas pelo poder público.

Até a divulgação ampla dos conceitos de desenvolvimento sustentável, ocorrida nos anos 1990 principalmente com a Conferência das Nações Unidas sobre o Meio Ambiente e o Desenvolvimento Humano (Eco 92), a gestão e o gerenciamento dos resíduos sólidos no país compreendia basicamente em realizar a limpeza urbana, coleta e disposição final, que eram realizados sem a preocupação com os aspectos econômicos, financeiros, sociais, ambientais e legais, gerados com o manejo dos resíduos sólidos.

Desde então, a sociedade, empresas e poder público passaram a considerar que a questão ambiental dos resíduos sólidos teria que inserir-se em um processo de gestão e gerenciamento, com administração responsável de todas as etapas da cadeia produtiva dos resíduos sólidos, baseada numa política ambiental com regras e limites. 
A necessidade de se normatizar a gestão e gerenciamento dos resíduos sólidos fez com que se editassem políticas públicas, como a Política Estadual de Resíduos Sólidos do Estado de São Paulo e a Política Nacional de Resíduos Sólidos, entre outras pertinentes ao assunto.

O Decreto Estadual $n^{\circ}$ 54.645/2009 que regulamenta dispositivos da Lei $\mathrm{n}^{\circ} 12.300$ de 16 de março de 2006, que institui a Política Estadual de Resíduos Sólidos, apresenta gerenciamento de resíduos sólidos como: "conjunto de ações encadeadas e articuladas aplicadas aos processos de segregação, coleta, caracterização, classificação, manipulação, acondicionamento, transporte, armazenamento, recuperação, reutilização, reciclagem, tratamento e disposição final dos resíduos sólidos”. No mesmo decreto, gestão de resíduos sólidos é o “conjunto de decisões estratégicas e de ações voltadas à busca de soluções para os resíduos sólidos, envolvendo políticas, instrumentos e aspectos institucionais e financeiros".

Com base na Política Nacional de Resíduos Sólidos, os conceitos são apresentados em seu Capítulo II, art. $3^{\circ}$ como:

$X$ - gerenciamento de resíduos sólidos: conjunto de ações exercidas, direta ou indiretamente, nas etapas de coleta, transporte, transbordo, tratamento e destinação final ambientalmente adequada dos resíduos sólidos e disposição final ambientalmente adequada dos rejeitos, de acordo com plano municipal de gestão integrada de resíduos sólidos ou com plano de gerenciamento de resíduos sólidos, exigidos na forma desta Lei;

XI - gestão integrada de resíduos sólidos: conjunto de ações voltadas para a busca de soluções para os resíduos sólidos, de forma a considerar as dimensões política, econômica, ambiental, cultural e social, com controle social e sob a premissa do desenvolvimento sustentável;

Para Philipi Jr. (2012, p.231), a Política Nacional de Resíduos Sólidos ao conceituar a gestão integrada dos resíduos sólidos abarcou não somente os aspectos operacionais do processo, mas levou o conceito a dimensões mais amplas como:

- $\quad$ Dimensão política: ao reconhecer a importância política, a lei permite tratar dos acordos necessários e da superação de eventuais conflitos de interesse 
que representem barreiras à implementação de boas práticas e soluções economicamente viáveis para os resíduos sólidos.

- Dimensão econômica: ao manter a dimensão econômica no conceito de gestão integrada, a lei favorece o reforço à necessidade prática de se viabilizar as soluções para resíduos sólidos, bem como abre o caminho para a definição e a implantação dos instrumentos econômicos que favoreçam as posturas ambientalmente saudáveis por parte dos diversos atores sociais.

- Dimensão ambiental: ao manter a dimensão ambiental, a lei aponta a essência da gestão dos resíduos, que é a minimização dos impactos ambientais.

- Dimensão cultural: como novidade do conceito, essa dimensão aponta para a necessidade de levar em consideração os hábitos e os valores das populações locais, quando da definição dos métodos e procedimentos a serem implantados para o gerenciamento dos resíduos sólidos.

- Dimensão social: a PNRS aponta ainda a necessidade de controle social.

\subsection{MARCOS REGULATÓRIOS APLICADOS AOS PLANOS DE RESÍDUOS SÓLIDOS}

A sustentabilidade da área ambiental depende de como vamos lidar com os resíduos sólidos, daí a importância dos marcos legais.

A necessidade de um conjunto de leis e normas que visassem regular a gestão e a destinação adequada dos resíduos sólidos, levou o país e seus estados a adotarem um arcabouço legal com o propósito de possibilitar a implantação de instrumentos legais tais como: a Política Nacional de Saneamento Básico (Lei Federal $n^{\circ} 11.445 / 2007$ ), a Lei de Consórcios Públicos (Lei Federal $n^{\circ} 11.107 / 2005$ ), a Política Nacional de Resíduos Sólidos (Lei Federal $n^{\circ} 12.305 / 2010$ ) e a Política Estadual de Resíduos Sólidos do Estado de São Paulo (Lei Estadual n 12.300/2006). 


\subsubsection{Política Nacional de Saneamento Básico}

O Brasil conta com um marco regulatório para o saneamento básico desde 2007, quando foi promulgada a Lei 11.445, que estabeleceu as diretrizes gerais para o setor e institui o manejo dos resíduos sólidos como um dos princípios básicos na prestação de serviços e no seu artigo $3^{\circ}$, inciso I, item3, define um conjunto de serviços, infraestruturas e instalações operacionais para a limpeza pública e o manejo dos resíduos sólidos.

A lei considera que a limpeza pública e o manejo dos resíduos sólidos como serviços públicos devem ser compostos das atividades de:

- Coleta, transbordo e transporte dos resíduos;

- Triagem para fins de reuso ou reciclagem; tratamento, incluindo compostagem e disposição final dos resíduos;

- Varrição, capina e poda de árvores em vias e logradouros públicos e outros serviços de limpeza pública urbana.

Estabeleceu como diretrizes na prestação de serviço de saneamento básico, que os serviços públicos de limpeza urbana e manejo de resíduos sólidos devem ser objeto de planejamento integrado.

O titular deve elaborar sua própria legislação, mais detalhada quanto ao planejamento, formulando ações efetivas e concretas, estabelecendo a regulação e fiscalização, a prestação de serviços com regras, a exigência de contratos precedidos de estudo de viabilidade técnica e financeira, definição de regulamento por lei, definição de entidade de regulação e controle social, para o relacionamento entre titulares e prestadores de serviços, sempre por meio de contratos, incluindo a reversão de serviços e de bens a eles vinculados, quando do término de contratos de delegação.

A lei determina ainda que a sustentabilidade econômico financeira dos serviços de limpeza urbana e manejo de resíduos sólidos seja garantida, mediante a cobrança pela prestação dos serviços, por meio de taxas ou tarifas e 
outros preços públicos, em conformidade com o regime de prestação do serviço ou de suas atividades, e fixou diretrizes básicas para as condições e situações em que os serviços podem ser interrompidos, relacionando direitos e obrigações mínimas de prestadores de serviços e usuários.

Essa lei incluiu a prestação regionalizada de serviços de saneamento, ou seja, quando uma mesma entidade presta serviço a dois ou mais municípios, a qual deve ter regulação e fiscalização unificadas, possibilitando ganhos de escala na gestão dos resíduos sólidos, com equipes técnicas permanentes e capacitadas, tornando mais eficiente a aplicação dos recursos técnicos, humanos e financeiros de forma a garantir a sustentabilidade dos serviços.

Para efeito, a lei estabelece ainda:

- Regras para o relacionamento entre prestadores de atividades complementares do mesmo serviço, exigindo a formalização de contratos entre prestadores de etapas interdependentes do mesmo serviço;

- Diretrizes gerais para a regulação dos serviços, a qual deve ser exercida por entidades com autonomia decisória, administrativa, orçamentária e financeira;

- Regulação e a fiscalização dos serviços, que podem ser exercidas diretamente pelo titular, ou podem ser delegadas a entidade estadual, de outro município ou de consórcio de municípios;

Antes da vigência da LSB o setor de saneamento básico se auto regulava, fez-se necessário um marco regulatório que definisse regras mínimas para os serviços. A promulgação da lei criou um arcabouço legal que estabeleceu a organização entre os titulares do setor de saneamento básico, prestadores de serviços e usuários.

Este marco regulatório é de grande importância para o país, pois proporciona um ambiente equilibrado e juridicamente seguro para o setor de saneamento básico, que permitirá ganhos principalmente para a população, em termos de saúde pública, meio ambiente e cidadania. 


\subsubsection{Política Nacional dos Resíduos Sólidos}

A Lei Federal $n^{\circ}$ 12.305/2010, que estabelece a Política Nacional de Resíduos Sólidos - PNRS constitui-se em um grande avanço legal ao promover efetivamente ações que garantam a correta gestão dos resíduos sólidos gerados no Brasil.

Promulgada em 2 de agosto de 2010, a Política Nacional de Resíduos Sólidos veio atender as especificações da Constituição Federal, promulgada em 1988, pois tais especificações não são abordadas somente no que tange ao tema específico sobre os encaminhamentos referentes ao equilíbrio ambiental que garanta a sustentabilidade, mas também no que concerne a abordagem de uma gestão compartilhada e democrática, conforme pressupõe a carta magna de modo geral em todo o seu texto.

A PNRS "perfila-se entre as modernas leis dos países avançados nesse campo, como a União Europeia" (Juras e Araújo, 2012, p.75). Busca não só traçar uma uniformidade de ações no país, mas também pressupõe a elaboração de regulamentação em âmbito estadual e municipal, garantindo assim as características locais de cada região. Conforme define o texto legal:

Art. $4^{\circ}$ A Política Nacional de Resíduos Sólidos reúne o conjunto de princípios, objetivos, instrumentos, diretrizes, metas e ações adotados pelo Governo Federal, isoladamente ou em regime de cooperação com Estados, Distrito Federal, Municípios ou particulares, com vistas à gestão integrada e ao gerenciamento ambientalmente adequado dos resíduos sólidos. (Brasil, 2010)

Envolve na gestão dos resíduos sólidos não somente o gerenciamento público, mas também a sociedade como um todo, buscando compartilhar a responsabilidade de cooperação entre os diferentes setores, que Machado (2012, p. 45) assim explica:

Cooperar é agir conjuntamente e não separadamente e ou de forma antagônica. Trata-se de uma integração na política dos resíduos sólidos, na formulação de normas e na sua implementação, entre o poder público, as empresas e os segmentos da sociedade.

A Lei traz uma concepção contemporânea e apresenta os seguintes objetivos que devem ser cumpridos:

- Proteção da saúde pública e da qualidade ambiental; 
- Não geração, redução, reutilização, reciclagem e tratamento dos resíduos sólidos, bem como disposição final ambientalmente adequada dos rejeitos;

- Estímulo à adoção de padrões sustentáveis de produção e consumo de bens e serviços;

- Adoção, desenvolvimento e aprimoramento de tecnologias limpas como forma de minimizar impactos ambientais;

- Redução do volume e da periculosidade dos resíduos perigosos;

- Incentivo à indústria da reciclagem, tendo em vista fomentar o uso de matériasprimas e insumos derivados de materiais recicláveis e reciclados;

- Gestão integrada de resíduos sólidos;

- Articulação entre as diferentes esferas do poder público, e destas com o setor empresarial, com vistas na cooperação técnica e financeira para a gestão integrada de resíduos sólidos;

- Capacitação técnica continuada na área de resíduos sólidos;

- Regularidade, continuidade, funcionalidade e universalização da prestação dos serviços públicos de limpeza urbana e manejo de resíduos sólidos, com adoção de mecanismos gerenciais e econômicos que assegurem a recuperação dos custos dos serviços prestados, como forma de garantir sua sustentabilidade operacional e financeira, observada a Lei $n^{\circ} 11.445$, de 5 de janeiro de 2007;

- Prioridade, nas aquisições e contratações governamentais, para:

- Produtos reciclados e recicláveis;

- Bens, serviços e obras que considerem critérios compatíveis com padrões de consumo social e ambientalmente sustentáveis;

- Integração dos catadores de materiais reutilizáveis e recicláveis nas ações que envolvam a responsabilidade compartilhada pelo ciclo de vida dos produtos;

- Estímulo à implementação da avaliação do ciclo de vida do produto; 
- Incentivo ao desenvolvimento de sistemas de gestão ambiental e empresarial voltados à melhoria dos processos produtivos e ao reaproveitamento dos resíduos sólidos, incluída a recuperação e o aproveitamento energético;

- Estímulo à rotulagem ambiental e ao consumo sustentável.

A preocupação com a gestão dos resíduos sólidos vem evoluindo, apesar de ter sido ignorada por muito tempo, provavelmente devido ao fato de que os efeitos poluidores destes resíduos demorem a aparecer. Já os prejuízos causados pela falta de uma gestão ambientalmente adequada são imediatos, como a geração de problemas sociais, a presença de trabalho infantil em lixões, de saúde pública e problemas ambientais e econômicos.

A nova lei também assimila a diretriz da Agenda 21, apontando o papel da sociedade, poder público, produtores e consumidores na alteração dos padrões de produção e consumo de produtos, pois todos são geradores de resíduos e devem ser responsáveis por estes.

A PNRS integra a Política Nacional do Meio Ambiente (PNMA) e tem articulação com a Política Nacional de Educação Ambiental (PNEA), com a Política Federal de Saneamento Básico e com a Lei dos Consórcios.

A Política articula-se com a Lei 9.974/2000 que determina que as empresas produtoras e comercializadoras de agrotóxicos serão responsáveis pela destinação de embalagens vazias por elas fabricadas, e ainda com a Lei 9.966/2000, que dispõe sobre a prevenção, o controle e a fiscalização da poluição, causada por óleo e outras substâncias nocivas ou perigosas em águas sob jurisdição nacional.

A Política Nacional de Resíduos Sólidos no seu art. $6^{\circ}$ lista uma série de princípios e nenhum é menos importante que outro, no entanto é interessante atentar ao princípio do poluidor-pagador, que impõe aos agentes econômicos responsabilizarem-se pelos custos ambientais associados as suas atividades, ou seja, a obrigação de recuperar ou indenizar os danos causados. 
Para Machado (2012, p.43) este princípio levou a instituição de um outro princípio da PNRS, o princípio da responsabilidade compartilhada. Para o mesmo autor:

Este mesmo princípio tem ligação direta com os dois primeiros objetivos da Lei de Política Nacional de Resíduos Sólidos: proteção da saúde pública e da qualidade ambiental e a não geração, a redução, a reutilização, a reciclagem e o tratamento dos resíduos sólidos, bem como a disposição final ambientalmente adequada dos rejeitos. Esses são os comportamentos legalmente corretos na gestão dos resíduos sólidos e, portanto, a violação dessas obrigações gerais acarreta a incidência de encargos financeiros aos poluidores.

0 princípio do poluidor-pagador tem como base o fato de o meio ambiente ser um bem comum do povo, e que os custos sociais em que se enquadram os danos ambientais devem ser considerados nos custos de produção dos resíduos, pois quando os agentes econômicos não consideram os custos sociais, ou apenas não o pagam, estes custos são externalizados para a sociedade.

Já o princípio do protetor-recebedor tem lógica inversa do princípio poluidor-pagador, criando uma relação de proteger-receber beneficiando financeiramente pessoas que em proveito da comunidade exerçam serviço de proteção ambiental. O princípio pode ser observado no chamado “ICMS Ecológico" em que se recebe uma compensação econômica em retribuição a proteção proporcionada.

Também consta entre os princípios contidos no artigo $6^{\circ}$, a visão sistêmica na gestão de resíduos sólidos, ligado ao princípio do desenvolvimento sustentável, definindo que a proteção do meio ambiente e o desenvolvimento socioeconômico devem ser ponderados. Segundo Machado (2012, p.46), “deve considerar as variantes ambiental, social, cultural, econômica, tecnológica e de saúde pública na gestão dos resíduos sólidos."

A PNRS inova ao falar do princípio da ecoeficiência, demandando o uso mais eficiente de materiais e energia, visando reduzir impactos ambientais e custos econômicos. 
Sendo considerado o problema ambiental de toda a sociedade, um dos princípios expressos é a cooperação entre poder público, setor empresarial e a sociedade. Este princípio é compatível ao da responsabilidade compartilhada pelo ciclo de vida dos produtos, e reconhece o resíduo sólido reutilizável e reciclável como um bem econômico de valor social, gerador de trabalho, renda e promotor da cidadania.

Tem-se também como princípio, o reconhecimento do resíduo sólido reutilizável e reciclável como um bem econômico de valor social, gerador de trabalho, renda e promotor da cidadania, como é o caso dos catadores.

Ainda está listado o princípio da proporcionalidade e da razoabilidade. A razoabilidade impede que atos administrativos sejam inaceitáveis quando ponderados os valores que estruturam o Estado. A proporcionalidade diz respeito ao fim de uma disposição de cunho normativo e o meio que será empregado, devendo ambos serem proporcionais.

A PNRS apresenta entre outros objetivos, a proteção da saúde pública e da qualidade ambiental, a não geração, redução, reutilização, reciclagem e tratamento dos resíduos sólidos, agregada à disposição final ambientalmente adequada dos rejeitos. A não geração e a redução de resíduos sólidos estão ligados com o objetivo de estimular a adoção de padrões sustentáveis de produção e consumo de bens e serviços, com o desenvolvimento de tecnologias limpas como forma de minimizar impactos ambientais. Na mesma linha, vem a redução do volume e da periculosidade dos resíduos.

Como é possível observar até a presente data não se consolidou o que pressupõe a referida Lei e as discussões ainda ocorrem em função dos diversos aspectos da sua abrangência. Dentre eles podemos citar também a logística reversa que consiste no recolhimento das embalagens de determinados produtos pelas próprias empresas que a produziram, ou o aporte financeiro no seu recolhimento.

Nesse contexto e constituindo outro fator de discussão, estão inseridos os catadores de materiais recicláveis que vem se apresentado no país de forma marginalizada pelo poder público brasileiro, uma vez que seu trabalho não era reconhecido. 
Diferente do que ocorre nos Estados Unidos e União Europeia, no Brasil os catadores de materiais recicláveis se constituíram na sua maioria em associações e ou cooperativas e finalmente obtiveram seu reconhecimento formal somente a partir da PNRS.

O Movimento Nacional de Materiais Recicláveis (MNCR), fundado no ano de 2001 buscou regulamentar a situação dos catadores de materiais recicláveis e "Durante muitos anos provocou a sociedade e o poder público para a necessidade de um marco regulatório para a produção e a destinação final de resíduos sólidos no país, antes mesmo de se ouvir falar em aquecimento global e mudanças climáticas”. (MNCR, 2012, p.416)

É importante acrescentar uma visão geral do catador de materiais recicláveis no Brasil:

0 MNCR estima que existam cerca de 800 mil catadores em atividade no Brasil, a maior parte trabalhando nas ruas e nos lixões. Os catadores são responsáveis pela coleta de $90 \%$ de tudo que é reciclado hoje, mas têm renda média nacional mensal que varia entre R\$ 136,00 a R\$ 318,00 por catador, segundo dados do Departamento de Economia da Universidade Federal da Bahia (Geri/UFBA) e do MNCR. Um catador chega a coletar de 2 a 3 toneladas de materiais recicláveis por mês, segundo dados do MNCR.

Parte dos catadores está em situação de pobreza extrema, muitos em situação de rua. Só na cidade de São Paulo, dos 16 mil moradores de rua, estima-se que $30 \%$ sobrevivem exclusivamente da coleta de materiais recicláveis. A fragilidade econômica abre caminho para a exploração de pequenos e médios empresários que se utilizam da mão de obra barata e sem vínculos empregatícios dos catadores para a compra dos recicláveis por preços irrisórios. Há casos sérios de violação de direitos humanos em que esses trabalhadores são submetidos a horas de trabalho a fio sem qualquer salubridade, há casos de servidão por dívida ao comprador, vínculos por meio de pequenos vícios, trabalho infantil e análogo à escravidão.

A cadeia produtiva dos recicláveis brasileira é muito admirada, mas esconde um ciclo de injustiça e exploração que beneficia centenas de empresas que se auto intitulam socialmente responsáveis. Verdadeiros cartéis de compradores submetem catadores à condição de mão de obra barata. Ameaças e assassinatos são constantes e numerosos em todo o Brasil.

Hoje, esse é o retrato da cadeia produtiva no Brasil, da qual os catadores são agentes principais, mas também os que menos se beneficiam dela. (MNCR, 2012, p. 422 e 423). 
Atualmente, os municípios brasileiros gastam milhões para enterrar o lixo produzido, a PNRS propõe uma gestão de responsabilidades compartilhada pelo lixo produzido, assim tornam-se responsáveis pelos custos os geradores dos resíduos: indústria, comércio e consumidor final, e poderá desta forma reconhecer o trabalho do catador, seja em associações ou cooperativas ou como contratação de seus serviços pelas prefeituras municipais, como já ocorre em alguns poucos municípios.

Porém, a Lei não foi tão coerente quanto deveria, durante sua tramitação houve uma manobra e um parágrafo foi retirado, o que acabou favorecendo a implantação de incineradores. No texto inicial propunha-se a adoção de incineradores como última forma de destinação final do lixo.

O papel das cooperativas e outras entidades associativas de catadores na minimização do volume de resíduos sólidos gerados e na redução dos impactos ambientais a eles associados é reconhecido na Lei ao prever benefícios aos municípios que inserirem catadores ao seu sistema de coleta seletiva, além de prever que o setor empresarial deverá atuar em parceria com catadores na implantação da logística reversa.

O sistema declaratório anual de resíduos sólidos, apresentado como instrumento da PNRS, reúne informações sobre a execução dos planos de gerenciamento de resíduos sólidos, atribuídos tanto aos empreendedores públicos quanto aos privados que tenham atividade que gere determinados tipos de resíduos. Estes resíduos estão especificados no art. 20 da Lei 12.305/2010.

Já o monitoramento e a fiscalização não se limitarão apenas aos órgãos integrantes do Sistema Nacional do Meio Ambiente (SISNAMA), mas também aos entes públicos, bem como às áreas de vigilância sanitária e de controle agropecuário, consolidando uma visão inter e multidisciplinar para a Política Nacional de Resíduos Sólidos.

A cooperação técnica e financeira entre os setores públicos e privados na área de pesquisa e na educação ambiental é uma das formas de integrar a sociedade, e é caracterizado como instrumento da Política Nacional de Resíduos Sólidos. 
A Lei 12.305/2010 criou ainda o Sistema Nacional de Informações sobre Gestão dos Resíduos Sólidos (SINIR) para colaborar e articular junto com o Sistema Nacional de Informações em Saneamento Básico (SINISA) e com o Sistema Nacional de Informações sobre o Meio Ambiente (SINIMA), confirmando o caráter inter e multidisciplinar conferido a Política Nacional de Resíduos Sólidos.

Um dispositivo que a lei abarca é a permissão para implantação de tecnologias de recuperação energética de resíduos sólidos urbanos, como por exemplo a produção de biogás em aterros sanitários, desde que tenham sua viabilidade técnica e ambiental comprovadas e possuam um programa de monitoramento de emissão de gases tóxicos. O aproveitamento energético é considerado uma das alternativas corretas para a destinação dos resíduos, porém o seu controle, em especial na incineração, deve ser rigoroso, devido a geração de substancias tóxicas.

No seu art. 10 está explícita a regra geral que incumbe ao poder público local a gestão integrada dos resíduos sólidos gerados em seu território, dando competência de fiscalizar e controlar aos órgãos estaduais e federais do SISNAMA.

Ficou estabelecido também que os diferentes níveis de governo respondem em conjunto pela organização do Sistema Nacional de Informações Sobre a Gestão de Resíduos Sólidos e deverão trabalhar em conjunto com o SINISA e o SINIMA, visando uma maior obtenção de dados consistentes para o planejamento de gestão.

Outro aspecto abordado pela PNRS é a Educação Ambiental voltada para a diminuição da produção de resíduos e a promoção da sua reutilização e reciclagem. Abordagem esta que deve constar nos Planos de Gestão Integrada de Resíduos Sólidos (PGIRS) a serem elaborados pelos municípios e que receberão incentivos para sua constituição com o recebimento de recursos financeiros de entidades federais.

Com o lançamento da PNRS uma silenciosa revolução está se desenvolvendo no Brasil com o envolvimento dos governos e sociedade, 
estimulando uma nova consciência ambiental na gestão dos resíduos sólidos, para tanto estruturou-se um amplo número de instrumentos, que dentre os principais destacam-se os planos de resíduos, obrigando todos os Estados, Distrito Federal, Municípios e alguns geradores de resíduos a elaborarem um plano de gestão de seus resíduos (fig. 3).

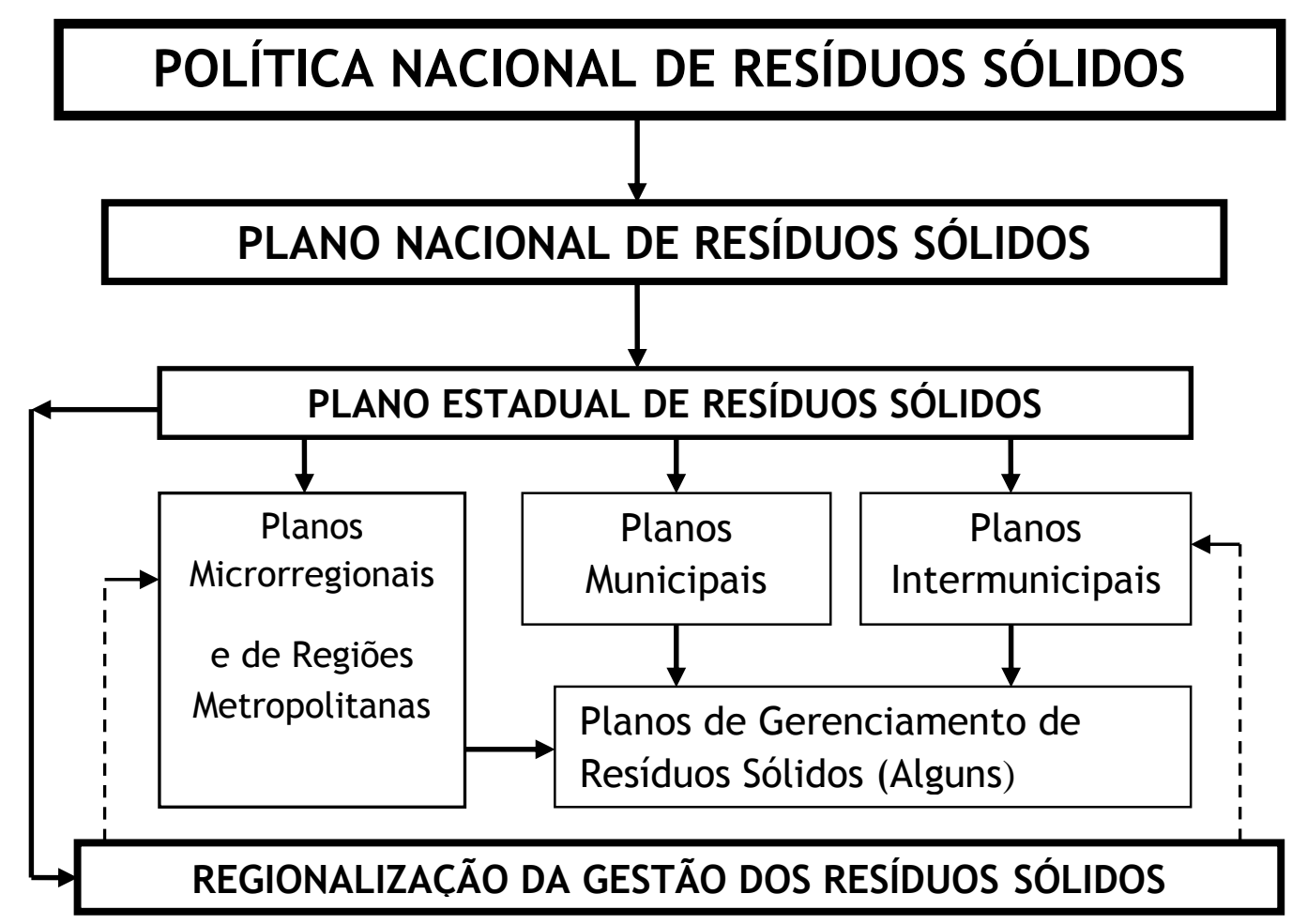

Figura 3: Formulação da gestão dos resíduos sólidos pela PNRS

Quatro importantes instrumentos estão previstos na PNRS e tem se apresentado como grandes desafios, mas que solucionarão em um curto espaço de tempo os problemas da destinação final dos resíduos sólidos de forma adequada:

- Todos os lixões deverão ser fechados até 2014, devendo ser criados aterros;

- A partir de 2014 será proibido dispor em aterros sanitários resíduos que sejam passíveis de reutilização ou reciclagem;

- Todos os entes federados deverão elaborar seus planos de gestão de resíduos sólidos;

- A responsabilidade compartilhada de todos os envolvidos na cadeia do ciclo de vida do produto. 
Também formulou a seguinte hierarquia na gestão dos resíduos sólidos: não geração, redução, reutilização, reciclagem, tratamento dos resíduos sólidos e disposição final ambientalmente adequada dos rejeitos, instituindo uma ordem de precedência que deixa de ser voluntária e passa a ser obrigatória e definiu metas para redução da geração de resíduos.

Os desafios propostos pela destinação correta dos resíduos produzidos pela população não se encerram com a promulgação da Lei, apenas se iniciam, tendo em vista que nosso país tem como característica grandes dificuldades na instituição de Leis e regulamentações seja qual for sua abrangência. Serão necessários esforços de toda a sociedade, incluindo a importância da elaboração dos Planos: Nacional, Estadual e Municipal de Resíduos Sólidos.

Ressalta-se a importância da PNRS na condução de soluções na gestão dos resíduos propondo em seu texto "o incentivo à adoção de consórcios ou de outras formas de cooperação, objetivando a elevação de escalas de aproveitamento e redução dos custos envolvidos (art. 8 $8^{\circ}$, XIX)" (YOSHIDA, 2012, p.14). Tal aspecto se observa na condução de soluções em municípios de pequeno porte que terão como forma de solução na destinação correta dos resíduos a implantação de consórcios distribuídos pelas diversas regiões dos estados que compõem o país.

Quanto aos planos de resíduos sólidos, o art.14 traz uma lista completa dos planos de resíduos sólidos demandados na Lei 12.305/2010, caracterizando apenas os planos municipais como planos de gestão integrada e assegurando a publicidade ao conteúdo de todos os planos de resíduos sólidos, até mesmo nos formulados por empreendedores privados.

Com diversas configurações são apresentados planos que busquem contemplar a obrigatoriedade não somente do poder público, mas também dos setores da iniciativa privada que fazem parte da cadeia dos resíduos sólidos. São planos de resíduos sólidos:

$$
\begin{aligned}
& \text { I - o Plano Nacional de Resíduos Sólidos; } \\
& \text { II - os planos estaduais de resíduos sólidos; }
\end{aligned}
$$


III - os planos microrregionais de resíduos sólidos e os planos de resíduos sólidos de regiões metropolitanas ou aglomerações urbanas;

IV - os planos intermunicipais de resíduos sólidos;

$\checkmark$ - os planos municipais de gestão integrada de resíduos sólidos;

$\mathrm{VI}$ - os planos de gerenciamento de resíduos sólidos (BRASIL, 2010).

\subsubsection{Do Plano Nacional de Resíduos Sólidos}

O Brasil enfrenta atualmente 0 grande desafio de destinar corretamente o lixo (resíduos) produzido pela sua população, buscando assim tornar-se um país que atende uma gestão sustentável. 0 aumento da produção de resíduos, dentre os diversos fatores que contribuem para sua expansão, deve-se ao aumento populacional, ao processo de urbanização ocorrido nas últimas décadas, aos avanços tecnológicos e ao desenvolvimento socioeconômico brasileiro.

Buscando garantir a destinação correta dos resíduos e a implementação de ações nos âmbitos municipal, estadual e nacional, os municípios, estados e governo federal deveriam no prazo de dois anos elaborarem planos de "metas de redução, reutilização e reciclagem, com o objetivo de reduzir a quantidade de resíduos sólidos e rejeitos encaminhados para disposição no solo" (BESEN, 2012, p. 398).

Foi atribuído ao Ministério do Meio Ambiente a elaboração do Plano Nacional de Resíduos Sólidos, devendo relacionar-se com os Planos nacionais de Mudanças do Clima (PNMC), de Recursos Hídricos (PNRH), de Saneamento Básico (PLANSAB) e de Produção e Consumo (Ministério do Meio Ambiente, 2012).

O plano deve definir metas, diretrizes, mecanismos, conceitos e propostas para diversos setores da economia, com estabelecimento de metas para a redução, reutilização e reciclagem de resíduos e o aproveitamento energético dos gases gerados nas unidades de disposição final de resíduos sólidos. 
O Plano Nacional de Resíduos Sólidos teve início com a regulamentação da PNRS, através do Decreto 7.404/2010 que encarregou a um Comitê Interministerial, sob a coordenação do Ministério do Meio Ambiente, a responsabilidade de elaborar e implementar o plano, com o propósito de estabelecer metas, ações e programas para os próximos 20 anos, devendo ser atualizado a cada 4 anos, tendo como conteúdo mínimo:

- Diagnóstico da situação atual dos resíduos sólidos;

- Proposição de cenários, incluindo tendências internacionais e macroeconômicas;

- Metas de redução, reutilização, reciclagem, entre outras, com vistas a reduzir a quantidade de resíduos e rejeitos encaminhados para disposição final ambientalmente adequada;

- Metas para o aproveitamento energético dos gases gerados nas unidades de disposição final de resíduos sólidos;

- Metas para a eliminação e recuperação de lixões, associadas à inclusão social e à emancipação econômica de catadores de materiais reutilizáveis e recicláveis;

- Programas, projetos e ações para o atendimento das metas previstas;

- Normas e condicionantes técnicas para o acesso a recursos da União, para a obtenção de seu aval ou para o acesso a recursos administrados, direta ou indiretamente, por entidade federal, quando destinados a ações e programas de interesse dos resíduos sólidos;

- Medidas para incentivar e viabilizar a gestão regionalizada dos resíduos sólidos;

- Diretrizes para o planejamento e demais atividades de gestão de resíduos sólidos das regiões integradas de desenvolvimento instituídas por lei complementar, bem como para as áreas de especial interesse turístico;

- Normas e diretrizes para a disposição final de rejeitos e, quando couber, de resíduos;

- Meios a serem utilizados para o controle e a fiscalização, no âmbito nacional, de sua implementação e operacionalização, assegurado o controle social. 
Parágrafo único. O Plano Nacional de Resíduos Sólidos será elaborado mediante processo de mobilização e participação social, incluindo a realização de audiências e consultas públicas.

O Plano Nacional de Resíduos Sólidos está sendo construído em processo participativo, com a realização de audiências e consultas públicas, recebendo contribuições dos diversos setores da cadeia envolvida na questão dos resíduos sólidos.

A versão preliminar do plano foi apresentada em audiências públicas oficiais nas cinco regiões do país, em uma audiência oficial nacional e duas audiências não oficiais. Nestas audiências foram apresentadas 1000 propostas, com a presença de 2800 participantes, sendo 1250 representantes da sociedade, 800 do empresariado e 750 do governo, e na consulta pública feita através da internet foram postadas 450 propostas (MMA, 2012).

A audiência nacional ocorrida em Brasília definiu o texto final do plano que deveria ter entrado em vigor ainda no ano de 2012, instituindo diretrizes e metas para a eliminação de lixões, a inclusão social dos catadores de materiais reutilizáveis e recicláveis, bem como nortear os demais planos de manejo e gestão dos resíduos sólidos.

O plano contém a seguinte estrutura:

- Capítulo 1 - Diagnóstico da Situação dos Resíduos Sólidos no Brasil;

- Capítulo 2 - Cenários;

- $\quad$ Capítulo 3 - Educação Ambiental;

- $\quad$ Capitulo 4 - Diretrizes e Estratégias;

- $\quad$ Capítulo 5 - Metas;

- $\quad$ Capítulo 6 - Programas e Ações de Resíduos Sólidos;

- Capítulo 7 - Participação e Controle Social na Implementação e Acompanhamento do Plano.

Durante a fase inicial do plano foram apresentadas metas quantitativas de curto, médio e longo prazos para resíduos sólidos, definidas em períodos de 4 em 4 anos vinculados aos prazos do Plano Plurianual do Governo 
Brasileiro, compatibilizando a exigência legal, a capacidade de investimento e gerenciamento.

As metas foram definidas para um horizonte temporal até o ano de 2031, em três cenários definidos como Planos de Metas Desfavorável, Intermediário e Favorável, e somente para o cumprimento do Plano de Metas Favorável estão previstos a disponibilização de recursos financeiros dos governos federal, estaduais, municipais e da iniciativa privada no montante aproximado de $\$ 4,3$ milhões de dólares.

Os Estados da Federação também estão obrigados a elaborarem seus planos de resíduos sólidos para que possam ter acesso a recursos federais destinados a empreendimentos e serviços relacionados aos resíduos sólidos. Dos vinte e seis Estados do Brasil mais o Distrito Federal, somente 7 Estados concluíram seus planos, sendo que Pernambuco finalizou seu plano em 2011, Rio Grande do Norte, Maranhão, Santa Catarina, Acre e Amazonas em 2012 e Roraima em 2013.

\subsubsection{Dos Planos Estaduais de Resíduos Sólidos}

A Lei 12.305/2010 determina que os estados devem elaborar um plano estadual de resíduos sólidos na forma por ela prescrita para que possam começar a receber recursos da União, ou controlados pelo governo federal direcionados a gestão de resíduos sólidos.

Quanto ao conteúdo mínimo é muito similar ao plano nacional, devendo conter diagnóstico, proposição de cenários e metas para a redução, reutilização e reciclagem de resíduos e o aproveitamento energético dos gases gerados nas unidades de disposição final de resíduos sólidos, bem como para a eliminação e recuperação de lixões, consideradas a inclusão social e a emancipação econômica dos catadores de materiais reutilizáveis e recicláveis. Também consta no conteúdo mínimo, normas e condicionantes para o acesso a recursos do estado ou administrados por entidade estadual. 
A lei prioriza os estados que instituírem microrregiões para integrar a organização, o planejamento e a execução das ações a cargo de municípios limítrofes na gestão dos resíduos sólidos.

A CF/88 define três tipos de unidades regionais, as regiões metropolitanas, aglomerações urbanas e microrregiões. Os estados possuem liberdade para decidir as funções públicas e os municípios a serem incluídos nas unidades regionais a serem criadas, porém a prioridade dada para estados que optarem pela instituição de microrregiões direcionadas à coordenação na gestão dos resíduos sólidos faz parecer que a liberdade decisória dos estados é retirada.

É permitido aos estados a elaboração de planos microrregionais de resíduos sólidos, assim como planos específicos para regiões metropolitanas ou aglomerações urbanas, devendo conter a participação dos municípios no processo de elaboração do plano, sem afetar prerrogativas dos governos municipais.

Segundo Crespo e Costa (2012, p. 289), alguns estados estão buscando a regionalização para a gestão dos resíduos sólidos, que são:

- Região Nordeste: Bahia, Sergipe, Alagoas, Pernambuco, Rio Grande do Norte, Paraíba, Ceará, Piauí e Maranhão.

- Região Norte: Pará, Acre e Rondônia.

- Região Centro-oeste: Distrito Federal, Goiás e Mato Grosso.

- Região Sudeste: Minas Gerais, Rio de Janeiro e Espírito Santo.

- Região Sul: Paraná e Santa Catarina.

\subsubsection{A Regionalização da Gestão dos Resíduos Sólidos}

O plano dispõe que todos os Estados Brasileiros deveriam concluir os estudos de regionalização da gestão dos resíduos sólidos em 2012 e a lei prevê ainda que o poder público fomente parecerias com os Estados com o oferecimento de linhas de financiamento para a realização de estudos de regionalização.

0 quadro 1 apresenta algumas linhas de financiamento público para a gestão e gerenciamento de resíduos sólidos no país. 


\begin{tabular}{|c|c|c|c|c|}
\hline Origem do Recurso & Desembolso & Projetos & Ações Financiadas & Destino \\
\hline $\begin{array}{l}\text { Ministério das } \\
\text { Cidades/Caixa Econômica } \\
\text { Federal }\end{array}$ & Reembolsável & $\begin{array}{l}\text { Saneamento para } \\
\text { Todos }\end{array}$ & $\begin{array}{l}\text { Acondicionamento, } \\
\text { coleta e transporte, } \\
\text { transbordo, triagem, } \\
\text { reciclagem } \\
\text { destinação final dos } \\
\text { resíduos oriundos das } \\
\text { atividades d de } \\
\text { construção civil. }\end{array}$ & $\begin{array}{l}\text { Municípios com } \\
\text { população acima de } \\
150 \text { mil habitantes ou } \\
\text { integrantes de regiões } \\
\text { metropolitanas e } \\
\text { próximas a grandes } \\
\text { cidades. }\end{array}$ \\
\hline $\begin{array}{l}\text { Banco Nacional de } \\
\text { Desenvolvimento } \\
\text { Econômico e Social } \\
\text { (BNDES) }\end{array}$ & Reembolsável & $\begin{array}{l}\text { Projetos } \\
\text { Multissetoriais } \\
\text { Integrados Urbanos }\end{array}$ & $\begin{array}{l}\text { Saneamento } \\
\text { ambiental } \\
\text { (abastecimento de } \\
\text { água, esgotamento } \\
\text { sanitário, resíduos } \\
\text { sólidos e drenagem } \\
\text { urbana). }\end{array}$ & $\begin{array}{l}\text { Estados, Municípios e } \\
\text { o Distrito Federal }\end{array}$ \\
\hline $\begin{array}{l}\text { Banco Nacional de } \\
\text { Desenvolvimento } \\
\text { Econômico e Social } \\
\text { (BNDES) }\end{array}$ & Não Reembolsável & $\begin{array}{l}\text { Projetos de caráter } \\
\text { social: geração de } \\
\text { emprego e renda, } \\
\text { serviços urbanos, } \\
\text { saúde, educação e } \\
\text { desportos, justiça, } \\
\text { meio ambiente, } \\
\text { desenvolvimento } \\
\text { rural. }\end{array}$ & $\begin{array}{l}\text { Investimentos fixos, } \\
\text { inclusive aquisição de } \\
\text { máquinas e } \\
\text { equipamentos } \\
\text { importados, sem } \\
\text { similar nacional, no } \\
\text { mercado interno e de } \\
\text { máquinas e } \\
\text { equipamentos usados; } \\
\text { capacitação; capital } \\
\text { de giro; despesas pré- } \\
\text { operacionais }\end{array}$ & $\begin{array}{l}\text { Pessoas jurídicas de } \\
\text { direito público interno } \\
\text { e pessoas jurídicas de } \\
\text { direito privado, com } \\
\text { ou sem fins lucrativos. }\end{array}$ \\
\hline $\begin{array}{l}\text { Ministério do Meio } \\
\text { Ambiente através } \\
\text { do Fundo Nacional } \\
\text { de Meio Ambiente - } \\
\text { Criado pela Lei No } \\
7.797 \text { de } 10 \text { de } \\
\text { julho de } 1989\end{array}$ & Não Reembolsável & $\begin{array}{l}\text { Elaborados a partir } \\
\text { dos inventários e } \\
\text { cadastros de resíduos } \\
\text { sólidos Industriais }\end{array}$ & $\begin{array}{l}\text { Resíduos sólidos } \\
\text { industriais. }\end{array}$ & $\begin{array}{l}\text { Instituições públicas } \\
\text { pertencentes à } \\
\text { administração } \\
\text { direta e indireta em } \\
\text { âmbito } \\
\text { federal, estadual e } \\
\text { municipal. }\end{array}$ \\
\hline $\begin{array}{l}\text { Ministério da } \\
\text { Saúde/Fundação } \\
\text { Nacional da Saúde } \\
\text { - FUNASA }\end{array}$ & Não Reembolsável & $\begin{array}{l}\text { Programa de } \\
\text { saneamento } \\
\text { ambiental }\end{array}$ & $\begin{array}{l}\text { Implantação } \\
\text { ampliação } \\
\text { de aterros sanitários, } \\
\text { aquisição de } \\
\text { equipamento, veículo } \\
\text { automotor, unidade } \\
\text { de } \\
\text { triagem e/ou } \\
\text { compostagem e coleta } \\
\text { seletiva }\end{array}$ & $\begin{array}{l}\text { Municípios até } 50 \text { mil } \\
\text { habitantes (conforme } \\
\text { eixo de ação 2007- } \\
2010 \text { no componente } \\
\text { de infraestrutura } \\
\text { social e urbana do } \\
\text { Programa de } \\
\text { Aceleração do } \\
\text { Crescimento - PAC). }\end{array}$ \\
\hline $\begin{array}{l}\text { Ministério das } \\
\text { Cidades/Secretaria } \\
\text { Nacional de } \\
\text { Saneamento } \\
\text { Ambiental }\end{array}$ & Não Reembolsável & $\begin{array}{l}\text { Projetos de Gestão } \\
\text { de resíduos sólidos } \\
\text { urbanos. }\end{array}$ & 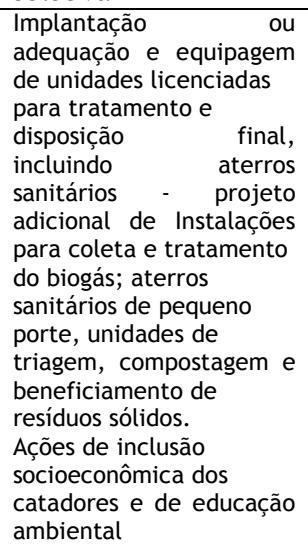 & 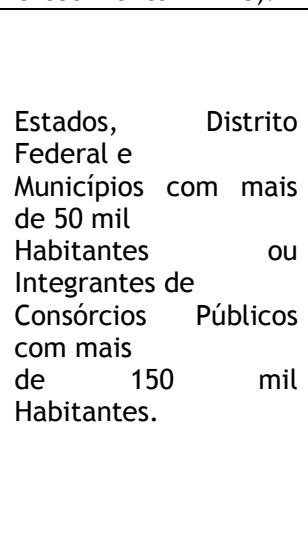 \\
\hline
\end{tabular}

\section{Quadro 1: Linhas de financiamento para gerenciamento de resíduos sólidos}


Atualmente 13 Estados realizaram a regionalização (fig. 2), sendo que 11 foram através de convênios com o Ministério do Meio Ambiente (Acre, Mato Grosso, Minas Gerais, Rio de Janeiro, Bahia, Sergipe, Alagoas, Pernambuco, Rio Grande do Norte, Ceará e Piauí) e dois sem convênios (Rio Grande do Sul e Espírito Santo).

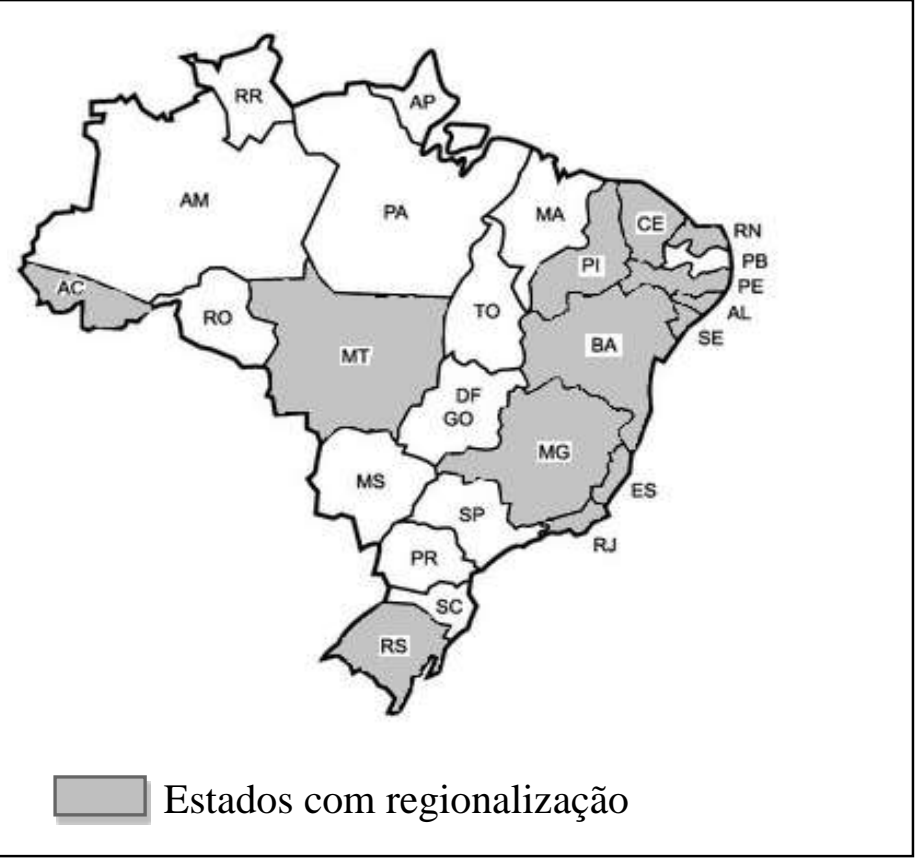

Figura 4: Estados que já desenvolveram regionalizações em seus territórios Fonte: Autor

A metodologia adotada para a sistematização da regionalização nos Estados varia de acordo com os critérios técnicos adotados e especificidades de cada Estado, e para análise selecionamos três exemplos situados em regiões distintas do Brasil.

\subsubsection{O Estado de Pernambuco}

Situado em uma das regiões menos desenvolvidas do país, Região Nordeste, possui uma população de 8.864.906 habitantes, com PIB correspondente a 2,5\% do PIB nacional (IBGE, 2011) e IDH = 0,718, ocupando a $23^{\circ}$ posição no Brasil (ONU, 2010).

Para formação da regionalização foram adotados os seguintes critérios:

- Demográficos (população urbana - sede e distritos); 
- Logísticos (malha viária existente, distância entre sedes urbanas e centralidade do município selecionado em relação aos demais);

- Econômicos (renda per capita do município);

- Ambientais (existência ou não de restrições de áreas para tratamento e destinação final);

- Infraestrutura física e operacional (existência ou não de aterros sanitários nos municípios e a experiência do município na operação);

- Sociais (presença ou não de catadores, organizados ou não).

Foram consideradas as seguintes diretrizes para o planejamento regional: cidade polo, distância máxima de $35 \mathrm{~km}$ entre as cidades, um aterro regional por grupo de municípios, maior número de municípios por sede operacional, evitar a transferência de resíduos entre bacias hidrográficas, manutenção das configurações de regionalização existentes, experiência comum na operação dos serviços de limpeza pública e a possibilidade de exploração do potencial energético do biogás gerado pelos resíduos sólidos.

O Estado de Pernambuco ficou dividido em 12 regionalizações no Plano Estadual de Resíduos Sólidos.

\subsubsection{O Estado de Minas Gerais}

Localizado na Região Sudeste, situado em uma das mais desenvolvidas do país, possui uma população de 19.728.701 habitantes, com PIB correspondente a 9,3\% do PIB nacional (IBGE, 2011) e IDH = 0,800, ocupando a $10^{\circ}$ posição no Brasil (ONU, 2010).

Para a regionalização proposta para o estado foram realizadas duas etapas, sendo a primeira um diagnóstico de todos os municípios agrupados em mesorregiões, microrregiões e regionais da Superintendência Regional de Regularização Ambiental, considerando os aspectos ambientais, socioeconômicos e de gestão dos resíduos sólidos.

Numa segunda etapa foi elaborado um prognóstico da geração dos resíduos analisando a projeção populacional até o ano de 2030 , a projeção dos resíduos domiciliares para cada ano, considerando a população estimada e a 
produção de resíduo per capita e a projeção da composição gravimétrica, a partir dos volumes gerados e a projeção populacional até 2030 .

Finalmente, para proposição da regionalização foram considerados três pilares: o socioeconômico, a caracterização dos resíduos sólidos urbanos e a logística de transporte, o pilar fundamental foi a logística, pois considerou-se as distâncias percorridas entre as sedes municipais e as cidades polo, buscando custos menores no transporte para sua viabilização.

O plano de regionalização do Estado foi formado por 51 territórios denominados Arranjos Territoriais Ótimos (ATOs).

\subsubsection{O Estado do Paraná}

O Estado situa-se na Região Sul do Brasil e possui população de 10.512.349 habitantes, com PIB correspondente a 5,8\% do PIB nacional (IBGE, 2011) e IDH $=0,820$, ocupando a $6^{\circ}$ posição no Brasil (ONU, 2010).

O início do processo de regionalização no Paraná deu-se de forma participativa com a proposição de critérios por técnicos da coordenação do convênio firmado com o Ministério do Meio Ambiente e foram considerados os aspectos dos meios físico, biótico e antrópico. Os critérios antrópicos, foram divididos em três subgrupos: social, econômico e político institucional.

Foram organizadas oficinas onde atribuiu-se notas para os vários critérios de cada aspecto (meio físico, biótico e antrópico), definindo os mais relevantes. Os critérios do meio antrópico foram considerados de maior importância, seguidos pelos do meio físico e depois biótico.

Numa nova etapa dos trabalhos, com os critérios definidos nas oficinas, iniciou-se a confecção de mapas temáticos relacionados ao diagnóstico e formatado um banco de dados único para utilização em um software de SIG, com a finalidade de gerenciamento de dados e produção de mapas.

Adotou-se o critério de população mínima por região de 20.000 habitantes e o custo do transporte foi considerado o de maior relevância entre os critérios econômicos, tendo grande importância na definição da logística, pois 
inicialmente a regionalização foi proposta considerando-se um raio de $100 \mathrm{~km} \mathrm{a}$ partir do centro de massas da região. Verificou-se que esse raio desconsiderava o atendimento de outros critérios, como por exemplo o de arranjos institucionais pré-existentes.

Assim, foi alterado para raios de até $200 \mathrm{~km}$, respeitando os limites de associações de municípios ou consórcios de saúde ou resíduos existentes, o que leva os municípios que compartilharem sistemas de tratamento ou aterros a implantarem estações de transbordo em municípios mais distantes.

A proposta de Regionalização da Gestão dos Resíduos Sólidos Urbanos do Estado do Paraná ficou composta por 20 regiões.

Os prazos definidos na PNRS demonstraram ser incompatíveis com a estrutura organizacional e técnica do Brasil, pois o Plano Nacional ainda não foi finalizado (junho de 2013) e as unidades da federação deveriam ter concluído seus planos até agosto de 2012, o que poucos conseguiram cumprir.

A PNRS e o Plano Nacional determinam metas para redução da geração de resíduos com a proibição de dispor resíduos e rejeitos em aterros a partir de 2014, mas se não houver investimento em educação ambiental para mudança de comportamento da população, estas metas bem como as do Plano Nacional sobre Mudança do Clima em alcançar o índice de reciclagem de 20\% em 2015, podem não ser cumpridas.

As regionalizações que deveriam estar formalizadas em 2013, ainda não foram concluídas em 14 unidades federativas dificultando a aplicação da Lei dos Consórcios Públicos com consequente recebimento de incentivos financeiros pelos municípios consorciados.

\subsubsection{Dos Planos Municipais de Gestão Integrada de Resíduos Sólidos}

Como nos planos estaduais, os planos municipais são obrigatórios para que os municípios tenham acesso a recursos do governo federal relacionados a limpeza urbana e ao manejo de resíduos sólidos. 
Terão prioridade no recebimento de recursos, os municípios que adotarem soluções consorciadas intermunicipais ou se inserirem voluntariamente nos planos microrregionais de resíduos elaborados pelos estados, também terão prioridade aqueles que implantarem a coleta seletiva com a participação dos catadores de materiais recicláveis.

O conteúdo mínimo do plano municipal de gestão integrada é mais detalhado que o plano estadual e encontra-se no art. 19 da Lei, que dispõe sobre as obrigações a serem observadas na elaboração dos seus planos, que são as seguintes:

I - diagnóstico da situação dos resíduos sólidos gerados no respectivo território, contendo a origem, o volume, a caracterização dos resíduos e as formas de destinação e disposição final adotadas;

II - identificação de áreas favoráveis para disposição final ambientalmente adequada de rejeitos, observado o plano diretor de que trata o $\$ 1^{\circ}$ do art. 182 da Constituição Federal e o zoneamento ambiental, se houver;

III - identificação das possibilidades de implantação de soluções consorciadas ou compartilhadas com outros Municípios, considerando, nos critérios de economia de escala, a proximidade dos locais estabelecidos e as formas de prevenção dos riscos ambientais;

IV - identificação dos resíduos sólidos e dos geradores sujeitos a plano de gerenciamento específico nos termos do art. 20 ou a sistema de logística reversa na forma do art. 33, observadas as disposições desta Lei e de seu regulamento, bem como as normas estabelecidas pelos órgãos do Sisnama e do SNVS;

V - procedimentos operacionais e especificações mínimas a serem adotados nos serviços públicos de limpeza urbana e de manejo de resíduos sólidos, incluída a disposição final ambientalmente adequada dos rejeitos e observada a Lei ${ }^{\circ} 11.445$, de 2007;

VI - indicadores de desempenho operacional e ambiental dos serviços públicos de limpeza urbana e de manejo de resíduos sólidos;

VII - regras para o transporte e outras etapas do gerenciamento de resíduos sólidos de que trata o art. 20, observadas as normas estabelecidas pelos órgãos do Sisnama e do SNVS e demais disposições pertinentes da legislação federal e estadual; 
VIII - definição das responsabilidades quanto à sua implementação e operacionalização, incluídas as etapas do plano de gerenciamento de resíduos sólidos a que se refere o art. 20 a cargo do poder público;

IX - programas e ações de capacitação técnica voltados para sua implementação e operacionalização;

$X$ - programas e ações de educação ambiental que promovam a não geração, a redução, a reutilização e a reciclagem de resíduos sólidos;

XI - programas e ações para a participação dos grupos interessados, em especial das cooperativas ou outras formas de associação de catadores de materiais reutilizáveis e recicláveis formadas por pessoas físicas de baixa renda, se houver;

XII - mecanismos para a criação de fontes de negócios, emprego e renda, mediante a valorização dos resíduos sólidos;

XIII - sistema de cálculo dos custos da prestação dos serviços públicos de limpeza urbana e de manejo de resíduos sólidos, bem como a forma de cobrança desses serviços, observada a Lei n 11.445 , de 2007;

XIV - metas de redução, reutilização, coleta seletiva e reciclagem, entre outras, com vistas a reduzir a quantidade de rejeitos encaminhados para disposição final ambientalmente adequada;

$X V$ - descrição das formas e dos limites da participação do poder público local na coleta seletiva e na logística reversa, respeitado o disposto no art. 33 , e de outras ações relativas à responsabilidade compartilhada pelo ciclo de vida dos produtos;

XVI - meios a serem utilizados para o controle e a fiscalização, no âmbito local, da implementação e operacionalização dos planos de gerenciamento de resíduos sólidos de que trata o art. 20 e dos sistemas de logística reversa previstos no art. 33;

XVII - ações preventivas e corretivas a serem praticadas, incluindo programa de monitoramento;

XVIII - identificação dos passivos ambientais relacionados aos resíduos sólidos, incluindo áreas contaminadas, e respectivas medidas saneadoras; XIX - periodicidade de sua revisão, observado prioritariamente o período de vigência do plano plurianual municipal. 
§ $1^{\circ} \mathrm{O}$ plano municipal de gestão integrada de resíduos sólidos pode estar inserido no plano de saneamento básico previsto no art. 19 da Lei $\mathrm{n}^{\circ} 11.445$, de 2007, respeitado o conteúdo mínimo previsto nos incisos do caput e observado o disposto no $\S 2^{\circ}$, todos deste artigo.

§ $2^{\circ}$ Para Municípios com menos de 20.000 (vinte mil) habitantes, o plano municipal de gestão integrada de resíduos sólidos terá conteúdo simplificado, na forma do regulamento.

$\S 3^{\circ} \mathrm{O}$ disposto no $\S 2^{\circ}$ não se aplica a Municípios:

I - integrantes de áreas de especial interesse turístico;

II - inseridos na área de influência de empreendimentos ou atividades com significativo impacto ambiental de âmbito regional ou nacional;

III - cujo território abranja, total ou parcialmente, Unidades de Conservação. $\S 4^{\circ} \mathrm{A}$ existência de plano municipal de gestão integrada de resíduos sólidos não exime o Município ou o Distrito Federal do licenciamento ambiental de aterros sanitários e de outras infraestruturas e instalações operacionais integrantes do serviço público de limpeza urbana e de manejo de resíduos sólidos pelo órgão competente do Sisnama.

$\S 5^{\circ} \mathrm{Na}$ definição de responsabilidades na forma do inciso VIII do caput deste artigo, é vedado atribuir ao serviço público de limpeza urbana e de manejo de resíduos sólidos a realização de etapas do gerenciamento dos resíduos a que se refere o art. 20 em desacordo com a respectiva licença ambiental ou com normas estabelecidas pelos órgãos do Sisnama e, se couber, do SNVS.

$\S 6^{\circ}$ Além do disposto nos incisos I a XIX do caput deste artigo, o plano municipal de gestão integrada de resíduos sólidos contemplará ações específicas a serem desenvolvidas no âmbito dos órgãos da administração pública, com vistas à utilização racional dos recursos ambientais, ao combate a todas as formas de desperdício e à minimização da geração de resíduos sólidos.

§ $7^{\circ} 0$ conteúdo do plano municipal de gestão integrada de resíduos sólidos será disponibilizado para o Sinir, na forma do regulamento.

$\S 8^{\circ} \mathrm{A}$ inexistência do plano municipal de gestão integrada de resíduos sólidos não pode ser utilizada para impedir a instalação ou a operação de 
empreendimentos ou atividades devidamente licenciados pelos órgãos competentes.

$\S 9^{\circ}$ Nos termos do regulamento, o Município que optar por soluções consorciadas intermunicipais para a gestão dos resíduos sólidos, assegurado que o plano intermunicipal preencha os requisitos estabelecidos nos incisos I a XIX do caput deste artigo, pode ser dispensado da elaboração de plano municipal de gestão integrada de resíduos sólidos.

$O$ Decreto $n^{\circ} 7.404 / 2010$ que regulamenta a PNRS, apresenta outros complementos, conforme especificados:

Art. 50. Os planos municipais de gestão integrada de resíduos sólidos serão elaborados consoante o disposto no art. 19 da Lei no 12.305, de 2010.

$\S 1^{\circ}$ Os planos municipais de gestão integrada de resíduos sólidos deverão ser atualizados ou revistos, prioritariamente, de forma concomitante com a elaboração dos planos plurianuais municipais.

$\S 2^{\circ}$ Os planos municipais de gestão integrada de resíduos sólidos deverão identificar e indicar medidas saneadoras para os passivos ambientais originados, entre outros, de:

I - áreas contaminadas, inclusive lixões e aterros controlados; e

II - empreendimentos sujeitos à elaboração de planos de gerenciamento de resíduos sólidos.

Para municípios com população até 20 mil habitantes, o conteúdo mínimo foi simplificado, salvo os municípios que integrarem áreas de especial interesse turístico, estiverem em áreas de influência de empreendimentos ou atividades com significativo impacto ambiental de âmbito regional ou nacional, ou contiver território, tanto total quanto parcial, em unidade de conservação e estão em 16 itens a seguir:

Art. 51. Os Municípios com população total inferior a vinte mil habitantes, apurada com base nos dados demográficos do censo mais recente da Fundação Instituto Brasileiro de Geografia Estatística - IBGE, poderão adotar planos municipais simplificados de gestão integrada de resíduos sólidos. 
$\S 1^{\circ}$ Os planos municipais simplificados de gestão integrada de resíduos sólidos referidos no caput deverão conter:

I - diagnóstico da situação dos resíduos sólidos gerados no respectivo território, com a indicação da origem, do volume e da massa, a caracterização dos resíduos e as formas de destinação e disposição final adotadas;

II - identificação das áreas favoráveis para disposição final ambientalmente adequada de rejeitos, observado o plano diretor de que trata o $\$ 1^{\circ}$ do art. 182 da Constituição e o zoneamento ambiental, quando houver;

III - identificação da possibilidade de implantação de soluções consorciadas ou compartilhadas com outros Municípios, considerando a economia de escala, a proximidade dos locais estabelecidos e as formas de prevenção dos riscos ambientais;

IV - identificação dos resíduos sólidos e dos geradores sujeitos ao plano de gerenciamento ou ao sistema de logística reversa, conforme os arts. 20 e 33 da Lei $\mathrm{n}^{\circ}$ 12.305, de 2010, observadas as disposições deste Decreto e as normas editadas pelos órgãos do SISNAMA e do SNVS;

$\mathrm{V}$ - procedimentos operacionais e especificações mínimas a serem adotadas nos serviços públicos de limpeza urbana e de manejo de resíduos sólidos, incluída a disposição final ambientalmente adequada de rejeitos, em consonância com o disposto na Lei $n^{\circ} 11.445$, de 2007, e no Decreto $n^{\circ} 7.217$, de 21 de junho de 2010;

$\mathrm{VI}$ - regras para transporte e outras etapas do gerenciamento de resíduos sólidos de que trata o art. 20 da Lei $n^{\circ}$ 12.305, de 2010, observadas as normas editadas pelos órgãos do SISNAMA e do SNVS, bem como as demais disposições previstas na legislação federal e estadual;

VII - definição das responsabilidades quanto à sua implementação e operacionalização pelo Poder Público, incluídas as etapas do plano de gerenciamento de resíduos sólidos;

VIII - programas e ações de educação ambiental que promovam a não geração, a redução, a reutilização, a coleta seletiva e a reciclagem de resíduos sólidos; 
IX - programas e ações voltadas à participação de cooperativas e associações de catadores de materiais reutilizáveis e recicláveis formadas por pessoas físicas de baixa renda, quando houver;

$X$ - sistema de cálculo dos custos da prestação dos serviços públicos de limpeza urbana e de manejo de resíduos sólidos, bem como a forma de cobrança desses serviços, observado o disposto na Lei n 11.445, de 2007;

$\mathrm{XI}$ - metas de coleta seletiva e reciclagem dos resíduos;

XII - descrição das formas e dos limites da participação do Poder Público local na coleta seletiva e na logística reversa, respeitado o disposto no art. 33 da Lei $n^{\circ} 12.305$, de 2010, e de outras ações relativas à responsabilidade compartilhada pelo ciclo de vida dos produtos;

XIII - identificação de áreas de disposição inadequada de resíduos e áreas contaminadas e respectivas medidas saneadoras; e

XIV - periodicidade de sua revisão.

$\S 2^{\circ} 0$ disposto neste artigo não se aplica aos Municípios:

I - integrantes de áreas de especial interesse turístico;

II - inseridos na área de influência de empreendimentos ou atividades com significativo impacto ambiental de âmbito regional ou nacional; ou

III - cujo território abranja, total ou parcialmente, unidades de conservação.

Deve integrar o plano municipal, procedimentos operacionais e outras especificações para os serviços públicos de limpeza urbana e de manejo de resíduos sólidos, disposições sobre o sistema de cobrança desses serviços e regras para o transporte e outras etapas do gerenciamento dos diferentes resíduos.

O plano definirá as responsabilidades quanto à sua execução, deixando claro quais são as tarefas assumidas pelo poder público nos planos de gerenciamento de resíduos sólidos, devendo estar explicito como ocorrerá a participação do poder público local na coleta seletiva e na logística reversa, bem como em outras ações relativas à responsabilidade compartilhada pelo ciclo de vida dos produtos.

O plano municipal deve apresentar programas e ações de capacitação técnica, de educação ambiental e de participação dos grupos interessados, além de 
apresentar mecanismos para a criação de fontes de negócios, emprego e renda por meio da valorização dos resíduos sólidos.

Cabe ao plano estabelecer metas quanto a redução, reutilização, coleta seletiva e reciclagem a fim de reduzir a quantidade de rejeitos que demandarão disposição final. Serão definidas, também, ações a serem desenvolvidas no âmbito dos órgãos da administração pública, buscando uma utilização racional dos recursos ambientais e o combate ao desperdício.

A Lei 12.305/2010 não escusa os municípios de licenciarem aterros sanitários e outros componentes do serviço público de limpeza urbana e manejo de resíduos sólidos, por não terem um plano formado.

A existência de um plano intermunicipal para a gestão de resíduos sólidos poderá eliminar a exigência de um plano municipal para os municípios optarem por soluções consorciadas, desde que seja observado o conteúdo mínimo previsto no Art. 19 da Lei 12.305/2010.

Os planos são elaborados de forma participativa e procuram com isto não se transformarem apenas em quesito burocrático e cumpridor de obrigação. Espera-se que com o engajamento de diversos setores da sociedade, possa ser um instrumento de forte impacto positivo para o meio ambiente, saúde pública e para a qualidade de vida.

\subsubsection{Política Estadual de Resíduos Sólidos}

O Estado de São Paulo, através da Lei 12.300 de 16/03/2006 (São Paulo, 2006) instituiu a Política Estadual de Resíduos Sólidos do Estado de São Paulo, que foi consolidada pela regulamentação do Decreto $n^{\circ}$ 54.645/2009 e pela Resolução 24/2010, expedida pela Secretaria Estadual do Meio Ambiente (SMA).

Esta Lei buscou consolidar uma visão sistêmica na gestão dos resíduos sólidos do Estado, editando um conjunto de princípios, diretrizes e instrumentos, voltados à busca de soluções para a gestão e gerenciamento dos resíduos sólidos. 
Por meio de seus instrumentos de planejamento, a Política Estadual procurou estruturar a gestão e o gerenciamento dos resíduos sólidos em seu Capítulo II. Que entre outros instrumentos se pode destacar o planejamento integrado e compartilhado, os planos de resíduos, o Inventário Estadual de Resíduos Sólidos, o Sistema Declaratório Anual de Resíduos Sólidos, o monitoramento dos indicadores da qualidade ambiental e os acordos voluntários ou propostos pelo Governo, por setores da economia e termos de compromissos, o que possibilita os acordos setoriais.

Um dos princípios da Política Estadual é a minimização dos resíduos sólidos por meio da sociedade, Poder Público e iniciativa privada, indicando as responsabilidades de todos os envolvidos no ciclo de vida dos resíduos sólidos.

Buscando promover a gestão integrada e compartilhada dos resíduos, a lei antes mesmo da Política Nacional (PNRS) já previa a implementação da logística reversa no estado e com a edição da Resolução n 24 a Secretaria do Meio Ambiente estabeleceu metas setoriais, antecipando-se às obrigações estabelecidas na PNRS para a logística reversa, com o recolhimento obrigatório de seus produtos por parte dos fornecedores.

Os produtos relacionados na Resolução como sendo impactantes ambientalmente são: filtros e embalagens de óleo lubrificante automotivo; lâmpadas fluorescentes; baterias automotivas; pneus; produtos eletroeletrônicos; embalagens de alimentos e bebidas; embalagens de produtos de higiene pessoal, de limpeza e embalagens de bens de consumo duráveis.

Os fabricantes, distribuidores ou importadores destes produtos são obrigados a manter, individualmente ou sob a forma de parcerias, postos de entrega voluntária para os resíduos pós-consumo; orientar os consumidores quanto à necessidade de devolução dos resíduos pós-consumo; cumprir metas de recolhimento; declarar a quantidade de produtos listados nos Incisos de I a VII do artigo $3^{\circ}$ produzidos, a quantidade de resíduos recolhidos e sua destinação no Sistema Declaratório Anual de Resíduos Sólidos, a partir do estabelecimento das metas de recolhimento; resíduos recolhidos deverão ser encaminhados para 
reciclagem, recuperação energética, reutilização ou outra destinação permitida pela Companhia Ambiental do Estado de São Paulo - CETESB.

O Decreto Estadual $n^{\circ} 54.645 / 2009$ estabelece responsabilidades de fornecedores, distribuidores e importadores de produtos que gerarem resíduos de significativo impacto ambiental após consumidos. Para tanto, os acordos setoriais ganharam importante papel para a aplicação efetiva da lei estadual.

No ano de 2012 a Secretaria do Meio Ambiente assinou com alguns setores os seguintes Termos de Compromissos:

- Pilhas e Baterias Portáteis

- Associação Brasileira da Indústria Elétrica e Eletrônica (ABINEE);

- Embalagens de Produtos de Higiene Pessoal, Perfumaria, Cosméticos, de Limpeza e Afins

- Associação Brasileira da Indústria de Higiene Pessoal, Perfumaria e Cosméticos (ABIHPEC) e;

- Associação Brasileira da Indústria de Produtos de Limpeza e Afins (ABIPLA).

- Embalagens de Agrotóxicos

- Instituto Nacional de Processamentos de Embalagens Vazias (INPEV) e;

- Associação Nacional de Distribuidores de Insumos Agrícolas e Veterinário (ANDAV).

- Embalagens Plásticas Usadas de Lubrificantes

- Sindicato Nacional das Empresas Distribuidoras de Combustíveis e de Lubrificantes (SINDICOM);

- Sindicato Interestadual das Indústrias Misturadoras e Envasilhadoras de Produtos Derivados de Petróleo (SIMEPETRO);

- Sindicato Interestadual do Comércio de Lubrificantes (SINDILUB);

- Sindicato do Comércio Varejista de Derivados de Petróleo do Estado de São Paulo (SINCOPETRO); 
- Sindicato do Comércio Varejista de Derivados de Petróleo de Campinas e Região (RECAP);

- Sindicato do Comércio Varejista de Derivados de Petróleo, Lava-Rápidos e Estacionamentos de Santos e Região (RESAN);

- Sindicato do Comércio Varejista de Derivados de Petróleo do A.B.C.D.M.R.RSP (REGRAN) e;

- Sindicato Nacional do Comércio Transportador, Revendedor, Retalhista de Combustíveis (SINDITRR).

- Pneus Inservíveis

- $\quad$ ASSOCIAÇÃO RECICLANIP.

- Aparelhos de Telefonia Móvel Celular e seus respectivos Acessórios

- VIVO S/A,

- TIM CELULAR S/A;

- Claro s/a;

- NEXTEL TELECOMUNICAÇÕES LTDA e;

- TNL PCS S/A.

- Óleos Lubrificantes

- Sindicato Nacional das Empresas Distribuidoras de Combustíveis e de Lubrificantes (SINDICOM);

- Sindicato Interestadual das Indústrias Misturadoras e Envasilhadoras de Produtos Derivados de Petróleo (SIMEPETRO);

- $\quad$ Sindicato Interestadual do Comércio de Lubrificantes (SINDILUB);

- Sindicato da Indústria de Reparação de Veículos e Acessórios do Estado de São Paulo (SINDIREPA) e;

- Sindicato Nacional da Indústria do Rerrefino de Óleos Minerais (SINDIRREFINO).

- Óleo Comestível

- Companhia de Saneamento Básico do Estado de São Paulo (SABESP) e; 
- Cargill Agrícola S/A.

As regras estaduais preveem ainda, o Sistema Declaratório Anual a ser atendido pelas fontes geradoras, transportadores e unidades receptoras de resíduos, que estão obrigadas a apresentar documento formal contendo as quantidades de resíduos gerados, armazenados, transportados e destinados.

Em caso ocorrências que envolvam resíduos sólidos e que coloquem o meio ambiente e a saúde pública em risco, a lei estadual em seu artigo 49, responsabiliza os atores e prevê medidas corretivas como:

I - Do gerador, nos eventos ocorridos em suas instalações;

II - Do gerador e do transportador, nos eventos ocorridos durante o transporte de resíduos sólidos;

III - Do gerador e do gerenciador de unidades receptoras, nos eventos ocorridos nas instalações destas últimas.

A legislação também procura incentivar a formação de consórcios entre municípios, assim como também, define objetivos, princípios, diretrizes e instrumentos para gestão integrada e compartilhada de resíduos sólidos, visando a cooperação intermunicipal, estimulando a busca de soluções consorciadas e a solução conjunta dos problemas de gestão de resíduos sólidos de todas as origens.

Busca criar incentivos aos municípios que se dispuserem a implantar, ou permitir a implantação, em seus territórios, de instalações licenciadas para tratamento e disposição final de resíduos sólidos, oriundos de qualquer outro município, estabelecendo no artigo 10 da PERS, que as unidades receptoras de resíduos de caráter regional e de uso intermunicipal, terão prioridade na obtenção de financiamentos pelos organismos oficiais de fomento.

\subsubsection{Lei de Consórcios Públicos}

O governo brasileiro, na busca de alternativas para viabilizar o acesso universal da população aos serviços de saneamento básico, estabelece a Lei dos Consórcios Públicos, Lei $\mathrm{n}^{\circ}$. 11.107 de 6 de abril de 2005, que dispõe sobre normas 
gerais de contratação de consórcios públicos e do Decreto $\mathrm{n}^{\circ} 6.017$, de 17 de janeiro de 2007, que regulamenta a lei supracitada, criando um ambiente normativo favorável para cooperação entre os entes federativos, permitindo que sejam utilizados com segurança os institutos previstos no artigo 241 da Constituição Federal e assim facilitando a implantação de consórcios intermunicipais para gestão e gerenciamento de resíduos sólidos entre outros.

A Emenda Constitucional $\mathrm{n}^{\circ}$ 19/1998 modificou o art. 241 da Constituição federal, dando fundamentação jurídica para o estabelecimento da Lei dos Consórcios Públicos nos seguintes termos:

União, os Estados, o Distrito Federal e os Municípios disciplinarão por meio de lei os consórcios públicos e os convênios de cooperação entre entes federados, autorizando a gestão associada de serviços públicos, bem com a transferência total ou parcial de encargos, serviços, pessoal e bens essenciais à continuidade dos serviços transferidos (BRASIL, 1998).

Lima (2003, p.63) dissertando sobre os modelos institucionais de associação entre municípios, conceitua a figura do consórcio intermunicipal de desenvolvimento como:

Também chamado de consórcio administrativo intermunicipal, apresenta-se como objetivo principal de dispor compartilhadamente os resíduos sólidos urbanos de dois ou mais municípios, representando um acordo celebrado entre Municípios pelo qual, reunidos os recursos administrativos, técnicos, econômicofinanceiros dos entes consorciados, são potencializados esforços para a implementação de unidades centralizadas para a disposição final [e tratamento] de resíduos de utilidade e de interesse intermunicipal para toda uma região.

O Decreto 6.017, de 17 de janeiro de 2007 definiu consórcio público como "pessoa jurídica formada exclusivamente por entes da Federação, na forma da Lei no 11.107, de 2005, para estabelecer relações de cooperação federativa, inclusive a realização de objetivos de interesse comum, constituída como associação pública, com personalidade jurídica de direito público e natureza autárquica, ou como pessoa jurídica de direito privado sem fins econômicos".

A lei estabelece em seu art. $3^{\circ}$ que o consórcio público será constituído por contrato cuja celebração dependerá da prévia subscrição de 
protocolo de intenções e quanto a personalização, determina era indispensável que os entes federados constituam uma personalidade jurídica, de direito público ou de direito privado para gerenciar e administrar o consórcio público.

Justen Filho (2006, p. 122-123), ressalta ainda, a importância da edição de lei ordinária, que autoriza todos os entes federativos envolvidos e aprovação de um protocolo de intenções, assinado pelos chefes do Poder Executivo pertencentes ao consórcio público.

As dificuldades técnicas e financeiras encontradas pelos municípios na gestão e gerenciamento dos resíduos sólidos, atreladas à legislações ambientais cada vez mais rígidas, tem impulsionado os municípios brasileiros na formação de consórcios públicos visando a implantação de solução conjunta na destinação dos resíduos sólidos.

$\mathrm{Na}$ busca por soluções mais adequadas de gestão e gerenciamento de resíduos, tanto o governo federal e os estaduais passaram a destinar maiores recursos na criação de programas e linhas de crédito, onde os municípios beneficiados são aqueles que apresentam projetos visando solucionar conjuntamente a gestão dos resíduos sólidos, gerando condições de continuidade dos serviços e manutenção de sua qualidade ao longo do tempo. A população assume o papel fiscalizador, estimulada pelos órgãos de controle ambiental, Ministério Público e pelas organizações não-governamentais voltadas para a defesa do meio ambiente.

Assim, municípios com áreas mais adequadas para a instalação dessas unidades operacionais, quando se consorciam com cidades vizinhas para receber os seus resíduos, podem negociar algumas vantagens por serem os hospedeiros, tais como: isenção do custo de vazamento ou alguma compensação urbanística custeada pelos outros consorciados.

Este modelo que vem timidamente tomando vulto em função do interesse econômico, advindo do ganho de escala é a união de municípios para ações conjuntas que visem à adequação dos partícipes às legislações e exigências da sociedade. De modo geral estas associações são formalizadas através da criação 
de Consórcios Intermunicipais que já podem ser encontradas em vários estados do país como Rio Grande do Sul, São Paulo e Goiás (Furtado e Petroni, 2003).

No Estado de São Paulo, um dos exemplos de maior sucesso no campo do consórcio é aquele formado pelos municípios de Jundiaí, Campo Limpo Paulista, Cajamar, Louveira, Várzea Paulista e Vinhedo, que operam o aterro sanitário de Várzea Paulista.

Com estudos realizados no Estado do Rio Grande do Sul sobre consórcios intermunicipais para aterro sanitário, Cotrim e Reichert (2000), identificaram a viabilidade econômica do empreendimento em função dos ganhos de escala, proporcionados pela aglutinação dos resíduos sólidos num único ponto de destino, o que acarreta num rateio das despesas administrativas entre os partícipes. Ressaltam ainda, as barreiras existentes quanto à aceitação deste tipo de empreendimento por parte da população, não quanto à intermunicipalidade, mas sim, quanto a própria existência de aterros sanitários.

Oliveira (2004,p. 28), aponta alguns fatores para a formação dos consórcios públicos de gestão de resíduos sólidos:

É importante considerar a proximidade das sedes dos municípios, bem como a facilidade de acesso e a disposição e a boa vontade dos prefeitos envolvidos no processo em buscar soluções conjuntas para os problemas de seus municípios. No entanto, só a proximidade entre os entes consorciados não garante o sucesso do consórcio, a região também deve apresentar rodovias que facilitem o trafego dos veículos de coleta de resíduos ao aterro sanitário. Além destes fatores descritos, o que geralmente inviabiliza a constituição dos consórcios são a incompatibilidade de ideais partidários e a vaidade política. Por isso, deve-se asseverar que no processo de negociação, sejam abordados somente os possíveis benefícios que o consórcio poderá proporcionar à região e, não, as disputas políticas internas ou externas as suas comunas.

A Política Nacional de Resíduos Sólidos em seu art. 8 , inciso XIX, tem como um dos seus instrumentos, o incentivo à adoção de consórcios ou de outras formas de cooperação entre os entes federados, com vistas à elevação das escalas de aproveitamento e à redução dos custos envolvidos.

No art. 18, a PNRS aponta uma série de incentivos à formação consorciada na gestão de resíduos, pois estabelece que “ (...) serão priorizados no 
acesso aos recursos da União os Municípios que: optarem por soluções consorciadas intermunicipais para a gestão dos resíduos sólidos, incluída a elaboração e implementação de plano intermunicipal, ou que se inserirem de forma voluntária nos planos microrregionais de resíduos sólidos referidos” (BRASIL, 2010).

Também refere-se ao consorciamento, quando no art. 19 estabelece que nos planos municipais de gestão de resíduos sólidos, os municípios deverão identificar as possibilidades de implantação de soluções consorciadas ou compartilhadas com outros Municípios, considerando nos critérios de economia de escala, a proximidade dos locais estabelecidos e as formas de prevenção dos riscos ambientais (BRASIL, 2010), e no art. 45 menciona a prioridade na obtenção dos incentivos instituídos pelo Governo Federal dos consórcios públicos, que viabilizem a descentralização e a prestação de serviços públicos relacionados aos resíduos sólidos.

O trabalho financiado pelo Ministério do Meio Ambiente no ano de 2002, com apoio da Cetec, da CTZ e CEF, denominado “Estimativa do Déficit de Investimento em Equipamentos para Coleta de Lixo, Desativação de Lixões e Infraestrutura para a Implantação de Aterros Sanitários no Brasil”, já identificava que o compartilhamento na operação de aterros de resíduos sólidos de maior porte, é mais vantajoso para os municípios, pois proporciona redução de custos de investimento per capita e economia de escala.

Com o objetivo de comprovar essas vantagens, o estudo analisou o custo de implantação de modelo teórico de um aterro sanitário para uma municipalidade com população entre 20 e 50 mil habitantes no estado de Minas Gerais e apurou que o custo total para o referido aterro seria de $\mathrm{R} \$ 394.654,23$. Verificando que o custo per capita deste aterro para atender a uma população de 20 mil pessoas custaria em torno de R\$19,73/hab. e para uma população de 50 mil habitantes seria de $\mathrm{R} \$ 7,89 / \mathrm{hab}$., constatando que é proporcionalmente mais vantajoso operar um aterro maior do que vários pequenos (Cetec, 2002).

Lima (2003, p.44) alega que: “Os municípios de pequeno porte não possuem recursos suficientes para a implantação de serviços mais complexos, os 
que coloca, quase sempre, em situação de dependência em relação aos grandes municípios ou municípios-pólo".

A Lei dos Consórcios juntamente com a Política Nacional dos Resíduos Sólidos vem trazer perspectivas reais de ganhos de escala, ambiental, econômico e social para os municípios brasileiros na gestão e gerenciamentos de seus resíduos sólidos através do consorciamento. 


\section{4 \\ METODOLOGIA}

\subsection{Considerações Gerais}

Neste capítulo são apresentadas as premissas e aspectos que nortearam a definição da estrutura metodológica desta investigação acadêmica.

Segundo Goldenber (1997), um assunto atual pode ser motivo de uma pesquisa acadêmica e Gil (1999) salienta que uma pesquisa é requerida quando os dados disponíveis não estejam estrategicamente organizados de forma a identificálos ao problema. 
Para Andrade (1997) a escolha do tema deve firmar-se em critérios de relevância como:

- Importância científica e contribuição para o enriquecimento das informações disponíveis;

- De exequibilidade, como o acesso a bibliografia e a disponibilidade de tempo;

- De oportunidade, como a contemporaneidade da pesquisa.

A metodologia utilizada nesta tese constituiu-se em pesquisas:

- Bibliográfica

- Documental, feita por meio de análises de documentos formais e informais, relatórios, mapas entre outros;

- De campo, através de coleta de dados obtidos em visitas técnicas e sistematização desses dados, em planilhas, mapas, relatórios, gráficos e cruzamentos de dados.

\subsection{Delineamento do Estudo}

Este trabalho tem como enfoque principal apresentar contribuições ao Plano de Resíduos Sólidos do Estado de São Paulo através de análises de informações contidas nas fontes disponíveis e nas pesquisas utilizadas na elaboração do estudo.

\subsection{Universo de Estudo}

Estudou-se a respeito da situação dos resíduos sólidos, sintetizando as questões e apresentando as observações finais sobre estes resíduos no Estado de São Paulo.

\subsection{Período de Referência}

$O$ período de referência da análise foi compreendido entre $1^{\circ}$ de janeiro de 2012 a 31 de maio de 2013. 


\subsection{Geografia de Análise}

O levantamento dos dados desse estudo abrangeu todas as Agências Ambientais regionais da Cesteb no Estado de São Paulo. Vale ressaltar que o pesquisador procurou alcançar a abrangência geográfica de todos os municípios paulistas. Esta etapa foi elaborada através de envio de e-mails e pesquisa nos sites oficiais. Entretanto, não obteve respostas suficientes para que se validassem os resultados estatisticamente.

A disponibilidade de informações revelou-se em muitos casos uma limitação ao percurso desejável para os trabalhos, pois não se encontrou dados sobre todos os resíduos sólidos.

\subsection{Pesquisa Bibliográfica}

A pesquisa bibliográfica utiliza-se fundamentalmente das contribuições dos diversos autores sobre determinado assunto, enquanto a pesquisa documental utiliza-se de materiais que não receberam tratamento analítico. As fontes de pesquisa documental são mais diversificadas e dispersas do que as da pesquisa bibliográfica. Conforme Gil (1999), na pesquisa documental existem os documentos de primeira mão, ou seja, aqueles que não receberam nenhum tratamento analítico, tais como os documentos conservados em órgãos públicos e instituições privadas, e os documentos de segunda mão que de alguma forma já foram analisados, tais como: relatórios de pesquisa; relatórios de empresas; tabelas estatísticas e outros.

Segundo o mesmo autor, há vantagens e limitações neste tipo de pesquisa.

Vantagens:

- Os documentos constituem-se fonte rica e estável de dados;

- Baixo custo, pois exige praticamente apenas disponibilidade de tempo do pesquisador;

- Não exige contato com os sujeitos da pesquisa. 
Como limitação, as críticas mais frequentes referem-se a inexistência da representatividade e a subjetividade dos dados.

\section{- REVISÃO TEÓRICA}

A primeira fase desse procedimento metodológico consistiu-se na revisão de literatura sobre os assuntos pertinentes aos temas da gestão e gerenciamento dos resíduos sólidos domiciliares, das legislação pertinente e dos consórcios públicos no Brasil e no contexto internacional, consultando as principais fontes de informações: livros, dissertações, teses, periódicos nacionais e internacionais, jornais, revistas, vídeos, artigos científicos, manuais, Internet (rede mundial de computadores), relatórios técnicos, legislações, bem como também uma pesquisa documental junto a órgãos públicos e ambientais (Ministério do Meio Ambiente, Secretarias Municipais, CETESB, Comitês de Bacias, IBGE, Sistema Estadual de Análise de Dados - SEADE etc.) para aquisição de dados, relatórios, planos e documentos formais e informais sobre a questão estudada.

\section{- PESQUISA DOCUMENTAL}

A pesquisa documental foi realizada de forma sistemática e racional, buscando conhecimentos válidos e verdadeiros sobre os resíduos sólidos e constituiu-se em:

- Pesquisa descritiva: foram observados, registrados e analisados os dados quantitativos e qualitativos publicados por entidades do setor público ou privado responsáveis pela gestão e gerenciamento dos resíduos sólidos, em particular sobre o Estado de São Paulo;

- Pesquisa quantitativa: os dados publicados foram trabalhados e apresentados em tabelas e gráficos, de forma a ajudar nas interpretações e conclusões. 


\subsection{Pesquisa de Campo}

Utilizando-se os métodos de observação direta intensiva e extensiva, foram feitas visitas técnicas para se conhecer alguns modelos de gestão e gerenciamento compartilhados entre municípios da União Europeia e foram avaliadas as questões referentes aos empregados nas cidades de Porto e Lustosa (Portugal), Lille (França), Bruxelas (Bélgica) e Segovia (Espanha), possibilitando o conhecimento da realidade de cada localidade e suas potencialidades.

\subsection{Estudo de Regionalização}

Nesta etapa da pesquisa buscou-se a organização espacial do território do Estado de São Paulo, propondo estudos de regionalização para constituição de consórcios de gestão e manejo dos resíduos sólidos, de modo que pudesse ser utilizado como parâmetro para uma futura composição desses consórcios.

0 ambiente de trabalho nesta etapa foi desenvolvido dentro de um ambiente de Sistemas de Informação Geográfica (SIG), ferramenta que permite trabalhar cruzando diversas informações sobre uma determinada região geográfica, o que possibilita vários estudos de análise espacial.

Para execução do estudo foram analisados o mapa rodoviário do Estado de São Paulo, produzido pelo DER, o mapa de divisão territorial dos municípios do estado, o mapa com as divisões administrativas, o mapa com a divisão em regiões do estado utilizado para promover reuniões do Programa Município Verde Azul, microrregiões do Instituto Brasileiro de Geografia e Estatística (IBGE), regiões de associações de municípios e o mapa de divisão das Bacias Hidrográficas, partindo da análise das regiões com centralidades regionais e considerando as suas interdependências, tais como: ambiental, infraestruturas viárias, geração e disposição de resíduos.

Nesta análise considerou-se as várias regionalizações existentes e que se compõe em consórcios ligados a gestão e gerenciamento de resíduos sólidos, procurando assim, identificar as lógicas e proposições já existentes no estado. 


\subsection{Fontes de Dados}

As principais fontes de dados utilizadas foram obtidas através de fontes primárias, com o envio de questionário a todas as Agências Ambientais da Cetesb.

Este trabalho também foi elaborado por meio de fontes secundárias de informações pesquisadas em de sítios da internet, como estas:

- ABRELPE - Associação Brasileira de Empresas de Limpeza Pública e Resíduos Especiais;

- IBGE - Instituto Brasileiro de Geografia e Estatística;

- MMA - Ministério do Meio Ambiente

- CETESB - Companhia de Tecnologia de Saneamento Ambiental do Estado de São Paulo;

- INFRAERO - Empresa Brasileira de Infraestrutura Aeroportuária

- DAESP - Departamento Aeroviário do Estado de São Paulo

\subsection{Softwares Utilizados no Estudo}

Os softwares utilizados foram:

- Microsoft Word 2007 para Windows;

- Microsoft Excel 2007 para Windows;

- Adobe Reader XI para Windows;

- AutoCAD 2010 para Windows;

- TerraView para Windows. 
4.11 Fluxograma da tese

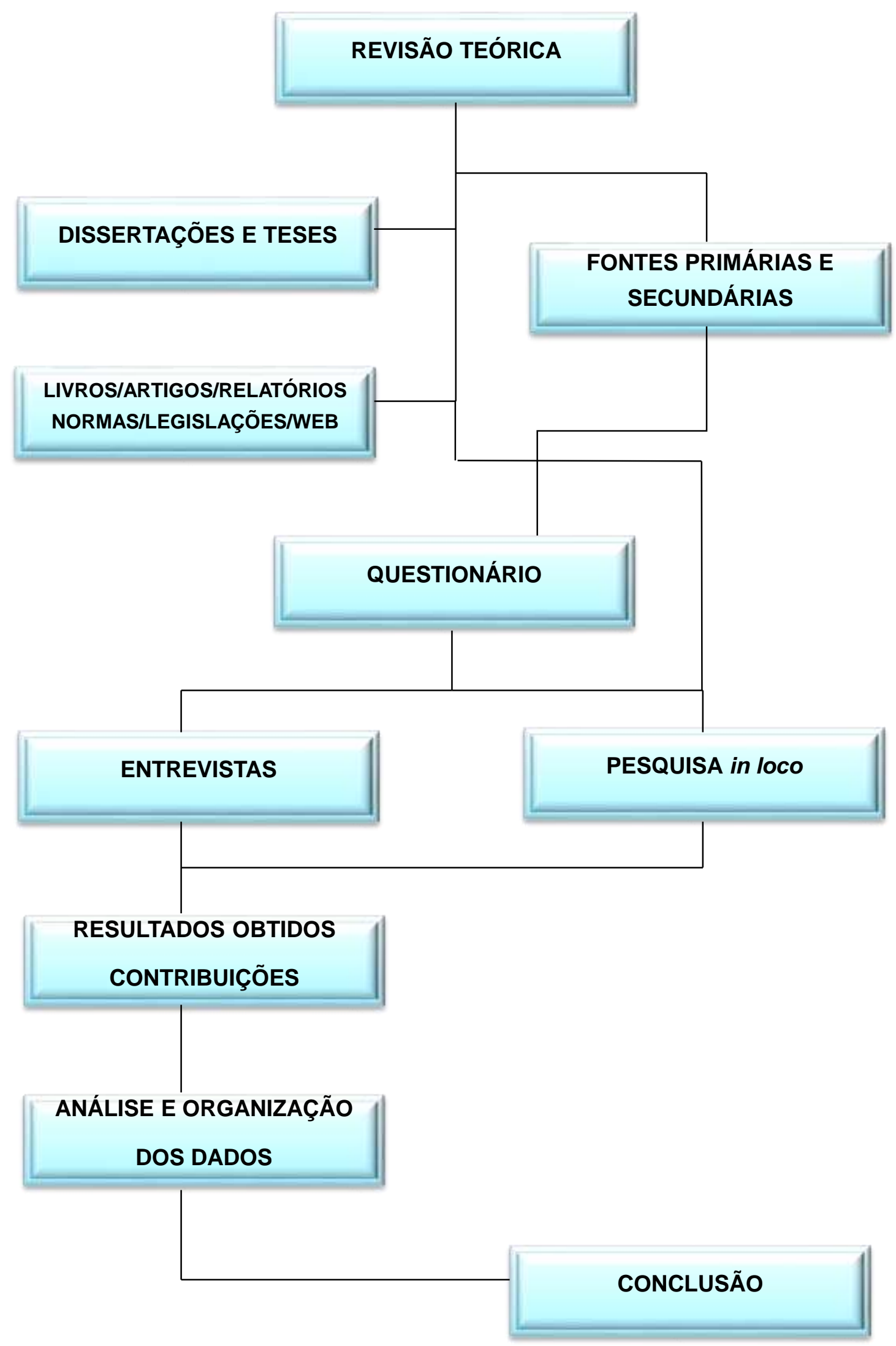




\section{RESULTADOS}

\subsection{A GESTÃO E GERENCIAMENTO DOS RESÍDUOS SÓLIDOS NO CONTEXTO EUROPEU}

Este capítulo tem por objetivo apresentar o resultado das visitas técnicas realizadas para conhecimento do processo de gestão de resíduos sólidos, infraestruturas e equipamentos utilizados em alguns consórcios intermunicipais localizados em Portugal, Espanha, Bélgica e França.

Para que os objetivos das visitas técnicas fossem alcançados, o pesquisador fez num primeiro momento contato com os administradores dos sistemas de cada consórcio, agendando as datas para as visitas, posteriormente 
foram enviados questionários para que se apurassem dados relativos a gestão dos resíduos sólidos e finalmente as visitas aos locais para conhecimento dos sistemas e processos relativos a gestão dos resíduos de cada localidade.

A adoção da “Diretiva Embalagens" (Diretiva 94/62/CE) e da "Diretiva Aterros” (Diretiva 1999/31/CE) pela União Europeia, levou a Organização das Nações Unidas (ONU) e a International Solid Waste Association (ISWA) a eleger os Estados-membros da comunidade como os que atingiram o grau mais avançado do mundo em termos de gestão dos resíduos.

A gestão adequada dos resíduos sólidos deve estar baseada em condições ambientais ideais, considerando todos os aspectos abrangidos desde a geração até a sua disposição final, buscando a implementação da reciclagem associada a novos padrões de produção e consumo (Paulella e Scapim,1996).

A US EPA - United States Environmental Protection Agency (1989), caracteriza o gerenciamento como sendo aquele que abrange o uso de práticas administrativas, com manejo seguro e efetivo, e fluxos de resíduos sólidos, com o mínimo de impactos sobre a saúde e o ambiente.

Apesar de parecerem similares, há diferenças entre os conceitos de gestão e de gerenciamento dos resíduos sólidos. Segundo Leite (1997), “o conceito de gestão de resíduos sólidos abrange atividades referentes à tomada de decisões estratégicas e à organização do setor para esse fim, envolvendo instituições, políticas, instrumentos e meios"; já o termo gerenciamento de resíduos sólidos "refere-se aos aspectos tecnológicos e operacionais trativos, gerenciais, econômicos, ambientais e de desempenho: produtividade e qualidade, por exemplo, e relaciona-se à prevenção, redução, segregação, reutilização, acondicionamento, coleta, transporte, tratamento, recuperação de energia e destinação final de resíduos sólidos”.

Atualmente os resíduos sólidos são melhores gerenciados nos países em desenvolvimento como o Brasil, mas ainda presenciamos diversos impactos ambientais oriundos das deficiências de gestão e gerenciamos no país. 
Os países desenvolvidos apresentam grande experiência nesta questão, em especial após a edição de Diretivas pela União Europeia, que visam proteger o ambiente e a saúde humana.

\subsubsection{A Sociedade Ponto Verde (SPV)}

A PRO EUROPE s.p.r.l. (PACKAGING RECOVERY ORGANISATION EUROPE), fundada em 1996, está baseada em Bruxelas, na Bélgica e constitui-se em uma organização privada, sem fins lucrativos, que atua no mercado europeu com a finalidade de organizar e gerir a reciclagem de embalagens através de um Sistema Integrado de Gestão de Resíduos de Embalagens.

Criada por um conjunto de empresas que colocam embalagens no mercado, coopera com organizações nacionais (Sociedade Ponto Verde) de 35 países, assegurando o cumprimento da legislação comunitária da EU, que determina que todas as empresas embaladoras são responsáveis pela gestão e destino final das próprias embalagens. No entanto, as embaladoras podem delegar essa responsabilidade para a Sociedade Ponto Verde local mediante acordo. 


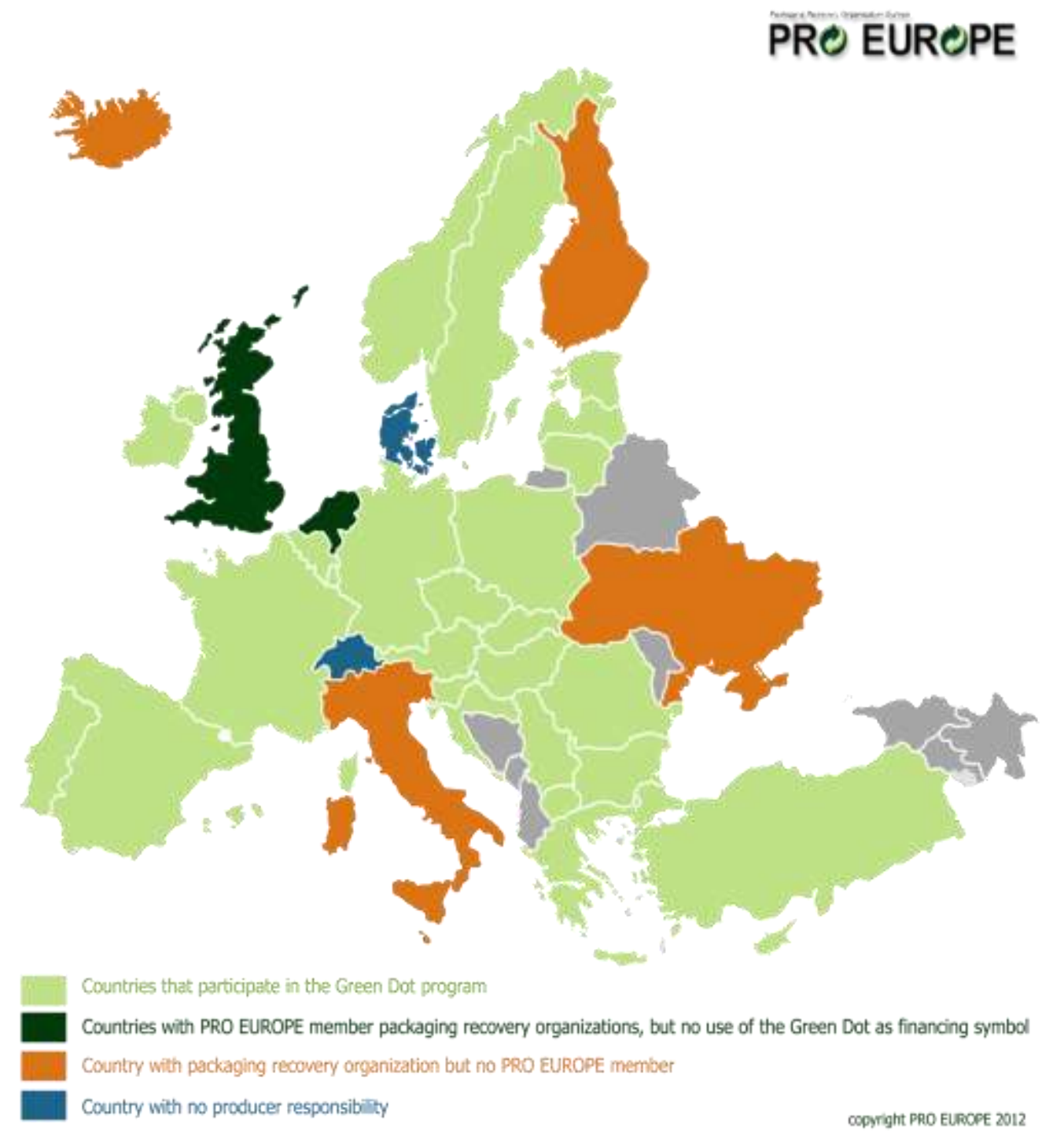

Figura 5. Países que participam do programa Green Dot.

Fonte: PRO EUROPE, 2013.

A PRO EUROPE disponibiliza a utilização de um símbolo (ver figura 6) denominado "Green Dot", através das organizações nacionais que adotarem seus critérios, para as empresas produtoras de embalagens que contribuírem financeiramente com uma determinada quantia à SPV, para que possam arcar com as despesas pela gestão e destino final das próprias embalagens.

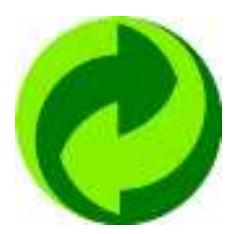

Figura 6. Símbolo Ponto Verde (Geen Dot)

Fonte: PRO EUROPE, 2013. 


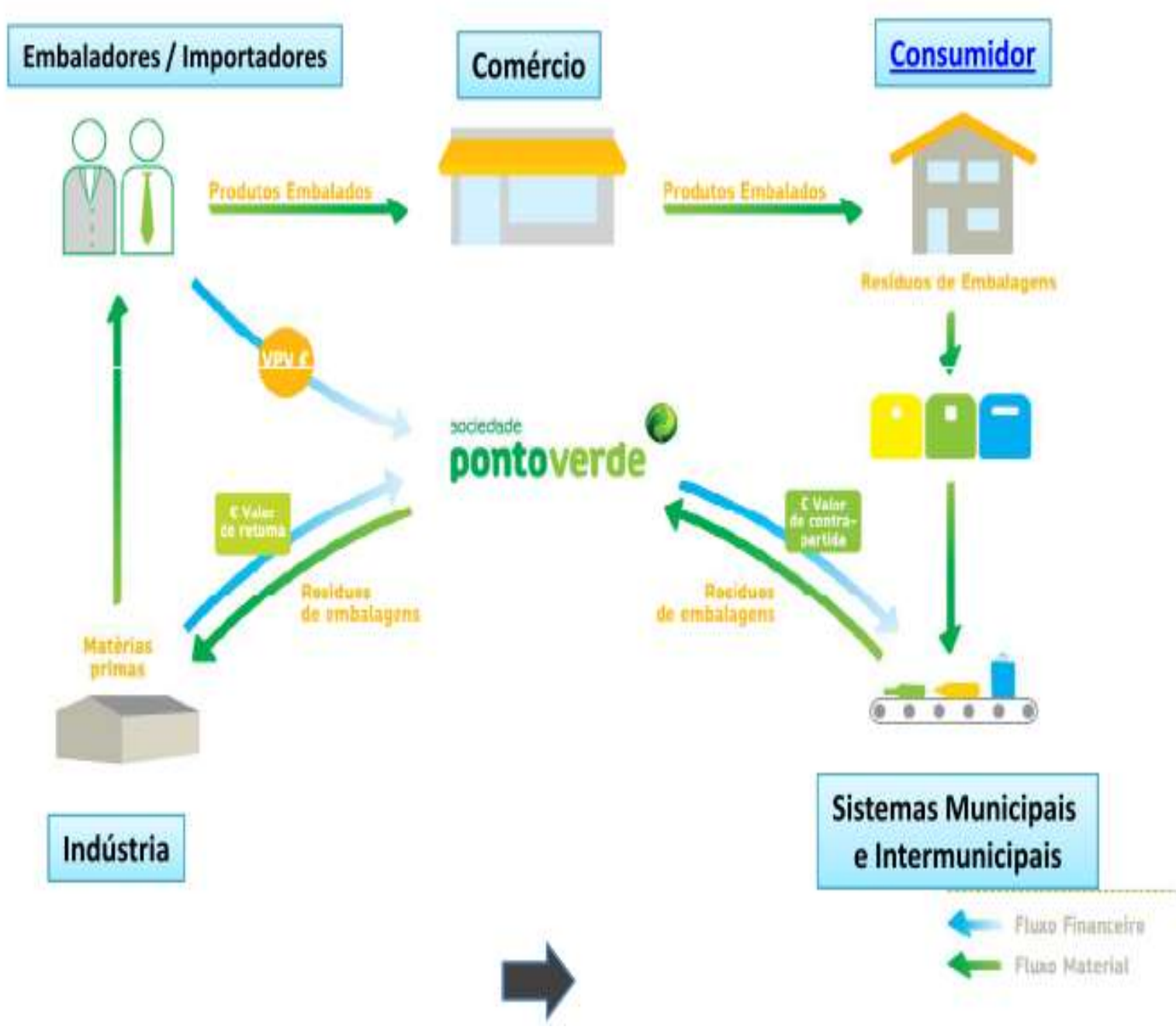

Figura 7. Fluxos do Sistema Integrado de Gestão de Resíduos de Embalagens da Sociedade Ponto Verde

Fonte: SPV, 2013

O símbolo Ponto Verde identificado na embalagem indica que a empresa embaladora pagou um ecovalor (valor Ponto Verde) para SPV se responsabilizar pela sua gestão e destinação, promovendo não só a valorização das embalagens, mas também contribuindo para o cumprimento das metas impostas pela União Europeia.

O Canada formalizou convênio de cooperação com a Sociedade Ponto Verde para adoção de sistema semelhante. O Brasil deveria procurar uma cooperação com a PRO EUROPE, buscando informações e conhecimentos para uma possível adoção de sistema semelhante no país, uma vez que a PNRS determina a implantação de Sistemas de Logística Reversa. 


\subsubsection{Visitas técnicas em Portugal}

Portugal mesmo encontrando dificuldades para cumprir as metas e prazos estabelecidos pelas Diretivas da União Europeia, tem alcançado êxito no seu sistema de gestão, promovendo uma revolução na gestão dos RSU com a implementação de 30 sistemas de consórcios de resíduos sólidos (16 municipais e 14 multimunicipais) e encerrando os 341 lixões que existiam, cobrindo integralmente o país com adequado tratamento dos resíduos produzidos. Cumprindo-se assim, embora com um pequeno atraso, o estipulado no Plano Estratégico dos Resíduos Sólidos Urbanos (PERSU). Atualmente são 23 consórcios, devido ao agrupamento de alguns sistemas.
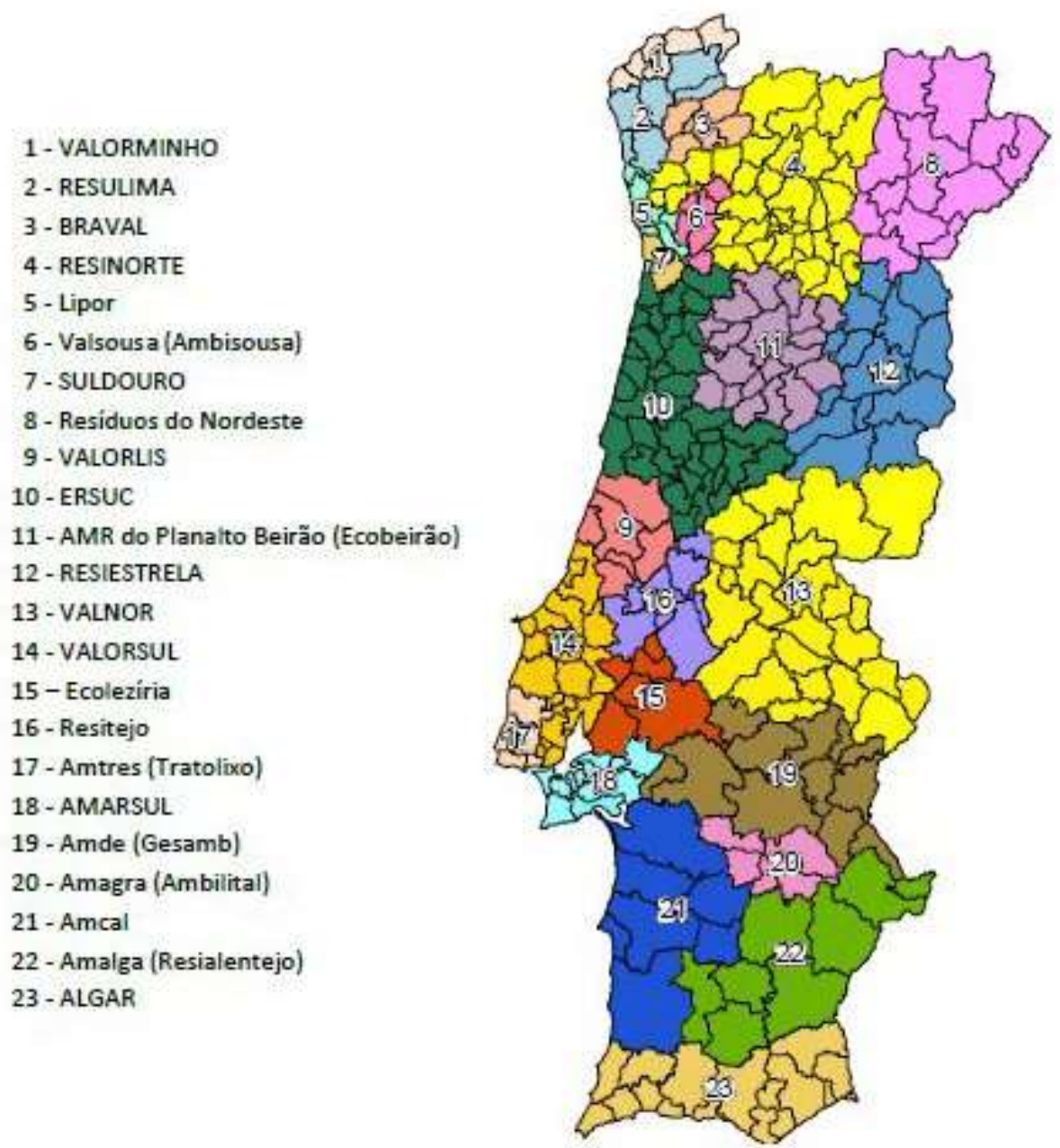

Figura 8: Mapa com a localização dos Sistemas de Gestão de Resíduos - Portugal Fonte: APA, 2011 
O país reorganizou-se criando os seguintes modelos de sistemas de gestão e gerenciamento de resíduos:

- Sistema Municipal: gerido por um município ou uma associação de municípios que não estejam abrangidos por um sistema multimunicipal e que podem ser associados a empresas com qualquer tipo de estrutura de capital;

- Sistema Multimunicipal: sistema que sirva no mínimo a dois municípios e de capital majoritariamente público, sendo obrigatoriamente a sua criação e concessão objetos de Decreto-lei;

- Sistema Intermunicipal: sistema gerido por uma Associação de Municípios, através de uma empresa intermunicipal, concessionária ou não.

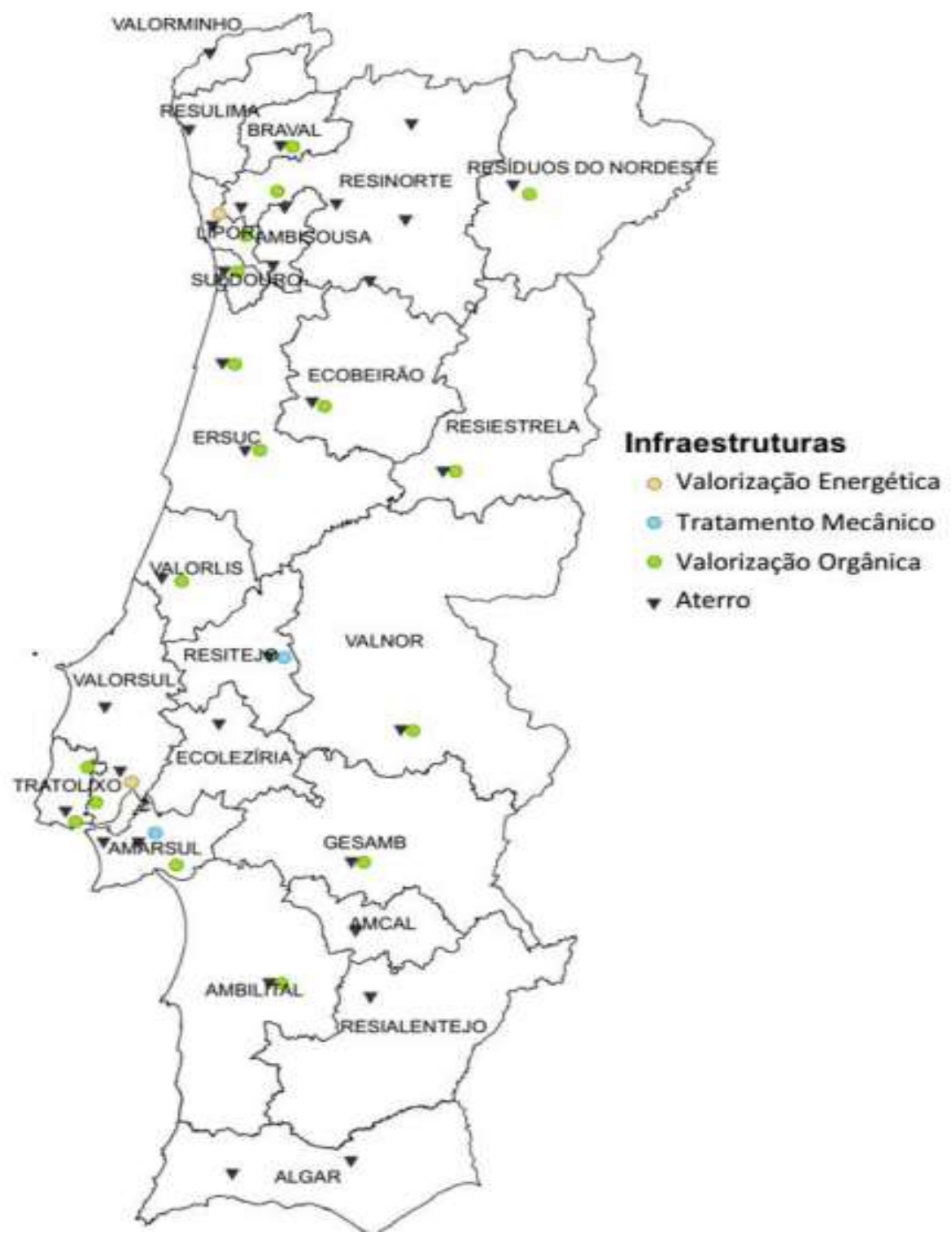

Figura 9: Mapa das infraestruturas e equipamentos - Portugal Fonte: APA, 2011 
O PERSU possibilitou ao país a estruturação de uma ampla rede de apoio a gestão dos seus resíduos, foram implantadas as seguintes infraestruturas e equipamentos:

- 199 ecocentros;

- 30 estações de triagem;

- 90 estações de transferência;

- 11 estações de valorização orgânica;

- 3 estações de valorização energética;

- 41 aterros sanitários;

- 40.938 contentores verdes;

- 34.400 contentores azuis;

- 33.473 contentores amarelos;

- 32.377 ecopontos;

- Recolha porta-a-porta para uma população de 488.426 habitantes.

A Comissão da União Europeia impôs metas para a eliminação dos lixões até o ano de 2000 e verifica-se na figura 6, a evolução do número de erradicação preconizada no PERSU I, porém só alcançada em janeiro de 2002.

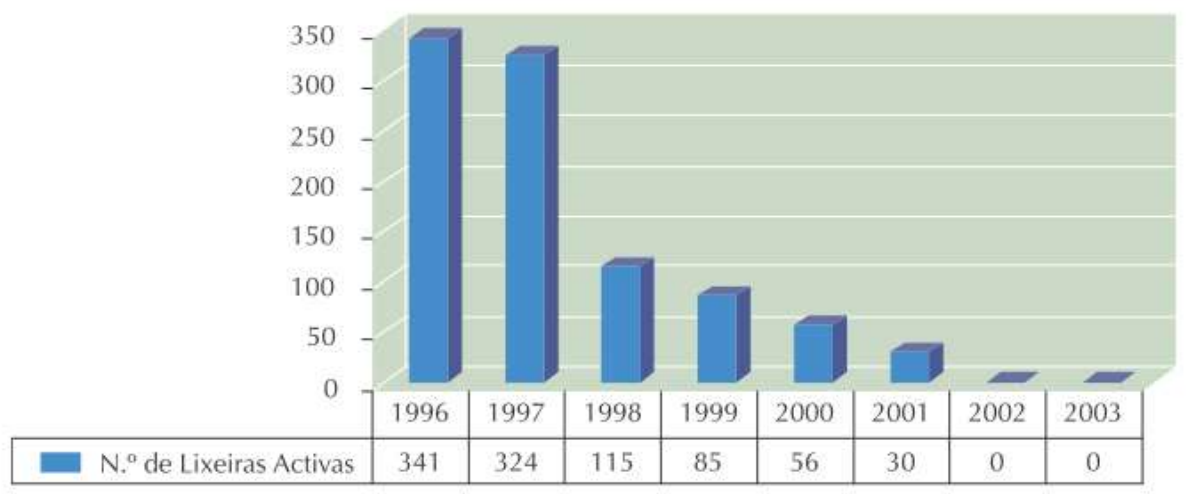

Figura 10: Evolução do número de lixeiras (lixões) entre 1996 e 2003

Fonte: PERSU II, 2011

Também para reciclagem e valorização de embalagens foram definas metas, porém estas foram prorrogadas devido ao atraso de alguns países, entre eles Portugal e em 2005 foi feita revisão da Diretiva para adaptação de prazos. A figura 
11 apresenta a comparação das metas definidas no PERSU I para 2005 e a situação verificada nesse mesmo ano. Observa-se que os objetivos quantitativos para o período não foram atingidos.

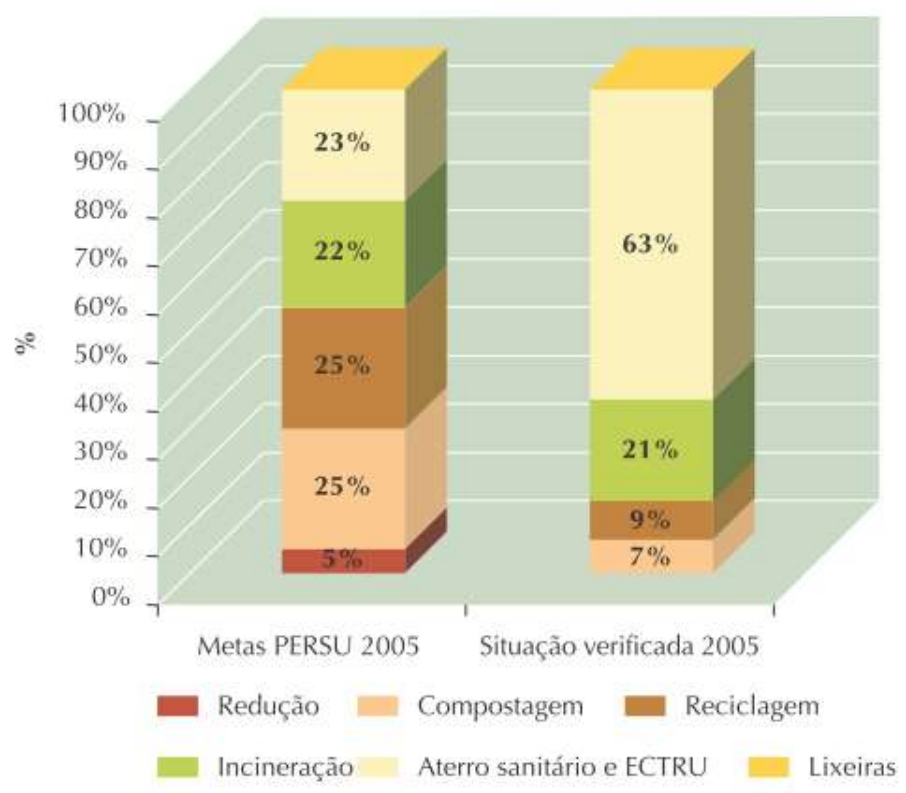

Figura 11: Comparação das metas definidas no PERSU I para 2005 e a situação verificada nesse mesmo ano.

Fonte: PERSU II, 2011

Segundo Russo (2005), o PERSU rompia com o paradigma tradicional do modelo de gestão individual municipal e passou para um novo modelo de "gestão integrada", em âmbito nacional, ou seja, evoluía-se de um sistema individual para uma política específica de RSU, com sistemas geridos por entidades de exploração multi e intermunicipais dos setores público e privado.

\subsubsection{Visita técnica ao Lipor}

O Seviço Intemunicipalizado de Gestão de Resíduos do grande Porto (Lipor) foi fundado em 1982 com objetivos de promover a reciclagem, valorização, tratamento e aproveitamento final dos resíduos sólidos, assim como a gestão, manutenção e desenvolvimento das infraestruturas necessárias.

O consórcio é composto por oito municípios: Espinho, Gondomar, Maia, Matosinhos, Porto, Póvoa de Varzim, Valongo e Vila do Conde, sendo responsável pela gestão de cerca de $10 \%$ do total de resíduos sólidos urbanos produzidos em Portugal. 


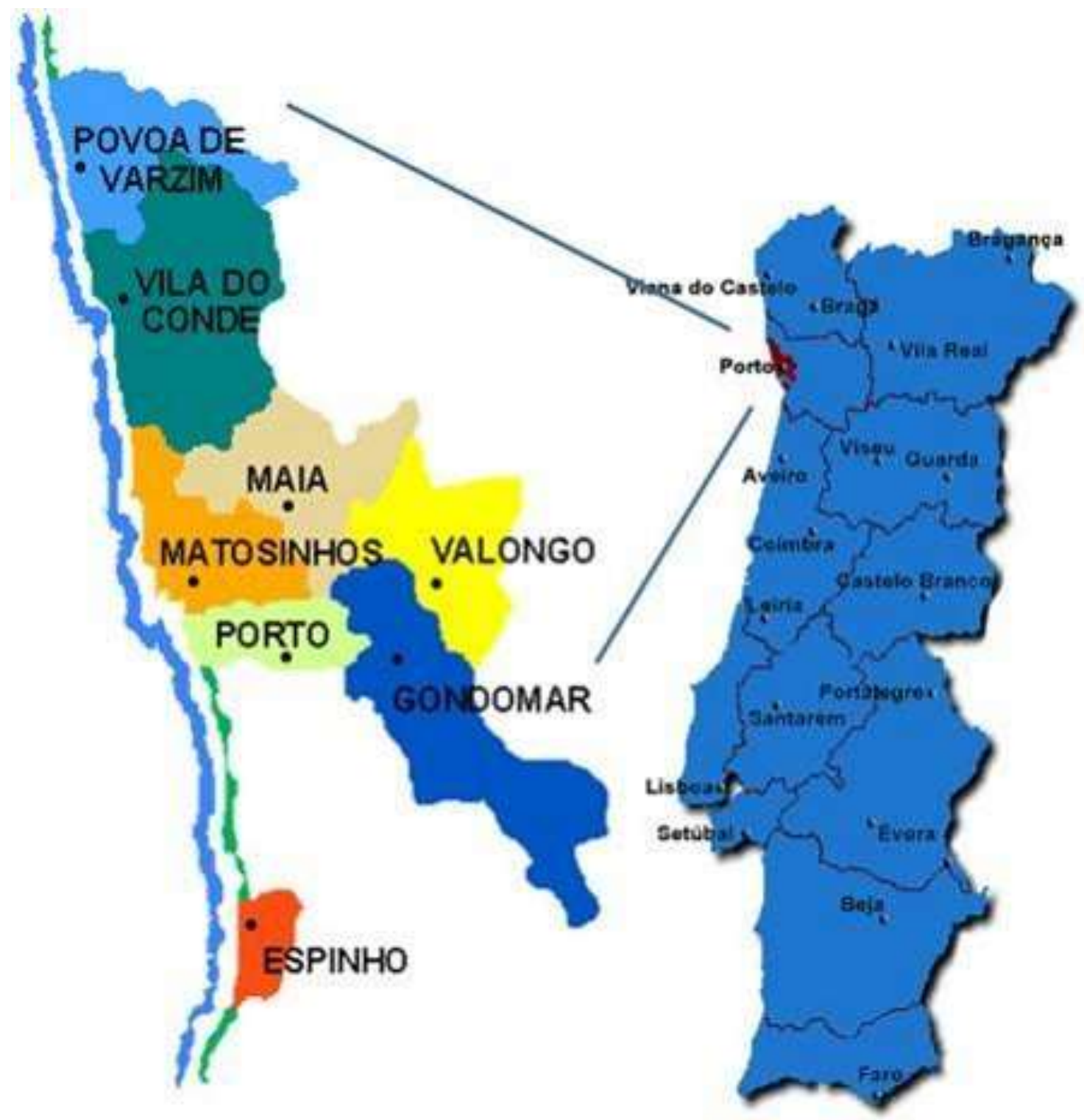

Figura 12. Localização dos municípios que formam a Lipor Fonte: Lipor, 2007

O Lipor desde sua fundação tem procurado evoluir nas mais variadas formas de valorização dos resíduos, objetivando o cumprimento das diretivas estratégicas estabelecidas pela União Europeia. Torna-se exemplo de modelo de gestão integrada de resíduos sólidos não só para Portugal como para outros países como o Brasil. A figura 13 apresenta o sistema da Lipor. 


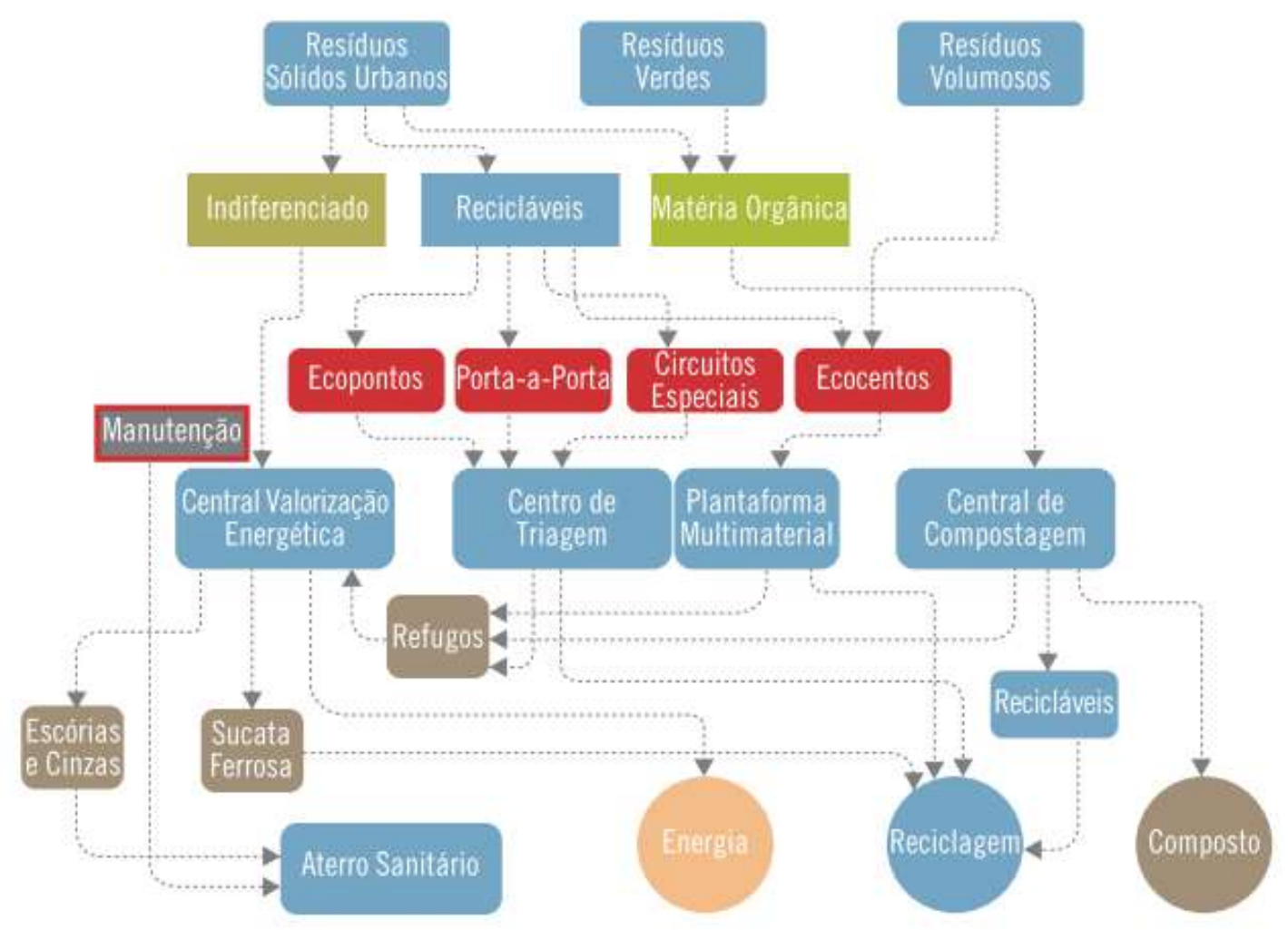

Figura 13. Sistema integrado de gestão de resíduos da Lipor

Fonte: Lipor, 2007

O sistema atende anualmente uma população de 984.987 (Census, 2011), com produção anual de 510.518 toneladas e produção per capita de 1,42 $\mathrm{kg} / \mathrm{hab}$. e tem alcançado objetivos, certificações e prêmios com a gestão sustentável, tais como:

- Inauguração do Centro de Triagem - 1992;

- Certificação Qualidade e Ambiente do Centro de Triagem 2002;

- Certificação Qualidade e Ambiente do Centro de Valorização Energética- 2004;

- Inauguração da Central de Valorização Orgânica - 2005;

- Certificação AS 8000 e Certificação CVO - SIQASS - 2009;

- Prêmio Energy Efficiency Awards no âmbito do Barômetro da Eficiência Energética - 2010. 


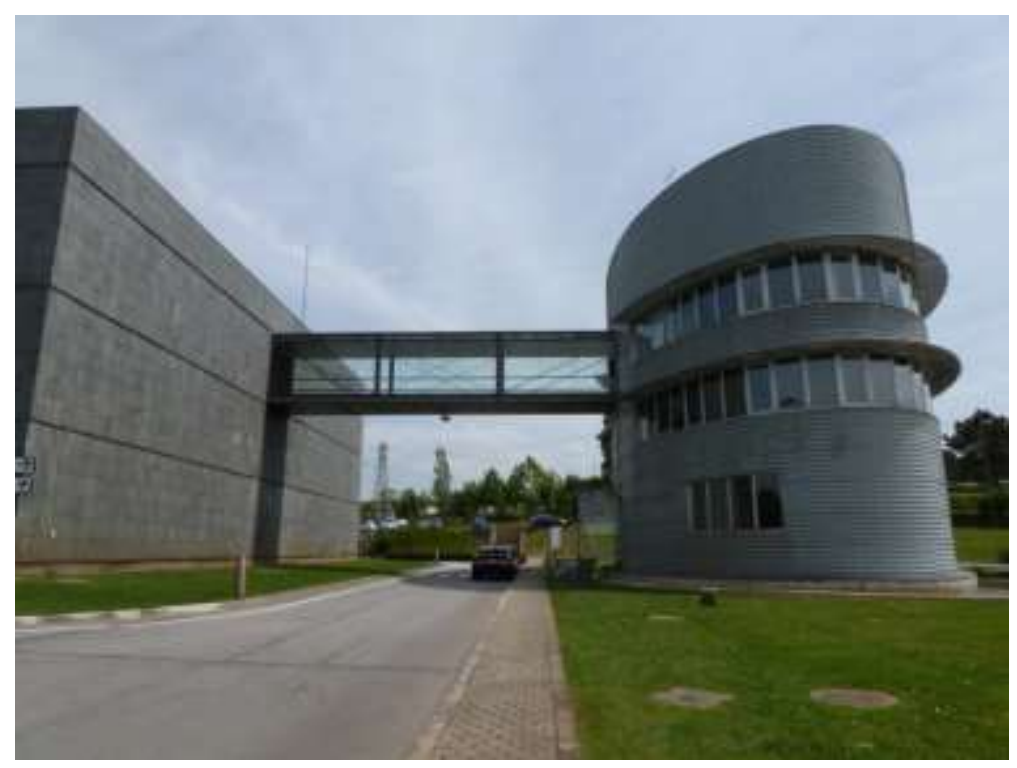

Figura 14. Sede administrativa da Lipor

Fonte: Autor, 2012

Desde que foi constituída como Associação de Municípios em 1982 a Lipor vem desenvolvendo ações no sentido de proporcionar melhorias, ampliando e construindo infraestruturas destinadas a valorizar os resíduos por ela recebidos como:

\section{- CENTRO DE TRIAGEM (CT)}

Possui capacidade de processamento de materiais até 35.000 toneladas por ano, oriundos da coleta comum e de projetos de coleta seletiva, com o objetivo de separar o máximo de materiais a serem reciclados.

O CT conta com duas linhas de processamento, sendo uma para produtos planos, como papel e papelão, e outra destinada aos produtos volumosos, onde são separadas e segregadas as embalagens plásticas e metálicas. 


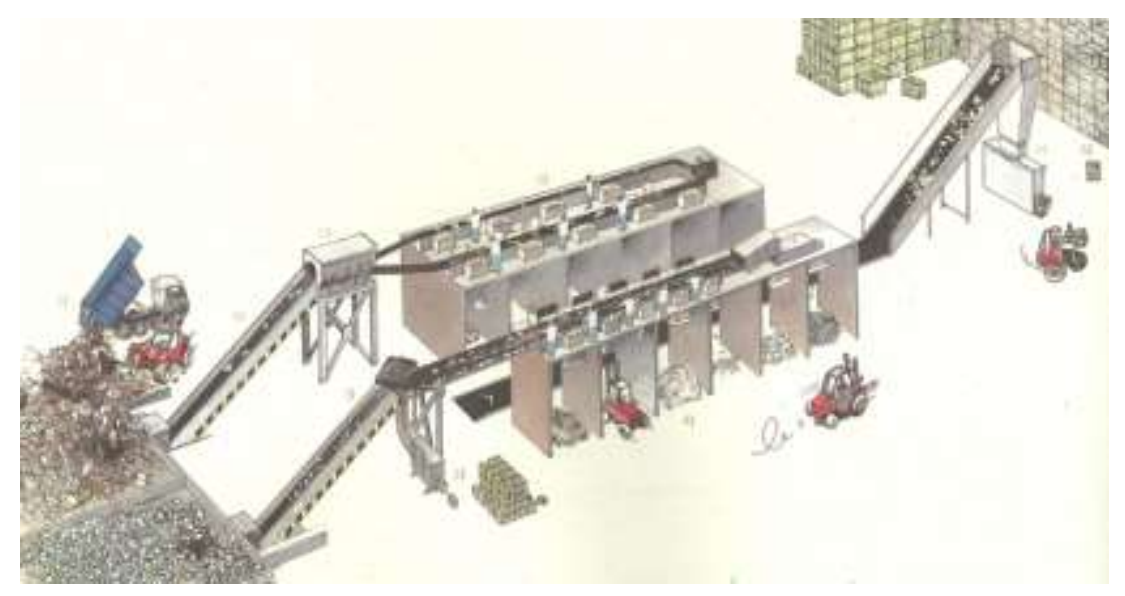

Figura 15. Esquema de triagem de resíduos

Fonte: Lipor, 2012

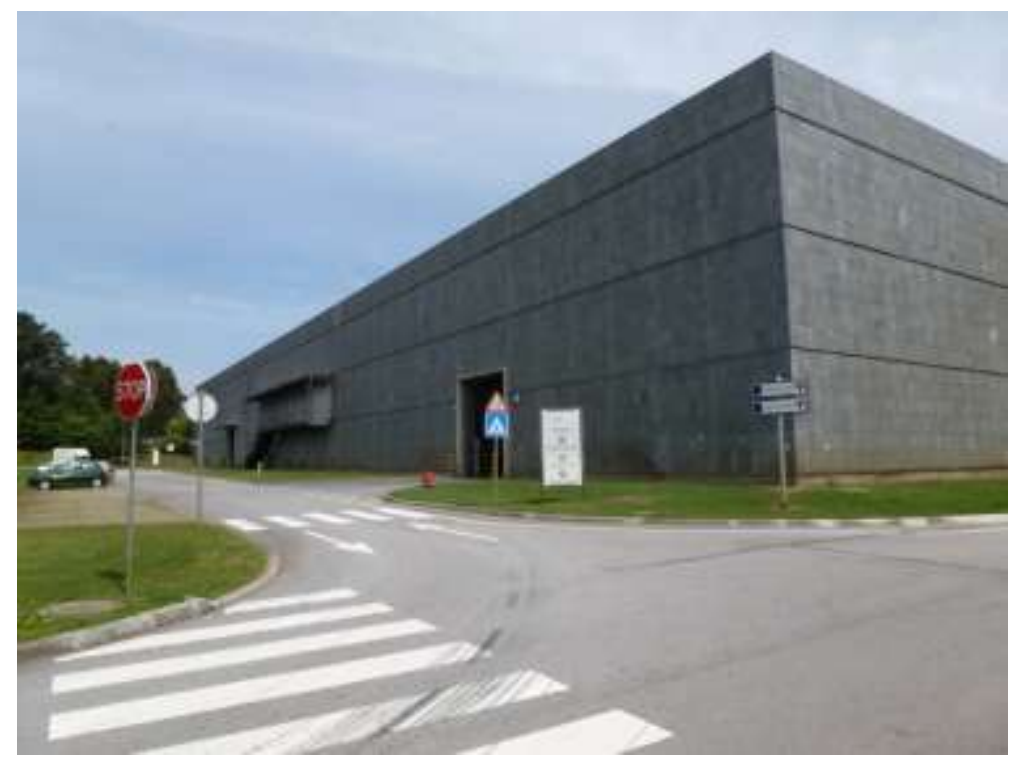

Figura 16. Centro de Triagem da Lipor

Fonte: Autor, 2012

$O$ centro é referência no desenvolvimento ambiental e de qualidade, tendo obtido a certificação segundo as normas NP EN ISO 9001 e NP EN ISO 14001 em 2002 e, posteriormente, em 2006 no âmbito da higiene, segurança e saúde no trabalho, segundo o referencial normativo OHSAS 18001/NP/4397. 


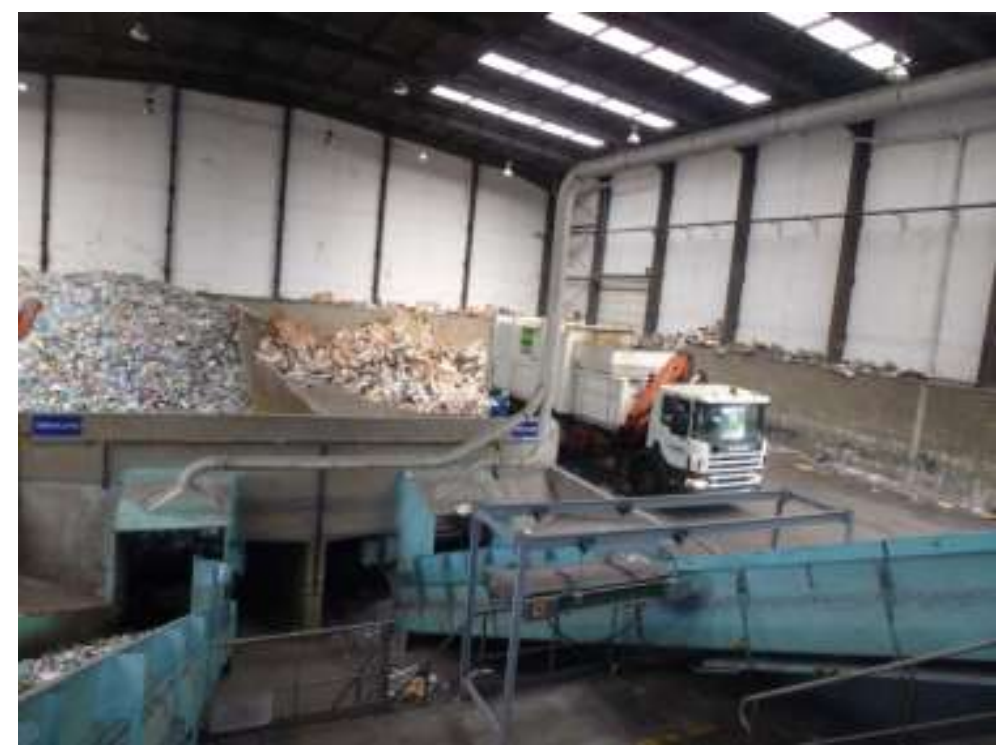

Figura 17. Área de recepção de resíduos

Fonte: Autor, 2012

Todo o material separado pela população e que estejam de acordo com as especificações técnicas determinadas, são submetidos a uma separação suplementar e posteriormente enfardados e acondicionados para serem vendidos para as indústrias recicladoras.

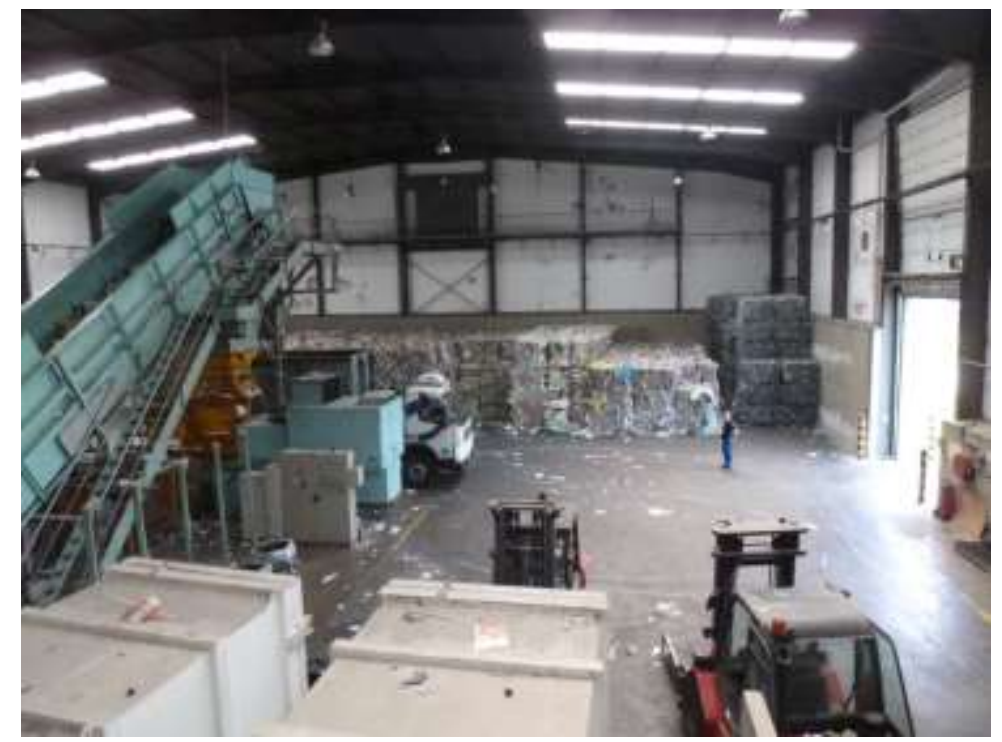

Figura 18. Área de materiais enfardados e acondicionados

Fonte: Autor, 2012 
Os resíduos de equipamentos elétricos e eletrônicos (REEE) depositados no ecocentros ou recolhidos por meio de coleta seletiva são destinados a uma plataforma específica de recepção e triagem para preparação e posterior envio para empresas reutilizadoras ou recicladoras.

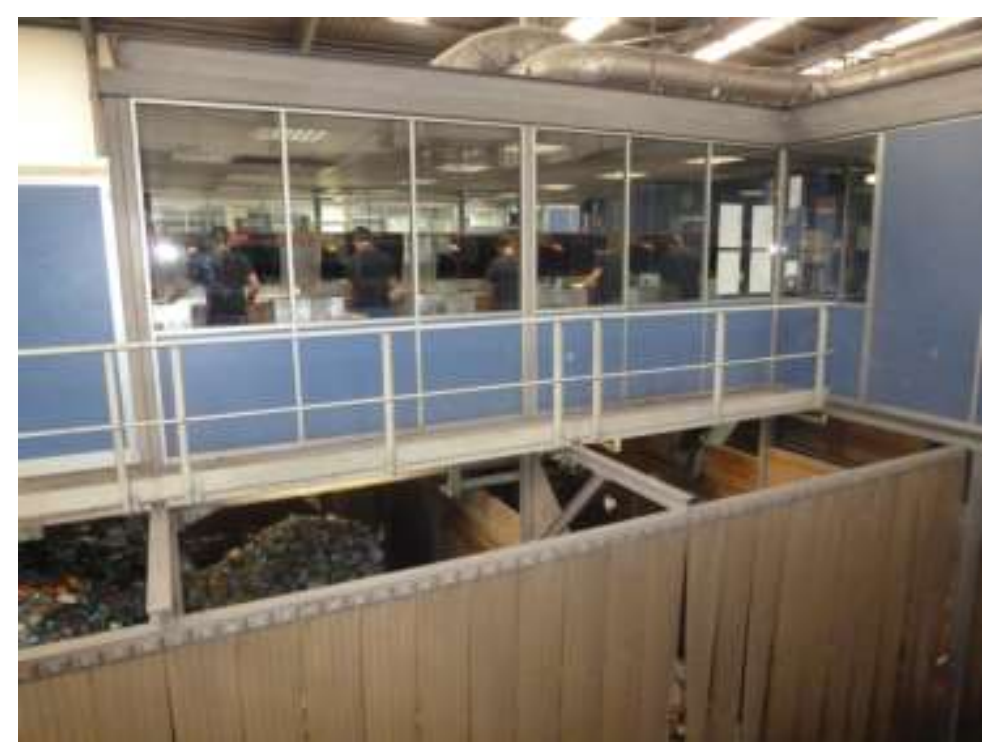

Figura 19. Plataforma de triagem de resíduos

Fonte: Autor, 2012

\section{- CENTRO DE VALORIZAÇÃO ORGÂNICA (CVO)}

A moderna central de compostagem inaugurada em maio de 2005, com capacidade anual de processamento de 60.000 toneladas de resíduos orgânicos por meio de um sistema multi-túnel de degradação microbiológica natural, opera em condições aeróbias otimizadas e controladas, um processo muito rápido de degradação nos túneis devido às condições de elevada aerobiose, resultantes de arejamento e oxigenação intensivos e homogêneos, assim como um controle de temperatura que reduz as emissões de odores.

A produção de um composto orgânico natural de elevado valor agronômico através da compostagem em condições controladas tem sido um dos principais elementos da gestão integrada de resíduos da Lipor. 
A CVO recebe diariamente os resíduos orgânicos provenientes de diversos circuitos de coleta seletiva, bem como resíduos verdes previamente triados em parques, jardins e resíduos verdes de cemitérios.

Anualmente, estima-se a produção de 20.000 toneladas do composto com propriedades benéficas para solos pobres em matéria orgânica, comercialmente denominado de NUTRIMAIS, distribuído nas versões em pó e granulado.

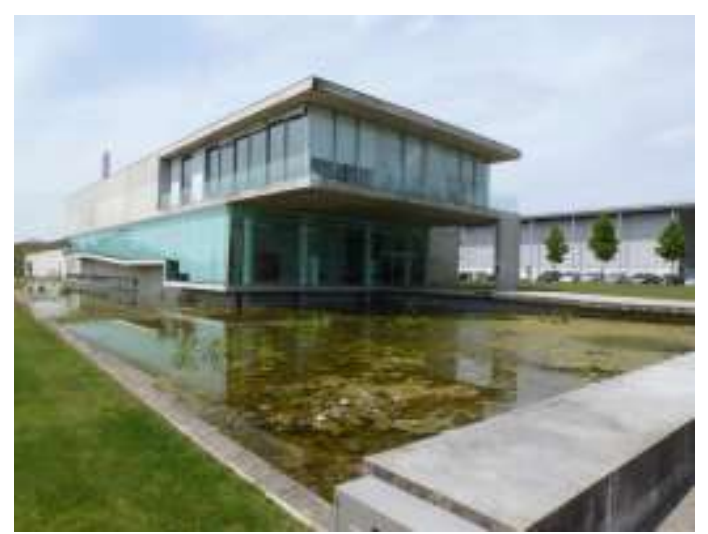

Figura 20 - Centro de Valorização Orgânica

Fonte: Autor, 2011.

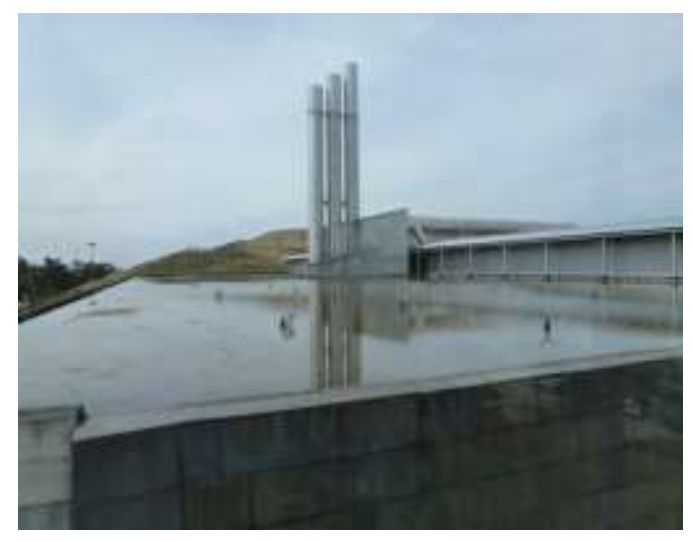

Figura 21 - Cobertura dos tuneis com lâmina d'àgua para resfriamento Fonte: Autor, 2011.

\section{- CENTRO DE VALORIZAÇÃO ENERGÉTICA (CVE)}

Os resíduos que ainda não tem aproveitamento nas cadeias de valorização pela reciclagem e compostagem são encaminhados para a CVE onde são incinerados, aproveitando o seu poder calorífico para produção de energia elétrica.

Situada no município de Maia, possui uma capacidade média instalada para tratamento de um total de até 1.000 toneladas por dia, produzindo cerca de 25 Mwh de energia, que é suficiente para abastecer uma população de 150.000 habitantes. 


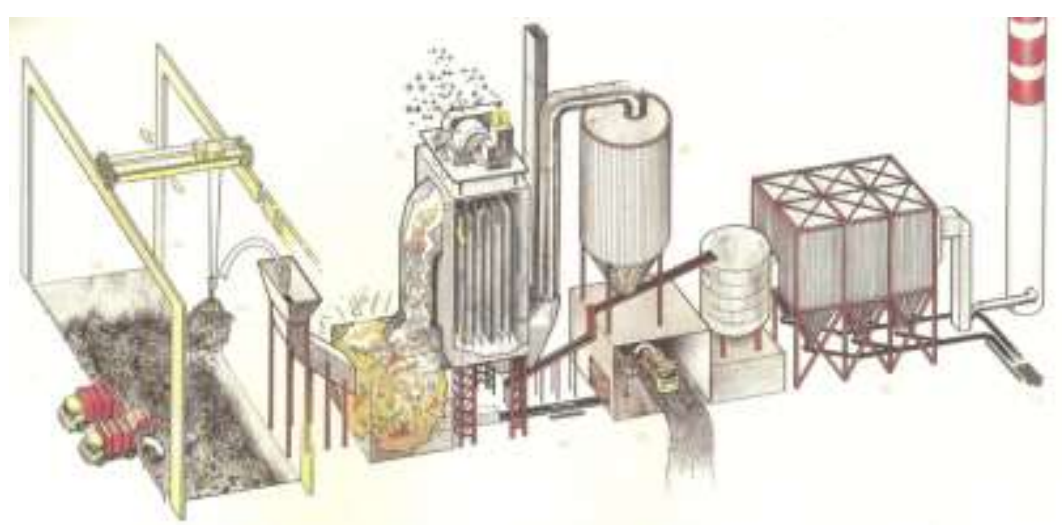

Figura 22. Esquema do Centro de Valorização Energética

Fonte: Lipor, 2012

Os resíduos provenientes dos oito municípios participantes do consórcio são depositados em uma fossa de recepção com capacidade para seis dias de produção e, posteriormente, são transferidos para duas linhas de tratamento, onde são incinerados de forma controlada, a temperaturas elevadas $\left(1000^{\circ} \mathrm{C}\right.$ a $1200^{\circ} \mathrm{C}$ ). Este processo é complementado por um complexo sistema de tratamento de gases, por via semiúmida, o que permite que as emissões gasosas resultantes do processo estejam perfeitamente controladas e, naturalmente, dentro dos limites impostos pela legislação.

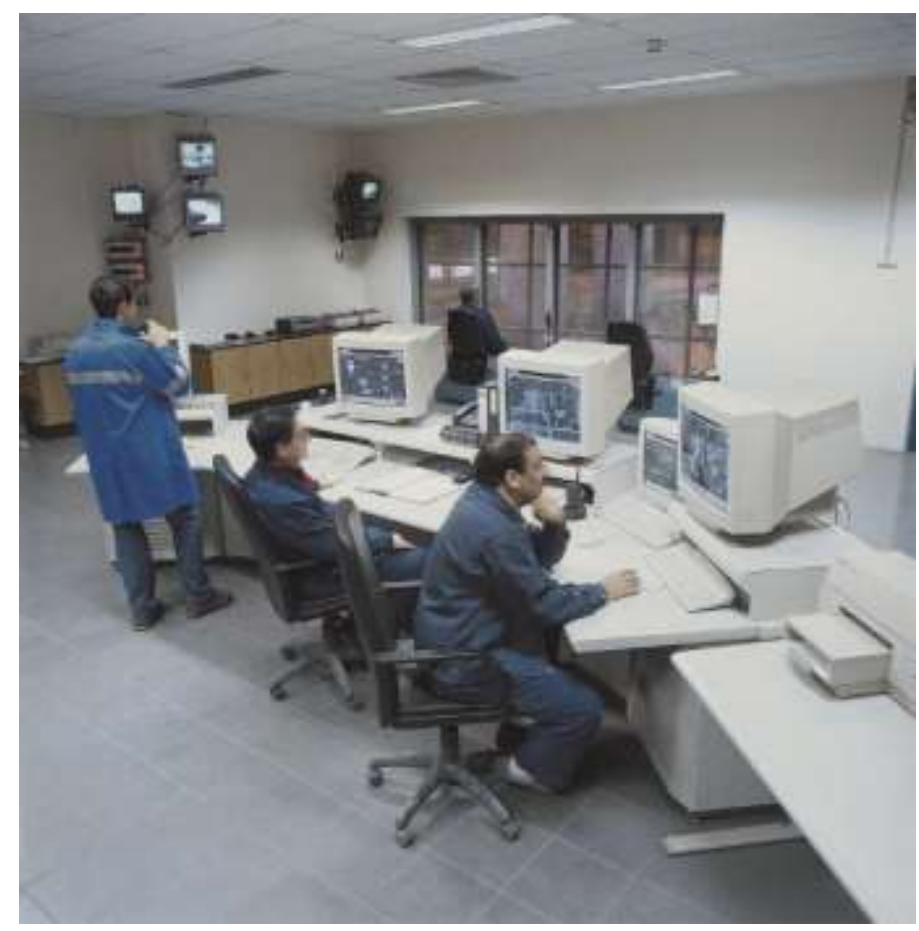

Figura 23. Sala de controle do Centro de Valorização Energética

Fonte: Lipor, 2012 
O processo de incineração produz dois tipos de subprodutos, as escórias e as cinzas. Das escórias é ainda possível separar as sucatas ferrosas, por meio de separadores eletromagnéticos, permitindo, assim, o encaminhamento para o circuito da reciclagem de uma quantidade significativa de metais ferrosos. As cinzas, devidamente inertizadas, são enviadas para o aterro sanitário da Maia e depositadas em um alvéolo específico.

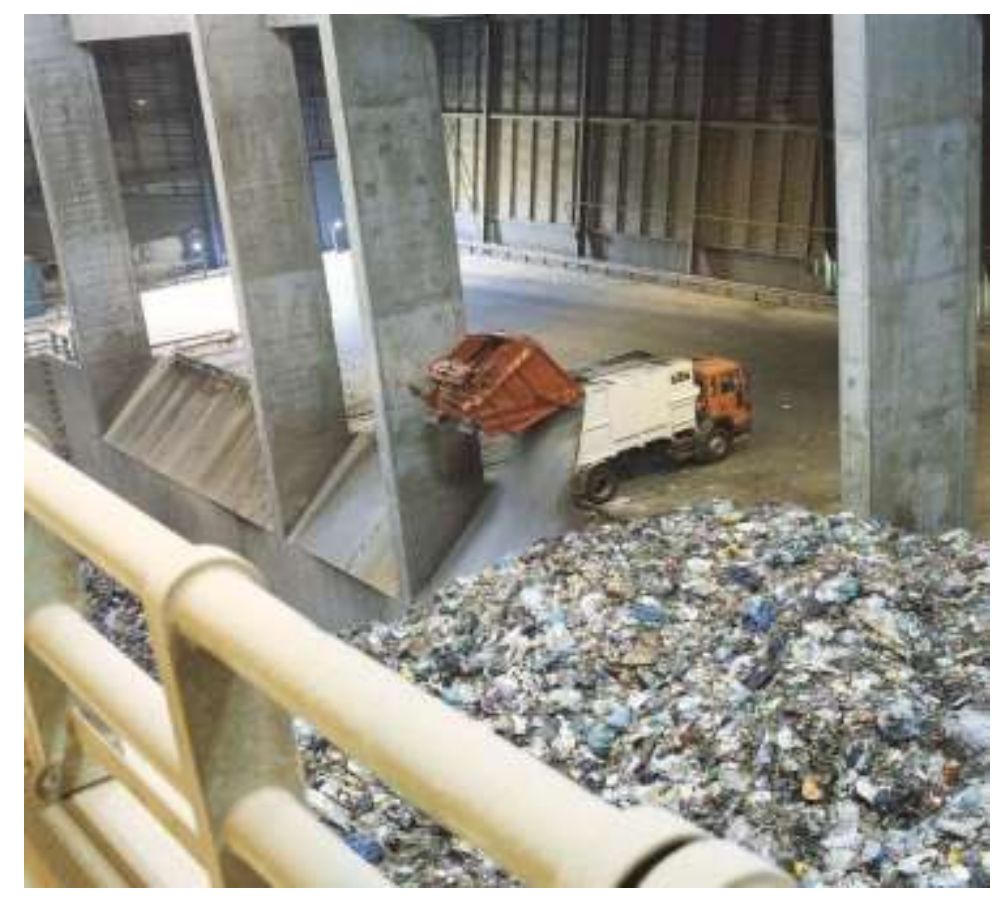

Figura 24. Fossa de recepção do Centro de Valorização Energética

Fonte: Lipor, 2012

\section{- CONFINAMENTO TÉCNICO}

Sendo o confinamento técnico o último estágio do sistema de gestão, valorização e tratamento de resíduos da Lipor, o Aterro Sanitário da Maia torna-se uma infraestrutura indispensável para o fechamento deste ciclo. Inaugurado em 2001 em uma área anexa a Central de Valorização energética, possui capacidade útil para deposição de $520.000 \mathrm{~m} 3$ de subprodutos resultantes do processo de valorização energética e resíduos brutos originários de qualquer um dos polos de tratamento da Lipor, quando estes momentaneamente estiverem impossibilitados de tratá-los. 
Possui dois alvéolos, organizados em três monoaterros específicos, sendo um para cada tipo de resíduos, permitindo acondicionar de forma segura os subprodutos da Central de Valorização Energética, as escórias e as cinzas após um processo de inertização, enquanto que os resíduos brutos são encaminhados a um terceiro monoaterro.

\section{- PROJETOS DE COLETA SELETIVA}

O sistema da Lipor vem desenvolvendo e implementado projetos de circuitos para coleta seletiva de resíduos, procurando atender às necessidades da população e das metas projetadas. Estão sendo executados os seguintes projetos:

- Coleta Seletiva Porta a Porta.

O Sistema Porta a Porta é peça fundamental no âmbito do projeto da Reciclagem Multimaterial, sendo um sistema de coleta seletiva de resíduos de embalagens plásticas e metálicas, e de papel e papelão, em dias de semana e horários pré definidos. A forma de acondicionamento de resíduos varia consoante a tipologia das habitações das zonas alvo, podendo ser por sacos, cestos ou contentores coloridos. Os recipientes azuis são utilizados para depositar a fração de papel e cartão, enquanto que os amarelos são usados para a deposição seletiva da fração de embalagens plásticas e metálicas.

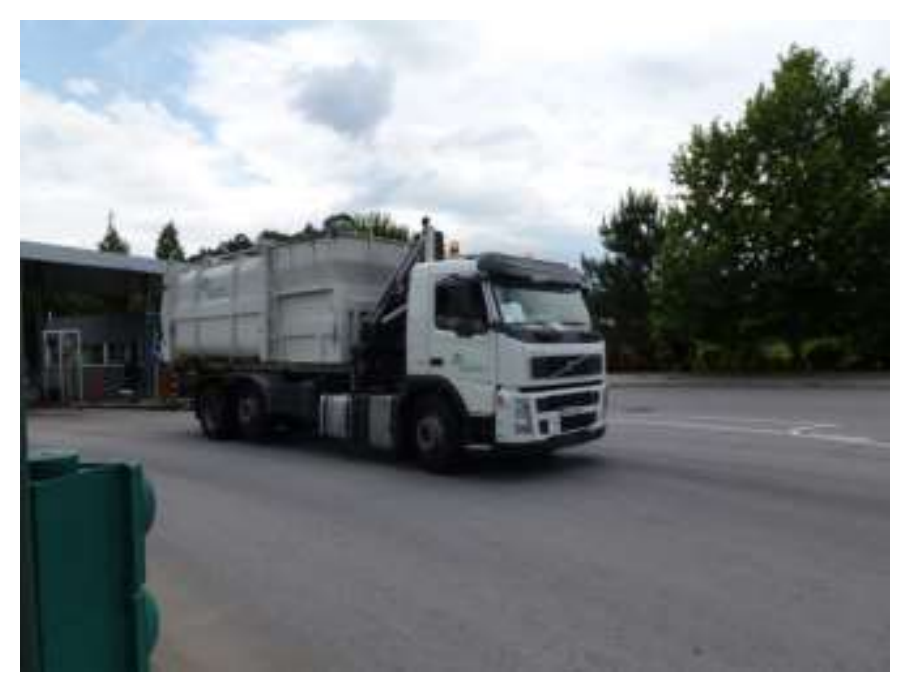

Figura 25. Equipamento de coleta de resíduos Fonte: Autor, 2012 
- Ecopontos.

O sistema de ecopontos é o mais utilizado pela população, sendo constituído por um conjunto de contenedores para o depósito de resíduos e normalmente estão dispostos também recipientes vermelhos que se destinam ao descarte de pilhas e baterias.

A rede de ecopontos conta com cerca de 2.850 unidades, contabilizando os ecopontos situados na via pública e os das escolas, estando à disposição dos munícipes 1 ecoponto para 390 habitantes.

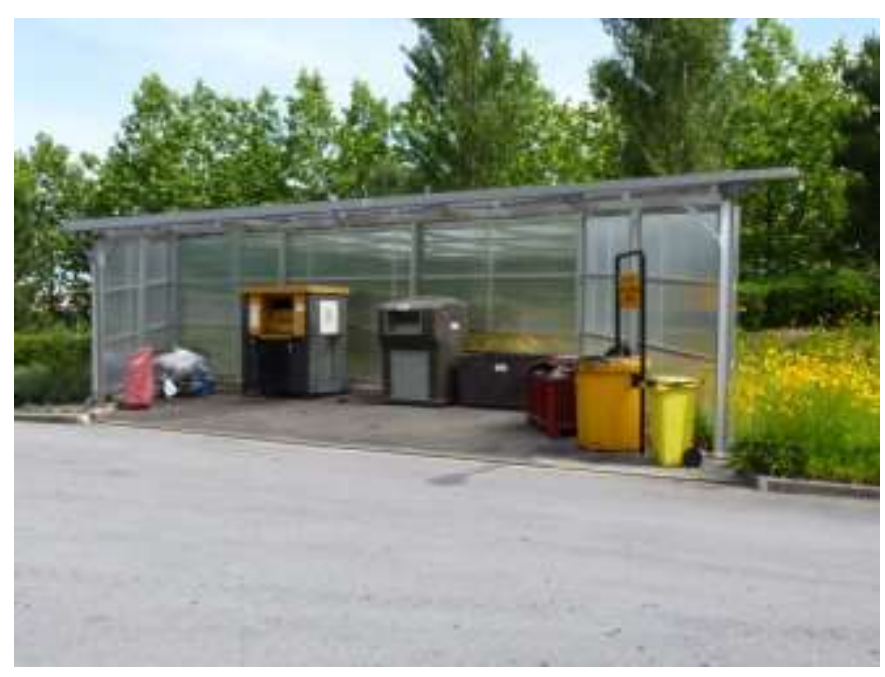

Figura 26. Ecoponto

Fonte: Autor, 2012

\section{- Ecocentros.}

São unidades amplas e cercadas que possuem um conjunto de contenedores de grandes dimensões, destinados à coleta seletiva de materiais valorizáveis. A disposição de resíduos é feita de forma voluntária e gratuita, podendo ser depositados materiais diversos, como papel, papelão, plástico, vidros, resíduos verdes, madeiras, volumosos, de sucatas metálicas e não metálicas, entulhos, resíduos de equipamentos elétricos e eletrônicos, pilhas baterias e óleos de motor, entre outros. 


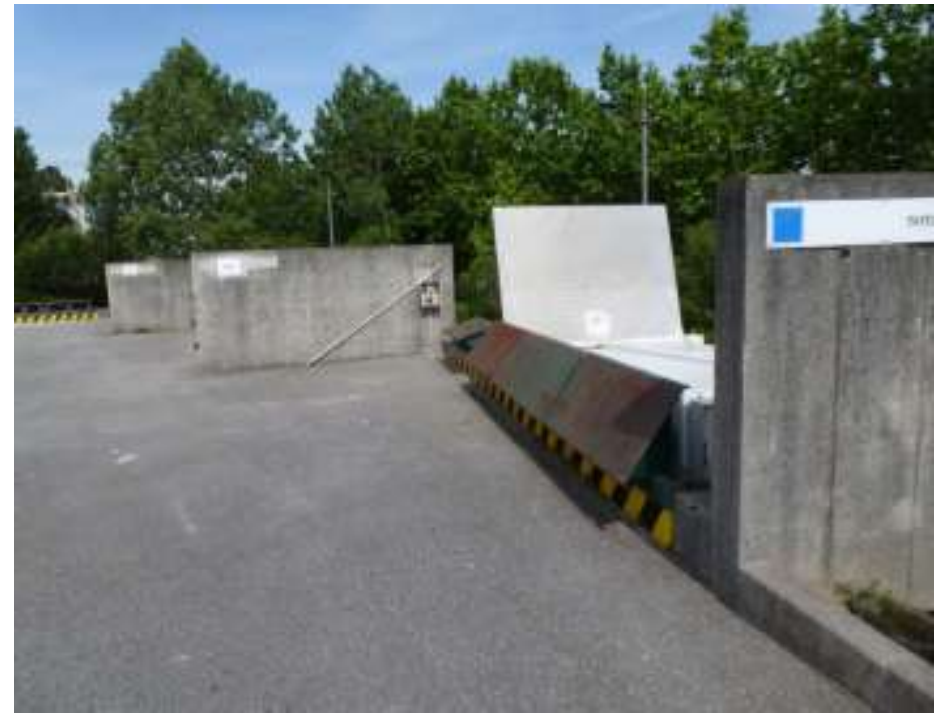

Figura 27. Ecocentro

Fonte: Autor, 2011.

\section{- Ecofone.}

É um serviço gratuito de coleta de resíduos (papel e cartão, vidro, embalagens de plástico e metal), disponível através de uma linha telefônica, para todos os habitantes da cidade do Porto, com especial incidência nos setores do comércio, serviços e restauração. É agendado o dia e hora da coleta com o cliente, sendo que a quantidade mínima de resíduos não pode ser inferior a $10 \mathrm{~kg}$. 0 projeto já efetuou mais de 52.000 coletas junto a empresas, estabelecimentos comerciais e residenciais, totalizando mais de 2.189 toneladas.

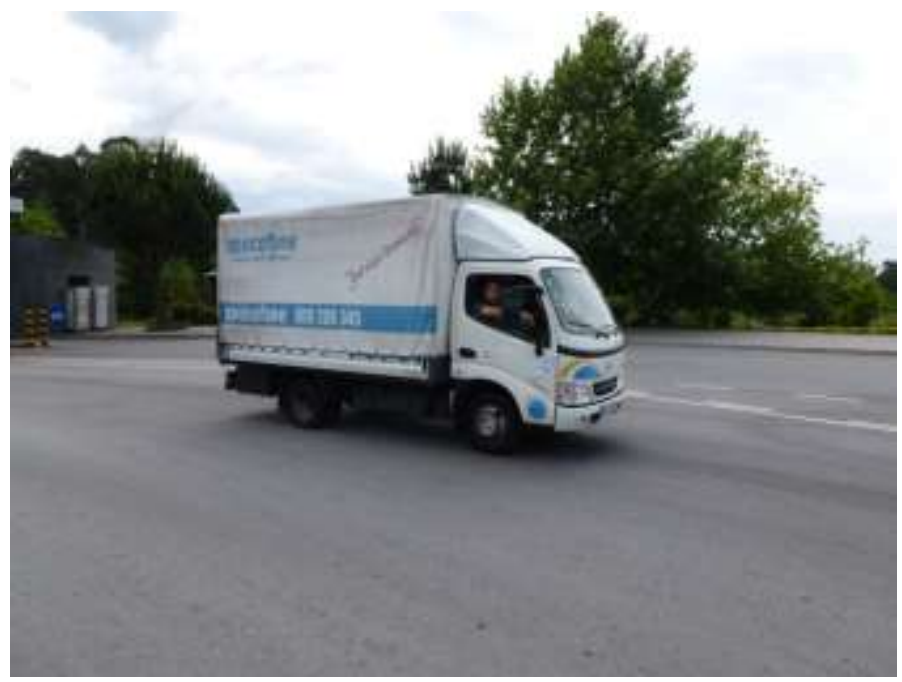

Figura 28. Veículo utilizado no Projeto Ecofone Fonte: Autor, 2012 
- Ecomóvel.

Coleta em domicílio de materiais recicláveis, através de agendamento telefônico do dia e horário de coleta.

- Projeto C\&D.

É um serviço destinado a coleta e valorização dos resíduos da construção e demolição, especificamente de materiais recicláveis (papel e papelão, plásticos, metais/sucatas, embalagens de madeiras provenientes de canteiros de obras localizados nos municípios associados). São utilizados big bags, devidamente identificados, para a disposição correta dos materiais no local da obra.

- Educação Ambiental.

Em 1996 foi criado o Gabinete de Informação Lipor (GIL) para promoção de diversas atividades, com o objetivo de sensibilizar a população no sentido de adotar práticas mais sustentáveis em relação aos resíduos sólidos.

Para tanto a Lipor dispõe de dois ambientes destinados a educação e sensibilização ambiental, sendo uma exclusiva para crianças (figura 30) e outra para a população em geral (figura 31).

São desenvolvidas ações e atividades para adoção de atitudes ambientalmente corretas em relação a água, a energia, a mobilidade e as questões de sustentabilidade, como redução, reutilização e separação na origem dos resíduos sólidos. 


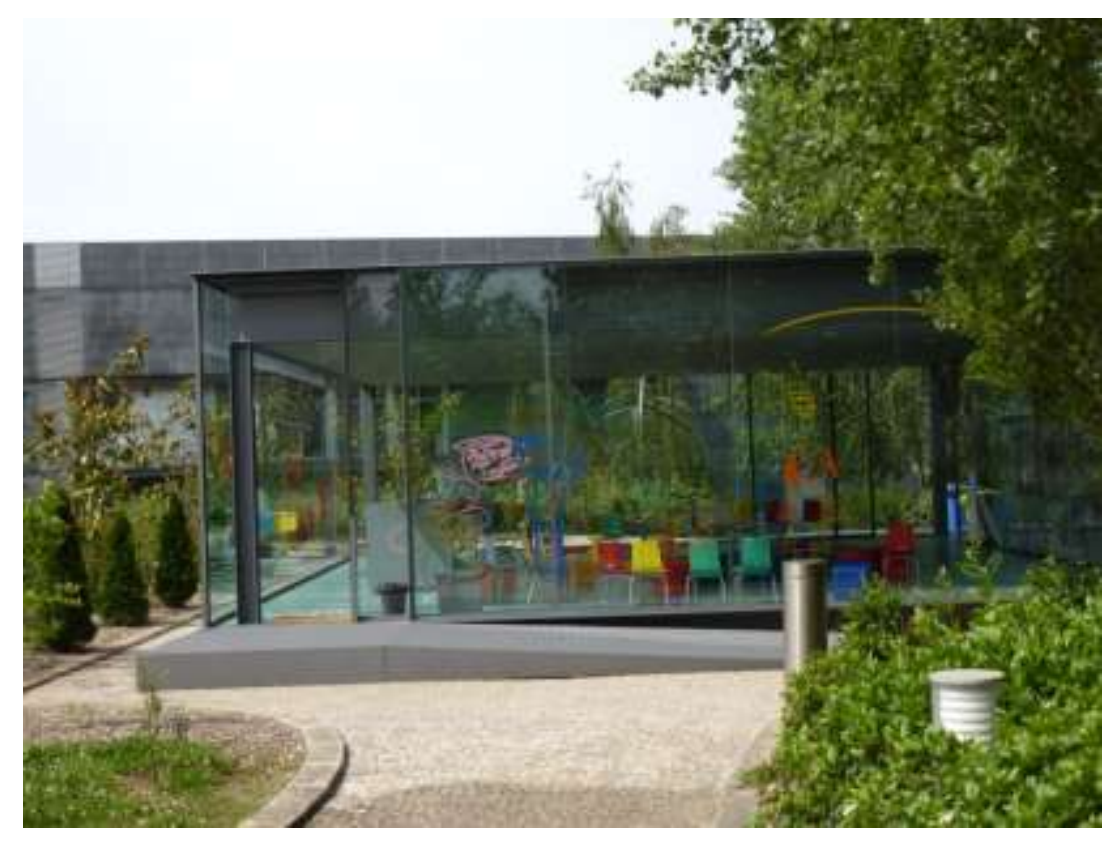

Figura 29. Centro de educação ambiental

Fonte: Autor, 2012

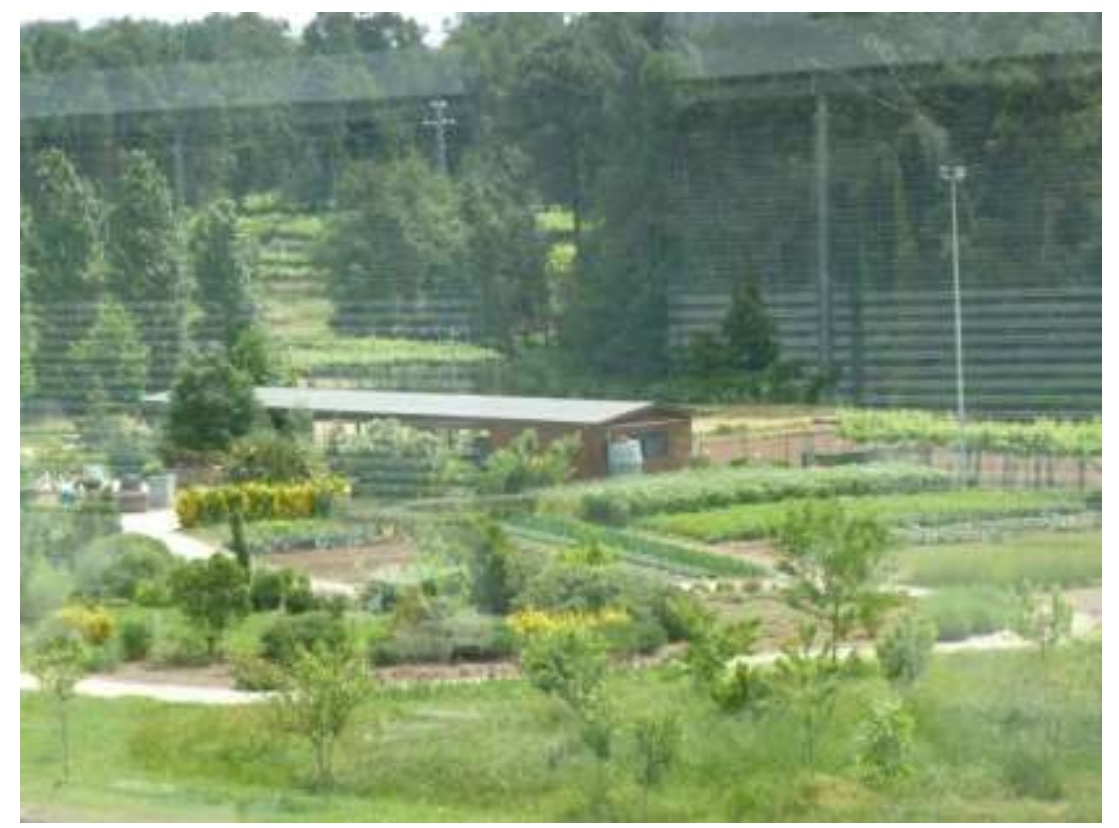

Figura 30. Centro de educação Horta da Formiga

Fonte: Autor, 2012 


\subsubsection{Visita Técnica ao Ambisousa}

A Empresa Intermunicipal de Tratamento e Gestão de Resíduos Sólidos (Ambisousa) iniciou suas atividades em 25 de novembro de 2002 cobrindo a área geográfica do Vale do Sousa e o consórcio é composto por seis municípios: Castelo de Paiva, Felgueiras, Lousada, Paços de Ferreira, Paredes e Penafiel.

A sede situa-se em Lousada, atende uma população estimada de 330.000 habitantes, atuando na exploração da atividade de recolha, transferência, tratamento e deposição de resíduos sólidos, de tratamento e rejeição de efluentes, e de limpeza e higiene públicas.

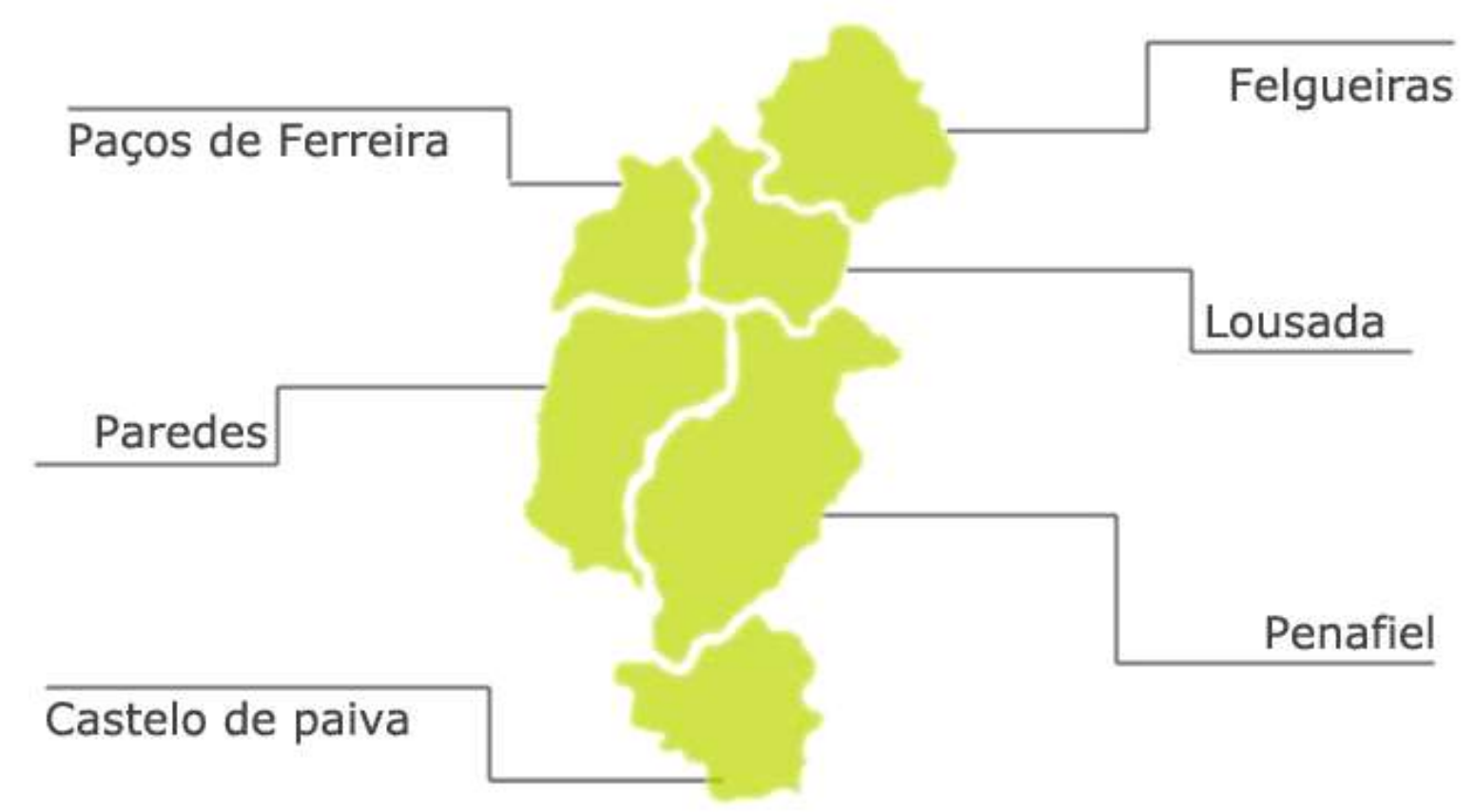

Figura 31. Municípios que integram a Ambisousa Fonte: Ambisousa, 2011

Cronograma dos principais atividades de gestão da Ambisousa:

- 14/10/2002 - Criação da Ambisousa;

- 02/01/2003 - Início da Exploração da Estação de Triagem de Lustosa;

- 02/07/2003 - Início da Exploração do Aterro Sanitário de Penafiel; 
- 24/11/2004 - Início da Exploração do Aterro Sanitário de Lustosa;

- 02/10/2006 - Início da Exploração da Estação de Triagem de Cristelo;

- 12/07/2007 - Início da Exploração da Central de Valorização Energética de Biogás da Pan-Eco Ambisousa Energias Renováveis, Ltda;

- 27/04/2009 - Início da Exploração da Central de Valorização Energética de Biogás do Aterro Sanitário de Lustosa;

- 02/06/2010 - Início da Exploração Aterro para Resíduos de Construção e Demolição de Rio Mau;

- 02/06/2010 - Início da Exploração da Estação de Triagem de Penafiel.

- INFRAESTRUTURAS:

- Aterro Sanitário de Lustosa

Situado na Serra de Campelos na freguesia de Lustosa, o aterro (Figura 33) iniciou suas atividades em 1998, com previsão de um tempo de vida útil de 10 anos e capacidade para receber 420.000 toneladas de resíduos urbanos, não perigosos, dos municípios consorciados. Em fevereiro de 2004 a sua capacidade de recepção foi atingida precocemente e em novembro do mesmo ano um novo alvéolo foi construído, quando a Ambisousa assumiu a sua gestão.

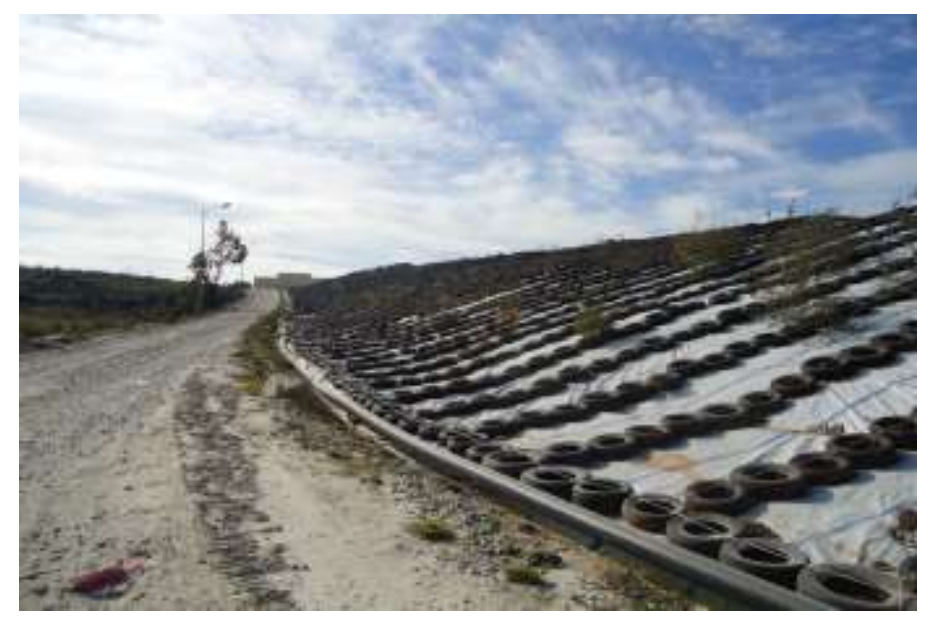

Figura 32. Aterro Sanitário de Lustosa

Fonte: Autor, 2011 
- Central de Valorização Energética de Lustosa

$\mathrm{O}$ aterro recebeu tratamento para se adequar as normas europeias e foi impermeabilizado na sua cobertura com manta PAD, fixada por meio de pneus descartados pela população.

Uma empresa italiana foi contratada para perfurar poços de coleta e instalar tubulações condutoras para coleta do biogás produzido, evitando assim a emissão de gases de efeito estufa.

Uma Central de Valorização Energética (Figura 34) foi construída no ano de 2009, sendo operada com o gás coletado no aterro e no ano de 2010 produziu 4.232.926 Kwh, sendo suficiente para abastecer as instalações da área do aterro e o excedente vendido para a concessionária de energia.

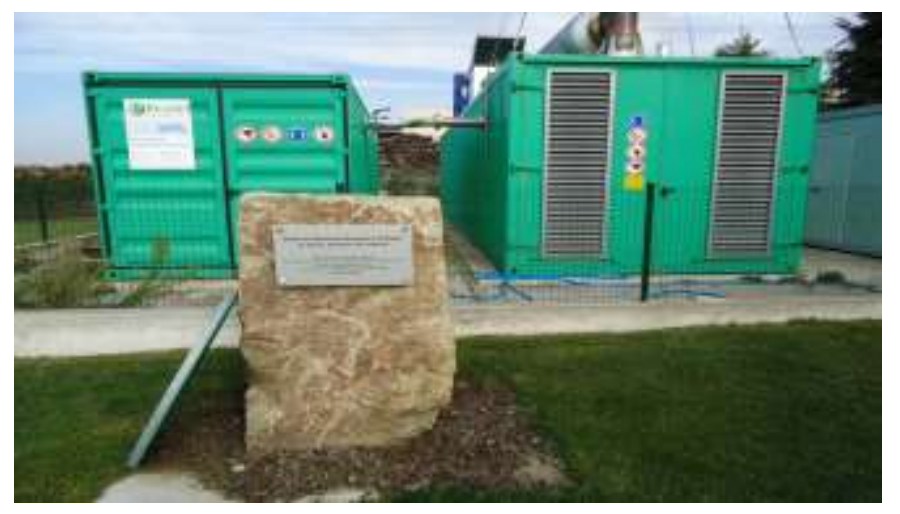

Figura 33. Central de Valorização Energética de Lustosa

Fonte: Autor, 2011

\section{- Aterro Sanitário de Penafiel}

Inaugurado no ano de 1999 para atender os conselhos de Castela de Paiva, Paredes e Penafiel, foi delegado a responsabilidade de sua exploração à Ambisousa no ano de 2003.

Construído na encosta de uma montanha da Serra da Boneca, em Penafiel, ocupa uma área de 5,4 hectares para disposição de resíduos domiciliares. 


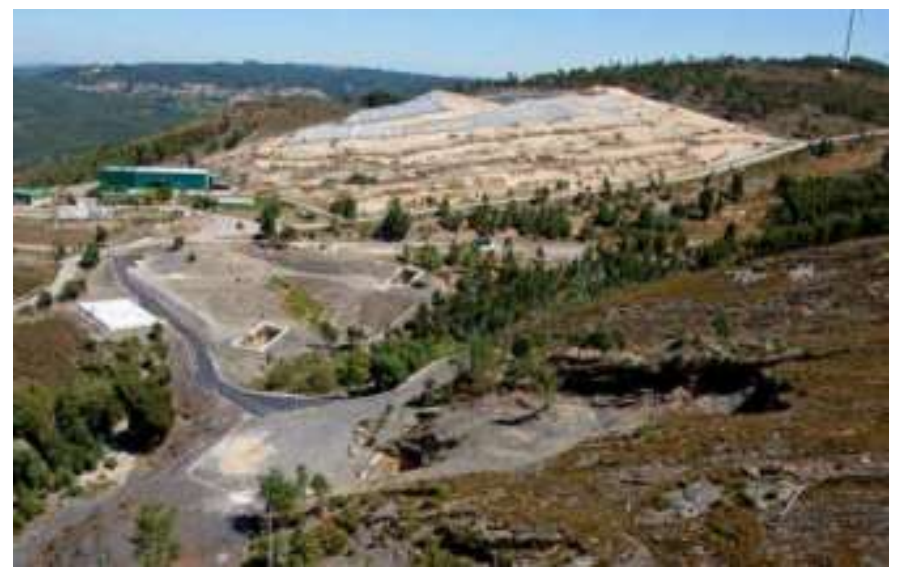

Figura 34. Aterro Sanitário de Penafiel

Fonte: Ambisousa, 2012

- Aterro de Inertes de Rio Mau

Paralelamente aos aterros sanitários de Penafiel e Lustosa, a Ambisousa possui um aterro de inertes no município de Penafiel, com capacidade total de 124.000 toneladas. Este aterro destina a deposição de resíduos provenientes de obras de construção, reforma e demolição, não passíveis de valorização.

O aterro está possibilitando a requalificação ambiental de uma antiga área de exploração de pedra ardósia, que com a extração resultou numa área com significativas alterações no meio ambiente. 0 aterramento por meio de resíduos de construção e demolição permitirá a recomposição aproximada do relevo original e a criação de parque para recreação.

- Central de Triagem de Lustosa

Esta estação separa os resíduos sólidos urbanos provenientes da coleta seletiva, com exceção dos vidros que são encaminhados diretamente dos recipientes coletores para as indústrias recicladoras.

Os resíduos recebidos são encaminhados a uma esteira e transportados para uma plataforma de triagem, onde os materiais volumosos são separados manualmente e, posteriormente, segregados da seguinte forma: 
- Papel e papelão;

- Embalagens de politereftalato de etileno (PET);

- Embalagens de polietileno de alta densidade (PEAD);

- Sacos e embalagens de filme plástico;

- Embalagens de poliestireno expandido;

- Embalagens de cloreto de polivinila (PVC);

- Metais ferrosos separados por um eletroímã;

- Metais não ferrosos;

- Rejeitos (depositados em um conteiner situado ao final da esteira).

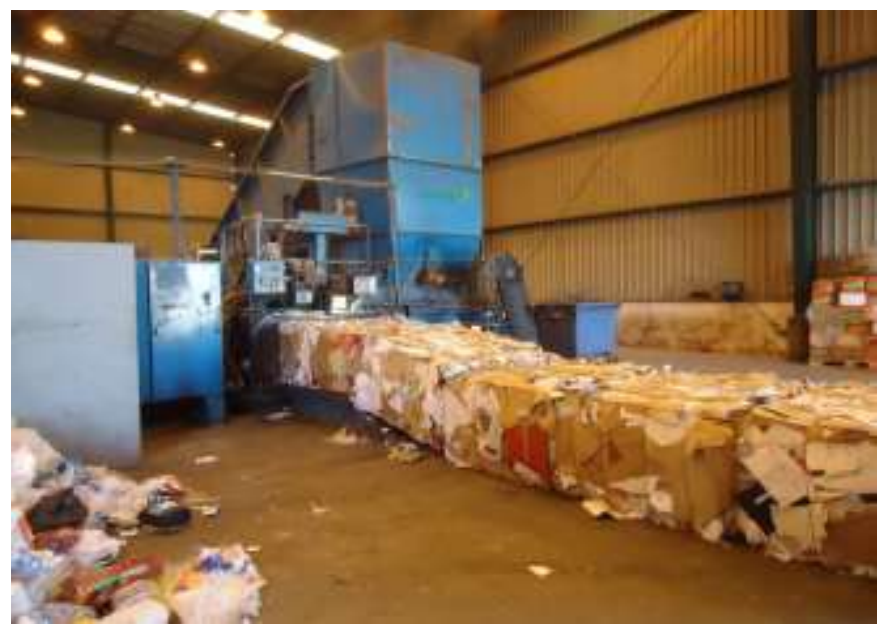

Figura 35. Central de Triagem de Lustosa

Fonte: Autor, 2011

- Estação de Triagem de Penafiel

Localizada dentro das instalações do Aterro Sanitário de Penafiel, a estação recebe resíduos domiciliares, efetua a separação e armazenamento do material segregado que irá para a reciclagem com valorização através de Sociedade Ponto Verde. Também é efetuada a recepção e triagem de resíduos de equipamentos elétricos e eletrônicos, que são enviados para unidades de tratamento e valorização, bem como a recepção de colchões que são desmontados, seguindo o têxtil para aterro e as molas aproveitadas para sucata. 
- Organograma do Ciclo de Resíduos Recicláveis:

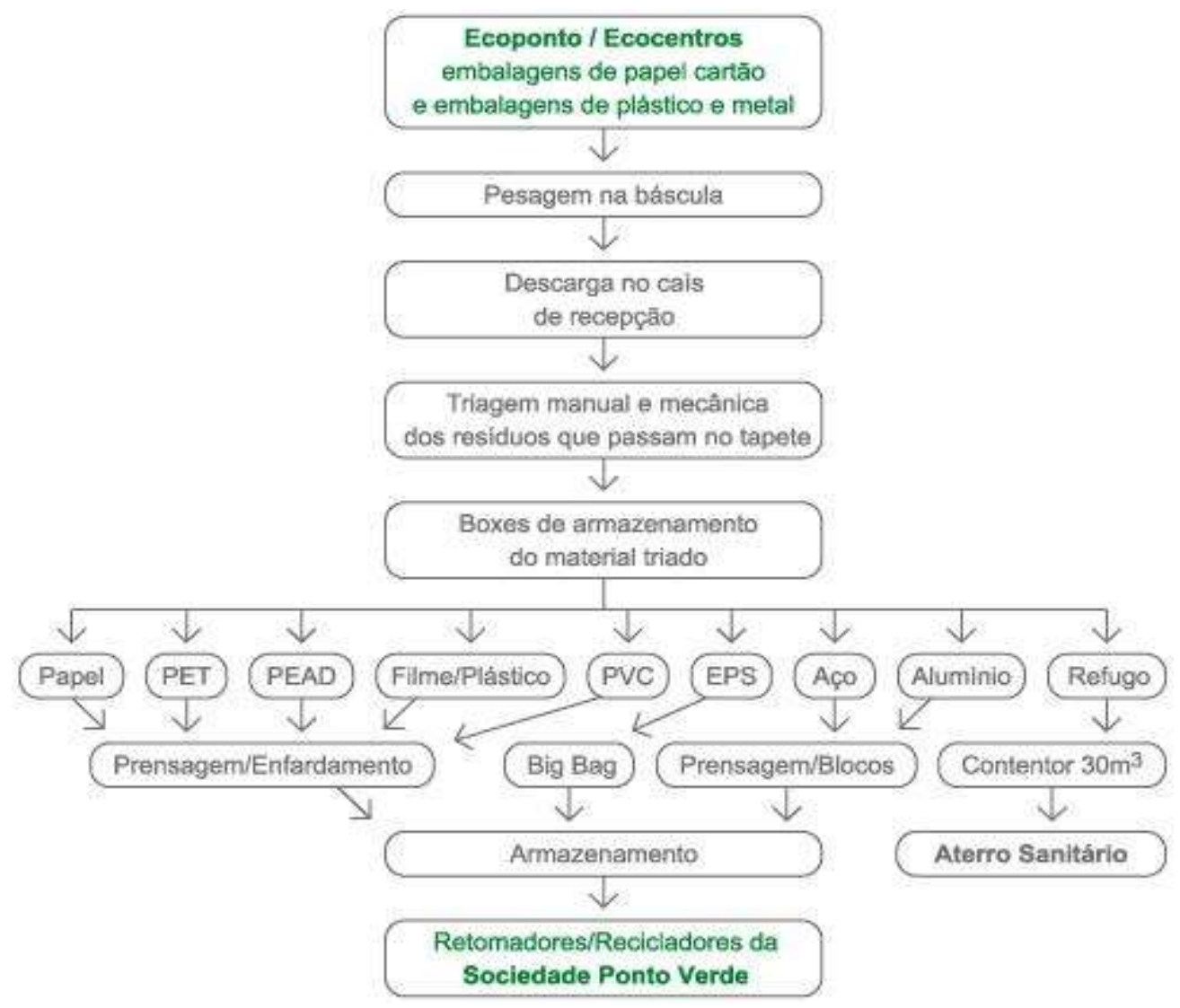

Figura 36. Organograma do ciclo de resíduos recicláveis na Ambisousa Fonte: Ambisousa, 2012

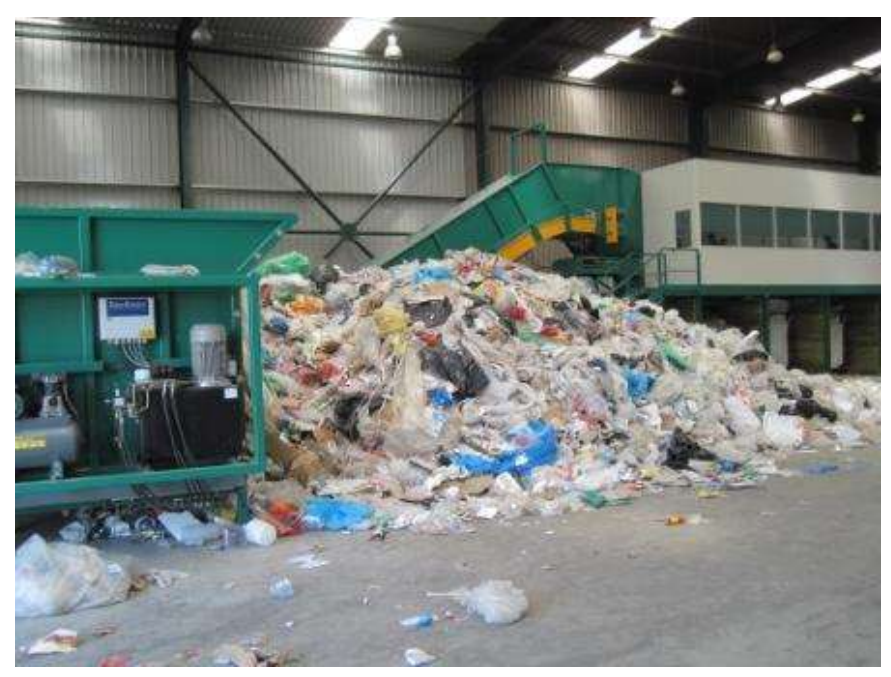

Figura 37. Estação de Triagem de Penafiel

Fonte: Autor, 2011 
- Central de Valorização Energética de Penafiel

A central produz a partir do biogás originário dos resíduos depositados no Aterro de Penafiel, aproximadamente 4,7 milhões de quilowatt por hora, o que corresponde ao consumo médio de energia de 500 residências, além de reduzir a emissão para a atmosfera de gases com efeito estufa

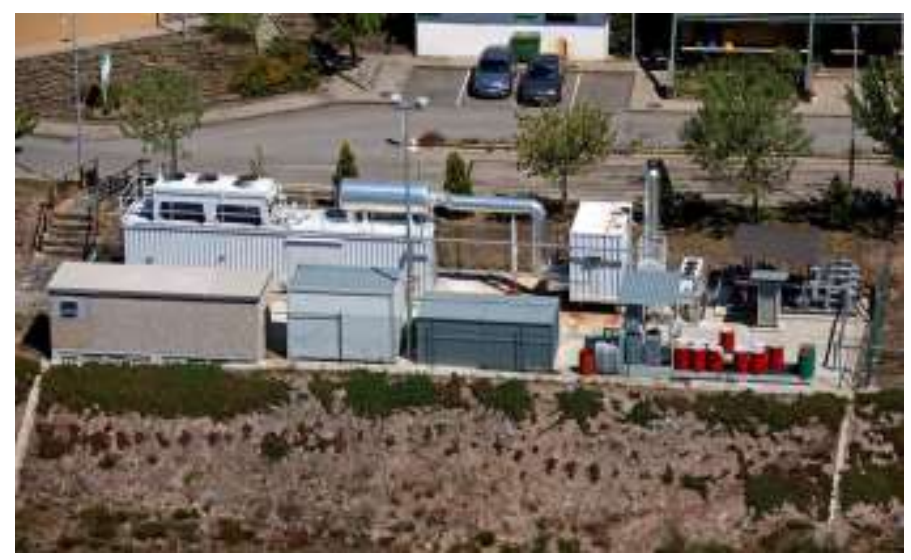

Figura 38. Central de Valorização Energética de Penafiel

Fonte: Ambisousa, 2011

\subsubsection{Visita Técnica em Segóvia - Espanha}

O Consórcio Provincial de Medio Ambiente é constituido pela Diputación, pelas mancomunidades e pelos ayuntamientos da província de Segovia, com o objetivo de promover a gestão dos resíduos sólidos urbanos.

Com um acordo entre a Diputación de Segovia, Ayuntamiento de Segovia e a Junta de Castilla y León, foi construído, no ano de 2001, o Centro de Tratamento de Resíduos Urbano de Los Huertos em Segovia, com capacidade para gestão de aproximadamente 69.000 toneladas de resíduos urbanos por ano. 


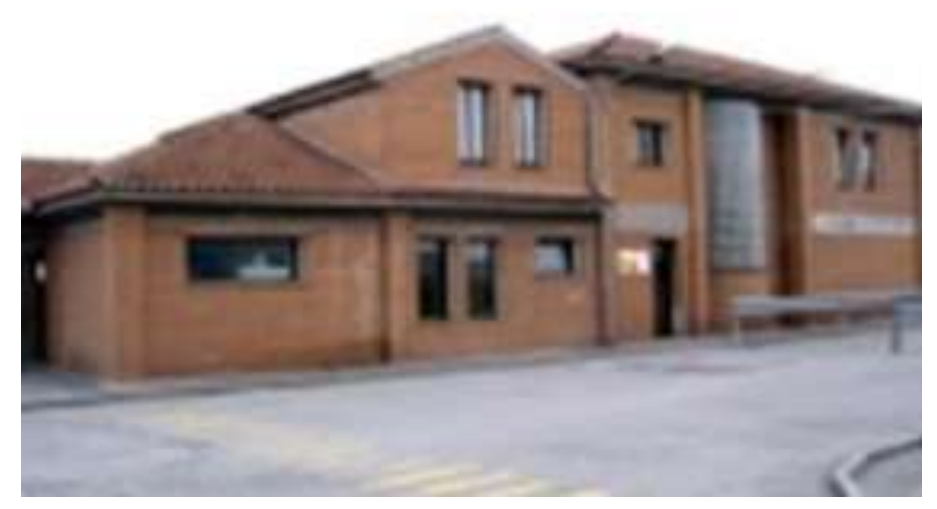

Figura 39. Centro de Tratamento de Resíduos - Segovia

Fonte: Autor, 2011

O consórcio realiza a coleta seletiva não só nas cidades como também na área rural da província em comunidades com mais de 500 habitantes e nas com mais de 300 que se situam próximas às rotas de recolha. Após a coleta, os resíduos são encaminhados a planta de tratamento e colocados em uma fossa (Figura 12), para só depois serem levados para a triagem, evitando assim que parte desses redíduos seja levada pelo vento.

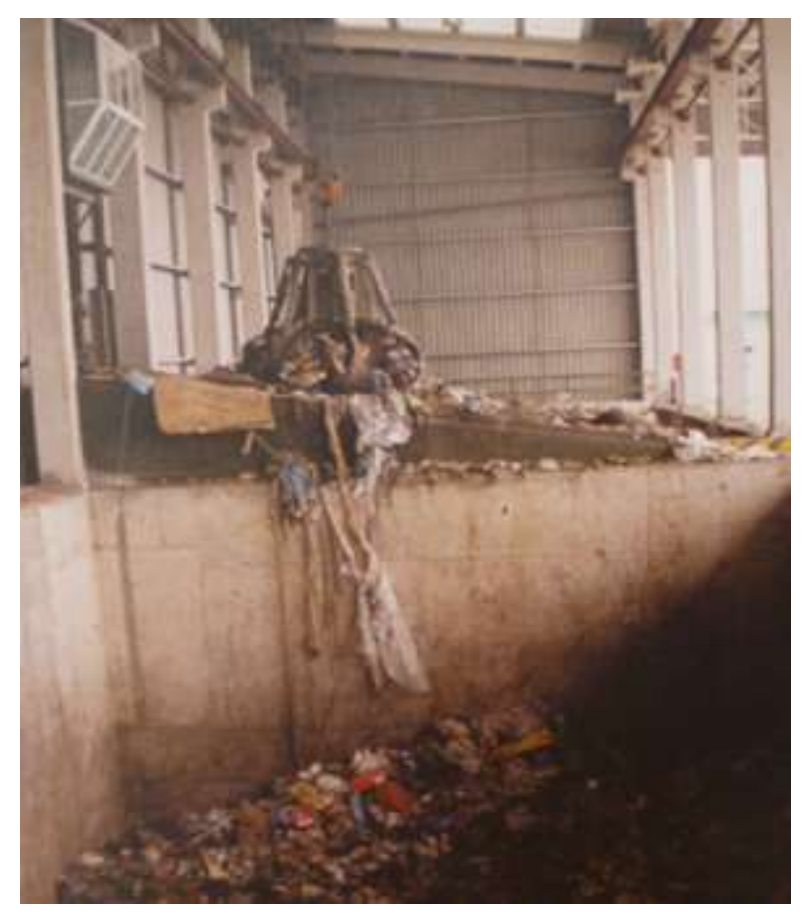

Figura 40. Fossa para depósito de resíduos Fonte: Autor, 2011 
O centro de tratamento é dotado de um sistema de separação seletiva dos resíduos recolhidos tanto das residências como os provenientes dos ecopontos, denominados "Pontos Limpos", atendendo a todas as 209 comunidades que participam do consórcio.

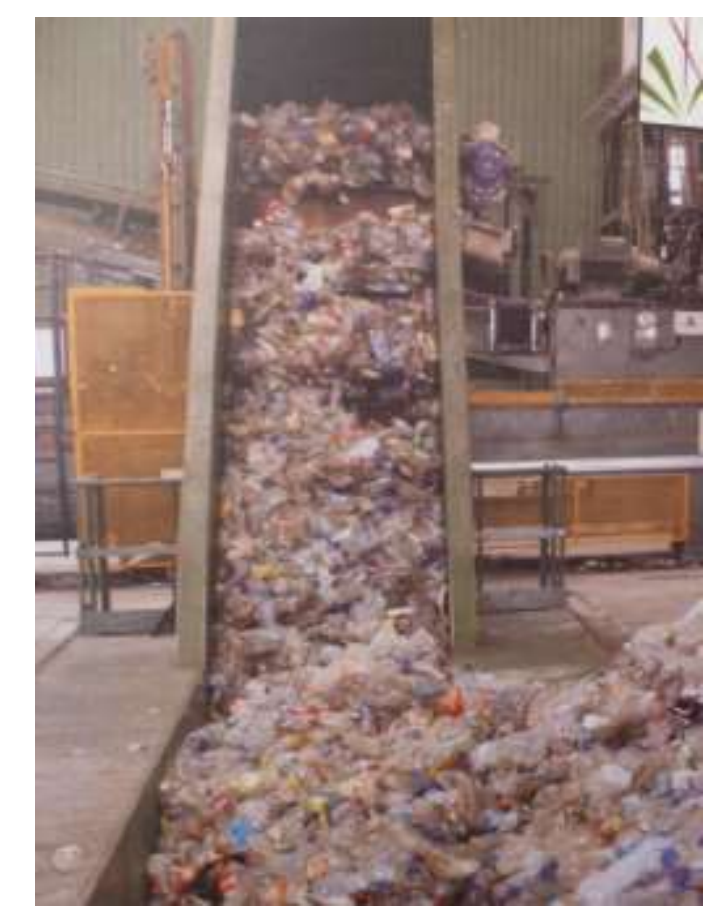

Figura 41. Esteira de triagem de resíduos - Segovia Fonte: Autor, 2011

A matéria orgânica recolhida não é depositada em aterro, pois o centro possui um sistema de compostagem em túneis, onde sofre uma decomposição com controle de temperatura, umidade e ventilação, transformandose em um composto para aplicação na agricultura.

Finalmente os resíduos que não podem ser aproveitados são compactados, enfardados (Figura 43) e encaminhados para depósito em um aterro. 


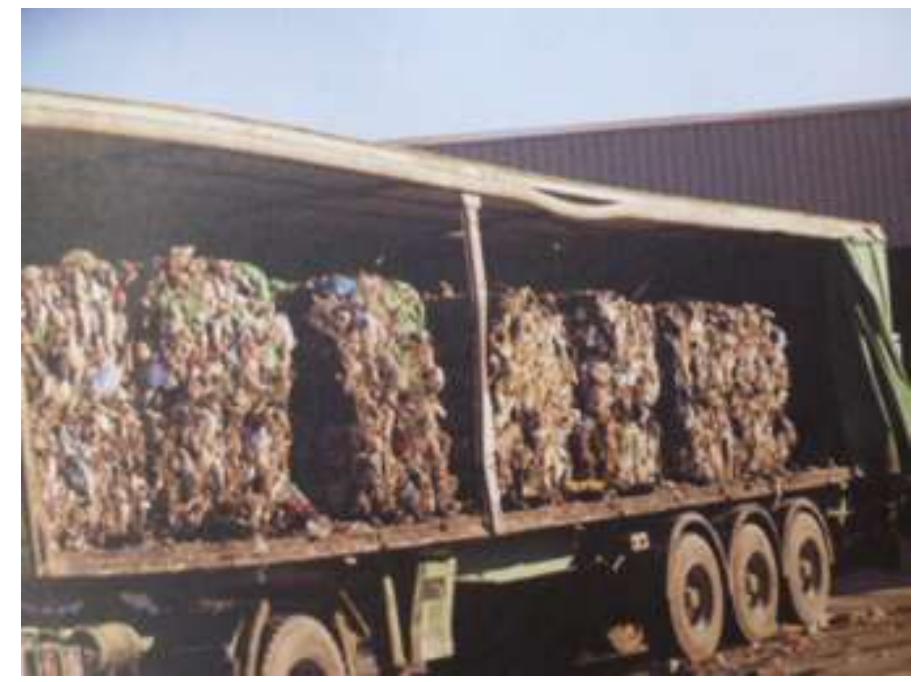

Figura 42. Resíduos compactados e enfardados - Segovia Fonte: Autor, 2011

\subsubsection{Visita Técnica em Bruxelas - Bélgica}

A Agência Regional Bruxelles Propreté é a Agência Regional de Limpeza Pública responsável pela coleta dos resíduos urbanos da região metroplitana de Bruxelas. Possui uma planta de gestão de resíduos com um centro de triagem (figura 44) para valorização dos resíduos recicláveis.

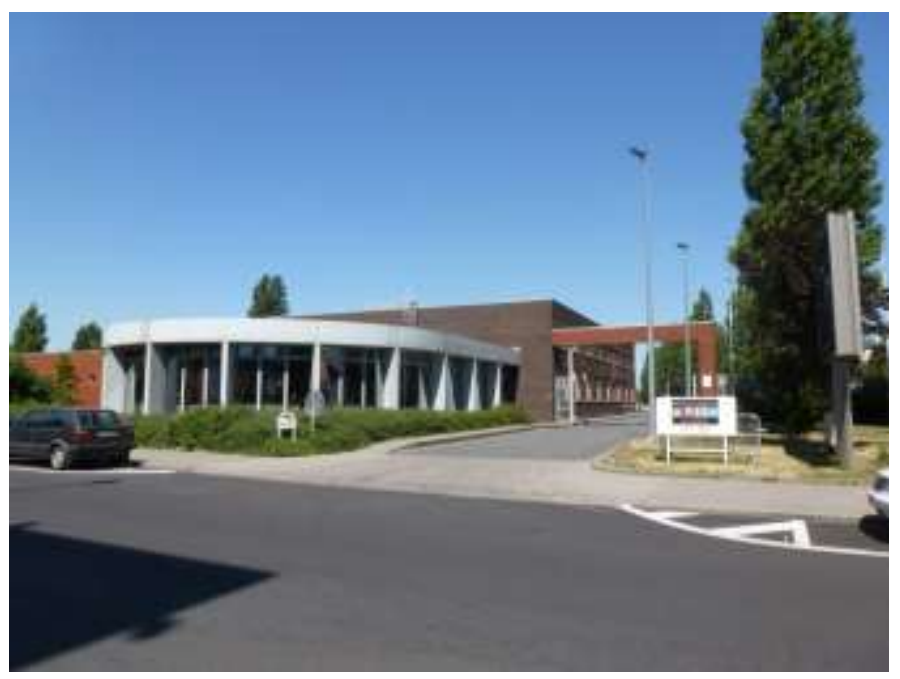

Figura 43. Centro de triagem de resíduos - Bruxelas

Fonte: Autor, 2011

0 centro tem capacidade para o processamento de 20 mil toneladas para a linha de embalagens plásticas e metálicas, 80 mil toneladas para papel e 
papelão, e ainda possui instalações para recepção de frascos e garrafas de vidro, resíduos de jardim, volumosos, resíduos elétricos e eletrônicos, resíduos de construção, sucata etc.

A unidade de triagem é composta por duas linhas de separação, sendo uma esteira para segregação do papel e papelão, e a outra uma plataforma de triagem de embalagens plásticas e metálicas.

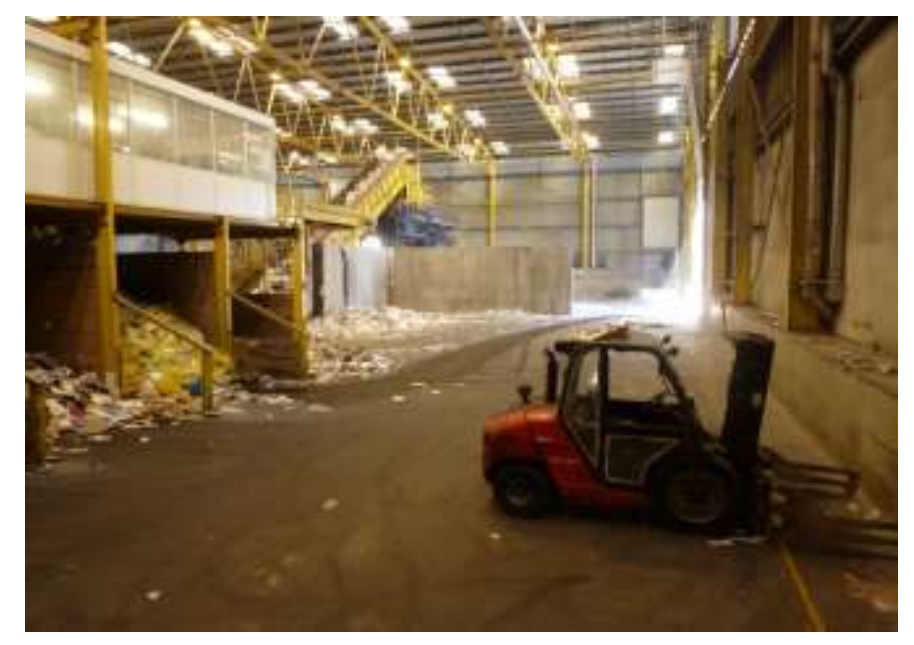

Figura 44. Plataforma de triagem de resíduos - Bruxelas

Fonte: Autor, 2011

Além disso, a Bruxelles Propreté efetua a coleta de resíduos químicos, lâmpadas, pilhas e baterias, para garantir que eles estejam dispostos de acordo com normas e respeite o meio ambiente.

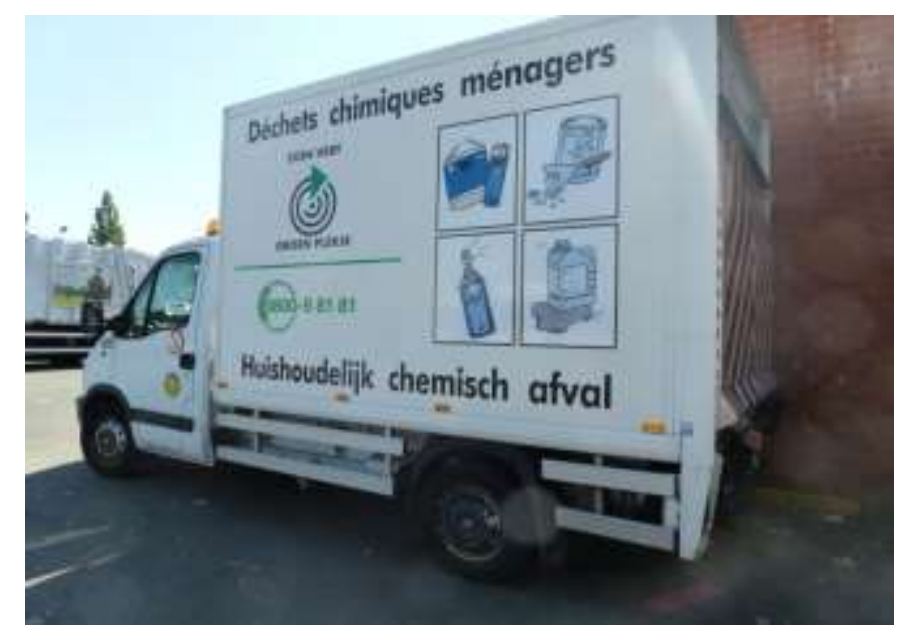

Figura 45. Caminhão coletor de resíduos químicos - Bruxelas

Fonte: Autor, 2011 
Durante o ano de 2011 a Agência Regional de Limpeza Pública promoveu a separação e comercialização das seguintes quantidades de resíduos:

- Papel de diferentes qualidades - 51.400 toneladas;

- Papelão - 13.000 toneladas;

- PET incolor - 2.400 toneladas;

- PET azul - 1.100 toneladas;

- PET verde - 250 toneladas;

- Embalagens de bebidas - 1.300 toneladas;

- Aço - 2.700 toneladas;

- Alumínio - 350 toneladas.

A Bruxelles Propreté implementou normas para a população quanto à forma de disposição de seus resíduos para a coleta regular, obrigando o morador da região do consórcio regional de Bruxelas a separar e classificar todos os resíduos domésticos. Em caso de descumprimento das obrigações, o morador poderá ser multado num valor de 62,50 euros, buscando remover a sensação de impunidade daqueles que não prezam pela limpeza pública.

São passíveis de multas os seguintes atos entre outros:

- Fazer pichações, marcas, inscrições, postagem de cartazes em espaços públicos;

- Não observar os dias e horas de colocar para coleta os sacos de lixo;

- Não separar e acondicionar os resíduos em sacos, de acordo com as cores definidas;

- Não usar sacos regulamentados;

- Criar despejo ilegal de sacos de lixo, volumosos, resíduos de construção e demolição etc.;

- Não coletar os dejetos de seu cão na via pública; 
- Não requerer o serviço de coleta em casa ou os locais determinados para o descarte de volumosos;

- Não enviar os resíduos químicos para os locais determinados.

A coleta de resíduos verdes é realizada de porta em porta em sacos plásticos e em contêineres distribuídos pelo consórcio, em parques e empresas de jardinagem, e são encaminhados para uma usina na planta de gestão da Bruxelles Propreté, onde são transformados em um composto orgânico que é comercializado como adubo para a agricultura e jardinagem.

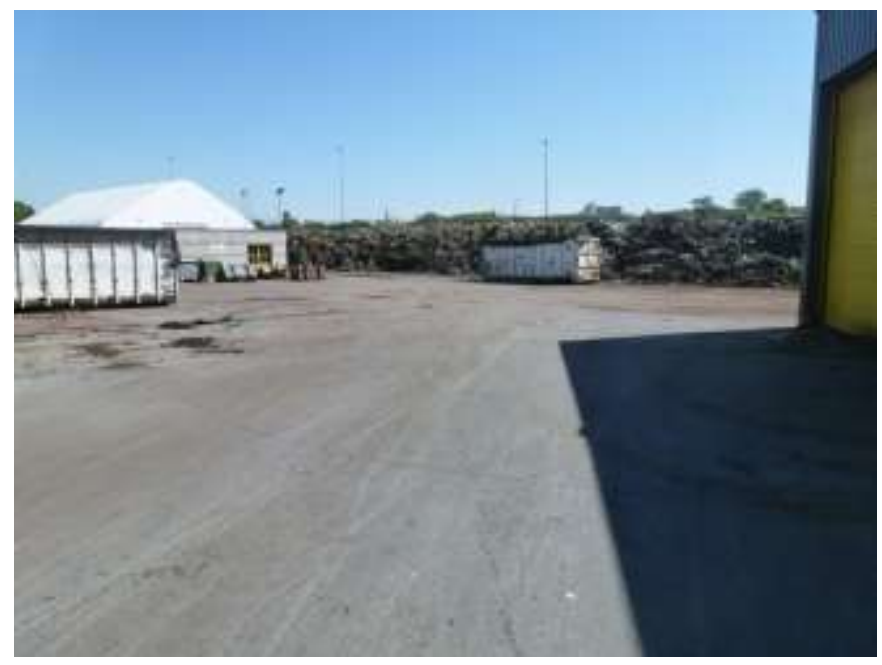

Figura 46. Usina de compostagem - Bruxelas

Fonte: Autor, 2011

O tratamento dos resíduos para os quais ainda não há reciclagem é feito pela Bruxelas Electrabel Energy, em uma unidade de recuperação de energia por incineração. A planta está na vanguarda em termos de recuperação de energia e proteção ambiental.

Atualmente são incineradas aproximadamente 469.000 toneladas de resíduos, sendo 338.000 toneladas de lixo doméstico e 131.000 de resíduos de empresas e indústrias, produzindo 262 milhões de kWh suficientes para abastecer a operação da planta e 65.000 residências. 


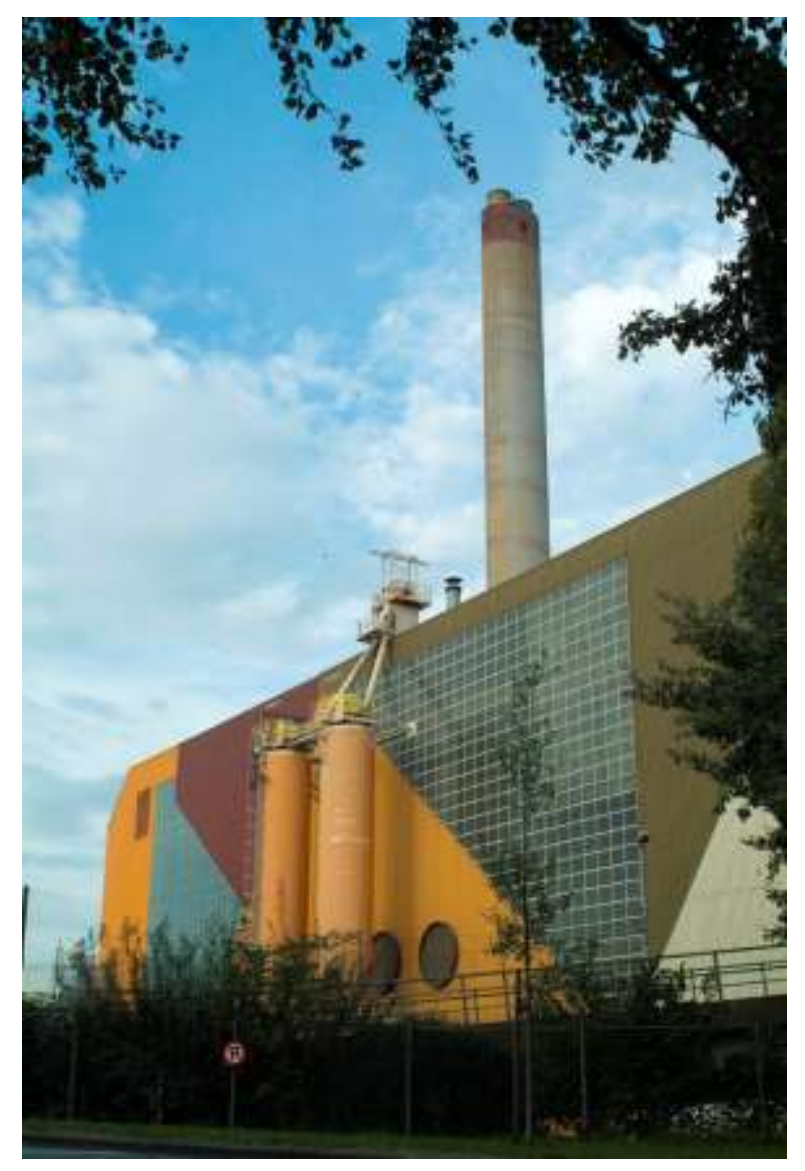

Figura 47. Unidade de recuperação de energia - Bruxelas Fonte: Autor, 2011

\subsubsection{Visita Técnica em Lille - França}

A Lille Metrópole Communauté Urbaine (LMCU) é a responsável pelo consórcio intermunicipal de gestão de resíduos sólidos da Região Metropolitana de Lille, situada no norte da França, é composta por 85 municípios com população total de 1.091 .438 habitantes.

O padrão de gestão de resíduos adotado pela LMCU tem como pilares o desenvolvimento sustentável e a modernização, implantando equipamentos de última geração e projetos que tem como razão principal proporcionar à população o melhor serviço com qualidade ambiental. 


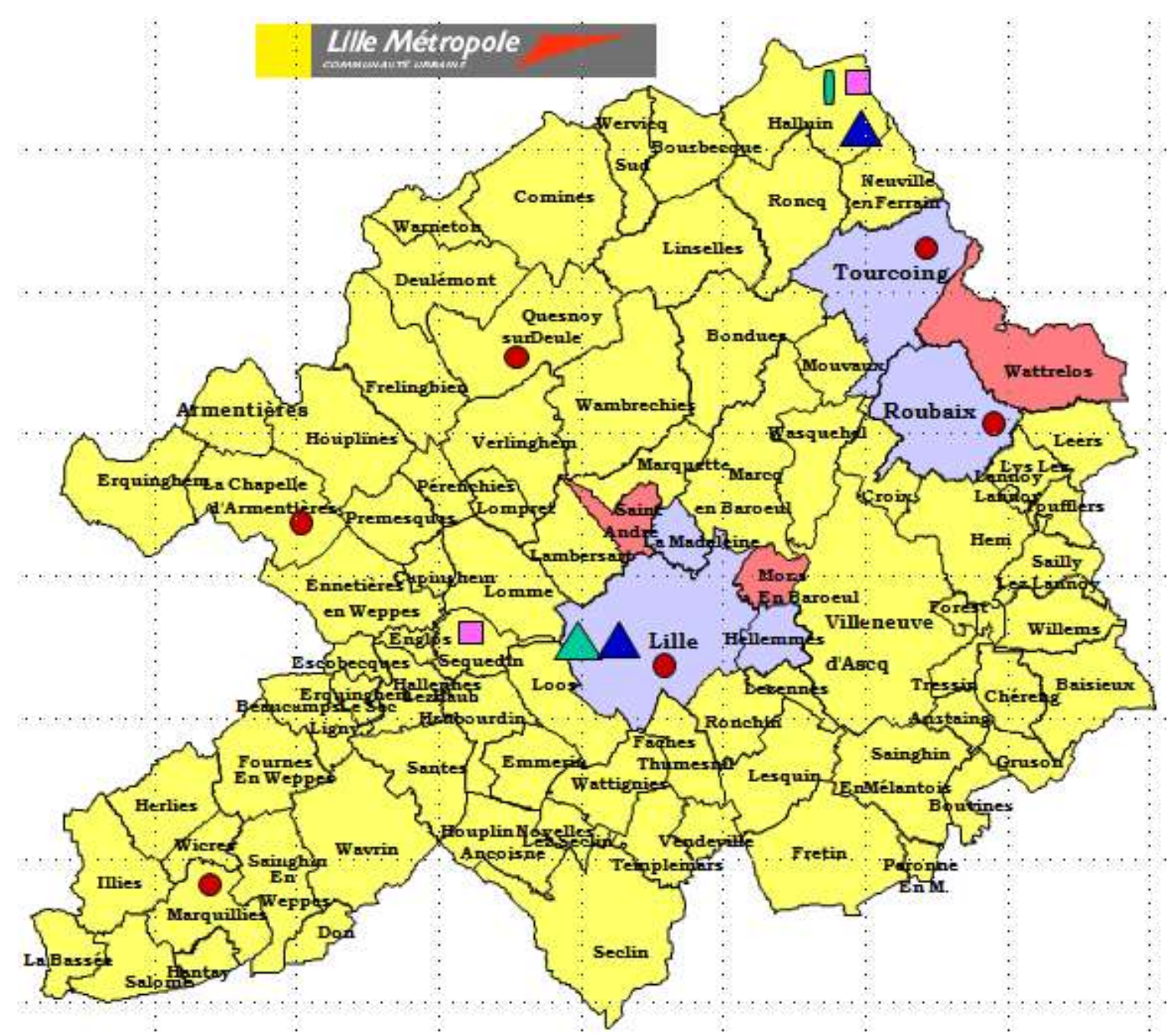

A Centro de Triagem Centro de Valorização Energética

\section{Estaçãode Transbordọ $\bigcirc$ Ecopontos}

Figura 48. Infraestruturas de Gestão de RSU - Lille Fonte: Autor, adaptado de LMCU, 2011

Desta forma, a metrópole de Lille organizou ações e construiu equipamentos necessários para a valorização de seus resíduos tais como: 


\section{- COLETA SELETIVA}

Com a implantação da coleta de resíduos porta a porta e uma rede de centros de recolha, a LMCU contribui com os objetivos da União Europeia quanto à gestão de resíduos, da seguinte forma:

- A Diretiva 2008/98/CE da EU estabelece atingir uma meta de 50\% de reciclagem até o ano de 2020, assim Lille criou a coleta seletiva de papel, metal, plástico e vidro, desde o início 1990;

- A EU pede aos Estados-Membros a universalização da coleta até o ano de 2015, o que a LMCU efetua desde o final de 2008;

- Com a coleta seletiva de resíduos biológicos e tratamento no Centro de Valorização Orgânica, Lille busca alcançar os objetivos da Diretiva 1999/31/CE, que exige a redução das contribuições de matéria orgânica em aterros de 65\% até 2015 em relação a 1995.

Atualmente todos os habitantes da metrópole são obrigados a separar os seus resíduos e colocá-los para coleta seletiva de acordo com o calendário estabelecido para sua região, que determina dia e tipo de resíduo que deve ser colocado para ser recolhido. Todos os contêineres são identificados por código de barras, com endereço da residência correspondente (Figura 50).

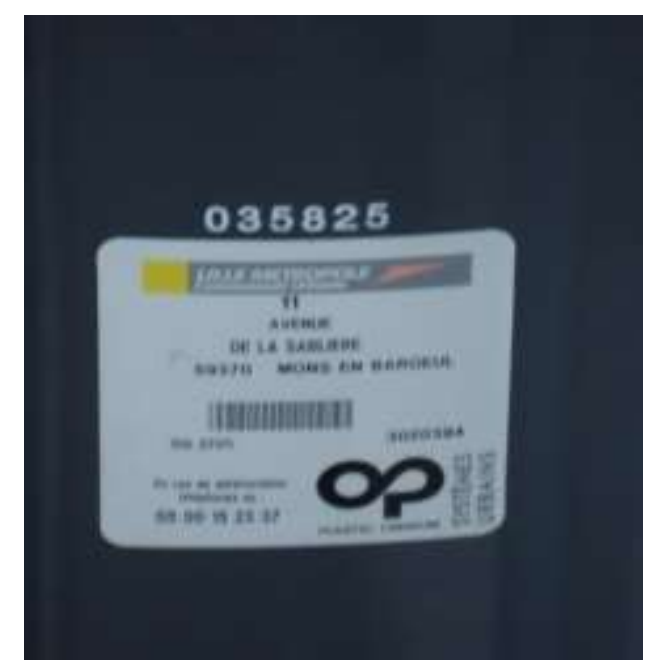

Figura 49. Identificação de contêineres

Fonte: Autor, 2011 
Para a execução dos serviços de coleta, os moradores pagam uma taxa anual equivalente a $15,41 \%$ do nosso Imposto Predial Territorial Urbano exclusivamente para o custeio das atividades operacionais do serviço. Todos os materiais recicláveis e os não recicláveis são coletados uma vez por semana, entretanto, nas áreas onde a densidade populacional é densa, os resíduos não recicláveis são recolhidos duas vezes por semana.

Foram registrados os seguintes dados sobre a coleta de resíduos no ano de 2011:

- 434.117 toneladas de lixo doméstico;

- $400 \mathrm{~kg}$ de resíduos domésticos per capita;

- $120 \mathrm{~kg}$ lixo limpo e seco coletado per capita;

- $80 \mathrm{~kg}$ de resíduos recolhidos por habitante em locais públicos;

- 118.312 toneladas de resíduos recicláveis;

- 31.454 toneladas de resíduos orgânicos;

- 266.813 toneladas de resíduos não recicláveis;

- 214 estabelecimentos públicos e privados também estão envolvidos na coleta seletiva.

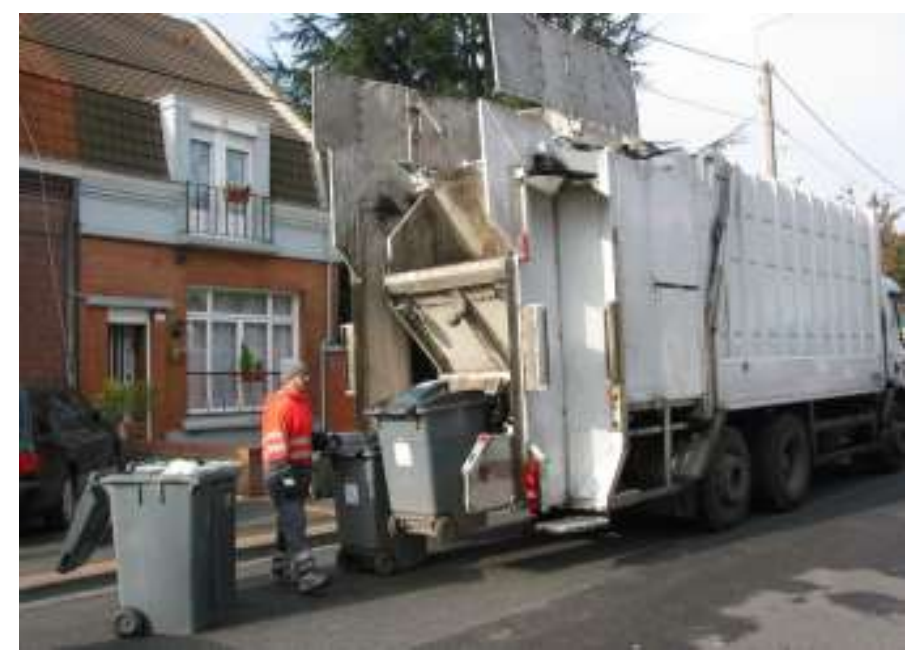

Figura 50. Caminhão para coleta de resíduos - Lille

Fonte: Autor, 2011 


\section{- ECOCENTROS E ECOPONTOS}

Lille possui nove instalações de deposição voluntária para eliminação de resíduos, coletando principalmente os volumosos, que devido ao seu volume ou natureza não podem ser levados pela coleta regular. Esses resíduos também são coletados em sistema porta a porta, uma vez por mês com data estabelecida. No total foram coletados 61.887 toneladas no ano de 2011.

Os centros de reciclagem estão equipados para coletar os seguintes tipos de resíduos:

- Lixo doméstico especial e resíduos de equipamentos elétricos e eletrônicos que não são permitidos nas coletas de porta em porta;

- Resíduos de construção e demolição que também não são aceitos na recolha de resíduos volumosos;

- Resíduos verdes quando produzidos por indivíduos que excedam a capacidade dos contêineres.

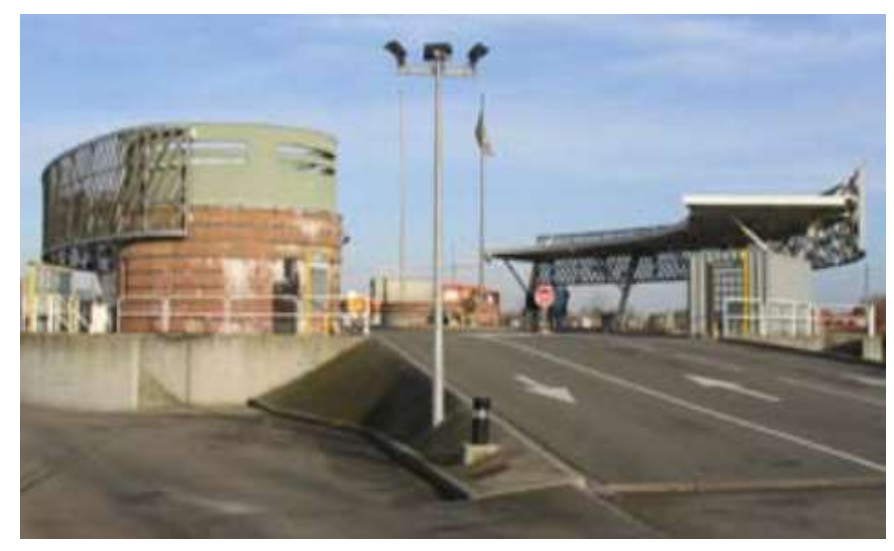

Figura 51. Ecocentro - Lille

Fonte: Autor, 2011 


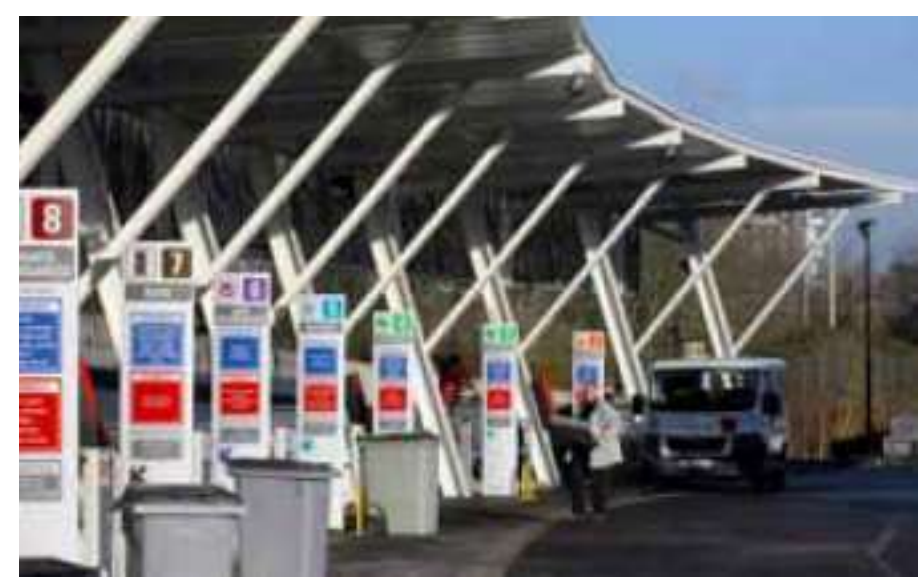

Figura 52. Vista interna de um ecocentro - Lille

Fonte: Autor, 2011

\section{- CENTROS DE TRIAGENS}

Para gestão dos recicláveis a Lille Metrópole Communauté Urbaine construiu dois centros de triagens em seu território, sendo um na cidade de Lille e outro em Halluin.

As atividades de segregação e classificação dos resíduos são quase totalmente automatizadas, com separação em função do peso, transparência, magnetismo e material, entre outros. A classificação é realizada, primeiramente, por um conjunto de máquinas e o refino é feito manualmente (exceto a parte de vidro, que é refinado por uma máquina de classificação óptica).

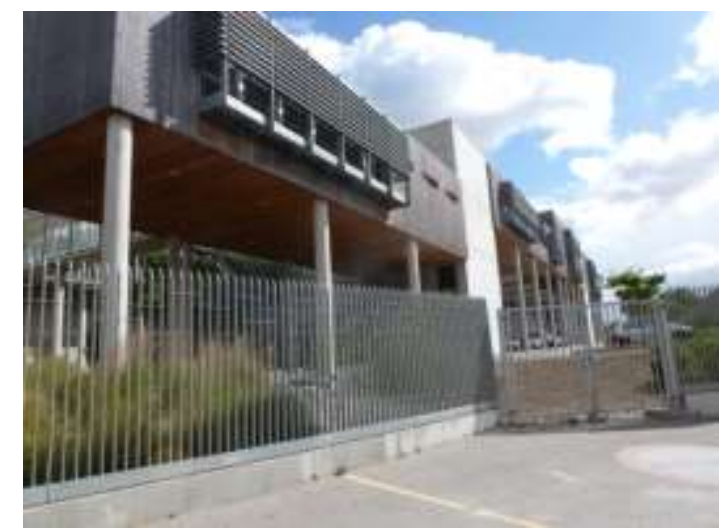

Figura 53. Centro de Triagem - Lille Fonte: Autor, 2011.

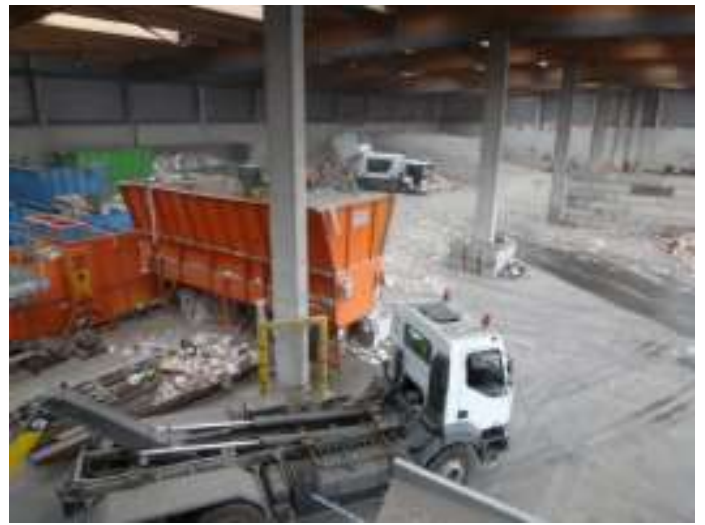

Figura 54. Pátio de descarga de materiais CT - Lille Fonte: Autor, 2011. 


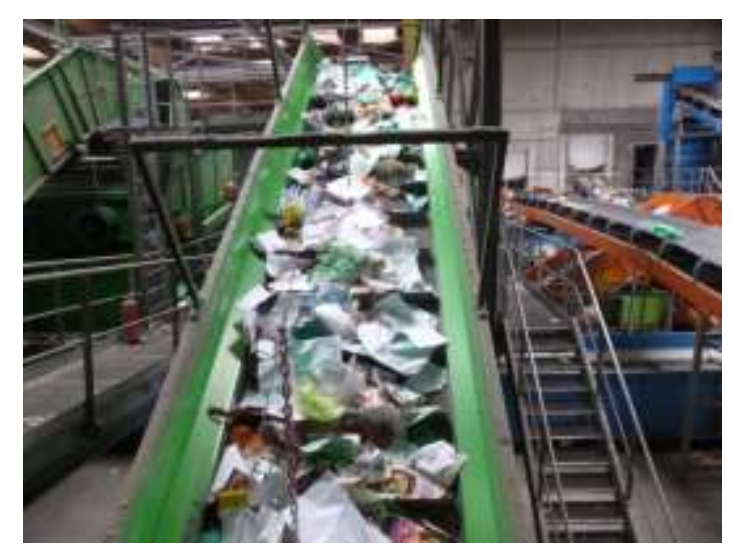

Figura 55. Esteira do Centro de Triagem - Lille Fonte: Autor, 2011.

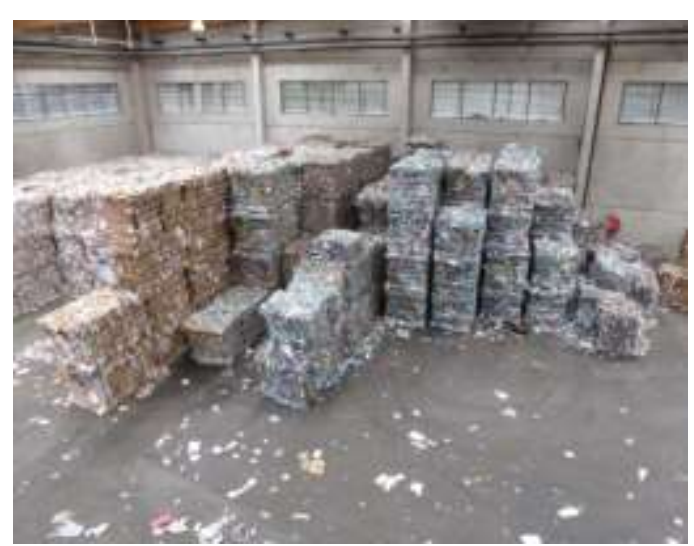

Figura 56. Depósito de materiais enfardados CT - Lille

Fonte: Autor, 2011.

No ano de 2011 os centros de triagem processaram 117.396 toneladas de recicláveis, dos quais somente 21.235 toneladas foram enviadas para a valorização energética, atingindo assim, uma taxa de valorização de $77 \%$ dos materiais recicláveis.

\section{- CENTRO DE VALORIZAÇÃO ORGÂNICA (CVO)}

Após a implantação da coleta seletiva em 1994, Lille optou também pela coleta seletiva de resíduos biodegradáveis, com a construção de um Centro de Valorização Orgânica no ano de 2007.

Um quarto do lixo doméstico da comunidade é resíduo orgânico que é coletado no sistema porta a porta e transferido para o CVO, juntamente com os resíduos verdes provenientes das aparas de gramas, podas de árvores e cascas, bem como sobras de refeitórios e restaurantes. 


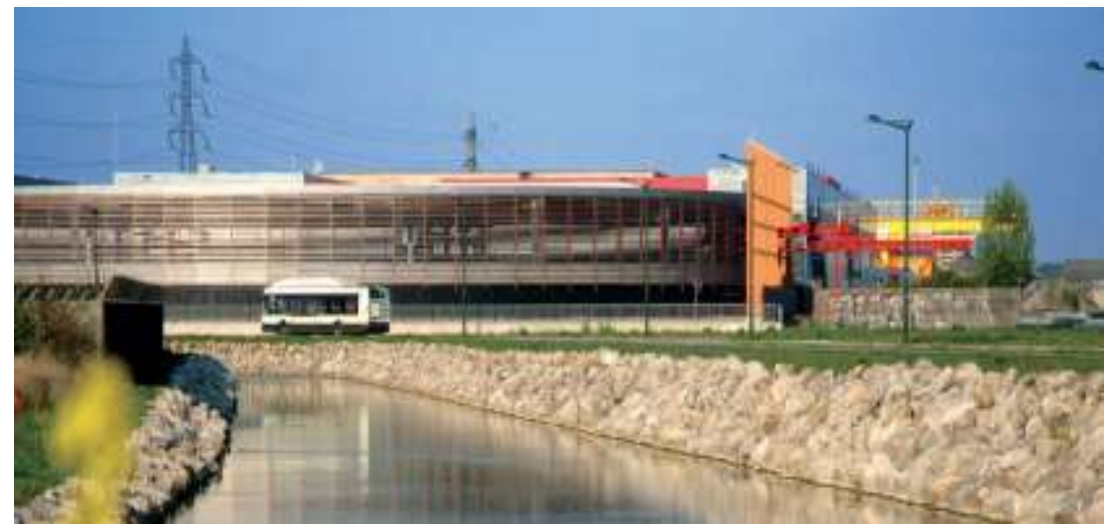

Figura 57. Centro de Valorização Orgânica - Lille Fonte: Autor, 2011

Dois produtos principais são produzidos no tratamento por digestão anaeróbia e compostagem intensiva dos resíduos biodegradáveis: biogás e um composto orgânico.

O biogás é o Biometano refinado, sendo uma fonte de energia limpa e renovável, que substitui a injeção de gás natural fóssil na rede de gás. A fração de resíduo fermentável é degradada por bactérias produzindo uma mistura de metano e átomos de dióxido de carbono por meio de equipamentos de última geração, compostos por três digestores com capacidade de 2.000 metros cúbicos que executam a degradação anaeróbia em três semanas.

No ano de 2011 foram produzidos 240.960 Nm3 de Biogás que foram injetados na rede.

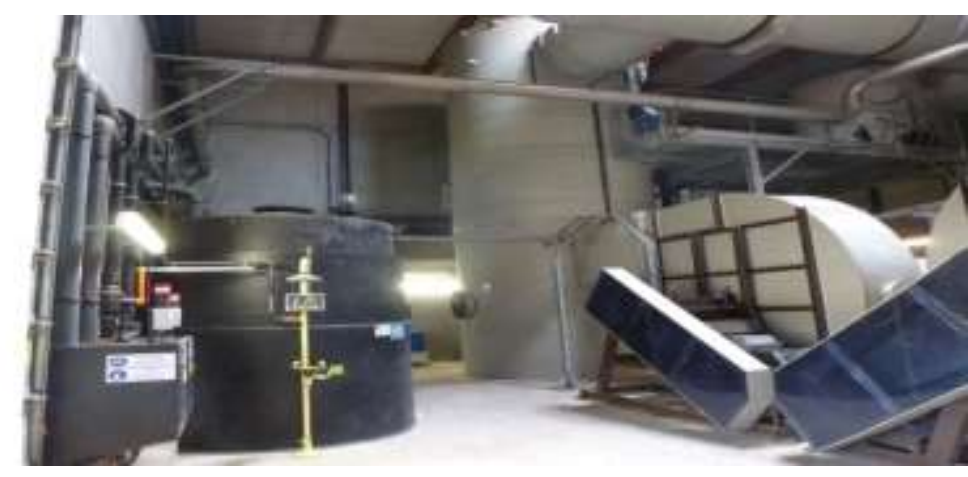

Figura 58. Armazenamento do biogás - Lille

Fonte: Autor, 2011 
A produção de biometano no CVO de Lille tem sido referência na França e Europa para o setor de combustível de biometano produzido a partir de resíduos orgânicos.

A implantação de tubulações que interligam a rede de distribuição de gás natural da cidade e a garagem de ônibus do transporte coletivo da metrópole, ocorridas em 2011, possibilitou que o biometano fosse injetado à rede da garagem durante o dia e à noite abastecendo as residências e outros veículos.

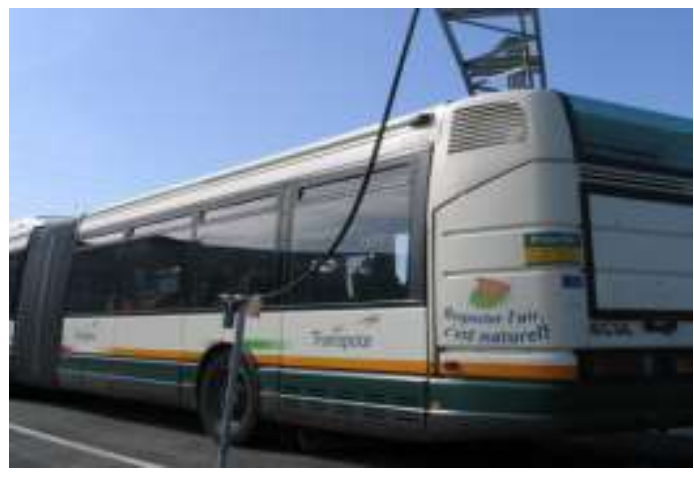

Figura 59. Ônibus abastecendo com biometano - Lille

Fonte: Autor, 2011.

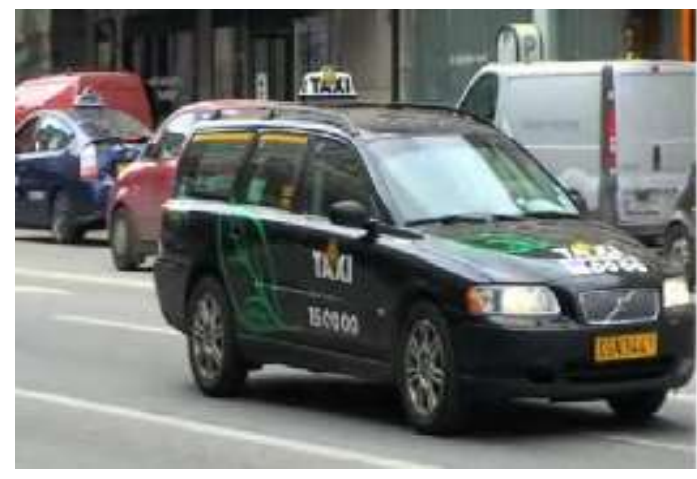

Figura 60. Automóvel movido a biometano - Lille Fonte: Autor, 2011.

O composto é produzido por degradação natural do material, em um sistema de 22 túneis independentes que controlam as condições de degradação com injeção de oxigênio por ventilação forçada e a climatização interna. Ao final de três semanas de maturação o composto está pronto para ser comercializado.

No que diz respeito à mitigação dos impactos ambientais associados à instalação, a Central de Valorização Orgânica (CVO) é totalmente fechada, assegurando-se assim o controle integral dos odores através de um processo de tratamento do ar por lavagem e biofiltração.

No ano de 2011 foram produzidos para uso na agricultura e jardinagem 18.253 toneladas do composto orgânico. 


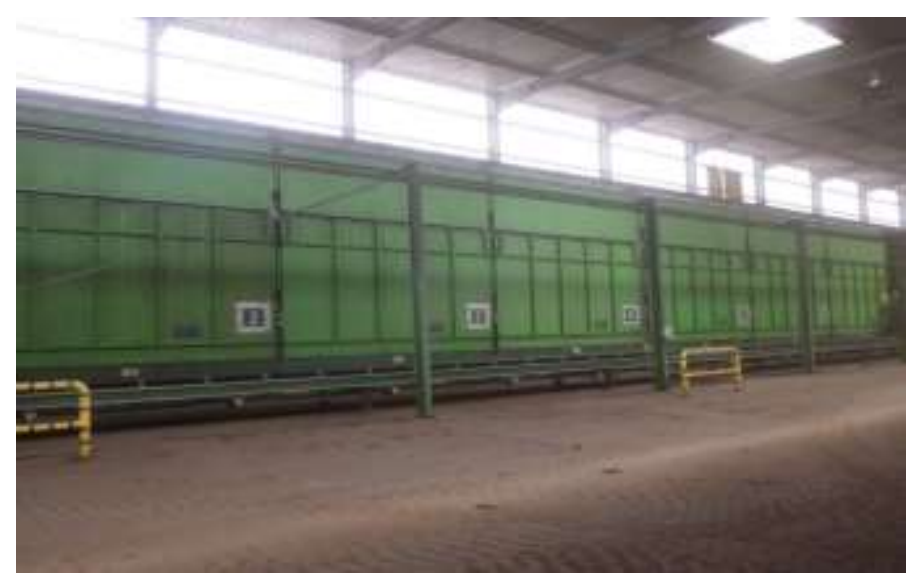

Figura 61. Túneis de produção de composto orgânico - Lille Fonte: Autor, 2011

Em relação aos líquidos gerados durante o processo tem-se um especial cuidado na sua recirculação, após um tratamento prévio, evitando-se assim a sua descarga para o exterior.

São ainda recolhidas as águas pluviais através de um sistema de canais a céu aberto instalado no lado externo da estrutura, diminuindo significativamente o consumo de água.

\section{- CENTRO DE TRANFERÊNCIA E MANUTENÇÃO}

O CVO recebe por meio de transporte em caminhões coletores os resíduos orgânicos da região sul da metrópole, mas uma fração de outros tipos de resíduos vem misturados a estes. Assim foi necessário construir um centro de transferência e manutenção, que permite a transferência de contêineres com resíduos, por transporte fluvial, para serem valorizados no centro de Valorização Energética em Halluin.

Aproveitando a logística do sistema, o mesmo barco que transporta resíduos para serem incinerados, retorna com os resíduos da parte norte passíveis de serem degradados e valorizados no Centro de Valorização Orgânica. Em 2012, 115.487 toneladas de lixo foram transportadas pelo CTM. 


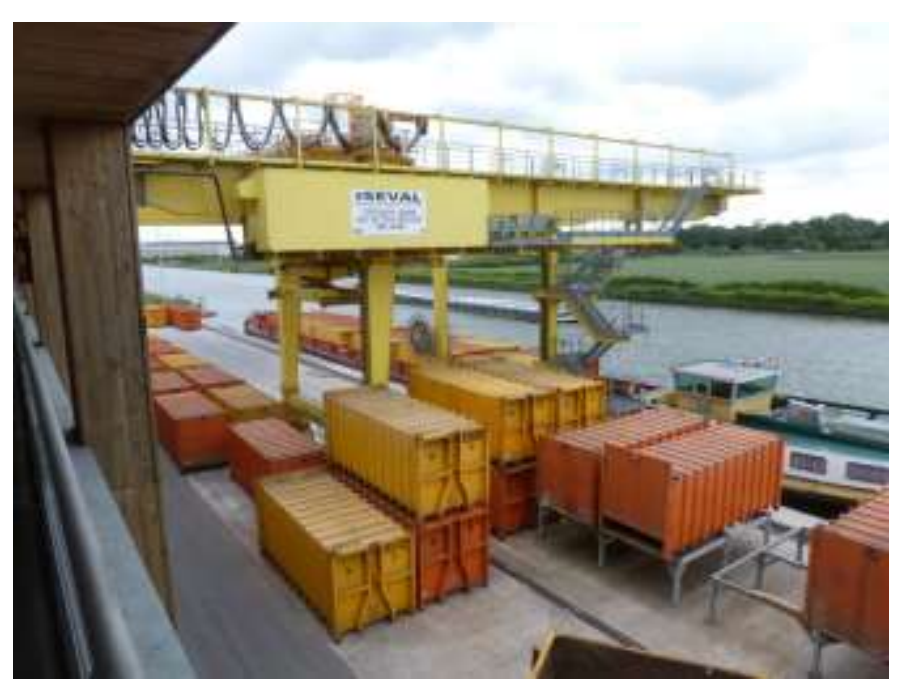

Figura 62. Cais de embarque - Lille Fonte: Autor, 2011 


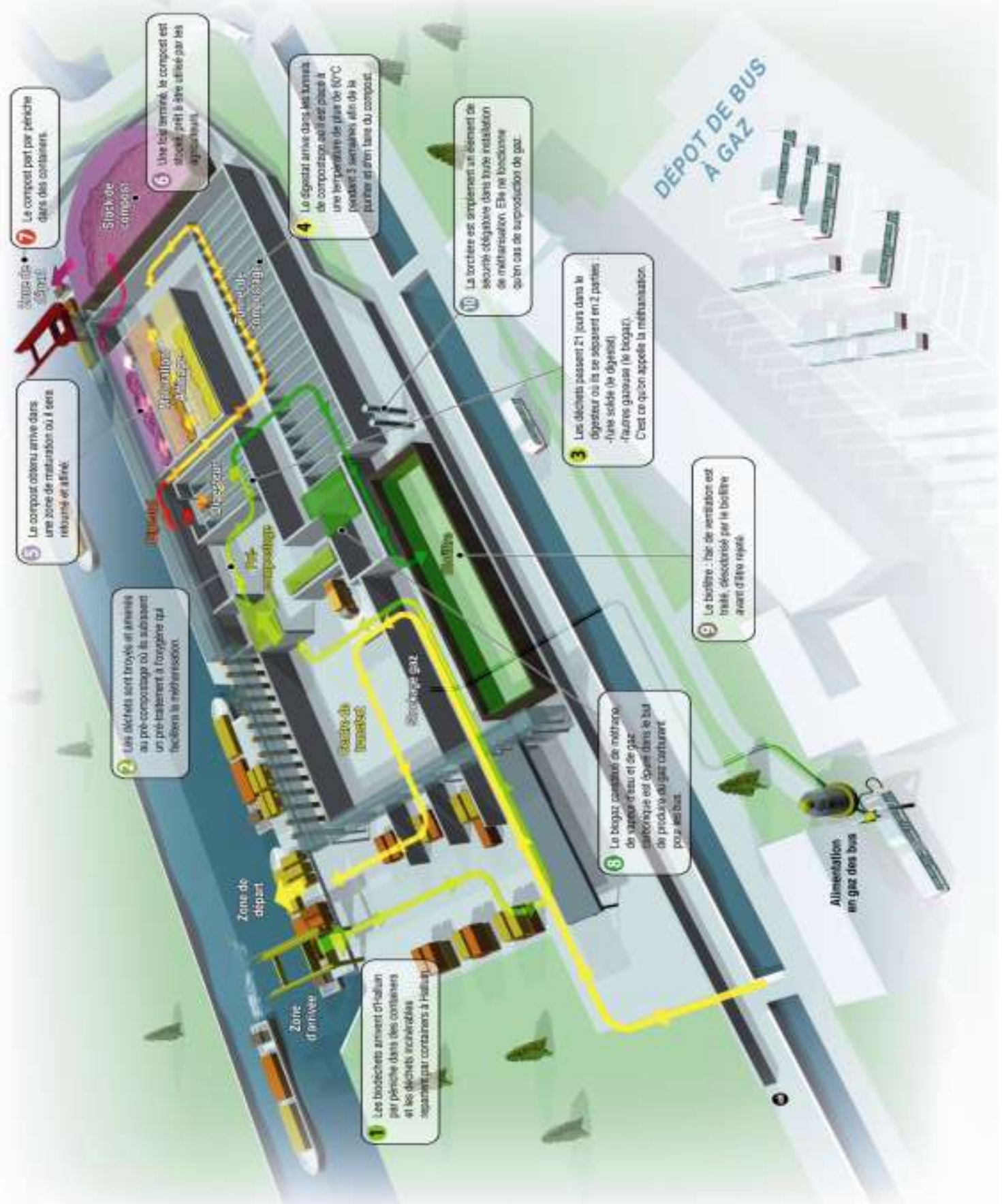

Figura 63. Ciclo dos resíduos no CVO - Lille Fonte: Lille Métropole, 2011

\section{- CENTRO DE VALORIZAÇÃO ENERGÉTICA}

O Centro de Valorização de Energia (CVE) de Halluin foi batizado com o nome de uma estrela, Antares. 0 incinerador foi dimensionado para recuperação 
de energia de 350 mil toneladas por ano, utilizando a recolha de resíduos limpos e secos da região metropolitana.

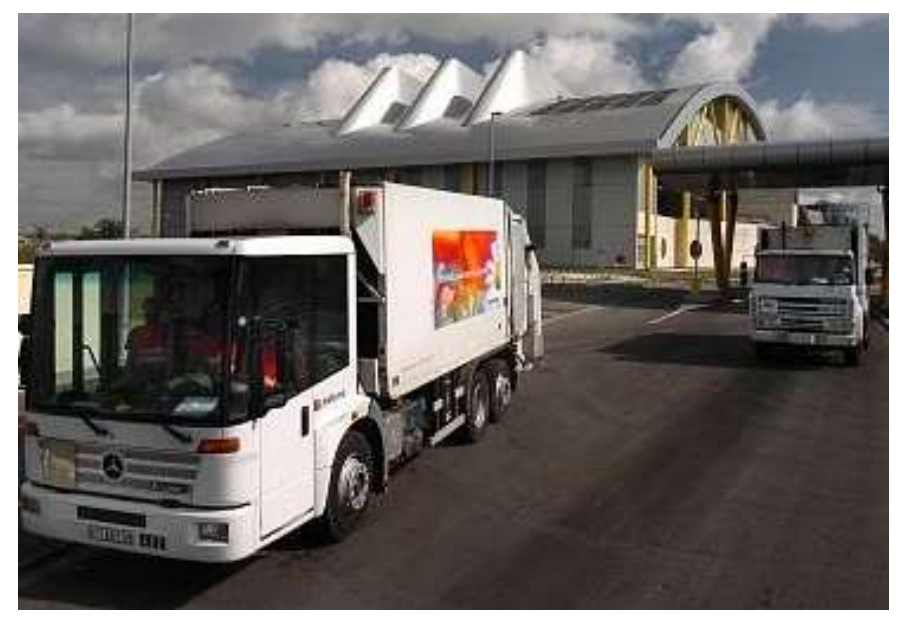

Figura 64. Centro de Valorização Energética - Lille Fonte: Lille Métropole, 2011

Colocado em operação comercial no final de 2000, com tecnologia nova, veio para substituir três outros incineradores fechados no ano de 1998, utiliza o calor gerado pela combustão de resíduos para produzir eletricidade, que é usada na própria planta e o excedente vendido para a concessionária local de energia. Sendo que em torno de $40 \%$ da energia vendida é suficiente para cobrir os custos operacionais do complexo.

A produção equivale ao consumo anual de 25.000 famílias e no ano de 2011 recebeu 347.532 toneladas de resíduos não recicláveis, produzindo 170.595 Mwh, sendo que 133.384 Mwh vendidos à concessionária e 37.211 para consumo próprio. 


\subsection{CARACTERÍSTICAS GERAIS DO ESTADO DE SÃO PAULO}

O Estado de São Paulo está localizado na região sudeste brasileira e delimita-se ao norte e nordeste com o Estado de Minas Gerais, ao sul com Paraná, a leste com o Rio de Janeiro, a oeste com o Mato Grosso do Sul e a sudeste com o Oceano Atlântico.

A figura 66 mostra a localização geográfica do Estado de São Paulo no Brasil e no globo terrestre.

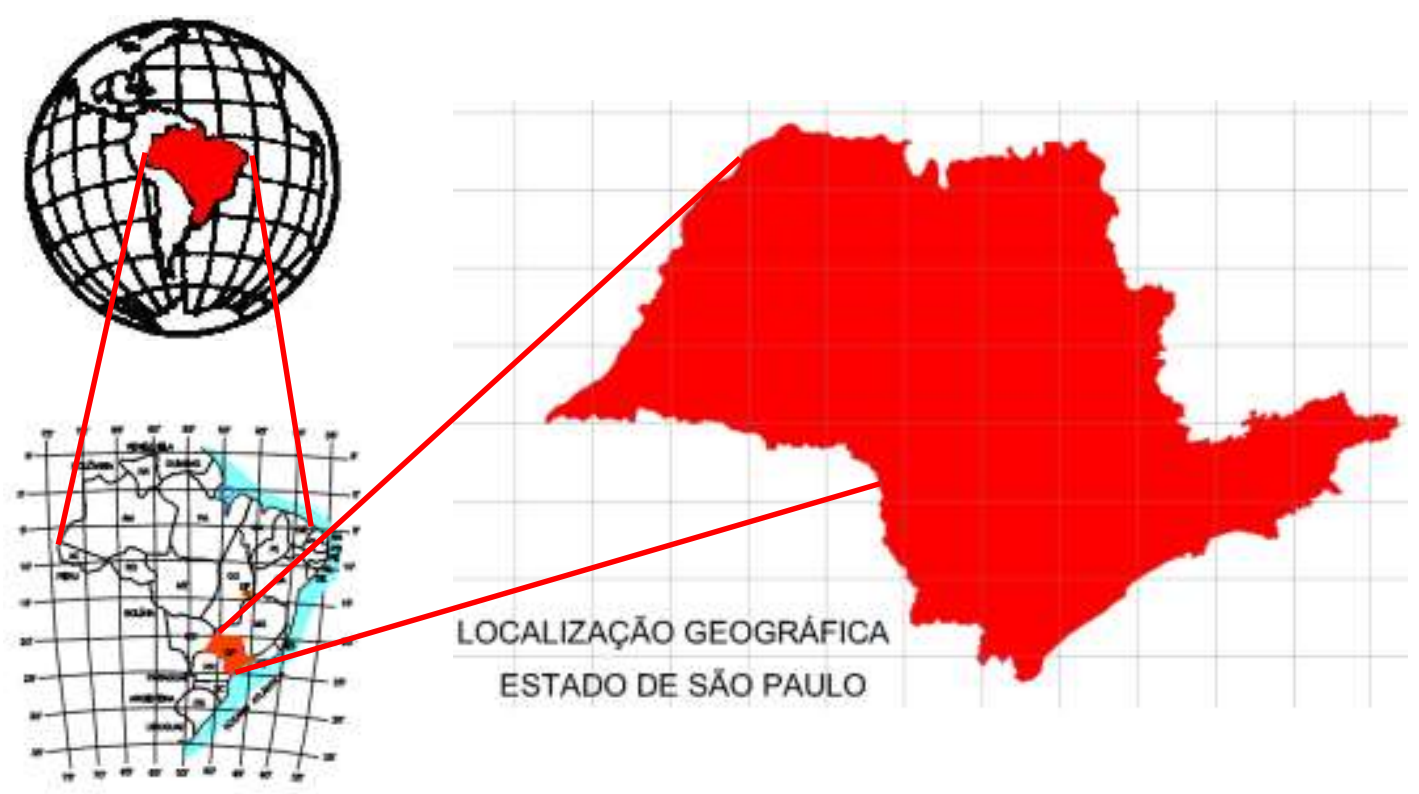

Figura 65. Localização do Estado de São Paulo

É conhecido como a "locomotiva do Brasil" por ter o maior Produto Interno Bruto (PIB) entre os estados brasileiros, apesar de possuir apenas 2,91\% da superfície brasileira. A média de crescimento alcançada do PIB entre os anos de 2006 e 2010 foi de 5,0\% ao ano, enquanto que a população no mesmo período cresceu à taxa de apenas 1,1\% ao ano. 


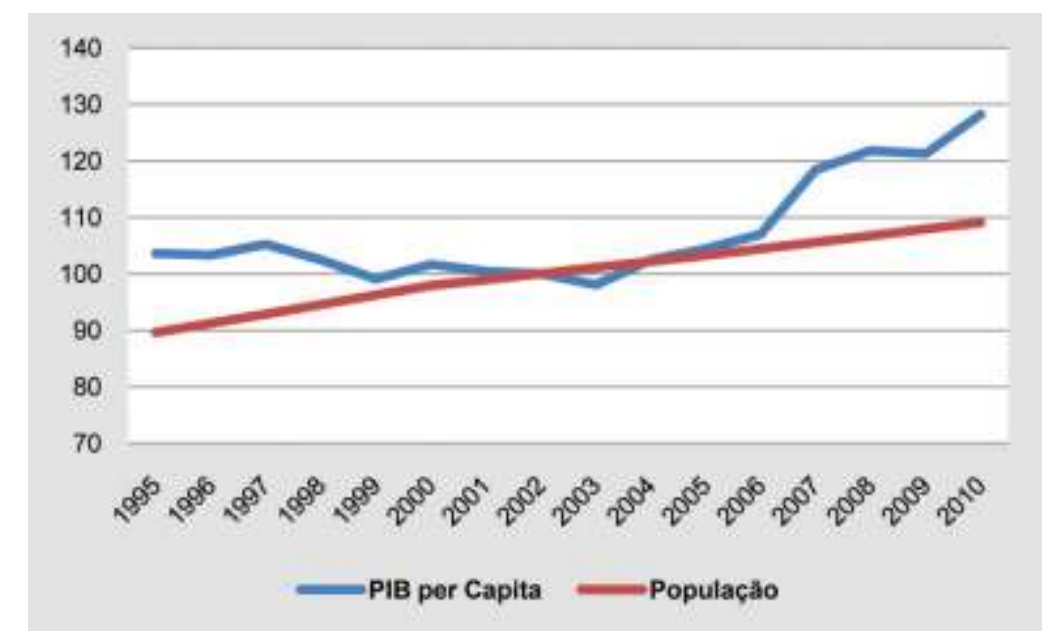

Quadro 2. Evolução do PIB per capita e da população do Est. De São Paulo - 1995-2010

Fonte: IBGE e Fundação Seade, 2011.

São Paulo é um estado geograficamente pequeno, que se caracteriza por uma grande diversidade e contrastes na ocupação do espaço, em resultado sobretudo da colonização com a distribuição populacional ao longo da faixa litorânea, que proporcionou um desenvolvimento sócio-econômico e urbano acentuado deste espaço.

É o estado mais populoso do Brasil, com população de 41.252.160 habitantes, conforme o censo de 2010, possui 645 municípios assentados em uma área superficial de $248.209,4 \mathrm{~km}^{2}$ e estão ordenados, de acordo com legislação estadual em 42 regiões de governo, 14 regiões administrativas e 4 regiões metropolitanas.

As regiões metropolitanas são compostas por: Região Metropolitana da Baixada Santista, Região Metropolitana de Campinas, Região Metropolitana de São Paulo e Região Metropolitana do Vale do Paraíba e Litoral Norte, que em conjunto com as aglomerações urbanas do Estado, correspondem a $78 \%$ da população estadual, compreendida em 151 municípios. 


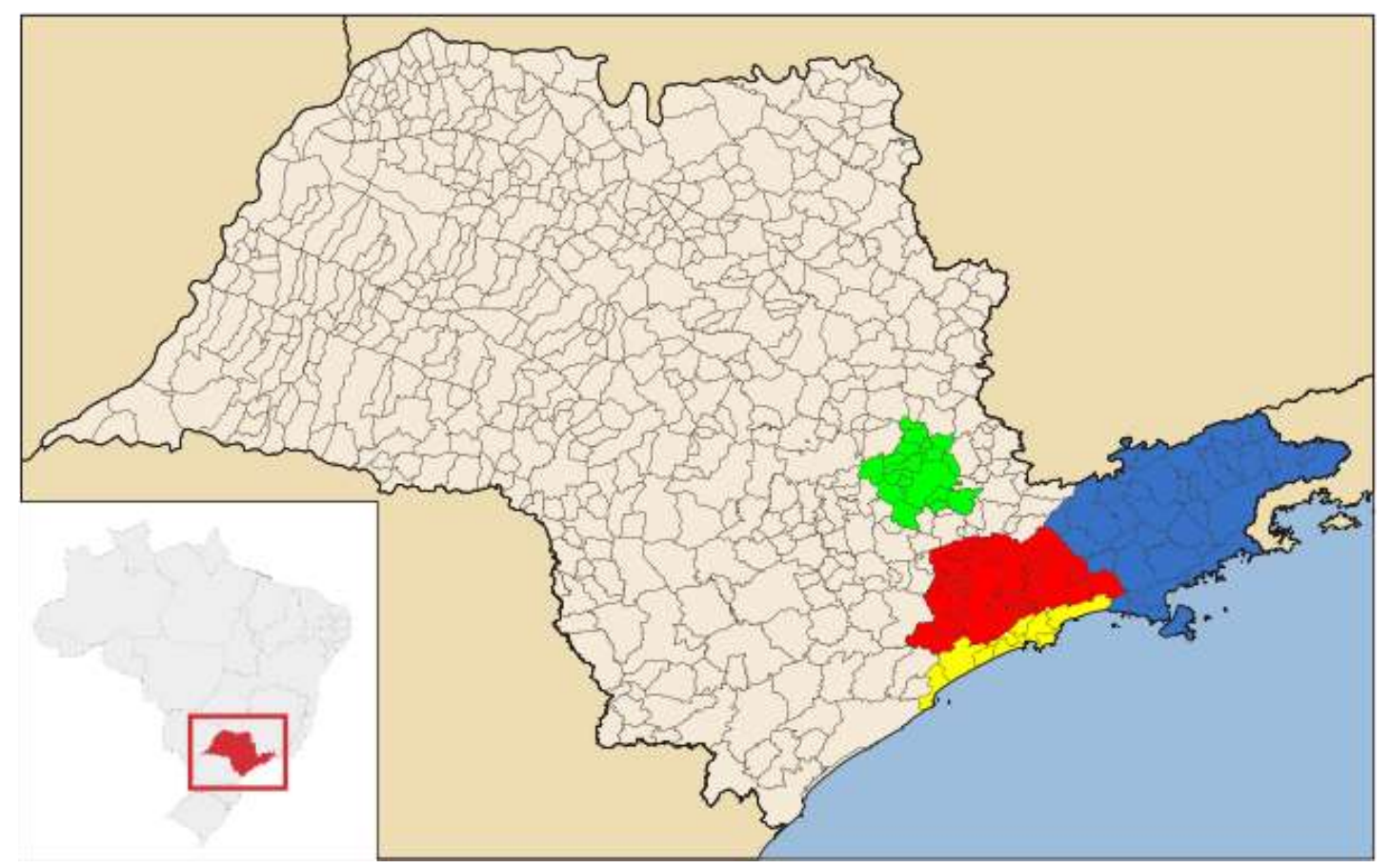

Figura 66. Localização das Regiões Metropolitanas do Est. de São Paulo Fonte: Wikipedia, 2012.

São Paulo possui uma das maiores malhas rodoviárias do país, com uma extensa rede de 198.877 quilômetros, composta por estradas administradas pelo Departamento de Estradas de Rodagem do Estado de São Paulo (DER-SP), pelo Governo Federal, por concessionárias e estradas municipais, interligando todos os municípios por rodovias pavimentadas.

Sua malha ferroviária reúne cinco dos principais corredores do Brasil. O de maior movimentação de carga do país, que liga a região de Jundiaí ao porto de Santos; o que integra com a rede da Ferrovia Centro Atlântica (FCA) por meio da antiga Mogiana, passando pelo Triângulo Mineiro e chegando ao Nordeste; outro que integra o Mato Grosso através das Ferrovias Bandeirantes S/A (Ferroban) e da Ferrovia Norte-Brasil (Ferronorte); o corredor operado pela Ferrovia Novoeste que vai até o Mato Grosso do Sul e o que vem da região do sul do Brasil.

São Paulo está localizado nas bacias hidrográficas do Paraná e na do Atlântico Sudeste e tem como principais rios paulistas o Tietê e o Paranapanema. 
Tabela 1. UGRHIs segundo classificação numérica.

\begin{tabular}{lc}
\hline Nome & UGRHI \\
\hline Mantiqueira & 1 \\
Paraíba do Sul & 2 \\
Litoral Norte & 3 \\
Pardo & 4 \\
Capivari/Jundiaí/Piracicaba & 5 \\
Alto Tietê & 6 \\
Baixada Santista & 7 \\
Sapucaí/Grande & 8 \\
Mogi-Guaçu & 9 \\
Médio Tiete/Sorocaba & 10 \\
Ribeira do Iguape/Litoral Sul & 11 \\
Baixo Pardo/Grande & 12 \\
Tietê/Jacaré & 13 \\
Alto Paranapanema & 14 \\
Turvo Grande & 15 \\
Tietê/Batalha & 16 \\
Médio Paranapanema & 17 \\
São José dos Dourados & 18 \\
Baixo Tietê & 19 \\
Aguapeí & 20 \\
Peixe & 21 \\
Pontal do Paranapanema & 22 \\
\hline & \\
\hline & \\
\hline
\end{tabular}

A Lei estadual $n^{\circ} 9.034$ de 27 de dezembro de 1994 estabeleceu a divisa do Estado de São Paulo em 22 bacias hidrográficas, denominadas Unidade de Gerenciamento de Recursos Hídricos (UGRHI), conforme figura 68. 


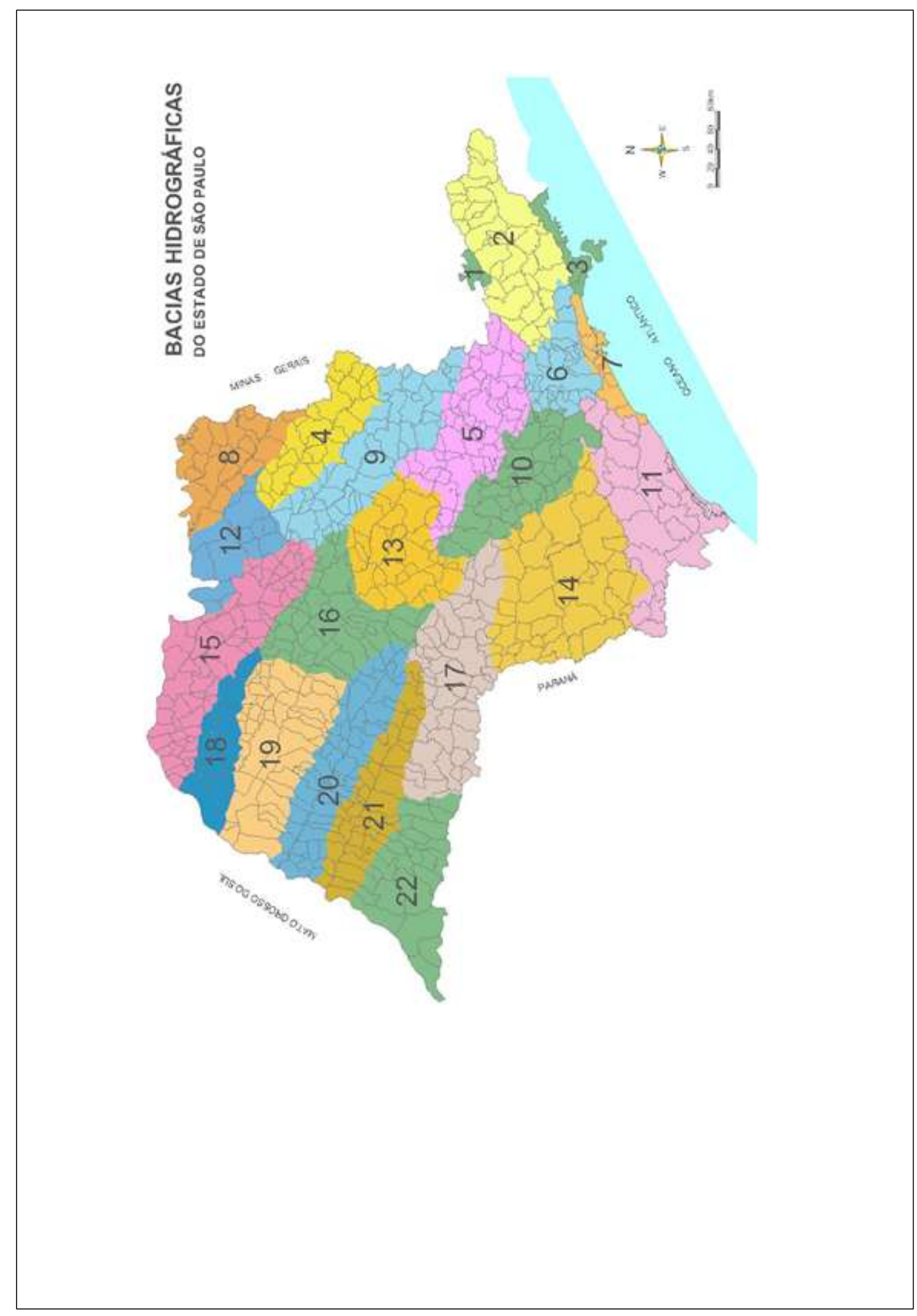

Figura 67. Bacias Hidrográficas do Estado de São Paulo Fonte: Autor, 2013. 
A hidrografia paulista é muito rica e é utilizada na geração de energia, transporte e abastecimento.

A captação de água subterrânea para abastecimento público é predominante na região oeste do Estado, onde é farta a disponibilidade proporcionada pelos aquíferos Bauru e Guarani, nas demais regiões os mananciais superficiais são responsáveis pelo abastecimento e em todo o estado, $85 \%$ da água consumida pela população provém da captação superficial (IBGE, 2010).

O relevo do território paulista é formado principalmente por uma planície litorânea estreita e por planaltos e depressões no restante do território.

O clima é predominantemente tropical, com estações úmidas e secas definidas em quase a totalidade do Estado, com exceção das encostas da Serra do Mar que possui uma estação seca muito curta.

A vegetação do Estado é muito diversificada, estando presente representantes de diversos biomas do Brasil, que pela posição geográfica do Estado ocorrem associações de floras tropicais com outras tipicamente de regiões subtropicais.

Levantamento executado pelo Governo do Estado por meio da Secretaria do Meio Ambiente em 2005, indicou uma área remanescente de 3.457.301 hectares, abrangendo todas as diferentes fitofisionomias e que correspondem a $13,94 \%$ da superfície estadual, sendo que a maior parte da vegetação natural é composta por matas $(5,76 \%)$ e capoeiras $(5,96 \%)$.

A CETESB - Companhia Ambiental do Estado de São Paulo, é o órgão delegado do Governo Paulista para a gestão ambiental de seu território, acompanhando a eficácia das ações de controle ambiental, dos programas e das políticas implementadas. Para o cumprimento destes propósitos foram implantadas 50 Agências Ambientais com atuação em todo o Estado (Figura 69). 


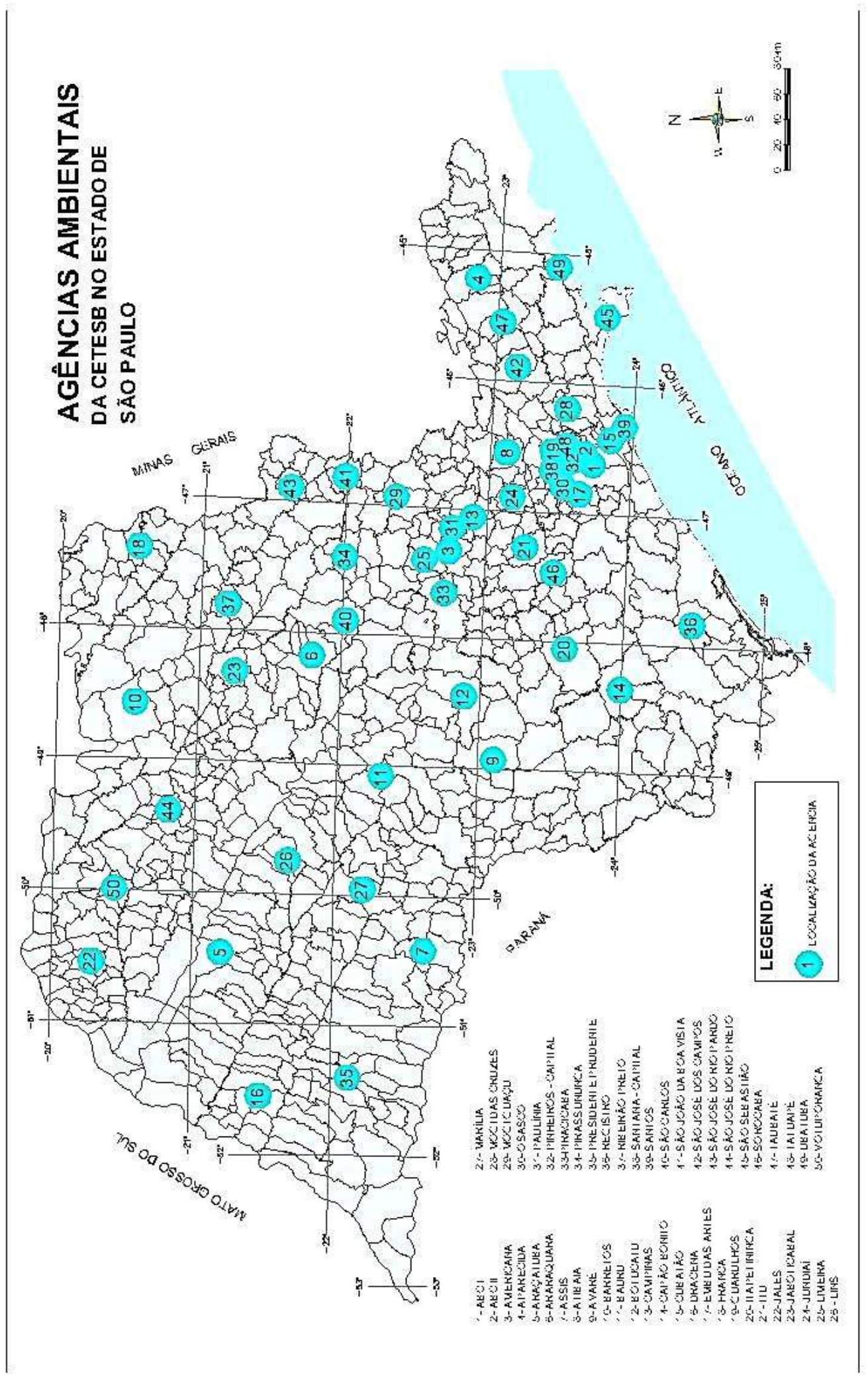

Figura 68. Agências Ambientais do Estado de São Paulo

Fonte: Autor, 2013. 


\subsection{RESíDUOS SÓLIDOS - ESTADO DE SÃO PAULO}

\subsubsection{Resíduos domiciliares}

Quanto à questão de gerenciamento e gestão dos resíduos sólidos no Estado, a Cetesb publica anualmente, desde 1997, uma sistematização de dados, com informações sobre as condições ambientais e sanitárias dos sistemas de disposição e tratamento dos resíduos domiciliares.

A Figura 70 mostra o avanço alcançado na disposição final dos resíduos, com o aperfeiçoamento dos sistemas de controle e qualidade da poluição ambiental, pois em 1997 apenas 27 dos municípios paulistas se enquadravam na condição de adequado e os demais se apresentavam em condições inadequadas.

No Inventário Estadual de Resíduos Sólidos Domiciliares do ano de 2011 (Cetesb, 2012) a situação identificava que somente 23 municípios encontramse nas condições inadequadas e o restante do Estado em condições adequadas.

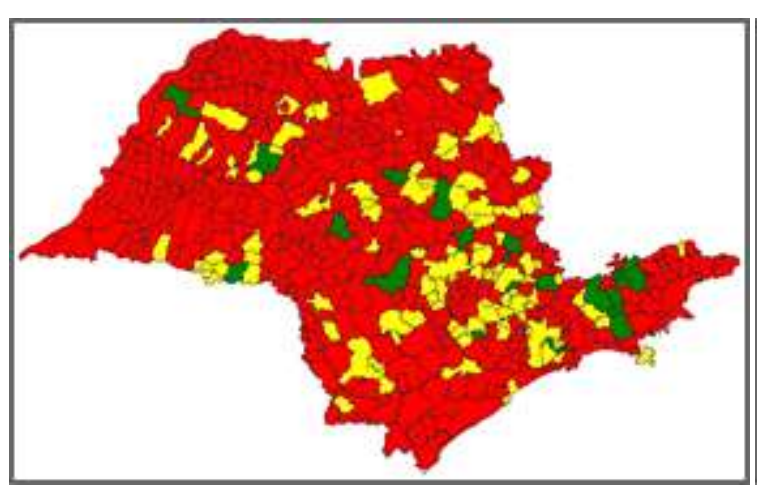

Inadequado

Controlado

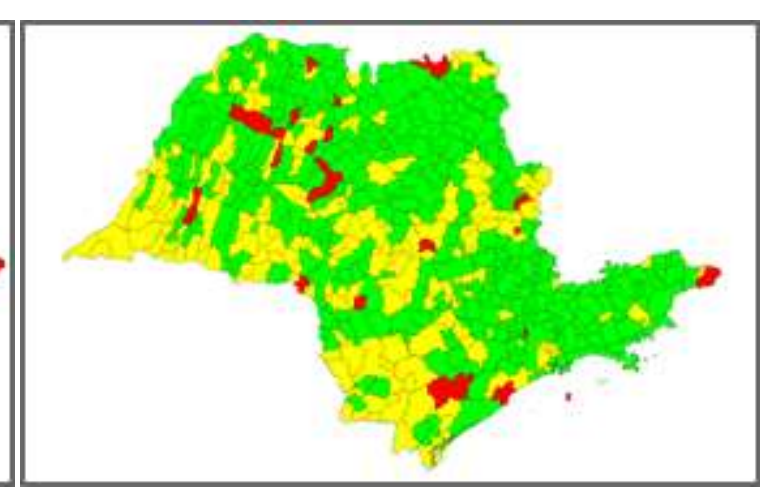

Adequado

Figura 69. IQR-Índice de Qualidade de Aterro de Resíduos no Est. De São Paulo Fonte: Cetesb, 2012

Instrumentos como o Inventário Estadual de Resíduos Sólidos dão condições para que o Estado e seus municípios possam conhecer como está a 
qualidade de seus sistemas de tratamento e disposição final de resíduos domiciliares, perante os critérios adotados pela Cetesb, mas não avaliam as condições da gestão e gerenciamento de seus resíduos.

Os técnicos da Cetesb periodicamente inspecionam essas instalações com objetivos de não só fiscalizar a atuação dos municípios ou empresas, mas também coletar dados para a elaboração do Inventário Anual.

O Índice da Qualidade de Aterros de Resíduos (IQR) é apurado por meio de um questionário padronizado, composto por três partes relativas as características locacionais, estruturais e operacionais, permitindo avaliar as condições ambientais e sanitárias dos sistemas de disposição final e de tratamento dos resíduos sólidos urbanos nos municípios paulistas, analisando e organizando as informações obtidas, para compor o Inventário Estadual de Resíduos Sólidos Domiciliares.

Foram utilizados neste trabalho os dados do Inventário do ano de 2011 para a análise dos resíduos sólidos domiciliares do Estado de São Paulo. As informações dos municípios são apresentadas de acordo com o seu enquadramento nas UGRHI's paulistas, quanto as condições de tratamento e disposição dos resíduos.

\section{- Geração per capita}

A taxa de geração per capita relaciona a quantidade de resíduos sólidos gerados diariamente e o número de habitantes de determinado município ou região. A Cetesb adota os seguintes índices de produção "per capita":

Até 100.000 hab. $\Rightarrow>0,4 \mathrm{~kg} /$ hab.dia
De 100.001 a $200.000=>0,5 \mathrm{~kg} /$ hab.dia
De 200.001 a $500.000=>0,6 \mathrm{~kg} /$ hab.dia
Maior que $500.00 \mathrm{hab} .=>0,7 \mathrm{~kg} /$ hab.dia

Com a produção diária dos resíduos em $t /$ dia dos municípios foi elaborado um mapa da produção anual de resíduos urbanos por município do Estado de São Paulo. 


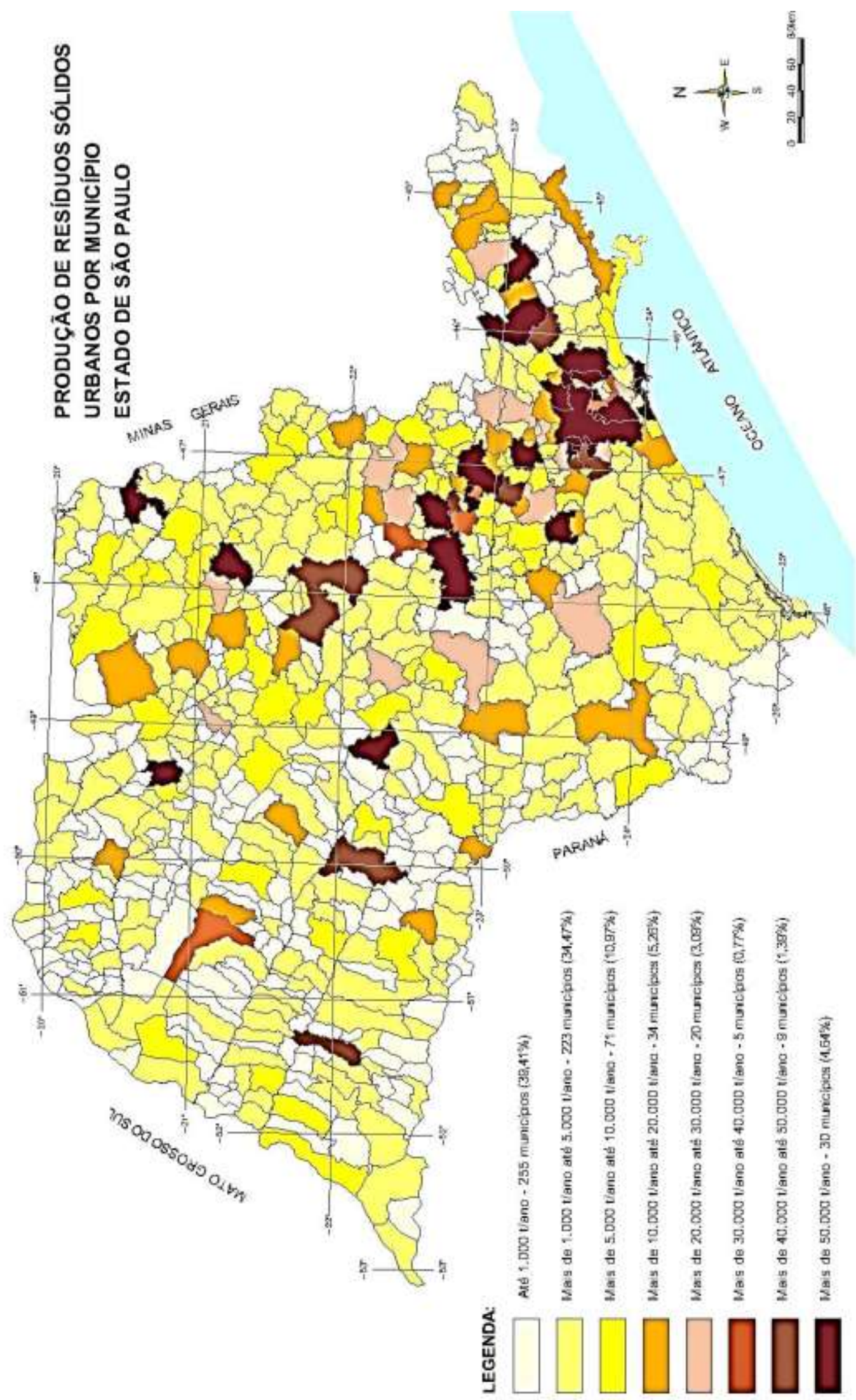

Figura 70. Produção por município do Estado de São Paulo

Fonte: Autor, 2013. 
O Estado produz diariamente 28.348,74 t/dia de resíduos domiciliares. Apurou-se que $84,84 \%$ (549) dos municípios produzem até 10.000 t/ano, sendo que aproximadamente $40 \%$ (255) produzem até 1.000 t/ano e que os 30 municípios com maior produção anual superam as 50.000 t/ano, correspondendo a 4,64\% do total do estado (figura 71).

Também do referido inventário foi possível identificar quais são os aterros particulares do Estado que recebem resíduos domiciliares:

Tabela 2. Lista de aterros particulares e quantidade recebida/dia

\begin{tabular}{c|c}
\hline ATERRO (município) & Quant. (t/dia) \\
\hline Cachoeira Paulista & 199,76 \\
Caieiras & 581,61 \\
Catanduva & 76,03 \\
Guará & 34,66 \\
Guatapará & 891,70 \\
Indaiatuba & 5,07 \\
Iperó & 35,75 \\
Itapevi & $5.207,57$ \\
Jardinópolis & 44,49 \\
Leme & 89,68 \\
Mauá & 602,56 \\
Meridiano & 231,17 \\
Onda Verde & 275,25 \\
Parapuã & 9,05 \\
Paulínia & 614,71 \\
Santana de Parnaíba & 602,86 \\
Santa Isabel & 512,70 \\
Santos & 291,32 \\
S J Boa Vista & 2,72 \\
São Paulo & 144,65 \\
São Pedro & 68,59 \\
Tremembé & 89,79 \\
\hline
\end{tabular}

Fonte: Autor, 2013. 


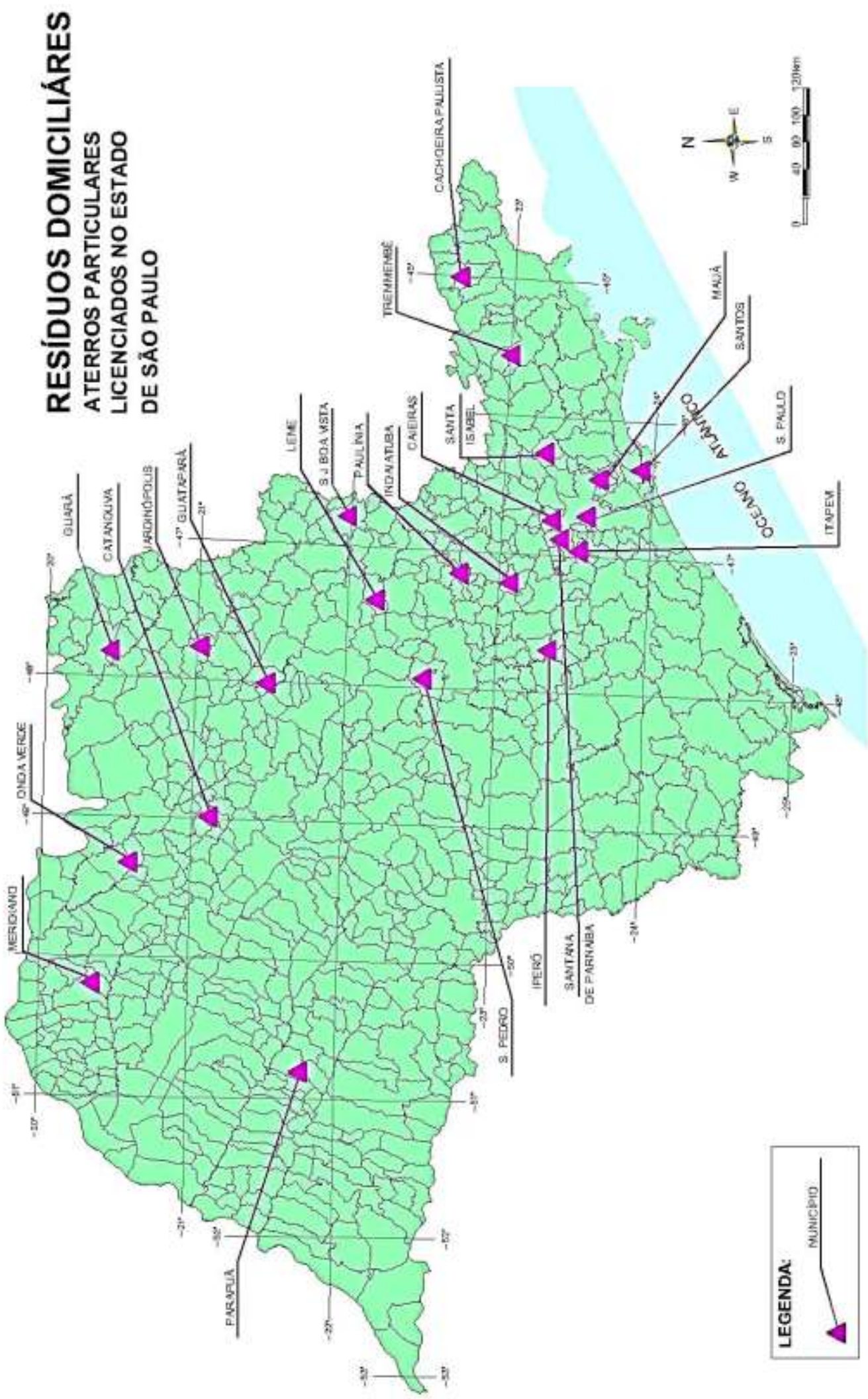

Figura 71. Aterros particulares licenciados no Estado de São Paulo Fonte: Autor, 2013. 
Tabela 3. Aterros particulares - quantidade e município que dispõe

\begin{tabular}{|l|r|l|}
\hline \multicolumn{1}{|c|}{ MUNICÍPIO } & Lixo (t/dia) & \multicolumn{1}{|c|}{ Dispõe em } \\
\hline APARECIDA & 13,80 & Cachoeira Paulista \\
\hline CANAS & 1,65 & Cachoeira Paulista \\
\hline CRUZEIRO & 30,14 & Cachoeira Paulista \\
\hline CUNHA & 4,85 & Cachoeira Paulista \\
\hline GUARATINGUETÁ & 53,67 & Cachoeira Paulista \\
\hline LAVRINHAS & 2,44 & Cachoeira Paulista \\
\hline LORENA & 32,21 & Cachoeira Paulista \\
\hline PORANGABA & 1,63 & Cachoeira Paulista \\
\hline QUADRA & 0,34 & Cachoeira Paulista \\
\hline RIOLÂNDIA & 3,40 & Cachoeira Paulista \\
\hline SÃO JOÃO DO PAU D'ALHO & 0,68 & Cachoeira Paulista \\
\hline SERTÃOZINHO & 54,97 & Cachoeira Paulista \\
\hline BOM JESUS DOS PERDÕES & 7,12 & Caieiras \\
\hline CAIEIRAS & 34,21 & Caieiras \\
\hline CAJAMAR & 25,53 & Caieiras \\
\hline CAMPO LIMPO PAULISTA & 29,95 & Caieiras \\
\hline EMBU-GUAÇU & 24,61 & Caieiras \\
\hline FRANCISCO MORATO & 77,87 & Caieiras \\
\hline FRANCO DA ROCHA & 61,45 & Caieiras \\
\hline IGUAPE & 9,91 & Caieiras \\
\hline ILHA COMPRIDA & 3,68 & Caieiras \\
\hline ITAPECERICA DA SERRA & 76,55 & Caieiras \\
\hline JUQUITIBA & 8,95 & Caieiras \\
\hline MAIRIPORÃ & 28,86 & Caieiras \\
\hline MIRACATU & 4,21 & Caieiras \\
\hline SÃO JOSÉ DO RIO PARDO & 18,43 & Caieiras \\
\hline SÃO MANUEL & 15,02 & Caieiras \\
\hline SUZANO & & Catanduva \\
\hline VARGEM & Caieiras \\
\hline ARIRANHA & Caieiras \\
\hline EMBAÚBA & & \\
\hline IBITINGA & & Catanduva \\
\hline
\end{tabular}




\begin{tabular}{|c|c|c|}
\hline MUNICÍPIO & $\begin{array}{l}\text { Lixo } \\
\text { (t/dia) }\end{array}$ & Dispõe em \\
\hline ITAJOBI & 4,87 & Catanduva \\
\hline NOVAIS & 1,71 & Catanduva \\
\hline NOVO HORIZONTE & 13,74 & Catanduva \\
\hline OUROESTE & 3,08 & Catanduva \\
\hline PANORAMA & 5,69 & Catanduva \\
\hline PIEDADE & 9,53 & Catanduva \\
\hline SALTO DE PIRAPORA & 12,71 & Catanduva \\
\hline ITUVERAVA & 14,64 & Guará \\
\hline BURITIZAL & 1,33 & Guará \\
\hline MONTE ALTO & 17,91 & Guará \\
\hline SÃO JOÃO DAS DUAS PONTES & 0,78 & Guará \\
\hline ÁGUAS DE SANTA BÁRBARA & 1,71 & Guatapará \\
\hline ALTINÓPOLIS & 5,46 & Guatapará \\
\hline AMÉRICO BRASILIENSE & 13,88 & Guatapará \\
\hline ANALÂNDIA & 1,38 & Guatapará \\
\hline ARARAQUARA & 122,81 & Guatapará \\
\hline BARIRI & 12,09 & Guatapará \\
\hline BEBEDOURO & 28,61 & Guatapará \\
\hline CRAVINHOS & 12,46 & Guatapará \\
\hline DESCALVADO & 11,14 & Guatapará \\
\hline DUMONT & 3,20 & Guatapará \\
\hline JAÚ & 64,18 & Guatapará \\
\hline MARÍLIA & 125,06 & Guatapará \\
\hline PIRAPOZINHO & 9,46 & Guatapará \\
\hline POLONI & 1,94 & Guatapará \\
\hline POTIM & 6,02 & Guatapará \\
\hline RIBEIRÃO DOS ÍNDIOS & 0,74 & Guatapará \\
\hline RIBEIRÃO PRETO & 427,42 & Guatapará \\
\hline SEBASTIANÓPOLIS DO SUL & 0,95 & Guatapará \\
\hline SERRA AZUL & 3,29 & Guatapará \\
\hline TAMBAÚ & 7,97 & Guatapará \\
\hline UCHOA & 3,53 & Guatapará \\
\hline LINS & 28,41 & Guatapará \\
\hline ELIAS FAUSTO & 5,07 & Indaiatuba \\
\hline BOITUVA & 18,58 & Iperó \\
\hline IPERÓ & 7,17 & Iperó \\
\hline
\end{tabular}




\begin{tabular}{|c|c|c|}
\hline MUNICÍPIO & $\begin{array}{c}\text { Lixo } \\
\text { (t/dia) }\end{array}$ & Dispõe em \\
\hline PONTES GESTAL & 0,85 & Iperó \\
\hline SÃO SEBASTIÃO DA GRAMA & 3,18 & Iperó \\
\hline SEVERÍNIA & 5,97 & Iperó \\
\hline ARAÇARIGUAMA & 7,01 & Itapevi \\
\hline COTIA & 123,09 & Itapevi \\
\hline JANDIRA & 54,81 & Itapevi \\
\hline MAIRINQUE & 13,96 & Itapevi \\
\hline SÃO PAULO & $5.000,00$ & Itapevi \\
\hline VALPARAÍSO & 8,70 & Itapevi \\
\hline BRODOWSKI & 8,36 & Jardinópolis \\
\hline CAJURU & 8,39 & Jardinópolis \\
\hline JARDINÓPOLIS & 14,66 & Jardinópolis \\
\hline MORRO AGUDO & 11,27 & Jardinópolis \\
\hline ONDA VERDE & 1,23 & Jardinópolis \\
\hline SÃO JOÃO DE IRACEMA & 0,58 & Jardinópolis \\
\hline SANTA BÁRBARA D'OESTE & 89,68 & Leme \\
\hline DIADEMA & 233,15 & Mauá \\
\hline ITANHAÉM & 34,96 & Mauá \\
\hline RIBEIRÃO DO SUL & 1,32 & Mauá \\
\hline RINÓPOLIS & 3,45 & Mauá \\
\hline SANTANA DE PARNAÍBA & 55,71 & Mauá \\
\hline SANTÓPOLIS DO AGUAPEÍ & 1,67 & Mauá \\
\hline SANTOS & 251,52 & Mauá \\
\hline SÃO SEBASTIĨ̃O & 20,80 & Mauá \\
\hline FERNANDÓPOLIS & 25,18 & Meridiano \\
\hline SÃO VICENTE & 200,42 & Meridiano \\
\hline URÂNIA & 2,97 & Meridiano \\
\hline VISTA ALEGRE DO ALTO & 2,60 & Meridiano \\
\hline BADY BASSITT & 5,55 & Onda Verde \\
\hline GUAPIAÇU & 6,42 & Onda Verde \\
\hline NOVA GRANADA & 7,17 & Onda Verde \\
\hline NUPORANGA & 2,49 & Onda Verde \\
\hline OURO VERDE & 2,89 & Onda Verde \\
\hline PRESIDENTE EPITÁCIO & 15,48 & Onda Verde \\
\hline SÃO JOSÉ DA BELA VISTA & 3,00 & Onda Verde \\
\hline SÃO JOSÉ DO RIO PRETO & 232,25 & Onda Verde \\
\hline
\end{tabular}




\begin{tabular}{|c|c|c|}
\hline MUNICÍPIO & $\begin{array}{c}\text { Lixo } \\
\text { (t/dia) }\end{array}$ & Dispõe em \\
\hline IACRI & 2,01 & Parapuã \\
\hline AMERICANA & 127,08 & Paulínia \\
\hline ARTUR NOGUEIRA & 16,31 & Paulínia \\
\hline CAPIVARI & 18,57 & Paulínia \\
\hline CESÁRIO LANGE & 4,25 & Paulínia \\
\hline CONCHAL & 9,61 & Paulínia \\
\hline COSMÓPOLIS & 22,27 & Paulínia \\
\hline ENGENHEIRO COELHO & 4,73 & Paulínia \\
\hline ESPÍRITO SANTO DO PINHAL & 14,94 & Paulínia \\
\hline HOLAMBRA & 3,36 & Paulínia \\
\hline HORTOLÂNDIA & 97,89 & Paulínia \\
\hline ITATIBA & 34,79 & Paulínia \\
\hline ITUPEVA & 16,08 & Paulínia \\
\hline JAGUARIÚNA & 17,65 & Paulínia \\
\hline LOUVEIRA & 14,67 & Paulínia \\
\hline MOGI-MIRIM & 32,52 & Paulínia \\
\hline MOMBUCA & 1,08 & Paulínia \\
\hline MONTE MOR & 18,73 & Paulínia \\
\hline MORUNGABA & 4,07 & Paulínia \\
\hline NOVA ODESSA & 20,44 & Paulínia \\
\hline PARISI & 0,66 & Paulínia \\
\hline PEDRO DE TOLEDO & 2,83 & Paulínia \\
\hline PIQUEROBI & 1,07 & Paulínia \\
\hline SANTO ANDRÉ & 100,00 & Paulínia \\
\hline SANTO ANTÔNIO DA ALEGRIA & 1,88 & Paulínia \\
\hline SOCORRO & 10,06 & Paulínia \\
\hline TEJUPÁ & 1,24 & Paulínia \\
\hline URU & 0,43 & Paulínia \\
\hline VARGEM GRANDE PAULISTA & 17,52 & Paulínia \\
\hline ÁGUAS DA PRATA & 2,72 & S J Boa Vista \\
\hline ARUJÁ & 29,23 & Santa Isabel \\
\hline BIRITIBA MIRIM & 9,91 & Santa Isabel \\
\hline CARAGUATATUBA & 39,31 & Santa Isabel \\
\hline ITAQUAQUECETUBA & 195,31 & Santa Isabel \\
\hline MOGI DAS CRUZES & 216,83 & Santa Isabel \\
\hline NAZARÉ PAULISTA & 5,62 & Santa Isabel \\
\hline
\end{tabular}




\begin{tabular}{|c|c|c|}
\hline MUNICÍPIO & $\begin{array}{c}\text { Lixo } \\
\text { (t/dia) }\end{array}$ & Dispõe em \\
\hline SAGRES & 0,73 & Santa Isabel \\
\hline SANTA ERNESTINA & 2,05 & Santa Isabel \\
\hline BARUERI & 145,95 & Santana de Parnaíba \\
\hline CARAPICUÍBA & 222,90 & Santana de Parnaíba \\
\hline JUNDIAÍ & 214,58 & Santana de Parnaíba \\
\hline PIRAJU & 10,26 & Santana de Parnaíba \\
\hline SANTA ROSA DE VITERBO & 9,17 & Santana de Parnaíba \\
\hline BERTIOGA & 19,28 & Santos \\
\hline CUBATÃO & 59,76 & Santos \\
\hline GUARUJÁ & 175,61 & Santos \\
\hline MONGAGUÁ & 18,78 & Santos \\
\hline POTIRENDABA & 5,60 & Santos \\
\hline SANTO ANTÔNIO DO PINHAL & 1,55 & Santos \\
\hline SÃO PEDRO & 10,74 & Santos \\
\hline ATIBAIA & 58,15 & São Paulo \\
\hline FERRAZ DE VASCONCELOS & 81,33 & São Paulo \\
\hline PINHALZINHO & 2,61 & São Paulo \\
\hline SUD MENNUCCI & 2,56 & São Paulo \\
\hline ÁGUAS DE SÃO PEDRO & 1,11 & São Pedro \\
\hline ARARAS & 56,75 & São Pedro \\
\hline IPEÚNA & 2,12 & São Pedro \\
\hline SÃO MIGUEL ARCANJO & 8,61 & São Pedro \\
\hline CAÇAPAVA & 29,23 & Tremembé \\
\hline CAMPOS DO JORDÃO & 19,10 & Tremembé \\
\hline ILHABELA & 11,43 & Tremembé \\
\hline MONTEIRO LOBATO & 0,72 & Tremembé \\
\hline SANTO ANTÔNIO DE POSSE & 7,60 & Tremembé \\
\hline SANTO EXPEDITO & 1,00 & Tremembé \\
\hline SÃO PEDRO DO TURVO & 2,07 & Tremembé \\
\hline TARABAI & 2,47 & Tremembé \\
\hline TORRE DE PEDRA & 0,59 & Tremembé \\
\hline TREMEMBÉ & 14,94 & Tremembé \\
\hline TURIÚBA & 0,63 & Tremembé \\
\hline TOTAL & $10.611,68$ & \\
\hline
\end{tabular}


Considerando-se a disposição diária dos resíduos domiciliares no Estado de São Paulo, observa-se que 177 municípios, que correspondem a 37,40 \% da quantidade de resíduos geradas diariamente, utilizam aterros particulares para disposição final de seus resíduos e o restante dos municípios paulistas deposita em aterros públicos.

A Lei Federal $n^{\circ} 12.305 / 2010$ define a responsabilidade pelo gerenciamento de resíduos sólidos. 0 art. 10 da referida lei incumbe ao Distrito Federal e aos municípios a gestão integrada dos resíduos sólidos gerados nos respectivos territórios, bem como da responsabilidade do gerador pelo gerenciamento de resíduos.

Em âmbito municipal, os serviços de gerenciamento, prestação de serviços de limpeza pública e manejo de resíduos sólidos estão delegados a secretarias municipais, departamentos ou setores da administração pública, que realizam os serviços com equipe própria, ou através de concessões à empresas privadas, cooperativas, associações ou ainda, através de parcerias públicoprivadas.

\subsubsection{Limpeza Pública}

A legislação brasileira responsabiliza os municípios pela execução da limpeza pública, mas não aponta uma regulamentação que apoie a administração pública na execução de uma norma que assegure recursos necessários para a execução destes serviços, devendo gerenciar e prestar os serviços de maneira direta ou através de contratação de empresas prestadoras de serviços.

Os serviços de limpeza pública cobrem atividades como:

- Varrição;

- Capina e raspagem;

- Poda de árvores;

- Roçagem; 
- Limpeza de ralos/boca de lobo/galerias;

- Limpeza de feiras;

- Lavagem de logradouros;

- Limpeza de terrenos baldios, locais turísticos, rios, lagoas, etc.

Com base nos dados do SINIS 2011, tem-se uma amostra com 377 municípios, que correspondem a $86,95 \%$ da população do Estado de São Paulo, todos os municípios informaram realizar serviços de varrição, apenas 38 executam estes serviços de forma mecanizada e 10 realizam através de varredores contratados por empresas privadas.

\subsubsection{Serviços de coleta}

Segundo o SINIS 2011, no Estado de São Paulo são executados diversas formas de coleta de resíduos sólidos, que consiste em recolher os resíduos acondicionados pelo produtor para encaminhá-los, mediante transporte adequado, a uma destinação final licenciada (tratamento ou disposição final em aterro sanitário ou outra tecnologia licenciada pelo órgão ambiental).

A frequência da coleta de resíduos é determinada por fatores econômicos, técnicos e culturais do município, tendo as seguintes frequências: diária, duas ou três vezes por semana e uma vez por semana, podendo ainda variar em bairros e zonas centrais, turísticas e comerciais, realizada porta a porta, através de veículos apropriados ao tipo de resíduo a ser coletado, considerando seu volume/peso e condições específicas de tráfego do município.

Os resíduos gerados pelos serviços de limpeza pública podem ser coletados de forma independente ou juntamente com os resíduos domésticos através da coleta regular domiciliar. 


\subsubsection{Resíduos de Construção e Demolição}

São considerados resíduos de construção civil os resíduos gerados nas construções, reformas, reparos e demolições de obras de construção civil, incluídos os resultantes da preparação e escavação de terrenos para obras civis, os quais são de responsabilidade do gerador dos mesmos.

O gerenciamento destes resíduos não é de responsabilidade legal dos municípios, porém verifica-se que alguns disponibilizam o serviço de coleta e disposição mediante pagamento de taxa específica ou não.

Não foi encontrado dados sobre a produção de resíduos de construção e demolição para o Estado de São Paulo, somente estudos de caso como os efetuados por Marques Neto (2003) para São Carlos, Pinto (1999) para Ribeirão Preto e Castro (2003) para Santos entre outros.

Carneiro et al.(2001) aponta uma geração per capita para o Brasil em torno de 0,4 toneladas por habitante/dia, o que aponta uma produção diária para o estado de 16.500 .864 toneladas.

Com base nos dados do SINIS 2011, dos 377 municípios que participaram da pesquisa, 151 municípios que correspondem a $40 \%$ dos participantes, não executam a coleta dos serviços dos resíduos sólidos da construção civil.

\subsubsection{Resíduos Sólidos Industriais}

A gestão de resíduos industriais é efetuada no Estado de São Paulo por empresas devidamente licenciadas pela Agência Ambiental - CETESB. Estas empresas podem fazer armazenamentos temporários, tratamentos e destinos finais adequados para os resíduos ou podem ser apenas intermediários no processo, transferindo os resíduos para outras entidades que executem o tratamento e os enviam para o destino final adequado.

A legislação brasileira impõe a responsabilização ao gerador de resíduos pelo seu ciclo, o que se traduz na obrigação de retomar e valorizar 
materiais, isto deve gerar uma reação em cadeia através da produção comercialização - consumo - pós-consumo, transmitindo para o próximo integrante deste ciclo uma parte da responsabilidade.

O manejo dos resíduos sólidos industriais utiliza a NBR 10.004/2004, que classifica os resíduos em:

1. Classe I: Perigosos

2. Classe II: Não perigosos;

a) Não inertes.

b) Inertes.

Fazem parte dos resíduos industriais os gerados em processos produtivos industriais, de pesquisa, de transformação de matérias-primas e substâncias orgânicas ou inorgânicas em novos produtos, bem como os provenientes das atividades extrativas, de mineração, de montagem e manipulação de produtos acabados, indústrias químicas e ainda, os resíduos de estações de tratamento de água e esgoto.

A CETESB, desde o final da década de 1970, tem realizado levantamentos de dados de indústrias, empregando metodologias utilizadas em outros países com experiência nesta área.

Os dados disponíveis sobre os resíduos industriais do Estado na CETESB, ainda são os da avaliação efetuada no ano de 1996 com o Inventário de Resíduos Industriais, que contou com uma amostra de 1.470 unidades industriais. 0 total quantificado foi que as indústrias do Estado de São Paulo geraram, no referido ano mais de 500 mil toneladas de resíduos sólidos perigosos, sendo cerca de 20 milhões de toneladas de resíduos sólidos não-inertes e não-perigosos, e mais de um milhão de toneladas de resíduos inertes.

Com relação à destinação final obteve-se que $53,6 \%$ dos resíduos perigosos são tratados, $30,7 \%$ são armazenados e os $15,7 \%$ restantes são 
depositados no solo e, dentre os maiores geradores de resíduos industriais classe I, destacam os seguintes segmentos do setor:

Tabela 4. Maiores geradores de resíduos industriais classe I no Estado de São Paulo em 1996.

\begin{tabular}{|l|c|}
\hline \multicolumn{1}{|c|}{ Indústria } & $\times 1.000$ t/ano \\
\hline Química & 177,4 \\
\hline Material transporte & 116,8 \\
\hline Couros e peles & 76,3 \\
\hline Metalúrgica & 76,3 \\
\hline Minerais não metálicos & 28,0 \\
\hline Papel e papelão & 26,7 \\
\hline Material elétrico & 10,3 \\
\hline Mecânica & 5,5 \\
\hline Produtos alimentares & 3,3 \\
\hline Produtos Farmacêuticos & 3,2 \\
\hline Têxtil & 2,6 \\
\hline Outros & 9,3 \\
\hline
\end{tabular}

Fonte: CETESB. Inventário de Resíduos Industriais. 1996

Também são encontradas empresas de resíduos com instalações devidamente licenciadas que, apesar de não possuírem a gestão de resíduos como atividade principal, incorporam resíduos no seu processo industrial, tais como as cimenteiras.

A tabela 5 apresenta as unidades de empresas privadas receptoras de resíduos industriais no Estado de São Paulo, desconsiderando unidades que não 
exercem atividades específicas de tratamento, tais como depósitos temporários, centrais de triagem e recicladores.

Tabela 5. Unidades de empresas privadas receptoras de resíduos industriais no Estado de São Paulo.

\begin{tabular}{|l|c|}
\hline \multicolumn{1}{|c|}{ Tecnologia } & Quantidade \\
\hline Aterros Classe I & 4 \\
\hline Aterros Classe II-A & 31 \\
\hline Incineradoras & 5 \\
\hline Tratamento Biológico & 1 \\
\hline Dessorção & 1 \\
\hline Cimenteiras - coprocessamento & 4 \\
\hline Blendagem - coprocessamento & 2 \\
\hline
\end{tabular}

Fonte: Autor, 2013.

Foi enviado um questionário à todas as agências ambientais do Estado de São Paulo com o objetivo de efetuar o levantamento dos aterros industriais existentes no território paulista e encontrou-se a situação descrita na tabela 6 . 
Tabela 6. Respostas da agência ambientais sobre aterros de resíduos industrial no Estado de São Paulo.

\section{Perguntas:}

1- Em algum dos municípios que são atendidos por esta Agência existe Aterro Industrial ?

2- Em caso afirmativo, que classe de resíduos o aterro recebe?

3- Em qual município se localiza o aterro e qual é a empresa responsável?

\begin{tabular}{|c|c|c|c|c|c|}
\hline \multirow{3}{*}{$\begin{array}{l}\text { AGÊNCIA } \\
\text { AMBIENTAL }\end{array}$} & \multicolumn{5}{|c|}{ RESPOSTAS } \\
\hline & \multicolumn{2}{|c|}{ Questão 1} & \multirow{2}{*}{$\frac{\text { Questão } 2}{\text { Classe }}$} & \multicolumn{2}{|c|}{ Questão 3} \\
\hline & Sim & Não & & Município & Empresa \\
\hline \multirow{2}{*}{$A B C I$} & $x$ & & II-A e II-B & Mauá & $\begin{array}{l}\text { Boa Hora Central de } \\
\text { Trat. Resíd. Ltda }\end{array}$ \\
\hline & $x$ & & II-A e II-B & Mauá & $\begin{array}{l}\text { Lara Central de Trat. } \\
\text { de Resíd. Ltda }\end{array}$ \\
\hline$A B C$ II & & $x$ & & & \\
\hline Americana & & $x$ & & & \\
\hline Aparecida & $x$ & & II-A e II-B & Cachoeira Paulista & $\begin{array}{l}\text { Vale Soluções } \\
\text { Ambientais Ltda }\end{array}$ \\
\hline Araçatuba & & $x$ & & & \\
\hline Araraquara & & $x$ & & & \\
\hline Assis & & $x$ & & & \\
\hline Atibaia & & $x$ & & & \\
\hline Avaré & & $x$ & & & \\
\hline Barretos & & $x$ & & & \\
\hline Bauru & $x$ & & II-A e II-B & Piratininga & Estre Ambiental S/A \\
\hline Botucatu & & $x$ & & & \\
\hline Campinas & & $x$ & & & \\
\hline Capão Bonito & & $x$ & & & \\
\hline Cubatão & & $x$ & & & \\
\hline Dracena & & $x$ & & & \\
\hline Embu das Artes & & $x$ & & & \\
\hline Franca & $x$ & & II-A & Guará & Ambitec S.A. \\
\hline Guarulhos & & $x$ & & & \\
\hline Itapetininga & & $x$ & & & \\
\hline Itu & & $x$ & & & \\
\hline Jales & & $x$ & & & \\
\hline Jaboticabal & $x$ & & II-A e II-B & Guatapará & CGR Guatapará \\
\hline Jundiaí & $x$ & & II-A & Indaiatuba & $\begin{array}{l}\text { Corpus Saneamento e } \\
\text { Obras Ltda. }\end{array}$ \\
\hline Limeira & & $x$ & & & \\
\hline Lins & & $x$ & & & \\
\hline Marília & $x$ & & II-A & Quatá & Revita Engenharia S.A. \\
\hline
\end{tabular}




\begin{tabular}{|c|c|c|c|c|c|}
\hline \multirow{2}{*}{ Mogi das Cruzes } & $x$ & & II e III & Santa Isabel & $\begin{array}{l}\text { Anaconda Amb. } \\
\text { Empreend. Ltda }\end{array}$ \\
\hline & $\mathrm{X}$ & & II-A & Itaquaquecetuba & $\begin{array}{l}\text { Pajoan central de } \\
\text { Tratam. De Resíd. }\end{array}$ \\
\hline Mogi Guaçu & & $x$ & & & \\
\hline \multirow{3}{*}{ Osasco } & $\mathrm{X}$ & & I e II-A & Caieiras & $\begin{array}{l}\text { Essencis Soluções Amb. } \\
\text { S.A. }\end{array}$ \\
\hline & $x$ & & I e II-A & Itapevi & $\begin{array}{l}\text { Estre Ambiental S/A - } \\
\text { CGR Itapevi }\end{array}$ \\
\hline & $x$ & & II-A & Sant. de Parnaíba & $\begin{array}{l}\text { Tecipar Eng. E Meio } \\
\text { Ambiente Ltda }\end{array}$ \\
\hline Paulínia & $x$ & & II-A e II-B & Paulínia & Estre Ambiental S/A \\
\hline Pinheiros & & $x$ & & & \\
\hline \multirow{2}{*}{ Piracicaba } & $\mathrm{x}$ & & II-A & São Pedro & $\begin{array}{l}\text { Construrban Logística } \\
\text { Abiental Ltda }\end{array}$ \\
\hline & $\mathrm{X}$ & & II-A & Rio Claro & $\begin{array}{l}\text { Pref. Municipal de Rio } \\
\text { Claro }\end{array}$ \\
\hline Pirassununga & & $x$ & & & \\
\hline $\begin{array}{l}\text { Presidente } \\
\text { Prudente } \\
\end{array}$ & & $\mathrm{X}$ & & & \\
\hline Registro & & $x$ & & & \\
\hline \multirow[b]{2}{*}{ Ribeirão Preto } & $x$ & & II-A e II-B & Jardinópolis & CGR Jardinópolis \\
\hline & $\mathrm{X}$ & & II-A & $\begin{array}{c}\text { Santa R. de } \\
\text { Viterbo }\end{array}$ & $\begin{array}{l}\text { PH\& Serviços } \\
\text { Ambientais Ltda } \\
\end{array}$ \\
\hline \multirow{2}{*}{ Santana } & $\mathrm{X}$ & & II-B & São Paulo & $\begin{array}{l}\text { Essencis Soluções Amb. } \\
\text { S.A. }\end{array}$ \\
\hline & $x$ & & II-A e II-B & São Paulo & $\begin{array}{l}\text { CDR Pedreira-Centro } \\
\text { de Disp. Resíd. }\end{array}$ \\
\hline Santos & $\mathrm{X}$ & & II-A e II-B & Santos & $\begin{array}{l}\text { Terrestre Ambiental } \\
\text { Ltda }\end{array}$ \\
\hline São Carlos & & $x$ & & & \\
\hline $\begin{array}{l}\text { São João da Boa } \\
\text { Vista }\end{array}$ & & $x$ & & & \\
\hline \multirow{2}{*}{$\begin{array}{l}\text { São José dos } \\
\text { Campos }\end{array}$} & $x$ & & II-A e II-B & Jambeiro & Engep Ambiental Ltda \\
\hline & $X$ & & I, II-A e II-B & São J. dos Campos & $\begin{array}{l}\text { Essencis Ecossistema } \\
\text { Ltda }\end{array}$ \\
\hline \multicolumn{6}{|l|}{$\begin{array}{l}\text { São José do Rio } \\
\text { Pardo }\end{array}$} \\
\hline \multirow{2}{*}{$\begin{array}{l}\text { São José do Rio } \\
\text { Preto }\end{array}$} & $x$ & & II-A & Catanduva & CGR Catanduva \\
\hline & $x$ & & II-A & Onda Verde & $\begin{array}{l}\text { Constroeste Constr. E } \\
\text { Partic. Ltda }\end{array}$ \\
\hline São Sebastião & & $x$ & & & \\
\hline \multirow{2}{*}{ Sorocaba } & $\mathrm{X}$ & & I e II-A & Sorocaba & $\begin{array}{l}\text { Pref. Mun. de } \\
\text { Sorocaba/URBES }\end{array}$ \\
\hline & $x$ & & II-A e II-B & Iperó & $\begin{array}{l}\text { Proactiva Maio } \\
\text { Ambiente Brasil Ltda }\end{array}$ \\
\hline Taubaté & $x$ & & I; II-A e II-B & Tremembé & $\begin{array}{l}\text { Resicontrol Soluções } \\
\text { Amb. Ltda }\end{array}$ \\
\hline Ubatuba & & $x$ & & & \\
\hline Votuporanga & & $\mathrm{x}$ & & & \\
\hline
\end{tabular}

As figuras de números 72 a 78 a seguir apresentam as plantas de localização das unidades receptoras de resíduos industriais no Estado de São Paulo. 


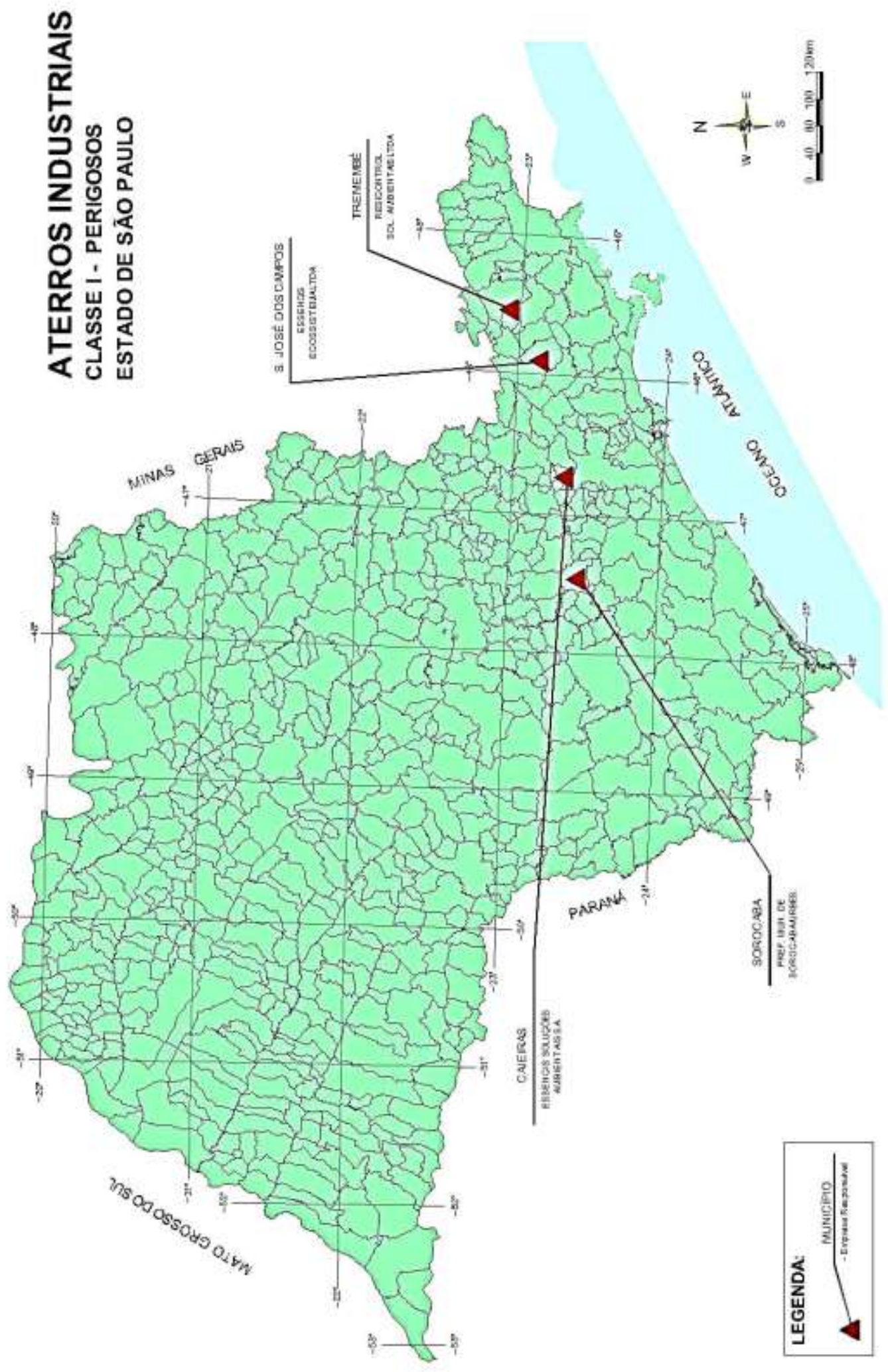

Figura 72. Localização dos aterros Classe I do Estado de São Paulo Fonte: Autor, 2013. 


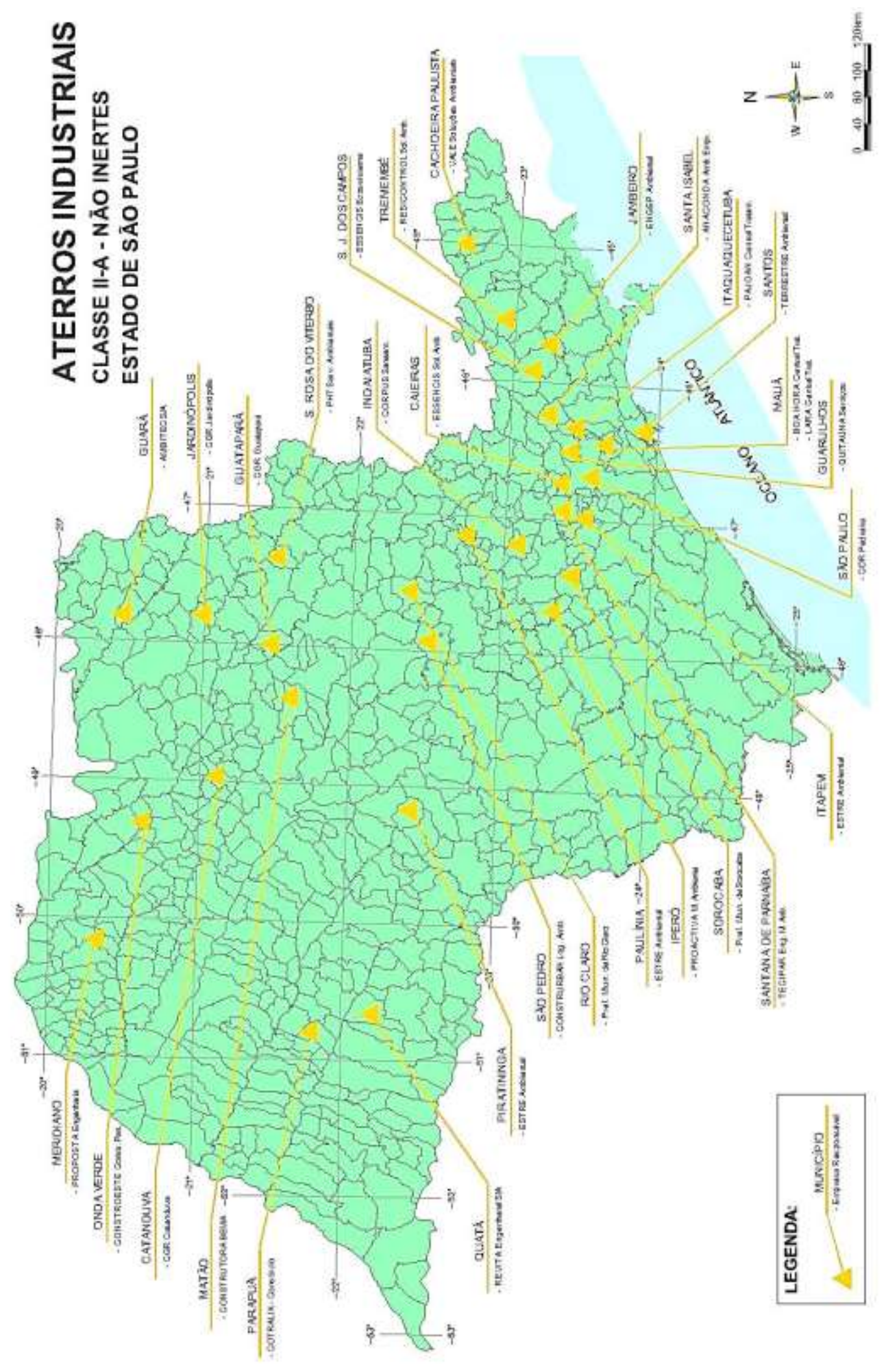

Figura 73. Aterros Classe II-A do Estado de São Paulo

Fonte: Autor, 2013. 


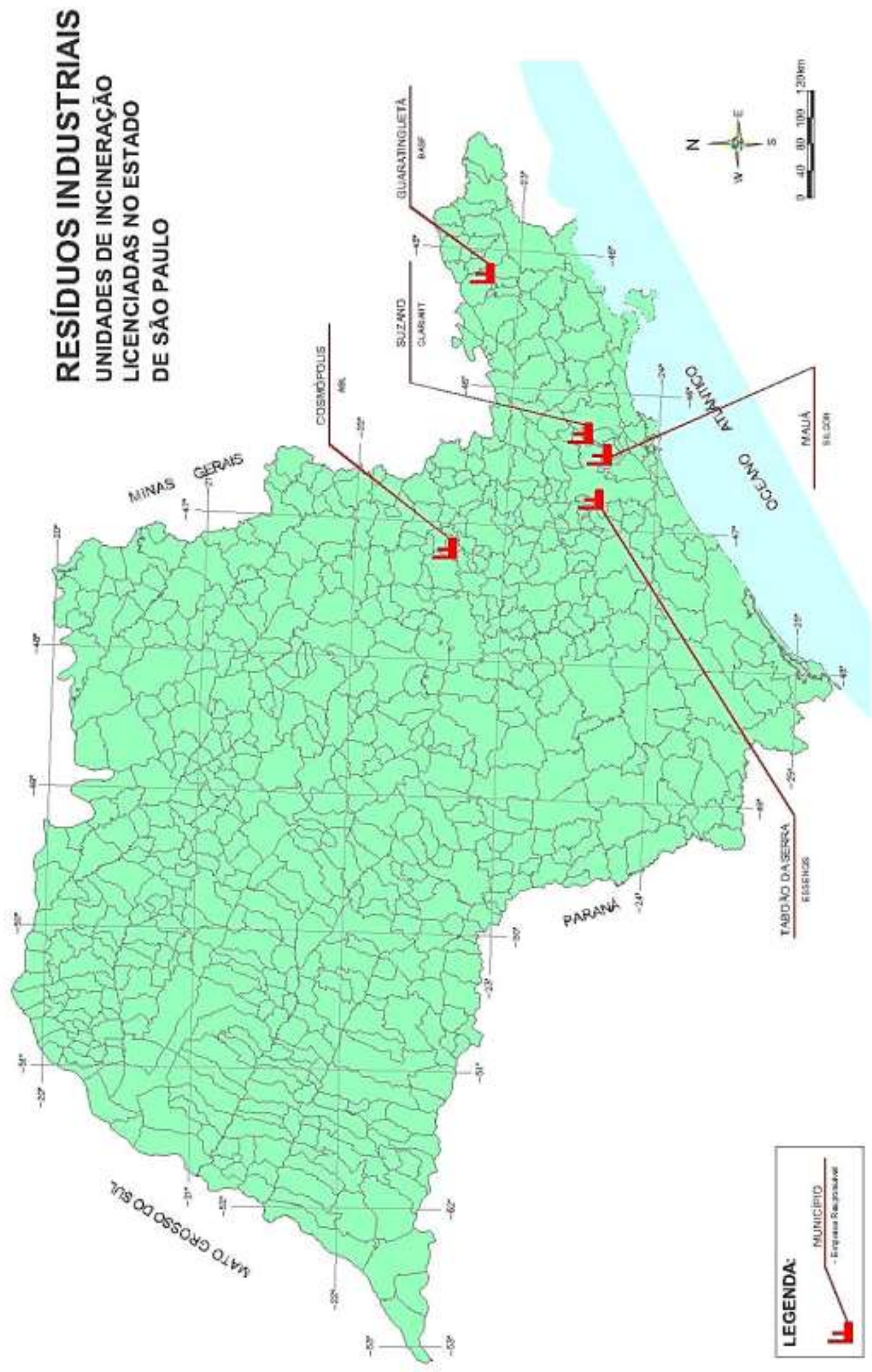

Figura 74. Unidades de incineração licenciadas no Estado de São Paulo Fonte: Autor, 2013. 


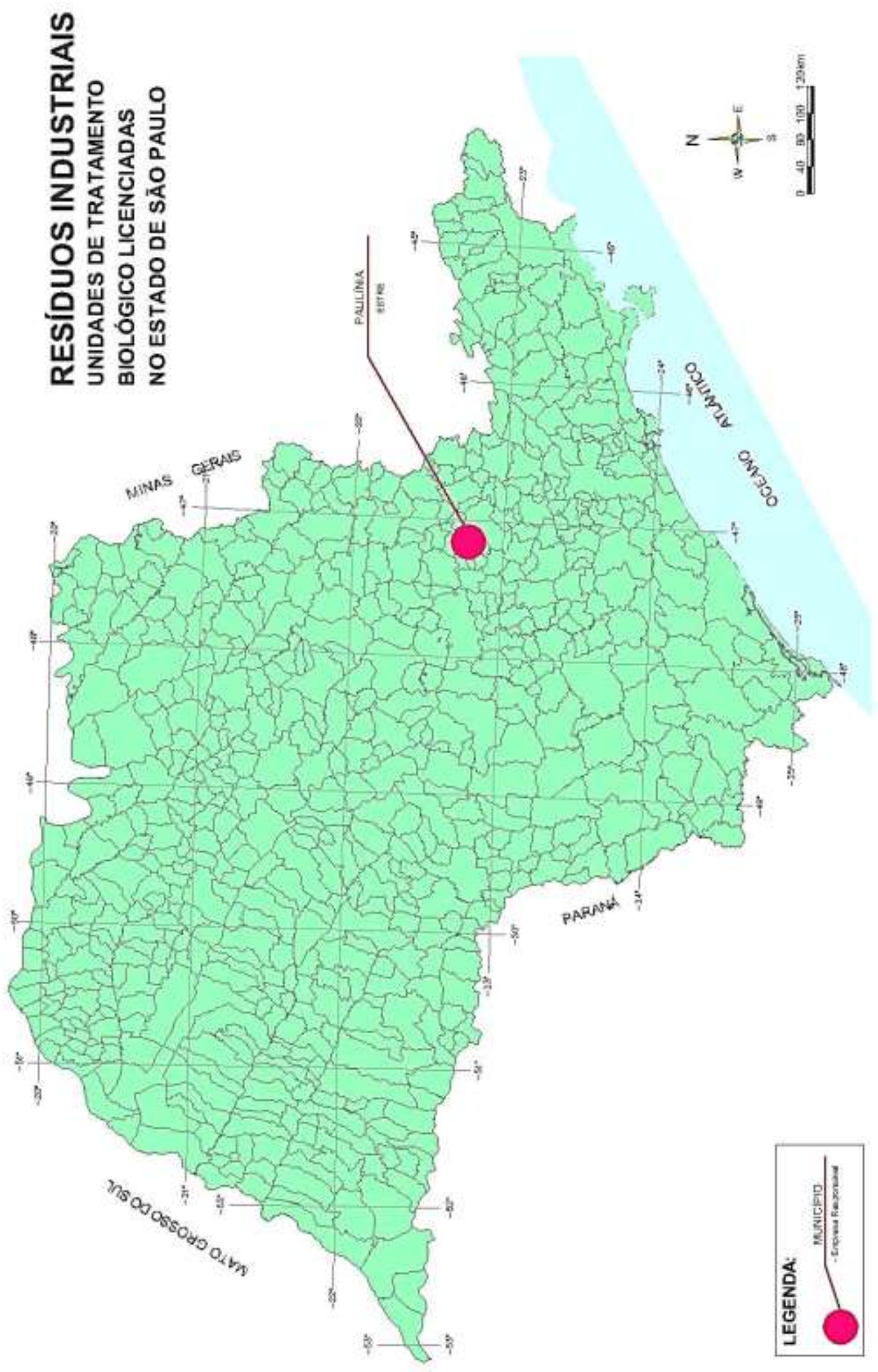

Figura 75. Unidades de tratamento biológico licenciadas no Estado de São Paulo

Fonte: Autor, 2013. 


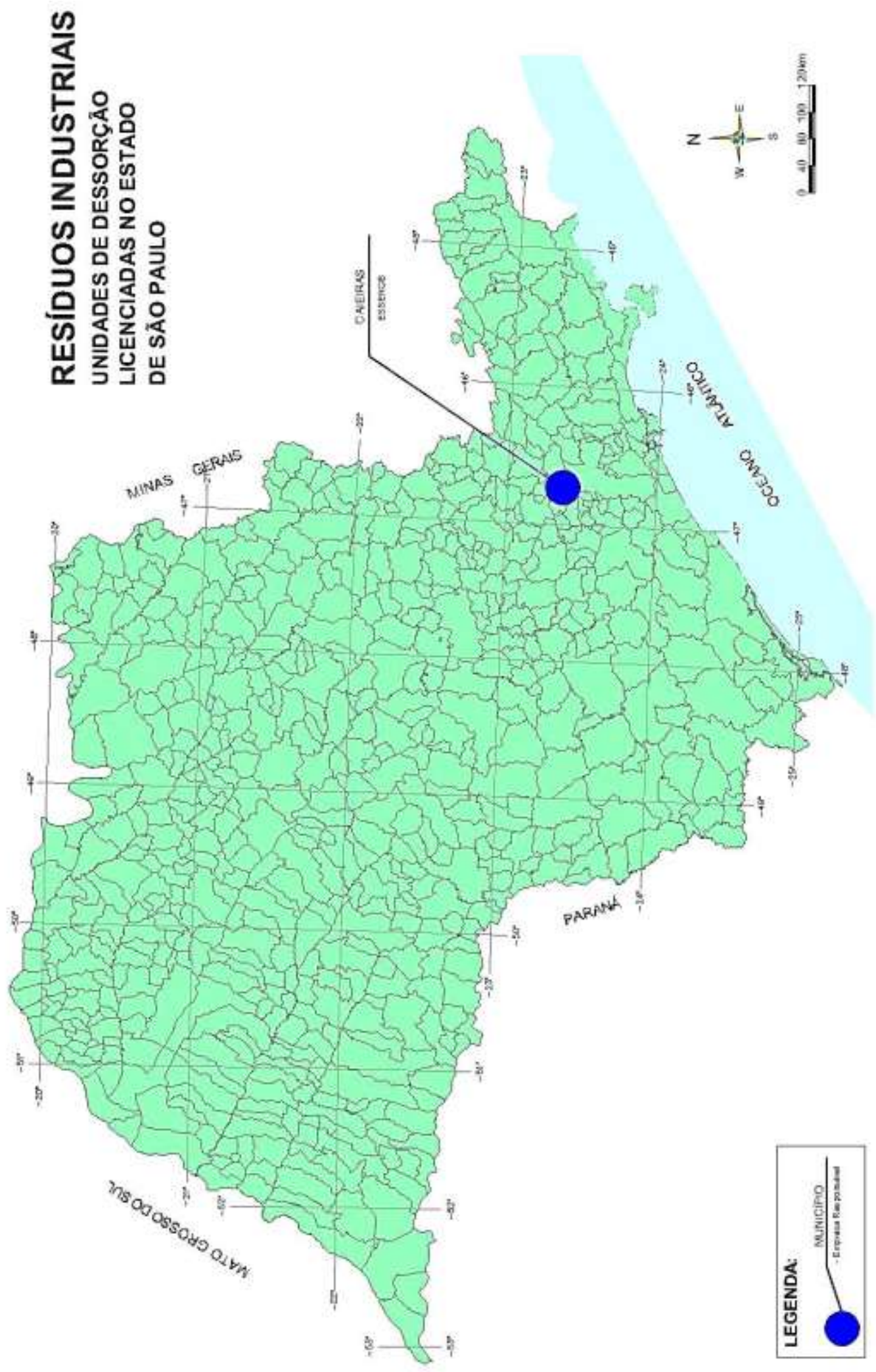

Figura 76. Unidades de dessorção licenciadas no Estado de São Paulo

Fonte: Autor, 2013. 


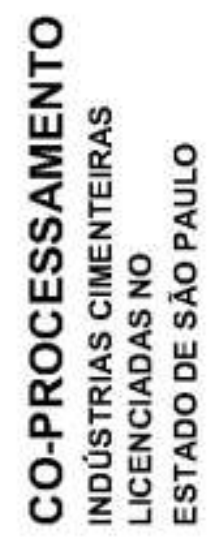




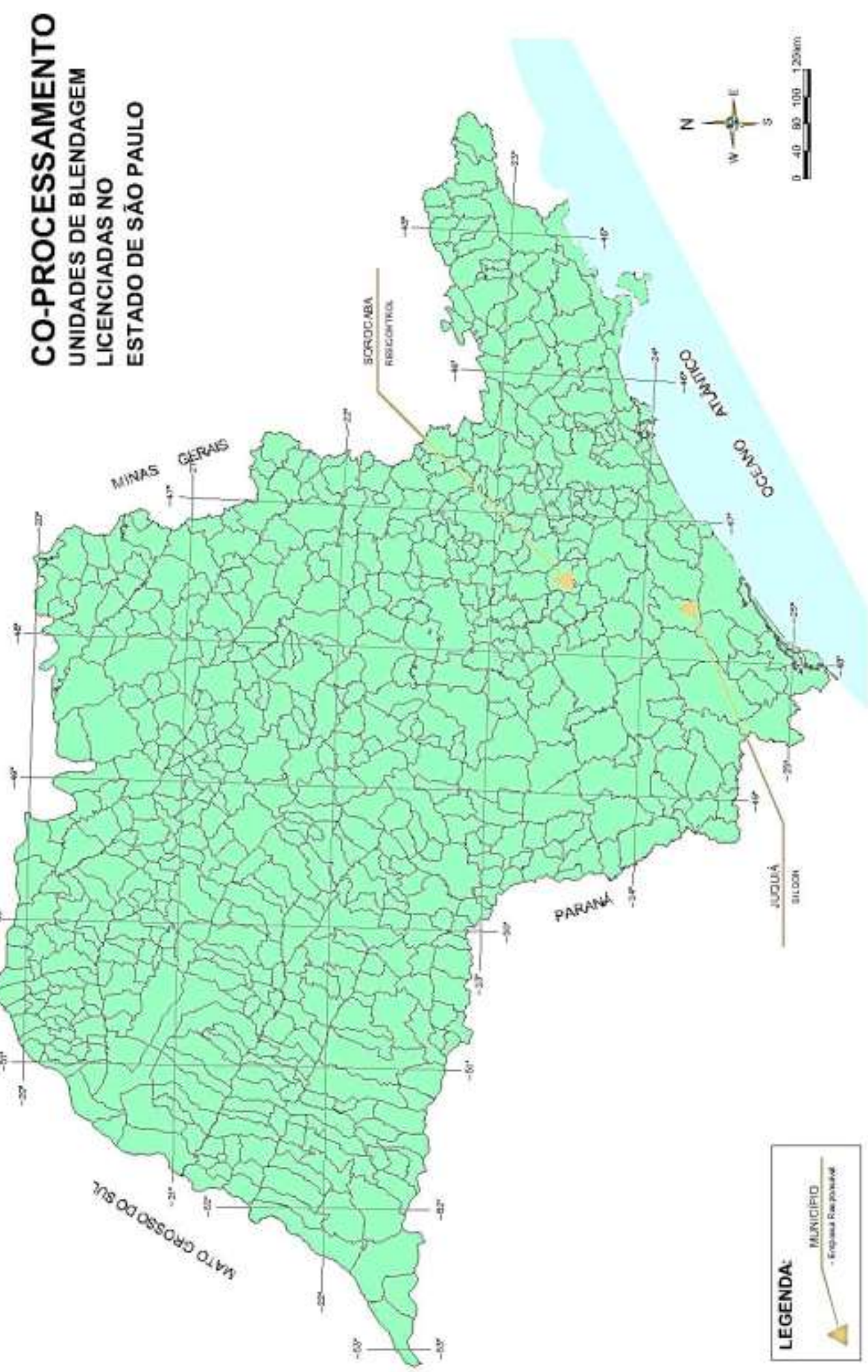

Figura 78. Unidades de blendagem licenciadas do Estado de São Paulo Fonte: Autor, 2013. 
O estado de São Paulo, sendo o estado mais avançado do país, deveria incentivar estudos para a implantação de centros de tratamento dos resíduos perigosos nos moldes dos implantados em Portugal (ver Anexo B - Regime jurídico do licenciamento da instalação e da exploração dos CIRVER).

Os Centros Integrados de Reciclagem, Valorização e Eliminação de Resíduos Perigosos (CIRVER), são unidades que permitem, através da aplicação das melhores tecnologias disponíveis, uma solução específica para cada tipo de resíduo, otimizando as condições de tratamento e minimizando os custos.

Os CIRVER são uma alternativa à co-incineração e apresentam-se como uma solução ambientalmente mais sustentável na gestão dos resíduos industriais através de processos físico-químicos, podendo posteriormente ser utilizados como matéria prima no mesmo processo ou em outro diferente.

- Resíduos de Equipamentos Elétricos e Eletrônicos -REEE

Os resíduos elétricos e eletrônicos são os oriundos do descarte de equipamentos tais como: televisores, computadores pessoais - incluindo os seus componentes, como discos rígidos, placas-mãe etc. - aparelhos celulares e geladeiras entre outros.

Atualmente não existem registros oficiais sobre o lixo elétrico e eletrônico no Estado de São Paulo. Segundo o CEMPRE (2010), pesquisas indicam que $5 \%$ dos detritos mundiais produzidos atualmente são de resíduos de REEE.

O Estado de Minas Gerais realizou seu Diagnóstico da Geração de Resíduos Eletroeletrônicos (FEAM, 2009) e concluiu que o Brasil produz cerca de 2,6 kg por ano destes resíduos por habitante.

A Figura 79 apresenta o mapa dos destinadores de equipamentos eletro eletrônicos encontrados por meio de fontes secundárias no Estado de São Paulo. 


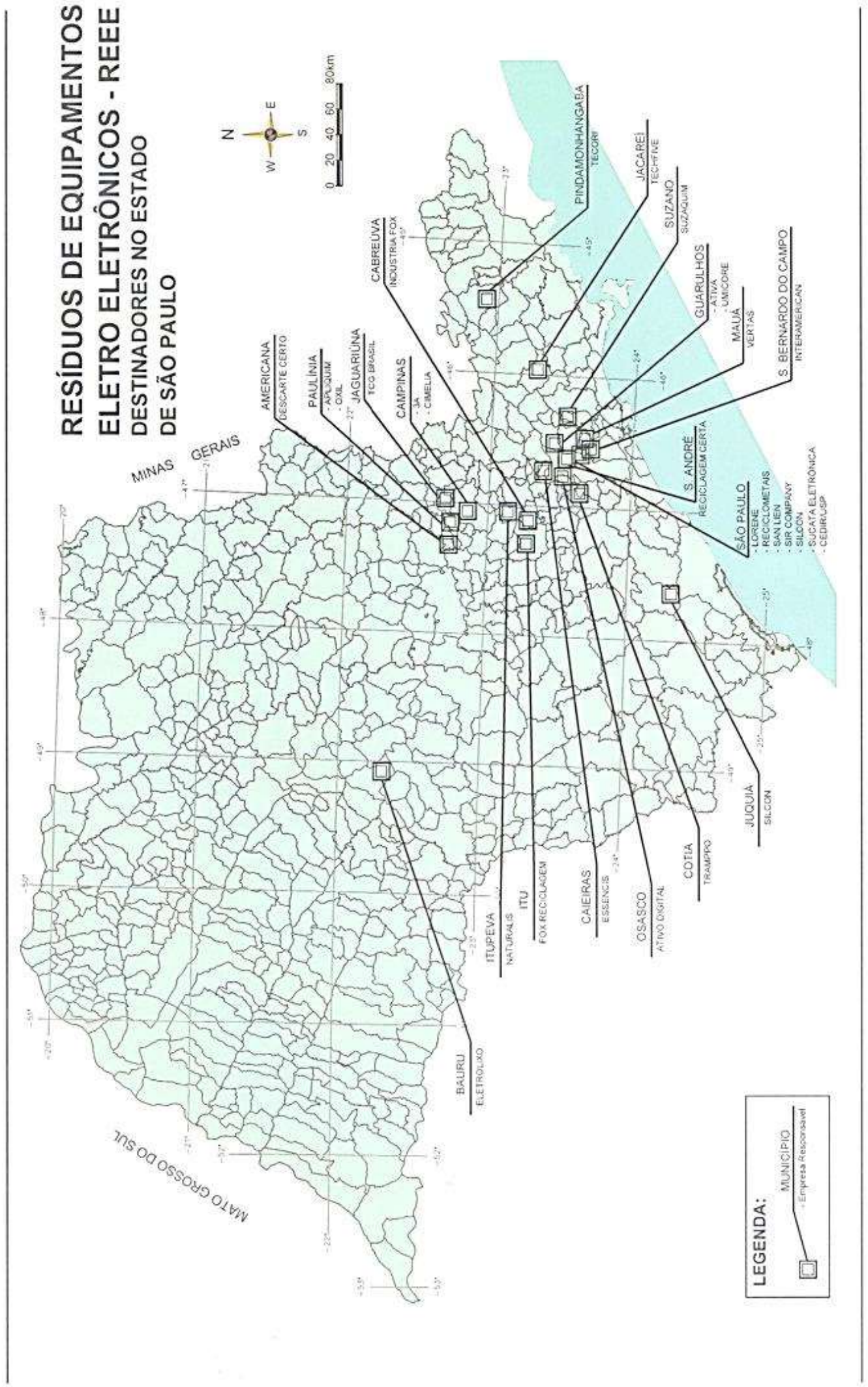

Figura 79. Destinadores de equipamentos eletro eletrônicos

Fonte: Autor, 2013. 


\subsection{ESTUDOS PARA PLANO DE REGIONALIZAÇÃO}

\subsubsection{Consórcios Existentes}

Para início dos estudos de regionalização da gestão dos resíduos sólidos no Estado foi efetuado o levantamento dos consórcios de gestão ou serviços de manejo de resíduos sólidos existentes.

Tabela 7. Consórcios intermunicipais com gestão ou serviços de manejo de resíduos sólidos existentes no Estado de São Paulo

\begin{tabular}{|c|c|c|}
\hline $\begin{array}{l}\text { NOME DO } \\
\text { CONSÓRCIO }\end{array}$ & \begin{tabular}{|l} 
ANO DE \\
FORMAÇÃO
\end{tabular} & MUNICÍPIOS PARTICIPANTES \\
\hline $\begin{array}{l}\text { Consorcio Intermunicipal de } \\
\text { Saneamento Básico da Região } \\
\text { do Circuito das Águas }\end{array}$ & 2010 & $\begin{array}{l}\text { Aguas de Lindoia, Amparo, Itapira, } \\
\text { Lindóia, Monte Alegre do Sul, } \\
\text { Morungaba, Pedra Bela, } \\
\text { Pinhalzinho, Serra Negra, Socorro, } \\
\text { Santo Antônio de Posse e Tuiuti. }\end{array}$ \\
\hline $\begin{array}{l}\text { Consórcio Intermunicipal de } \\
\text { Saneamento Ambiental CONSAB }\end{array}$ & 2009 & $\begin{array}{l}\text { Artur Nogueira, Cosmópolis, } \\
\text { Engenheiro Coelho, Holambra, } \\
\text { Conchal, Santo Antônio de Posse e } \\
\text { Mogi-Mirim }\end{array}$ \\
\hline $\begin{array}{l}\text { CIVAP CONSORCIO } \\
\text { INTERMUNICIPAL DO VALE DO } \\
\text { PARANAPANEMA }\end{array}$ & 2008 & $\begin{array}{l}\text { Assis, Borá, Campos Novos Pta, } \\
\text { Cândido Mota, Cruzália, Echaporã, } \\
\text { Florínea, João Ramalho, Ibirarema, } \\
\text { lepê, Lutécia, Maracaí, Nantes, } \\
\text { Oscar Bressane, Palmital, } \\
\text { Paraguaçu Pta, Platina, Quatá, } \\
\text { Rancharia e Tarumã. }\end{array}$ \\
\hline $\begin{array}{l}\text { CONSORCIO INTERM. PARA } \\
\text { TRATAMENTO E DISPOSICCÃO } \\
\text { FINAL DE LIXO - COTRALIX }\end{array}$ & 1996 & Bastos, lacri, Parapuã e Rinópolis \\
\hline $\begin{array}{l}\text { Consórcio Intermunicipal de } \\
\text { Manejo de Resíduos Sólidos da } \\
\text { RMC-CONSIMARES }\end{array}$ & 2010 & $\begin{array}{l}\text { Sumaré, Hortolândia, Monte Mor, } \\
\text { Santa Barbara do Oeste, } \\
\text { Americana, Nova Odessa, Elias } \\
\text { Fausto e Capivari }\end{array}$ \\
\hline $\begin{array}{l}\text { Consórcio Intermunicipal do } \\
\text { Grande } A B C\end{array}$ & 2009 & $\begin{array}{l}\text { Mauá, Ribeirão Pires, Rio Grande } \\
\text { da Serra, Santo André, São } \\
\text { Bernardo do Campo e São Caetano } \\
\text { do Sul }\end{array}$ \\
\hline $\begin{array}{l}\text { Consórcio Intermunicipal para } \\
\text { Gestão de Resíduos Sólidos }\end{array}$ & & $\begin{array}{l}\text { Dracena, Ouro Verde, Tupi Paulista } \\
\text { e Junqueirópolis }\end{array}$ \\
\hline $\begin{array}{l}\text { CIGA -Consórcio Interm. para } \\
\text { gestão ambiental e de resíduos } \\
\text { sólidos integrada }\end{array}$ & 2009 & Salto e Indaiatuba \\
\hline SIGEINRES & 2010 & Barretos e Bebedouro \\
\hline
\end{tabular}


Os Estudos de Regionalização estão associados à questão da implementação de Consórcios Públicos nos moldes da lei 11.107/2005 e seu Decreto regulamentador e da Lei de Saneamento Básico (Lei 11.445/2007).

A existência de arranjos ou consórcios intermunicipais já estabelecidos em uma região pode facilitar a implementação da regionalização no estado e adoção de ações regionalizadas.

A tabela 7 apresenta os consórcios intermunicipais de gestão ou serviços de manejo de resíduos sólidos existentes.

A figura 80 identifica no mapa do Estado os consórcios existentes e as figuras de número 81 a 89 detalham cada consórcio com os respectivos municípios. 


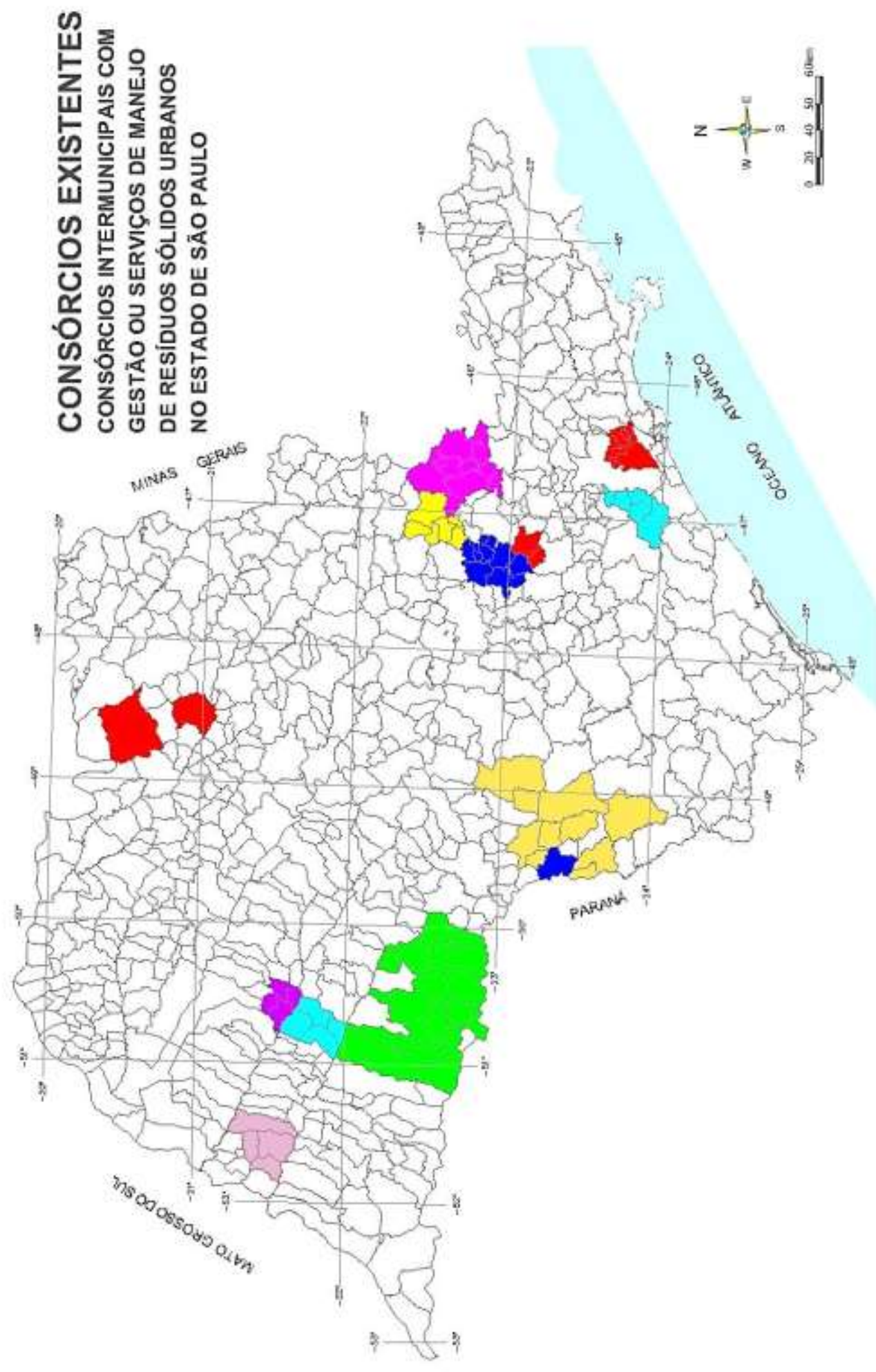

Figura 80. Consórcios intermunicipais com gestão ou serviços de manejo de resíduos sólidos existentes no Estado de São Paulo.

Fonte: Autor, 2013. 


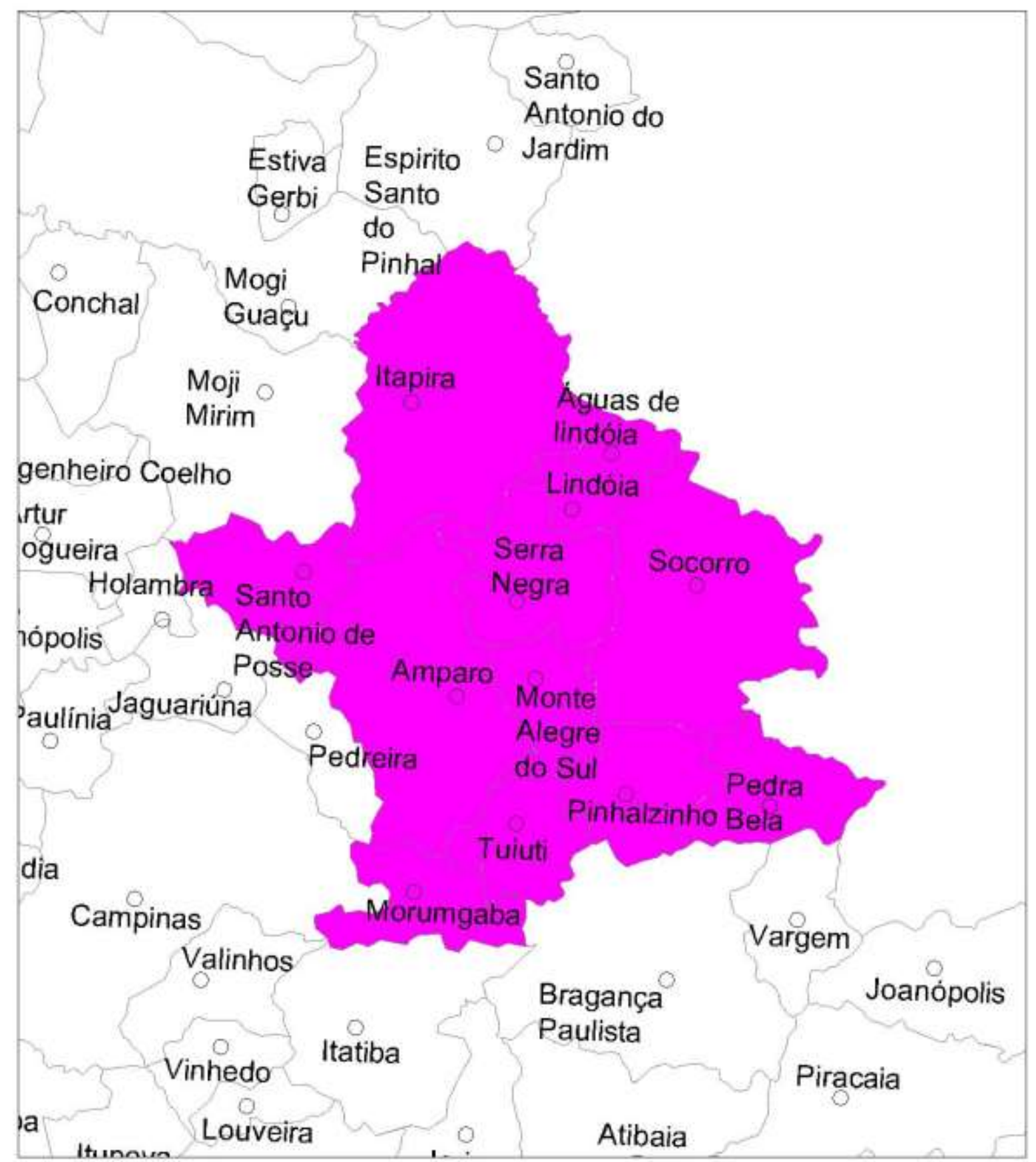

\section{CONSÓRCIO INTERMUNICIPAL DE SANEAMENTO BÁSICO DO CIRCUITO DAS ÁGUAS}

Figura 81. Consórcio Intermunicipal de Saneamento do Circuito das Águas

Fonte: Autor, 2013. 


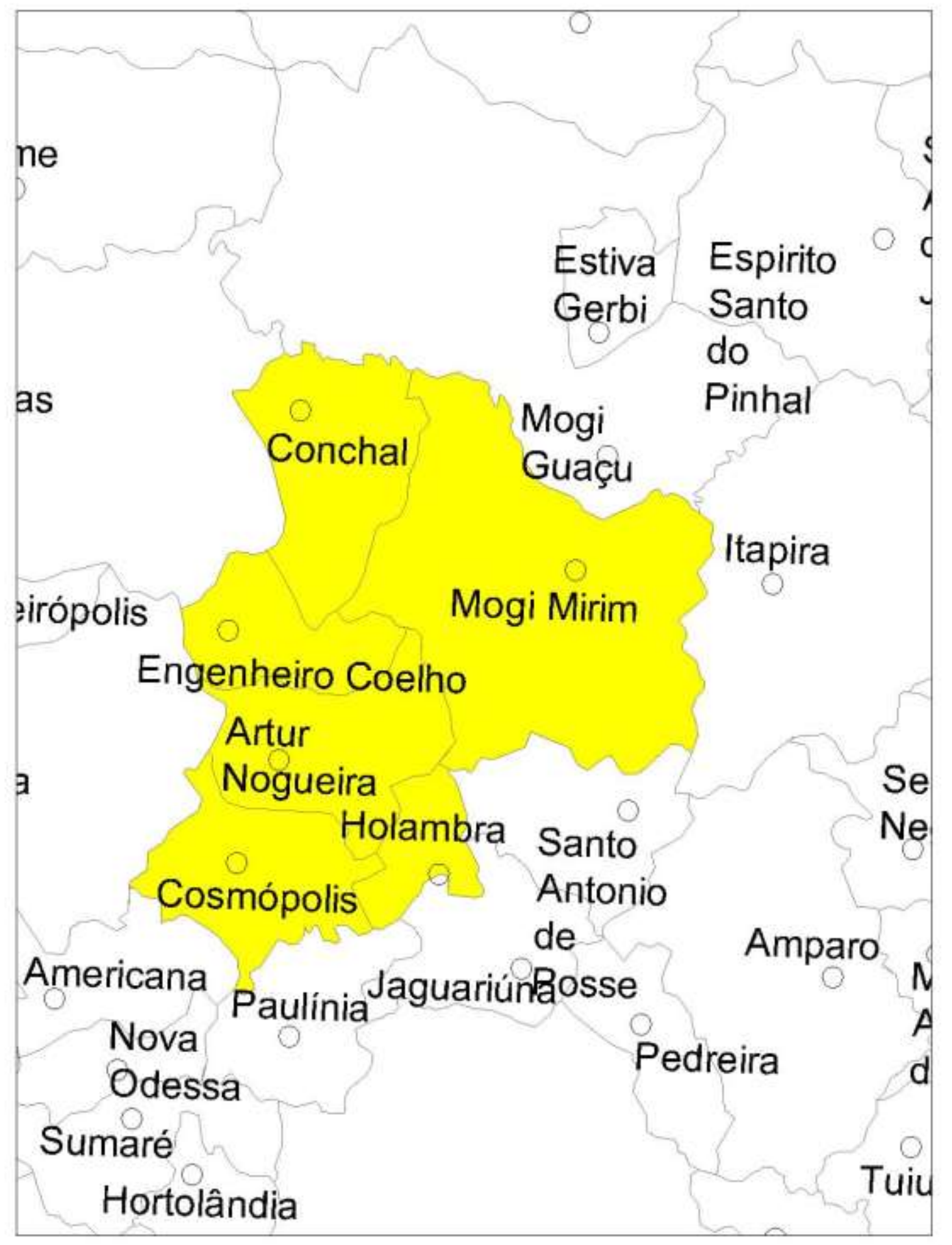

CONSÓRCIO INTERMUNICIPAL DE SANEAM. AMBIANTA - CONSAB

Figura 82. Consórcio Intermunicipal de Saneamento Ambiental - CONSAB

Fonte: Autor, 2013. 


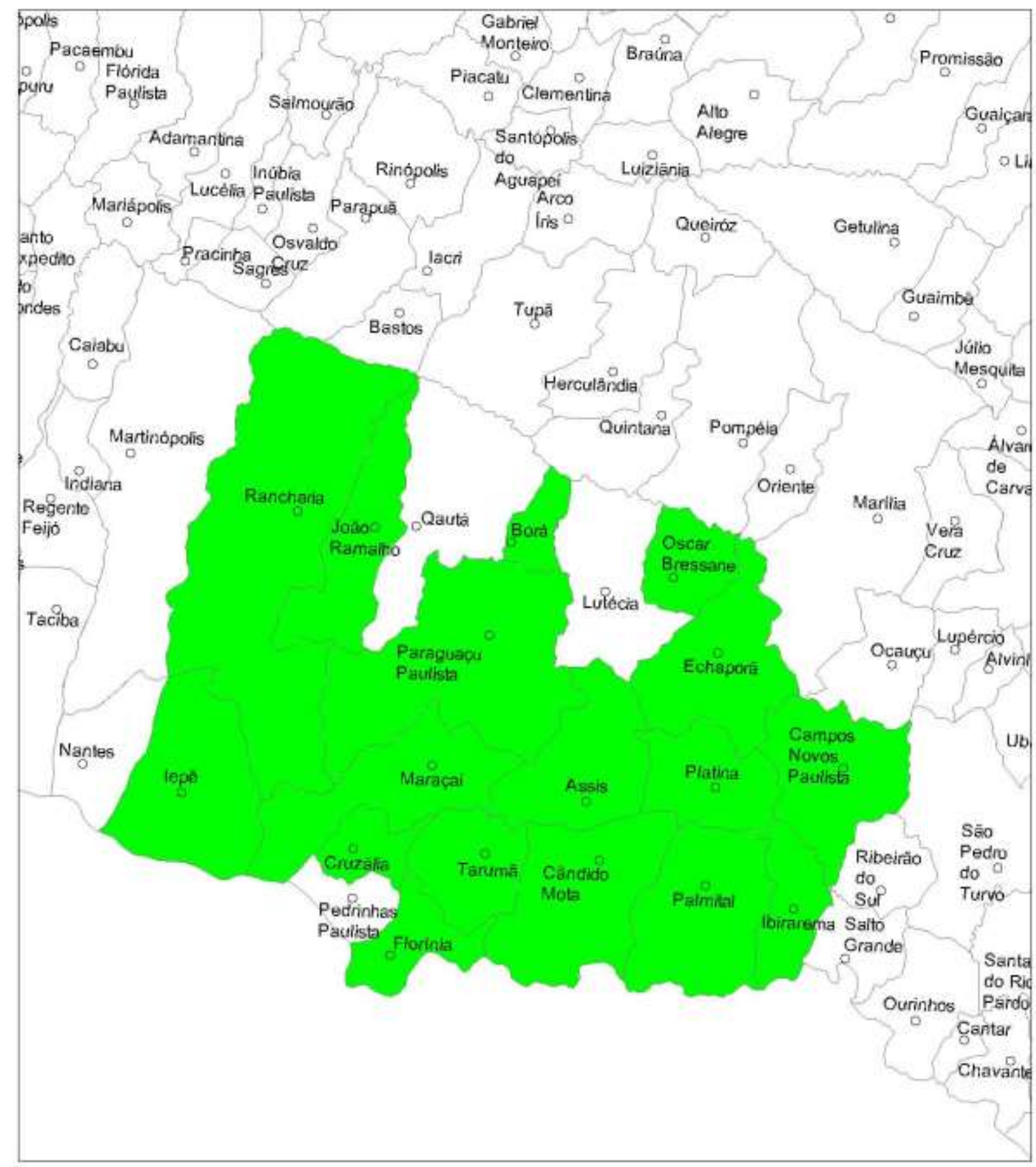

CIVAP - CONSÓRCIO INTERMUNICIPAL DO VALE DO PARANAPANEMA

Figura 83. CIVAP - Consórcio Intermunicipal do Vale do Paranapanema

Fonte: Autor, 2013. 


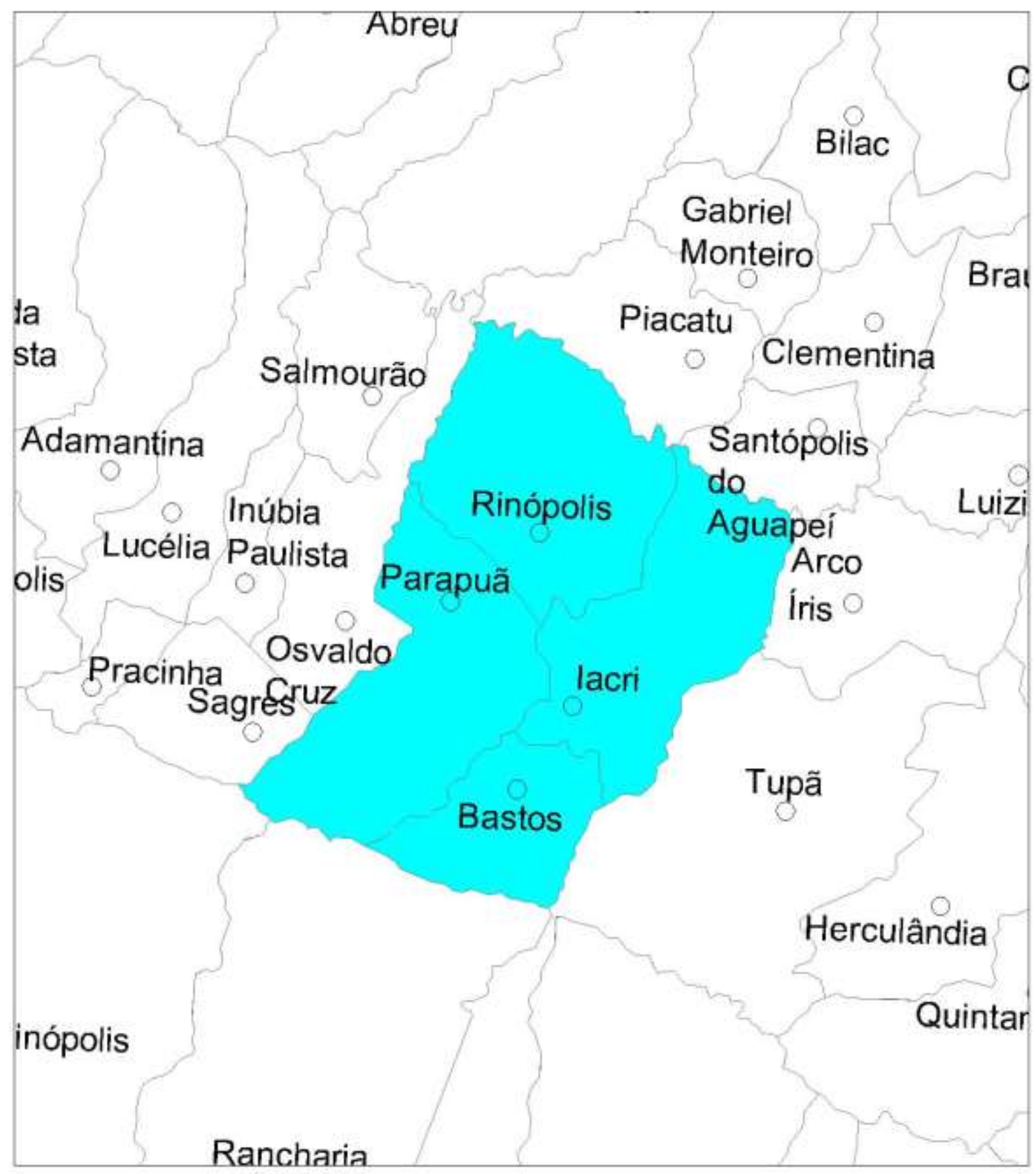

CONSÓRCIO INTERMUNICIPAL PARA TRATAMENTO E DISPOSIÇÃO FINAL DE LIXO - COTRALIX

Figura 84. Consórcio Intermunicipal para Tratamento e Disposição Final de Lixo - COTRALIX

Fonte: Autor, 2013. 


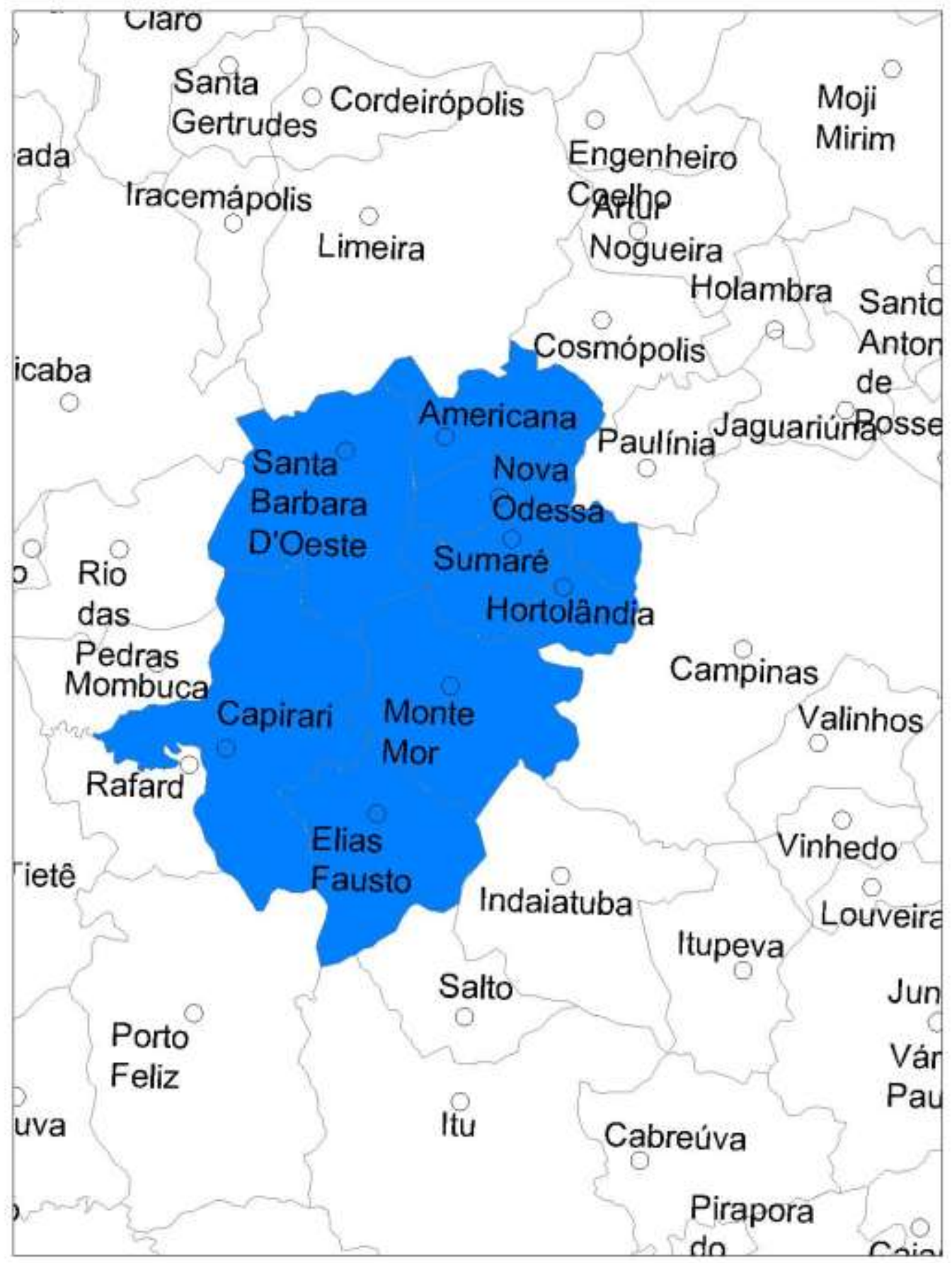

\section{CONSÓRCIO INTERMUNICIPAL DE MANEJO DE RESÍDUOS SÓLIDOS - CONSIMARES}

Figura 85. Consórcio Intermunicipal de Manejo de Resíduos Sólidos da RMC - CONSIMARES

Fonte: Autor, 2013. 


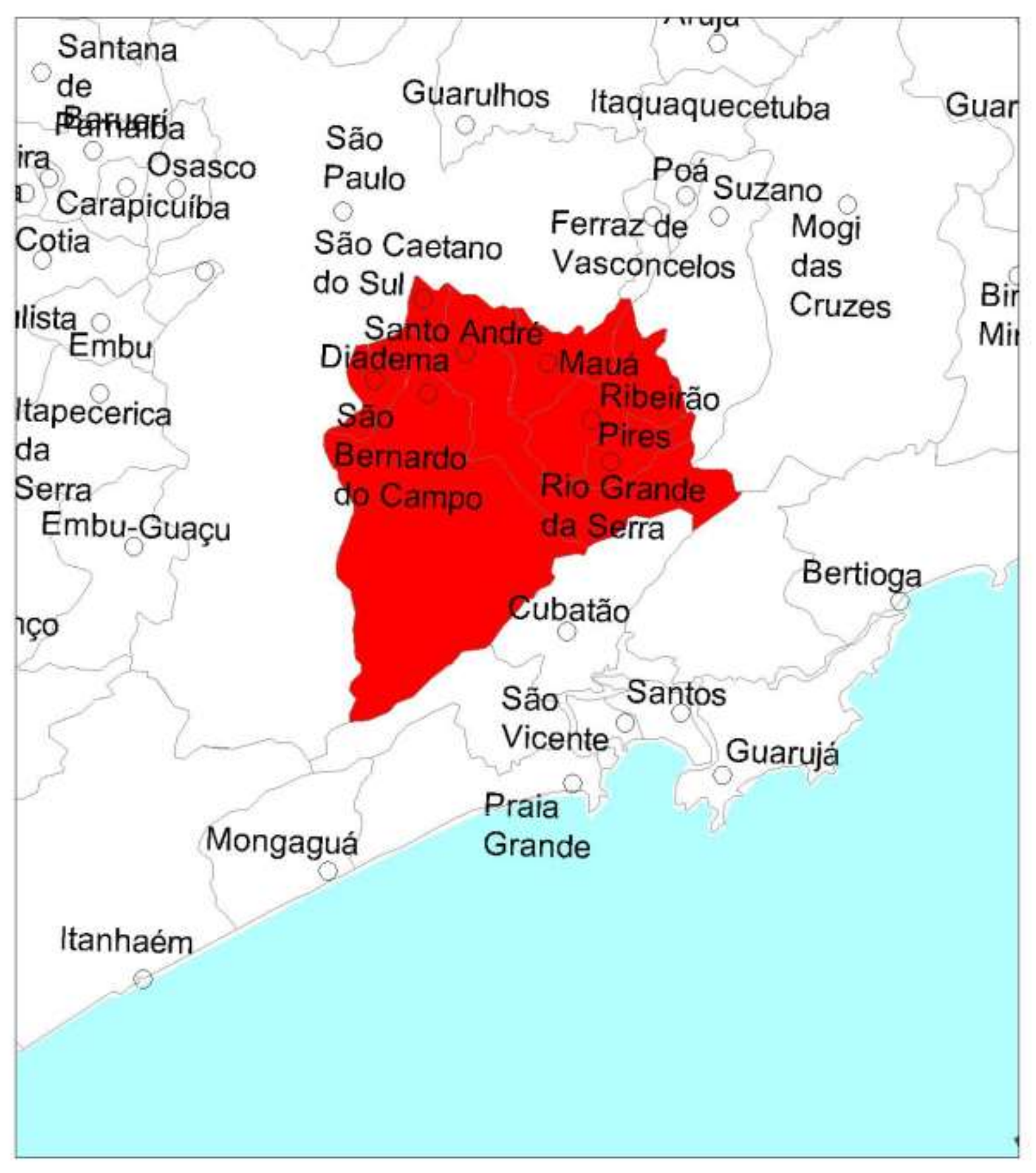

\section{CONSÓRCIO INTERMUNICIPAL DO GRANDE ABC}

Figura 86. Consórcio Intermunicipal do Grande $A B C$

Fonte: Autor, 2013. 


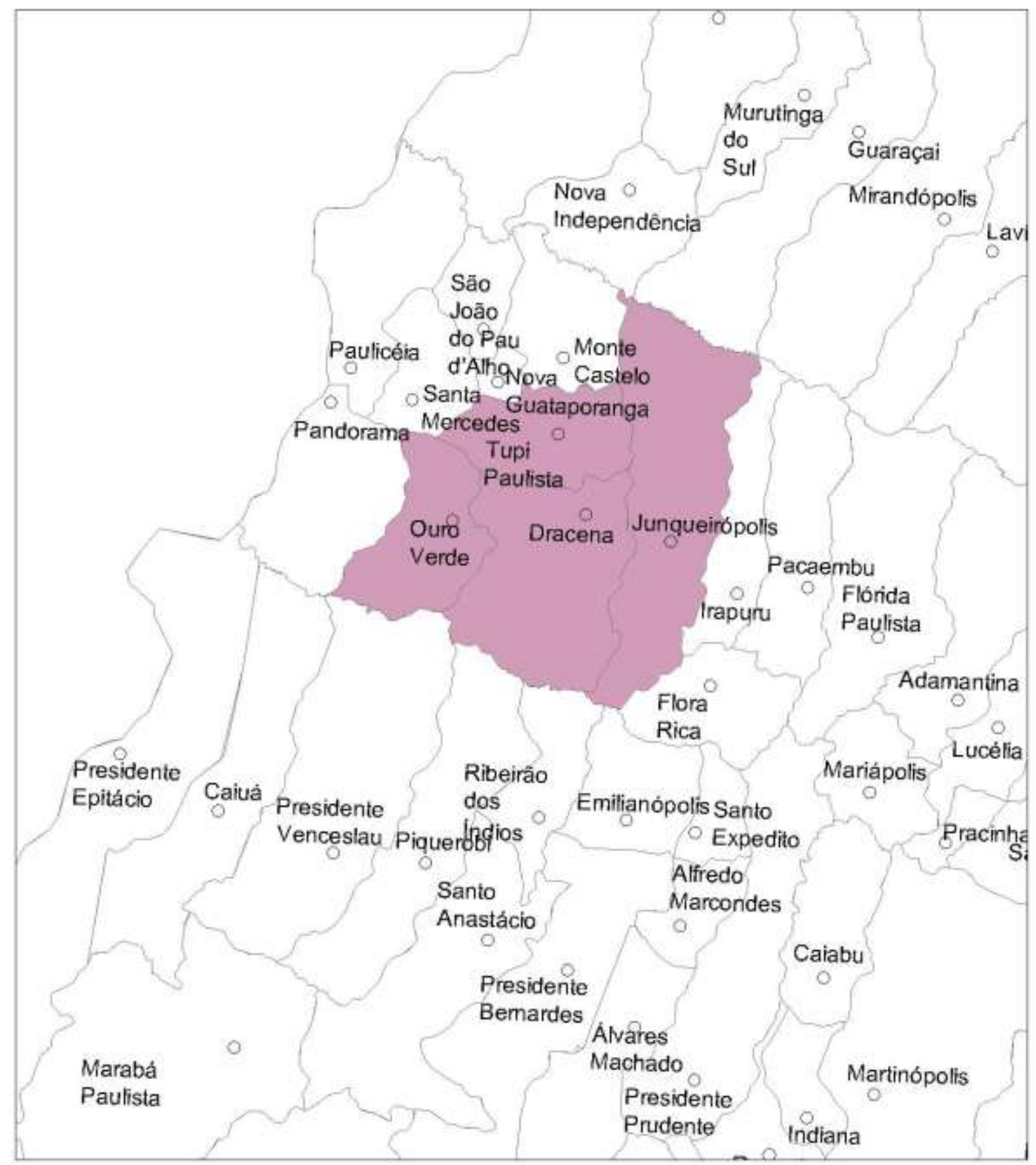

\section{CONSÓRCIO INTERMUNICIPAL PARA GESTÃO DE RESÍDUOS SÓLIDOS}

Figura 87. Consórcio Intermunicipal para Gestão de Resíduos Sólidos

Fonte: Autor, 2013. 


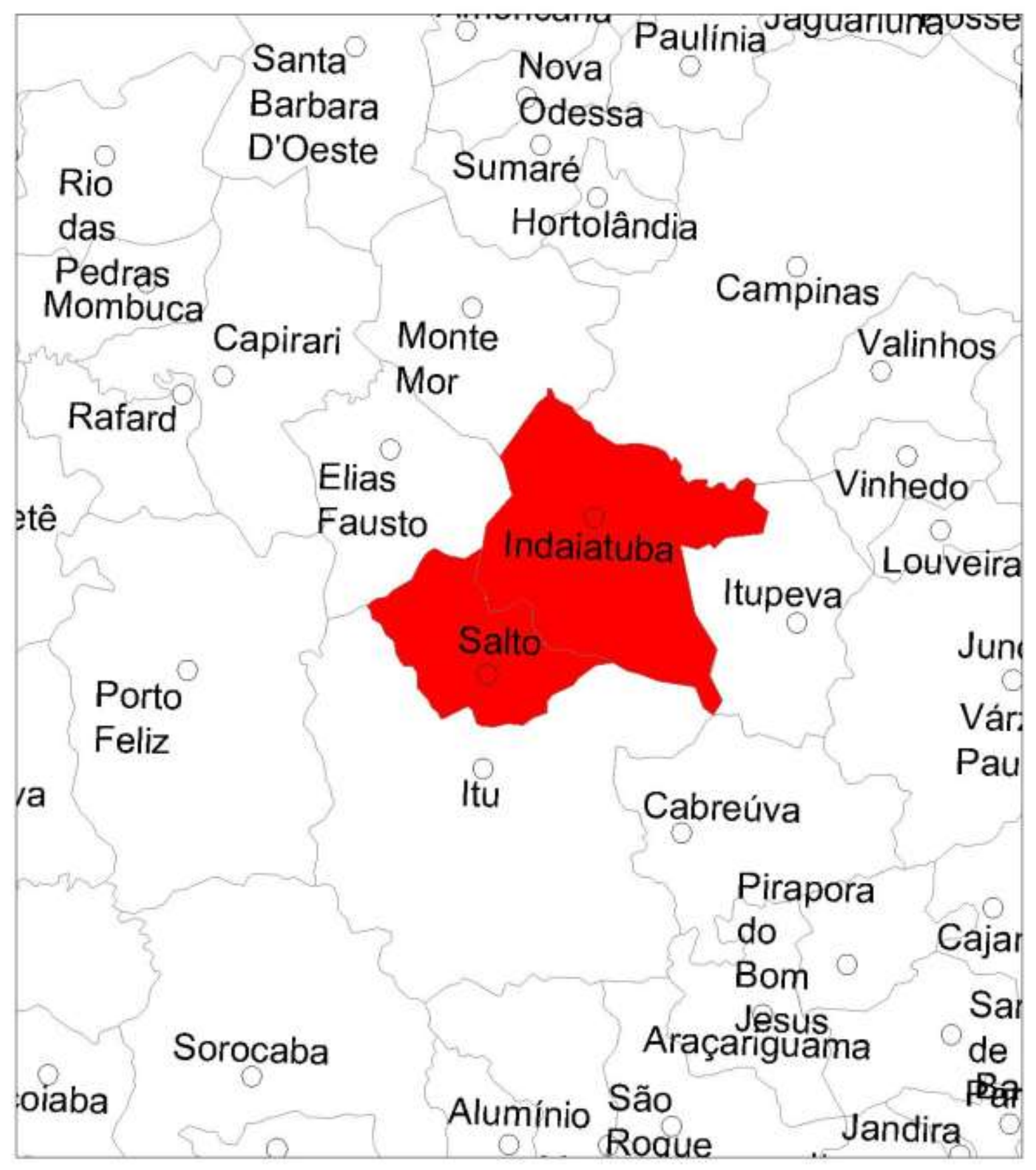

CIGA - CONSÓRCIO INTERMUNICIPAL PARA GESTÃO AMBIENTAL E DE RESÍDUOS SÓLIDOS INTEGRADA

Figura 88. CIGA - Consórcio Intermunicipal para Gestão Ambiental e de Resíduos Sólidos Integrada

Fonte: Autor, 2013. 


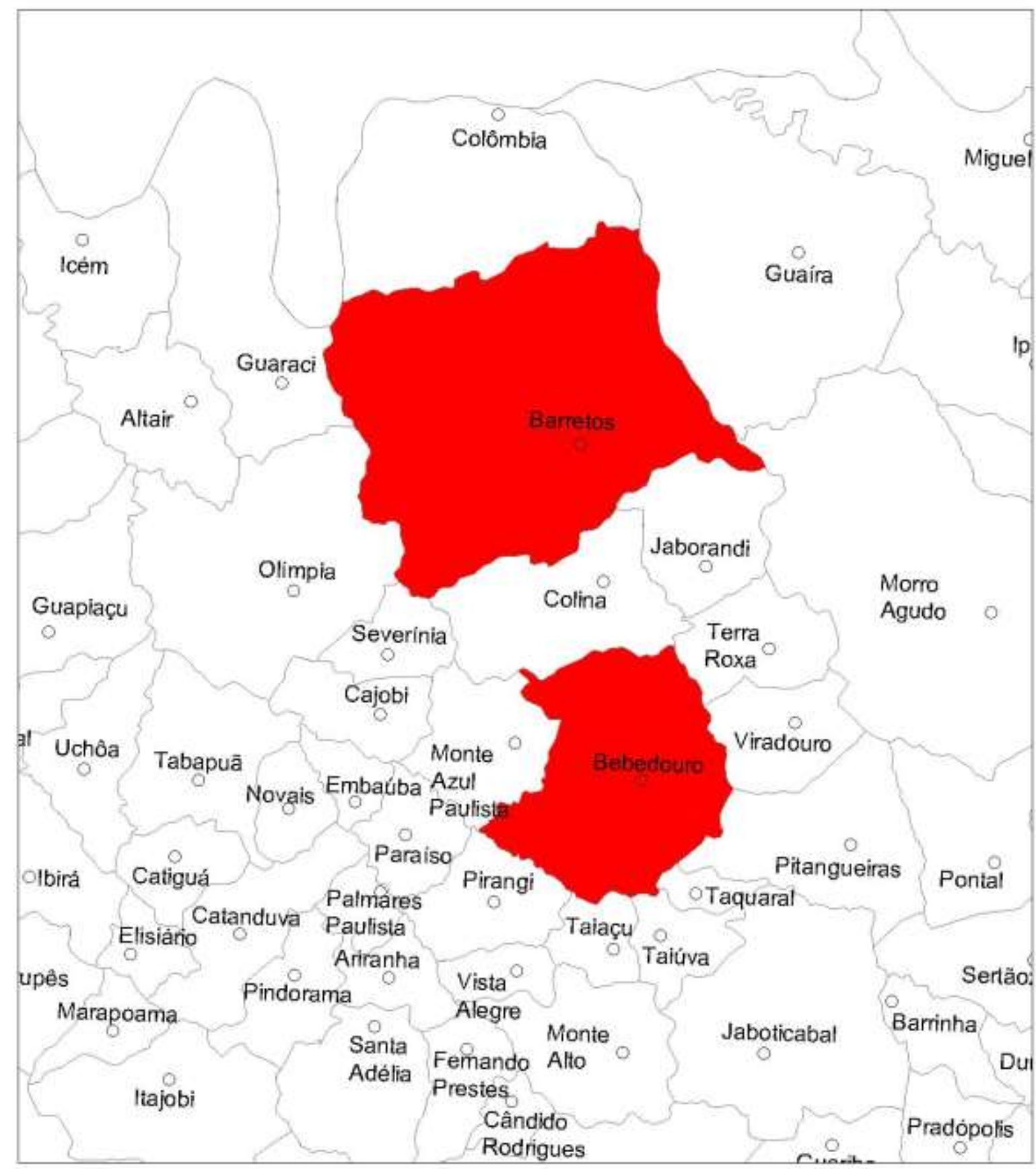

\section{CONSÓRCIO INTERMUNICIPAL PARA GESTÃO INTEGRADA DE RESÍDUOS - SIGEINRES}

Figura 89. Consórcio Intermunicipal para Gestão Integrada de Resíduos Sólidos SIGEINRES

Fonte: Autor, 2013. 
Tabela 8. Proposta de regionalização do Estado de São Paulo - Cenário 1

\begin{tabular}{|c|c|c|c|}
\hline CONSÓRCIO & MUNICÍPIOS & $\begin{array}{l}\text { GERAÇÃO DE } \\
\text { RSU (t/dia) }\end{array}$ & $\begin{array}{l}\text { GERAÇÃO } \\
\text { TOTAL DE } \\
\text { RSU (t/dia) }\end{array}$ \\
\hline \multirow{12}{*}{$\begin{array}{c}\text { Consórcio } \\
\text { Intermunicipal de } \\
\text { Saneamento Básico do } \\
\text { Circuito das Águas }\end{array}$} & Itapira & & \multirow{12}{*}{77,98} \\
\hline & Santo Antônio da Posse & & \\
\hline & Socorro & & \\
\hline & Amparo & & \\
\hline & Águas de Lindóia & & \\
\hline & Lindóia & & \\
\hline & Serra Negra & & \\
\hline & Morungaba & & \\
\hline & Tuiuti & & \\
\hline & Pinhalzinho & & \\
\hline & Pedra Bela & & \\
\hline & Monte Alegre do Sul & & \\
\hline \multirow{6}{*}{$\begin{array}{c}\text { Consórcio } \\
\text { Intermunicipal de } \\
\text { Saneamento Básico - } \\
\text { CONSAB }\end{array}$} & Conchal & & \multirow{6}{*}{77,98} \\
\hline & Mogi Mirim & & \\
\hline & Engenheiro Coelho & & \\
\hline & Artur Nogueira & & \\
\hline & Holambra & & \\
\hline & Cosmópolis & & \\
\hline \multirow{12}{*}{$\begin{array}{c}\text { Consórcio } \\
\text { Intermunicipal do Vale } \\
\text { do Paranapanema }\end{array}$} & Rancharia & & \multirow{12}{*}{77,98} \\
\hline & João Ramalho & & \\
\hline & lepê & & \\
\hline & Borá & & \\
\hline & Paraguaçu Paulista & & \\
\hline & Maraçaí & & \\
\hline & Cruzália & & \\
\hline & Florínea & & \\
\hline & Tarumã & & \\
\hline & Assis & & \\
\hline & Cândido Mota & & \\
\hline & Oscar Bressane & & \\
\hline
\end{tabular}




\begin{tabular}{|c|c|c|c|}
\hline CONSÓRCIO & MUNICÍPIOS & $\begin{array}{l}\text { GERAÇÃO DE } \\
\text { RSU (t/dia) }\end{array}$ & $\begin{array}{l}\text { GERAÇÃO } \\
\text { TOTAL DE } \\
\text { RSU (t/dia) }\end{array}$ \\
\hline \multirow{4}{*}{$\begin{array}{c}\text { Consórcio } \\
\text { Intermunicipal para } \\
\text { Tratamento e } \\
\text { Disposição Final de Lixo } \\
\text { COTRALIX }\end{array}$} & Rinópolis & & \multirow{4}{*}{7,98} \\
\hline & Parapuã & & \\
\hline & lacri & & \\
\hline & Bastos & & \\
\hline & Americana & & \\
\hline & Nova Odessa & & \\
\hline Consorcio & Sumaré & & \\
\hline Intermunicipal do & Hortolândia & & 77,98 \\
\hline Grande $A B C$ & Monte Mor & & \\
\hline & Capivari & & \\
\hline & Elias Fausto & & \\
\hline Consórcio & Guataporanga & & \\
\hline Intermunicipal para & Tupi Paulista & & \\
\hline Gestão de Resíduos & Ouro Verde & & 77,98 \\
\hline Sólidos & Dracena & & \\
\hline & Junqueirópolis & & \\
\hline $\begin{array}{c}\text { Consórcio } \\
\text { Intermunicipal para }\end{array}$ & Indaiatuba & & 7700 \\
\hline & Salto & & \\
\hline $\begin{array}{l}\text { Consórcio } \\
\text { Intermunicipal para }\end{array}$ & Barretos & & \\
\hline SIGEINRES & Bebedouro & & \\
\hline$N^{\circ}$ de municíp & ios: & Geração Total: & \\
\hline
\end{tabular}




\subsubsection{Regionalização}

O objetivo geral dessa etapa do estudo é propor arranjos territoriais no Estado de São Paulo para a implementação de soluções integradas e consorciadas em conformidade com a Política Nacional de Resíduos Sólidos PNRS (Lei 12.305/2010).

A regionalização é uma ferramenta importante e eficiente para a viabilidade da gestão e do planejamento dos resíduos sólidos no território paulista e para alcançar este objetivo vários critérios foram fundamentais no processo de elaboração.

critérios:

A regionalização foi elaborada considerando basicamente os seguintes

a)- Cidades polo;

b)- Raios máximos de distância entre os municípios;

c)- Logístico;

d)- Um aterro regional por agrupamento;

e)- Os consórcios de resíduos existentes.

Para proposição da regionalização foram feitos dois cenários baseados na rede de influência das cidades do Estado de São Paulo.

Foram observados as seguintes diretrizes para o planejamento dos agrupamentos municipais:

a)-Cidades polo: o conceito de cidade polo foi apoiado em estudo efetuado pelo IBGE sobre as regiões de influência das cidades brasileiras, que visa subsidiar o planejamento e decisão estatal do território quanto à localização das atividades econômicas e consumo.

O estudo apresenta uma hierarquia dos centros urbanos em que as cidades foram classificadas em cinco níveis, por sua vez subdivididos em subníveis como metrópoles, capital regional, centro sub-regional, centro de zona, centro local. 
No estado de São Paulo o estudo aponta a cidade de São Paulo designada como Grande Metrópole Nacional; Campinas como Capital Regional A; São José do Rio Preto e Ribeirão Preto como Capitais Regionais B; Santos, São José dos Campos, Sorocaba, Piracicaba, Bauru, Marília, presidente Prudente, Araraquara e Araçatuba como Capitais Regionais C.

Fazem parte da rede de influência estadual os Centros Sub-regionais A, Franca, Limeira, São Carlos, Rio Claro, Jaú, Botucatu, Catanduva e Barretos. Os Centros Sub-regionais B são: Itapetininga, Bragança Paulista, Araras, Guaratinguetá, Assis, Avaré, Andradina, Registro e Itapeva. As demais cidades são denominadas Centro Local, cuja centralidade e atuação não extrapolam os limites do seu município.

b)- Raios máximos de distância entre os municípios: para os cenários propostos foram adotados dois raios centralizados na cidades polo. No cenário 1 foi adotado o raio de 50 quilômetros a partir da sede urbana do município polo até a sede urbana dos municípios a serem agrupados. A distância de $50 \mathrm{~km}$ foi adotada em função do caminhão que efetua o transporte dos resíduos percorrerem essa distância no período de uma hora. No cenário 2, foi adotado um raio de $100 \mathrm{~km}$, o que será justificado na sua composição.

c)- Logístico: a acessibilidade é fundamental para os agrupamentos, pois a malha viária existente entre a cidade-polo em relação as demais sedes municipais pode inviabilizar economicamente a participação na regionalização.

d)- Um aterro regional por agrupamento: atualmente a grande maioria dos municípios paulistas depositam seus resíduos em aterros controlados e a regionalização propõe que cada região possua um aterro sanitário.

e)- Os consórcios de resíduos existentes: procurou-se manter as configurações dos consórcios existentes dentro de uma mesma regionalização, no sentido de aproveitar a experiência adquirida.

\subsubsection{Cenário 1}

As figuras de números de 90 à 124 compõem a planificação. 


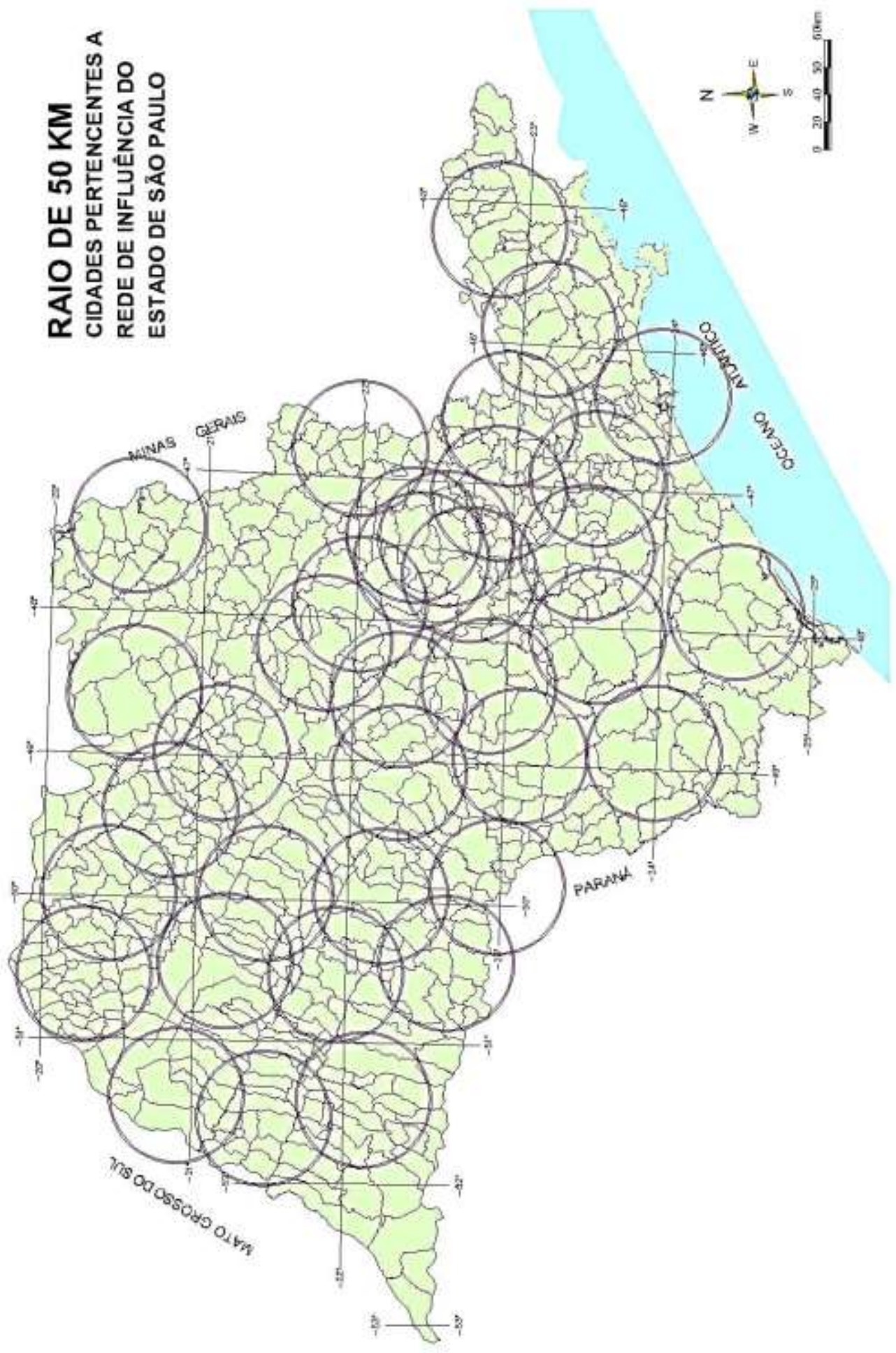

Figura 90. Mapa identificando raio de $50 \mathrm{~km}$ das cidades polo do Estado de São Paulo

Fonte: Autor, 2013. 


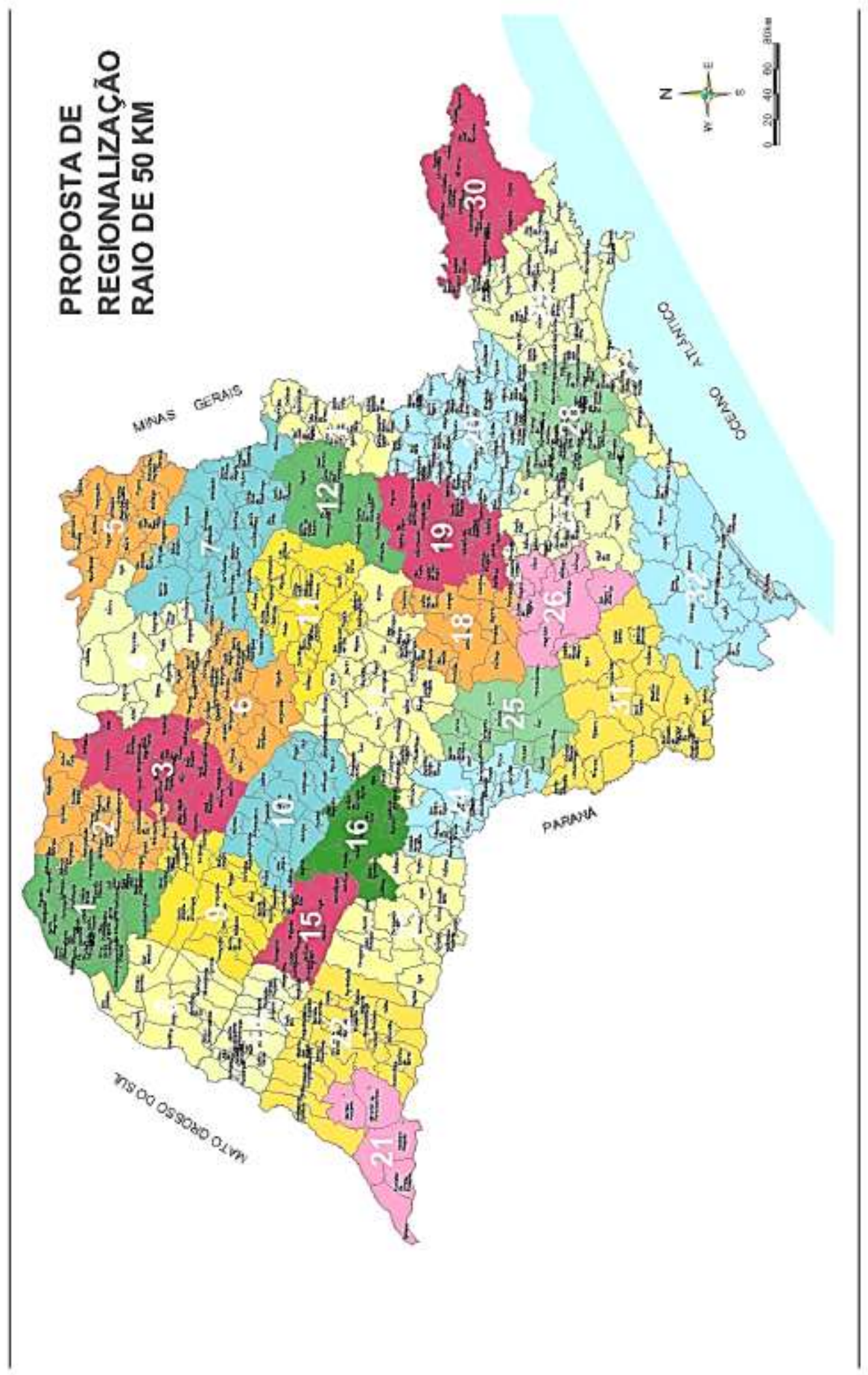

Figura 91. Mapa de proposta de regionalização - raio de $50 \mathrm{~km}$ das cidades polo do Estado de São Paulo

Fonte: Autor, 2013. 


\section{- Região 1}

Município polo: Jales

Tabela 9. Municípios e produção diária de resíduos domiciliares da Região 1 - Raio de $50 \mathrm{~km}$

\begin{tabular}{|c|c|}
\hline Município & RSU (t/dia) \\
\hline APARECIDA D'OESTE & 1,45 \\
\hline ASPÁSIA & 0,50 \\
\hline AURIFLAMA & 5,20 \\
\hline DIRCE REIS & 0,51 \\
\hline DOLCINÓPOLIS & 0,78 \\
\hline ESTRELA D'OESTE & 2,73 \\
\hline ‘FERNANDÓPOLIS & 25,18 \\
\hline GENERAL SALGADO & 3,63 \\
\hline GUARANI D'OESTE & 0,69 \\
\hline GUZOLÂNDIA & 1,62 \\
\hline INDIAPORÃ & 1,35 \\
\hline JALES & 17,72 \\
\hline MARINÓPOLIS & 0,67 \\
\hline MESÓPOLIS & 0,59 \\
\hline NOVA CANAÃ PAULISTA & 0,35 \\
\hline NOVA CASTILHO & 0,30 \\
\hline OUROESTE & 3,08 \\
\hline PALMEIRA D'OESTE & 2,89 \\
\hline PARAPUÃ & 3,55 \\
\hline PONTALINDA & 1,37 \\
\hline POPULINA & 1,36 \\
\hline
\end{tabular}




\begin{tabular}{|l|r|}
\hline RUBINÉIA & 0,95 \\
\hline SANTA ALBERTINA & 1,96 \\
\hline SANTA CLARA D'OESTE & 0,63 \\
\hline SANTA FÉ DO SUL & 11,32 \\
\hline SANTA RITA D'OESTE & 0,71 \\
\hline SANTA SALETE & 0,33 \\
\hline SANTANA DA PONTE PENSA & 0,43 \\
\hline SÃO FRANCISCO & 0,87 \\
\hline SÃO JOÃO DAS DUAS & 0,78 \\
\hline PONTES & 0,58 \\
\hline SÃO JOÃO DE IRACEMA & 0,92 \\
\hline SUZANÁPOLIS & 1,85 \\
\hline TRÊS FRONTEIRAS & 0,55 \\
\hline TURMALINA & 2,97 \\
\hline URÂNIA & 0,58 \\
\hline VITÓRIA BRASIL & 100,92 \\
\hline
\end{tabular}

Fonte: Autor, 2013. 


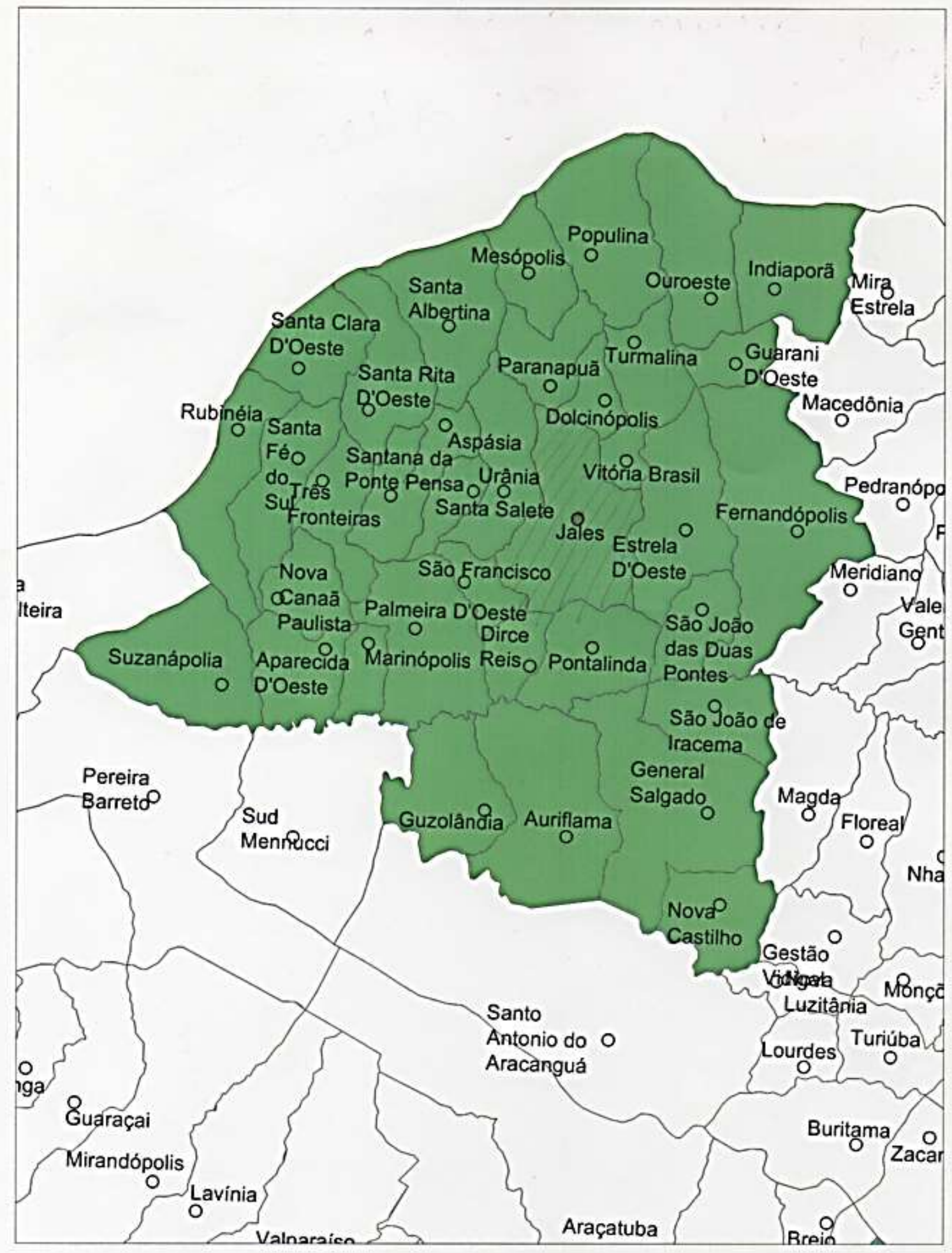

\section{REGIONALIZAÇÃO RAIO DE $50 \mathrm{KM}$ REGIÃO - 1}

Figura 92. Regionalização Rio 50 km - Região 1

Fonte: Autor, 2013. 


\section{- Região 2}

Município polo: Votuporanga

Tabela 10. Municípios e produção diária de resíduos domiciliares da Região 2 - Raio de $50 \mathrm{~km}$

\begin{tabular}{|l|r|}
\hline \multicolumn{1}{|c|}{ MUnicípio } & RSU (t/dia) \\
\hline MIRA ESTRELA & 0,76 \\
\hline CARDOSO & 4,30 \\
\hline RIOLÂNDIA & 3,40 \\
\hline PAULO DE FARIA & 3,10 \\
\hline MACEDÔNIA & 1,11 \\
\hline PONTES GESTAL & 0,85 \\
\hline AMÉRICO DE CAMPOS & 1,92 \\
\hline ÁLVARES FLORENCE & 1,05 \\
\hline PARISI & 0,66 \\
\hline PEDRANÓPOLIS & 0,63 \\
\hline COSMORAMA & 1,97 \\
\hline VOTUPORANGA & 33,20 \\
\hline VALENTIM GENTIL & 4,94 \\
\hline MERIDIANO & 1,06 \\
\hline MAGDA & 0,97 \\
\hline FLOREAL & 3,49 \\
\hline NHANDEARA & 0,95 \\
\hline SEBASTIANÓPOLIS DO SUL & 2,72 \\
\hline MACAUBAL & 1,07 \\
\hline POLONI & \\
\hline & \\
\hline
\end{tabular}

Fonte: Autor, 2013. 


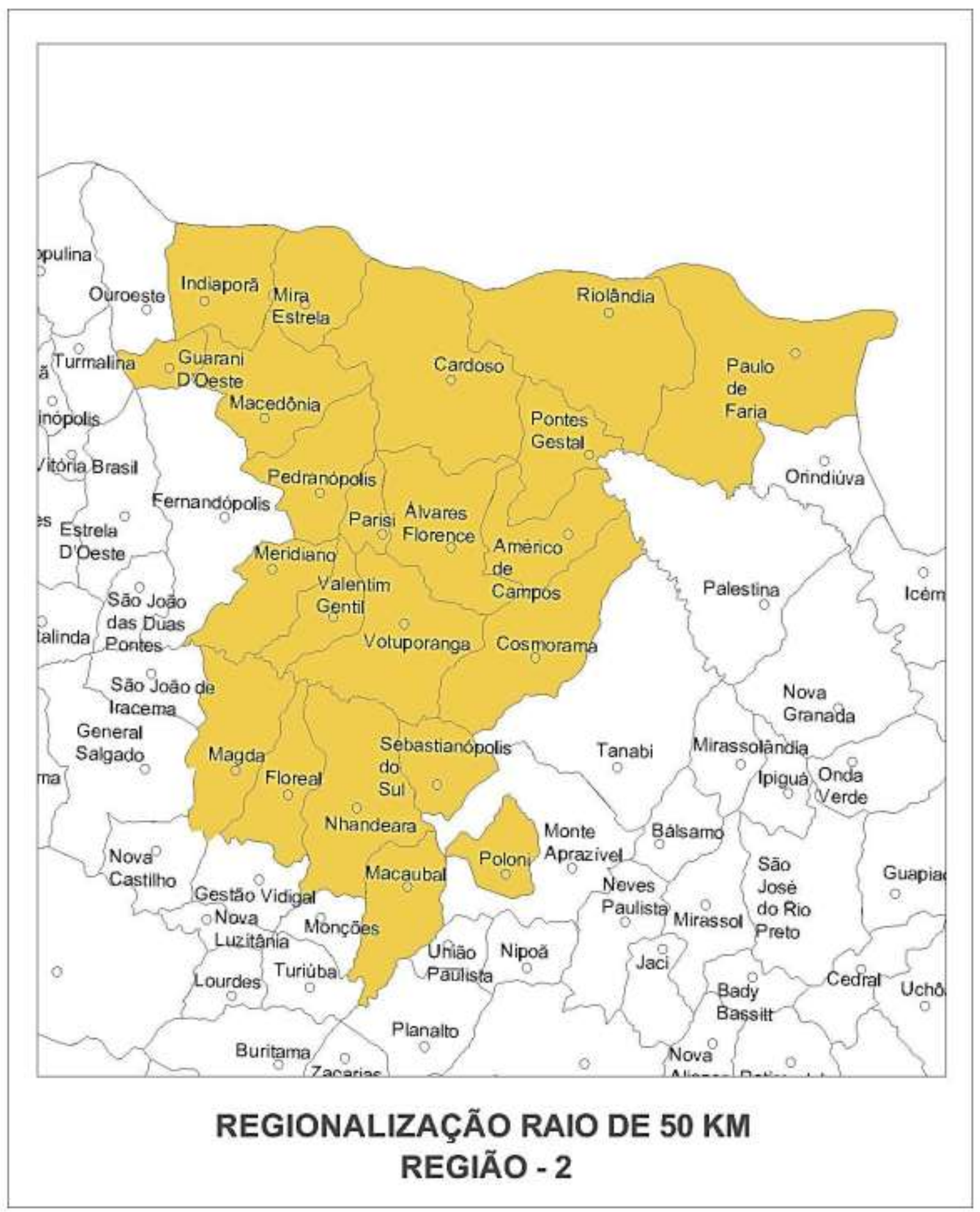

Figura 93. Regionalização Rio 50 km - Região 2

Fonte: Autor, 2013. 


\section{- Região 3}

Município polo: São José do Rio Preto

Tabela 11. Municípios e produção diária de resíduos domiciliares da Região 3 - Raio de $50 \mathrm{~km}$

\begin{tabular}{|l|r|}
\hline \multicolumn{1}{|c|}{ MUnicípio } & RSU (t/dia) \\
\hline BADY BASSITT & 5,55 \\
\hline BÁLSAMO & 3,01 \\
\hline CEDRAL & 2,55 \\
\hline GUAPIAÇU & 6,42 \\
\hline ICÉM & 2,58 \\
\hline IPIGUÁ & 1,10 \\
\hline JACI & 1,99 \\
\hline JOSÉ BONIFÁCIO & 11,99 \\
\hline MIRASSOL & 21,14 \\
\hline MIRASSOLÂNDIA & 1,41 \\
\hline MONTE APRAZÍVEL & 3,53 \\
\hline NEVES PAULISTA & 8,01 \\
\hline NIPOÃ & 3,16 \\
\hline NOVA GRANADA & 1,55 \\
\hline ONDA VERDE & 232,25 \\
\hline ORINDIÚVA & 7,17 \\
\hline PALESTINA & 1,53 \\
\hline PLANALTO & \\
\hline SÃO JOSÉ DO RIO PRETO & \\
\hline TANABI & \\
\hline UCHOA & \\
\hline
\end{tabular}




\begin{tabular}{|l|r|}
\hline UNIÃO PAULISTA & 0,50 \\
\hline NOVA ALIANÇA & 1,98 \\
\hline POTIRENDABA & 5,60 \\
\hline UBARANA & 1,97 \\
\hline ADOLFO & 1,28 \\
\hline MENDONÇA & 1,54 \\
\hline & \\
\hline
\end{tabular}

Fonte: Autor, 2013. 


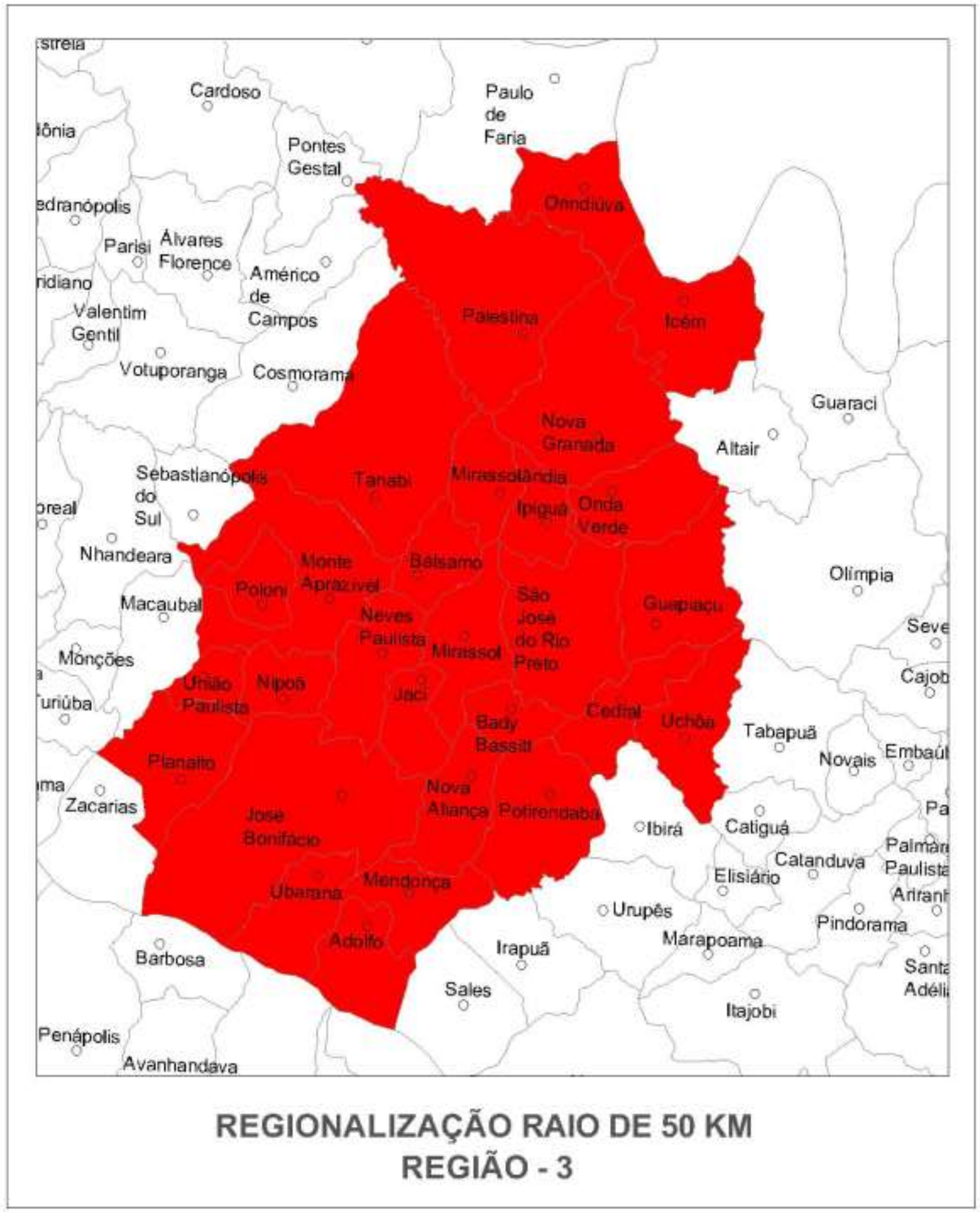

Figura 94. Regionalização Rio 50 km - Região 3

Fonte: Autor, 2013. 


\section{- Região 4}

Município polo: Barretos

Tabela 12. Municípios e produção diária de resíduos domiciliares da Região 4 - Raio de $50 \mathrm{~km}$

\begin{tabular}{|l|r|}
\hline \multicolumn{1}{|c|}{ Município } & RSU (t/dia) \\
\hline ALTAIR & 1,22 \\
\hline GUARACI & 3,60 \\
\hline OLÍMPIA & 19,01 \\
\hline COLÔMBIA & 1,73 \\
\hline BARRETOS & 54,65 \\
\hline SEVERÍNIA & 5,97 \\
\hline COLINA & 6,51 \\
\hline BEBEDOURO & 28,61 \\
\hline JABORANDI & 2,47 \\
\hline TERRA ROXA & 3,26 \\
\hline VIRADOURO & 6,76 \\
\hline GUAÍRA & 14,51 \\
\hline IPUÃ & 5,49 \\
\hline & 153,78 \\
\hline
\end{tabular}

Fonte: Autor, 2013. 


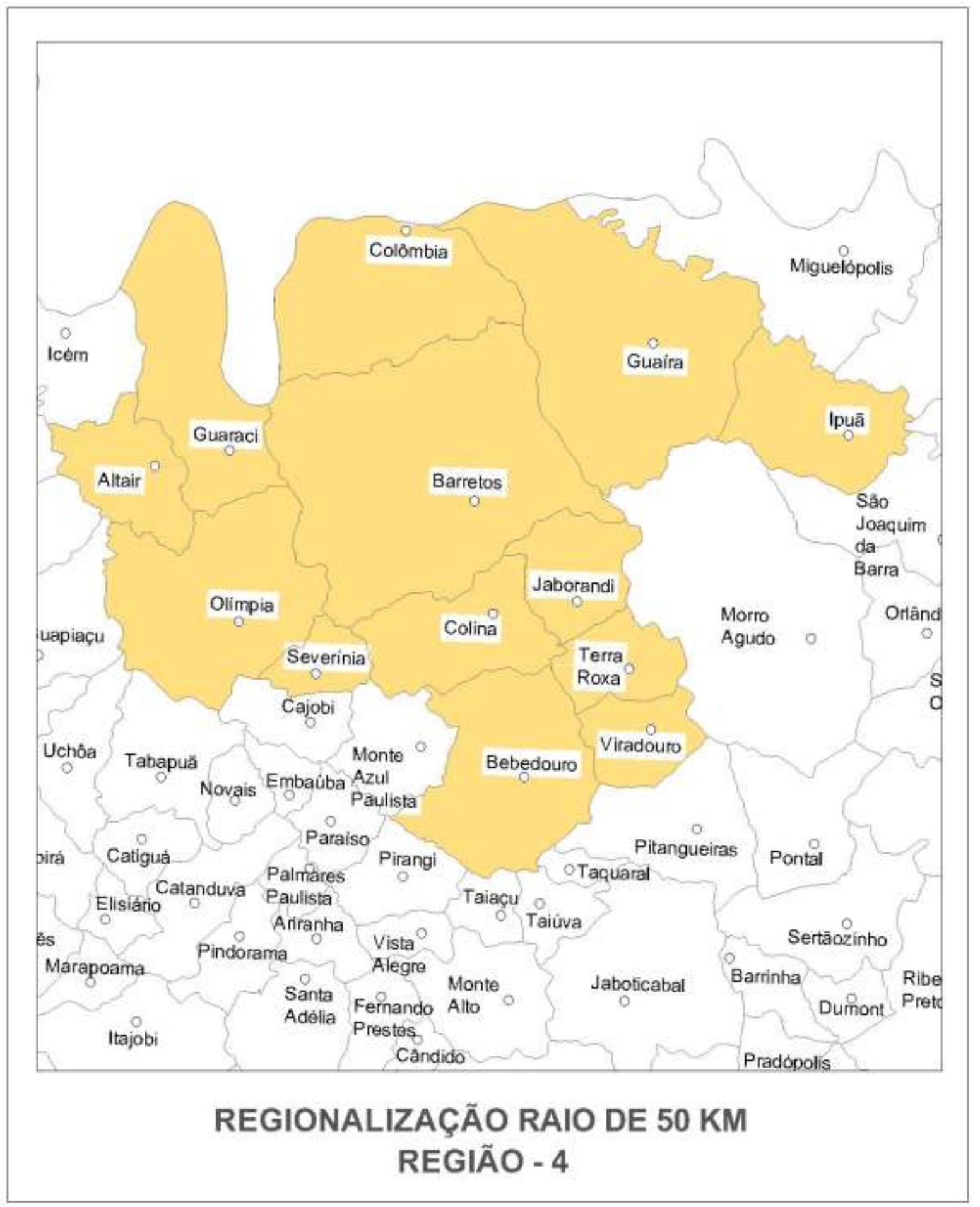

Figura 95. Regionalização Rio 50 km - Região 4

Fonte: Autor, 2013. 


\section{- Região 5}

Município polo: Franca

Tabela 13. Municípios e produção diária de resíduos domiciliares da Região 5 - Raio de $50 \mathrm{~km}$

\begin{tabular}{|l|r|}
\hline \multicolumn{1}{|c|}{ MUnicípio } & RSU (t/dia) \\
\hline MIGUELÓPOLIS & 7,75 \\
\hline ITUVERAVA & 14,64 \\
\hline GUARÁ & 7,72 \\
\hline SÃO JOAQUIM DA BARRA & 18,42 \\
\hline NUPORANGA & 2,49 \\
\hline IGARAPAVA & 10,60 \\
\hline ARAMINA & 1,94 \\
\hline BURITIZAL & 1,33 \\
\hline JERIQUARA & 1,04 \\
\hline RIBEIRÃO CORRENTE & 1,37 \\
\hline SÃO JOSÉ DA BELA VISTA & 3,00 \\
\hline RIFAINA & 1,21 \\
\hline PEDREGULHO & 4,65 \\
\hline CRISTAIS PAULISTA & 2,23 \\
\hline FRANCA & 189,23 \\
\hline RESTINGA & 2,10 \\
\hline PATROCÍNIO PAULISTA & 4,24 \\
\hline ITIRAPUÃ & 1,98 \\
\hline & 275,93 \\
\hline
\end{tabular}

Fonte: Autor, 2013. 


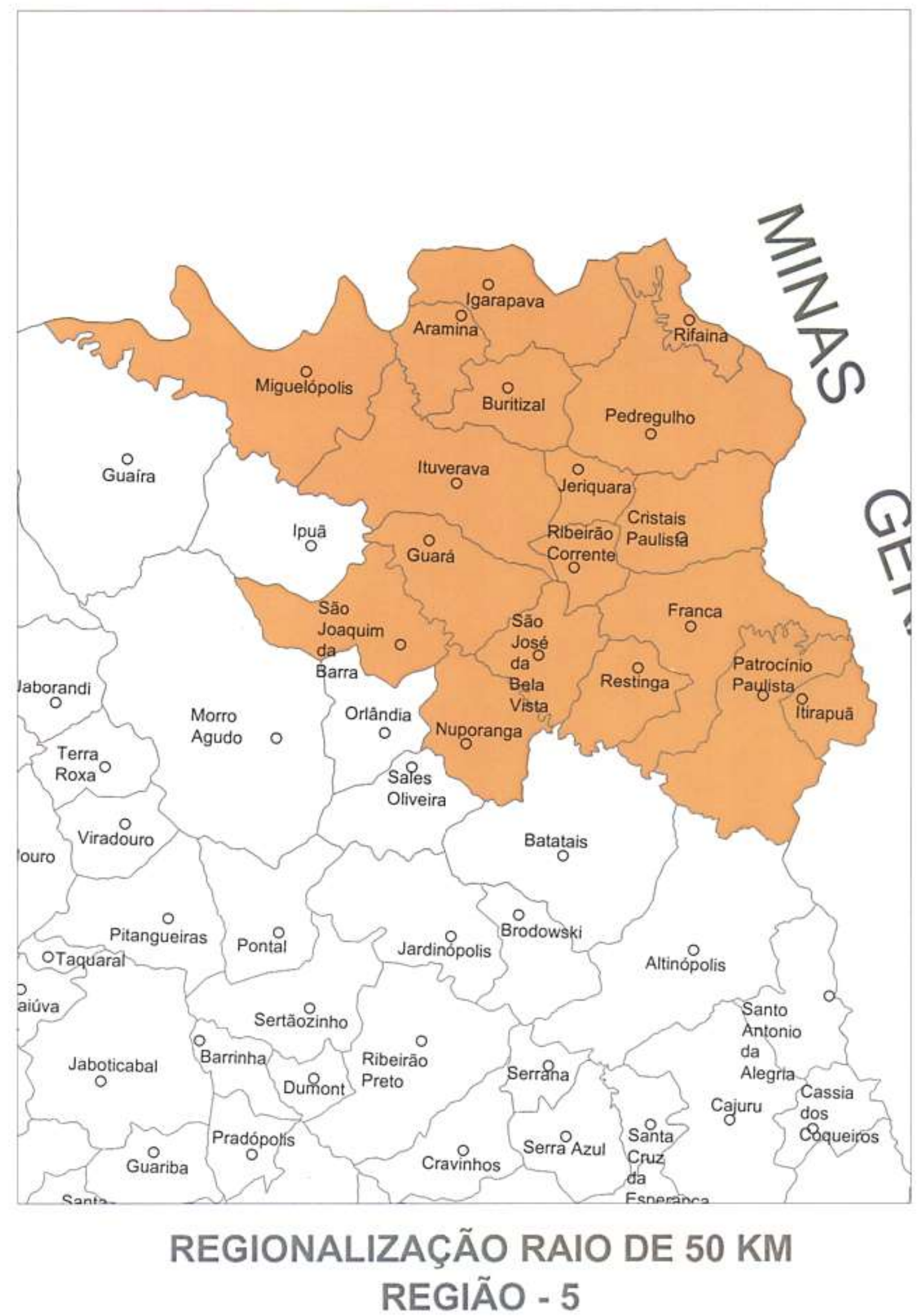

Figura 96. Regionalização Rio 50 km - Região 5

Fonte: Autor, 2013. 


\section{- Região 6}

Município polo: Catanduva

Tabela 14. Municípios e produção diária de resíduos domiciliares da Região 6 - Raio de $50 \mathrm{~km}$

\begin{tabular}{|c|c|}
\hline Município & RSU (t/dia) \\
\hline CAJOBI & 3,67 \\
\hline MONTE AZUL PAULISTA & 7,07 \\
\hline TABAPUÃ & 4,23 \\
\hline NOVAIS & 1,71 \\
\hline EMBAÚBA & 0,82 \\
\hline PARAÍSO & 2,09 \\
\hline PIRANGI & 3,83 \\
\hline TAIAÇU & 2,14 \\
\hline TAIÚVA & 1,99 \\
\hline CATIGUÁ & 2,64 \\
\hline CATANDUVA & 56,22 \\
\hline PALMARES PAULISTA & 4,32 \\
\hline ARIRANHA & 3,27 \\
\hline VISTA ALEGRE DO ALTO & 2,60 \\
\hline MONTE ALTO & 17,91 \\
\hline PINDORAMA & 5,75 \\
\hline IBIRÁ & 4,06 \\
\hline ELISIÁRIO & 1,16 \\
\hline SANTA ADÉLIA & 5,45 \\
\hline FERNANDO PRESTES & 1,88 \\
\hline CÂNDIDO RODRIGUES & 0,86 \\
\hline
\end{tabular}




\begin{tabular}{|l|r|} 
URUPÊS & 4,55 \\
\hline MARAPOAMA & 0,89 \\
\hline ITAJOBI & 4,87 \\
\hline IRAPUÃ & 2,61 \\
\hline SALES & 1,99 \\
\hline NOVO HORIZONTE & 13,74 \\
\hline BORBOREMA & 5,28 \\
\hline ITÁPOLIS & 14,59 \\
\hline \multicolumn{2}{|c|}{ TOTAL } \\
\hline
\end{tabular}

Fonte: Autor, 2013. 


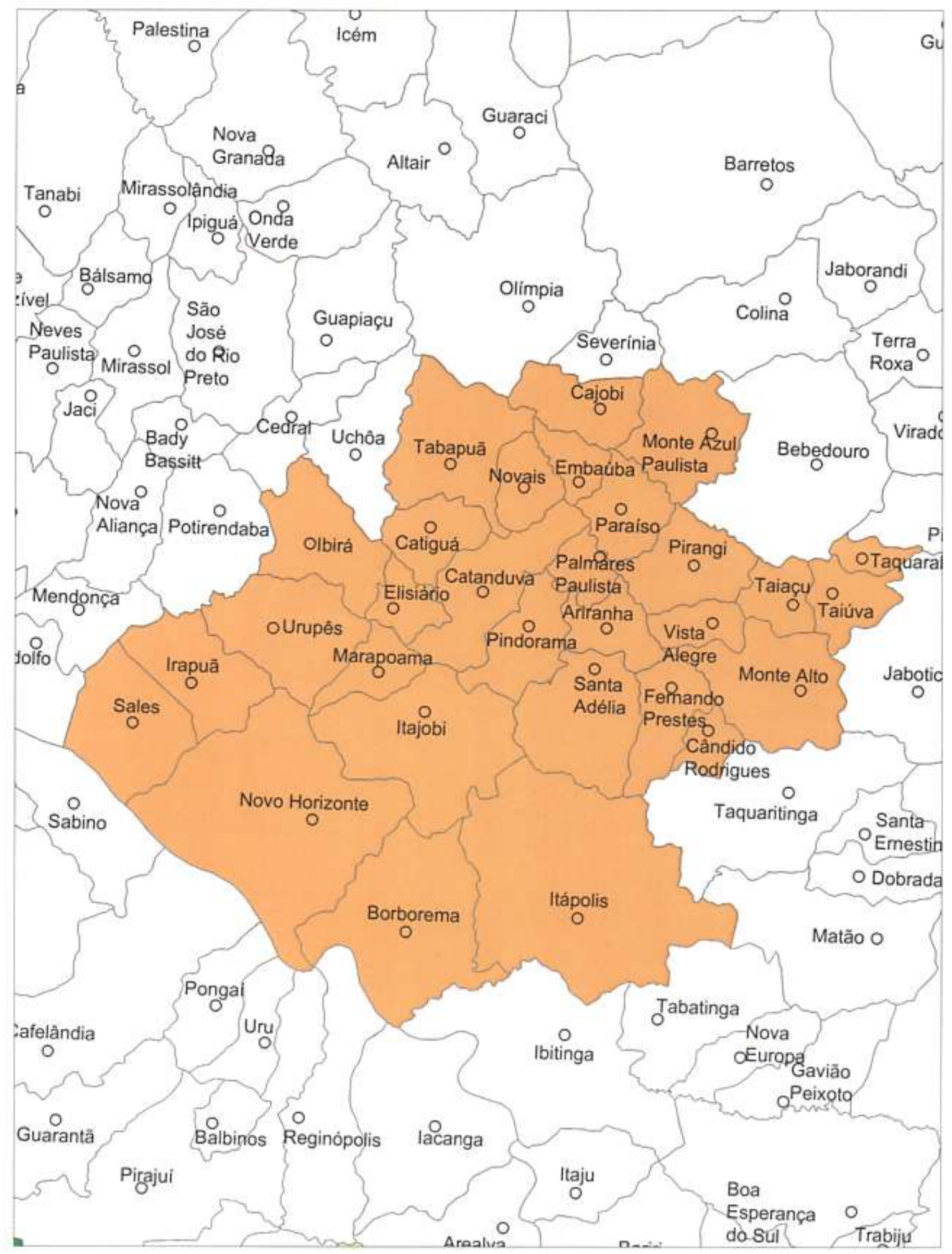

\section{REGIONALIZAÇÃO RAIO DE 50 KM REGIÃO - 6}

Figura 97. Regionalização Rio 50 km - Região 6

Fonte: Autor, 2013. 


\section{- Região 7}

Município polo: Ribeirão Preto

Tabela 15. Municípios e produção diária de resíduos domiciliares da Região 7 - Raio de $50 \mathrm{~km}$

\begin{tabular}{|c|c|}
\hline Município & RSU (t/dia) \\
\hline ALTINÓPOLIS & 5,46 \\
\hline BARRINHA & 11,40 \\
\hline BATATAIS & 20,12 \\
\hline BRODOWSKI & 8,36 \\
\hline CAJURU & 8,39 \\
\hline CÁSSIA DOS COQUEIROS & 0,71 \\
\hline CRAVINHOS & 12,46 \\
\hline DUMONT & 3,20 \\
\hline JABOTICABAL & 27,94 \\
\hline JARDINÓPOLIS & 14,66 \\
\hline MOCOCA & 24,48 \\
\hline MORRO AGUDO & 11,27 \\
\hline ORLÂNDIA & 15,62 \\
\hline PITANGUEIRAS & 13,70 \\
\hline PONTAL & 16,12 \\
\hline PRADÓPOLIS & 6,57 \\
\hline RIBEIRÃO PRETO & 427,42 \\
\hline SALES OLIVEIRA & 3,86 \\
\hline $\begin{array}{l}\text { SANTA CRUZ DA } \\
\text { ESPERANÇA }\end{array}$ & 0,53 \\
\hline SANTA ROSA DE VITERBO & 9,17 \\
\hline $\begin{array}{l}\text { SANTO ANTÔNIO DA } \\
\text { ALEGRIA }\end{array}$ & 1,88 \\
\hline SÃO SIMÃO & 5,19 \\
\hline SERRA AZUL & 3,29 \\
\hline SERRANA & 15,58 \\
\hline SERTÃOZINHO & 54,97 \\
\hline TAQUARITINGA & 20,52 \\
\hline TOTAL & 742,86 \\
\hline
\end{tabular}

Fonte: Autor, 2013. 


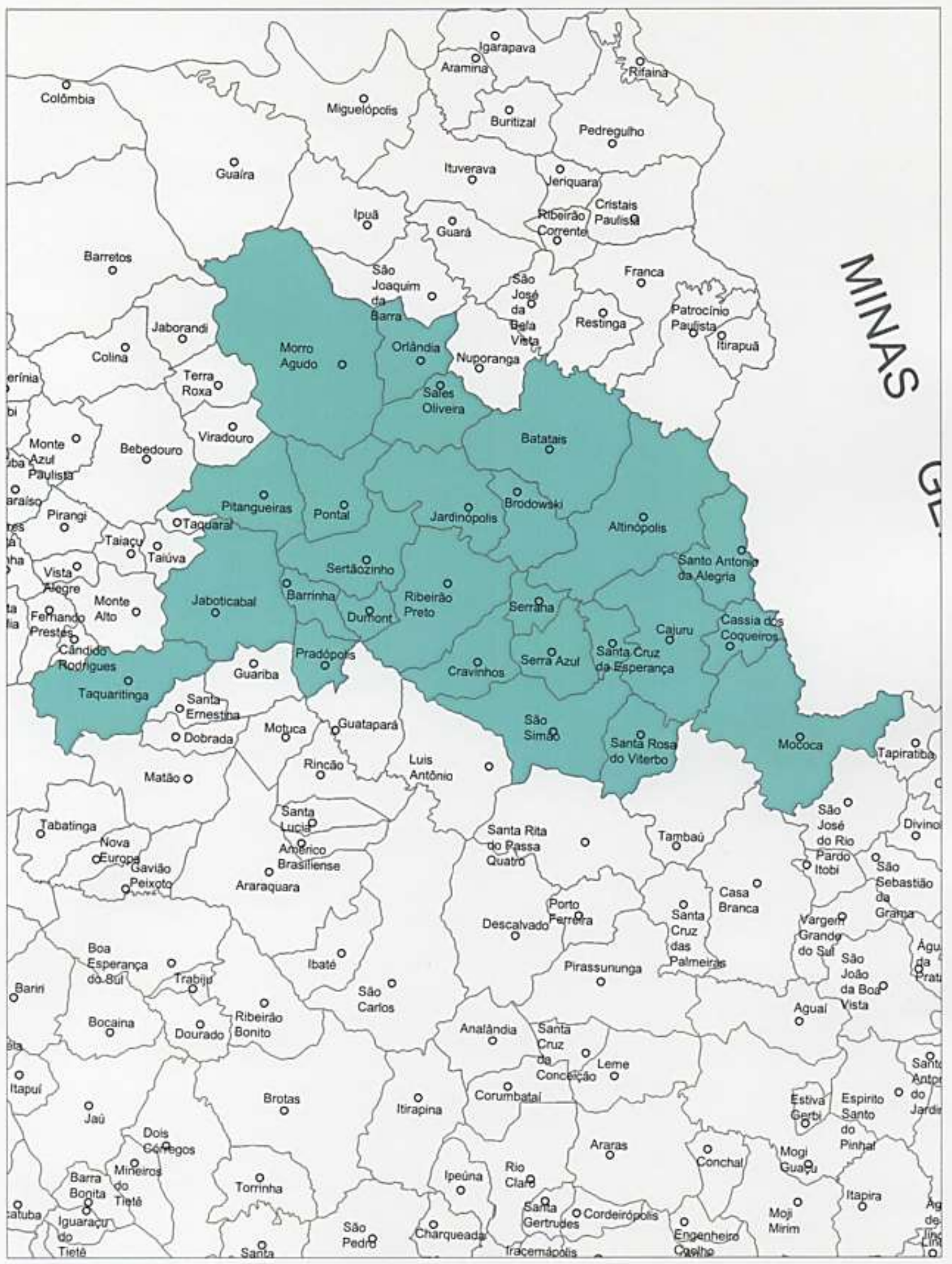

\section{REGIONALIZAÇÃO RAIO DE 50 KM REGIÃO - 7}

Figura 98. Regionalização Rio 50 km - Região 7

Fonte: Autor, 2013. 


\section{- Região 8}

Município polo: Andradina

Tabela 16. Municípios e produção diária de resíduos domiciliares da Região 8 - Raio de $50 \mathrm{~km}$

\begin{tabular}{|l|r|}
\hline \multicolumn{1}{|c|}{ Município } & RSU (t/dia) \\
\hline ILHA SOLTEIRA & 9,44 \\
\hline ITAPURA & 1,41 \\
\hline PEREIRA BARRETO & 9,29 \\
\hline SUD MENNUCCI & 2,56 \\
\hline CASTILHO & 5,51 \\
\hline ANDRADINA & 20,66 \\
\hline MURUTINGA DO SUL & 1,03 \\
\hline GUARAÇAÍ & 2,65 \\
\hline MIRANDÓPOLIS & 9,82 \\
\hline LAVÍNIA & 1,77 \\
\hline CASTILHO & 5,51 \\
\hline NOVA INDEPENDÊNCIA & 1,00 \\
\hline \multicolumn{1}{|c|}{ TOTAL } & $\mathbf{7 0 , 6 4}$ \\
\hline
\end{tabular}

Fonte: Autor, 2013. 


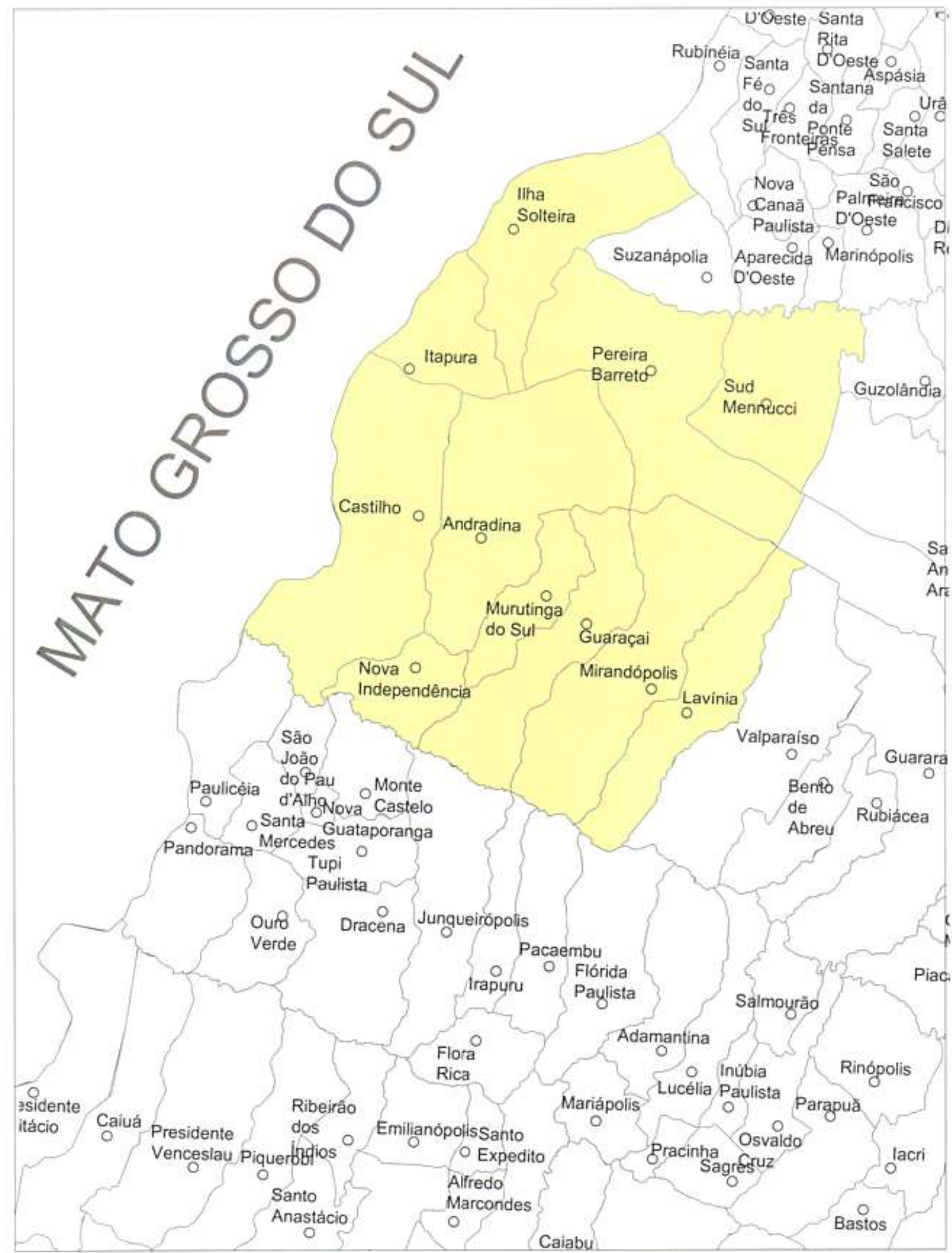

\section{REGIONALIZAÇÃO RAIO DE 50 KM \\ REGIÃO - 8}

Figura 99. Regionalização Rio 50 km - Região 8

Fonte: Autor, 2013. 


\section{- Região 9}

Município polo: Araçatuba

Tabela 17. Municípios e produção diária de resíduos domiciliares da Região 9 - Raio de $50 \mathrm{~km}$

\begin{tabular}{|c|c|}
\hline Município & RSU (t/dia) \\
\hline MONÇÕES & 0,74 \\
\hline TURIÚBA & 0,63 \\
\hline LOURDES & 0,70 \\
\hline NOVA LUZITÂNIA & 1,25 \\
\hline GASTÃO VIDIGAL & 1,52 \\
\hline BURITAMA & 5,86 \\
\hline $\begin{array}{l}\text { ZACARIAS } \\
\text { SANTO ANTÔNIO DO } \\
\text { ARACANGUÁ }\end{array}$ & $\begin{array}{l}0,74 \\
2,41 \\
\end{array}$ \\
\hline BREJO ALEGRE & 0,85 \\
\hline ARAÇATUBA & 89,50 \\
\hline BIRIGUI & 53,28 \\
\hline COROADOS & 1,72 \\
\hline GLICÉRIO & 1,35 \\
\hline GUARARAPES & 11,38 \\
\hline BILAC & 2,62 \\
\hline CLEMENTINA & 2,74 \\
\hline GABRIEL MONTEIRO & 0,90 \\
\hline SANTÓPOLIS DO AGUAPEÍ & 1,67 \\
\hline PIACATU & 1,88 \\
\hline RUBIÁCEA & 0,63 \\
\hline BENTO DE ABREU & 0,99 \\
\hline VALPARAÍSO & 8,70 \\
\hline TOTAL & 192,06 \\
\hline
\end{tabular}

Fonte: Autor, 2013. 


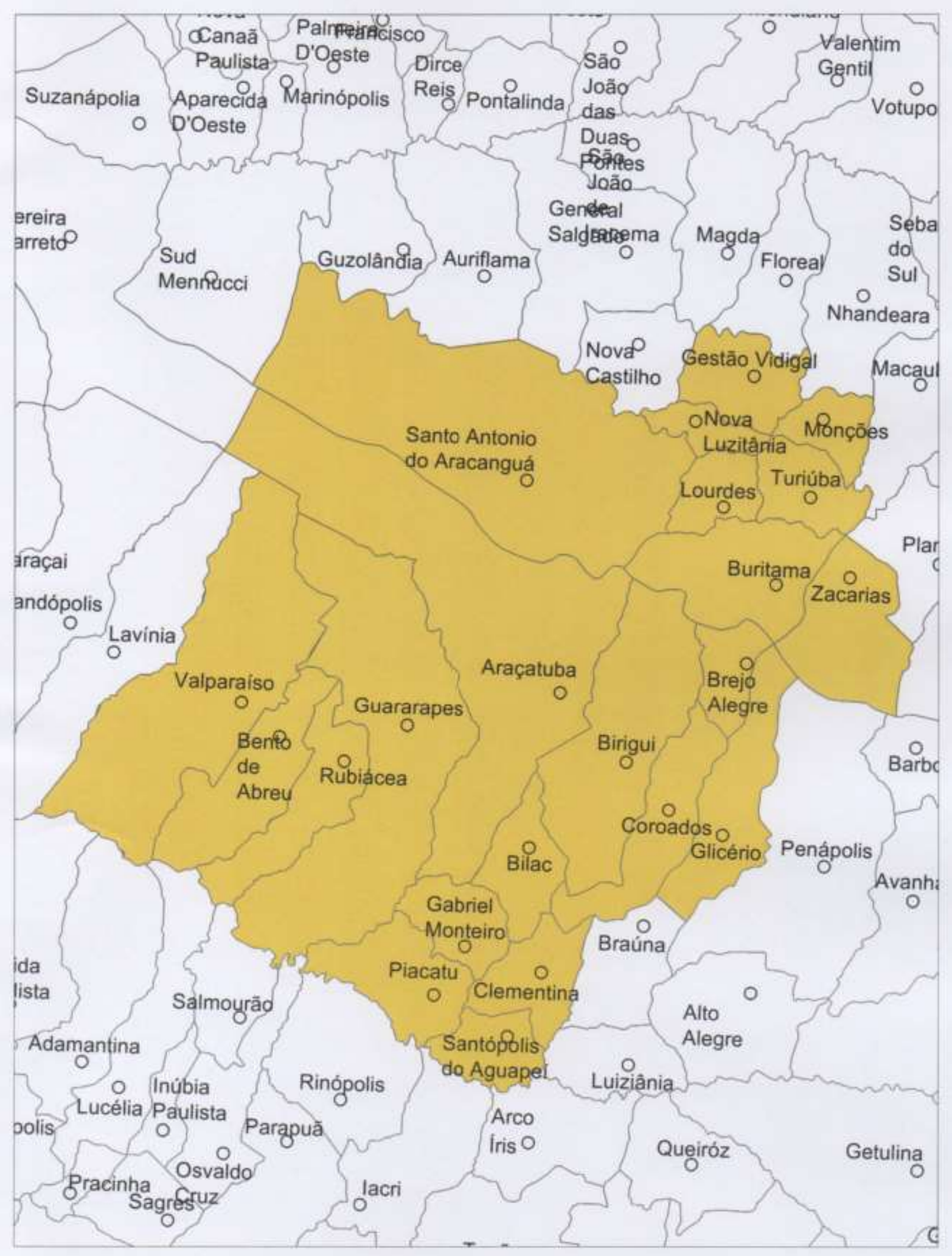

\section{REGIONALIZAÇÃO RAIO DE 50 KM REGIÃO - 9}

Figura 100. Regionalização Rio 50 km - Região 9

Fonte: Autor, 2013. 


\section{- Região 10}

Município polo: Lins

Tabela 18. Municípios e produção diária de resíduos domiciliares da Região 10 Raio de 50 km

\begin{tabular}{|l|r|}
\hline \multicolumn{1}{|c|}{ Município } & RSU (t/dia) \\
\hline BRAÚNA & 1,77 \\
\hline LUIZIÂNIA & 1,87 \\
\hline ALTO ALEGRE & 1,29 \\
\hline PENÁPOLIS & 22,47 \\
\hline BARBOSA & 2,25 \\
\hline AVANHANDAVA & 3,89 \\
\hline PROMISSÃO & 12,15 \\
\hline GETULINA & 3,34 \\
\hline GUAIÇARA & 3,92 \\
\hline LINS & 28,41 \\
\hline GUAIMBÊ & 1,90 \\
\hline SABINO & 1,84 \\
\hline CAFELÂNDIA & 5,79 \\
\hline GUARANTÃ & 2,19 \\
\hline PONGAÍ & 1,16 \\
\hline URU & 0,43 \\
\hline BALBINOS & 0,50 \\
\hline PIRAJUÍ & 7,47 \\
\hline & $\mathbf{1 0 2 , 6 2}$ \\
\hline
\end{tabular}

Fonte: Autor, 2013. 


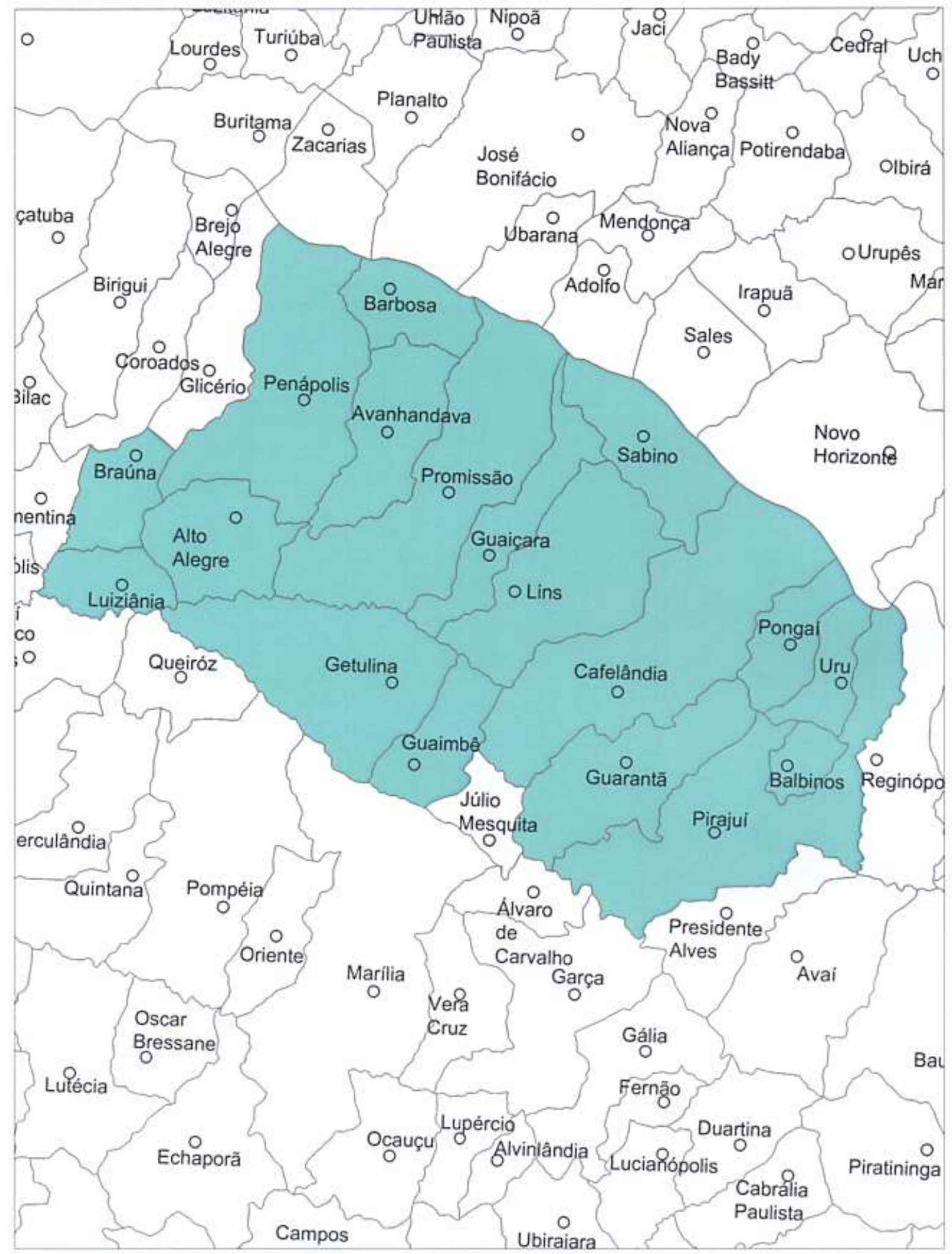

\section{REGIONALIZAÇÃO RAIO DE 50 KM REGIÃO - 10}

Figura 107. Regionalização Rio 50 km - Região 10

Fonte: Autor, 2013. 


\section{- Região 11}

Município polo: Araraquara

Tabela 19. Municípios e produção diária de resíduos domiciliares da Região 11 Raio de 50 km

\begin{tabular}{|l|r|}
\hline \multicolumn{1}{|c|}{ MunicípIO } & RSU (t/dia) \\
\hline GUARIBA & 14,03 \\
\hline SANTA ERNESTINA & 2,05 \\
\hline DOBRADA & 3,13 \\
\hline MOTUCA & 1,25 \\
\hline GUATAPARÁ & 2,06 \\
\hline RINCÃO & 3,39 \\
\hline LUÍS ANTÔNIO & 4,48 \\
\hline SANTA LÚCIA & 3,11 \\
\hline AMÉRICO BRASILIENSE & 13,88 \\
\hline MATÃO & 30,30 \\
\hline ARARAQUARA & 122,81 \\
\hline IBATÉ & 11,93 \\
\hline SÃO CARLOS & 129,12 \\
\hline RIBEIRÃO BONITO & 4,51 \\
\hline DOURADO & 3,15 \\
\hline TRABIJU & 0,57 \\
\hline BOA ESPERANÇA DO SUL & 4,90 \\
\hline GAVIÃO PEIXOTO & 1,44 \\
\hline NOVA EUROPA & 3,51 \\
\hline TABATINGA & 5,08 \\
\hline IBITINGA & 20,62 \\
\hline & 385,32 \\
\hline
\end{tabular}

Fonte: Autor, 2013. 


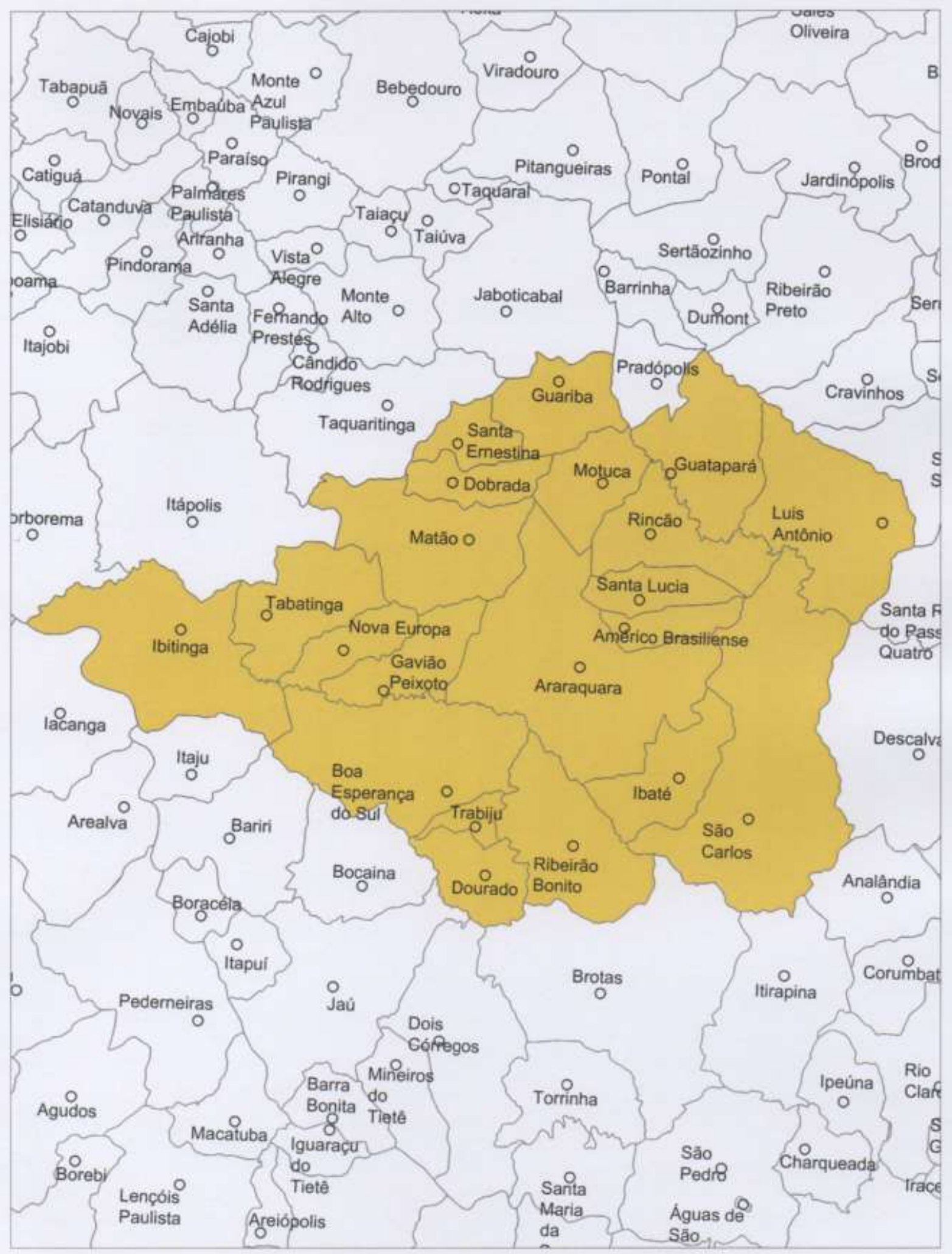

\section{REGIONALIZAÇÃO RAIO DE 50 KM REGIÃO - 11}

Figura 102. Regionalização Rio 50 km - Região 11

Fonte: Autor, 2013. 


\section{- Região 12}

Município polo: Pirassununga

Tabela 20. Municípios e produção diária de resíduos domiciliares da Região 12 Raio de 50 km

\begin{tabular}{|l|r|}
\hline \multicolumn{1}{|c|}{ Município } & RSU (t/dia) \\
\hline TAMBAÚ & 7,97 \\
\hline $\begin{array}{l}\text { SANTA RITA DO PASSA } \\
\text { QUATRO }\end{array}$ & 9,49 \\
\hline CASA BRANCA & 9,30 \\
\hline $\begin{array}{l}\text { SANTA CRUZ DAS } \\
\text { PALMEIRAS }\end{array}$ & 11,73 \\
\hline PORTO FERREIRA & 20,31 \\
\hline DESCALVADO & 11,14 \\
\hline PIRASSUNUNGA & 25,83 \\
\hline SANTA CRUZ DA & 1,09 \\
\hline CONCEIÇÃO & 36,28 \\
\hline LEME & 0,84 \\
\hline CORUMBATAÍ & 1,38 \\
\hline ANALÂNDIA & 5,68 \\
\hline ITIRAPINA & $\mathbf{1 4 1 , 0 3}$ \\
\hline
\end{tabular}

Fonte: Autor, 2013. 


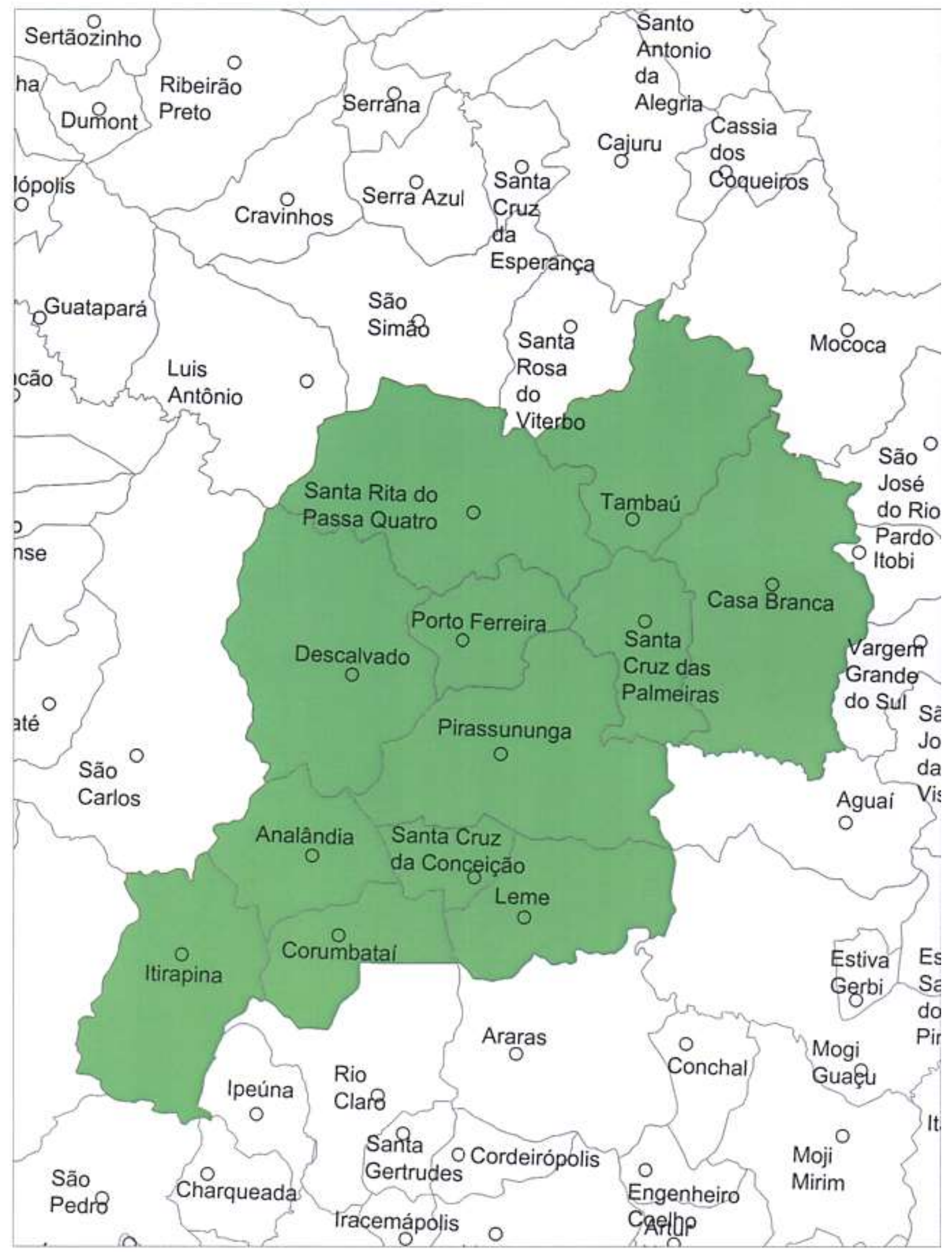

\section{REGIONALIZAÇÃO RAIO DE 50 KM}

\section{REGIÃO - 12}

Figura 103. Regionalização Rio 50 km - Região 12

Fonte: Autor, 2013. 


\section{- Região 13}

Município polo: São João da Boa Vista

Tabela 21. Municípios e produção diária de resíduos domiciliares da Região 13 Raio de $50 \mathrm{~km}$

\begin{tabular}{|l|r|}
\hline \multicolumn{1}{|c|}{ Município } & RSU (t/dia) \\
\hline ITAPIRA & 25,58 \\
\hline CACONDE & 5,06 \\
\hline DIVINOLÂNDIA & 2,98 \\
\hline SÃO JOSÉ DO RIO PARDO & 18,43 \\
\hline ITOBI & 2,72 \\
\hline SÃO SEBASTIÃO DA GRAMA & 3,18 \\
\hline VARGEM GRANDE DO SUL & 15,00 \\
\hline SÃO JOÃO DA BOA VISTA & 32,31 \\
\hline ÁGUAS DA PRATA & 2,72 \\
\hline AGUAÍ & 11,71 \\
\hline SANTO ANTÔNIO DO & 1,41 \\
\hline JARDIM & 14,94 \\
\hline ESPÍRITO SANTO DO & 3,23 \\
\hline PINHAL & 65,62 \\
\hline ESTIVA GERBI & $\mathbf{2 0 4 , 8 9}$ \\
\hline MOGI GUAÇU & \\
\hline
\end{tabular}

Fonte: Autor, 2013. 


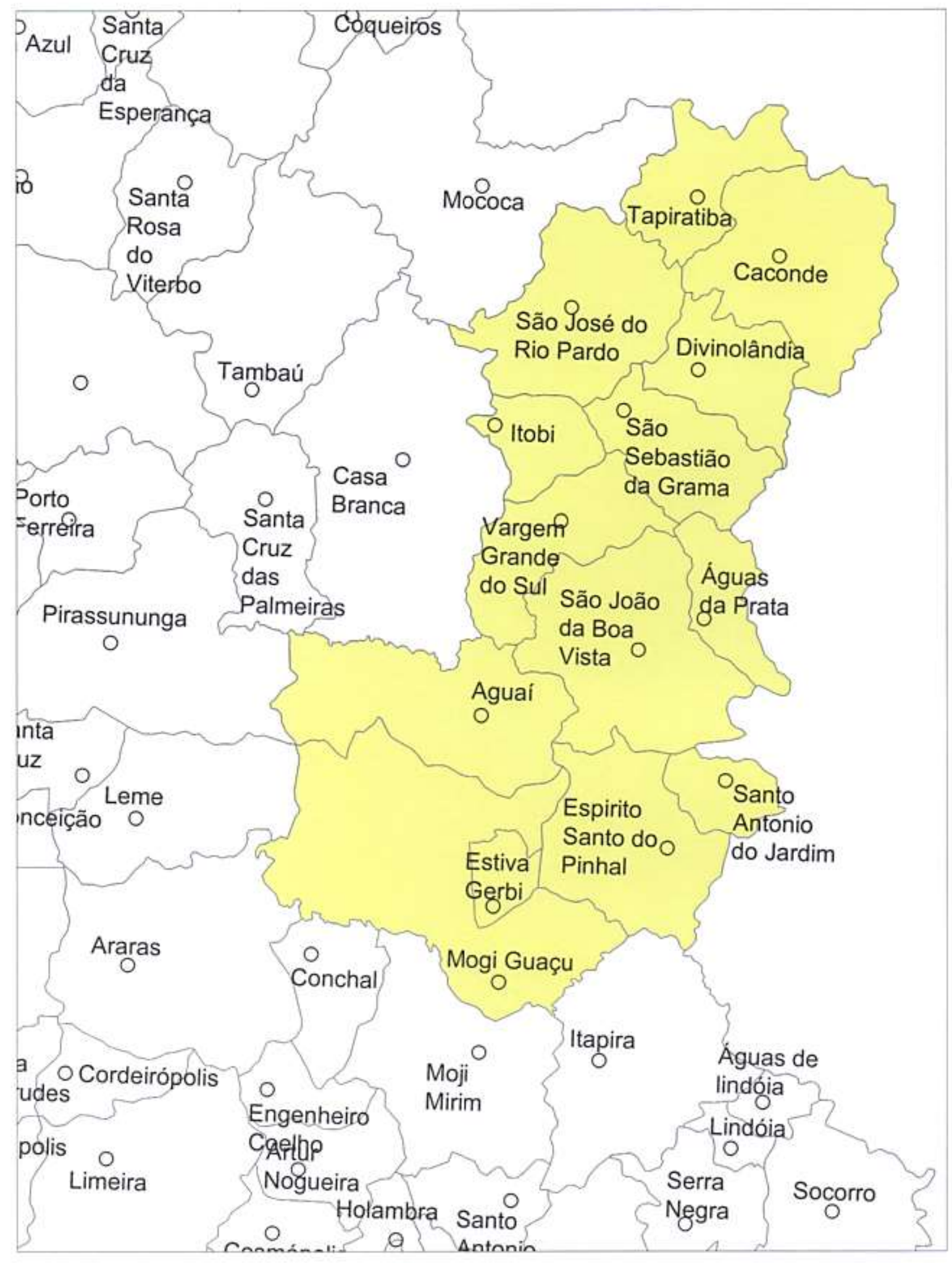

\section{REGIONALIZAÇÃO RAIO DE 50 KM REGIÃO - 13}

Figura 104. Regionalização Rio 50 km - Região 13

Fonte: Autor, 2013. 


\section{- Região 14}

Município polo: Dracena

Tabela 22. Municípios e produção diária de resíduos domiciliares da Região 14 Raio de 50 km

\begin{tabular}{|l|r|}
\hline \multicolumn{1}{|c|}{ Município } & RSU (t/dia) \\
\hline PAULICÉIA & 2,13 \\
\hline PANORAMA & 5,69 \\
\hline SANTA MERCEDES & 0,98 \\
\hline SÃO JOÃO DO PAU D'ALHO & 0,68 \\
\hline NOVA GUATAPORANGA & 0,76 \\
\hline MONTE CASTELO & 1,28 \\
\hline TUPI PAULISTA & 4,51 \\
\hline OURO VERDE & 2,89 \\
\hline DRACENA & 16,06 \\
\hline JUNQUEIRÓPOLIS & 6,20 \\
\hline IRAPURU & 2,21 \\
\hline PACAEMBU & 3,91 \\
\hline FLORA RICA & 0,56 \\
\hline FLÓRIDA PAULISTA & 4,10 \\
\hline ADAMANTINA & 12,79 \\
\hline MARIÁPOLIS & 1,26 \\
\hline & $\mathbf{6 6 , 0 1}$ \\
\hline
\end{tabular}

Fonte: Autor, 2013. 


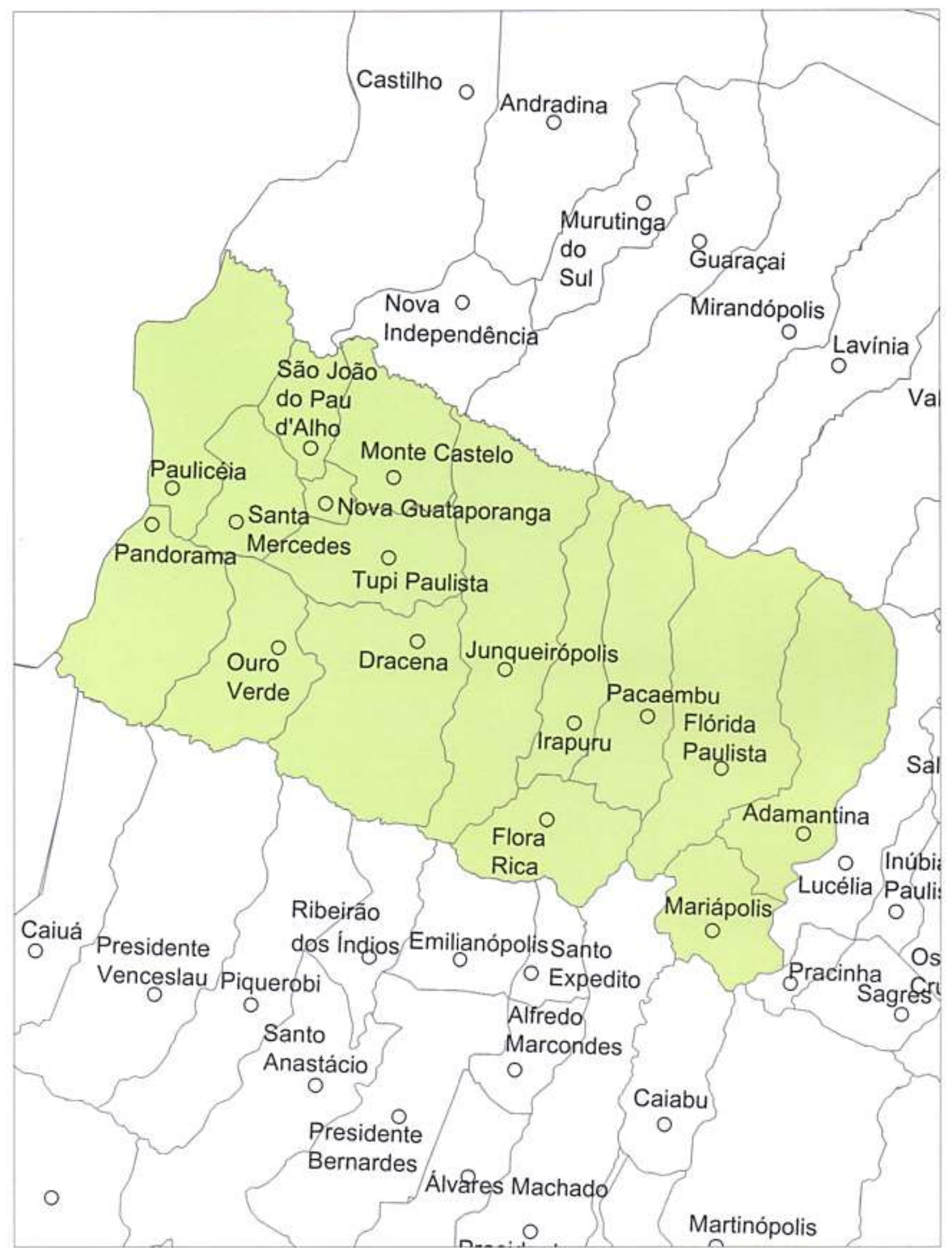

\section{REGIONALIZAÇÃO RAIO DE 50 KM REGIÃO - 14}

Figura 105. Regionalização Rio 50 km - Região 14

Fonte: Autor, 2013. 


\section{- Região 15}

Município polo: Tupã

Tabela 23. Municípios e produção diária de resíduos domiciliares da Região 15 Raio de 50 km

\begin{tabular}{|l|r|}
\hline \multicolumn{1}{|c|}{ Município } & RSU (t/dia) \\
\hline LUCÉLIA & 6,93 \\
\hline PRACINHA & 0,57 \\
\hline SALMOURÃO & 1,74 \\
\hline INÚBIA PAULISTA & 1,28 \\
\hline SAGRES & 0,73 \\
\hline OSVALDO CRUZ & 11,15 \\
\hline PARAPUÃ & 3,55 \\
\hline RINÓPOLIS & 3,45 \\
\hline IACRI & 2,01 \\
\hline BASTOS & 7,04 \\
\hline ARCO-ÍRIS & 0,43 \\
\hline TUPÃ & 24,38 \\
\hline HERCULÂNDIA & 3,19 \\
\hline QUINTANA & 2,21 \\
\hline & $\mathbf{6 8 , 6 5}$ \\
\hline
\end{tabular}

Fonte: Autor, 2013. 


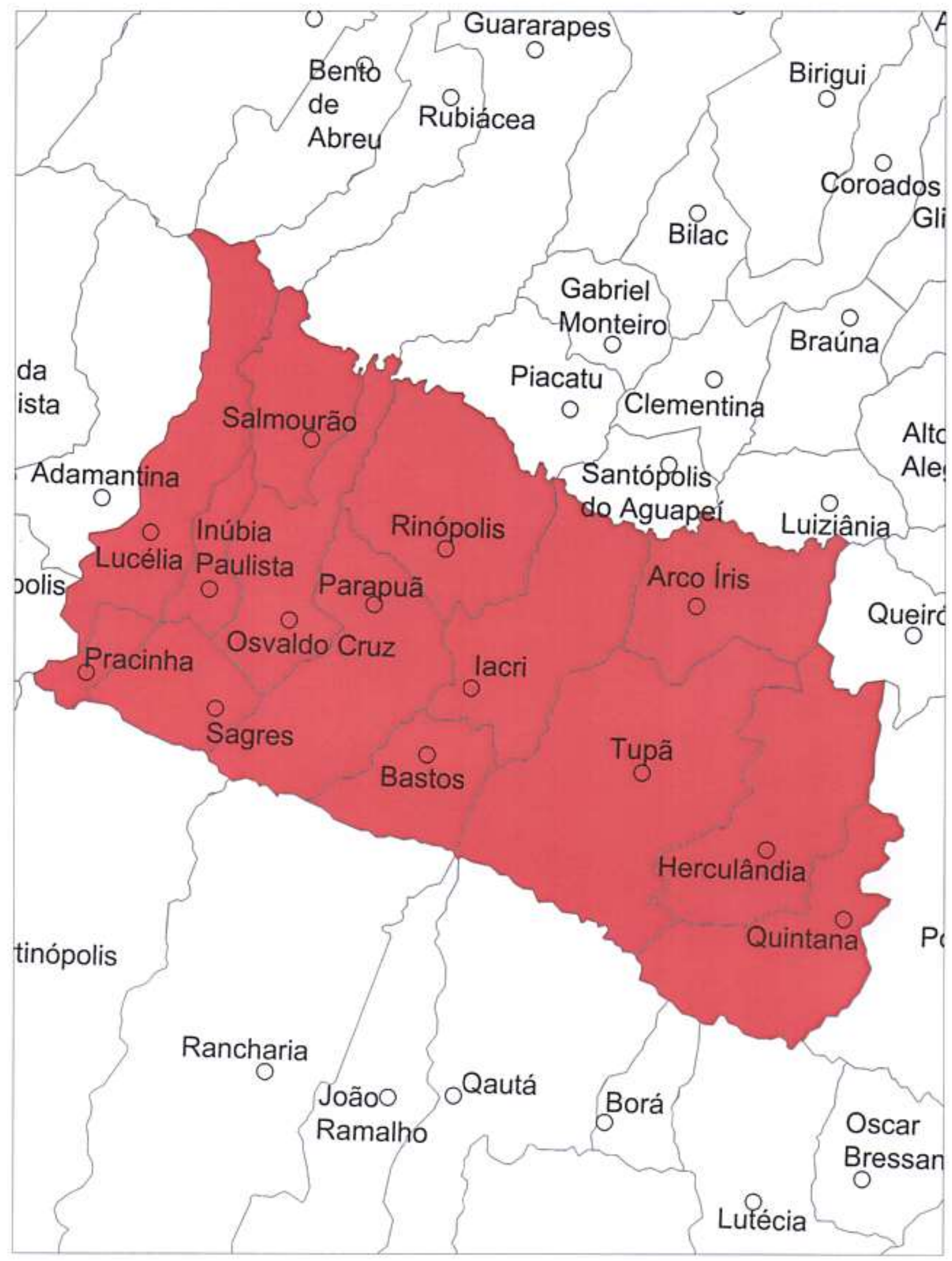

\section{REGIONALIZAÇÃO RAIO DE 50 KM}

\section{REGIÃO - 15}

Figura 106. Regionalização Rio 50 km - Região 15

Fonte: Autor, 2013. 


\section{- Região 16}

Município polo: Marília

Tabela 24. Municípios e produção diária de resíduos domiciliares da Região 16 Raio de 50 km

\begin{tabular}{|l|r|}
\hline \multicolumn{1}{|c|}{ Município } & RSU (t/dia) \\
\hline GÁLIA & 2,07 \\
\hline ÁLVARO DE CARVALHO & 1,19 \\
\hline GARÇA & 15,68 \\
\hline ALVINLÂNDIA & 1,08 \\
\hline LUPÉRCIO & 1,55 \\
\hline OCAUÇU & 1,33 \\
\hline VERA CRUZ & 3,74 \\
\hline JÚLIO MESQUITA & 1,69 \\
\hline MARÍLIA & 125,06 \\
\hline ORIENTE & 2,29 \\
\hline POMPÉIA & 7,48 \\
\hline QUEIROZ & 0,97 \\
\hline OSCAR BRESSANE & 0,84 \\
\hline LUCÉLIA & 6,93 \\
\hline & $\mathbf{1 7 1 , 8 9}$ \\
\hline
\end{tabular}

Fonte: Autor, 2013. 


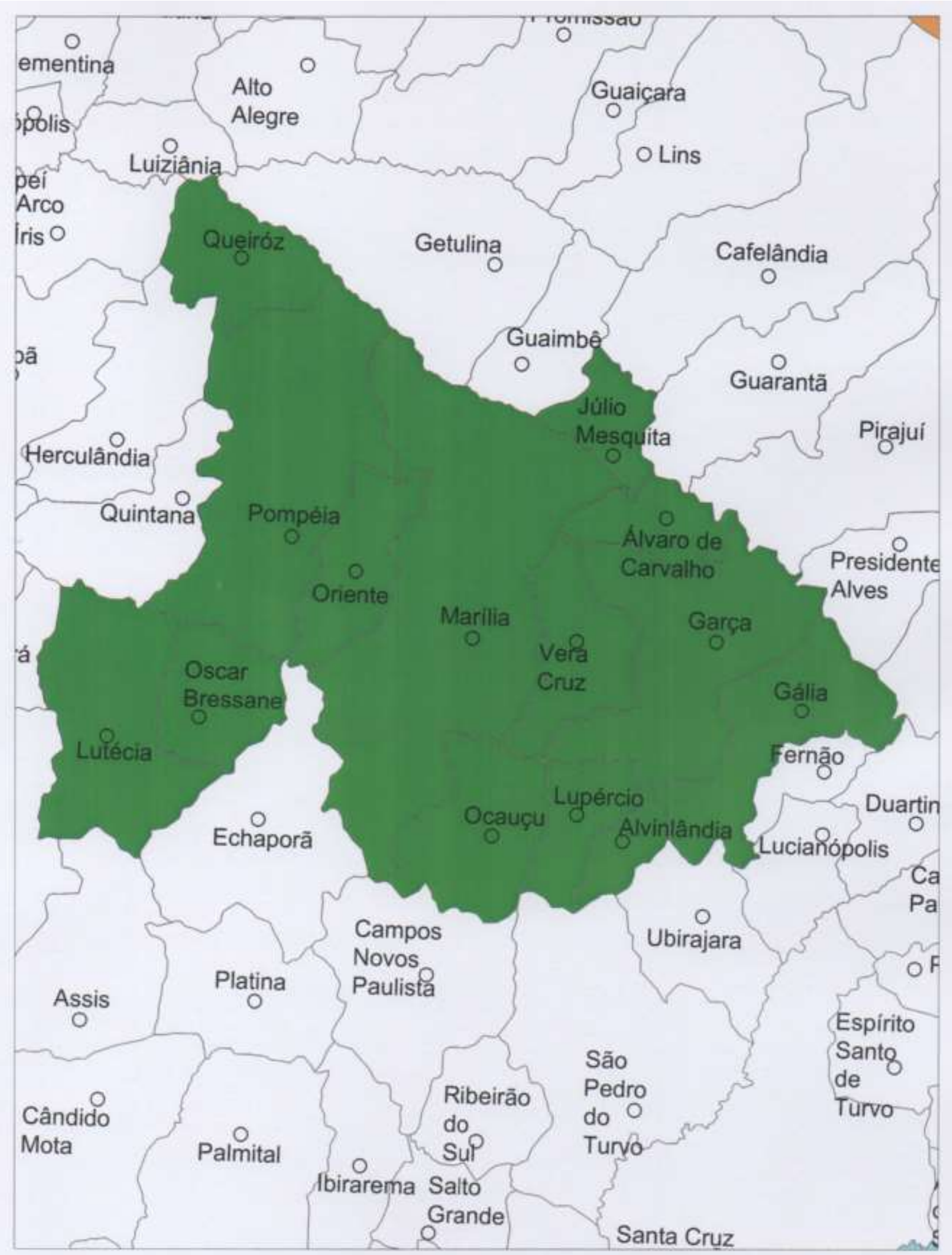

\section{REGIONALIZAÇÃO RAIO DE 50 KM REGIÃO - 16}

Figura 107. Regionalização Rio 50 km - Região 16

Fonte: Autor, 2013. 


\section{- Região 17}

Município polo: Bauru

Tabela 25. Municípios e produção diária de resíduos domiciliares da Região 17 -

Raio de $50 \mathrm{~km}$

\begin{tabular}{|l|r|}
\hline \multicolumn{1}{|c|}{ MUNICÍPIO } & RSU (t/dia) \\
\hline REGINÓPOLIS & 1,79 \\
\hline IACANGA & 3,54 \\
\hline ITAJU & 0,96 \\
\hline BARIRI & 12,09 \\
\hline BOCAINA & 4,04 \\
\hline BROTAS & 7,51 \\
\hline DOIS CÓRREGOS & 9,44 \\
\hline JAÚ & 64,18 \\
\hline ITAPUÍ & 4,71 \\
\hline BORACÉIA & 1,55 \\
\hline AREALVA & 2,48 \\
\hline AVAÍ & 1,34 \\
\hline PRESIDENTE ALVES & 1,37 \\
\hline BAURU & 204,17 \\
\hline PEDERNEIRAS & 15,58 \\
\hline BARRA BONITA & 13,80 \\
\hline MINEIROS DO TIETÊ & 4,62 \\
\hline IGARAÇU DO TIETÊ & 9,31 \\
\hline MACATUBA & 6,33 \\
\hline LENÇÓIS PAULISTA & 24,21 \\
\hline BOREBI & 0,81 \\
\hline AGUDOS & 13,26 \\
\hline PIRATININGA & 4,18 \\
\hline CABRÁLIA PAULISTA & 1,50 \\
\hline DUARTINA & 4,39 \\
\hline FERNÃO & 0,34 \\
\hline LUCIANÓPOLIS & $\mathbf{4 1 9}, 71$ \\
\hline UBIRAJARA & \\
\hline PAULISTÂNIA & \\
\hline & TOT \\
\hline
\end{tabular}




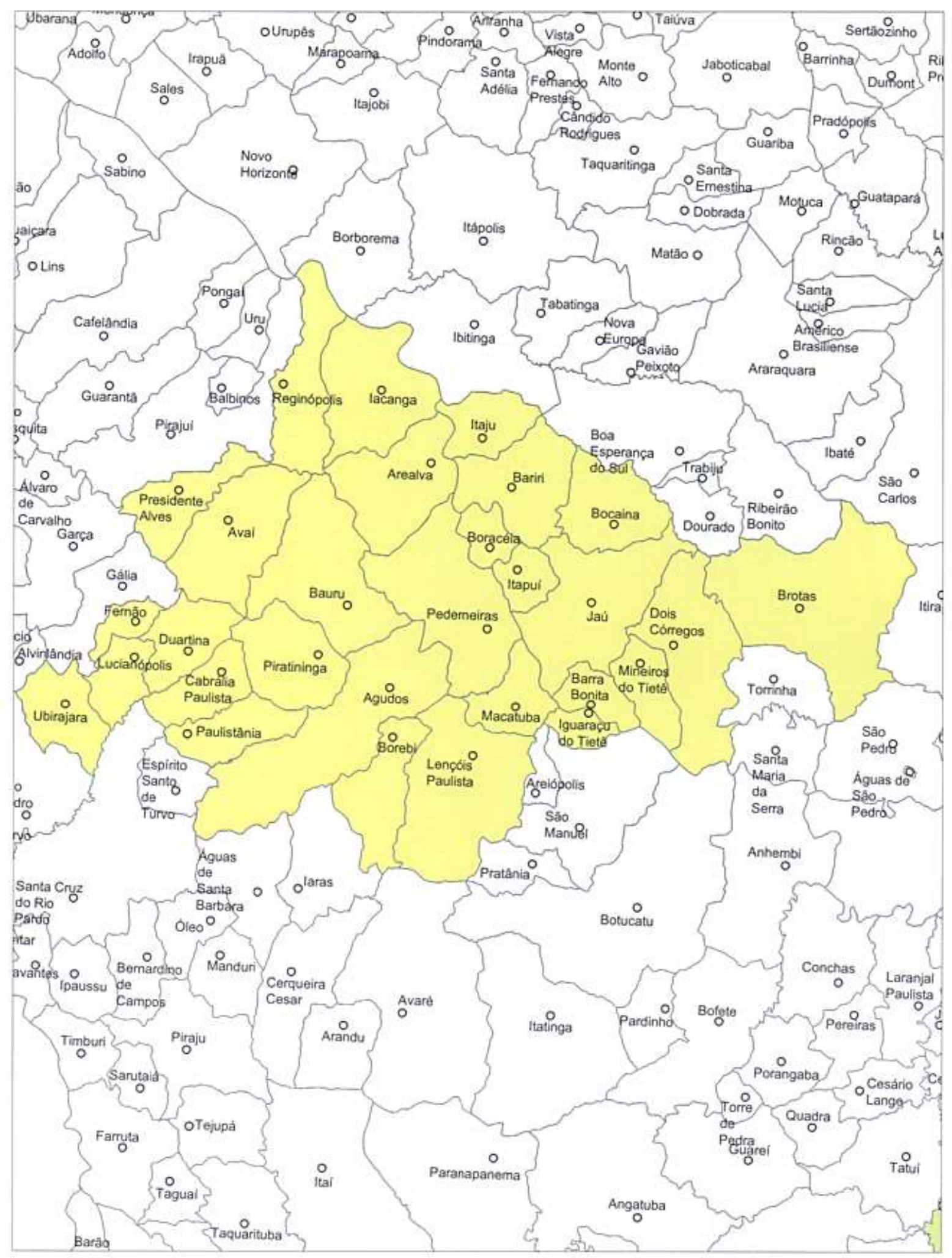

\section{REGIONALIZAÇÃO RAIO DE 50 KM REGIÃO - 17}

Figura 108. Regionalização Rio 50 km - Região 17

Fonte: Autor, 2013. 


\section{- Região 18}

Município polo: Botucatu

Tabela 26. Municípios e produção diária de resíduos domiciliares da Região 18 Raio de 50 km

\begin{tabular}{|l|r|}
\hline \multicolumn{1}{|c|}{ Município } & RSU (t/dia) \\
\hline TORRINHA & 3,19 \\
\hline SANTA MARIA DA SERRA & 1,93 \\
\hline ANHEMBI & 1,73 \\
\hline CONCHAS & 5,31 \\
\hline PORANGABA & 1,63 \\
\hline BOFETE & 2,50 \\
\hline PARDINHO & 1,78 \\
\hline ITATINGA & 6,64 \\
\hline BOTUCATU & 62,04 \\
\hline PRATÂNIA & 1,41 \\
\hline SÃO MANUEL & 15,02 \\
\hline AREIÓPOLIS & 3,77 \\
\hline & TOTAL \\
\hline
\end{tabular}

Fonte: Autor, 2013. 


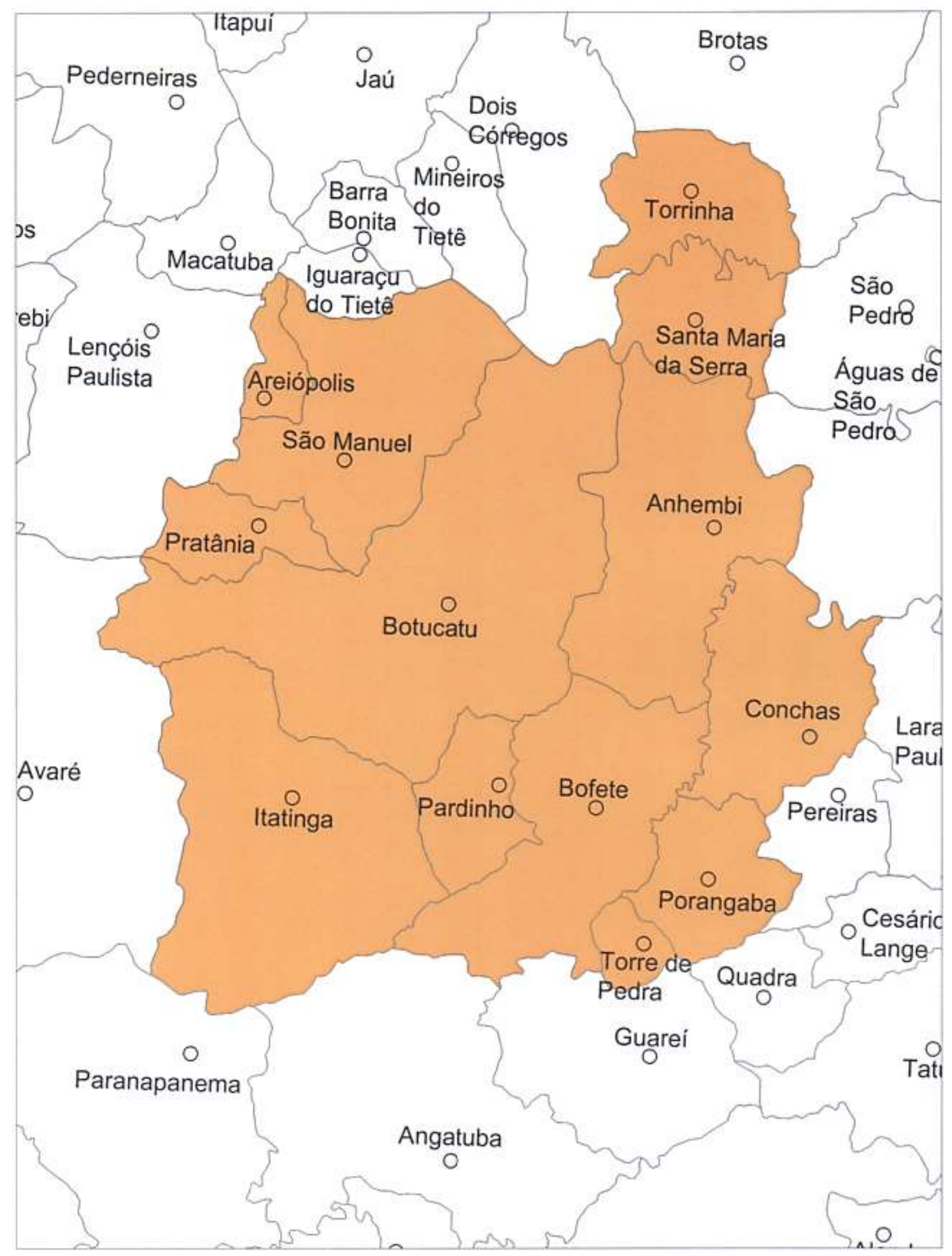

\section{REGIONALIZAÇÃO RAIO DE 50 KM REGIÃO - 18}

Figura 109. Regionalização Rio 50 km - Região 18

Fonte: Autor, 2013. 


\section{- Região 19}

Município polo: Piracicaba

Tabela 27. Municípios e produção diária de resíduos domiciliares da Região 19 Raio de $50 \mathrm{~km}$

\begin{tabular}{|l|r|}
\hline \multicolumn{1}{|c|}{ MunicípIO } & RSU (t/dia) \\
\hline ARARAS & 56,75 \\
\hline RIO CLARO & 91,54 \\
\hline IPEÚNA & 2,12 \\
\hline SANTA GERTRUDES & 8,74 \\
\hline CORDEIRÓPOLIS & 7,67 \\
\hline LIMEIRA & 161,88 \\
\hline IRACEMÁPOLIS & 7,98 \\
\hline CHARQUEADA & 5,53 \\
\hline SÃO PEDRO & 10,74 \\
\hline ÁGUAS DE SÃO PEDRO & 1,11 \\
\hline PIRACICABA & 215,64 \\
\hline AMERICANA & 127,08 \\
\hline SANTA BÁRBARA D'OESTE & 89,68 \\
\hline RIO DAS PEDRAS & 11,60 \\
\hline SALTINHO & 2,39 \\
\hline MOMBUCA & 1,08 \\
\hline CAPIVARI & 18,57 \\
\hline RAFARD & 3,04 \\
\hline TIETÊ & 13,54 \\
\hline JUMIRIM & 0,66 \\
\hline LARANJAL PAULISTA & 9,13 \\
\hline PEREIRAS & 2,02 \\
\hline & $\mathbf{8 4 8 , 4 7}$ \\
\hline
\end{tabular}

Fonte: Autor, 2013. 


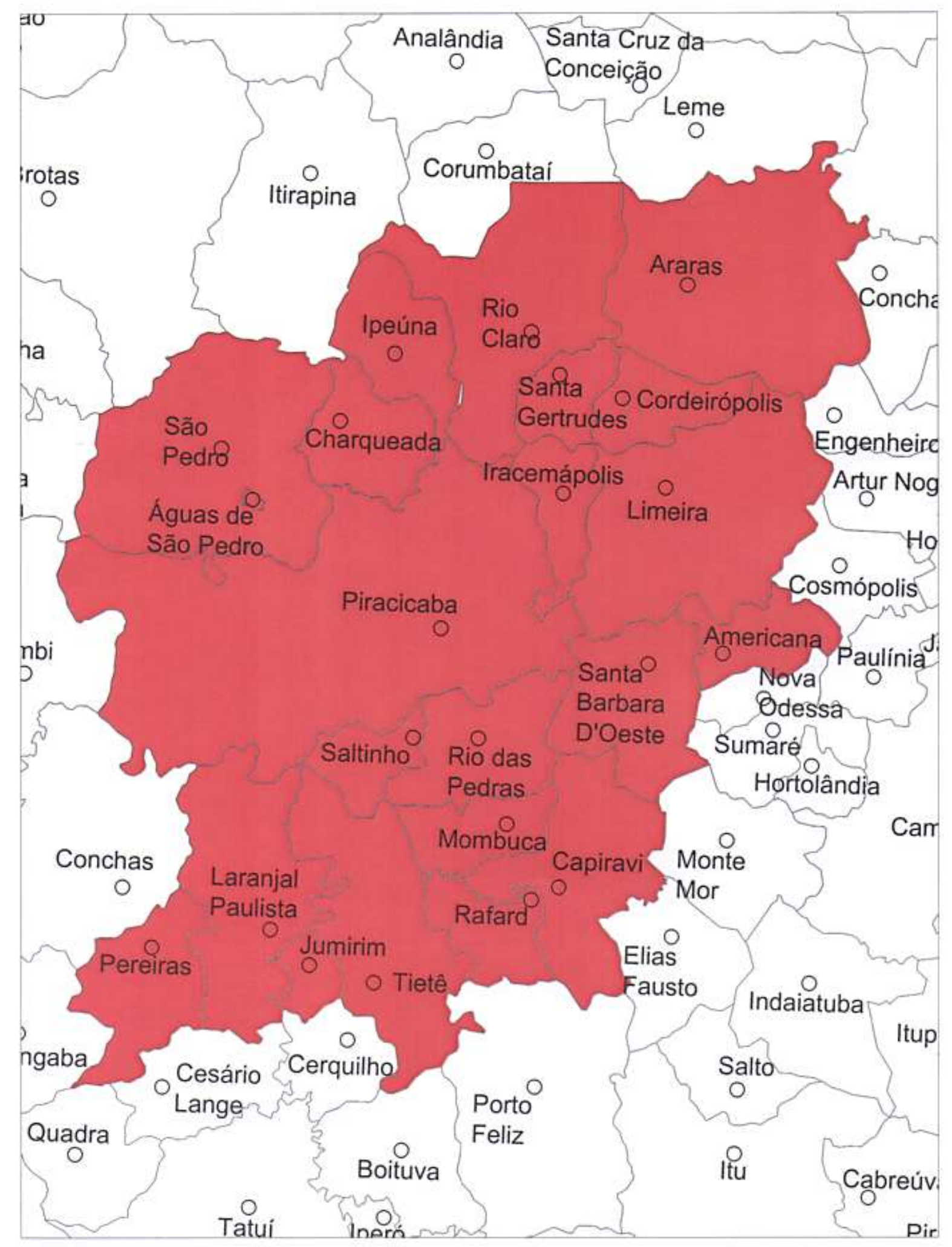

\section{REGIONALIZAÇÃO RAIO DE 50 KM REGIÃO - 19}

Figura 110. Regionalização Rio 50 km - Região 19

Fonte: Autor, 2013. 


\section{- Região 20}

Município polo: Campinas

Tabela 28. Municípios e produção diária de resíduos domiciliares da Região 20 Raio de $50 \mathrm{~km}$

\begin{tabular}{|l|r|}
\hline \multicolumn{1}{|c|}{ MUNicíPIO } & RSU (t/dia) \\
\hline CONCHAL & 9,61 \\
\hline MOGI-MIRIM & 32,52 \\
\hline ITAPIRA & 25,58 \\
\hline ÁGUAS DE LINDÓIA & 6,88 \\
\hline LINDÓIA & 2,73 \\
\hline SOCORRO & 10,06 \\
\hline SERRA NEGRA & 9,22 \\
\hline MONTE ALEGRE DO SUL & 1,65 \\
\hline AMPARO & 20,86 \\
\hline SANTO ANTÔNIO DE POSSE & 7,60 \\
\hline HOLAMBRA & 3,36 \\
\hline ARTUR NOGUEIRA & 16,31 \\
\hline ENGENHEIRO COELHO & 4,73 \\
\hline COSMÓPOLIS & 22,27 \\
\hline PAULÍNIA & 33,77 \\
\hline JAGUARIÚNA & 17,65 \\
\hline PEDREIRA & 16,68 \\
\hline TUIUTI & 1,20 \\
\hline BRAGANÇA PAULISTA & 71,94 \\
\hline PINHALZINHO & 2,61 \\
\hline PEDRA BELA & 0,58 \\
\hline VARGEM & 1,80 \\
\hline JOANÓPOLIS & 4,75 \\
\hline PIRACAIA & 10,10 \\
\hline NAZARÉ PAULISTA & 5,62 \\
\hline BOM JESUS DOS PERDÕES & 7,12 \\
\hline ATIBAIA & 58,15 \\
\hline JARINU & 79,15 \\
\hline ITATIBA & \\
\hline CAMPINAS & \\
\hline
\end{tabular}




\begin{tabular}{|c|c|}
\hline NOVA ODESSA & 20,44 \\
\hline SUMARÉ & 144,06 \\
\hline HORTOLÂNDIA & 97,89 \\
\hline MONTE MOR & 18,73 \\
\hline ELIAS FAUSTO & 5,07 \\
\hline VALINHOS & 51,68 \\
\hline VINHEDO & 25,13 \\
\hline MORUNGABA & 4,07 \\
\hline LOUVEIRA & 14,67 \\
\hline SALTO & 52,86 \\
\hline INDAIATUBA & 122,24 \\
\hline ITUPEVA & 16,08 \\
\hline JUNDIAÍ & 214,58 \\
\hline VÁRZEA PAULISTA & 54,09 \\
\hline CAMPO LIMPO PAULISTA & 29,95 \\
\hline TOTAL & $2.069,36$ \\
\hline
\end{tabular}

Fonte: Autor, 2013. 


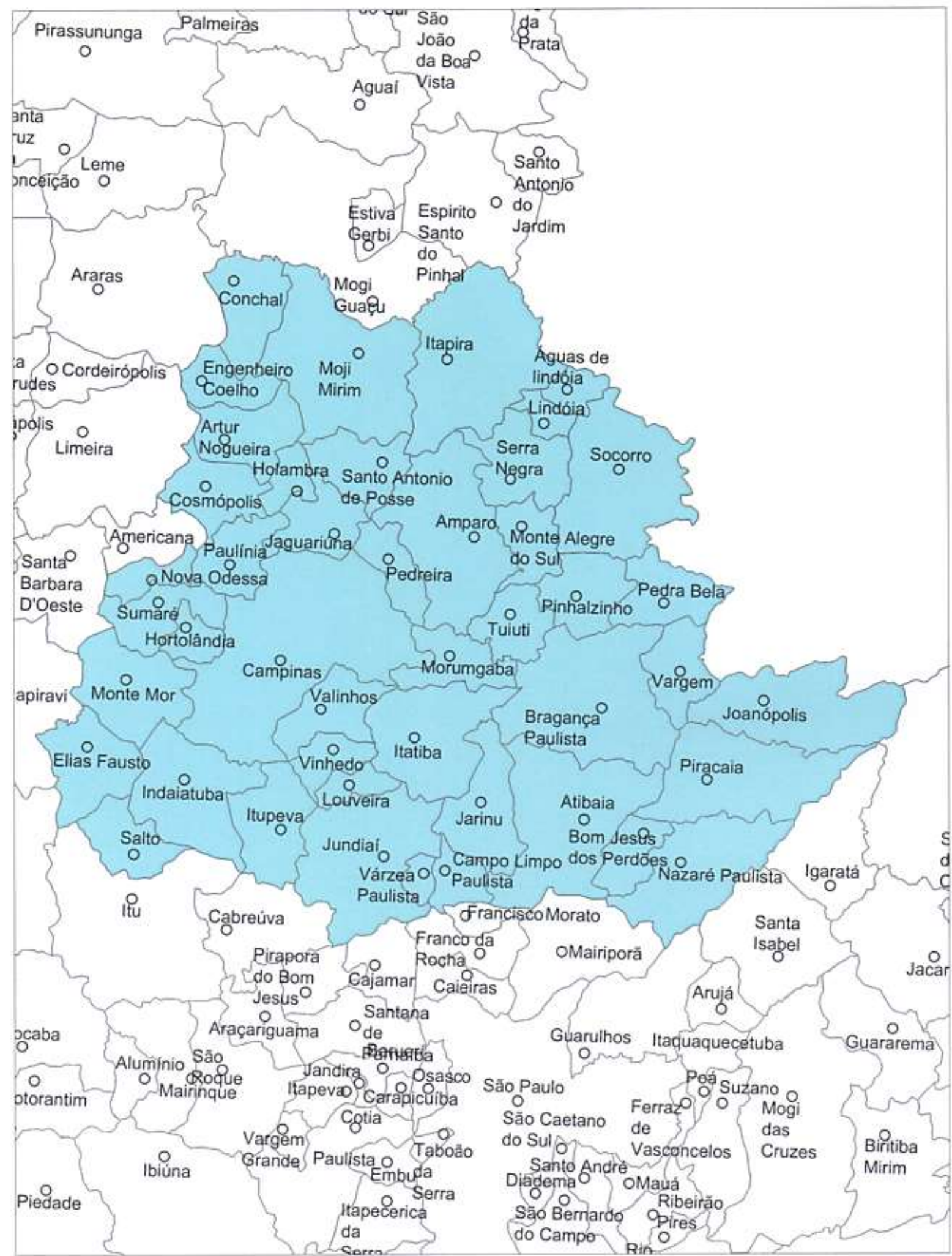

\section{REGIONALIZAÇÃO RAIO DE 50 KM REGIÃO - 20}

Figura 111. Regionalização Rio 50 km - Região 20

Fonte: Autor, 2013. 


\section{- Região 21}

Município polo: Mirante do Paranapanema

Tabela 29. Municípios e produção diária de resíduos domiciliares da Região 21 Raio de 50 km

\begin{tabular}{|l|r|}
\hline \multicolumn{1}{|c|}{ Município } & RSU (t/dia) \\
\hline MARABÁ PAULISTA & 0,87 \\
\hline $\begin{array}{l}\text { MIRANTE DO } \\
\text { PARANAPANEMA }\end{array}$ & 4,03 \\
\hline TEODORO SAMPAIO & 6,98 \\
\hline $\begin{array}{l}\text { EUCLIDES DA CUNHA } \\
\text { PAULISTA }\end{array}$ & 2,43 \\
\hline ROSANA & 6,23 \\
\hline TOTAL & $\mathbf{2 0 , 5 4}$ \\
\hline
\end{tabular}

Fonte: Autor, 2013. 


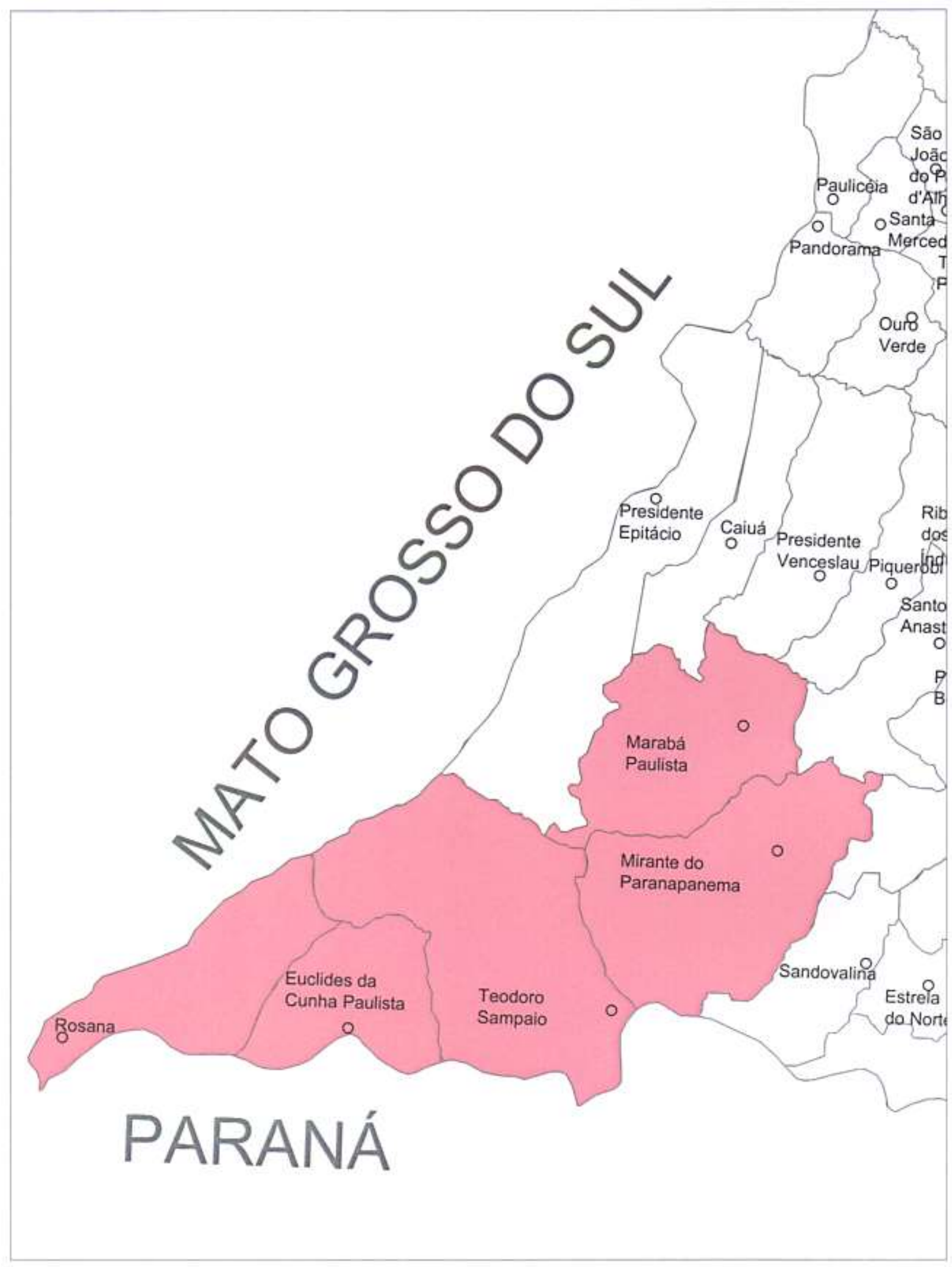

\section{REGIONALIZAÇÃO RAIO DE 50 KM REGIÃO - 21}

Figura 112. Regionalização Rio 50 km - Região 21

Fonte: Autor, 2013. 


\section{- Região 22}

Município polo: Presidente Prudente

Tabela 30. Municípios e produção diária de resíduos domiciliares da Região 22 Raio de 50 km

\begin{tabular}{|l|r|}
\hline \multicolumn{1}{|c|}{ MunicípIO } & RSU (t/dia) \\
\hline PRESIDENTE EPITÁCIO & 15,48 \\
\hline CAIUÁ & 0,78 \\
\hline PRESIDENTE VENCESLAU & 14,53 \\
\hline PIQUEROBI & 1,07 \\
\hline RIBEIRÃO DOS ÍNDIOS & 0,74 \\
\hline EMILIANÓPOLIS & 1,00 \\
\hline SANTO EXPEDITO & 1,00 \\
\hline ALFREDO MARCONDES & 1,31 \\
\hline SANTO ANASTÁCIO & 7,62 \\
\hline PRESIDENTE BERNARDES & 4,17 \\
\hline ÁLVARES MACHADO & 8,50 \\
\hline CAIABU & 1,33 \\
\hline PRESIDENTE PRUDENTE & 122,86 \\
\hline MARTINÓPOLIS & 8,18 \\
\hline INDIANA & 1,65 \\
\hline REGENTE FEIJÓ & 6,86 \\
\hline TACIBA & 1,95 \\
\hline ANHUMAS & 1,23 \\
\hline PIRAPOZINHO & 9,46 \\
\hline TARABAI & 2,47 \\
\hline NARANDIBA & 1,25 \\
\hline ESTRELA DO NORTE & 0,84 \\
\hline SANDOVALINA & 1,05 \\
\hline \multicolumn{1}{|c|}{ TOTAL } & $\mathbf{2 1 5}$ \\
\hline
\end{tabular}

Fonte: Autor, 2013. 


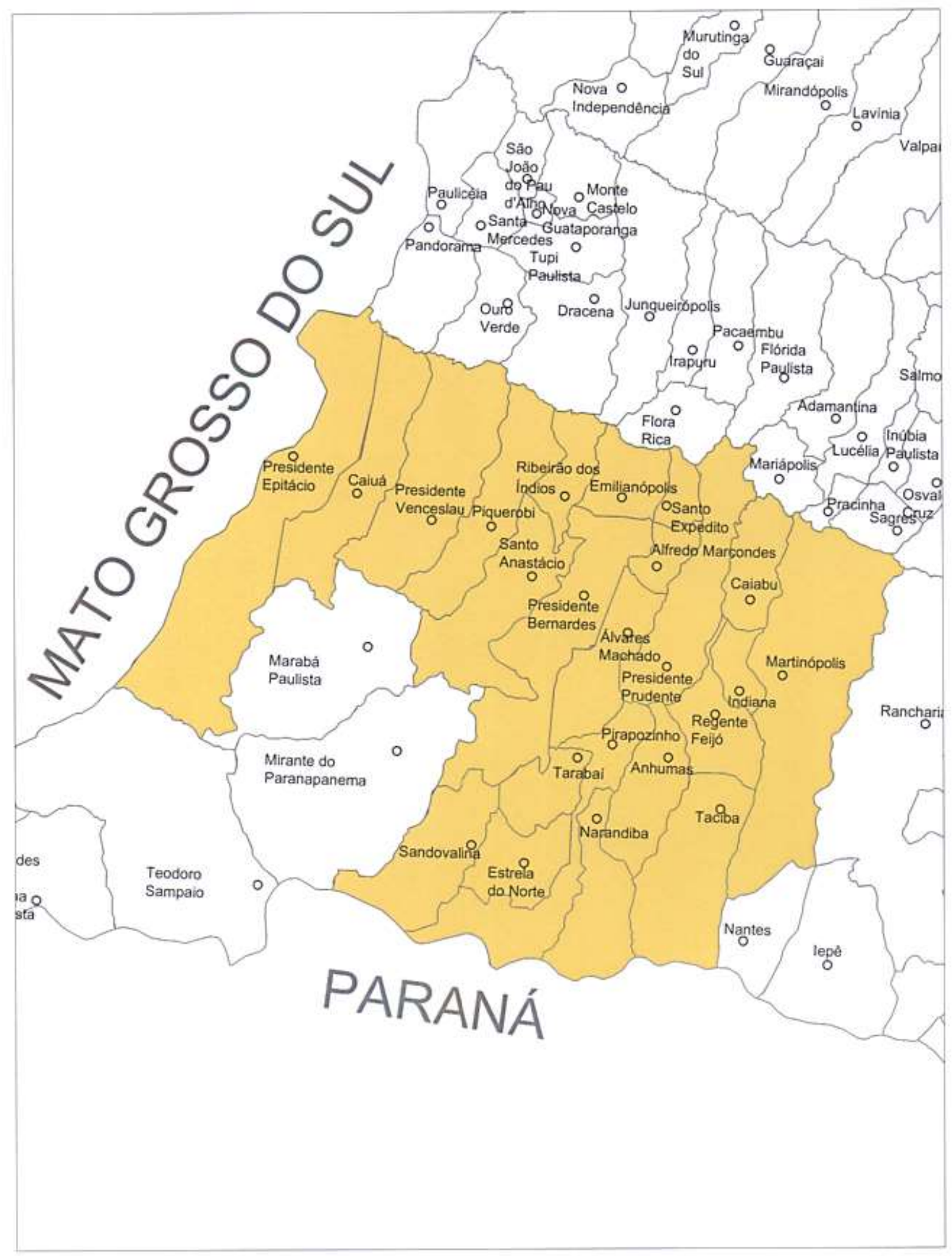

\section{REGIONALIZAÇÃO RAIO DE 50 KM REGIÃO - 22}

Figura 113. Regionalização Rio 50 km - Região 22

Fonte: Autor, 2013. 


\section{- Região 23}

Município polo: Assis

Tabela 31. Municípios e produção diária de resíduos domiciliares da Região 23 Raio de 50 km

\begin{tabular}{|l|r|}
\hline \multicolumn{1}{|c|}{ Município } & RSU (t/dia) \\
\hline ECHAPORÃ & 2,00 \\
\hline PLATINA & 1,01 \\
\hline PALMITAL & 7,78 \\
\hline CÂNDIDO MOTA & 11,26 \\
\hline ASSIS & 36,63 \\
\hline TARUMÃ & 4,91 \\
\hline FLORÍNEA & 1,00 \\
\hline PEDRINHAS PAULISTA & 0,99 \\
\hline CRUZÁLIA & 0,60 \\
\hline MARACAÍ & 4,84 \\
\hline PARAGUAÇU PAULISTA & 15,40 \\
\hline BORÁ & 0,25 \\
\hline QUATÁ & 4,84 \\
\hline JOÃO RAMALHO & 1,43 \\
\hline RANCHARIA & 10,33 \\
\hline IEPÊ & 2,72 \\
\hline NANTES & 0,98 \\
\hline & $\mathbf{1 0 6 , 9 7}$ \\
\hline
\end{tabular}

Fonte: Autor, 2013. 


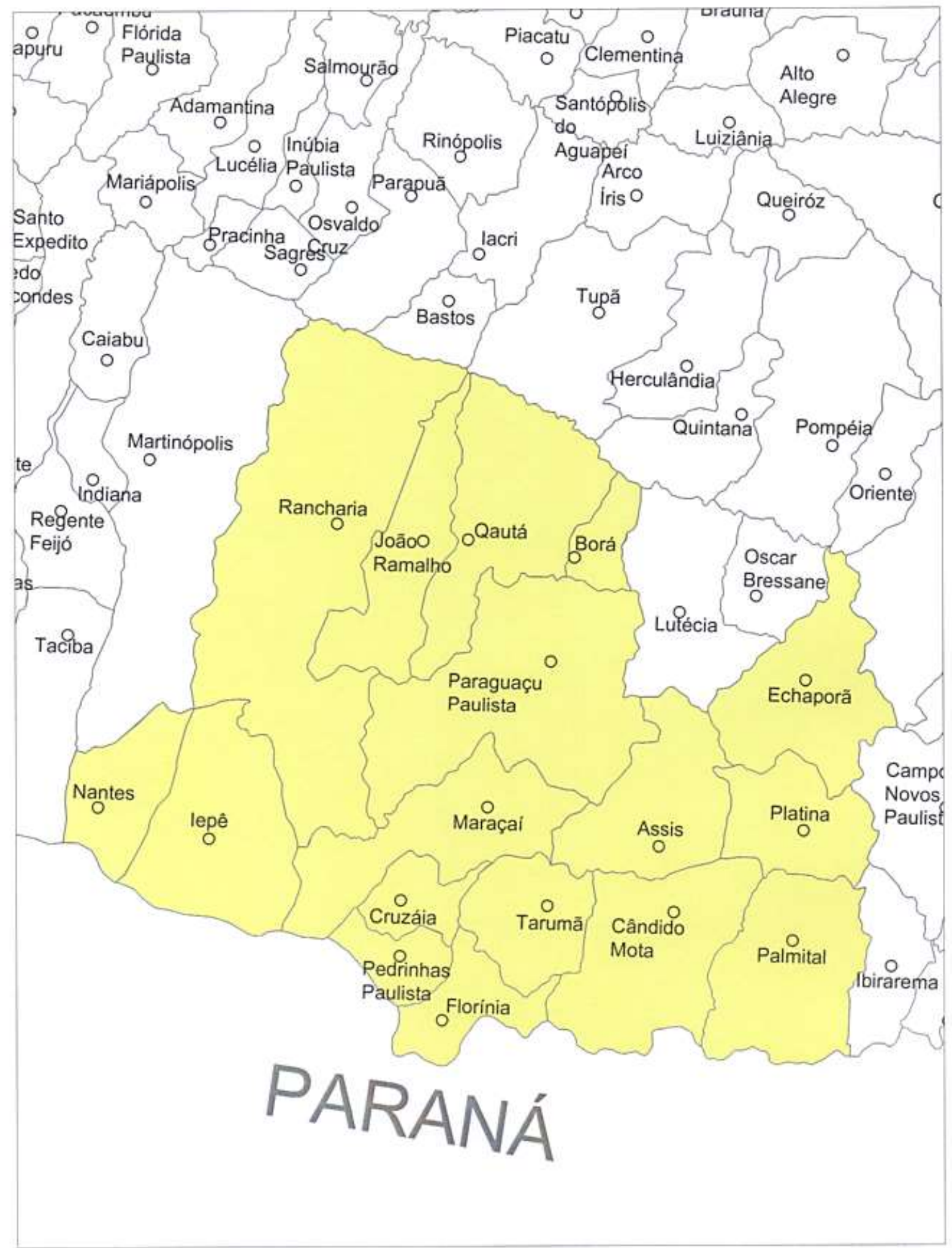

\section{REGIONALIZAÇÃO RAIO DE 50 KM REGIÃO - 23}

Figura 114. Regionalização Rio 50 km - Região 23

Fonte: Autor, 2013. 


\section{- Região 24}

Município polo: Ourinhos

Tabela 32. Municípios e produção diária de resíduos domiciliares da Região 24 Raio de 50 km

\begin{tabular}{|l|r|}
\hline \multicolumn{1}{|c|}{ Município } & RSU (t/dia) \\
\hline CAMPOS NOVOS PAULISTA & 1,42 \\
\hline IBIRAREMA & 2,51 \\
\hline RIBEIRÃO DO SUL & 1,32 \\
\hline SALTO GRANDE & 3,18 \\
\hline SÃO PEDRO DO TURVO & 2,07 \\
\hline OURINHOS & 50,53 \\
\hline SANTA CRUZ DO RIO & 16,15 \\
\hline PARDO & 1,68 \\
\hline CANITAR & 4,45 \\
\hline CHAVANTES & 5,07 \\
\hline IPAUSSU & 0,70 \\
\hline ÓLEO & 1,47 \\
\hline ESPÍRITO SANTO DO & 3,86 \\
\hline TURVO & 0,77 \\
\hline BERNARDINO DE CAMPOS & 10,26 \\
\hline TIMBURI & 1,18 \\
\hline PIRAJU & 4,90 \\
\hline SARUTAIÁ & $\mathbf{1 1 1 , 5 1}$ \\
\hline FARTURA & \\
\hline & TOTAL \\
\hline
\end{tabular}

Fonte: Autor, 2013. 


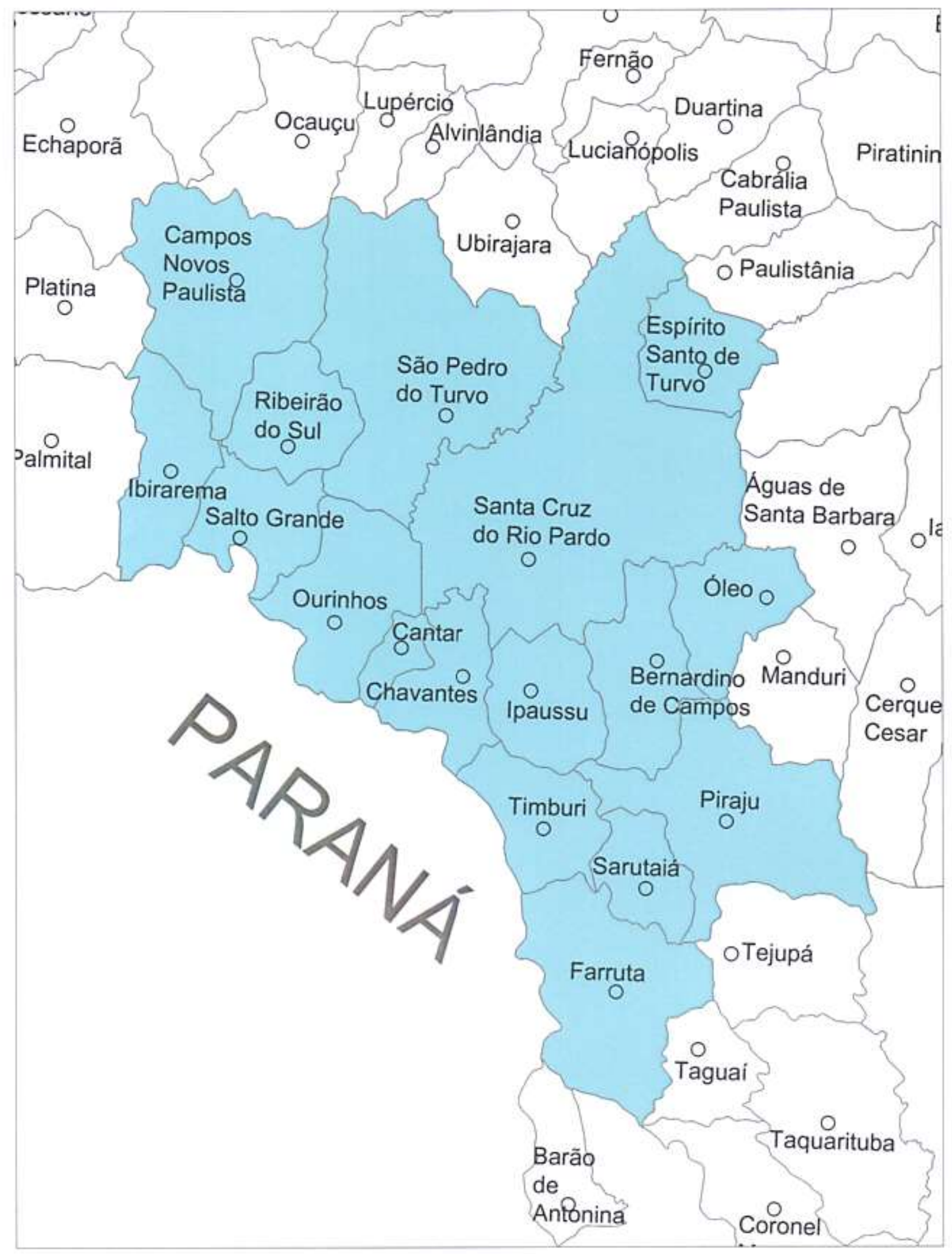

\section{REGIONALIZAÇÃO RAIO DE 50 KM REGIÃO - 24}

Figura 115. Regionalização Rio 50 km - Região 24

Fonte: Autor, 2013. 


\section{- Região 25}

Município polo: Avaré

Tabela 33. Municípios e produção diária de resíduos domiciliares da Região 25 Raio de 50 km

\begin{tabular}{|l|r|}
\hline \multicolumn{1}{|c|}{ Município } & RSU (t/dia) \\
\hline ÁGUAS DE SANTA BÁRBARA & 1,71 \\
\hline IARAS & 1,18 \\
\hline MANDURI & 3,13 \\
\hline CERQUEIRA CÉSAR & 6,35 \\
\hline AVARÉ & 31,95 \\
\hline ARANDU & 1,85 \\
\hline TEJUPÁ & 1,24 \\
\hline TAGUAÍ & 3,18 \\
\hline TAQUARITUBA & 7,84 \\
\hline ITAÍ & 7,61 \\
\hline MIRANTE DO & 4,03 \\
\hline PARANAPANEMA & $\mathbf{7 0 , 0 6}$ \\
\hline \multicolumn{2}{|c|}{ TOTAL }
\end{tabular}

Fonte: Autor, 2013. 


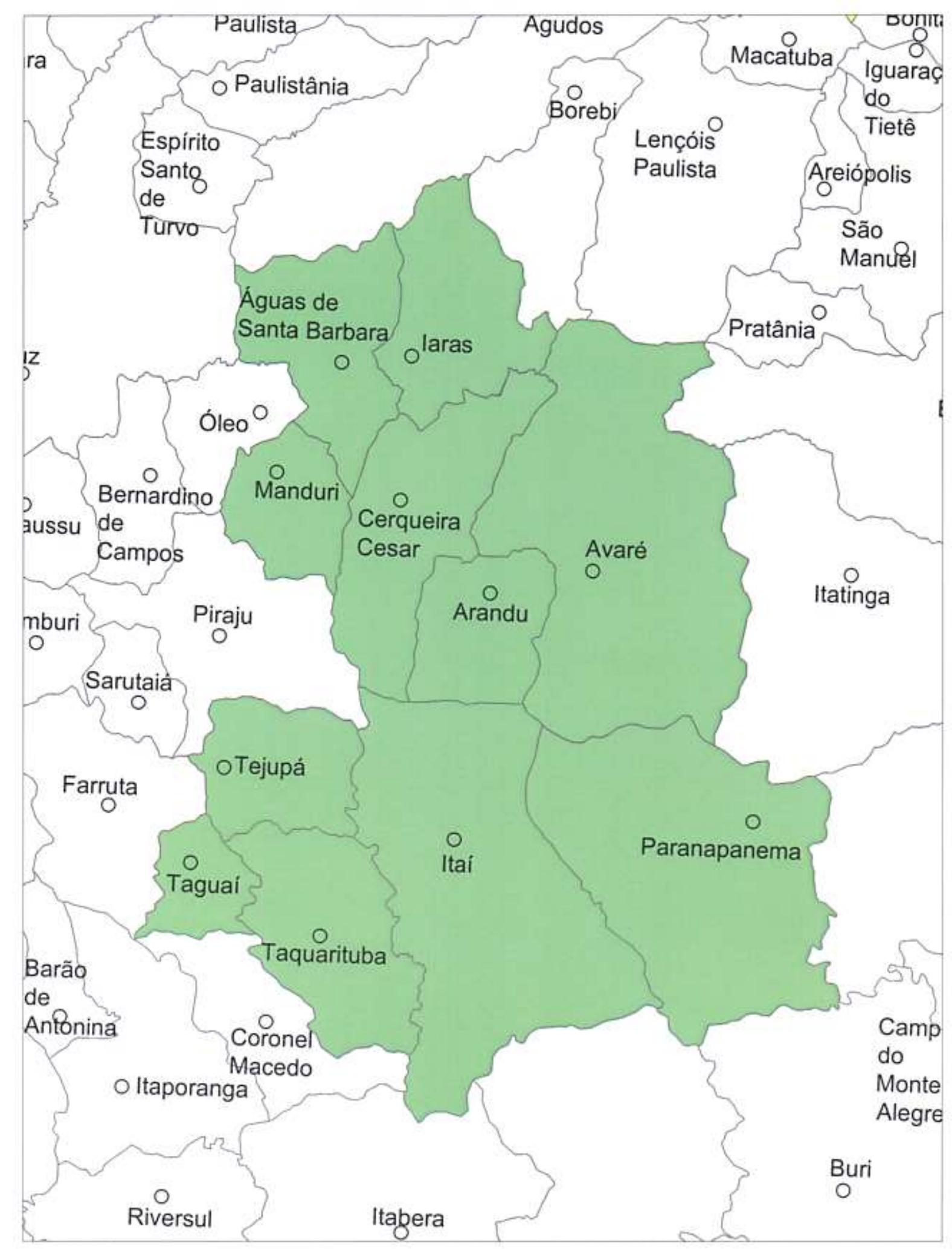

\section{REGIONALIZAÇÃO RAIO DE 50 KM REGIÃO - 25}

Figura 116. Regionalização Rio 50 km - Região 25

Fonte: Autor, 2013. 


\section{- Região 26}

Município polo: Itapetininga

Tabela 34. Municípios e produção diária de resíduos domiciliares da Região 26 Raio de 50 km

\begin{tabular}{|l|r|}
\hline \multicolumn{1}{|c|}{ Município } & RSU (t/dia) \\
\hline TATUÍ & 51,64 \\
\hline QUADRA & 0,34 \\
\hline TORRE DE PEDRA & 0,59 \\
\hline GUAREÍ & 3,44 \\
\hline ANGATUBA & 6,45 \\
\hline CAMPINA DO MONTE & 1,89 \\
\hline ALEGRE & 66,18 \\
\hline ITAPETININGA & 1,50 \\
\hline ALAMBARI & 2,69 \\
\hline SARAPUÍ & 8,61 \\
\hline SÃO MIGUEL ARCANJO & $\mathbf{1 4 3 , 3 2}$ \\
\hline \multicolumn{2}{|c|}{ TOTAL }
\end{tabular}

Fonte: Autor, 2013. 


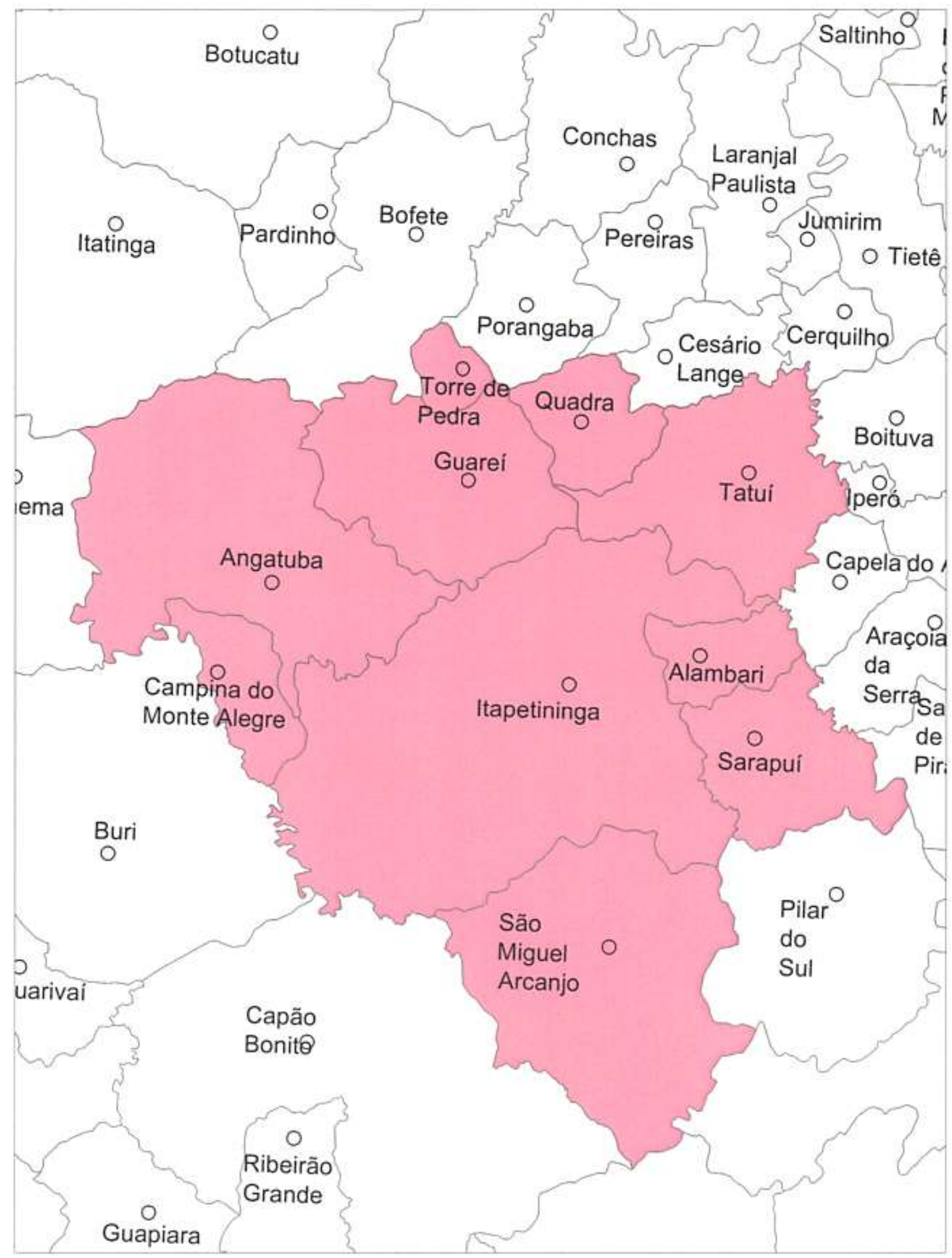

\section{REGIONALIZAÇÃO RAIO DE 50 KM REGIÃO - 26}

Figura 117. Regionalização Rio 50 km - Região 26

Fonte: Autor, 2013. 


\section{- Região 27}

Município polo: Sorocaba

Tabela 35. Municípios e produção diária de resíduos domiciliares da Região 27 Raio de 50 km

\begin{tabular}{|l|r|}
\hline \multicolumn{1}{|c|}{ Município } & RSU (t/dia) \\
\hline CESÁRIO LANGE & 4,25 \\
\hline CERQUILHO & 15,32 \\
\hline BOITUVA & 18,58 \\
\hline PORTO FELIZ & 16,53 \\
\hline IPERÓ & 7,17 \\
\hline CAPELA DO ALTO & 5,89 \\
\hline ARAÇOIABA DA SERRA & 7,66 \\
\hline SOROCABA & 411,41 \\
\hline ITU & 72,81 \\
\hline ALUMÍNIO & 5,69 \\
\hline MAIRINQUE & 13,96 \\
\hline IBIÚNA & 10,05 \\
\hline SALTO DE PIRAPORA & 12,71 \\
\hline PIEDADE & 9,53 \\
\hline PILAR DO SUL & 8,36 \\
\hline TAPIRAÍ & 2,28 \\
\hline VOTORANTIM & 52,81 \\
\hline & $\mathbf{6 7 5 , 0 0}$ \\
\hline
\end{tabular}

Fonte: Autor, 2013. 


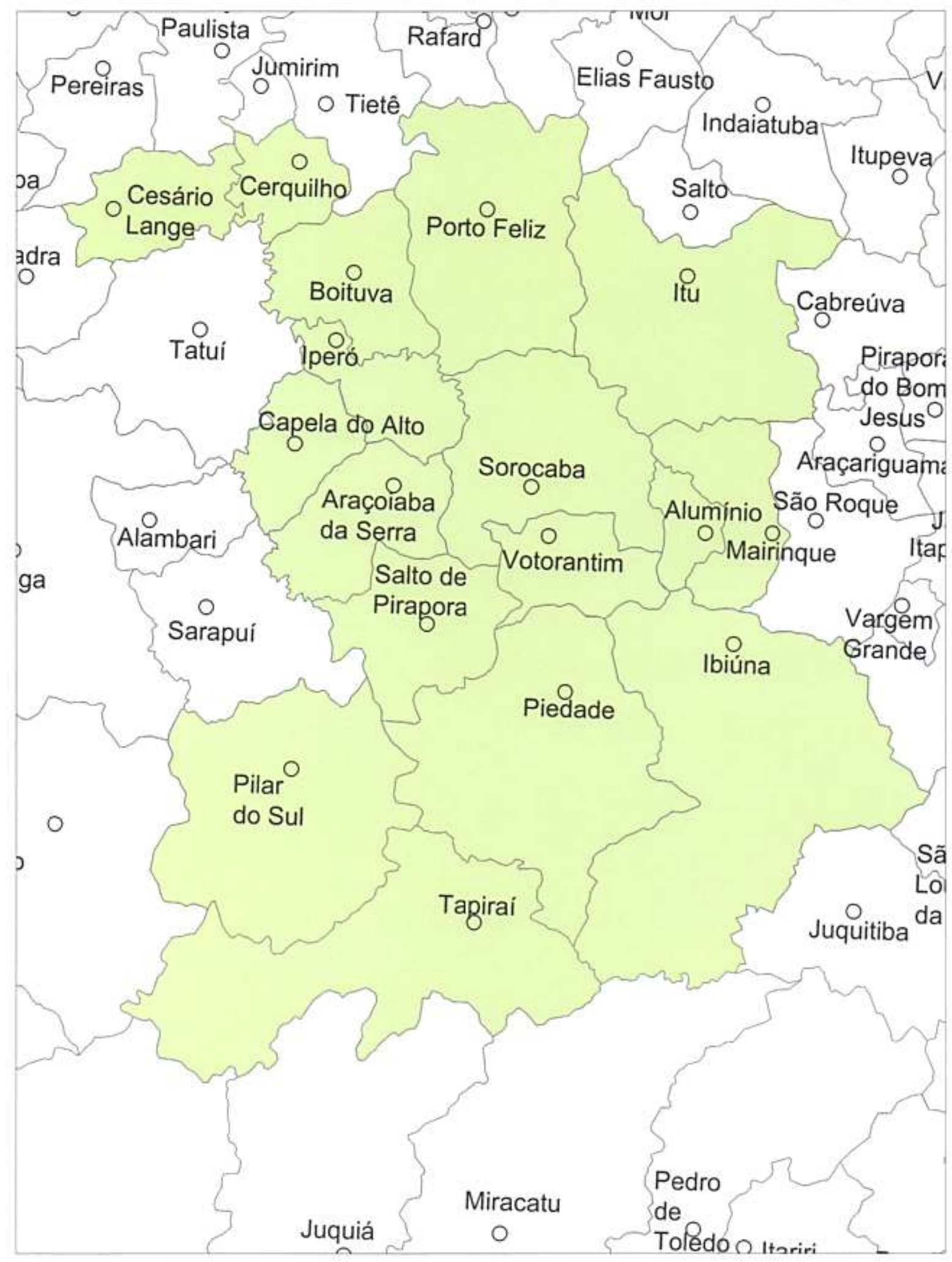

\section{REGIONALIZAÇÃO RAIO DE 50 KM REGIÃO - 27}

Figura 118. Regionalização Rio 50 km - Região 27

Fonte: Autor, 2013. 


\section{- Região 28}

Município polo: Itapevi

Tabela 36. Municípios e produção diária de resíduos domiciliares da Região 28 Raio de 50 km

\begin{tabular}{|l|r|}
\hline \multicolumn{1}{|c|}{ MunicípIO } & RSU (t/dia) \\
\hline ARAÇARIGUAMA & 7,01 \\
\hline ARUJÁ & 29,23 \\
\hline BARUERI & 145,95 \\
\hline CABREÚVA & 14,33 \\
\hline CAIEIRAS & 34,21 \\
\hline CAJAMAR & 25,53 \\
\hline CARAPICUÍBA & 222,90 \\
\hline COTIA & 123,09 \\
\hline DIADEMA & 233,15 \\
\hline EMBU & 145,64 \\
\hline EMBU-GUAÇU & 24,61 \\
\hline FERRAZ DE VASCONCELOS & 81,33 \\
\hline FRANCO DA ROCHA & 61,45 \\
\hline GUARULHOS & 863,41 \\
\hline ITAPECERICA DA SERRA & 76,55 \\
\hline ITAPEVA & 29,71 \\
\hline ITAQUAQUECETUBA & 195,31 \\
\hline JANDIRA & 54,81 \\
\hline JUQUITIBA & 8,95 \\
\hline MAIRIPORÃ & 28,86 \\
\hline MAUÁ & 252,71 \\
\hline OSASCO & 467,48 \\
\hline PIRAPORA DO BOM JESUS & 6,40 \\
\hline POÁ & 52,56 \\
\hline RIBEIRÃO PIRES & 56,86 \\
\hline RIO GRANDE DA SERRA & 17,80 \\
\hline SANTANA DE PARNAÍBA & 55,71 \\
\hline SANTO ANDRÉ & 100,00 \\
\hline SÃO BERNARDO DO CAMPO & 53,16 \\
\hline SÃO CAETANO DO SUL & \\
\hline
\end{tabular}




\begin{tabular}{|l|r|}
\hline SÃO LOURENÇO DA SERRA & 5,14 \\
\hline SÃO PAULO & $12.850,10$ \\
\hline SÃO ROQUE & 28,93 \\
\hline SUZANO & 153,45 \\
\hline TABOÃO DA SERRA & 148,88 \\
\hline $\begin{array}{l}\text { VARGEM GRANDE } \\
\text { PAULISTA }\end{array}$ & 17,52 \\
\hline TOTAL & $\mathbf{1 7 . 2 2 4 , 6 8}$ \\
\hline
\end{tabular}

Fonte: Autor, 2013. 


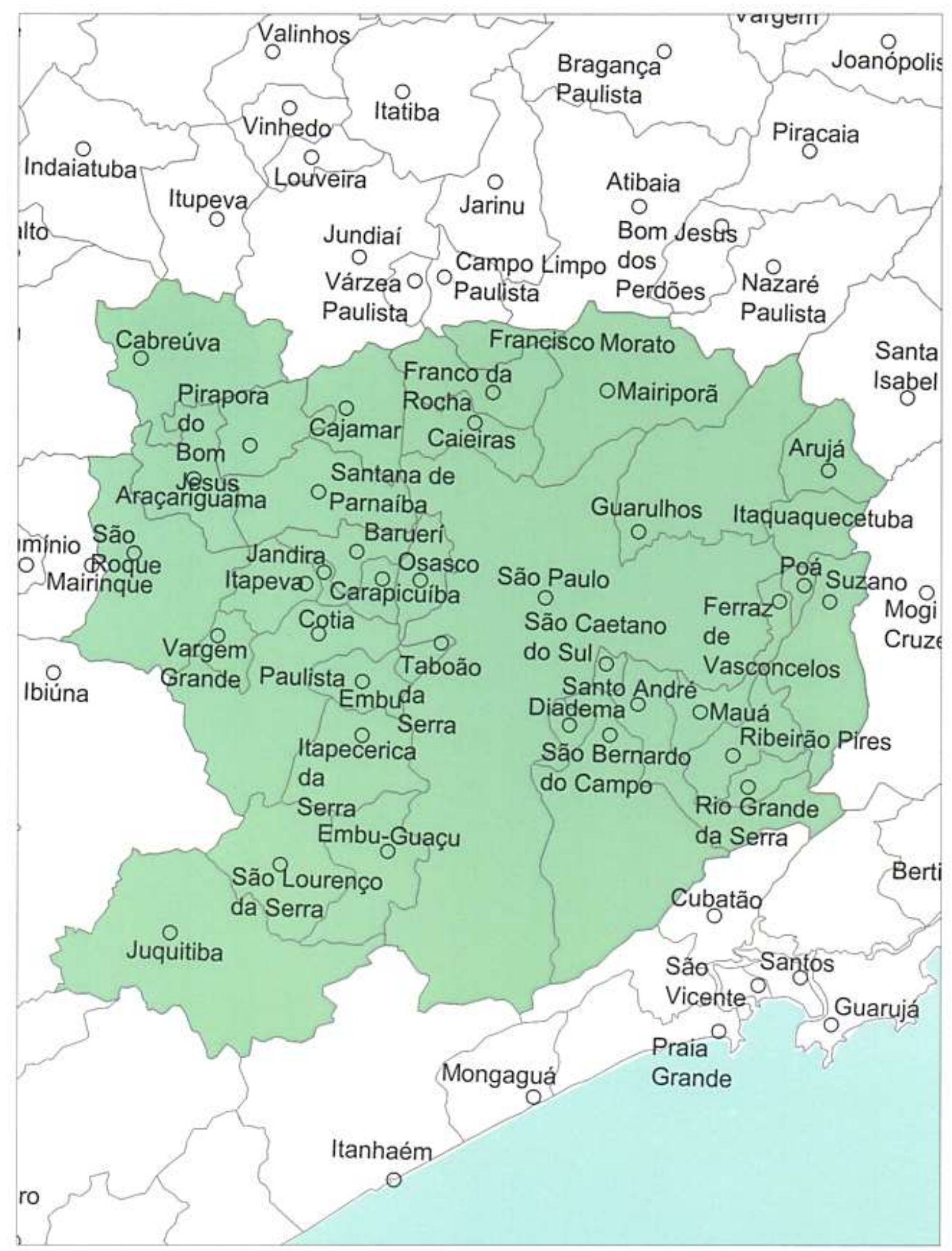

\section{REGIONALIZAÇÃO RAIO DE 50 KM REGIÃO - 28}

Figura 119. Regionalização Rio 50 km - Região 28

Fonte: Autor, 2013. 


\section{- Região 29}

Município polo: São José dos Campos

Tabela 37. Municípios e produção diária de resíduos domiciliares da Região 29 Raio de 50 km

\begin{tabular}{|l|r|}
\hline \multicolumn{1}{|c|}{ MunicípIO } & RSU (t/dia) \\
\hline SANTA ISABEL & 16,00 \\
\hline IGARATÁ & 2,82 \\
\hline SÃO JOSÉ DOS CAMPOS & 436,74 \\
\hline MONTEIRO LOBATO & 0,72 \\
\hline SANTO ANTÔNIO DO & 1,55 \\
\hline PINHAL & 14,94 \\
\hline TREMEMBÉ & 165,16 \\
\hline TAUBATÉ & 29,23 \\
\hline CAÇAPAVA & 2,47 \\
\hline SÃO LUÍS DO PARAITINGA & 0,88 \\
\hline REDENÇÃO DA SERRA & 1,04 \\
\hline JAMBEIRO & 125,88 \\
\hline JACAREÍ & 9,00 \\
\hline GUARAREMA & 216,83 \\
\hline MOGI DAS CRUZES & 9,91 \\
\hline BIRITIBA MIRIM & 4,01 \\
\hline SALESÓPOLIS & 4,88 \\
\hline SANTA BRANCA & 2,10 \\
\hline PARAIBUNA & 1,11 \\
\hline NATIVIDADE DA SERRA & 31,12 \\
\hline UBATUBA & 39,31 \\
\hline CARAGUATATUBA & 11,43 \\
\hline ILHABELA & 20,80 \\
\hline SÃO SEBASTIÃO & $\mathbf{1 4 7 , 9 4}$ \\
\hline & \\
\hline & TOTAL \\
\hline
\end{tabular}

Fonte: Autor, 2013. 


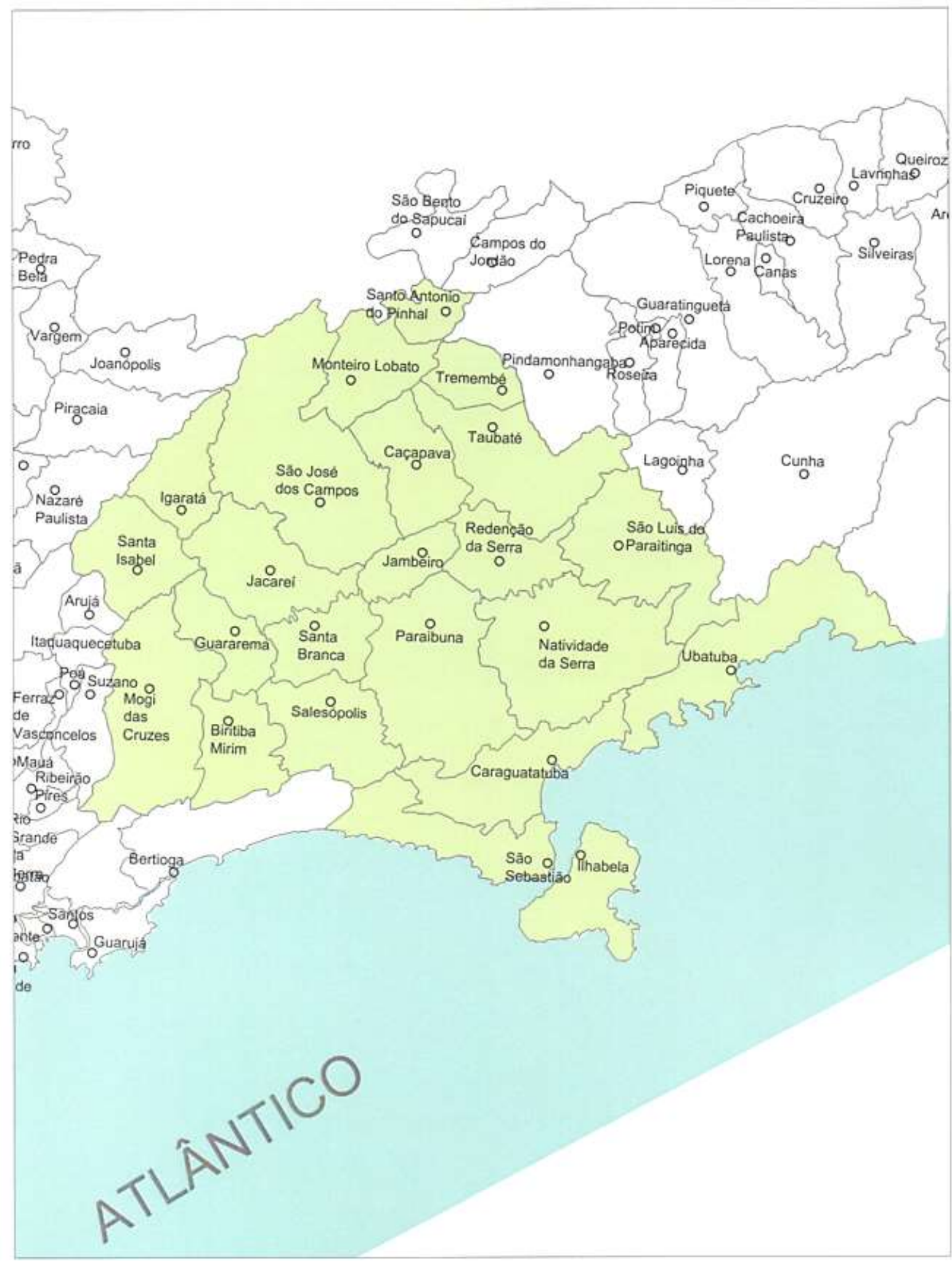

\section{REGIONALIZAÇÃO RAIO DE 50 KIM REGIÃO - 29 \\ Figura 120. Regionalização Rio 50 km - Região 29}

Fonte: Autor, 2013. 


\section{- Região 30}

Município polo: Guaratinguetá

Tabela 38. Municípios e produção diária de resíduos domiciliares da Região 30 Raio de $50 \mathrm{~km}$

\begin{tabular}{|l|r|}
\hline \multicolumn{1}{|c|}{ Município } & RSU (t/dia) \\
\hline SÃO BENTO DO SAPUCAÍ & 2,02 \\
\hline CAMPOS DO JORDÃO & 19,10 \\
\hline PINDAMONHANGABA & 71,63 \\
\hline ROSEIRA & 3,68 \\
\hline APARECIDA & 13,80 \\
\hline GUARATINGUETÁ & 53,67 \\
\hline POTIM & 6,02 \\
\hline LAGOINHA & 1,25 \\
\hline CUNHA & 4,85 \\
\hline LORENA & 32,21 \\
\hline PIQUETE & 5,25 \\
\hline CANAS & 1,65 \\
\hline CACHOEIRA PAULISTA & 9,90 \\
\hline CRUZEIRO & 30,14 \\
\hline LAVRINHAS & 2,44 \\
\hline QUEIROZ & 0,97 \\
\hline AREIAS & 0,99 \\
\hline SILVEIRAS & 1,16 \\
\hline SÃO JOSÉ DO BARREIRO & 1,15 \\
\hline ARAPEÍ & 0,75 \\
\hline BANANAL & 3,28 \\
\hline & $\mathbf{2 6 5 , 8 9}$ \\
\hline
\end{tabular}

Fonte: Autor, 2013. 


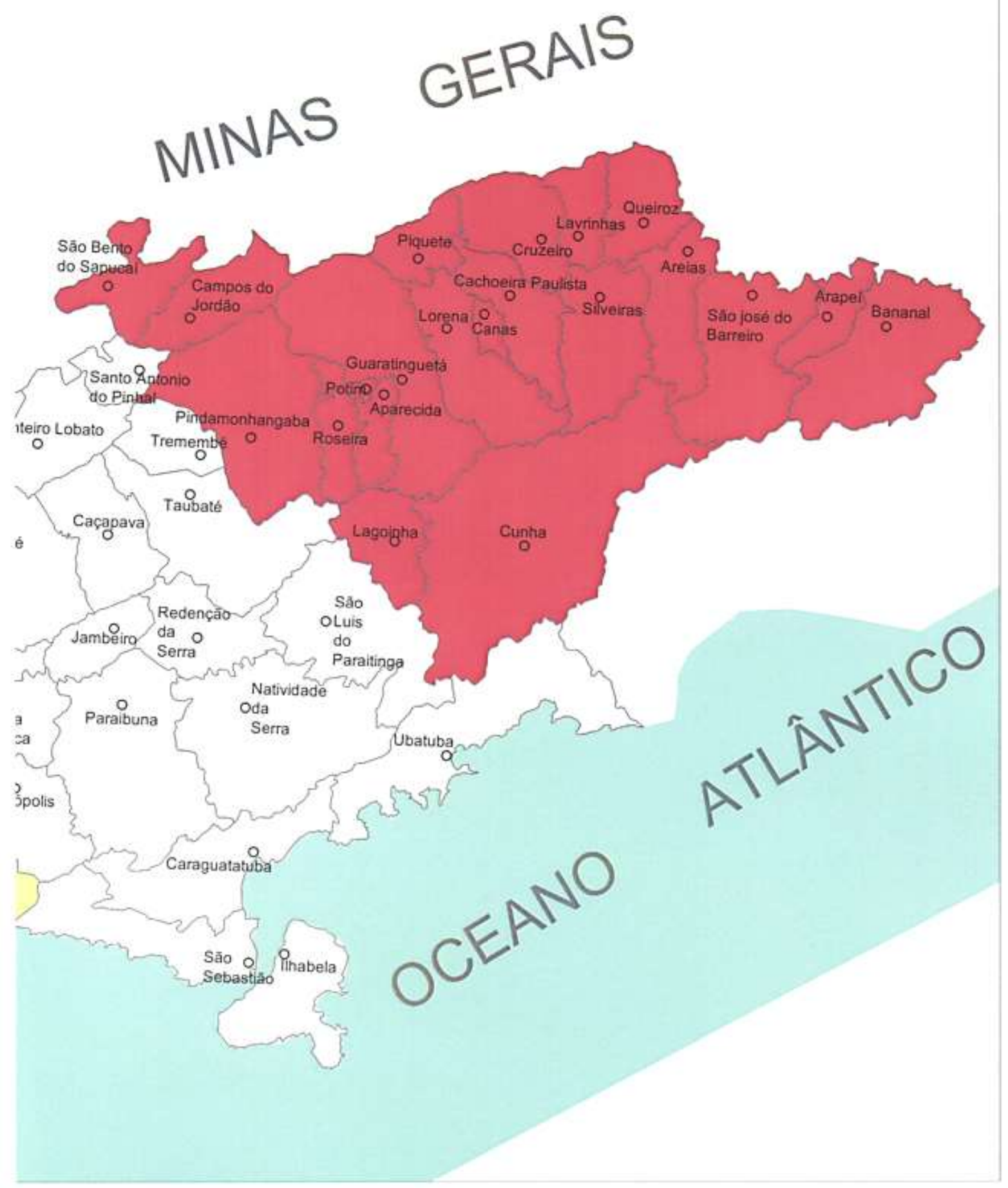

\section{REGIONALIZAÇÃO RAIO DE 50 KM REGIÃO - 30}

Figura 121. Regionalização Rio 50 km - Região 30

Fonte: Autor, 2013. 


\section{- Região 31}

Município polo: Itapeva

Tabela 39. Municípios e produção diária de resíduos domiciliares da Região 31 Raio de 50 km

\begin{tabular}{|l|r|}
\hline \multicolumn{1}{|c|}{ MunicípIO } & RSU (t/dia) \\
\hline BARÃO DE ANTONINA & 0,77 \\
\hline ITAPORANGA & 4,42 \\
\hline CORONEL MACEDO & 1,53 \\
\hline RIVERSUL & 1,77 \\
\hline ITABERÁ & 4,83 \\
\hline ITARARÉ & 17,75 \\
\hline ITAPEVA & 29,71 \\
\hline BURI & 6,02 \\
\hline TAQUARIVAÍ & 1,14 \\
\hline CAPÃO BONITO & 15,12 \\
\hline RIBEIRÃO GRANDE & 0,94 \\
\hline GUAPIARA & 2,87 \\
\hline RIBEIRÃO BRANCO & 3,67 \\
\hline NOVA CAMPINA & 2,33 \\
\hline BOM SUCESSO DE ITARARÉ & 0,98 \\
\hline BARRA DO CHAPÉU & 0,62 \\
\hline ITAPIRAPUÃ PAULISTA & 0,76 \\
\hline RIBEIRA & 0,49 \\
\hline APIAÍ & 7,24 \\
\hline ITAÓCA & 0,70 \\
\hline & $\mathbf{1 0 3 , 6 7}$ \\
\hline
\end{tabular}

Fonte: Autor, 2013. 


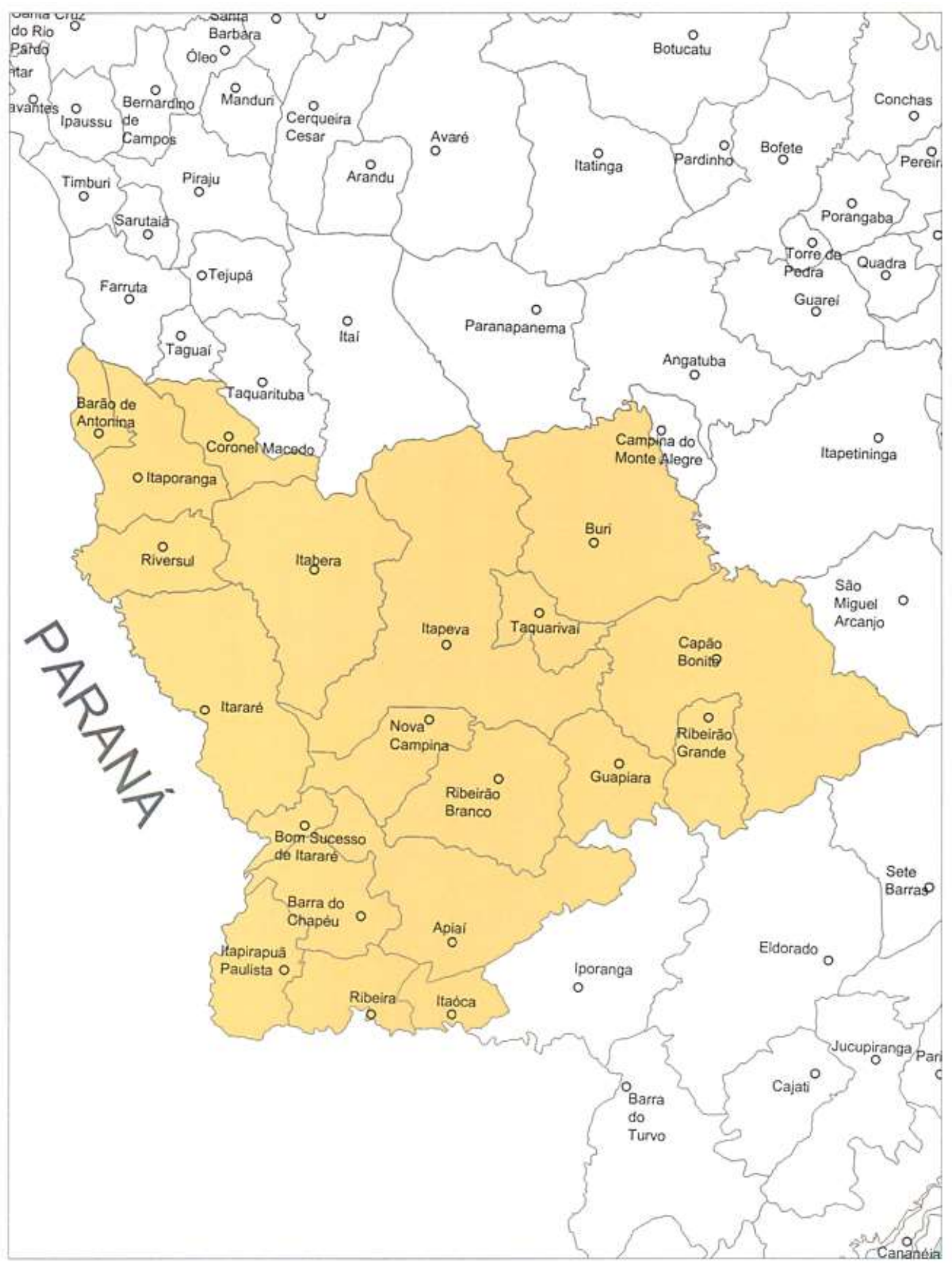

\section{REGIONALIZAÇÃO RAIO DE 50 KM REGIÃO - 31}

Figura 122. Regionalização Rio 50 km - Região 31

Fonte: Autor, 2013. 


\section{- Região 32}

Município polo: Registro

Tabela 40. Municípios e produção diária de resíduos domiciliares da Região 32 Raio de 50 km

\begin{tabular}{|l|r|}
\hline \multicolumn{1}{|c|}{ Município } & RSU (t/dia) \\
\hline ITARIRI & 3,99 \\
\hline PEDRO DE TOLEDO & 2,83 \\
\hline MIRACATU & 4,21 \\
\hline JUQUIÁ & 4,83 \\
\hline SETE BARRAS & 2,86 \\
\hline REGISTRO & 19,28 \\
\hline IGUAPE & 9,91 \\
\hline ILHA COMPRIDA & 3,68 \\
\hline ELDORADO & 2,89 \\
\hline IPORANGA & 0,96 \\
\hline BARRA DO TURVO & 1,26 \\
\hline CAJATI & 8,27 \\
\hline JACUPIRANGA & 3,75 \\
\hline PARIQUERA-AÇU & 5,08 \\
\hline CANANÉIA & 4,17 \\
\hline & $\mathbf{7 7 , 9 8}$ \\
\hline
\end{tabular}

Fonte: Autor, 2013. 


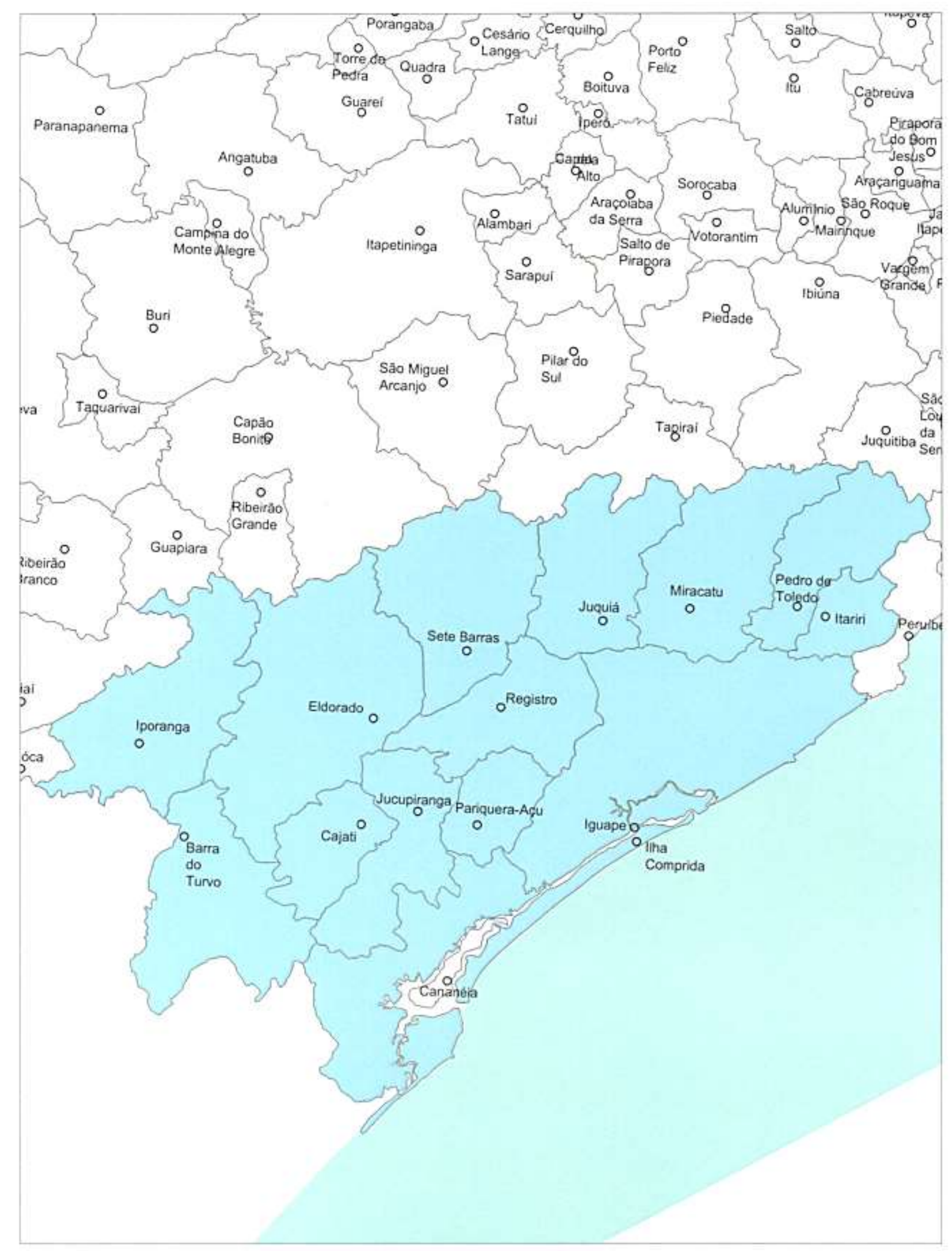

\section{REGIONALIZAÇÃO RAIO DE 50 KM REGIÃO - 32}

Figura 123. Regionalização Rio 50 km - Região 32

Fonte: Autor, 2013. 


\section{- Região 33}

Município polo: Santos

Tabela 41. Municípios e produção diária de resíduos domiciliares da Região 33 Raio de $50 \mathrm{~km}$

\begin{tabular}{|c|c|}
\hline Município & RSU (t/dia) \\
\hline BERTIOGA & 19,28 \\
\hline GUARUJÁ & 175,61 \\
\hline SANTOS & 251,52 \\
\hline SÃO VICENTE & 200,42 \\
\hline CUBATÃO & 59,76 \\
\hline PRAIA GRANDE & 160,38 \\
\hline MONGAGUÁ & 18,78 \\
\hline ITANHAÉM & 34,96 \\
\hline PERUÍBE & 23,89 \\
\hline TOTAL & 944,60 \\
\hline
\end{tabular}

Fonte: Autor, 2013. 


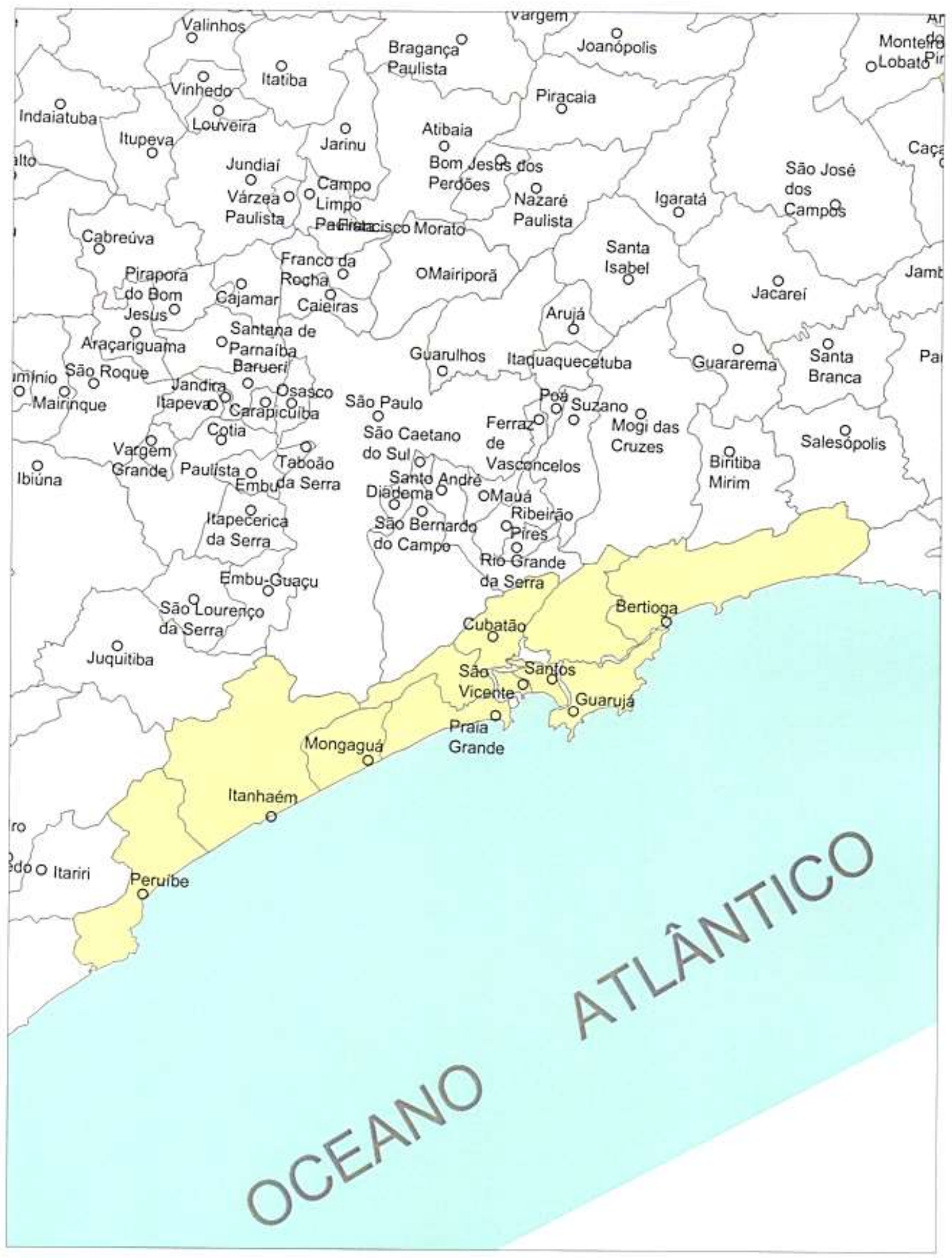

\section{REGIONALIZAÇÃO RAIO DE 50 KM REGIÃO - 33}

Figura 124. Regionalização Rio 50 km - Região 33

Fonte: Autor, 2013. 
Tabela 42. Proposta de regionalização do Estado de São Paulo - Cenário 1

\begin{tabular}{|c|c|c|}
\hline $\begin{array}{l}\text { REGIÃO } \\
\text { MUNICÍPIO } \\
\text { POLO }\end{array}$ & MUNICÍPIOS & $\begin{array}{l}\text { GERAÇÃO DE } \\
\text { RSU (t/dia) }\end{array}$ \\
\hline $\begin{array}{c}\text { Região } 1 \text { - } \\
\text { Jales }\end{array}$ & $\begin{array}{l}\text { Aparecida D’Oeste, Aspásia, Auriflama, Dirce } \\
\text { Reis, Dolcinópolis, Estrela D’Oeste, } \\
\text { Fernandópolis, General Salgado, Guarani } \\
\text { D’Oeste, Guzolândia, Indiaporã, Jales, } \\
\text { Marinópolis, Mesópolis, Nova Canaã Paulista, } \\
\text { Nova Castilho, Ouroeste, Palmeira D’Oeste, } \\
\text { Parapuã, Pontalinda, Populina, Rubinéia, Santa } \\
\text { Albertina, Santa Clara D’Oeste, Santa Fé do } \\
\text { Sul, Santa Rita D’Oeste, Santa Salete, Santana } \\
\text { da Ponte Pensa, São Francisco, São João das } \\
\text { Duas Pontes, São João de Iracema, Suzanápolis, } \\
\text { Três Fronteiras, Turmalina, Urânia e Vitória } \\
\text { Brasil. }\end{array}$ & 100,92 \\
\hline $\begin{array}{c}\text { Região } 2 \text { - } \\
\text { Votuporanga }\end{array}$ & $\begin{array}{l}\text { Mira Estrela, Cardoso, Riolândia, Paulo de } \\
\text { Faria, Macedônia, Pontes Gestal, Américo de } \\
\text { Campos, Álvares Florence, Parisi, Pedranópolis, } \\
\text { Cosmorama, Votuporanga, Valentim Gentil, } \\
\text { Meridiano, Magda, Floreal, Nhandeara, } \\
\text { Sebastianópolis do Sul, Macaubal e Poloni. }\end{array}$ & 69,23 \\
\hline $\begin{array}{c}\text { Região } 3 \text { - } \\
\text { São José do } \\
\text { Rio Preto }\end{array}$ & $\begin{array}{l}\text { Bady Bassit, Bálsamo, Cedral, Guapiaçu, Icém, } \\
\text { Ipiguá, Jaci, José Bonifácio, Mirassol, } \\
\text { Mirassolândia, Monte Aprazível, Neves Paulista, } \\
\text { Nipoã, Nova Granada, Onda Verde, Orindiúva, } \\
\text { Palestina, Planalto, São José do Rio Preto, } \\
\text { Tanabi, Uchoa, União Paulista, Nova Aliança, } \\
\text { Potirendaba, Ubarana, Adolfo e Mendonça. }\end{array}$ & 343,63 \\
\hline
\end{tabular}




\begin{tabular}{|c|c|c|}
\hline $\begin{array}{l}\text { REGIÃO } \\
\text { MUNICÍPIO } \\
\text { POLO }\end{array}$ & MUNICÍPIOS & $\begin{array}{l}\text { GERACCÃO DE } \\
\text { RSU (t/dia) }\end{array}$ \\
\hline $\begin{array}{l}\text { Região } 4 \text { - } \\
\text { Barretos }\end{array}$ & $\begin{array}{l}\text { Altair, Guaraci, Olímpia, Colômbia, Barretos, } \\
\text { Severínia, Colina, Bebedouro, Jaborandi, Terra } \\
\text { Roxa, Viradouro, Guaíra e Ipuã. }\end{array}$ & 153,78 \\
\hline $\begin{array}{l}\text { Região } 5 \text { - } \\
\text { Franca }\end{array}$ & $\begin{array}{l}\text { Miguelópolis, Ituverava, Guará, São Joaquim da } \\
\text { Barra, Nuporanga, Igarapava, Aramina, Rifaina, } \\
\text { Buritizal, Jeriquara, Ribeirão Corrente, São } \\
\text { José da Bela Vista, Pedregulho, Cristais } \\
\text { Paulista, Franca, Restinga, patrocínio Paulista } \\
\text { e Itirapuã. }\end{array}$ & 275,93 \\
\hline $\begin{array}{l}\text { Região } 6 \text { - } \\
\text { Catanduva }\end{array}$ & $\begin{array}{l}\text { Cajobi, Monte Azul paulista, Tabapuã, Novais, } \\
\text { Embaúba, Paraíso, Pirangi, Taiaçu, Taiúva, } \\
\text { Catiguá, Catanduva, Palmares Paulista, } \\
\text { Ariranha, Vista Alegre do Alto, Pindorama, } \\
\text { Ibirá, Elisiário, Santa Adélia, Fernando Prestes, } \\
\text { Cândido Rodrigues, Urupês, Marapoama, } \\
\text { Itajobi, Irapuã, Sales, Novo Horizonte, } \\
\text { Borborema e Itápolis. }\end{array}$ & 182,90 \\
\hline $\begin{array}{c}\text { Região } 7 \text { - } \\
\text { Ribeirão Preto }\end{array}$ & $\begin{array}{l}\text { Altinópolis, Barrinha, Batatais, Brodowisk, } \\
\text { Cajuru, Cássia dos Coqueiros, Cravinhos, } \\
\text { Dumont, Jaboticabal, Jardinópolis, Mococa, } \\
\text { Morro Agudo, Orlândia, Pitangueiras, Pontal } \\
\text { Pradópolis, Ribeirão Preto, Sales Oliveira, } \\
\text { Santa Cruz da Esperança, Santa Rosa do } \\
\text { Viterbo, Santo Antônio da Alegria, São Simão, } \\
\text { Serra Azul, Serrana, Sertãozinho e Taquaritinga }\end{array}$ & 742,86 \\
\hline $\begin{array}{l}\text { Região } 8 \text { - } \\
\text { Andradina }\end{array}$ & $\begin{array}{l}\text { Itha Solteira, Itapuã, Pereira Barreto, Sud } \\
\text { Menucci, Castilho, Andradina, Muritinga do Sul, } \\
\text { Guaraçaí, Mirandópolis, Lavínia, Castilho e } \\
\text { Nova Independência. }\end{array}$ & 70,64 \\
\hline $\begin{array}{l}\text { Região } 9 \text { - } \\
\text { Araçatuba }\end{array}$ & $\begin{array}{l}\text { Monções, Toriúba, Lourdes, Nova Luzitânia, } \\
\text { Gastão Vidigal, Buritama, Zacarias, Santo } \\
\text { Antônio do Arancanguá, Brejo Alegre, } \\
\text { Araçatuba, Birigui, Coroados, Glicério, } \\
\text { Guararapes, Bilac, Clementina, Gabriel } \\
\text { Monteiro, Santópolis do Aguapé, Piacatu, } \\
\text { Rubiacea, Bento de Abreu e Valparaíso. }\end{array}$ & 192,06 \\
\hline $\begin{array}{l}\text { Região } 10 \text { - } \\
\text { Lins }\end{array}$ & $\begin{array}{l}\text { Braúna, Luiziânia, Alto Alegre, Penápolis, } \\
\text { Barbosa, Avanhandava, Promissão, Getulina, } \\
\text { Guaiçara, Lins, Guaimbé, Sabino, Cafelândia, } \\
\text { Guarantã, Pongaí, Uru, Balbinos e Pirajuí. }\end{array}$ & 102,62 \\
\hline
\end{tabular}




\begin{tabular}{|c|c|c|}
\hline $\begin{array}{l}\text { REGIÃO } \\
\text { MUNICÍPIO } \\
\text { POLO }\end{array}$ & MUNICÍPIOS & $\begin{array}{l}\text { GERAÇÃO DE } \\
\text { RSU (t/dia) }\end{array}$ \\
\hline $\begin{array}{l}\text { Região } 11 \text { - } \\
\text { Araraquara }\end{array}$ & $\begin{array}{l}\text { Guariba, Santa Ernestina, Dobrada, Motuca, } \\
\text { Guatapará, Rincão, Luís Antônio, Santa Lúcia, } \\
\text { Américo Brasiliense, Matão, Araraquara, Ibaté, } \\
\text { São Carlos, Ribeirão Bonito, Dourado, Trabiju, } \\
\text { Boa esperança do Sul, Gavião Peixoto, Nova } \\
\text { Europa, Tabatinga e Ibitinga. }\end{array}$ & 385,32 \\
\hline $\begin{array}{l}\text { Região } 12 \text { - } \\
\text { Pirassununga }\end{array}$ & $\begin{array}{l}\text { Tambaú, Santa Rita do Passa Quatro, Casa } \\
\text { Branca, Santa Cruz das Palmeiras, Porto } \\
\text { Ferreira, Descalvado, Pirassununga, Santa Cruz } \\
\text { da Conceição, Leme, Corumbataí, Analândia, } \\
\text { Itirapina. }\end{array}$ & 141,03 \\
\hline $\begin{array}{l}\text { Região } 13 \text { - } \\
\text { São João da } \\
\text { Boa Vista }\end{array}$ & $\begin{array}{l}\text { Itapira, Caconde, Divinolândia, São José do Rio } \\
\text { Pardo, Itobi, São Sebastião da Grama, Vargem } \\
\text { Grande do Sul, São João da Boa Vista, Águas da } \\
\text { Prata, Aguaí, Santo Antônio do Jardim, Espírito } \\
\text { Santo do Pinhal, Estiva Gerbi e Mogi Guaçu. }\end{array}$ & 204,89 \\
\hline $\begin{array}{l}\text { Região } 14 \text { - } \\
\text { Dracena }\end{array}$ & $\begin{array}{l}\text { Paulicéia, Panorama, Santa Mercedes, São João } \\
\text { do pau D’Alho, Nova Guataporanga, Monte } \\
\text { Castelo, Tupi Paulista, Ouro Verde, Dracena, } \\
\text { Junqueirópolis, Irapuru, Pacaembu, Flora Rica, } \\
\text { Flórida Paulista, Adamantina e Mariápolis. }\end{array}$ & 66,01 \\
\hline $\begin{array}{l}\text { Região } 15 \text { - } \\
\text { Tupã }\end{array}$ & $\begin{array}{l}\text { Lucélia, Pracinha, Salmourão, Inúbia Paulista, } \\
\text { Sagres, Osvaldo Cruz, Parapuã, Rinópolis, lacri, } \\
\text { Bastos, Arco-Iris, Tupã, Herculândia e } \\
\text { Quintana. }\end{array}$ & 68,65 \\
\hline $\begin{array}{l}\text { Região } 16 \text { - } \\
\text { Marília }\end{array}$ & $\begin{array}{l}\text { Gália, Álvaro de Carvalho, Garça, Alvinlândia, } \\
\text { Lupércio, Ocauçu, Vera Cruz, Júlio Mesquita, } \\
\text { Marília, Oriente, Pompéia, Queiroz, Oscar } \\
\text { Bressane e Lucélia. }\end{array}$ & 171,89 \\
\hline $\begin{array}{l}\text { Região } 17 \text { - } \\
\text { Bauru }\end{array}$ & $\begin{array}{l}\text { Reginópolis, lacanga, Itaju, Bariri, Bocaina, } \\
\text { Brotas, Dois Córregos, jaú, Itapui, Boracéia, } \\
\text { Arealva, Avaí, Presidente Alves, Bauru, } \\
\text { Pederneiras, Barra Bonita, Mineiros do Tietê, } \\
\text { Igaraçu do Tietê, Macatuba, Lençóis Paulista, } \\
\text { Borebi, Agudos, Piratininga, Cabrália Paulista, } \\
\text { Duartina, Fernão, Lucianópolis, Ubirajara, } \\
\text { Paulistânia. }\end{array}$ & 419,98 \\
\hline $\begin{array}{l}\text { Região } 18 \text { - } \\
\text { Botucatu }\end{array}$ & $\begin{array}{l}\text { Torrinha, Santa Maria da Serra, Anhembi, } \\
\text { Conchas, Porangaba, Bofete, Pardinho, } \\
\text { Itatinga, Botucatu, Pratânia, São Miguel, } \\
\text { Areiópolis. }\end{array}$ & 106,95 \\
\hline
\end{tabular}




\begin{tabular}{|c|c|c|}
\hline $\begin{array}{l}\text { REGIÃO } \\
\text { MUNICÍPIO } \\
\text { POLO }\end{array}$ & MUNICÍPIOS & $\begin{array}{l}\text { GERAÇÃO DE } \\
\text { RSU (t/dia) }\end{array}$ \\
\hline $\begin{array}{l}\text { Região } 19 \text { - } \\
\text { Piracicaba }\end{array}$ & $\begin{array}{l}\text { Araras, Rio Claro, Ipeúna, Cordeirópolis, Santa } \\
\text { Gertrudes, Limeira, Iracemápolis, Charqueada, } \\
\text { São Pedro, Águas de São Pedro, Piracicaba, } \\
\text { Americana, Santa Bárbara D’Oeste, Rio das } \\
\text { Pedras, Saltinho, Mombuca, Capivari, Rafard, } \\
\text { Tietê, Jurumirim, Laranjal Paulista e Pereiras. }\end{array}$ & 848,47 \\
\hline $\begin{array}{c}\text { Região } 20 \text { - } \\
\text { Campinas }\end{array}$ & $\begin{array}{l}\text { Conchal, Mogi-Mirim, Itapira, Águas de Lindóia, } \\
\text { Lindóia, Socorro, Serra Negra, Monte Alegre do } \\
\text { Sul, Amparo, Santo Antônio de Posse, } \\
\text { Holambra, Artur Nogueira, Engenheiro Coelho, } \\
\text { Cosmópolis, Paulínia, Jaguariúna, Pedreira, } \\
\text { Tuiuti, Bragança Paulista, Pinhalzinho, Pedra } \\
\text { Bela, Vargem, Joanópolis, Piracaia, Nazaré } \\
\text { Paulista, Bom Jesus dos Perdões, Atibaia, } \\
\text { Jarinu, Itatiba, Campinas, Nova Odessa, } \\
\text { Sumaré, Hortolândia, Monte Mor, Elias Fausto, } \\
\text { Valinhos, Vinhedo, Morungaba, Louveira, Salto, } \\
\text { Indaiatuba, Itupeva, Jundiaí, Várzea Paulista e } \\
\text { Campo Limpo Paulista. }\end{array}$ & $2.069,36$ \\
\hline $\begin{array}{c}\text { Região } 21 \text { - } \\
\text { Mirante do } \\
\text { Paranapanema }\end{array}$ & $\begin{array}{l}\text { Marabá Paulista, Mirante do Paranapanema, } \\
\text { Teodoro Sampaio, Euclides da Cunha Paulista e } \\
\text { Rosana. }\end{array}$ & 20,54 \\
\hline $\begin{array}{l}\text { Região } 22 \text { - } \\
\text { Presidente } \\
\text { Prudente }\end{array}$ & $\begin{array}{l}\text { Presidente Epitácio, Caiuá, Presidente } \\
\text { Venceslau, Piquerobi, Ribeirão dos Índios, } \\
\text { Emilianópolis, Santo Expedito, Alfredo } \\
\text { Marcondes, Santo Anastácio, Presidente } \\
\text { Bernardes, Alvares Machado, Caiabu, } \\
\text { Presidente Prudente, Martinópolis, Indiana, } \\
\text { Regente Feijó, Taciba, Anhumas, Pirapozinho, } \\
\text { Tarabai, Narandiba, Estrela do Norte e } \\
\text { Sandovalina. }\end{array}$ & 215,32 \\
\hline
\end{tabular}




\begin{tabular}{|c|c|c|}
\hline $\begin{array}{l}\text { REGIÃO } \\
\text { MUNICÍPIO } \\
\text { POLO }\end{array}$ & MUNICÍPIOS & $\begin{array}{l}\text { GERAÇÃO DE } \\
\text { RSU (t/dia) }\end{array}$ \\
\hline $\begin{array}{c}\text { Região } 23 \text { - } \\
\text { Assis }\end{array}$ & $\begin{array}{l}\text { Echaporã. Platina, Palmital, Cândido Mota, } \\
\text { Assis, Tarumã, Florínea, Pedrinhas Paulista, } \\
\text { Cruzália, Maracaí, Paraguaçu Paulista, Borá, } \\
\text { Quatá, João ramalho, Rancharia, lepê e } \\
\text { Nantes. }\end{array}$ & 106,97 \\
\hline $\begin{array}{c}\text { Região } 24 \text { - } \\
\text { Ourinhos }\end{array}$ & $\begin{array}{l}\text { Campos Novos Paulista, Ibirarema, Ribeirão do } \\
\text { Sul, Salto Grande, São Pedro do Turvo, } \\
\text { Ourinhos, Santa Cruz do Rio Pardo. Canitar, } \\
\text { Chavantes, Ipaussu, Óleo, Espírito Santo do } \\
\text { Turvo, Bernardino de Campos, Timburi, Piraju, } \\
\text { Sarutaiá e Fartura. }\end{array}$ & 115,51 \\
\hline $\begin{array}{c}\text { Região } 25 \text { - } \\
\text { Avaré }\end{array}$ & $\begin{array}{l}\text { Águas de Santa Bárbara, laras, Manduri, } \\
\text { Cerqueira César, Avaré, Arandu, Tejupá, } \\
\text { Taguaí, Taquarituba, Itaí e Mirante do } \\
\text { Paranapanema. }\end{array}$ & 70,06 \\
\hline $\begin{array}{l}\text { Região } 26 \text { - } \\
\text { Itapetininga }\end{array}$ & $\begin{array}{l}\text { Tatuí, Quadra, Torre de Pedra, Guareí, } \\
\text { Angatuba, Campina do Monte Alegre, } \\
\text { Itapetininga, Alambari, Sarapuí e São Miguel } \\
\text { Arcanjo. }\end{array}$ & 143,32 \\
\hline $\begin{array}{c}\text { Região } 27 \text { - } \\
\text { Sorocaba }\end{array}$ & $\begin{array}{l}\text { Cesário Lange, Cerquilho, Boituva, Porto Feliz, } \\
\text { Iperó, Capela do Alto, Araçoiaba da Serra, } \\
\text { Sorocaba, Itu, Alumínio, Mairinque, Ibiúna, } \\
\text { Salto de Pirapora, Piedade, Pilar do Sul, Tapiraí } \\
\text { e Votorantim. }\end{array}$ & 675,00 \\
\hline $\begin{array}{c}\text { Região } 28 \text { - } \\
\text { Itapevi }\end{array}$ & $\begin{array}{l}\text { Araçariguama, Arujá, Barueri, Cabreúva, } \\
\text { Caieiras, Cajamar, Carapicuíba, Cotia, } \\
\text { Diadema, Embú, Embu-Guaçu, Ferraz de } \\
\text { Vasconcelos, Franco da Rocha, Guarulhos, } \\
\text { Itapecirica da Serra, Itapeva, Itaququecetuba, } \\
\text { Jandira, Juquitiba, Mairiporã, Mauá, Osasco, }\end{array}$ & \\
\hline
\end{tabular}




\begin{tabular}{|c|c|c|}
\hline $\begin{array}{l}\text { REGIÃO } \\
\text { MUNICÍPIO } \\
\text { POLO }\end{array}$ & MUNICÍPIOS & $\begin{array}{l}\text { GERAÇÃO DE } \\
\text { RSU (t/dia) }\end{array}$ \\
\hline & $\begin{array}{l}\text { Pirapora do Bom Jesus, Poá, Ribeirão Pires, Rio } \\
\text { grande da Serra, Santana de Parnaíba, Santo } \\
\text { André, São Bernardo do Campo, São Caetano do } \\
\text { Sul, São Lourenço da Serra, São Paulo, São } \\
\text { Roque, Suzano, Taboão da Serra e Vargem } \\
\text { Grande Paulista. }\end{array}$ & $17.224,68$ \\
\hline $\begin{array}{c}\text { Região } 29 \text { - } \\
\text { São José dos } \\
\text { Campos }\end{array}$ & $\begin{array}{l}\text { Santa Isabel, Igaratá, São José dos Campos, } \\
\text { Monteiro lobato, Santo Antônio do Pinhal, } \\
\text { Tremembé, Taubaté, Caçapava, São Luís do } \\
\text { Paraitinga, Redenção da Serra, Jambeiro, } \\
\text { Jacareí, Guararema, Mogi das Cruzes, Biritiba } \\
\text { Mirim, Salesópolis, Santa Branca, Paraibuna, } \\
\text { Natividade da Serra, Ubatuba, Caraguatatuba, } \\
\text { Ilha Bela e São Sebastião. }\end{array}$ & $1.147,94$ \\
\hline $\begin{array}{l}\text { Região } 30 \text { - } \\
\text { Guaratinguetá }\end{array}$ & $\begin{array}{l}\text { São Bento do Sapucaí, Campos do Jordão, } \\
\text { Pindamonhangaba, Roseira, Aparecida, } \\
\text { Guaratinguetá, Potim, Lagoinha, Cunha, } \\
\text { Lorena, Piquete, Canas, Cachoeira Paulista, } \\
\text { Cruzeiro, Lavrinhas, Queiroz, Areias, Silveiras, } \\
\text { São José do Barreiro, Arapeí e Bananal. }\end{array}$ & 265,89 \\
\hline $\begin{array}{c}\text { Região } 31 \text { - } \\
\text { Itapeva }\end{array}$ & $\begin{array}{l}\text { Barão de Antonina, Itaporanga, Coronel } \\
\text { Macedo, Riversul, Itaberá, Itararé, Itapeva, } \\
\text { Buri, Taquarivaí, Capão Bonito, Ribeirão } \\
\text { Grande, Guarapiara, Ribeirão Branco, Nova } \\
\text { Campina, Bom Sucesso do Itararé, Barra do } \\
\text { Chapéu, Itapirapuã Paulista, Ribeira, Apiaí e } \\
\text { Itaóca }\end{array}$ & 103,67 \\
\hline
\end{tabular}




\begin{tabular}{|c|l|c|}
\hline $\begin{array}{c}\text { REGIÃO } \\
\text { MUNICÍPIO } \\
\text { POLO }\end{array}$ & \multicolumn{1}{c|}{ MUNICÍPIOS } & $\begin{array}{c}\text { GERAÇÃO DE } \\
\text { RSU (t/dia) }\end{array}$ \\
\hline $\begin{array}{c}\text { Região } 32- \\
\text { Registro }\end{array}$ & $\begin{array}{l}\text { Itariri, Predro de Toledo, Miracatu, Juquiá, } \\
\text { Sete Barras, Registro, Iguape, Ilha Comprida, } \\
\text { Eldorado, Ibiporanga, Barra do Turvo, Cajati, } \\
\text { Jacupiranga, Pariquera-Açu e Cananéia. }\end{array}$ & 77,98 \\
\hline $\begin{array}{c}\text { Região } 33- \\
\text { Santos }\end{array}$ & $\begin{array}{l}\text { Bertioga, Guarujá, Santos, São Vicente, } \\
\text { Cubatão, Praia Grande, Mongaguá, Itanhaém e } \\
\text { Peruíbe. }\end{array}$ & 977,60 \\
\hline
\end{tabular}

\subsubsection{Cenário 2}

Para formulação deste segundo cenário consideramos os critérios adotados para o primeiro cenário, porém com a diferença do raio adotado que neste caso passou a ser de 100 quilômetros, pois se considerou atender ao disposto em um estudo desenvolvido pela associação Brasileira de empresas de Tratamento de Resíduos (ABETRE) em conjunto com a Fundação Getúlio Vargas (FGV), sobre os "Aspectos Econômicos e Financeiros da Implantação e Operação de Aterros Sanitários”.

Este estudo é um importante passo para que os profissionais, administradores, pesquisadores e demais interessados pela área de resíduos sólidos, possam ter subsídios para modelar e orçar todas as etapas do ciclo de vida dos aterros sanitários.

Partindo da premissa de que a vida de um aterro deve gerar recursos suficientes para as obras de encerramento de suas atividades e para um longo período com despesas realizando tratamento de percolados, monitoramento ambiental e geotécnico, manutenção das instalações, segurança e de todas as demais etapas de engenharia, utilizou técnicas de engenharia econômica e de 
análise de projetos de investimentos, para encontrar o preço médio de equilíbrio que possibilitasse a viabilidade do empreendimento.

Foram considerados três portes hipotéticos de aterro: pequeno porte, com capacidade de recebimento de 100 t/dia; médio porte com 800 t/dia e grande porte com 2.000 t/dia, para um horizonte de 42 anos, sendo 2 anos para préimplantação e implantação, 20 anos de vida útil e 20 anos para encerramento, monitoramento e pó-encerramento.

O estudo da FGV e da ABETRE apontam detalhadamente a economia de escala dos investimentos para soluções de agrupamentos de municípios na disposição ambientalmente adequada de seus resíduos.

Nos quadros à seguir o estudo aponta as premissas de engenharia e as estimativas de custo por etapa para aterros sanitários típicos.

Quadro 3 - Premissas de engenharia para aterros típicos.

\begin{tabular}{|c|c|c|c|c|c|}
\hline IT & DESCRIÇĀO & UNIDADE & GRANDE & MÉdIO & PEQUENO \\
\hline & $\begin{array}{l}\text { PORTE DO EMPREENDIMENTO } \\
\text { (modelagem da capacidade) }\end{array}$ & & & & \\
\hline & Capacidade de recebimento & t/dia & 2.000 & 800 & 100 \\
\hline & Vida útil & anos & 20 & 20 & 20 \\
\hline & Monitoramento pós-encerramento & anos & 20 & 20 & 20 \\
\hline & Capacidade total & $\mathrm{t}$ & 14.600 .000 & 5.840 .000 & 730.000 \\
\hline & Densidade (residuo disposto) & $t / m^{3}$ & 0,9 & 0,9 & 0,9 \\
\hline & Capacidade volumétrica - residuos & $\mathrm{m}^{3}$ & 16.222 .222 & 6.488 .889 & 811.111 \\
\hline & Capacidade volumétrica - solo de cobertura & $m^{3}$ & 3.244 .444 & 1.297 .778 & 162.222 \\
\hline & Capacidade volumétrica - total & $\mathrm{m}^{2}$ & 19.466.667 & 7.786 .667 & 973.333 \\
\hline & $\begin{array}{l}\text { TERRENO } \\
\text { (modelagem geométrica) }\end{array}$ & & & & \\
\hline & Altura das camadas & $\mathrm{m}$ & 5 & 5 & 5 \\
\hline & Número de camadas & camadas & 8 & 6 & 4 \\
\hline & Altura total & $\mathrm{m}$ & 40 & 30 & 20 \\
\hline & Taludes & inclinação & $2: 1$ & $2: 1$ & $2: 1$ \\
\hline & Largura da base & $\mathrm{m}$ & 718 & 524 & 231 \\
\hline & Largura do topo & $\mathrm{m}$ & 478 & 344 & 111 \\
\hline & Área de disposição & $\mathrm{m}^{2}$ & 514.834 & 274.987 & 53.144 \\
\hline & Aproveitamento de área & $\mathrm{m}^{3} / \mathrm{m}^{2}$ & 38 & 28 & 18 \\
\hline & Área adicional (instalações, acessos, isolamento. & $\%$ & $50 \%$ & $55 \%$ & $60 \%$ \\
\hline & Área adicional (instalações, acessos, isolamento. & $m^{2}$ & 257.417 & 151.243 & 31.886 \\
\hline & Área de reserva legal & $\mathrm{m}^{2}$ & 193.063 & 106.558 & 21.258 \\
\hline & Área total do terreno & $\mathrm{m}^{2}$ & 965.314 & 532.788 & 106.288 \\
\hline & Perimetro total & $\mathrm{m}$ & 3.930 & 2.920 & 1.304 \\
\hline & Volume de terraplenagem & $\mathrm{m}^{3}$ & 3.244 .444 & 1.297 .778 & 162.222 \\
\hline
\end{tabular}

Fonte: Abetre e FGV, 2008 
Quadro 4 - Estimativa de custos para aterros típicos.

\begin{tabular}{|c|c|c|c|c|c|}
\hline IT & DESCRIÇÃO & DURAÇÃO & $\begin{array}{c}\text { GRANDE } \\
2.000 \mathrm{t} / \mathrm{dia}\end{array}$ & $\begin{array}{c}\text { MÉDIO } \\
800 \mathrm{t} / \text { dia }\end{array}$ & $\begin{array}{l}\text { PEQUENO } \\
100 \mathrm{t} / \mathrm{da}\end{array}$ \\
\hline 1. & PRÉ-IMPLANTAÇÃO & 1 ano & 4.065 & 2.298 & 608 \\
\hline 1.1 & Estudo de viabilidade & & 150 & 90 & 45 \\
\hline 1.2 & Aquisição do terreno & & 3.051 & 1.683 & 344 \\
\hline 1.3 & Projeto e licenciamento & & 828 & 502 & 206 \\
\hline 1.4 & Impostos e taxas & & 37 & 23 & 14 \\
\hline 2. & IMPLANTAÇĀO & 1 ano & 18.170 & 9.180 & 2.669 \\
\hline 2.1 & Infraestrutura geral & & 1.172 & 824 & 580 \\
\hline 2.2 & Células de disposição & & 13.536 & 6.048 & 984 \\
\hline 2.3 & Sist. de trat. de liquidos percolados & & 1.050 & 726 & 343 \\
\hline 2.4 & Sist. de drenagem de águas superficiais & & 413 & 241 & 72 \\
\hline 2.5 & Areas verdes & & 1.041 & 646 & 220 \\
\hline 2.6 & Instalações de apoio & & 551 & 401 & 311 \\
\hline 2.7 & Administração & & 180 & 180 & 127 \\
\hline 2.8 & Impostos e taxas & & 227 & 113 & 32 \\
\hline
\end{tabular}

\begin{tabular}{|c|c|c|c|c|c|}
\hline IT & DESCRIÇĀO & DURAÇÃO & $\begin{array}{c}\text { GRANDE } \\
2.000 \mathrm{t} / \mathrm{dia}\end{array}$ & $\begin{array}{c}\text { MÉDIO } \\
800 \mathrm{t} / \mathrm{dia}\end{array}$ & $\begin{array}{l}\text { PEQUENO } \\
100 \mathrm{t} / \mathrm{da}\end{array}$ \\
\hline 3. & OPERACÃO & 20 anos & 461.494 & 206.485 & 45.468 \\
\hline 3.1 & Células de disposição (cont. de 2.2) & & 121.826 & 54.435 & 8.857 \\
\hline 3.2 & Disposiçāo de resíduos & & 171.077 & 74.479 & 18.584 \\
\hline 3.3 & Sist. de drenagem de percolados e gases & & 2.618 & 1.104 & 157 \\
\hline 3.4 & Tatamento de percolados & & 72.000 & 27.600 & 3.600 \\
\hline 3.5 & Sist. de drenagem de águas superficiais (cont. de & 2.4) & 3.717 & 2.171 & 644 \\
\hline 3.6 & Areas verdes & & 5.902 & 3.190 & 601 \\
\hline 3.7 & Monitoramento & & 6.000 & 4.320 & 1.920 \\
\hline 3.8 & Equipe de operação & & 15.552 & 8.976 & 4.320 \\
\hline 3.9 & Administração & & 62.400 & 30.000 & 6.720 \\
\hline 3.10 & Impostos e taxas & & 401 & 211 & 65 \\
\hline 4. & ENCERRAMENTO & 1 ano & 6.489 & 3.244 & 487 \\
\hline 5. & PÓS-ENCERRAMENTO & 20 anos & 35.576 & 15.328 & 3.212 \\
\hline 5.1 & Tratamento de percolados & & 28.800 & 11.040 & 1.440 \\
\hline 5.2 & Areas verdes & & 381 & 208 & 40 \\
\hline 5.3 & Monitoramento & & 1.500 & 1.080 & 480 \\
\hline 5.4 & Equipe de operação & & 1.824 & 1.536 & 960 \\
\hline 5.5 & Administração & & 2.910 & 1.380 & 270 \\
\hline 5.6 & Impostos e taxas & & 161 & 84 & 23 \\
\hline
\end{tabular}

Fonte: Abetre e FGV, 2008 
Quadro 5 - Resumo de custos e preços para aterros típicos.

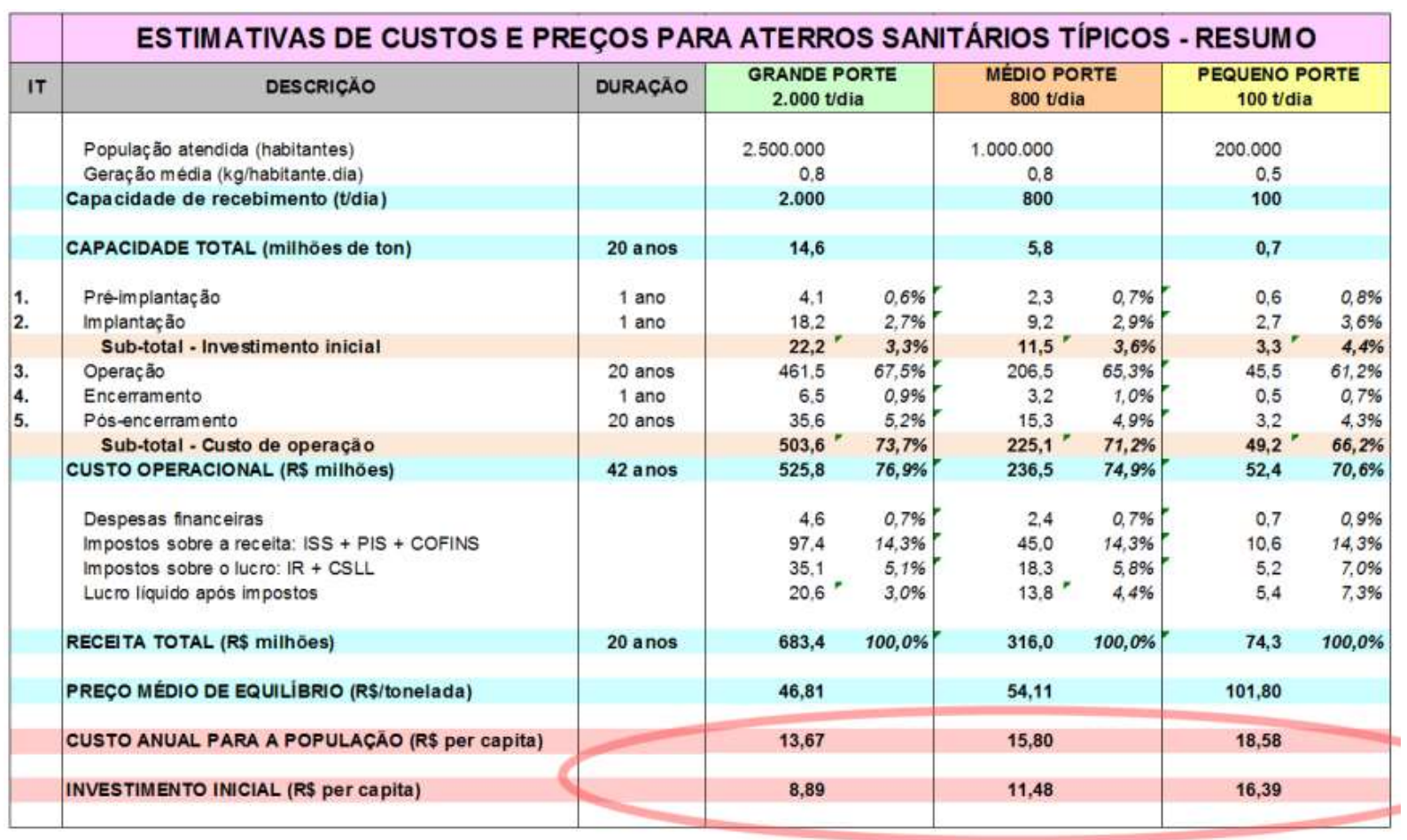

Fonte: Abetre e FGV, 2008

Para o presente cenário foram considerados os padrões de pequeno porte, médio e grande. A seguir as figuras de números 127 à 139 apresentam a regionalização do cenário 2 . 


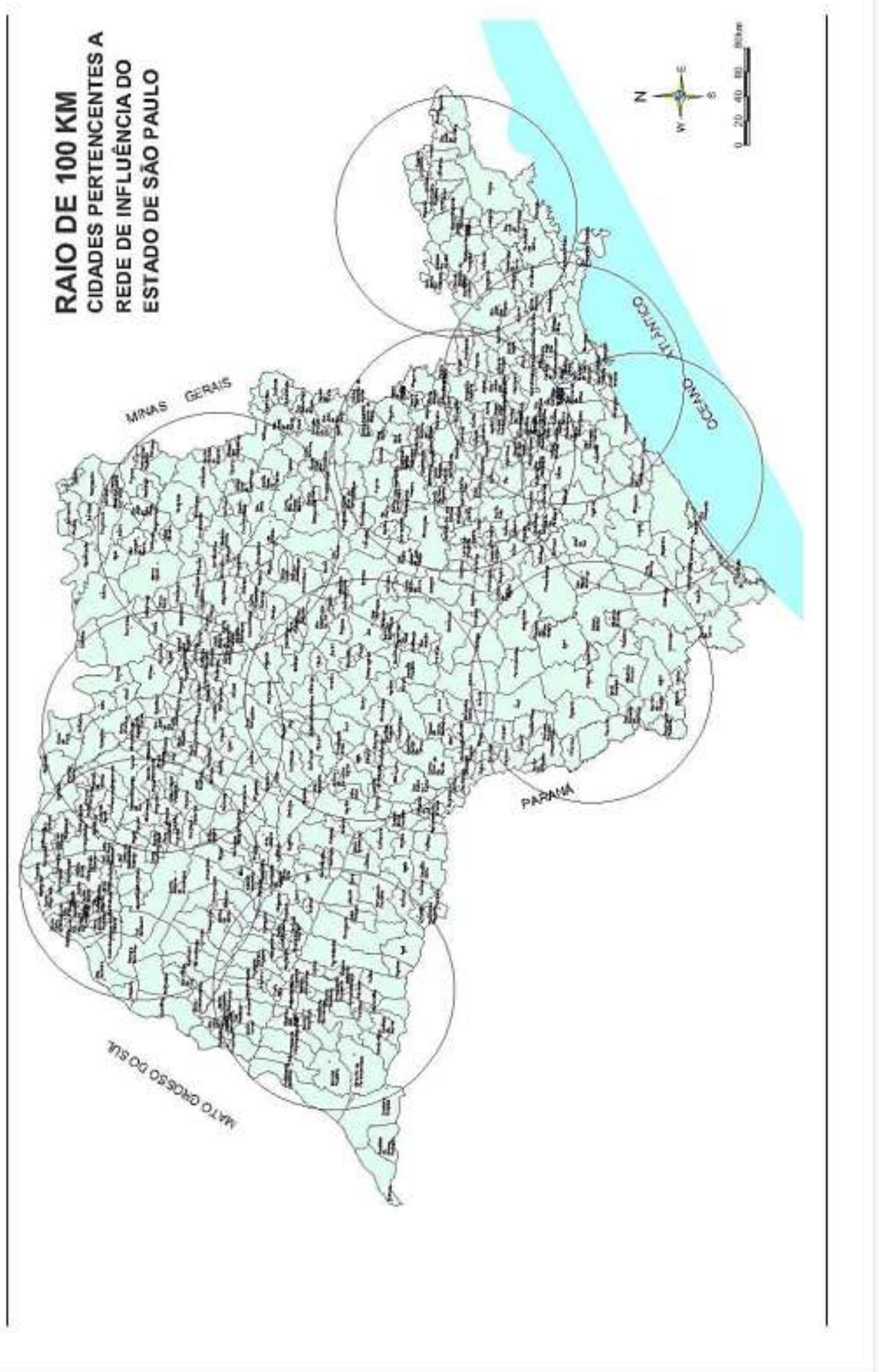

Figura 125. Mapa identificando raio de $100 \mathrm{~km}$ das cidades polo do Estado de São Paulo

Fonte: Autor, 2013. 


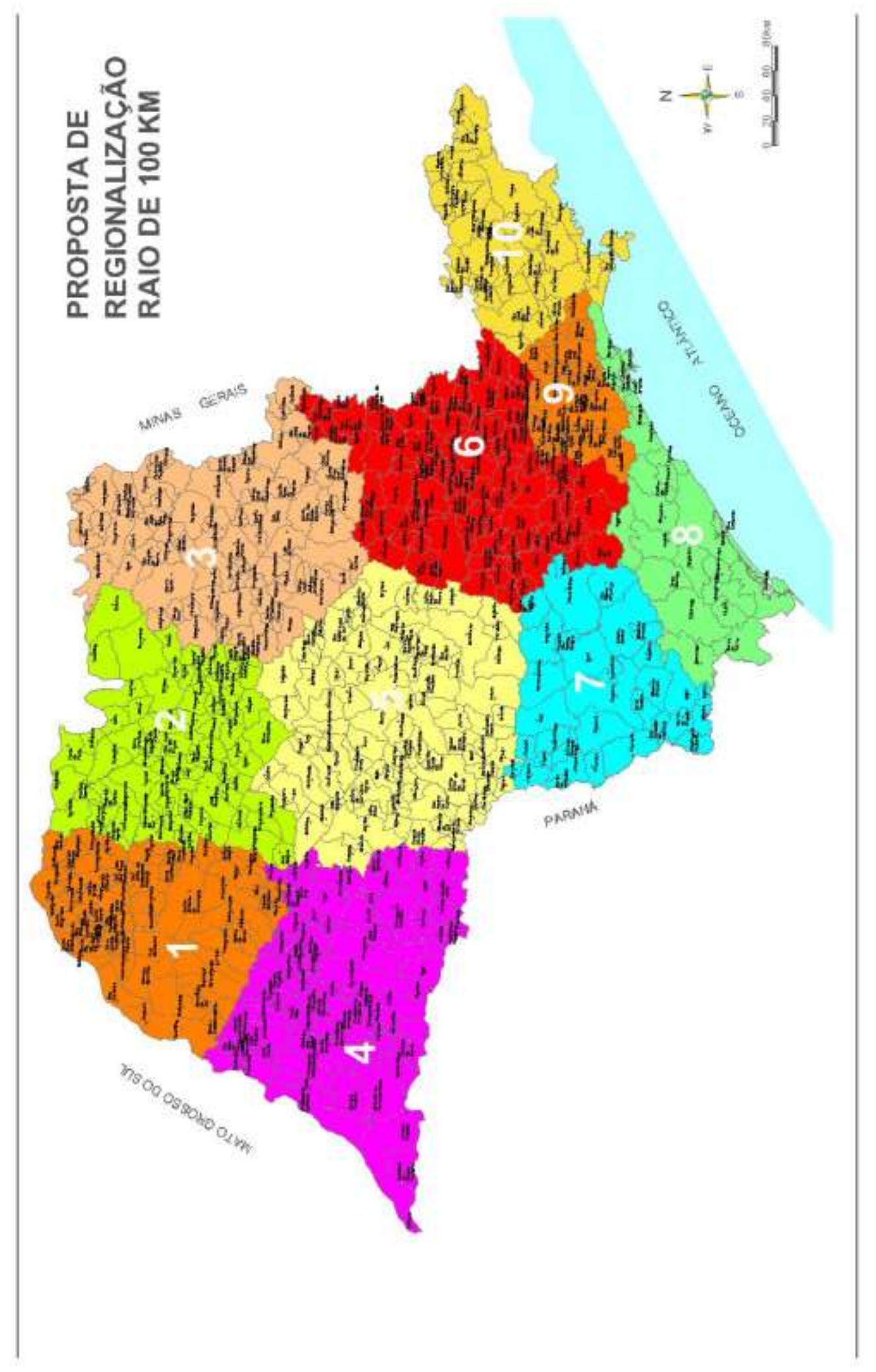

Figura 126. Proposta de regionalização - raio de $100 \mathrm{~km}$ das cidades polo do Estado de São Paulo

Fonte: Autor, 2013. 


\section{- Região 1}

Município polo: Auriflama

Tabela 43. Municípios e produção diária de resíduos domiciliares

$$
\text { da Região } 1 \text { - Raio de } 100 \text { km }
$$

\begin{tabular}{|l|r|}
\hline MUNICÍPIO & RSU(t/dia) \\
\hline CASTILHO & 5,5052 \\
\hline NOVA INDEPENDÊNCIA & 1,0032 \\
\hline MURUTINGA DO SUL & 1,0332 \\
\hline GUARAÇAÍ & 2,6504 \\
\hline ANDRADINA & 20,6648 \\
\hline MIRANDÓPOLIS & 9,8244 \\
\hline LAVÍNIA & 1,7688 \\
\hline VALPARAÍSO & 8,7048 \\
\hline BENTO DE ABREU & 0,9856 \\
\hline RUBIÁCEA & 0,6324 \\
\hline GUARARAPES & 11,3772 \\
\hline PIACATU & 1,8832 \\
\hline GABRIEL MONTEIRO & 0,9024 \\
\hline CLEMENTINA & 2,7424 \\
\hline ARAÇATUBA & 89,5030 \\
\hline BILAC & 2,6196 \\
\hline BIRIGUI & 53,2810 \\
\hline COROADOS & 1,7176 \\
\hline GLICÉRIO & 1,3480 \\
\hline BREJO ALEGRE & 0,8508 \\
\hline BURITAMA & 5,8560 \\
\hline LOURDES & 0,7008 \\
\hline SANTO ANTÔNIO DO & 2,4052 \\
\hline ARACANGUÁ & 1,2540 \\
\hline NOVA LUZITÂNIA & 1,5192 \\
\hline GASTÃO VIDIGAL & 0,3012 \\
\hline NOVA CASTILHO & 3,6300 \\
\hline GENERAL SALGADO & 9,2920 \\
\hline PEREIRA BARRETO & \\
\hline SUD MENNUCCI & \\
\hline
\end{tabular}




\begin{tabular}{|c|c|}
\hline $\begin{array}{l}\text { GUZOLÂNDIA } \\
\text { SÃO JOÃO DAS DUAS } \\
\text { PONTES } \\
\end{array}$ & $\begin{array}{l}1,6204 \\
0,7824 \\
\end{array}$ \\
\hline SÃO JOÃO DE IRACEMA & 0,5836 \\
\hline PONTALINDA & 1,3664 \\
\hline DIRCE REIS & 0,5136 \\
\hline PALMEIRA D'OESTE & 2,8904 \\
\hline MARINÓPOLIS & 0,6664 \\
\hline APARECIDA D'OESTE & 1,4460 \\
\hline SUZANÁPOLIS & 0,9156 \\
\hline ITAPURA & 1,4056 \\
\hline ILHA SOLTEIRA & 9,4388 \\
\hline RUBINÉIA & 0,9484 \\
\hline SANTA FÉ DO SUL & 11,3160 \\
\hline SANTA CLARA D'OESTE & 0,6276 \\
\hline SANTA RITA D'OESTE & 0,7060 \\
\hline NOVA CANAÃ PAULISTA & 0,3472 \\
\hline TRÊS FRONTEIRAS & 1,8464 \\
\hline SANTANA DA PONTE PENSA & 0,4336 \\
\hline SANTA ALBERTINA & 1,9600 \\
\hline MESÓPOLIS & 0,5864 \\
\hline POPULINA & 1,3592 \\
\hline OUROESTE & 3,0768 \\
\hline INDIAPORÃ & 1,3476 \\
\hline MIRA ESTRELA & 0,7572 \\
\hline ASPÁSIA & 0,5020 \\
\hline PARANAPUÃ & 1,3628 \\
\hline SANTA SALETE & 0,3288 \\
\hline URÂNIA & 2,9748 \\
\hline SÃO FRANCISCO & 0,8652 \\
\hline JALES & 17,7196 \\
\hline DOLCINÓPOLIS & 0,7780 \\
\hline TURMALINA & 0,5544 \\
\hline VITÓRIA BRASIL & 0,5756 \\
\hline ESTRELA D'OESTE & 2,7316 \\
\hline FERNANDÓPOLIS & 25,1768 \\
\hline GUARANI D'OESTE & 0,6932 \\
\hline MACEDÔNIA & 1,1088 \\
\hline
\end{tabular}




\begin{tabular}{|c|c|}
\hline PEDRANÓPOLIS & 0,6332 \\
\hline FLOREAL & 0,9704 \\
\hline MAGDA & 1,0568 \\
\hline MERIDIANO & 1,0660 \\
\hline TOTAL & 352,55 \\
\hline
\end{tabular}

Fonte: Autor, 2013. 


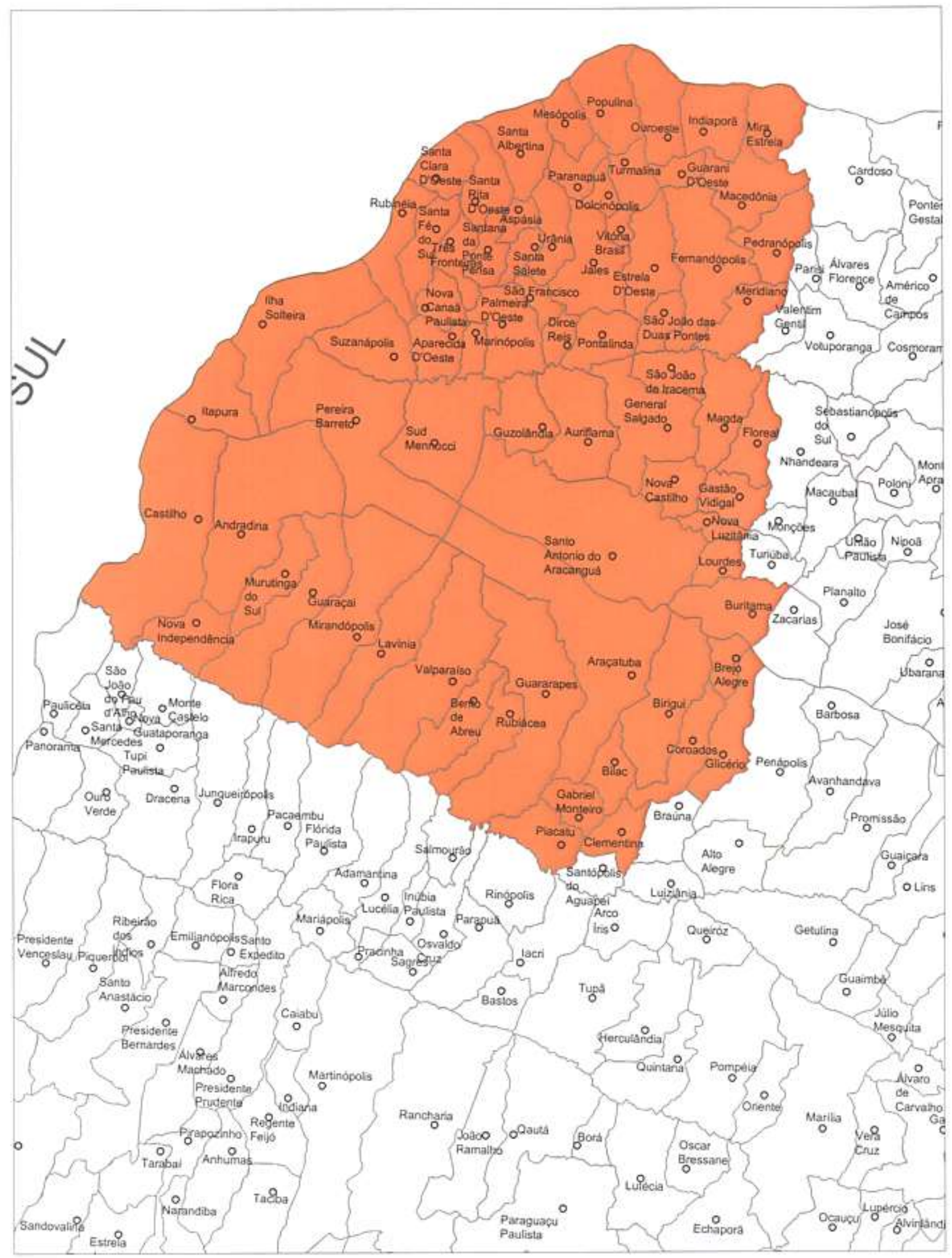

\section{REGIONALIZAÇÃO RAIO DE 100 KM REGIÃO - 1}

Figura 127. Regionalização Rio 100 km - Região 1

Fonte: Autor, 2013. 


\section{- Região 2}

Município polo: São José do Rio Preto

Tabela 44. Municípios e produção diária de resíduos domiciliares da Região 2 - Raio de 100 km

\begin{tabular}{|l|r|}
\hline \multicolumn{1}{|c|}{ MUNICÍPIO } & RSU(t/dia) \\
\hline SÃO JOSÉ DO RIO PRETO & 232,246 \\
\hline MIRASSOL & 21,137 \\
\hline MIRASSOLÂNDIA & 1,411 \\
\hline IPIGUÁ & 1,097 \\
\hline BADY BASSITT & 5,552 \\
\hline CEDRAL & 2,554 \\
\hline GUAPIAÇU & 6,425 \\
\hline ONDA VERDE & 1,229 \\
\hline NOVA GRANADA & 7,172 \\
\hline BÁLSAMO & 3,013 \\
\hline TANABI & 8,735 \\
\hline MONTE APRAZÍVEL & 8,014 \\
\hline POLONI & 1,938 \\
\hline NIPOÃ & 1,546 \\
\hline NEVES PAULISTA & 3,163 \\
\hline JACI & 1,989 \\
\hline NOVA ALIANÇA & 1,981 \\
\hline POTIRENDABA & 5,603 \\
\hline IBIRÁ & 4,059 \\
\hline UCHOA & 3,533 \\
\hline CATIGUÁ & 2,644 \\
\hline TABAPUÃ & 4,232 \\
\hline NOVAIS & 1,711 \\
\hline EMBAÚBA & 0,823 \\
\hline PARAÍSO & 2,088 \\
\hline MONTE AZUL PAULISTA & 7,068 \\
\hline CAJOBI & 3,014 \\
\hline SEVERÍNIA & \\
\hline OLÍMPIA & \\
\hline
\end{tabular}




\begin{tabular}{|c|c|}
\hline COLINA & 6,510 \\
\hline BARRETOS & 54,648 \\
\hline GUAÍRA & 14,506 \\
\hline COLÔMBIA & 1,734 \\
\hline GUARACI & 3,602 \\
\hline ICÉM & 2,580 \\
\hline ALTAIR & 1,216 \\
\hline ORINDIÚVA & 2,132 \\
\hline PAULO DE FARIA & 3,103 \\
\hline PALESTINA & 3,725 \\
\hline COSMORAMA & 1,975 \\
\hline JOSÉ BONIFÁCIO & 11,986 \\
\hline UBARANA & 1,968 \\
\hline MENDONÇA & 1,540 \\
\hline SALES & 1,988 \\
\hline IRAPUÃ & 2,613 \\
\hline URUPÊS & 4,550 \\
\hline CATANDUVA & 56,223 \\
\hline ELISIÁRIO & 1,158 \\
\hline MARAPOAMA & 0,890 \\
\hline ITAJOBI & 4,866 \\
\hline NOVO HORIZONTE & 13,738 \\
\hline PINDORAMA & 5,750 \\
\hline PALMARES PAULISTA & 4,322 \\
\hline ARIRANHA & 3,269 \\
\hline SANTA ADÉLIA & 5,450 \\
\hline PIRANGI & 3,827 \\
\hline FERNANDO PRESTES & 1,882 \\
\hline VISTA ALEGRE DO ALTO & 2,601 \\
\hline CARDOSO & 4,298 \\
\hline PONTES GESTAL & 0,849 \\
\hline AMÉRICO DE CAMPOS & 1,918 \\
\hline ÁLVARES FLORENCE & 1,050 \\
\hline VOTUPORANGA & 33,198 \\
\hline VALENTIM GENTIL & 4,098 \\
\hline PARISI & 0,660 \\
\hline NHANDEARA & 3,488 \\
\hline
\end{tabular}




\begin{tabular}{|c|c|}
\hline SEBASTIANÓPOLIS DO SUL & 0,950 \\
\hline MACAUBAL & 2,717 \\
\hline PROMISSÃO & 12,146 \\
\hline PENÁPOLIS & 22,467 \\
\hline AVANHANDAVA & 3,890 \\
\hline BARBOSA & 2,250 \\
\hline ZACARIAS & 0,744 \\
\hline PLANALTO & 1,527 \\
\hline UNIÃO PAULISTA & 0,496 \\
\hline MONÇÕES & 0,736 \\
\hline TURIÚBA & 0,633 \\
\hline ALTO ALEGRE & 1,290 \\
\hline TOTAL & 693,36 \\
\hline
\end{tabular}

Fonte: Autor, 2013. 


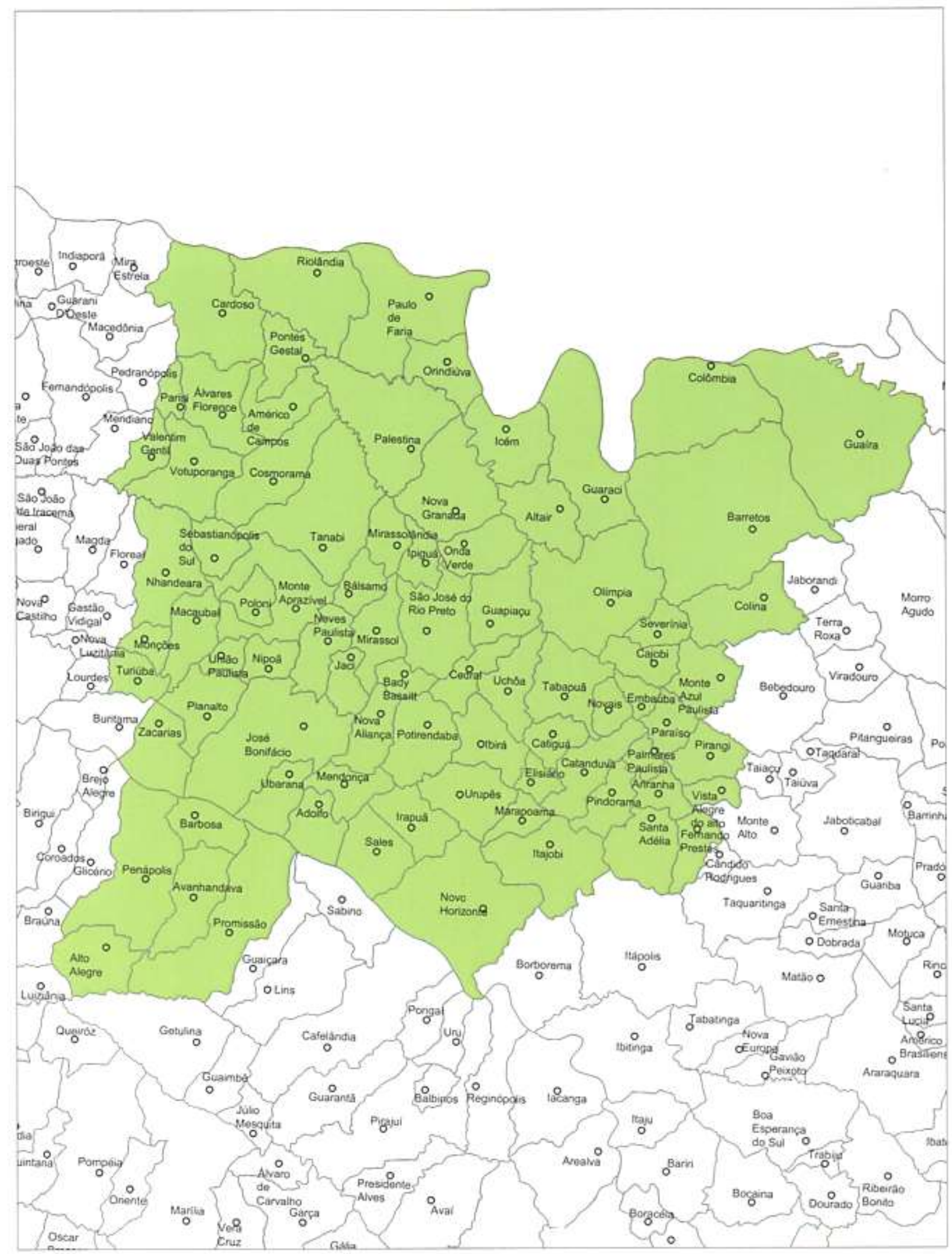

\section{REGIONALIZAÇÃO RAIO DE 100 KM REGIÃO - 2}

Figura 128. Regionalização Rio 100 km - Região 2

Fonte: Autor, 2013. 


\section{- Região 3}

Município polo: Ribeirão Preto

Tabela 45. Municípios e produção diária de resíduos domiciliares

$$
\text { da Região } 3 \text { - Raio de } 100 \text { km }
$$

\begin{tabular}{|l|r|}
\hline \multicolumn{1}{|c|}{ MUNICÍPIO } & RSU(t/dia) \\
\hline RIBEIRÃO PRETO & 427,4214 \\
\hline JARDINÓPOLIS & 14,6608 \\
\hline SERTÃOZINHO & 54,9705 \\
\hline DUMONT & 3,1960 \\
\hline CRAVINHOS & 12,4592 \\
\hline BARRINHA & 11,4024 \\
\hline PRADÓPOLIS & 6,5672 \\
\hline GUATAPARÁ & 2,0600 \\
\hline LUÍS ANTÔNIO & 4,4828 \\
\hline SÃO SIMÃO & 5,1900 \\
\hline SERRA AZUL & 3,2904 \\
\hline SERRANA & 15,5772 \\
\hline ALTINÓPOLIS & 5,4580 \\
\hline BRODOWSKI & 8,3580 \\
\hline SANTA CRUZ DA & 0,5328 \\
\hline ESPERANÇA & 20,1236 \\
\hline BATATAIS & 3,8624 \\
\hline SALES OLIVEIRA & 16,1152 \\
\hline PONTAL & 13,7020 \\
\hline PITANGUEIRAS & 27,9376 \\
\hline JABOTICABAL & 14,0316 \\
\hline GUARIBA & 1,8800 \\
\hline SANTO ANTÔNIO DA & 8,3892 \\
\hline ALEGRIA & 0,7132 \\
\hline CAJURU & 24,4800 \\
\hline CÁSSIA DOS COQUEIROS & 9,1700 \\
\hline MOCOCA & 7900 \\
\hline SANTA ROSA DE VITERBO & \\
\hline TAMBAÚ & SANTA RITA DO PASSA \\
\hline QUATRO & \\
\hline
\end{tabular}




\begin{tabular}{|c|c|}
\hline CASA BRANCA & 9,2996 \\
\hline $\begin{array}{l}\text { SANTA CRUZ DAS } \\
\text { PALMEIRAS }\end{array}$ & 11,7304 \\
\hline PIRASSUNUNGA & 25,8332 \\
\hline PORTO FERREIRA & 20,3112 \\
\hline DESCALVADO & 11,1432 \\
\hline RINCÃO & 3,3864 \\
\hline IBATÉ & 11,9292 \\
\hline SÃO CARLOS & 129,1170 \\
\hline ARARAQUARA & 122,8104 \\
\hline AMÉRICO BRASILIENSE & 13,8756 \\
\hline SANTA LÚCIA & 3,1132 \\
\hline DOBRADA & 3,1328 \\
\hline MOTUCA & 1,2528 \\
\hline MATÃO & 30,3028 \\
\hline SANTA ERNESTINA & 2,0532 \\
\hline TAQUARITINGA & 20,5232 \\
\hline ITIRAPUÃ & 1,9848 \\
\hline PATROCÍNIO PAULISTA & 4,2392 \\
\hline FRANCA & 189,2256 \\
\hline RESTINGA & 2,0960 \\
\hline MIGUELÓPOLIS & 7,7476 \\
\hline IGARAPAVA & 10,6036 \\
\hline ARAMINA & 1,9376 \\
\hline RIFAINA & 1,2064 \\
\hline PEDREGULHO & 4,6496 \\
\hline CRISTAIS PAULISTA & 2,2340 \\
\hline BURITIZAL & 1,3320 \\
\hline ITUVERAVA & 14,6424 \\
\hline JERIQUARA & 1,0396 \\
\hline RIBEIRÃO CORRENTE & 1,4 \\
\hline GUARÁ & 7,7 \\
\hline SÃO JOSÉ DA BELA VISTA & 3,0 \\
\hline NUPORANGA & 2,5 \\
\hline ORLÂNDIA & 15,6 \\
\hline SÃO JOAQUIM DA BARRA & 18,4 \\
\hline IPUÃ & 5,5 \\
\hline MORRO AGUDO & 11,3 \\
\hline
\end{tabular}




\begin{tabular}{|l|r|}
\hline MONTE ALTO & 17,9 \\
\hline CÂNDIDO RODRIGUES & 0,9 \\
\hline TAIÚVA & 2,0 \\
\hline TAIAÇU & 2,1 \\
\hline VIRADOURO & 6,8 \\
\hline BEBEDOURO & 28,6 \\
\hline TAQUARAL & 1,0 \\
\hline TERRA ROXA & 3,3 \\
\hline JABORANDI & 2,5 \\
\hline SÃO JOSÉ DO RIO PARDO & 18,4 \\
\hline TAPIRATIBA & 4,2 \\
\hline CACONDE & 5,1 \\
\hline \multicolumn{2}{|c|}{ TOTAL } \\
\hline
\end{tabular}

Fonte: Autor, 2013. 


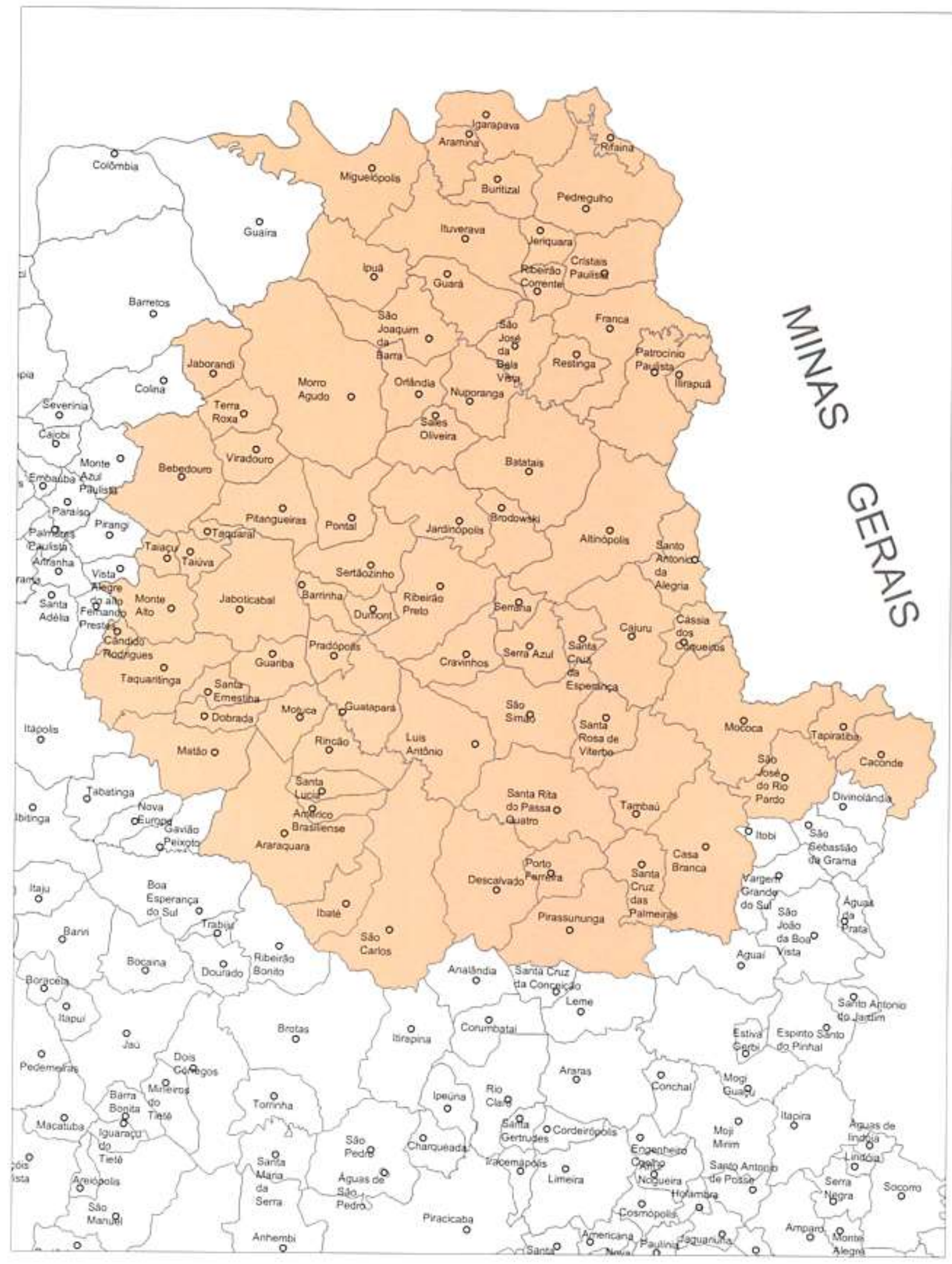

\section{REGIONALIZAÇÃO RAIO DE 100 KM REGIÃO - 3}

Figura 129. Regionalização Rio 100 km - Região 3

Fonte: Autor, 2013. 


\section{- Região 4}

Município polo: Presidente Prudente

Tabela 46. Municípios e produção diária de resíduos domiciliares da Região 4 - Raio de 100 km

\begin{tabular}{|l|r|}
\hline \multicolumn{1}{|c|}{ MUNICÍPIO } & RSU(t/dia) \\
\hline PRESIDENTE PRUDENTE & 122,8566 \\
\hline CAIABU & 1,3260 \\
\hline PALMITAL & 7,7848 \\
\hline ROSANA & 6,2312 \\
\hline EUCLIDES DA CUNHA & 2,4320 \\
\hline PAULISTA & 6,9808 \\
\hline TEODORO SAMPAIO & 15,4764 \\
\hline PRESIDENTE EPITÁCIO & 0,7820 \\
\hline CAIUÁ & 0,8720 \\
\hline MARABÁ PAULISTA & \\
\hline MIRANTE DO & 4,0332 \\
\hline PARANAPANEMA & 1,0456 \\
\hline SANDOVALINA & 9,4604 \\
\hline PIRAPOZINHO & 0,8404 \\
\hline ESTRELA DO NORTE & 2,4672 \\
\hline TARABAI & 14,5256 \\
\hline PRESIDENTE VENCESLAU & 1,0692 \\
\hline PIQUEROBI & 7,6240 \\
\hline SANTO ANASTÁCIO & 4,1744 \\
\hline PRESIDENTE BERNARDES & 8,4968 \\
\hline ÁLVARES MACHADO & 1,2540 \\
\hline NARANDIBA & 1,2320 \\
\hline ANHUMAS & 1,9536 \\
\hline TACIBA & 0,9848 \\
\hline NANTES & 6,8620 \\
\hline REGENTE FEIJÓ & 2,7196 \\
\hline IEPÊ & 4,8436 \\
\hline MARACAÍ & \\
\hline CRUZÁLIA & \\
\hline PEDRINHAS PAULISTA & \\
\hline
\end{tabular}




\begin{tabular}{|c|c|}
\hline FLORÍNEA & 0,9968 \\
\hline CÂNDIDO MOTA & 11,2560 \\
\hline TARUMÃ & 4,9124 \\
\hline PLATINA & 1,0132 \\
\hline ECHAPORÃ & 2,0004 \\
\hline ASSIS & 36,6284 \\
\hline INDIANA & 1,6480 \\
\hline MARTINÓPOLIS & 8,1848 \\
\hline RANCHARIA & 10,3324 \\
\hline JOÃO RAMALHO & 1,4252 \\
\hline QUATÁ & 4,8376 \\
\hline PARAGUAÇU PAULISTA & 15,4000 \\
\hline BORÁ & 0,2512 \\
\hline LUTÉCIA & 0,8588 \\
\hline OSCAR BRESSANE & 0,8392 \\
\hline HERCULÂNDIA & 3,1884 \\
\hline TUPÃ & 24,3764 \\
\hline |ACRI & 2,0116 \\
\hline BASTOS & 7,0396 \\
\hline MARINÓPOLIS & 0,6664 \\
\hline PARAPUÃ & 3,5520 \\
\hline OSVALDO CRUZ & 11,1480 \\
\hline SAGRES & 0,7268 \\
\hline SALMOURÃO & 1,7404 \\
\hline INÚBIA PAULISTA & 1,2792 \\
\hline PRACINHA & 0,5688 \\
\hline ALFREDO MARCONDES & 1,3072 \\
\hline RIBEIRÃO DOS ÍNDIOS & 0,7392 \\
\hline EMILIANÓPOLIS & 1,0020 \\
\hline SANTO EXPEDITO & 0,9988 \\
\hline MARIÁPOLIS & 1,2564 \\
\hline FLORA RICA & 0,5568 \\
\hline PAULICÉIA & 2,1348 \\
\hline PANORAMA & 5,6940 \\
\hline OURO VERDE & 2,8892 \\
\hline SÃO JOÃO DO PAU D'ALHO & 0,6804 \\
\hline SANTA MERCEDES & 0,9844 \\
\hline
\end{tabular}




\begin{tabular}{|l|r|}
\hline DRACENA & 16,0568 \\
\hline JUNQUEIRÓPOLIS & 6,2032 \\
\hline NOVA GUATAPORANGA & 0,7584 \\
\hline MONTE CASTELO & 1,2840 \\
\hline TUPI PAULISTA & 4,5064 \\
\hline IRAPURU & 2,2100 \\
\hline PACAEMBU & 3,9144 \\
\hline FLÓRIDA PAULISTA & 4,0972 \\
\hline ADAMANTINA & 12,7884 \\
\hline LUCÉLIA & 6,9296 \\
\hline QUEIROZ & 0,9708 \\
\hline ARCO-ÍRIS & 0,4348 \\
\hline SANTÓPOLIS DO AGUAPEÍ & 1,6672 \\
\hline LUIZIÂNIA & 1,8660 \\
\hline BRAÚNA & 1,7732 \\
\hline \multicolumn{2}{|c|}{ TOTAL } \\
\hline
\end{tabular}

Fonte: Autor, 2013. 


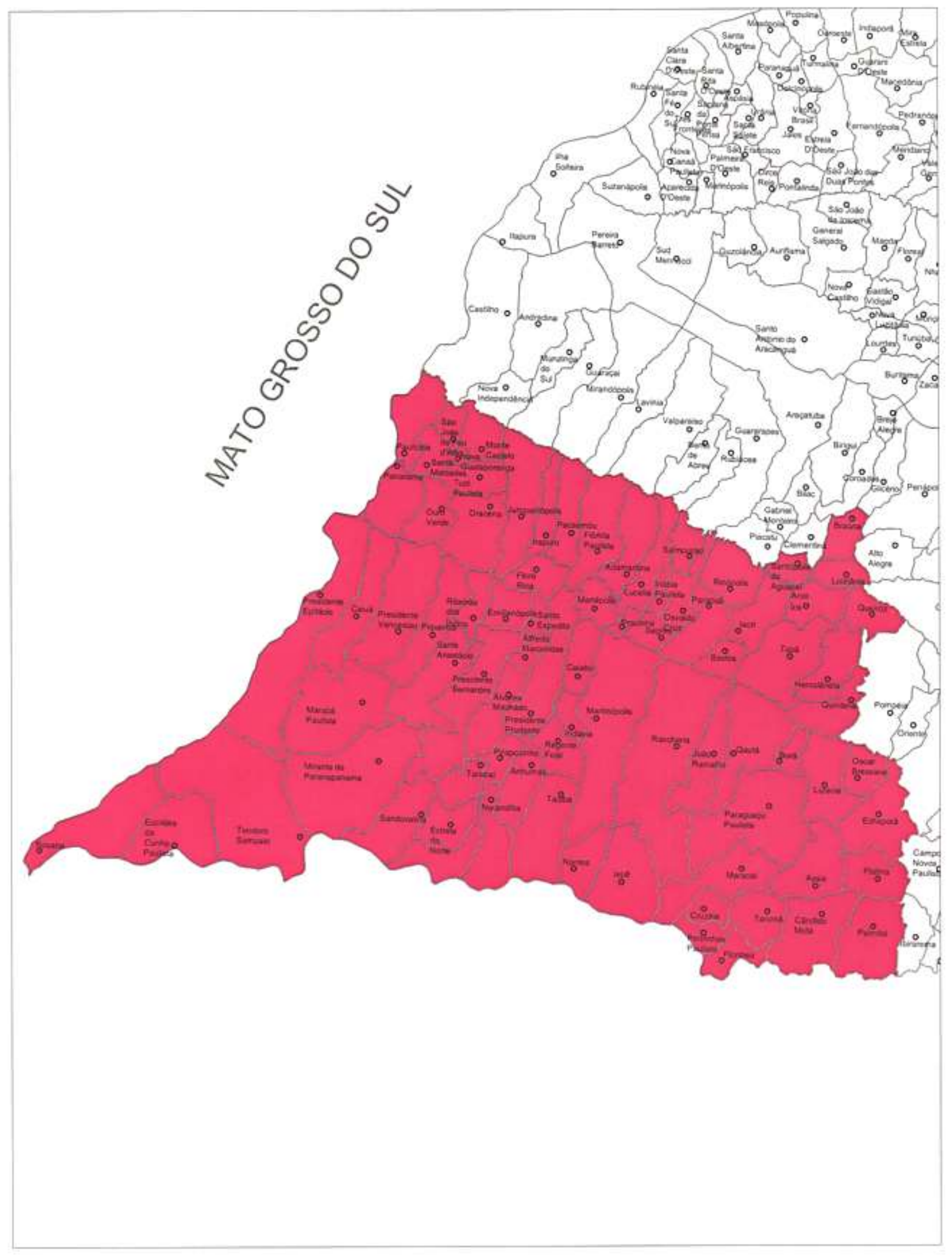

\section{REGIONALIZAÇÃO RAIO DE 100 KM REGIÃO - 4}

Figura 130. Regionalização Rio 100 km - Região 4

Fonte: Autor, 2013. 


\section{- Região 5}

Município polo: Bauru

Tabela 47. Municípios e produção diária de resíduos domiciliares da Região 5 - Raio de 100 km

\begin{tabular}{|l|r|}
\hline \multicolumn{1}{|c|}{ MunicípIO } & RSU(t/dia) \\
\hline BAURU & 204,1728 \\
\hline PEDERNEIRAS & 15,5764 \\
\hline AREALVA & 2,4848 \\
\hline AVAÍ & 1,3396 \\
\hline AGUDOS & 13,2572 \\
\hline PIRATININGA & 4,1804 \\
\hline BORBOREMA & 5,2752 \\
\hline ITÁPOLIS & 14,5944 \\
\hline TABATINGA & 5,0760 \\
\hline NOVA EUROPA & 3,5068 \\
\hline GAVIÃO PEIXOTO & 1,4376 \\
\hline REGINÓPOLIS & 1,7924 \\
\hline IACANGA & 3,5368 \\
\hline IBITINGA & 20,6156 \\
\hline ITAJU & 0,9580 \\
\hline BARIRI & 12,0884 \\
\hline BOA ESPERANÇA DO SUL & 4,9032 \\
\hline BORACÉIA & 1,5456 \\
\hline ITAPUÍ & 4,7052 \\
\hline BOCAINA & 4,0424 \\
\hline JAÚ & 64,1760 \\
\hline TRABIJU & 0,5720 \\
\hline RIBEIRÃO BONITO & 4,5136 \\
\hline DOURADO & 3,1480 \\
\hline BROTAS & 7,5108 \\
\hline DOIS CÓRREGOS & 9,4436 \\
\hline TORRINHA & 3,1884 \\
\hline SANTA MARIA DA SERRA & 1,9288 \\
\hline MINEIROS DO TIETÊ & \\
\hline
\end{tabular}




\begin{tabular}{|c|c|}
\hline BARRA BONITA & 13,7956 \\
\hline MACATUBA & 6,3256 \\
\hline SABINO & 1,8372 \\
\hline GETULINA & 3,3432 \\
\hline GUAIMBÊ & 1,9020 \\
\hline GUAIÇARA & 3,9184 \\
\hline LINS & 28,4052 \\
\hline CAFELÂNDIA & 5,7924 \\
\hline PONGAÍ & 1,1648 \\
\hline URU & 0,4284 \\
\hline GUARANTÃ & 2,1872 \\
\hline JÚLIO MESQUITA & 1,6936 \\
\hline PIRAJUÍ & 7,4660 \\
\hline BALBINOS & 0,5000 \\
\hline MARÍLIA & 125,0628 \\
\hline OCAUÇU & 1,3296 \\
\hline VERA CRUZ & 3,7368 \\
\hline ÁLVARO DE CARVALHO & 1,1916 \\
\hline PRESIDENTE ALVES & 1,3676 \\
\hline GARÇA & 15,6756 \\
\hline GÁLIA & 2,0708 \\
\hline LUPÉRCIO & 1,5496 \\
\hline ALVINLÂNDIA & 1,0820 \\
\hline FERNÃO & 0,3424 \\
\hline DUARTINA & 4,3928 \\
\hline LUCIANÓPOLIS & 0,7144 \\
\hline UBIRAJARA & 1,2976 \\
\hline CABRÁLIA PAULISTA & 1,5032 \\
\hline PAULISTÂNIA & 0,4848 \\
\hline $\begin{array}{l}\text { ESPÍRITO SANTO DO } \\
\text { TURVO }\end{array}$ & 1,4672 \\
\hline CAMPOS NOVOS PAULISTA & 1,4200 \\
\hline IBIRAREMA & 2,5140 \\
\hline SALTO GRANDE & 3,1828 \\
\hline RIBEIRÃO DO SUL & 1,3172 \\
\hline SÃO PEDRO DO TURVO & 2,0668 \\
\hline $\begin{array}{l}\text { SANTA CRUZ DO RIO } \\
\text { PARDO }\end{array}$ & 16,1460 \\
\hline ÁGUAS DE SANTA BÁRBARA & 1,7124 \\
\hline
\end{tabular}




\begin{tabular}{|l|r|}
\hline IARAS & 1,1800 \\
\hline BOREBI & 0,8096 \\
\hline LENÇÓIS PAULISTA & 24,2124 \\
\hline AREIÓPOLIS & 3,7684 \\
\hline IGARAÇU DO TIETÊ & 9,3144 \\
\hline SÃO MANUEL & 15,0192 \\
\hline BOTUCATU & 62,0430 \\
\hline PRATÂNIA & 1,4092 \\
\hline AVARÉ & 31,9464 \\
\hline ARANDU & 1,8472 \\
\hline CERQUEIRA CÉSAR & 6,3524 \\
\hline MANDURI & 3,1304 \\
\hline ÓLEO & 0,6988 \\
\hline BERNARDINO DE CAMPOS & 3,8648 \\
\hline OURINHOS & 50,5300 \\
\hline CANITAR & 1,6812 \\
\hline CHAVANTES & 4,4532 \\
\hline IPAUSSU & 5,0668 \\
\hline TIMBURI & 0,7680 \\
\hline PIRAJU & 10,2576 \\
\hline PARDINHO & 1,7764 \\
\hline ANHEMBI & 1,7344 \\
\hline BOFETE & 2,4972 \\
\hline POMPÉIA & 7,4808 \\
\hline ORIENTE & 2,2864 \\
\hline & 948,70 \\
\hline & \\
\hline & TOTAL \\
\hline
\end{tabular}

Fonte: Autor, 2013. 


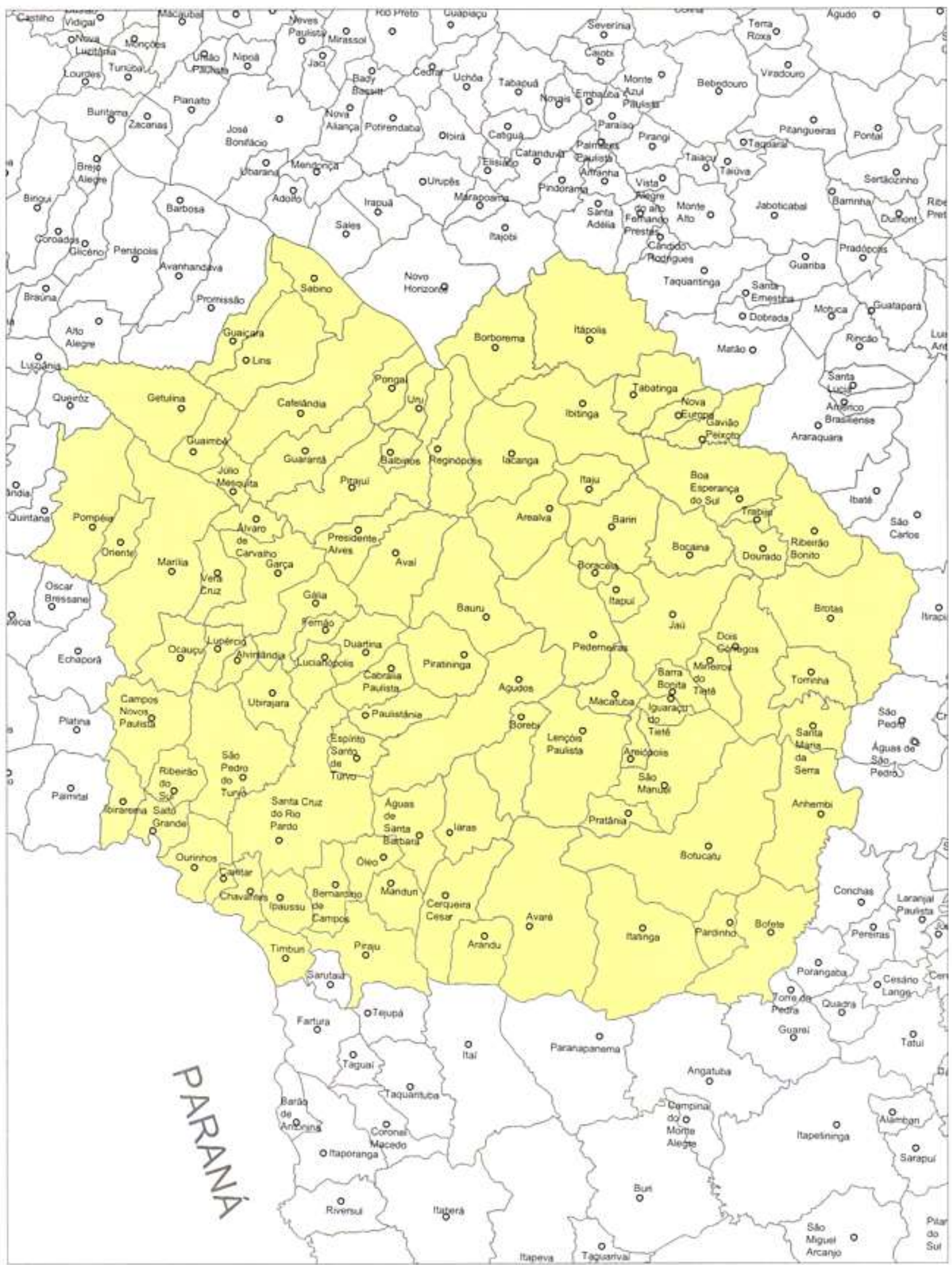

\section{REGIONALIZAÇÃO RAIO DE 100 KM REGIÃO - 5}

Figura 131. Regionalização Rio 100 km - Região 5

Fonte: Autor, 2013. 


\section{- Região 6}

Município polo: Campinas

Tabela 48. Municípios e produção diária de resíduos domiciliares da Região 6 - Raio de 100 km

\begin{tabular}{|c|c|}
\hline Município & RSU(t/dia) \\
\hline DIVINOLÂNDIA & 2,9836 \\
\hline SÃO SEBASTIÃO DA GRAMA & 3,1812 \\
\hline ITOBI & 2,7224 \\
\hline VARGEM GRANDE DO SUL & 14,9960 \\
\hline ÁGUAS DA PRATA & 2,7208 \\
\hline SÃO JOÃO DA BOA VISTA & 32,3052 \\
\hline AGUAÍ & 11,7100 \\
\hline $\begin{array}{l}\text { SANTO ANTÔNIO DO } \\
\text { JARDIM }\end{array}$ & 1,4088 \\
\hline $\begin{array}{l}\text { SANTO ANTÔNIO DO } \\
\text { PINHAL }\end{array}$ & 1,5452 \\
\hline MOGI GUAÇU & 65,6220 \\
\hline ESTIVA GERBI & 3,2336 \\
\hline LEME & 36,2760 \\
\hline $\begin{array}{l}\text { SANTA CRUZ DA } \\
\text { CONCEIÇÃO }\end{array}$ & 1,0932 \\
\hline ANALÂNDIA & 1,3808 \\
\hline ITIRAPINA & 5,6752 \\
\hline CORUMBATAÍ & 0,8388 \\
\hline RIO CLARO & 91,5355 \\
\hline ARARAS & 56,7540 \\
\hline CONCHAL & 9,6096 \\
\hline MOGI-MIRIM & 32,5228 \\
\hline ITAPIRA & 25,5776 \\
\hline ÁGUAS DE LINDÓIA & 6,8792 \\
\hline LINDÓIA & 2,7256 \\
\hline SOCORRO & 10,0608 \\
\hline SERRA NEGRA & 9,2248 \\
\hline IPEÚNA & 2,1156 \\
\hline ÁGUAS DE SÃO PEDRO & 1,1084 \\
\hline SÃO PEDRO & 10,7400 \\
\hline CHARQUEADA & 5,5316 \\
\hline
\end{tabular}




\begin{tabular}{|c|c|}
\hline SANTA GERTRUDES & 8,7356 \\
\hline CORDEIRÓPOLIS & 7,6700 \\
\hline ENGENHEIRO COELHO & 4,7272 \\
\hline ARTUR NOGUEIRA & 16,3068 \\
\hline HOLAMBRA & 3,3644 \\
\hline SANTO ANTÔNIO DE POSSE & 7,6044 \\
\hline AMPARO & 20,8556 \\
\hline PIRACICABA & 215,6424 \\
\hline IRACEMÁPOLIS & 7,9812 \\
\hline LIMEIRA & 161,8764 \\
\hline COSMÓPOLIS & 22,2664 \\
\hline JAGUARIÚNA & 17,6520 \\
\hline PEDREIRA & 16,6768 \\
\hline MONTE ALEGRE DO SUL & 1,6512 \\
\hline PEDRA BELA & 0,5772 \\
\hline VARGEM & 1,7968 \\
\hline JOANÓPOLIS & 4,7492 \\
\hline PIRACAIA & 10,1008 \\
\hline NAZARÉ PAULISTA & 5,6168 \\
\hline BOM JESUS DOS PERDÕES & 7,1236 \\
\hline ATIBAIA & 58,1490 \\
\hline BRAGANÇA PAULISTA & 71,9355 \\
\hline PINHALZINHO & 2,6140 \\
\hline TUIUTI & 1,2028 \\
\hline MORUNGABA & 4,0692 \\
\hline PAULÍNIA & 33,7736 \\
\hline AMERICANA & 127,0782 \\
\hline SANTA BÁRBARA D'OESTE & 89,6765 \\
\hline RIO DAS PEDRAS & 11,6036 \\
\hline CAMPINAS & 750,1452 \\
\hline CONCHAS & 5,3136 \\
\hline TORRE DE PEDRA & 0,5900 \\
\hline PORANGABA & 1,6328 \\
\hline QUADRA & 0,3360 \\
\hline TATUÍ & 51,6365 \\
\hline PEREIRAS & 2,0164 \\
\hline LARANJAL PAULISTA & 9,1304 \\
\hline
\end{tabular}




\begin{tabular}{|c|c|}
\hline SALTINHO & 2,3888 \\
\hline TIETÊ & 13,5388 \\
\hline JUMIRIM & 0,6600 \\
\hline CESÁRIO LANGE & 4,2520 \\
\hline CERQUILHO & 15,3212 \\
\hline MOMBUCA & 1,0784 \\
\hline CAPIVARI & 18,5680 \\
\hline RAFARD & 3,0436 \\
\hline BOITUVA & 18,5820 \\
\hline PORTO FELIZ & 16,5260 \\
\hline NOVA ODESSA & 20,4400 \\
\hline SUMARÉ & 144,0600 \\
\hline HORTOLÂNDIA & 97,8880 \\
\hline MONTE MOR & 18,7264 \\
\hline ELIAS FAUSTO & 5,0692 \\
\hline ITATIBA & 34,7920 \\
\hline IPERÓ & 7,1732 \\
\hline CAPELA DO ALTO & 5,8928 \\
\hline ARAÇOIABA DA SERRA & 7,6636 \\
\hline VALINHOS & 51,6835 \\
\hline JARINU & 7,5332 \\
\hline INDAIATUBA & 122,2434 \\
\hline VINHEDO & 25,1324 \\
\hline LOUVEIRA & 14,6684 \\
\hline ITUPEVA & 16,0804 \\
\hline JUNDIAÍ & 214,5822 \\
\hline VÁRZEA PAULISTA & 54,0930 \\
\hline CAMPO LIMPO PAULISTA & 29,9476 \\
\hline SALTO & 52,8580 \\
\hline CABREÚVA & 14,3256 \\
\hline ITU & 72,8095 \\
\hline SOROCABA & 411,4131 \\
\hline ARAÇARIGUAMA & 7,0140 \\
\hline SÃO ROQUE & 28,9348 \\
\hline MAIRINQUE & 13,9564 \\
\hline ALUMÍNIO & 5,6900 \\
\hline VOTORANTIM & 52,8050 \\
\hline
\end{tabular}




\begin{tabular}{|c|c|}
\hline SARAPUÍ & 2,6860 \\
\hline IBIÚNA & 10,0468 \\
\hline PILAR DO SUL & 8,3588 \\
\hline SALTO DE PIRAPORA & 12,7072 \\
\hline PIEDADE & 9,5324 \\
\hline TOTAL & $3.890,72$ \\
\hline
\end{tabular}

Fonte: Autor, 2013. 


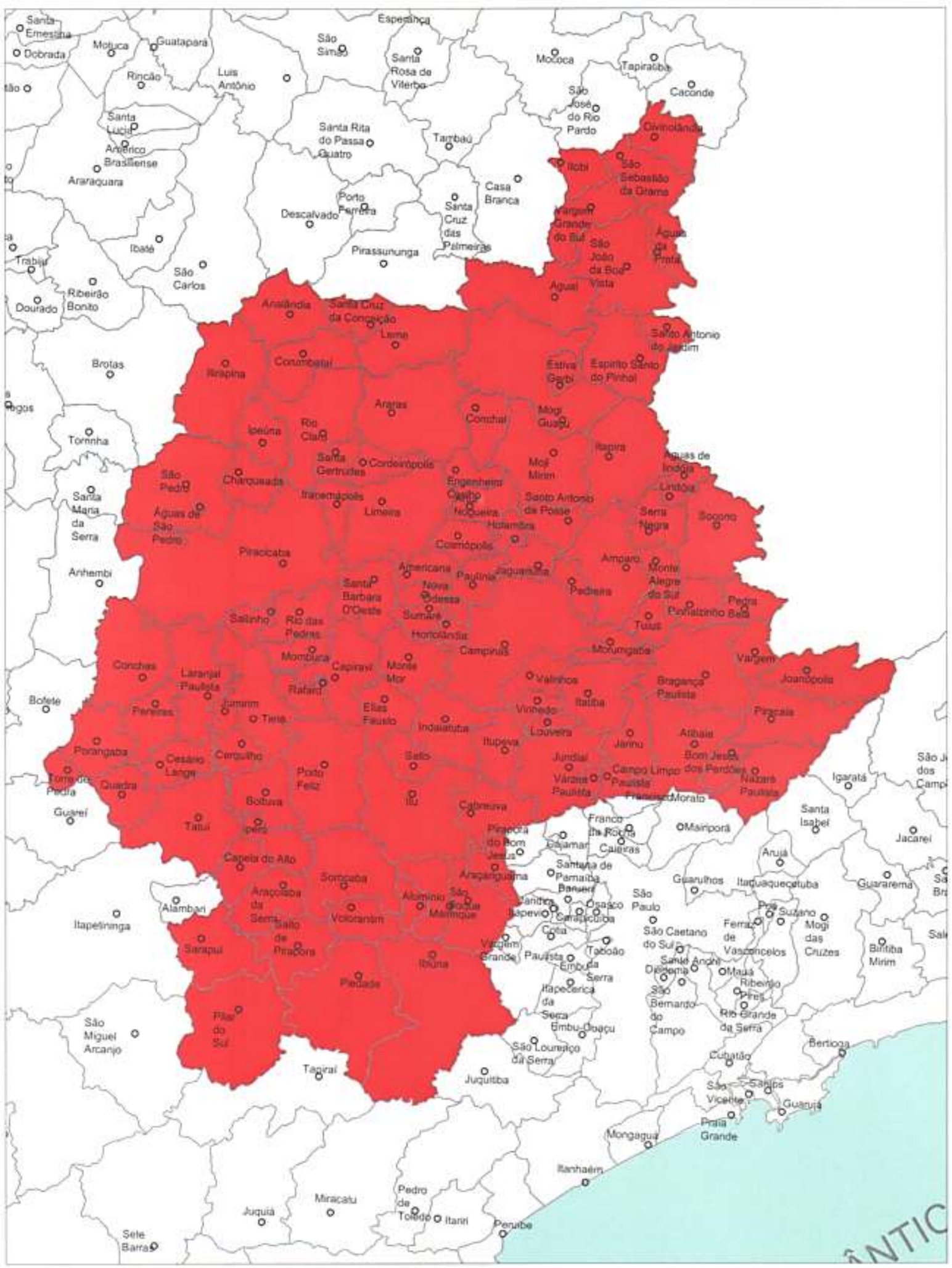

\section{REGIONALIZAÇÃO RAIO DE 100 KM REGIÃO - 6}

Figura 132. Regionalização Rio 100 km - Região 6

Fonte: Autor, 2013. 


\section{- Região 7}

Município polo: Itapeva

Tabela 49. Municípios e produção diária de resíduos domiciliares da Região 7 - Raio de 100 km

\begin{tabular}{|l|r|}
\hline \multicolumn{1}{|c|}{ MUNICÍPIO } & RSU(t/dia) \\
\hline SARUTAIÁ & 1,1800 \\
\hline BOM SUCESSO DE ITARARÉ & 0,9792 \\
\hline ITARARÉ & 17,7472 \\
\hline BARRA DO CHAPÉU & 0,6212 \\
\hline ITAPIRAPUÃ PAULISTA & 0,7616 \\
\hline RIBEIRA & 0,4928 \\
\hline ITAÓCA & 0,7044 \\
\hline APIAÍ & 7,2436 \\
\hline BARRA DO CHAPÉU & 0,6212 \\
\hline RIBEIRÃO BRANCO & 3,6712 \\
\hline GUAPIARA & 2,8720 \\
\hline RIBEIRÃO GRANDE & 0,9380 \\
\hline CAPÃO BONITO & 15,1160 \\
\hline BURI & 6,0200 \\
\hline ITAPEVA & 29,7092 \\
\hline NOVA CAMPINA & 2,3304 \\
\hline TAQUARIVAÍ & 1,1360 \\
\hline ITABERÁ & 4,8340 \\
\hline RIVERSUL & 1,7740 \\
\hline ITAPORANGA & 4,4176 \\
\hline BARÃO DE ANTONINA & 0,7712 \\
\hline FARTURA & 4,9028 \\
\hline TEJUPÁ & 1,2376 \\
\hline TAGUAÍ & 3,1768 \\
\hline CORONEL MACEDO & 1,5320 \\
\hline TAQUARITUBA & 7400 \\
\hline ITAÍ & \\
\hline PARANAPANEMA & \\
\hline ANGATUBA & \\
\hline
\end{tabular}




\begin{tabular}{|l|r|}
\hline $\begin{array}{l}\text { CAMPINA DO MONTE } \\
\text { ALEGRE }\end{array}$ & 1,8936 \\
\hline ITAPETININGA & 66,1810 \\
\hline SÃO MIGUEL ARCANJO & 8,6148 \\
\hline GUAREÍ & 3,4428 \\
\hline ALAMBARI & 1,4972 \\
\hline \multicolumn{2}{|r|}{ TOTAL } \\
\hline
\end{tabular}

Fonte: Autor, 2013. 


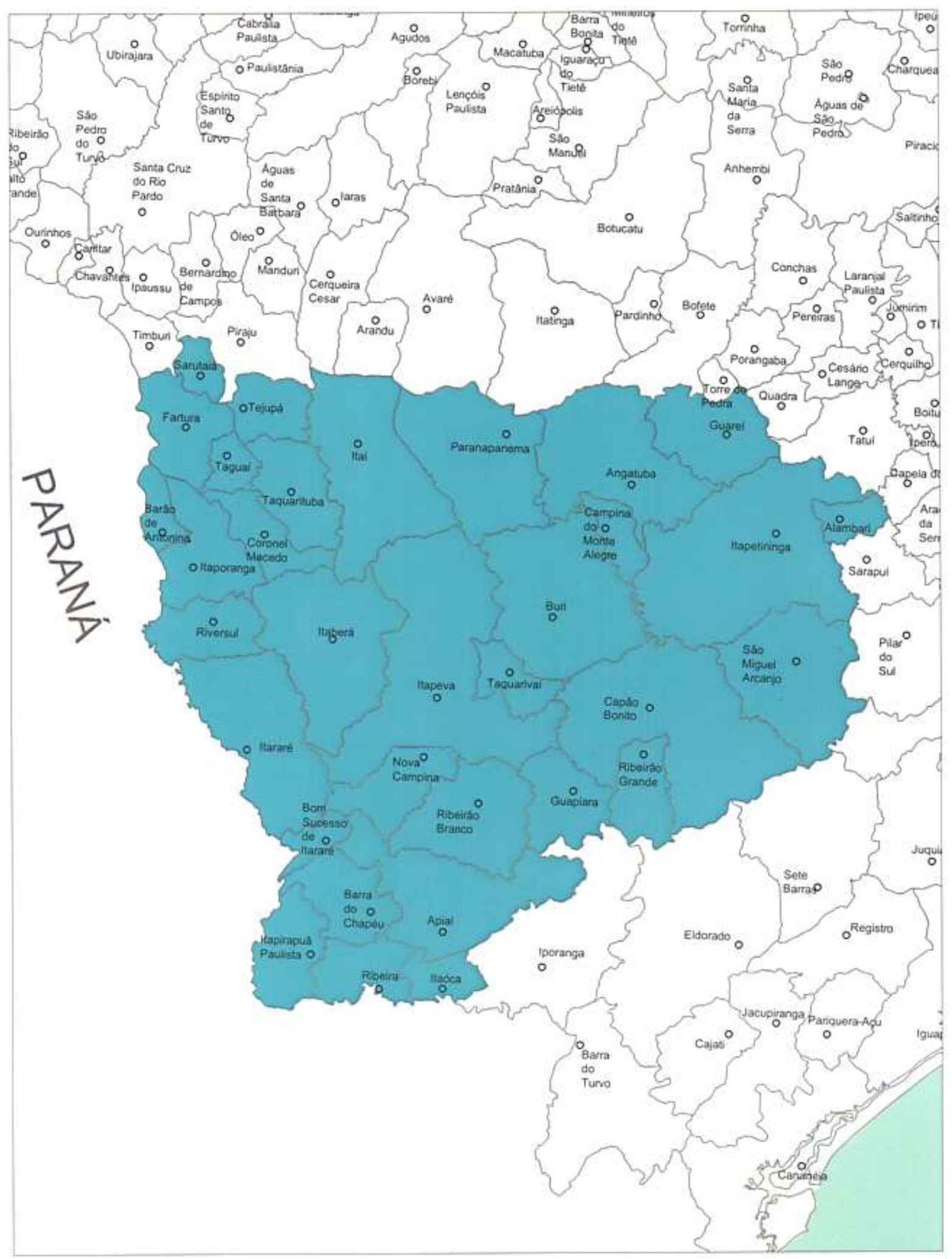

\section{REGIONALIZAÇÃO RAIO DE 100 KM REGIÃO - 7}

Figura 133. Regionalização Rio 100 km - Região 7

Fonte: Autor, 2013. 


\section{- Região 8}

Município polo: Juquiá

Tabela 50. Municípios e produção diária de resíduos domiciliares da

$$
\text { Região } 8 \text { - Raio de } 100 \text { km }
$$

\begin{tabular}{|l|r|}
\hline \multicolumn{1}{|c|}{ Município } & RSU(t/dia) \\
\hline ITARIRI & 3,9880 \\
\hline PEDRO DE TOLEDO & 2,8348 \\
\hline MIRACATU & 4,2064 \\
\hline TAPIRAí & 2,2792 \\
\hline JUQUIÁ & 4,8312 \\
\hline SETE BARRAS & 2,8644 \\
\hline REGISTRO & 19,2820 \\
\hline ELDORADO & 2,8896 \\
\hline IPORANGA & 0,9560 \\
\hline BARRA DO TURVO & 1,2648 \\
\hline CAJATI & 8,2692 \\
\hline JACUPIRANGA & 3,7504 \\
\hline PARIQUERA-AÇU & 5,0816 \\
\hline CANANÉIA & 4,1728 \\
\hline ILHA COMPRIDA & 3,6816 \\
\hline IGUAPE & 9,9120 \\
\hline PERUÍBE & 23,8948 \\
\hline ITANHAÉM & 34,9552 \\
\hline MONGAGUÁ & 18,7788 \\
\hline PRAIA GRANDE & 160,3842 \\
\hline CUBATÃO & 59,7600 \\
\hline SÃO VICENTE & 200,4186 \\
\hline SANTOS & 251,5170 \\
\hline GUARUJÁ & 175,6128 \\
\hline BERTIOGA & 19,2788 \\
\hline & $\mathbf{1 . 0 2 4 , 8 6}$ \\
\hline
\end{tabular}

Fonte: Autor, 2013. 


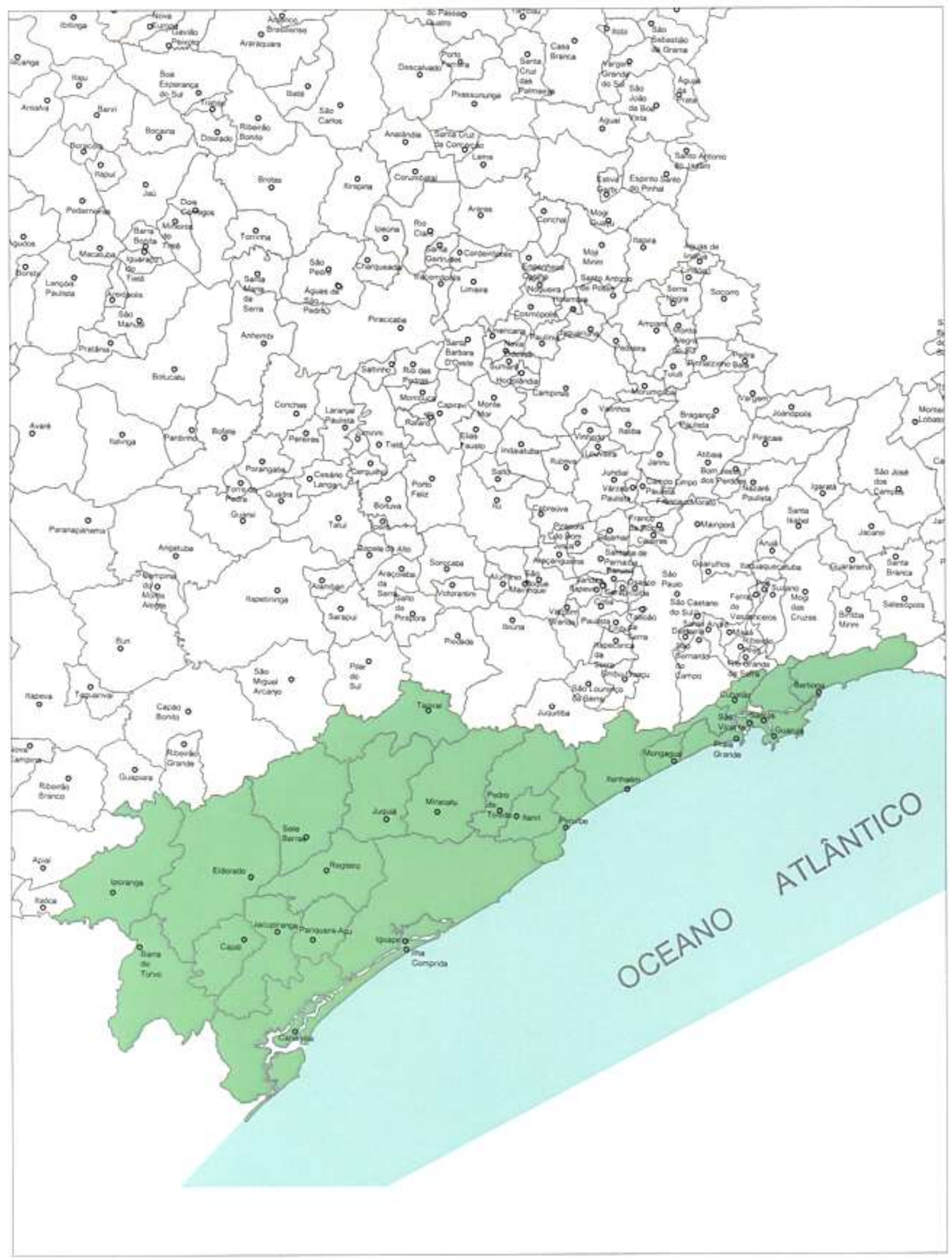

\section{REGIONALIZAÇÃO RAIO DE 100 KM REGIÃO - 8}

Figura 134. Regionalização Rio 100 km - Região 8

Fonte: Autor, 2013. 


\section{- Região 9}

Município polo: São Paulo

Tabela 51. Municípios e produção diária de resíduos domiciliares da Região 9 - Raio de 100 km

\begin{tabular}{|l|r|}
\hline \multicolumn{1}{|c|}{ MUnicípio } & \multicolumn{1}{r|}{ RSU(t/dia) } \\
\hline SALESÓPOLIS & 4,007 \\
\hline GUARAREMA & 9,000 \\
\hline SANTA ISABEL & 15,998 \\
\hline GUARULHOS & 863,405 \\
\hline MAIRIPORÃ & 28,859 \\
\hline FRANCISCO MORATO & 77,874 \\
\hline FRANCO DA ROCHA & 61,453 \\
\hline CAJAMAR & 25,531 \\
\hline PIRAPORA DO BOM JESUS & 6,396 \\
\hline SANTANA DE PARNAÍBA & 55,711 \\
\hline ITAPEVI & 122,227 \\
\hline VARGEM GRANDE & 17,516 \\
\hline PAULISTA & 123,092 \\
\hline COTIA & 5,138 \\
\hline SÃO LOURENÇO DA SERRA & 8,950 \\
\hline JUQUITIBA & 24,613 \\
\hline EMBU-GUAÇU & $12.850,100$ \\
\hline SÃO PAULO & 530,158 \\
\hline SÃO BERNARDO DO CAMPO & 76,547 \\
\hline ITAPECERICA DA SERRA & 9,914 \\
\hline BIRITIBA MIRIM & 195,311 \\
\hline ARUJÁ & 216,830 \\
\hline ITAQUAQUECETUBA & 474,900 \\
\hline MOGI DAS CRUZES & 153,446 \\
\hline SANTO ANDRÉ & 34,213 \\
\hline SUZANO & 467,478 \\
\hline CAIEIRAS & 222,901 \\
\hline OSASCO & 145,945 \\
\hline CARAPICUÍBA & \\
\hline BARUERI & \\
\hline
\end{tabular}




\begin{tabular}{|l|r|}
\hline JANDIRA & 54,807 \\
\hline TABOÃO DA SERRA & 148,876 \\
\hline EMBU & 145,638 \\
\hline DIADEMA & 233,146 \\
\hline SÃO CAETANO DO SUL & 74,981 \\
\hline POÁ & 52,555 \\
\hline FERRAZ DE VASCONCELOS & 81,328 \\
\hline MAUÁ & 252,710 \\
\hline RIBEIRÃO PIRES & 56,863 \\
\hline RIO GRANDE DA SERRA & 17,801 \\
\hline \multicolumn{2}{|c|}{ TOTAL } \\
\hline
\end{tabular}

Fonte: Autor, 2013. 


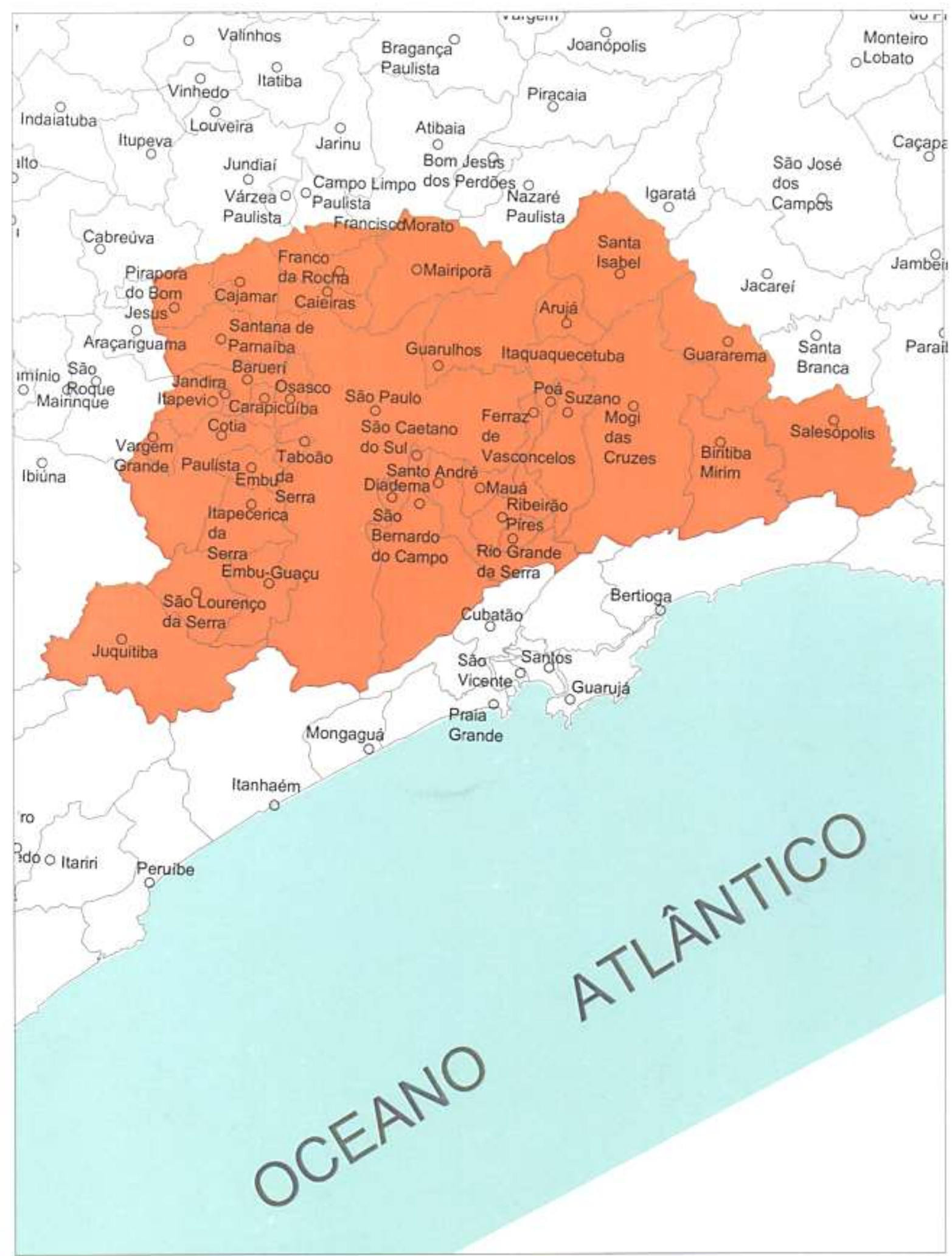

\section{REGIONALIZAÇÃO RAIO DE 100 KM REGIÃO - 9}

Figura 135. Regionalização Rio 100 km - Região 9

Fonte: Autor, 2013. 


\section{- Região 10}

Município polo: São José dos Campos

Tabela 52. Municípios e produção diária de resíduos domiciliares da Região 10 - Raio de 100 km

\begin{tabular}{|l|r|}
\hline \multicolumn{1}{|c|}{ MUnicÍpIO } & RSU(t/dia) \\
\hline BANANAL & 3,28 \\
\hline ARAPEÍ & 0,75 \\
\hline SÃO JOSÉ DO BARREIRO & 1,15 \\
\hline AREIAS & 0,99 \\
\hline QUEIROZ & 0,97 \\
\hline LAVRINHAS & 2,44 \\
\hline CRUZEIRO & 30,14 \\
\hline PIQUETE & 5,25 \\
\hline CACHOEIRA PAULISTA & 9,90 \\
\hline CANAS & 1,65 \\
\hline SILVEIRAS & 1,16 \\
\hline LORENA & 32,21 \\
\hline GUARATINGUETÁ & 53,67 \\
\hline APARECIDA & 13,80 \\
\hline CUNHA & 4,85 \\
\hline UBATUBA & 31,12 \\
\hline CARAGUATATUBA & 39,31 \\
\hline SÃO LUÍS DO PARAITINGA & 2,47 \\
\hline NATIVIDADE DA SERRA & 1,11 \\
\hline PARAIBUNA & 2,10 \\
\hline REDENÇÃO DA SERRA & 0,88 \\
\hline ILHABELA & 11,43 \\
\hline SÃO SEBASTIÃO & 20,80 \\
\hline SANTA BRANCA & 4,88 \\
\hline JACAREÍ & 125,88 \\
\hline SÃO JOSÉ DOS CAMPOS & 436,74 \\
\hline JAMBEIRO & 1,04 \\
\hline CAÇAPAVA & 23 \\
\hline MONTEIRO LOBATO & \\
\hline
\end{tabular}




\begin{tabular}{|l|r|}
\hline TAUBATÉ & 165,16 \\
\hline LAGOINHA & 1,25 \\
\hline IGARATÁ & 2,82 \\
\hline $\begin{array}{l}\text { SANTO ANTÔNIO DO } \\
\text { PINHAL }\end{array}$ & 1,55 \\
\hline SÃO BENTO DO SAPUCAÍ & 2,02 \\
\hline CAMPOS DO JORDÃO & 19,10 \\
\hline PINDAMONHANGABA & 71,63 \\
\hline TREMEMBÉ & 14,94 \\
\hline ROSEIRA & 3,68 \\
\hline POTIM & 6,02 \\
\hline \multicolumn{2}{|c|}{ TOTAL } \\
\hline
\end{tabular}

Fonte: Autor, 2013. 


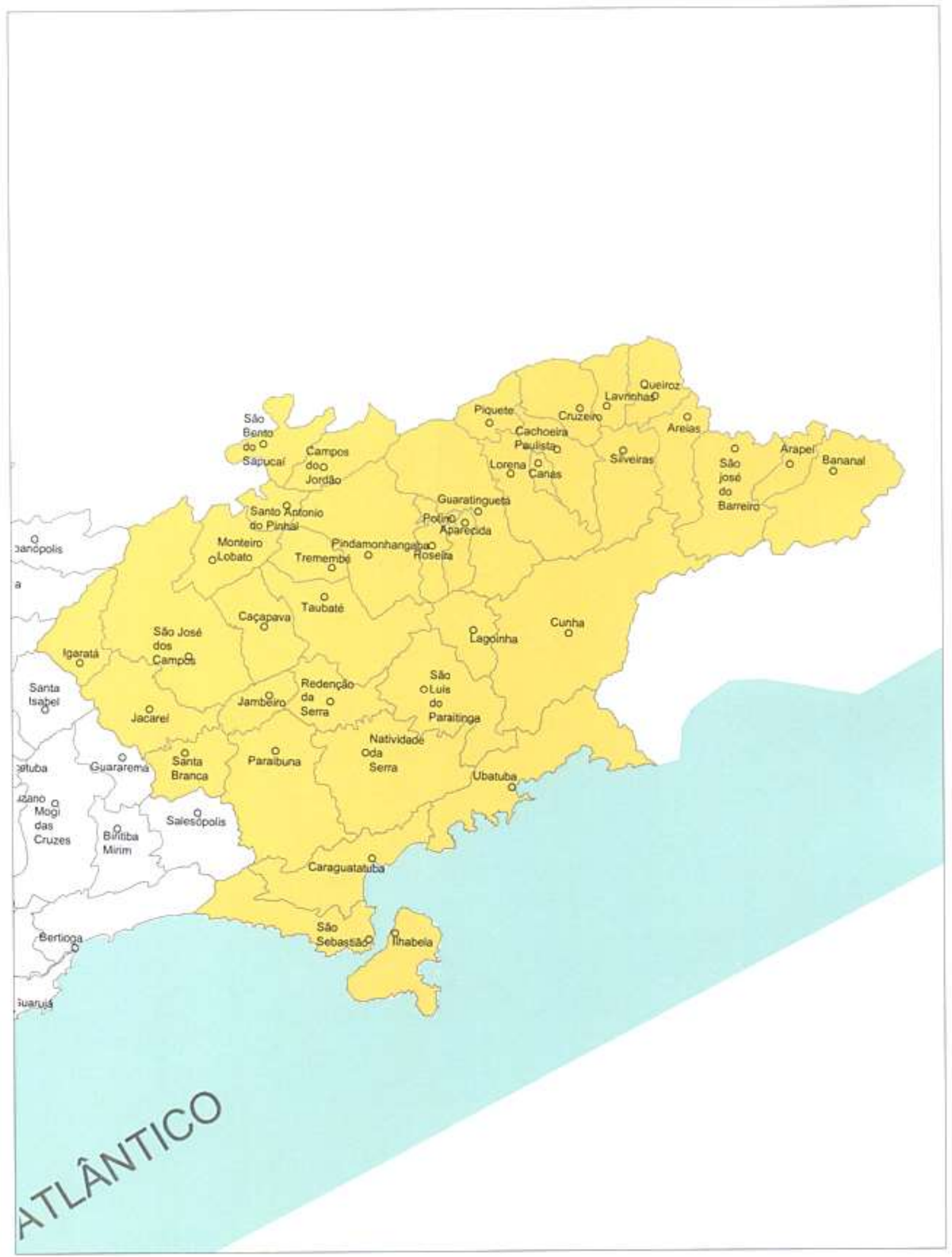

\section{REGIONALIZAÇÃO RAIO DE 100 KM REGIÃO - 10}

Figura 136. Regionalização Rio 100 km - Região 10

Fonte: Autor, 2013. 
Tabela 53. Proposta de regionalização do Estado de São Paulo - Cenário 2

\begin{tabular}{|c|c|c|}
\hline $\begin{array}{l}\text { REGIÃO } \\
\text { MUNICÍPIO } \\
\text { POLO }\end{array}$ & MUNICÍPIOS & $\begin{array}{l}\text { GERAÇÃO DE } \\
\text { RSU (t/dia) }\end{array}$ \\
\hline $\begin{array}{l}\text { Região } 1 \text { - } \\
\text { Auriflama }\end{array}$ & $\begin{array}{l}\text { Castilho, Nova Independência, Muritinga do Sul, } \\
\text { Guaraçaí, Andradina, Mirandópolis, Lavínia, } \\
\text { Valparaiso, Bento de Abreu, Rubiácea, } \\
\text { Guararapes, Piacatu, Gabriel monteiro, } \\
\text { Clementina, Araçatuba, Bilac, Birigui, } \\
\text { Coroados, Glicério, Brejo Alegre, Buritama, } \\
\text { Lourdes, Santo Antônio do Aracanguá, Nova } \\
\text { Luzitânia, Gastão Vidigal, Nova Castilho, } \\
\text { General Salgado, Pereira Barreto, Sud } \\
\text { Mennucci, Guzolândia, São João das Duas } \\
\text { Pontes, São João de Iracema, Pontalinda, Dirce } \\
\text { Reis, Palmeira D’Oeste, Marinópolis, Aparecida } \\
\text { D’Oeste, Suzanápolis, Itapura, Ilha Solteira, } \\
\text { Rubinéia, Santa Fé do Sul, Santa Clara D’Oeste, } \\
\text { Santa Rita D’Oeste, Nova Canaã paulista, Três } \\
\text { Fronteiras, Santana da Ponte Pensa, Santa } \\
\text { Albertina, Mesópolis, Populina, Ouroeste, } \\
\text { Indiaporã, Mira Estrela, Paranapuã, Santa } \\
\text { Salete, Urânia, São Francisco, Jales, } \\
\text { Dolcinópolis, Turmalina, Vitória Brasil, Estrela } \\
\text { D’Oeste, Fernandópolis, Guarani D’Oeste, } \\
\text { Macedônia, Pedranópolis, Floreal, Magda e } \\
\text { Meridiano. }\end{array}$ & 352,55 \\
\hline $\begin{array}{c}\text { Região } 2 \text { - São } \\
\text { José do Rio } \\
\text { Preto }\end{array}$ & $\begin{array}{l}\text { São José do Rio Preto, Mirassol, Mirassolândia, } \\
\text { Ipiguá, Bady Bassitt, Cedral, Guapiaçu, Onda } \\
\text { Verde, Nova Granada, Bálsamo, Tanabi, Monte } \\
\text { Aprazível, Poloni, Nipoã, Neves Paulista, Jaci, } \\
\text { Nova Aliança, Uchoa, Catiguá, Novais, } \\
\text { Embaúba, Paraíso, Monte Azul Paulista, Cajobi, }\end{array}$ & 693,36 \\
\hline
\end{tabular}




\begin{tabular}{|c|c|c|}
\hline $\begin{array}{l}\text { REGIÃO } \\
\text { MUNICÍPIO } \\
\text { POLO }\end{array}$ & MUNICÍPIOS & $\begin{array}{l}\text { GERAÇÃO DE } \\
\text { RSU (t/dia) }\end{array}$ \\
\hline & $\begin{array}{l}\text { Severínia, Olímpia, Colina, Barretos, Guaíra, } \\
\text { Colômbia, Guaraci, Icém Altair, Orindiúva, } \\
\text { Paulo de Faria, Palestina, Cosmorama, José } \\
\text { Bonifácio, Ubarana, Mendonça, Sales, Irapuã, } \\
\text { Urupes, Catanduva, Elisiário, Marapoama, } \\
\text { Itajobi, Novo Horizonte, Pindorama, Palmares } \\
\text { Paulista, Ariranha, Santa Adélia, Pirangi, } \\
\text { Fernando Prestes, Vista Alegre do Alto, } \\
\text { Cardoso, Pontes Gestal, Américo de Campos, } \\
\text { Alvares Florence, Votuporanga, Valentim } \\
\text { Gentil, Parisi, Nhandeara, Sebastianópolis do } \\
\text { Sul, Macaubal, Promissão, Penápolis, } \\
\text { Avanhandava, Barbosa, Zacarias, Planalto, } \\
\text { União Paulista, Monções, Turiúba e Alto Alegre. }\end{array}$ & \\
\hline $\begin{array}{c}\text { Região } 3 \text { - } \\
\text { Ribeirão Preto }\end{array}$ & $\begin{array}{l}\text { Ribeirão Preto, Jardinópolis, Sertãozinho, } \\
\text { Dumont, Cravinhos, Barrinha, Pradópolis, } \\
\text { Guatapará, Luís Antônio, São Simão, Serra } \\
\text { Azul, Serrana, Altinópolis, Brodowski, Santa } \\
\text { Cruz da Esperança, Batatais, Sales Oliveira, } \\
\text { Pontal, Pitangueiras, Jaboticabal, Guariba, } \\
\text { Santo Antônio da Alegria, Cajuru, Cássia dos } \\
\text { Coqueiros, Mococa, Santa Rosa de Viterbo, } \\
\text { Tambaú, Santa Rita do Passa Quatro, Casa } \\
\text { Branca, Santa Cruz das Palmeiras, } \\
\text { Pirassununga, Porto Ferreira, Descalvado, } \\
\text { Rincão, Ibaté, São Carlos, Araraquara, Américo } \\
\text { Brasiliense, Santa Lúcia, Dobrada, Motuca, } \\
\text { Matão, Santa Ernestina, Taquaritinga, Itirapuã, } \\
\text { Patrocínio Paulista, Franca, Restinga, }\end{array}$ & $1.554,35$ \\
\hline REGIÃO & MUNICÍPIOS & GERAÇÃO DE \\
\hline
\end{tabular}


Região 4 -

Presidente

Prudente
Miguelópolis, Igarapava, Aramina, Rifaina, Pedregulho, Cristais Paulistas, Buritizal, Ituverava, Jeriquara, Ribeirão Corrente, Guará, São José da Bela Vista, Nuporanga, Orlândia, São Joaquim da Barra, Ipuã, Morro Agudo, Monte Alto, Cândido Rodrigues, Taiúva, Taiaçu, Viradouro, Bebedouro, Taquaral, Terra Roxa, Jaborandi, São José do Rio Pardo, Tapiratiba e Caconde.

Presidente Prudente, Caiabu, Palmital, Rosana, Euclides da Cunha Paulista, Teodoro Sampaio, Presidente Epitácio, Caiuá, Marabá Paulista, Mirante do Paranapanema, Sandovalina, Pirapozinho, Estrela do Norte, Tarabaí, Presidente Venceslau, Piquerobi, Santo Anastácio, Presidente Bernardes, Álvares Machado, Narandiba, Anhaumas, Taciba, Nantes, Regente Feijó, lepê, Maracaí, Cruzália, Pedrinhas Paulista, Florínea, Cândido Mota, Tarumã, Platina, Echaporã, Assis, Indiana, Martinópolis, Rancharia, João Ramalho, Quatá, Paraguaçu Paulista, Borá, Lutécia, Oscar Bressane, Herculândia, Tupã, lacri, Bastos, Marinópolis, Parapuã, Osvaldo Cruz, Sagres, Salmourão, Inúbia Paulista, Pracinha, Alfredo Marcondes, Ribeirão dos Índios, Emilianópolis, Santo Expedito, Mariápolis, Flora Rica, Paulicéia, Panorama, Ouro Verde, São João do Pau D'Alho, Santa Mercedes, Dracena, Junqueirópolis, Nova Guataporanga, 


\begin{tabular}{|c|c|c|}
\hline $\begin{array}{l}\text { REGIÃO } \\
\text { MUNICÍPIO } \\
\text { POLO }\end{array}$ & MUNICÍPIOS & $\begin{array}{l}\text { GERAÇÃO DE } \\
\text { RSU (t/dia) }\end{array}$ \\
\hline & $\begin{array}{l}\text { Monte Castelo, Tupi Paulista, Irapuru, } \\
\text { Pacaembu, Flórida Paulista, Adamantina, } \\
\text { Lucélia, Queiroz, Arco-Iris, Santóppolis do } \\
\text { Aguapeí, Luiziânia e braúna. }\end{array}$ & \\
\hline $\begin{array}{c}\text { Região } 5 \text { - } \\
\text { Bauru }\end{array}$ & $\begin{array}{l}\text { Bauru, Pederneiras, Arealva, Avaí, Agudos, } \\
\text { Piratininga, Borborema, Itápolis, tabatinga, } \\
\text { Nova Europa, Gavião Peixoto, Reginópolis, } \\
\text { lacanga, Ibitinga, Itaju, Bariri, Boa Esperança } \\
\text { do Sul, Boracéa, Itapuí, Bocaina, Jaú, Trabiju, } \\
\text { Ribeirão Bonito, Dourado, Brotas, Dois } \\
\text { Córregos, Torrinha, Santa Maria da Serra, } \\
\text { Mineiros do Tietê, Barra Bonita, Macatuba, } \\
\text { Sabino, Getulina, Guaimbê, Guaiçara, Lins, } \\
\text { Cafelândia, Pongaí, Uru, Guarantã, Júlio } \\
\text { Mesquita, Pirajuí, Balbinos, Marília, Ocauçu, } \\
\text { Vera Cruz, Álvaro de Carvalho, Presidente } \\
\text { Alves, Garça, Gália, Lupércio, Alvilândia, } \\
\text { Fernão Duartina, Lucianópolis, Ubirajara, } \\
\text { Cabrália Paulista, Paulistânia, Espírito Santo do } \\
\text { Turvo, Campos Novos Paulista, Ibirarema, Salto } \\
\text { grande, Ribeirão do Sul, São Pedro do Turvo, } \\
\text { santa Cruz do Rio Pardo, Águas de Santa } \\
\text { Bárbara, laras, Borebi, Lençois Paulista, } \\
\text { Areiópolis, Igaraçu do Tietê, São Manuel, } \\
\text { Botucatu, Pratânia, Avaré, Arandu, Cerqueira } \\
\text { César, Manduri, Óleo, Bernardino de Campos, } \\
\text { Ourinhos, Canitar, Chavantes, Ipussu, Timburi, } \\
\text { Piraju, Pardinho, Anhambi, Bofete, Pompéia e } \\
\text { Oriente. }\end{array}$ & 948,70 \\
\hline
\end{tabular}




\begin{tabular}{|c|c|c|}
\hline $\begin{array}{c}\text { REGIÃO } \\
\text { MUNICÍPIO } \\
\text { POLO }\end{array}$ & MUNICÍPIOS & $\begin{array}{l}\text { GERAÇÃO DE } \\
\text { RSU (t/dia) }\end{array}$ \\
\hline $\begin{array}{l}\text { Região } 6 \text { - } \\
\text { Campinas }\end{array}$ & $\begin{array}{l}\text { Divinolândia, São Sebastião da Grama, Itobi, } \\
\text { Vargem Grande do Sul, Águas da Prata, São } \\
\text { João da Boa Vista, Aguaí, Santo Antônio do } \\
\text { Jardim, Santo Antônio do Pinhal, Mogi Guaçu, } \\
\text { Estiva Gerbi, Leme, Santa Cruz da Conceição, } \\
\text { Analândia, Itirapina, Corumbataí, Rio Claro, } \\
\text { Araras, Conchal, Mogi-mirim, Itapira, Águas de } \\
\text { Lindóia, Lindóia, Socorro, Serra Negra, Ipeúna, } \\
\text { Águas de São Pedro, São Pedro, Charqueada, } \\
\text { santa Gertrudes, Cordeirópolis, Engenheiro } \\
\text { Coelho, Artur Nogueira, Holambra, Santo } \\
\text { Antônio de Posse, Amparo, Piracicaba, } \\
\text { Iracemópolis, Limeira, Cosmópolis, Jaguariúna, } \\
\text { Pedreira, Monte Alegre do Sul, Pedra Bela, } \\
\text { Vargem, Joanópolis, Piracaia, Nazaré Paulista, } \\
\text { Bom Jesus dos Perdões, Atibaia, Bragança } \\
\text { Paulista, Pinhalzinho, Tuiuti, Morungaba, } \\
\text { Paulínia, Americana, Santa Bárbara D’Oeste, } \\
\text { Rio das Pedras, Campinas, Conchas, Torre de } \\
\text { Pedra, Porangaba, Quadra, Tatuí, Pereiras, } \\
\text { Laranjal Paulista, Saltinho, Tietê, Jumirim, } \\
\text { Cesário Lange, Cerquilho, Mombuca, Capivari, } \\
\text { Rafard, Boituva, Porto Feliz, Nova Odessa, } \\
\text { Sumaré, Hortolândia, Monte Mor, Elias fausto, } \\
\text { Itatiba, Iperó, Capela do Alto, Araçoiaba da } \\
\text { Serra, Valinhos, Jarinu, Indaiatuba, Vinhedo, } \\
\text { Louveira, Itupeva, Jundiaí, Várzea Paulista, } \\
\text { Campo Limpo Paulista, Salto, Cabreúva, Itu, } \\
\text { Sorocaba, Araçariguama, São Roque, Mairinqe, }\end{array}$ & $3.890,72$ \\
\hline
\end{tabular}




\begin{tabular}{|c|c|c|}
\hline $\begin{array}{l}\text { REGIÃO } \\
\text { MUNICÍPIO } \\
\text { POLO }\end{array}$ & MUNICÍPIOS & $\begin{array}{l}\text { GERAÇÃO DE } \\
\text { RSU (t/dia) }\end{array}$ \\
\hline & $\begin{array}{l}\text { Alumínio, Votorantim, Sarapuí, Ibiúna, Pilar do } \\
\text { Sul, Salto de Pirapora e Piedade. }\end{array}$ & \\
\hline $\begin{array}{c}\text { Região } 7 \text { - } \\
\text { Itapeva }\end{array}$ & $\begin{array}{l}\text { Sarutaiá, Bom Sucesso de Itararé, Barra do } \\
\text { Chapéu, Itapirapuã Paulista, Ribeira, Itaóca, } \\
\text { Apiaí, Barra do Chapéu, Ribeirão Branco, } \\
\text { Guapiara, Ribeirão grande, Capão Bonito, Buri, } \\
\text { Itapeva, Nova Campina, Taquravaí, Itaberá, } \\
\text { Riversul, Itaporanga, Barão de Antonina, } \\
\text { Fartura, Tejupá, Taguaí, Coronel Macedo, } \\
\text { Taquarituba, Itaí, Paranapanema, Angatuba, } \\
\text { Campina do Monte Alegre, Itapetininga, São } \\
\text { Miguel Arcanjo, Guareí e Alambari. }\end{array}$ & 224,16 \\
\hline $\begin{array}{r}\text { Região } 8 \\
\text { Juquiá }\end{array}$ & $\begin{array}{l}\text { Itariri, Pedro de Toledo, Miracatu, Tapiraí, } \\
\text { Juquiá, Sete Barras, Registro, Eldorado, } \\
\text { Iporanga, Barra do Turvo, Cajati, Jacupiranga, } \\
\text { Pariquera-Açu, Cananéia, Itha Comprida, } \\
\text { Iguape, Peruíbe, Itanhaém, Mongaguá, Praia } \\
\text { Grande, Cubatão, São Vicente, Santos, Guarujá } \\
\text { e Bertioga. }\end{array}$ & $1,024,86$ \\
\hline $\begin{array}{c}\text { Região } 9 \text { - São } \\
\text { Paulo }\end{array}$ & $\begin{array}{l}\text { Salesópolis, Guararema, Santa Isabel, } \\
\text { Guarulhos, Mairiporã, Francisco Morato, Franco } \\
\text { da Rocha, Cajamar, Pirapora do Bom Jesus, } \\
\text { Santana do Parnaíba, Itapevi, Vargem Grande } \\
\text { Paulista, Cotia, São Lourenço da Serra, } \\
\text { Juquitiba, Embu-Guaçu, São Paulo, São } \\
\text { Bernardo, Itapecirica da Serra, Biritiba Mirim, } \\
\text { Arujá, Itaquaquecetuba, Mogi das Cruzes, Santo } \\
\text { André, Suzano, Caieiras, Osasco, Carapicuíba, } \\
\text { Barueri, Jandira, Taboão da Serra, Embu, } \\
\text { Diadema, São Caetano do Sul, Poá, }\end{array}$ & $17.975,44$ \\
\hline
\end{tabular}




\begin{tabular}{|c|c|c|}
\hline \multirow[t]{2}{*}{$\begin{array}{l}\text { REGIÃO } \\
\text { MUNICÍPIO } \\
\text { POLO }\end{array}$} & MUNICÍPIOS & $\begin{array}{l}\text { GERAÇÃO DE } \\
\text { RSU (t/dia) }\end{array}$ \\
\hline & $\begin{array}{l}\text { Ferraz de Vasconcelos, Mauá, Ribeirão Pires e } \\
\text { Rio Grande da Serra. }\end{array}$ & \\
\hline $\begin{array}{c}\text { Região } 10 \text { - } \\
\text { São José dos } \\
\text { Campos }\end{array}$ & $\begin{array}{l}\text { Bananal, Arapeí, São José do Barreiro, Areias, } \\
\text { Queiroz, Lavrinhas, Cruzeiro, Piquete, } \\
\text { Cachoeira Paulista, Canas, Silveiras, Lorena, } \\
\text { Guaratinguetá, Aparecida, Cunha, Ubatuba, } \\
\text { Caraguatatuba, São Luís do Paraitinga, } \\
\text { Natividade da Serra, Paraibuna, Redenção da } \\
\text { Serra, Ilhabela, São Sebastião, Santa Branca, } \\
\text { Jacareí, São José dos Campos, Jambeiro, } \\
\text { Caçapava, Monteiro Lobato, Taubaté, } \\
\text { Lagoinha, Igaratá, Santo Antônio do Pinhal, São } \\
\text { Bento do Sapucaí, Campos do Jordão, } \\
\text { Pindamonhangaba, Tremembé, Roseira e } \\
\text { Potim. }\end{array}$ & $1.158,08$ \\
\hline
\end{tabular}




\section{DISCUSSÕES}

- DAS VISITAS TÉCNICAS

As visitas técnicas realizadas nos sistemas de gerenciamento de resíduos sólidos de Portugal, Espanha, Bélgica e França, possibilitaram ao visitante observar não só a realidade técnica administrativa dos consórcios, bem como suas instalações, organização dos equipamentos, logísticas e operações básicas inerentes a gestão de resíduos.

Durante as visitas e em entrevistas com os profissionais que acompanharam o pesquisador, pode-se apreender nos consórcios visitados que:

- O consorciamento proporciona ganhos de escala;

- A equipe técnica do consórcio é emancipada;

- A gestão não sofre influência política;

- A gestão deve ser de forma integrada; 
- A gestão dos resíduos sólidos deve estar inserida nos contextos regional, estadual e nacional;

- O Plano de Gestão de Resíduos Sólidos é importante instrumento para análise de indicadores e cumprimento de metas;

- Deve-se aplicar tecnologias de ponta na gestão dos resíduos sólidos;

- São grandes os desafios: diminuir a geração de resíduos, aumentar as taxas de reciclagem e reduzir as emissões de carbono;

- A higiene e a beleza arquitetônica devem ser agregadas aos locais de trabalho;

- Os sistemas de coleta devem ser mantidos com o pagamento de taxas específicas pelos usuários;

- Os sistemas devem possuir sustentabilidade econômica e financeira para promover modernizações e ampliações;

- Há forte presença de parceria público privada na questão da valorização energética dos resíduos;

- Deve-se implantar a valorização multimaterial, a valorização orgânica e a valorização energética dos resíduos como forma de ganho de capital;

- A existência de organizações como a Sociedade Ponto Verde fomentam a gestão dos recicláveis, dando credibilidade, recursos e contribuindo com a logística reversa de multimateriais; 
- DO PLANO ESTADUAL

- O Ordenamento do Território Paulista

o Plano deve conter um ordenamento territorial abrangente, especificando as atividades e usos da terra nas atividades de gestão de resíduos, principalmente nas áreas frágeis ambientalmente.

- Relação com outros Planos e Políticas

Diferentes áreas de planejamento estão diretamente relacionadas com a gestão de resíduos sólidos e devem ser consideradas. O Plano Estadual deve ser parte integrante de uma abordagem mais ampla, como o Plano Nacional, a fim de alcançar os objetivos globais fixados.

- O Planejamento Ambiental

O planejamento dos resíduos tem fortes ligações com o ambiental, pois deve fazer parte de uma planificação global para garantir que metas ambientais possam ser alcançadas.

- O Planejamento Energético

A produção de energia em instalações de resíduos através de centrais elétricas, plantas de incineração, biogás ou outros equipamentos industriais que utilizam resíduos como combustíveis, podem fazer parte das medidas adotadas para atingir metas de política climática.

\section{- Os Resíduos Domiciliares}

As informações disponíveis para descrever a conjuntura técnica e ambiental dos resíduos sólidos domiciliares no Estado de São Paulo, encontram-se limitadas ao Inventário Estadual elaborado pela Cetesb.

Os dados divulgados sobre a quantidade gerada por município no Inventário é de validade questionável, pois se baseia numa produção por habitante limitada a uma tabela com quatro faixas, sem considerar a pesagem dos resíduos, permitindo somente uma observação quantitativa aproximada da situação atual. 
O Ministério das Cidades (MCidades) define ainda coeficientes de geração per capita de RSU a serem utilizados de acordo com as faixas de população dos municípios, conforme apresentado na Tabela 54.

Tabela 54 - Geração média per capita de RSU por faixas de população, segundo o Ministério das Cidades

\begin{tabular}{|c|c|}
\hline $\begin{array}{c}\text { Faixa de população } \\
\text { (habitantes) }\end{array}$ & $\begin{array}{c}\text { Geração média per capita } \\
\text { (kg/hab.dia) }\end{array}$ \\
\hline até 15.000 & 0,60 \\
\hline de 15.001 a 50.000 & 0,65 \\
\hline de 50.001 a 100.000 & 0,70 \\
\hline de 100.001 a 200.000 & 0,80 \\
\hline de 200.001 a 500.000 & 0,90 \\
\hline de 500.001 a 1.000 .000 & 1,15 \\
\hline
\end{tabular}

Fonte: MCidades, 2009.

Faz-se necessário que o estado promova um levantamento da caracterização, quantificação e dos fluxos dos resíduos sólidos de seu território, para que se possa trabalhar com informações e dados precisos e válidos.

- Os resíduos Industriais

A realização de um novo Inventário Estadual dos Resíduos Industriais é essencial para que se conheça o conjunto de resíduos produzidos e manipulados pela indústria paulista.

O Plano Estadual deverá considerar a implantação da obrigatoriedade da apresentação anual por parte das indústrias de um inventário de seus resíduos industriais, contendo no mínimo dados sobre geração, destinação e disposição de resíduos sólidos. 
- Resíduos Elétricos e Eletrônicos

O Estado é omisso em suas ações para a gestão segura do lixo elétrico e eletrônico, que deve ser classificado como "Resíduos Classe I: Perigosos", pois possui elementos tóxicos e metais pesados como: Alumínio, Arsênico, Cádmio, Chumbo, Cobalto, Cobre, Cromo hexavalente, Estrôncio, Manganês, Mercúrio, Molibdênio, Níquel, Ouro, Prata, Paládio, Titânio, Tungstênio, Vanádio, Zinco; bem como solventes clorados, compostos orgânicos policromados, compostos de retardantes de chama bromados, PVC, plásticos e gases.

Assim, deverá em seu Plano estipular metas de reciclagem, considerando toda a cadeia, procurando transferir a atividade do setor informal para o formal, o que pode proporcionar a criação de empregos, redução de emissões gasosas, economia de energia e recursos naturais e, riscos ambientais.

\section{- Regionalização}

Vários cenários de regionalização são possíveis utilizando-se de diversos critérios técnicos, porém devemos atender às demandas da população do Estado, atendendo aos seus anseios por meio de oficinas ou audiências durante o processo de construção da regionalização.

Para todos os cenários foram considerados os dados do Inventário Estadual de Resíduos Domiciliares do Estado de São Paulo, ano de referência 2011, elaborado pela CETESB e o Mapa Rodoviário do Estado de São Paulo do Departamento de Estradas e Rodagem do Estado de São Paulo.

A regionalização proposta no cenário 1 demonstrou não ser a mais adequada, pois os custos para implantação de um aterro sanitário seriam muito elevados, não proporcionando um ganho de escala que justificasse o investimento.

No cenário 2 o arranjo de regionalização a vantagem refere-se à escala de produção de resíduos sólidos, o que proporciona menores custos de implantação, operação, encerramento e monitoramento. 
A tabela 55 demonstra o enquadramento da regionalização efetuada no cenário 2, adotando-se os parâmetros da ABETRE e FGV.

Tabela 55 - Enquadramento da regionalização

\begin{tabular}{|l|c|l|}
\hline \multicolumn{1}{|c|}{ Cidade pólo } & Prod. Resíduos (t/dia) & Enquadramento \\
\hline Auriflama & 352,55 & Pequeno porte \\
\hline S. J. do Rio Preto & 693,36 & Pequeno - médio \\
\hline Presidente Prudente & $1.554,35$ & Médio - grande \\
\hline Ribeirão Preto & 480,50 & Pequeno - médio \\
\hline Bauru & 948,70 & Médio porte \\
\hline Campinas & $3.890,72$ & Grande porte \\
\hline Itapeva & 224,16 & Pequeno porte \\
\hline Juquiá & $1.024,86$ & Médio porte \\
\hline São Paulo & $17.975,44$ & Grande porte \\
\hline S. J. dos Campos & $1.158,08$ & Médio porte \\
\hline
\end{tabular}

O anexo A apresenta o modelo de um questionário utilizado para efetuar o diagnóstico da gestão de resíduos sólidos do Estado de Alagoas. $O$ anexo $B$ é composto pelo regime jurídico adotado em Portugal para instalação e exploração dos Centros integrados de recuperação, valorização e eliminação de resíduos perigosos e no anexo C estão as sínteses dos planos da Holanda, Finlândia, Inglaterra e Escócia.

A elaboração do Plano de Gestão de Resíduos Sólidos poderá proporcionar ações associadas de melhoria do manejo desses resíduos, bem como, propiciar oportunidades de benefícios para a sustentabilidade ambiental, econômica e social ao Estado de São Paulo e seus municípios. 


\section{7 \\ CONCLUSÕES E SUGESTÕES}

A implementação da Política Nacional de Resíduos Sólidos (PNRS), instituída pela Lei Federal $n^{\circ} 12.305$ de 2 de agosto de 2010 e regulamentada pelo Decreto 7.404 de 23 de dezembro de 2010, tem se apresentado como um grande desafio para a maioria dos estados, principalmente quanto a proposição de seus planos de resíduos sólidos.

A PNRS sancionou conceitos e princípios pouco conhecidos e praticados anteriormente, possibilitando a adoção de novas ferramentas de gestão dos resíduos sólidos, dando condições para a implementação de acordos setoriais, logística reversa, coleta seletiva, responsabilidade compartilhada e elaboração dos planos de resíduos sólidos. 
O objetivo deste trabalho de pesquisa é elaborar contribuições ao Plano Estadual de Resíduos Sólidos do Estado de São Paulo, visando subsidiar o futuro plano paulista com diagnósticos e cenários do gerenciamento dos resíduos sólidos e também a partir dos objetivos a saber:

> Identificar os locais de disposição e tratamento de resíduos sólidos no Estado. Foram levantados por meio de questionários enviados às Agencias Ambientais da Cetesb e de fontes secundárias na internet;

> Estudar modelos de gestão e gerenciamento de resíduos sólidos europeus. Esta etapa foi cumprida através de visitas técnicas e entrevistas feitas pelo pesquisador com os gestores dos sistemas de gerenciamento de resíduos sólidos em Portugal, Espanha, Bélgica e França;

> Executar o levantamento dos consórcios públicos para gestão de resíduos sólidos existentes no Estado. Para cumprir esta etapa foram obtidas informações por meio do SINIS, sítios da internet e posteriormente checados através de telefonemas às prefeituras participantes dos consórcios;

> Sugerir soluções consorciadas para manejo de resíduos sólidos, com base nas Leis Federais $n^{\circ}$. 11.445/2007 (Política Nacional de Saneamento Básico) e $n^{\circ}$. 11.107/2005 (Lei de Consórcios Públicos) e seu Decreto n. 6. 017/2007, Lei Federal $n^{\circ}$ 9.795/1999 (Lei de Educação Ambiental), Lei $n^{\circ} 10.257 / 2001$ (Estatuto da Cidade), de Parceria Público-Privada (Lei $n^{\circ}$ 11.079/2004), ), e Lei n 12.305/2010 (Política Nacional de Resíduos Sólidos); e

> Realizar estudos de regionalização de gestão e manejo dos resíduos sólidos, estes objetivos foram plenamente cumpridos conforme proposição de dois cenários de regionalização para o estado de São Paulo.

Ao desenvolver esse estudo, foram conhecidas experiências internacionais de gestão de resíduos sólidos em que se verificou que é possível alcançar bons resultados se os entes federados constituírem consórcios. 
Esse instrumento demonstra um ganho de eficiência na gestão e nas finanças, através do ganho de escala, agregação de valor aos resíduos e maior facilidade na obtenção de recursos financeiros.

Também a implantação de uma organização como a Sociedade Ponto Verde de Portugal, possibilitaria um aporte financeiro aos municípios para melhorias na gestão de seus resíduos sólidos, agregando valor ao resíduo e possibilitando a expansão do mercado de reciclagem, com consequente queda no desperdício e geração de passivos.

Outras contribuições poderiam ser agregadas a proposta dessa tese, se os órgãos governamentais disponibilizassem dados para que se pudessem alcançar melhores resultados. São informações que deveriam ser de fácil acesso, pois são de interesse público e poderiam servir a pesquisas.

A dificuldade imposta pelos órgãos de administração pública no fornecimento dos dados e a baixa qualidade das informações dificultou a elaboração de outros instrumentos de contribuição.

A opção por esse estudo teve por base o fato de que a Política Nacional de Resíduos Sólidos determina que todos os entes federados devem elaborar seus planos de resíduos sólidos.

A pesquisa realizada via questionários, visitas técnicas e entrevistas in loco permitiu ao pesquisador propor contribuições ao Plano de Resíduos Sólidos do Estado de São Paulo, bem como ampliar a discussão sobre o tema para buscar soluções de gestão dos resíduos sólidos, que sirvam de alternativas para as administrações públicas na implantação de regionalizações e planejamento.

A realização da presente tese de doutorado permitiu identificar novas questões de interesse científico sobre o tema, que em futuras pesquisas recomenda-se considerar as seguintes linhas de investigação:

- Analisar como serão influenciados os modos de gerenciamento de RSU pelas novas leis como a Política Estadual de Mudanças Climáticas, a Política 
Nacional de Resíduos Sólidos, a Política Estadual de Resíduos Sólidos e do Plano Estadual de Resíduos.

- Realizar estudo sobre a gestão de veículos em final de vida, lodos de ETE e geração de energia, analisando a situação atual, possíveis evoluções e alternativas futuras, bem como executar inventário estadual, fluxos e tecnologias para tratamentos destes resíduos.

- Elaborar estudos sobre os custos da gestão dos resíduos sólidos urbanos nos sistemas públicos e privados.

- Utilizar o modelos de simulação, como LCA-IWM WASTE PROGNOSTIC TOOL entre outros, na análise dos resíduos sólidos urbanos de consórcios e municípios. 0 modelo (LCA-IWM) possui duas funções, a primeira efetua uma previsão da produção de RSU através da ferramenta designada Waste Prognostic Tool e a segunda a avalia os sistemas de gestão de resíduos utilizando a previsão da produção de resíduos sólidos urbanos, constituindo-se em um importante instrumento de planejamento e avaliação das estratégias de gestão para resíduos sólidos urbanos. 


\section{REFERÊNCIAS}

ABNT, Associação Brasileira de Normas e Técnicas. NBR 10.004. Resíduos sólidos: classificação. Rio de Janeiro: ABNT, 2004. 71p.

ABRELPE. Panorama de resíduos sólidos no Brasil. 2010. p.199.

ALMEIDA, J. R. de et al. Planejamento ambiental. $2^{\circ}$ ed. Rio de Janeiro: Thex, 1999,180p.

ANDRADE, M. M. Como preparar trabalhos para cursos de pós-graduação. São Paulo: Atlas, 1997.

ANDRADE, J. B. L. Determinação da composição gravimétrica dos resíduos de serviços de saúde de diferentes tipos de estabelecimentos geradores. In: Congresso Brasileiro de Engenharia Sanitária e Ambiental, 20., 1999, Rio de Janeiro: ABES, 1999. p.1666-1672. 
ANNES, J. B. Contabilidade ambiental na indústria- uma ferramenta para a produção mais limpa/Sistema de Gestão Ambiental. Disponível em: <http://www. stoa.usp.brs acesso em: 09 ago, 2012, 23:26.

APA. Plano Nacional de Resíduos 2011-2020. Lisboa, 2011. Disponível em: <http://www.apambiente.pt/> acesso em: 15 jul, 2012, 20:45.

BRANCO, S.M. Ecossistêmica. Uma abordagem integrada dos problemas do meio ambiente. São Paulo : Edgard Blucher, 1999, 224p.

BRASIL. Constituição da República Federativa do Brasil. Disponível em: <http://www.planalto.gov.br/ccivil_03/constituicao/constitui\%C3\%A7ao.htm> acesso em: 06 jan, 2011, 09:20.

BRASIL. Lei de saneamento básico. Disponível em: <http://www.planalto.gov.br/ccivil_03/_ato2007-2010/2007/lei/l11445.htm> acesso em: 21 out., 2011, 16:36.

BRASIL. Casa Civil. Institui a Política Nacional de Resíduos Sólidos e dá outras providências. Disponível em: <http://www.planalto.gov.br/ccivil_03/_ato20072010/2010/lei/l12305.htm> acesso em: 27 jan, 2011, 20:26.

BRASIL. Casa Civil, Dispõe sobre diretrizes da política urbana e dá outras providências. $\quad$ Disponível em:< http://www.planalto.gov.br/ccivil_03/Leis/LEIS_2001/L10257.htm> acesso em: 27 jan, 2011, 14:40.

BRASIL. Lei de Consórcios $n^{\circ} 11.107$ de 06 de dezembro de 2005. Dispõe sobre normas gerais de contratação de consórcios públicos e dá outras providências. <http://www.planalto.gov.br/ccivil_03/_ato2004-2006/2005/Lei/L11107.htm>. acesso em: 24 de Ago. 2011, 16:45.

BRASIL. Portaria Ministerial $\mathrm{n}^{\circ} 53$ de 01 de março de 1979. Dispõe sobre determinação de que projetos específicos de tratamento e disposição final de resíduos sólidos ficam sujeitos à aprovação de órgão estadual competente. <http://www.mp.sc.gov.br/legisla/fed_ato_port_res/portaria/1950_1979/pf053_79. htm>. acesso em: 13 de Fev. 2012, 17:43.

BRASIL. Pesquisa Nacional de Saneamento Básico 2010. Disponível em: <http://www.ibge.gov.br/home/estatistica/populacao/condicaodevida/pnsb2008/ PNSB_2008.pdf>. acesso em: 05 de jul. 2011. 13:10.

BRASIL. Pesquisa Nacional de Saneamento Básico 2002. Disponível em:<http://www.ibge.gov.br/home/estatistica/populacao/condicaodevida/pnsb/p nsb.pdf>. acesso em: 07 de jul. 2011. 10:04.

BIDONE F. R. A.; POVINELLI J. Conceitos básicos de resíduos sólidos. São Carlos SP, 1.999, EESC USP, 120 p. 
CALDAS, E. de L. Formação de agendas organizacionais locais: o caso dos Consórcio Intermunicipais. 2007. 227f. Tese (Doutorado em Ciência Política) - Faculdade de Letras, Filosofia e Ciências Humanas, Universidade de São Paulo, São Paulo.

CALDERONI S. Os bilhões perdidos no lixo. $4^{\circ}$ ed. São Paulo: Humanitas, FFLCH/USP, 2003, p. 346.

CARNEIRO, Alex Pires; CASSA, José Clodoaldo Silva; BRUM, Irineu Antônio Schadach. Reciclagem de entulho para a produção de materiais de construção - Projeto Entulho Bom. Salvador: EDUFBA; Caixa Econômica Federal, 2001.

CASTRO, L. O. A. Destinação dos resíduos de construção e demolição na área insular do município de Santos e seus impactos sanitários e ambientais. 2003. 111p. Dissertação de mestrado. Faculdade de Saúde Pública, universidade de São Paulo, São Paulo. 2003.

CANTÓIA, S. F. Educação Ambiental e coleta seletiva em Presidente Prudente: avaliando seus resultados no Conjunto Habitacional Ana Jacinta. 2007, $149 f$. Dissertação (Mestrado em Geografia) - Faculdade de Ciências e Tecnologia, Universidade Estadual Paulista, Presidente Prudente, 2007.

CEMPRE \pm COMPROMISSO EMPRESARIAL PARA RECICLAGEM. Publicações. CEMPRE (website). São Paulo, 2010. Disponível em: <http://www.cempre.org.br/artigos.php>. Acesso em: 20 Nov. 2010.

CENSUS. Censo de Portugal - 2011. Instituto Nacional de Estatística. Disponível em: http://censos.ine.pt/xportal/xmain?xpid=CENSOS\&xpgid=censos_quadros. Acesso em: 20 de fev. 2012. 04:47.

CEPAM. Levantamento Consórcios 2010. Disponível em: <http://www.cepam.sp.gov.br/arquivos/Estudo_consorcios/Cepam_levantamento_ consorcios2010.pdf>. Acesso em: 21 de mar. 2011. 21:27.

CETEC, Fundação Centro Tecnológico de Minas Gerais. Estimativa do Déficit de Investimento em Equipamentos para Coleta de Lixo, Desativação de Lixões e InfraEstrutura para a Implantação de Aterros Sanitários no Brasil. Projeto financiado pelo Ministério do Meio Ambiente. Belo Horizonte, 2002.

CETESB. Inventário Estadual de Resíduos Sólidos Domiciliares. Série Relatórios. 2011,186p.

CONSUMERS INTERNATIONAL. Consumo sustentável. São Paulo (SP): Consumers International - Programa das Nações Unidas para o Desenvolvimento Secretaria do Meio Ambiente - Instituto de Defesa do Consumidor; 1998.

CHRISTOFOLETTI, A. Modelagem de sistemas ambientais. $1^{\text {a }}$ ed. São Paulo: Edgar Blucher, 1999, 256p. 
CONFEDERAÇÃO NACIONAL DA INDÚSTRIA. I Conferência da Indústria Brasileira para o Meio Ambiente - CIBMA: propostas e compromissos. Brasília: CNI, 2008, p23.

COTRIM, S.L.S.; REICHERT, G.A. Consórcios Municipais para Aterros Sanitários: uma alternativa ambiental e economicamente viável. In: CONGRESSO INTERAMERICANO DE ENGENHARIA SANITÁRIA E AMBIENTAL, 27. Fortaleza: ABES, 2000.

CRUZ, M. do C. M. T.; ARAÚJO, F. de A. Consórcios intermunicipais paulistas rumo aos consórcios públicos - reflexões. Disponível em: <http://www.cepam.sp.gov.br/arquivos/artigos/Consorcio_final_site.pdf>. acesso em: 04 de

jul. 2011. 13:25.

DALLABRIDA V. R.; ZIMERMANN V. J. Descentralização na gestão pública e estruturas subnacionais de gestão do desenvolvimento: o papel dos consórcios intermunicipais. Disponível em:

http://www.rbgdr.net/revista/index.php/rbgdr/article/view/247/172>. Acesso em: 04 jul. 2011.

DEMAJOROVIC, J. et al. Demajorovic J, Besen GR, Rathsam AA. Os desafios da gestão compartilhada de resíduos sólidos face à lógica do mercado. In: JACOBI P., FERREIRA L. (orgs). Diálogos em Ambiente e Sociedade. São Paulo - ANPP, Annablume, 2006. P.389-410.

FEAM. Fundação Estadual do Meio Ambiente. 2009. Diagnóstico da Geração de Resíduos Eletroeletrônicos no Estado de Minas Gerais. Disponível em:

< http://ewasteguide.info/files/Rocha_2009_pt.pdf >. Acesso em: 1 de maio de 2012.

FERREIRA, J. A. Resíduos sólidos: perspectivas atuais. In SISINNO, C.L.S.; OLIVEIRA, R.M. (org.) Resíduos sólidos, ambiente e saúde: uma visão multidisciplinar. $2^{\circ}$ ed. Rio de Janeiro: Fiocruz, 200, 142p.

FONSECA. E. Iniciação ao estudo dos resíduos sólidos e da limpeza urbana. $2^{\circ}$ ed. João Pessoa: JCR, 2001, 130p.

FUNASA, Manual de Implantação de Consórcios Públicos em Saneamento <http://www.funasa.gov.br/internet/arquivos/biblioteca/eng/eng_manualCapacit acao.pdf>. Acesso em: 24 jan. 2012, 14:20.

FURLAN, W. Modelo de decisão para escolha de tecnologia para o tratamento de resíduos sólidos no âmbito de um município. Tese (Doutorado em Administração) Faculdade de Economia, Administração, e Contabilidade, Universidade de São Paulo, São Paulo, 2007.

FURTADO, G. A. P.; PETRONI, L. M. As inter-relações econômicas, sociais e ambientais de um Consórcio Intermunicipal para Aterro Sanitário. São Paulo, 2003. 
GIL, Antonio Carlos. Métodos e técnicas de pesquisa social. 5a. ed. São Paulo: Atlas, 1999. $207 \mathrm{p}$.

GOLDENBERG, Mirian. A arte de pesquisar: como fazer pesquisa qualitativa em ciências sociais. Rio de Janeiro: Record, 1997.

GONÇALVES, M. A. $O$ trabalho no lixo. 2006, 310 f. Tese (Doutorado em Geografia) Faculdade de Ciências e Tecnologia, Universidade Estadual Paulista, Presidente Prudente, 2006.

IBAM. Informações corporativas \& Experiências em Resíduos Sólidos. Disponível em: <http://www.ibam.org.br/media/arquivos/estudos/experiencia-recente.pdf.> Acesso em: 06 fev. 2012. 17:38.

IBGE - Instituto Brasileiro de Geografia e Estatística: IBGE Cidades@. Disponível em:< http://www.ibge.gov.br/cidadesat/topwindow.htm?1>. Acesso em: 17 jan. 2011, 10:45.

IBGE - Instituto Brasileiro de Geografia e Estatística. Regiões de Influência das Cidades-2007. Disponível em:< http://www.ibge.gov.br>. Acesso em: 13 fev. 20112. 12:20.

Idris, A., Inanc, B., and Hassan, M. N., Overview of waste disposal and landfills/dumps in Asian coutries, J Mater Cycles Waste Manag., 2004

Instituto Polis. Boletim Dicas: Consórcios intermunicipais. Disponível em: <http://www.polis.org.br/download/arquivo_boletim_100.pdf>. acesso em: $10 \mathrm{de}$ Jun. 2009. 15:42.

IKUTA, F.A. Resíduos sólidos urbanos em Presidente Prudente. 2010. 235f. Tese (Doutorado em Geografia) - Faculdade de Ciências e Tecnologia, Universidade Estadual Paulista, Presidente Prudente, 2010.

JACOBI, Pedro. (Org.) Gestão compartilhada dos resíduos sólidos no Brasil: inovação com inclusão social. São Paulo: Annablume, 2006. 164p.

JARDIM, N. S. et al. Lixo municipal: Manual de Gerenciamento Integrado. $2^{\circ}$ ed. São Paulo:Instituto de Pesquisas Tecnológicas, 1995, 277p.

JOHANNSSEN. L. M. (et al.) Health care waste management guide note. Health Nutrition and Population. 2000, 64p.

ARAUJO, S. M.V.G.; JURAS, I. A.G.M A responsabilidade compartilhada pelo ciclo de vida do produto In: PHILIPPI JR, Arlindo; JARDIM, Arnaldo; YOSHIDA, Consuelo; MACHADO FILHO, José Valverde (Org.). Política Nacional, Gestão e Gerenciamento de Resíduos Sólidos. Barueri,SP: Manole, 2012. 
JUSTEN FILHO, M. Novos sujeitos na Administração Pública: os consórcios criados pela Lei $n^{\circ}$ 11.107. In: Direito Administrativo: estudos em homenagem a Diogo de Figueiredo Moreira Neto, Rio de Janeiro: Lumen Juris, 2006, p. 690.

LEAL, A.C, et al. Resíduos sólidos no Pontal do Paranapanema. Presidente Prudente: Antonio Thomaz Júnior, 2004, 280p.

LEAL, A. C. Gestão das Águas no Pontal do Paranapanema - São Paulo. Campinas, 2000.Tese (Doutorado em Geociências - Área de concentração em Administração e Política de Recursos Minerais) - Instituto de Geociências - UNICAMP.

LEITE, W. C. de A. Estudo da gestão de resíduos sólidos: uma proposta de modelo tomando a Unidade de Gerenciamento de Recursos Hídricos (UGRHI - 5) como referência. Tese (Doutorado em Engenharia de Transporte) - Escola de Engenharia de São Carlos, Universidade de São Paulo, 1997.

LIMA, J. D. de. Gestão de resíduos sólidos urbanos no Brasil. João Pessoa: Associação Brasileira de Engenharia Sanitária e Ambiental Seção Paraíba, [2002?], v.1, 267p.

LIMA, J. D. de, Consórcio de desenvolvimento intermunicipal: Instrumento de integração regional. [S.l.: s.n.], 2003. 275p.

MACHADO, P. A. L. Princípios da Política Nacional de Resíduos Sólidos. In: Philippi Jr., A. (Coord.). Política nacional, gestão e gerenciamento de resíduos sólidos. São Paulo: Manole, 2012, cap. 2, p. 39- 56.

MARQUES NETO, J. C. Diagnóstico para estudo de Gestão dos Resíduos de Construção do Município de São Carlos. 155p. Dissertação (Mestrado em Hidráulica e Saneamento) - Escola de Engenharia de São Carlos, Universidade de São Paulo, São Carlos, 2003.

MICHAELIS: Dicionário de Português Online. Disponível em:< http://michaelis.uol.com.br>. Acesso em: 23 out. 2012, 09:25.

MIZIARA, R. Nos rastros dos restos: As trajetórias do lixo na cidade de São Paulo. São Paulo: EDUC/FAPESP, 2001. 235p.

MONTEIRO, J.H.P. et al. Manual de gerenciamento integrado de resíduos sólidos. Rio de Janeiro: IBAM, 2001, 200p.

NARUO, M. K. O estudo do consórcio entre municípios de pequeno porte para diposição final de resíduos sólidos urbanos utilizando sistema de informação geográfica. 2003. 286p. Dissertação (Mestrado em engenharia civil com ênfase em transporte) - Escola de Engenharia de São Carlos, Universidade de São Paulo, São Carlos, 2003.

OGATA, M. G. Os resíduos sólidos na organização do espaço e na qualidade do ambiente urbano: Uma contribuição geográfica ao estudo do problema na cidade de São Paulo. Rio de Janeiro. IBGE, 1983. 156p. 
OLIVEIRA, G. de. Consórcio intermunicipal para o manejo integrado de lixo em cinco municípios da região administrativa de Bauru. 2004. p.129. Dissertação (Mestrado em Geografia Área de Concentração Organização do Espaço) - Instituto de Geociências, Universidade Estadual Paulista, Rio Claro, 2004.

PAULELLA, E.D.; SCAPIM C.O.; 1996, Campinas: a gestão dos resíduos sólidos urbanos. Campinas, Secretaria de Serviços Públicos, Secretaria da Administração.

PHILIPPI JÚNIOR, Arlindo. (Ed.) Saneamento, saúde e ambiente. Barueri: Manole, 2005. 842p.

PICHTEL, J. Waste management practices: municipal, harzadous, and industrial. Boca Raton: CRC Press, 2005. 659p.

PINTO, T. P. Metodologia para gestão diferenciada de resíduos sólidos da construção urbana. 1999. 189p. Tese (Doutorado em Engenharia). Escola Politécnica, universidade de São Paulo, São Paulo. 1999.

POLAZ C.N.M \& TEIXEIRA B.A.N. Indicadores de sustentabilidade como ferramenta para a gestão municipal de resíduos sólidos. In: IV Encontro Nacional da Anppas, 2008, Brasília. DF, 2008.

RODRIGUES, A. M. Produção e Consumo do e no espaço: problemática ambiental urbana. São Paulo: Hucitec, 1998, 239p.

RUSSO, M. A. T. Avaliação dos processos de transformação de resíduos sólidos urbanos em aterro sanitário. 320p. Tese (Doutorado) - Universidade do Minho, Portugal, 2005.

SANTOS, R. F. dos; Planejamento Ambiental: teoria e prática. São Paulo: Oficina de Textos, 2004, 232p.

SANTOS, R. M. dos. Localização de centrais de resíduos sólidos para consórcios intermunicipais através da utilização de ferramentas logísticas e restrições de fatores ambientais. (Dissertação) Mestrado em Engenharia de Transporte - Escola de Engenharia de São Carlos, Universidade de São Paulo, 1997.

SISSINO, C. L. S.; MOREIRA, J. C. Avaliação da contaminação e poluição ambiental na área de influência do aterro controlado do Morro do Céu, Niterói, Brasil. Caderno de Saúde Pública, Rio de Janeiro, v. 12, n. 4, p. 515-523, 1996.

SCHALCH, V. Estratégias para a gestão e o gerenciamento de resíduos sólidos. 2002. 149f. Texto (Livre Docência) Escola de Engenharia de São Carlos - Departamento de Hidráulica e Saneamento, Universidade de São Paulo, São Carlos.

SCHALCH, V., LEITE, O. C. A., FERNANDES JÚNIOR, J. L., CASTRO, M. C. A. A. Gestão e Gerenciamento de Resíduos Sólidos. 2002. 97f. Apostila do Departamento de Hidráulica e Saneamento, Universidade de São Paulo, São Carlos. 
SCHNEIDER, F.V. et al. Manual de gerenciamento de resíduos sólidos. São Paulo: CLR Balieiro, 2001.

SERRANO, O. "Lixo, dignidade e sustentabilidade socioeconômica". In: Seminário Lixo e Cidadania: região do grande $A B C$ : Consórcio Intermunicipal do Grande ABC, 2001. P. 34-40.

SISSINO, C. L. S.; OLIVEIRA, R. M. Resíduos sólidos, ambiente e saúde: uma visão multidisciplinar. Rio de Janeiro: Editora Fiocruz, 2000.

SUETERGARY, D. M. A; BASSO, L. A.; VERDUM, R. (Org.) Ambiente e Lugar no Urbano: A Grande Porto Alegre. Editora da Universidade UFRGS, Porto Alegre: 2002, 239p. In: 0 ciclo do papel, da coleta ao processamento: personagens e estrutura. Verdum, R. ,pag. 187.

TCHOBANOGLOUS G. KREITH, F. Hand book of solid waste management. Mc GrawHill, 2002, 2 Ed. p 13.3-13.84.

TOMPKINS, J. A.; WHITE, J.A.; BOZER, Y.A.; FRAZELLE, E.H.; TANCHOCO, J.M.; TERVINO, J. (1996) Facilities Planning. 2. Ed. New York, John Wiley \& Sons.

US. EPA - UNITED ESTATES ENVIRONMENTAL PROTECTION AGENCY., 1989, The solid waste dilemma: an agenda for action. U.S. Government Print Office. Washington.

VITÓRIO, Donato. Logística Verde. Rio de Janeiro: Editora Ciência Moderna LTDA, 2008. 276p. Wikipedia, Disponível em:

< http://pt.wikipedia.org/wiki/Ficheiro:SaoPaulo_MetropolitanAreas.svg>. Acesso em: 09 jul. 2012, 13:45. 
ANEXOS 


\section{Anexo A - Questionário do diagnóstico de resíduos sólidos do Estado de Alagoas}

\section{DIAGNÓSTICO DE RESÍDUOS SÓLIDOS DO ESTADO DE ALAGOAS \\ QUESTIONÁRIO - SituAÇÃO dOS SERVIÇOS DE LIMPEZA URBANA / 2010}

Objetivo: Fornecer elementos para elaboração do Diagnóstico e Planos de Gestão Integrada dos Resíduos Sólidos dos municípios da Bacia do Rio São Francisco no Estado de Alagoas.

\section{A) IDENTIFICAÇÃO DO MUNICÍPIO}

A.1. Município:

A. 2. Número de Distritos:

Especificar:

A. 3. Principais atividades econômicas:

A.4. Descrição do sistema de abastecimento de água:

A.5. Descrição do sistema de esgoto:

B) INFORMAÇÕES GERAIS

B.1. Órgão ao qual o Setor de Limpeza Urbana está vinculado:

B.2. Há quanto tempo está vinculado?

B.2.1. Endereço do Setor de Limpeza Urbana:

Tel.: Fax: E-mail: 
Nome do responsável:

Tempo de Serviço:

B.3. Tipos de lixo produzido no município:
( ) Domiciliar
( ) Podas
( ) Comercial
( ) Agrícola

( ) Entulho

( ) Público

( ) Industrial

( ) Portos/Aeroportos/Terminais rodo ferroviários

( ) Serviços de

Saúde

( ) Outros - Especificar

B.3.1. Volume/dia de lixo coletado: $\mathrm{m}^{3} / \mathrm{dia}$ ou ton. / dia

B.3.2. A coleta atinge toda a área urbana do município? ( ) sim não

B.4. Quem executa o serviço de limpeza urbana?
( ) Prefeitura
( ) Outros
( ) Prefeitura e outros

B.5. Caso o serviço de limpeza urbana seja terceirizado, qual o nome da empresa?

B.6. Quais os serviços executados pela empreiteira?

B.7. A prefeitura cobra pelo serviço de limpeza urbana?

( ) $\operatorname{Sim}$

( ) Taxa ( ) Tarifa ( ) Junto com IPTU

( ) Outro. Especificar

( ) Não.

Porque?

\section{C) PLANO DIRETOR DE LIMPEZA URBANA}

C.1. O município possui Plano Diretor de Limpeza Urbana (PDLU) ou Plano de Gestão de Limpeza Urbana (PGLU)? ( ) Sim ( ) Não

C.1.1. Existe exemplar do PDLU ou PGLU no setor de limpeza urbana?
( ) $\operatorname{Sim}$
( ) Não 
C.1.2. O responsável pelo serviço já leu ou consultou o mesmo?
( ) $\operatorname{Sim}$
( ) Não

\section{D) EQUIPAMENTOS}

D.1. Qual o estado de conservação dos equipamentos?

\begin{tabular}{|l|l|l|l|l|l|l|l|}
\hline \multirow{2}{*}{ Equipamento/Tipo } & $\begin{array}{l}\text { Capacidad } \\
\text { e } \\
\end{array}$ & \multicolumn{4}{|l|}{ Condições } \\
\cline { 3 - 7 } & & O & B & R & RR & $\begin{array}{l}\text { Serviços } \\
\text { Realizados }\end{array}$ \\
\hline & & & & & & \\
\hline & & & & & & \\
\hline & & & & & & \\
\hline & & & & & & \\
\hline & & & & & & \\
\hline & & & & & & \\
\hline & & & & & & \\
\hline & & & & & & \\
\hline & & & & & & \\
\hline & & & & & & \\
\hline
\end{tabular}

Obs.: Incluir todos os equipamentos, tais como caçamba, coletor compactador, trator, retro-escavadeira, pá carregadeira, containers, etc.

$\mathrm{O}=$ Ótimo; $\mathrm{B}=\mathrm{Bom} ; \mathrm{R}=$ Regular; $\mathrm{RR}=$ Ruim

D.2. Existe algum equipamento sendo utilizado para outros serviços? ( ) Sim ( ) Não

D.2.1.Quais?

\section{E) COLETA DOMICILIAR}

E.1. A coleta domiciliar está sendo feita com que periodicidade?
( ) Diária
( ) Alternada
( ) Semanal
( ) Eventual

E.2. A coleta está abrangendo toda a área urbana do município?
( ) $\operatorname{Sim}$
( ) Não

E.3. A coleta domiciliar está abrangendo todos os distritos?
( ) Sim
( ) Não

E.3.1. Frequiência da coleta dos distritos:
( ) Diária
( ) Semanal
( ) Alternada
( ) Eventual

E.4. Caso haja plano, os roteiros utilizados são os estabelecidos pelo PDLU?
( ) $\operatorname{Sim}$
( ) Não 
E.5. Quantos roteiros de coleta existem na sede?

E.6. Caracterização dos roteiros

\begin{tabular}{|l|l|l|l|l|}
\hline Roteiro & $\begin{array}{l}\text { Localidades } \\
\text { Atendidas }\end{array}$ & Frequência & Viagens $\left(\mathrm{n}^{\circ}\right)$ & Equipamento \\
\hline & & & & \\
\hline & & & & \\
\hline & & & & \\
\hline & & & & \\
\hline & & & & \\
\hline & & & & \\
\hline & & & & \\
\hline & & & & \\
\hline
\end{tabular}

E.7. Quais os locais de difícil acesso/pontos críticos para realização do serviço de coleta no município?

\section{F. COLETA DIFERENCIADA}

F.1. A coleta dos serviços de saúde está sendo realizada separadamente?

Sim ( ) Não

F.1.1. A coleta dos serviços de saúde está sendo feita com que frequiência?
( ) Diária
( ) Alternada
( ) Semanal
( ) Eventual

F.1.2. Existe um veículo destinado a coletar exclusivamente o lixo dos serviços de saúde?
( ) Sim
( ) Não

F.1.3. Quantidade de lixo das unidades de saúde ton/dia ou $\mathrm{m}^{3} /$ dia.

F.2. Existe serviço especial de coleta (coleta comercial, entulho, podas, praia, etc.)?

( ) Sim.

Qual?

( ) Não 
F.2.1 Se existe, qual a periodicidade?
( ) Diária
( ) Alternada
( ) Semanal
( ) Eventual

F.3. Qual a produção diária de entulho? ton./dia ou $\mathrm{m}^{3} /$ dia.

F.4. Qual a freqüência da coleta nas feiras e mercado público?
( ) Diária
( ) Alternada
( ) Semanal

F.4.1. Quantidade de lixo coletada nas feiras e mercados ton/dia ou $\mathrm{m}^{3} /$ dia.
F.5. Existe coleta seletiva?
( ) $\operatorname{Sim}$
( ) Não

Por quê?

\section{G) VARRIÇÃO}

G.1. O serviço de varrição abrange toda a zona urbana? ( ) Sim ( ) Não

G.2. Qual o percentual da cidade atendido pela varrição? $\%$

G.3. Com que periodicidade está sendo feita a varrição?
No centro ( ) Diária
( ) Alternada
( ) Semanal

Eventual

Nos bairros ( ) Diária

( ) Alternada

( ) Semanal

Eventual

Nos distritos ( ) Diária

( ) Alternada

( ) Semanal

( )

Eventual

G.4. Quais as principais dificuldades encontradas para realização deste serviço?

G.5. Onde localizam-se os pontos mais críticos para a varrição?

\section{H) SERVIÇOS ESPECIAIS}

H.1. Quais os serviços especiais existentes?
( ) Limpeza de Praia
( ) Limpeza de boca de lobo

Capinação e Roçagem

( ) Pintura de meio-fio ( ) Limpeza de canais/drenagem 
( ) Outros. Especificar:

H.1.1. Com que freqüência é feita a capina das vias públicas?
( ) Anual
( ) Trimestral
( ) Eventual
( ) Semestral

( ) Mensal

\section{I) EQUIPAMENTOS DE PROTEÇÃO INDIVIDUAL - EPI}

I.1. É fornecido fardamento aos funcionários? ( ) Sim ( ) Não

I.2. Quais os equipamentos oferecidos?
( ) Luvas
( ) Capas
( ) Uniformes
( ) Botas e calçados
( ) Boné
( ) Outro

I.2.1. Qual a freqüência do fornecimento?

I.2.3. Qual o atual estado de conservação dos fardamentos?
( ) Ótima
( ) Boa
( ) Regular
( ) Ruim

J) GERENCIAMENTO DO SISTEMA DE LIMPEZA URBANA (SLU)

J.1. Houve mudança recente no organograma do SLU? ( ) Sim ( ) Não

J.2. Existe algum projeto de melhoria do SLU? ( ) Sim ( ) Não

Especificar

\section{L) QUADRO DE PESSOAL}

L.1. Qual o número de funcionários do setor?

L.1.1. Especifique o número de funcionários dos seguintes serviços:

\begin{tabular}{|l|l|l|l|}
\hline Discriminação & $\begin{array}{l}\text { Vinculado à } \\
\text { Prefeitura }\end{array}$ & $\begin{array}{l}\text { Não Vinculado à } \\
\text { Prefeitura }\end{array}$ & Total \\
\hline Coleta & & & \\
\hline Varrição & & & \\
\hline Serviços Especiais & & & \\
\hline Administrativo & & & \\
\hline
\end{tabular}

L.2. Existe alguma atividade de integração / valorização para os funcionários?
( ) Sim
( ) Não 


\section{2. 1.}

Quais?

L.3. Quais as doenças que mais afetam os funcionários?

L.4. Foi realizado algum treinamento nos últimos 3 anos (especifique qual, quando e quem promoveu)?

\section{M) FINANÇAS}

M.1. Qual o gasto da Prefeitura com o setor de limpeza urbana? R\$

M.2. Quanto por cento do orçamento a Prefeitura destina aos serviços de limpeza urbana pública? $\%$

\section{N) DESTINAÇÃO FINAL}

N.1. Qual o destino do lixo do município?
( ) Vazadouro a céu aberto / lixão
( ) Vazadouro em áreas alagadas
( ) Aterro controlado
( ) Aterro sanitário

( )

Aleatório

( ) Outros. Especificar:

N.2. Local atual de destinação do lixo coletado:

N.2.1. O local do destino final fica:

( ) Dentro do município no perímetro urbano

( ) Dentro do município fora do perímetro urbano

( ) Fora do município

Distância para a sede $\mathrm{km}$

( ) Próximo a residências

( ) Próximo a áreas com atividades agrícola pecuária

( ) Próximo a área de proteção ambiental ( ) Próximo a corpos d’água

( ) Outras áreas. Especificar: 
N.2.2. Quem é o proprietário da área utilizada para a disposição final dos resíduos?
( ) Prefeitura
( ) Entidade prestadora dos serviços

( )

Particular

( ) Outro Especificar:

N.3. Existe mais de um local para disposição final do lixo? ( ) Sim

( ) Não

N.3.1. Quantos?

Especificar o tipo: Local:

N.4. Croqui da cidade (pontos notáveis, localização da ETA, do lixão, etc.)

N.5. Como é feita a destinação final do lixo das unidades de saúde?
( ) Para o mesmo local dos demais resíduos
( ) Aterro de resíduos

especiais

( ) Outros Especificar:

N.6. A Prefeitura exerce algum controle na disposição do lixo industrial?
( ) Sim
( ) Não

N.7. Existe mais de um usuário (município, entidades, distritos) no local de destinação final?

( ) Sim ( ) Não

N.7.1. Quantos? Especificar: 
N.7.2. Caso exista, como se dá a operação da destinação final?

N.8. Planos ou intenções existentes para o destino final.

N.8.1. Qual a contribuição de cada participante organizacional?

Organizacional

Institucional

Financeira

\section{0) ASPECTOS SÓCIOAMBIENTAIS}

0.1. Existem catadores no lixão?
( ) Adultos
( ) Crianças e adolescentes
( ) Não sabe
( )

Não existem

0.1.1. Aproximadamente quantos catadores trabalham no lixão?

0.1 .2 Existem catadores residindo no lixão? ( ) Sim ( ) Não

0.2. Existem ações de Educação Ambiental sendo executadas no município? ( ) Sim ( ) Não

O.2.1. Quais?

\section{P) LEGISLAÇÃO}

P.1. Existe alguma legislação municipal que aborde a questão do lixo?

( ) $\operatorname{Sim}($ ) Não

P.2. Na lei orgânica do município existe algum artigo que trate a questão da limpeza urbana?

( ) Sim ( ) Não Obs. Se possível anexar 01 cópia da lei orgânica municipal

P.3. O Responsável pela Limpeza Urbana tem conhecimentos sobre a legislação vigente (Crimes Ambiental, Resoluções CONAMA, Normas Técnicas, etc.)? ( ) $\operatorname{Sim}$ ( ) Não 
P.3.1. Quais?

\section{Q) RESPONSÁVEL PELAS INFORMAÇÕES}

Q.1. Nome:

Q.2. Cargo:

Desde:

Q.3. Telefone para contato:

Q.4. e-mail:

Q.5.Data de realização 


\title{
Anexo B - Regime jurídico do licenciamento da instalação e da exploração dos CIRVER - Portugal
}

\author{
MINISTÉRIO DAS CIDADES, ORDENAMENTO DO TERRITÓRIO E AMBIENTE
}

\author{
Decreto-Lei n. ${ }^{\circ}$ 3/2004 de 3 de Janeiro
}

O programa político do XV Governo Constitucional, no domínio do ambiente, estabelece claramente uma linha de actuação em matéria de gestão de resíduos, nomeadamente de resíduos industriais perigosos, centrada na prevenção da sua produção e na promoção e desenvolvimento das opções de reutilização e reciclagem, garantindo um elevado nível de protecção da saúde pública e do ambiente.

Esta orientação estriba-se na estratégia da União Europeia estabelecida pela resolução do Conselho de 24 de Fevereiro de 1997, a qual refere que a gestão de resíduos, em particular dos perigosos, obriga à definição de uma hierarquia de preferência quanto aos destinos para cada tipo de resíduos, e tendo sempre em consideração que as soluções a adoptar devem respeitar os direitos à protecção da saúde pública e a um ambiente de vida humano, sadio e ecologicamente equilibrado.

Assim, a estratégia preconizada pelo Governo para a gestão de resíduos industriais assenta em seis princípios fundamentais: conhecer, em permanência, a sua quantidade e características, minimizar a sua produção na origem, promover a instalação - por fileira - de unidades de reutilização ou reciclagem, utilizar tecnologias de tratamento integradas e complementares que privilegiem a sua reutilização e reciclagem, promover a eliminação do passivo ambiental e garantir, tendencialmente, a auto-suficiência do País.

A aplicação destes princípios permitirá, por seu turno, a criação de um sistema integrado de tratamento de resíduos industriais, que contemple os seguintes componentes: inventariação permanente, acompanhamento e controlo do movimento dos resíduos, redução dos resíduos que necessitam de tratamento e 
destino final, constituição de uma bolsa de resíduos e construção de centros integrados de recuperação, valorização e eliminação de resíduos.

Dando sequência a esta estratégia e no sentido de criar condições objectivas que permitam a resolução do problema relativo ao correcto tratamento a aplicar aos resíduos industriais no seu todo, e aos perigosos em particular, avançando para uma solução satisfatória para todos os intervenientes, o Ministério das Cidades, Ordenamento do Território e Ambiente incumbiu seis universidades portuguesas, em colaboração com o Instituto Nacional de Estatística, através de um protocolo assinado em 27 de Maio de 2002, de realizarem um estudo de inventariação dos resíduos industriais produzidos em Portugal tendo como referência o ano 2001 e destinado a fazer uma reavaliação dos dados até então conhecidos.

Tendo já sido conhecidos os resultados desse estudo, que apontam para a produção anual de 254000 t de resíduos industriais perigosos, e atendendo às suas características, ficou patente a necessidade de dotar o País de centros integrados de recuperação, valorização e eliminação de resíduos perigosos (CIRVER).

Os CIRVER são unidades integradas que conjugam as melhores tecnologias disponíveis a custos comportáveis, permitindo viabilizar uma solução específica para cada tipo de resíduo, de forma a optimizar as condições de tratamento e a minimizar os custos do mesmo.

Através da utilização de processos físico-químicos e biológicos, os CIRVER permitem intervir na maioria das tipologias dos resíduos industriais perigosos, conduzindo à sua redução e valorização e à sua posterior utilização como matéria-prima no mesmo processo ou em processo de fabrico diferente.

Nestes centros, os resíduos que não possam ser sujeitos a processos físico-químicos e biológicos, na totalidade ou em parte, serão submetidos a operações de estabilização ou inertização antes de serem depositados em aterro. Tais processos reduzem significativamente a quantidade e a perigosidade dos resíduos a depositar em aterro e, portanto, a sua dimensão e impactes associados. 
Assim, pelo presente diploma define-se o regime jurídico do licenciamento da instalação e da exploração dos CIRVER, garantindo o necessário rigor e transparência de todo o processo que conduzirá à sua instalação no País.

ara o efeito, definem-se as regras do procedimento de licenciamento, o qual assume a forma de concurso público e compreende uma fase de préqualificação dos candidatos, uma fase de selecção de projectos e uma fase de emissão dos respectivos alvarás.

Este procedimento destina-se a avaliar a capacidade técnica, económica e financeira dos candidatos e a qualidade técnica e financeira dos respectivos projectos, bem como a garantir a instalação e exploração dos CIRVER em condições que permitam a salvaguarda da saúde pública e do ambiente.

É ainda criado o observatório nacional dos CIRVER, que integra representantes da Administração Pública e da sociedade civil, ao qual caberá monitorizar o seu funcionamento, complementando a actividade de controlo e fiscalização das autoridades competentes.

Foi ouvida a Associação Nacional de Municípios Portugueses. Assim:

Nos termos da alínea a) do n. ${ }^{\circ} 1$ do artigo $198 .^{\circ}$ da Constituição, o Governo decreta o seguinte:

\section{CAPÍTULO I}

\section{Disposições gerais}

\section{SECÇÃO I}

\section{Âmbito e conceitos gerais}

\section{Artigo $10^{\circ}$}

\section{Objecto}

1 - 0 presente diploma consagra o regime jurídico do licenciamento da instalação e da exploração dos centros integrados de recuperação, valorização e eliminação de resíduos perigosos, adiante designados por CIRVER. 
2 - Ficam excluídos do âmbito de aplicação do presente diploma os resíduos radioactivos.

3 - Um CIRVER inclui, necessariamente, as seguintes unidades de recuperação, valorização e eliminação de resíduos perigosos:

a) Unidade de classificação, incluindo laboratório, triagem e transferência;

b) Unidade de estabilização;

c) Unidade de tratamento de resíduos orgânicos;

d) Unidade de valorização de embalagens contaminadas;

e) Unidade de descontaminação de solos;

f) Unidade de tratamento físico-químico;

g) Aterro de resíduos perigosos.

\section{Artigo $2 .^{\circ}$}

\section{Objectivos}

Constitui objectivo primordial da política de recuperação, valorização e eliminação de resíduos perigosos garantir um alto nível de protecção da saúde pública e do ambiente, nomeadamente:

a) Concretizando o princípio da auto-suficiência;

b) Privilegiando a valorização dos resíduos perigosos;

c) Minimizando a quantidade de resíduos perigosos a depositar em aterro.

\section{Artigo $30^{\circ}$}

\section{Definições}

Para os efeitos do presente diploma, entende-se por:

a) «Resíduos» quaisquer substâncias ou objectos de que o detentor se desfaz ou tem intenção ou obrigação de se desfazer, nos termos previstos no Decreto-Lei n. ${ }^{\circ}$ 239/97, de 9 de Setembro, em conformidade com a Lista Europeia de Resíduos; b) «Resíduos perigosos» os resíduos que apresentem características de perigosidade para a saúde pública ou para o ambiente, em conformidade com a Lista Europeia de Resíduos; 
c) «Produtor» qualquer pessoa, singular ou colectiva, cuja actividade produza resíduos ou que efectue operações de tratamento, de mistura ou outras que alterem a natureza ou a composição dos resíduos;

d) «Detentor» qualquer pessoa, singular ou colectiva, incluindo o produtor, que tenha resíduos na sua posse;

e) «Gestão de resíduos» as operações de recolha, transporte, armazenagem, tratamento, valorização e eliminação de resíduos, incluindo a monitorização dos locais de descarga após o encerramento das respectivas instalações, bem como o planeamento dessas operações;

f) «Gestor do CIRVER» o titular do alvará de licença para gestão e exploração de um CIRVER;

g) «Recolha» a operação de apanha de resíduos com vista ao seu transporte; h) «Transporte» a operação de transferir os resíduos de um local para outro; i) «Armazenagem» a deposição temporária e controlada, por prazo não superior a 18 meses, de resíduos antes do seu tratamento, valorização ou eliminação;

j) «Recuperação» a reintrodução, em utilização análoga e sem alterações, de substâncias, objectos ou produtos nos circuitos de produção ou de consumo, por forma a evitar a produção de resíduos;

l) «Valorização» as operações que visem o reaproveitamento dos resíduos, identificadas no anexo II-B da Decisão n. ${ }^{\circ}$ 96/350/CE, da Comissão, de 24 de Maio; m) «Tratamento» quaisquer processos manuais, mecânicos, físicos, químicos ou biológicos que alterem as características de resíduos por forma a reduzir o seu volume ou perigosidade, bem como a facilitar a sua movimentação, valorização ou eliminação;

n) «Estações de transferência» as instalações onde os resíduos são descarregados com o objectivo de os preparar para serem transportados para outro local de tratamento, valorização ou eliminação;

o) «Estações de triagem» as instalações onde os resíduos são separados, mediante processos manuais ou mecânicos, em materiais constituintes destinados a valorização ou a outras operações de gestão;

p) «Eliminação» as operações que visem dar um destino final adequado aos resíduos, identificadas no anexo II-A da Decisão n. ${ }^{\circ}$ 96/350/CE, da Comissão, de 24 de Maio; 
q) «Aterro» a instalação de eliminação utilizada para a deposição controlada de resíduos acima ou abaixo da superfície do solo.

\section{Artigo $4 .^{\circ}$}

\section{Acesso à actividade}

A actividade de instalação e exploração de um CIRVER depende de licenciamento a conceder nos termos do regime consagrado no presente diploma.

\section{Artigo $5^{\circ}$}

\section{Licenciamento}

1 - O licenciamento previsto no artigo anterior abrange a instalação de um CIRVER e a sua exploração, sendo cada CIRVER titulado por dois alvarás de licença, um relativo à instalação e outro relativo à exploração.

2 - Face aos quantitativos de produção de resíduos estimados pelo concedente, serão licenciados, no máximo, dois CIRVER.

\section{SECÇÃO II}

\section{Entidades}

Artigo 6.

\section{Entidade licenciadora}

1 - A entidade competente para o licenciamento de um CIRVER é o membro do Governo responsável pela área do ambiente.

2 - À entidade licenciadora compete, nomeadamente, determinar a abertura do concurso, aprovar as peças concursais e licenciar os CIRVER através da homologação do acto de selecção dos projectos.

\section{Artigo $7 .^{\circ}$}

\section{Entidade coordenadora}

1 - A entidade coordenadora do procedimento de licenciamento é o Instituto dos Resíduos, adiante designado por INR.

2 - No exercício dessa coordenação, são, nomeadamente, funções do INR:

a) Preparar e submeter à entidade licenciadora as peças concursais; 
b) Submeter à entidade licenciadora uma proposta de composição da comissão de abertura e da comissão de análise;

c) Apoiar logisticamente as comissões de abertura e de análise;

d) Proceder à emissão dos alvarás de instalação e de exploração;

e) Remeter às entidades competentes de avaliação de impacte ambiental e de licença ambiental toda a documentação apresentada pelo candidato para os efeitos dos respectivos procedimentos;

f) Solicitar os pareceres previstos no presente diploma no âmbito do procedimento conducente à emissão dos alvarás de licença de instalação e de exploração, com excepção dos licenciamentos municipais;

g) Promover a compatibilidade dos licenciamentos e autorizações de terceiras entidades com o licenciamento do CIRVER.

\section{SECÇÃO III}

\section{Candidatos}

\section{Artigo $8 .^{\circ}$}

\section{Conceito}

São candidatos as entidades que, tendo apresentado, nos termos e com os pressupostos fixados no presente diploma, uma candidatura ao processo de concurso para atribuição de licença para instalação e exploração de um CIRVER, sejam admitidas nos termos do disposto no artigo $42 .^{\circ}$

\section{Artigo 9.}

\section{Nacionalidade dos candidatos}

1 - Os candidatos nacionais de outros Estados membros da União Europeia ou neles estabelecidos e das Partes Contratantes do Acordo do Espaço Económico Europeu e da Organização Mundial do Comércio concorrem em situação de igualdade com os nacionais, nos termos previstos nos respectivos tratados.

2 - Os candidatos referidos no número anterior devem apresentar os mesmos documentos que são exigidos aos candidatos nacionais, os quais, quando for caso disso, são emitidos pelas autoridades competentes do país de origem.

3 - No caso de na ordem jurídica do país de origem do candidato não existir documento idêntico ao especialmente requerido, pode o mesmo ser substituído por declaração sob compromisso de honra feita pelo candidato perante uma autoridade 
judiciária ou administrativa, notário ou outra autoridade competente do país de origem.

\section{Artigo 10.}

\section{Natureza dos candidatos}

1 - Os candidatos devem revestir a forma de sociedades comerciais, podendo ainda candidatar-se agrupamentos de empresas.

2 - São requisitos essenciais para a aquisição da condição de candidato pelas sociedades comerciais:

a) Regularidade da sua constituição, de acordo com a respectiva lei nacional;

b) Desenvolvimento de objecto social compatível com o exercício da actividade de gestor do CIRVER;

c) Capital social não inferior a $10 \%$ do investimento proposto, com um mínimo de (euro) 2500000, sendo que em qualquer dos casos o capital social deve estar integralmente subscrito e realizado;

d) Contabilidade actualizada e organizada de acordo com o Plano Oficial de Contabilidade e adequada à prestação das informações exigíveis durante as fases de implementação e execução do projecto licenciado.

3 - Sempre que a candidatura for apresentada por agrupamento de empresas ao abrigo do disposto na parte final do $\mathrm{n} .^{\circ} 1$ do presente artigo, os requisitos referidos no número anterior aplicar-se-ão a cada empresa individualmente considerada, com excepção do referido na alínea b), que se entende como aplicável pelo menos a uma das empresas, e na alínea c), em que prevalecerá a soma do valor do capital social afecto à construção do CIRVER pelas empresas envolvidas na candidatura. 4 - Da candidatura apresentada por agrupamento de empresas deve constar a modalidade jurídica da associação a adoptar para os efeitos do artigo seguinte. 5 - Não é permitida a substituição do candidato ou de alguma das empresas que o integrem após o acto de admissão das candidaturas. 


\section{Artigo $11 .^{\circ}$}

\section{Agrupamentos de empresas}

1 - No caso de o candidato se apresentar na modalidade de agrupamento de empresas nos termos do n. ${ }^{\circ} 1$ do artigo anterior, o mesmo deve indicar a natureza da entidade a quem será posteriormente concedida a licença.

2 - As entidades que compõem o agrupamento deverão designar na sua candidatura um representante comum para praticar todos os actos no âmbito do respectivo procedimento, incluindo a assinatura da candidatura, devendo, para o efeito, entregar instrumentos de mandato emitidos por cada uma das entidades.

3 - As empresas agrupadas e promotoras de candidatura são solidariamente responsáveis pelo cumprimento das obrigações que desta advierem.

4 - Cada uma das entidades que compõe o agrupamento deve adoptar as medidas adequadas a assegurar o cumprimento do regime previsto no presente diploma e das condições da licença.

\section{Artigo $12 .^{\circ}$}

\section{Impedimentos}

1 - São excluídas do procedimento concursal as entidades relativamente às quais se verifique que:

a) Não se encontram em situação regularizada relativamente a dívidas por impostos ao Estado Português ou ao Estado de que sejam nacionais ou onde se encontrem estabelecidas;

b) Não se encontram em situação regularizada relativamente a dívidas por contribuições para a segurança social em Portugal ou no Estado de que sejam nacionais ou onde se encontrem estabelecidas;

c) Se encontram em estado de falência, de liquidação, de cessação de actividade, sujeitas a qualquer meio preventivo da liquidação de patrimónios ou em qualquer situação análoga ou tenham o respectivo processo pendente;

d) Tenham sido objecto de aplicação da sanção acessória prevista na alínea e) do n. ${ }^{\circ} 1$ do artigo $21 .^{\circ}$ do Decreto-Lei n. ${ }^{\circ} 433 / 82$, de 27 de Outubro, com a redacção dada pelo Decreto-Lei n. ${ }^{\circ} 244 / 95$, de 14 de Setembro, durante o período de inabilidade legalmente previsto; 
e) Tenham sido objecto de aplicação da sanção acessória prevista no n. ${ }^{\circ} 1$ do artigo 5. ${ }^{\circ}$ do Decreto-Lei n. ${ }^{\circ} 396 / 91$, de 16 de Outubro, durante o período de inabilidade legalmente previsto;

f) Tenham sido objecto de aplicação de sanção administrativa ou judicial pela utilização ao seu serviço de mão-de-obra legalmente sujeita ao pagamento de impostos e contribuições para a segurança social não declarada nos termos das normas que imponham essa obrigação, em Portugal ou no Estado de que sejam nacionais ou onde se encontrem estabelecidas, durante o prazo de prescrição da sanção legalmente previsto.

2 - Sem prejuízo das excepções previstas no presente diploma, para comprovação negativa das situações referidas no número anterior, os candidatos devem apresentar declaração emitida conforme o modelo constante do programa do concurso.

3 - Sempre que a candidatura for apresentada por agrupamento de empresas, ao abrigo do disposto na parte final do $n .^{\circ} 1$ do artigo $10 .^{\circ}$, os impedimentos referidos no presente artigo serão aferidos em relação a cada empresa, individualmente considerada.

\section{Artigo $13 .^{\circ}$}

\section{Modificação dos requisitos dos candidatos}

1 - Uma vez apresentada a candidatura, qualquer modificação relativa aos requisitos enumerados no artigo $10 .^{\circ}$ ou no anúncio de abertura do concurso implica a necessidade de requerimento dirigido à comissão de abertura para a verificação da manutenção dos requisitos de candidatura.

2 - A perda de personalidade ou de capacidade jurídica de qualquer das empresas candidatas a licenciamento, individualmente ou em agrupamento de empresas, implica a imediata exclusão do concurso e, no caso dos agrupamentos de empresas, de todas as empresas que o constituem.

3 - Não é permitida a substituição do candidato após o acto de admissão das candidaturas. 


\section{Artigo $14 .^{\circ}$}

\section{Concorrência}

1 - São proibidos todos os actos ou acordos susceptíveis de falsear as regras de concorrência, o que, a suceder, importa a exclusão dos candidatos, considerandose inexistentes os projectos por eles apresentados, bem como todos os actos por eles praticados no procedimento de licenciamento.

2 - Se de um acto ou acordo lesivo da concorrência tiver resultado o licenciamento de um CIRVER, o mesmo é nulo, devendo a entidade licenciadora declarar a nulidade desse mesmo licenciamento e podendo proceder à expropriação por utilidade pública do prédio e das respectivas instalações.

3 - A ocorrência de qualquer dos factos previstos no n. ${ }^{\circ} 1$ deverá ser comunicada pela entidade licenciadora à entidade administrativa competente.

\section{Artigo $15 .^{\circ}$}

\section{Exclusão do concurso}

1 - Constitui justa causa de exclusão do concurso o incumprimento pelos candidatos dos deveres previstos no presente capítulo.

2 - Constitui ainda justa causa de exclusão do concurso a forte presunção de conluio entre os candidatos que consubstancie prática restritiva da concorrência, nos termos da Lei n. ${ }^{\circ} 18 / 2003$, de 11 de Junho.

\section{CAPÍTULO II}

Procedimento de licenciamento

\section{SECÇÃO I}

\section{Disposições gerais}

\section{Artigo $16 .^{\circ}$}

Tipo de procedimento

1 - o procedimento de licenciamento é o definido no presente diploma, compreendendo uma fase de pré-qualificação dos candidatos, uma fase de apreciação e selecção de projectos e uma fase de emissão dos respectivos alvarás. 2 - 0 procedimento de licenciamento assume a forma de concurso público. 


\section{Artigo 17.}

\section{Fases do procedimento}

0 procedimento de licenciamento compreende as seguintes fases:

a) Pré-qualificação, que integra as seguintes subfases:

i) Constituição da comissão de abertura;

ii) Abertura do procedimento;

iii) Apresentação das candidaturas;

iv) Apreciação das candidaturas;

b) Apreciação e selecção dos projectos, que integra as seguintes subfases:

i) Constituiçãa da comissão de análise;

ii) Convite e apresentação dos projectos;

iii) Análise dos projectos;

iv) Licenciamento;

c) Emissão dos alvarás, que integra as seguintes subfases:

i) Emissão do alvará de licença de instalação do CIRVER;

ii) Emissão do alvará de licença de exploração do CIRVER.

Artigo $18 .^{\circ}$

Responsabilidade pela tramitação

1 - A fase de pré-qualificação dos candidatos é da responsabilidade da comissão de abertura, constituída nos termos do artigo $27 .^{\circ}$

2 - A fase de apreciação e selecção dos projectos a licenciar é da responsabilidade da comissão de análise, constituída nos termos do artigo $44 .^{\circ}$

3 - A fase de emissão dos alvarás é da responsabilidade da entidade coordenadora.

\section{Artigo 19.}

\section{Dever de fundamentação}

Todos os actos administrativos a praticar devem ser fundamentados, nos termos dos artigos $124 .^{\circ}$ e $125 .^{\circ}$ do Código do Procedimento Administrativo. 


\section{Artigo $200^{\circ}$}

\section{Audiência prévia}

1 - As decisões previstas no presente diploma relativas às exclusões de candidatos, candidaturas e projectos, caso não sejam tomadas em acto público, devem ser precedidas da realização de audiência escrita dos candidatos objecto daquelas decisões.

2 - Os candidatos têm 10 dias após a notificação do projecto de decisão para se pronunciarem.

\section{Artigo $21 .^{\circ}$}

\section{Notificações}

Para os efeitos do procedimento de licenciamento, os candidatos devem indicar um endereço em território nacional para onde devem ser enviadas todas as notificações.

\section{Artigo 22. ${ }^{\circ}$}

\section{Contagem dos prazos}

1 - Com excepção do disposto no número seguinte, os prazos estabelecidos no presente diploma contam-se nos termos do artigo $72 .^{\circ}$ do Código do Procedimento Administrativo.

2 - Os prazos fixados no presente diploma para a apresentação de candidaturas e de projectos e para a manutenção dos projectos apresentados não se suspendem nos sábados, domingos e feriados.

\section{Artigo 23.}

\section{Esclarecimentos sobre os documentos patenteados}

1 - A comissão de abertura e a comissão de análise, por iniciativa própria ou por solicitação dos interessados, devem prestar os esclarecimentos necessários à boa compreensão e interpretação dos elementos expostos.

2 - Os pedidos de esclarecimento têm de ser entregues às comissões respectivas no decurso do primeiro terço do prazo fixado:

a) Para a apresentação da candidatura, caso incidam sobre os critérios de admissão das candidaturas; 
b) Para a apresentação do projecto, caso incidam sobre os critérios de apreciação e selecção dos projectos.

3 - Têm legitimidade para solicitar esclarecimentos:

a) Os candidatos ou potenciais candidatos, caso o pedido de esclarecimento incida sobre os critérios de admissão ou selecção das candidaturas;

b) Os candidatos seleccionados, caso o pedido de esclarecimento incida sobre os critérios de apreciação e selecção dos projectos.

4 - Os esclarecimentos devem ser prestados por escrito até ao fim do segundo terço dos prazos referidos no $n .^{\circ} 2$ do presente artigo.

5 - Dos esclarecimentos prestados juntar-se-á cópia ao livro de consulta, devendo ainda o teor destes ser comunicado:

a) A todos os interessados que procederam ou venham a proceder ao levantamento dos documentos que servem de base ao concurso e publicitado pelos meios julgados mais convenientes quando incidam sobre os critérios de admissão das candidaturas;

b) A todos os candidatos seleccionados quando incidam sobre os critérios de apreciação e selecção dos projectos.

\section{Artigo 24.}

\section{Esclarecimentos dos candidatos}

1 - Sempre que a comissão de abertura ou a comissão de análise tenham dúvidas sobre os documentos apresentados pelos candidatos ou sobre outros elementos que considerem relevantes para a apreciação das candidaturas ou dos projectos, podem solicitar esclarecimentos aos candidatos.

2 - Os candidatos dispõem de um prazo mínimo de cinco dias para prestarem os esclarecimentos solicitados.

3 - O prazo concreto para a prestação de esclarecimentos será fixado no respectivo pedido.

4 - Os candidatos que não cumpram o prazo que lhes for fixado serão excluídos do concurso. 


\section{Artigo $25 .^{\circ}$}

\section{Momento da prática dos actos procedimentais}

1 - 0 acto procedimental considera-se praticado no dia em que os documentos que o suportam derem entrada nos serviços da entidade coordenadora ou da entidade a quem seja dirigido, consoante o caso, independentemente do meio utilizado.

2 - 0 acto procedimental que for praticado sem ser mediante entrega pessoal ou correio sob registo carece de confirmação por um destes meios no prazo de cinco dias, sob pena de inexistência.

3 - 0 incumprimento dos prazos procedimentalmente prescritos apenas pode ser justificado por justo impedimento, tal como configurado no artigo $146 .^{\circ}$ do Código de Processo Civil.

4 - Não constitui justo impedimento o atraso dos serviços postais ou erro na transmissão por telecópia ou por meio informático.

\section{Artigo $26 .^{\circ}$}

\section{Dever de sigilo}

1 - Os membros das comissões de abertura e de análise, os funcionários e agentes das entidades que os apoiam e os peritos agregados, bem como todos aqueles que, no exercício das suas funções, tomarem conhecimento de elementos do concurso, estão obrigados a guardar sigilo e a promover as diligências necessárias à preservação da confidencialidade de tais elementos.

2 - A violação dos deveres previstos no número anterior fará incorrer o infractor em responsabilidade civil, criminal e disciplinar, nos termos legais.

\section{SECÇÃO II}

Fase de pré-qualificação

SUBSECÇÃO I

\section{Comissão de abertura}

\section{Artigo $27 .^{\circ}$}

\section{Constituição da comissão de abertura}

1 - A fase de pré-qualificação é conduzida pela comissão de abertura, composta por três membros efectivos e dois membros suplentes, designados pela entidade licenciadora mediante despacho. 
2 - O despacho constitutivo da comissão de abertura refere obrigatoriamente:

a) A identificação dos membros efectivos e suplentes;

b) A identificação do seu presidente;

c) A identificação do vogal que substitui o presidente nas suas faltas e impedimentos.

3 - Em caso de impedimento temporário ou permanente dos membros efectivos da comissão, a sua substituição é assegurada por membro suplente de acordo com a ordem da respectiva lista, o qual tem a obrigação de assumir todos os actos praticados e decisões tomadas anteriormente pela comissão.

\section{Artigo $28 .^{\circ}$}

\section{Funcionamento da comissão de abertura}

1 - A comissão de abertura entra em exercício de funções a partir do dia útil subsequente ao envio para publicação do anúncio de abertura do concurso.

2 - A comissão de abertura só pode reunir quando estiver presente a totalidade dos seus membros em efectividade de funções.

3 - A comissão de abertura será coadjuvada por um secretário por ela escolhido de entre os seus membros ou de entre o pessoal dos serviços da entidade coordenadora, neste caso com anuência do respectivo dirigente, a quem compete, designadamente, lavrar as actas.

4 - As deliberações são aprovadas por maioria de votos, não sendo admitidas abstenções, devendo a fundamentação constar da respectiva acta.

5 - Os membros da comissão de abertura que, relativamente a qualquer deliberação, votem vencidos devem ditar para a acta as razões da sua discordância com o sentido da deliberação.

\section{Artigo 29.}

\section{Competência da comissão de abertura}

1 - Compete à comissão de abertura a instrução de toda a fase de pré-qualificação do procedimento concursal, podendo, para o efeito, solicitar o apoio de outras entidades e agregar peritos, sem direito de voto, para a emissão de pareceres em áreas especializadas. 
2 - A comissão de abertura tem o dever de deliberar sobre a exclusão de candidatos do concurso quando tenha conhecimento da existência de factos susceptíveis de constituírem justa causa de exclusão nos termos do disposto no artigo $15 .^{\circ}$

3 - Tanto a comissão de abertura como os seus membros, individualmente considerados, podem solicitar, através do seu presidente, esclarecimentos aos candidatos nos termos do disposto no artigo $24 .^{\circ}$

\section{SUBSECÇÃO II}

Abertura do concurso

Artigo $300^{\circ}$

\section{Competência}

O concurso é aberto por despacho da entidade licenciadora.

\section{Artigo $31 .^{\circ}$}

Peças concursais

1 - São as seguintes as peças concursais:

a) Anúncio de abertura do concurso;

b) Programa do concurso;

c) Caderno de encargos.

2 - As peças concursais são objecto de aprovação por despacho da entidade licenciadora.

Artigo $32 .^{\circ}$

Conteúdo do anúncio de abertura do concurso

Do anúncio de abertura do concurso devem constar:

a) Indicação do objecto e prazo do concurso;

b) Indicação da entidade que promove a realização do concurso;

c) Endereço onde podem ser pedidos o programa do concurso e o caderno de encargos, respectiva data limite e custo do envio;

d) Constituição da comissão de abertura e da comissão de análise do concurso;

e) Local da prática dos actos concursais, referindo especificamente os serviços competentes para a recepção da documentação e o horário de funcionamento do serviço; 
f) Prazo para a solicitação dos esclarecimentos, nos termos do artigo $23 .^{\circ}$;

g) Prazo para a apresentação de candidaturas, especificando a hora e a data limite para a prática do acto de candidatura;

h) Modo de apresentação da candidatura;

i) Elementos da candidatura e documentos que a acompanham;

j) Requisitos de admissão dos candidatos;

l) Data, hora e local da realização do acto público do concurso;

m) Critérios de apreciação e selecção das candidaturas;

n) Prazo máximo para a apresentação de projectos;

o) Critérios de apreciação e classificação dos projectos;

p) Prazo durante o qual fica o candidato obrigado a manter o projecto;

q) Referência à existência do livro de consulta, com indicação do local e do horário em que se possibilita a sua consulta, bem como dos elementos que o constituem, nos termos do disposto no artigo $38 .^{\circ}$

\section{Artigo 33.}

\section{Publicitação do anúncio de abertura}

O anúncio de abertura do concurso é publicado na 3. ${ }^{a}$ série do Diário da República, no Jornal Oficial da União Europeia e em dois jornais de reconhecida expansão nacional, devendo ainda ser afixado nos lugares de estilo nas instalações da entidade coordenadora.

\section{SUBSECÇÃO III}

\section{Apresentação das candidaturas}

Artigo 34. ${ }^{\circ}$

\section{Prazo e local de entrega}

1 - 0 prazo e o local de entrega das candidaturas são os constantes do anúncio de abertura do concurso, nos termos do disposto na alínea g) do artigo $32 .{ }^{\circ}$

2 - 0 prazo definido para a entrega das candidaturas nunca pode ser inferior a 40 dias contados a partir da data do envio para publicação do anúncio de abertura do concurso. 


\section{Artigo 35.}

\section{Modo de apresentação da candidatura}

1 - A candidatura deve ser apresentada em invólucro opaco e fechado, em cujo rosto deve escrever-se a palavra «Candidatura» e a denominação do candidato.

2 - A candidatura é constituída pela declaração de candidatura e pelos documentos relativos à capacidade jurídica, à capacidade técnica, à capacidade financeira e aos requisitos específicos.

3 - As candidaturas, bem como os documentos que as acompanham, devem ser redigidas em língua portuguesa ou, não o sendo, devem ser acompanhadas de tradução devidamente legalizada e em relação à qual o candidato declara aceitar a prevalência, para todos os efeitos, sobre os respectivos originais.

\section{Artigo 36.}

\section{Documentos de instrução da candidatura}

1 - A candidatura deve ser obrigatoriamente instruída com os documentos indicados no presente artigo.

2 - A declaração de candidatura é realizada por pessoa com poderes bastantes para vincular o candidato e consiste em documento com a assinatura legalmente reconhecida donde constem:

a) Declaração da vontade de se propor como candidato à instalação e exploração de um CIRVER nos termos do presente diploma;

b) Declaração de aceitação das normas a que obedece o concurso e sujeição às obrigações decorrentes dos actos de candidatura, de apresentação de projecto e de atribuição de licença;

c) Declaração da veracidade das informações prestadas e da conformidade das cópias de documentos apresentadas com os respectivos originais.

3 - Os documentos tendentes à constatação da capacidade jurídica do candidato são:

a) Certidão actualizada da matrícula e inscrições em vigor, emitida pela conservatória do registo comercial competente;

b) Fotocópia simples dos estatutos;

c) Documento comprovativo da prestação de caução provisória, nos termos do disposto no artigo $37 .^{\circ}$; 
d) Documento comprovativo de estar em regular situação contributiva relativa à segurança social e a contribuições e impostos;

e) Declaração de conformidade da contabilidade organizada com o Plano Oficial de Contabilidade;

f) Documento emitido pela autoridade judicial ou administrativa competente que comprove que o candidato não se encontra em estado de falência, de liquidação, de cessação de actividade, sujeito a qualquer meio preventivo de liquidação de patrimónios ou em qualquer situação análoga ou que tenha o respectivo processo pendente.

\section{Artigo $37 .^{\circ}$}

\section{Caução provisória}

1 - Para garantia do compromisso assumido com a apresentação de candidatura e das obrigações inerentes ao concurso, os candidatos devem prestar uma caução no valor de (euro) 50000.

2 - A caução referida no número anterior é condição da apresentação da candidatura.

3 - A caução é prestada através de depósito, em dinheiro ou em títulos emitidos ou garantidos pelo Estado, à ordem do INR.

4 - O depósito referido no número anterior pode ser substituído por garantia bancária ou seguro-caução que ofereça garantias equivalentes àquele, à ordem do INR, e em qualquer dos casos devidamente documentados.

5 - Quando o depósito for efectuado em títulos, estes são avaliados pelo seu respectivo valor nominal, salvo se nos últimos três meses a média da cotação na Bolsa de Valores de Lisboa ficar abaixo do par, caso em que a avaliação será feita por $90 \%$ dessa média.

6 - A caução pode ser levantada pelos candidatos, devendo o INR promover as diligências necessárias para o efeito, quando:

a) $O$ projecto não tenha sido admitido;

b) Não tenha sido atribuída licença ao candidato;

c) $O$ concurso venha a ser anulado;

d) $O$ licenciamento caduque, nos termos do disposto na alínea b) do n. ${ }^{\circ} 1$ do artigo 63. ${ }^{\circ}$ do presente diploma. 
7 - Implica a perda da caução:

a) A não admissão da candidatura;

b) A exclusão do candidato;

c) A não apresentação do projecto;

d) A desistência da candidatura em qualquer fase do procedimento de concurso.

8 - A devolução da caução provisória, para os candidatos seleccionados, tem lugar após a prestação da caução relativa à instalação do CIRVER, prevista no artigo $60 .^{\circ}$

\section{Artigo $38 .^{\circ}$}

\section{Livro de consulta}

1 - A entidade coordenadora deve manter disponível, nas instalações da sua sede, um livro contendo todas as peças concursais, as actas das comissões de abertura e de análise dos projectos e os pedidos de esclarecimento solicitados, bem como as respectivas respostas, para livre consulta por qualquer interessado.

2 - Os interessados podem solicitar certidões do teor do livro de consulta. 3 - O livro de consulta é encerrado e arquivado pelos serviços da entidade licenciadora após a decisão de atribuição das licenças.

\section{Artigo 39.}

\section{Deserção}

1 - 0 concurso será declarado deserto quando:

a) Não seja apresentada nenhuma candidatura;

b) Não sejam admitidos candidatos;

c) Não seja seleccionada nenhuma candidatura;

d) Não seja seleccionado nenhum dos projectos, nos termos do disposto no artigo $57 .^{\circ}$

2 - O concurso será ainda declarado deserto quando, por qualquer causa superveniente, sejam excluídos todos os candidatos inicialmente admitidos.

3 - Caso o concurso seja declarado deserto ou seja anulado, nos termos do artigo $58 .^{\circ}$, poderá ser promovido o licenciamento com base em procedimento concursal por negociação, de acordo com o previsto no Regime Jurídico das Empreitadas de Obras Públicas. 


\section{SUBSECÇÃO IV}

\section{Apreciação das candidaturas}

Artigo 40.

\section{Acto público de apreciação das candidaturas}

1 - 0 acto público do concurso para a abertura dos pedidos de candidatura tem lugar às 10 horas do $1 .^{\circ}$ dia útil posterior ao termo do prazo para a entrega das candidaturas, definido no anúncio de abertura do concurso.

2 - Só podem intervir no acto público do concurso os representantes dos candidatos, até ao máximo de três elementos por candidato, desde que devidamente credenciados para os representarem no acto.

3 - O acto público do concurso é realizado pela comissão de abertura, à qual compete neste âmbito:

a) Confirmar a recepção dentro do prazo fixado dos envelopes contendo os pedidos de candidatura, bem como dos volumes que contêm os documentos e os elementos que os instruem;

b) Proceder à abertura dos envelopes que contêm os pedidos de candidatura, bem como dos volumes que contêm os documentos e os elementos correspondentes à identificação do candidato, do plano técnico e do plano económico-financeiro;

c) Rubricar os pedidos de candidatura, promovendo, em simultâneo, a chancela dos documentos originais que instruem os pedidos, bem como fixar um prazo para a consulta dos processos de candidatura pelos candidatos;

d) Verificar a qualidade dos intervenientes no acto;

e) Conceder aos candidatos um prazo máximo de dois dias úteis para procederem ao suprimento das eventuais omissões ou incorrecções verificadas no processo de candidatura, quando consideradas supríveis;

f) Aceitar e decidir, em sessão privada, sobre as reclamações que the sejam apresentadas no decurso do acto público pelos representantes dos candidatos, suspendendo o mesmo acto sempre que necessário.

4 - Após a análise das candidaturas, a comissão de abertura retira-se para deliberar sobre a admissão, admissão condicional e exclusão das mesmas.

5 - São excluídas as candidaturas que:

a) Não sejam recebidas no prazo fixado;

b) Estejam em situação de impedimento, nos termos do artigo $12 .^{\circ}$; 
c) Não cumpram o estabelecido nos artigos $10 .^{\circ}$ e $11 .^{\circ}$;

d) Incluam qualquer referência que seja indiciadora do projecto a apresentar.

\section{Artigo 41. ${ }^{\circ}$}

\section{Admissão condicional}

São admitidos condicionalmente os candidatos cujas candidaturas não se encontrem instruídas com todos os documentos mencionados no artigo $36 .^{\circ}$, devendo os elementos em falta ser apresentados no prazo fixado pela comissão, o qual não poderá ser inferior a dois dias, sob pena de exclusão do procedimento.

\section{Artigo 42. ${ }^{\circ}$}

\section{Exclusão e admissão definitiva}

1 - A comissão de abertura, imediatamente ou após o decurso do prazo concedido para a regularização das candidaturas admitidas condicionalmente, analisa as admissões condicionais e a competente junção da documentação em falta, procede à leitura da lista definitiva dos candidatos admitidos, elaborada de acordo com a ordem de entrada, e identifica os candidatos a excluir, com indicação dos respectivos motivos.

2 - A decisão prevista no número anterior apenas pode ser objecto de reclamação no próprio acto público, devendo a comissão de abertura suspender tal acto pelo tempo necessário à sua apreciação.

3 - Cumpridas as formalidades previstas nos números anteriores e decididas as eventuais reclamações apresentadas pelos candidatos relativamente a esta fase do acto público, o presidente da comissão encerra o mesmo.

\section{Artigo $43^{\circ}$}

\section{Selecção dos candidatos}

1 - Após a deliberação final de admissão e exclusão dos candidatos, a comissão de abertura procede à selecção dos candidatos admitidos, aferindo a idoneidade da sua capacidade técnica, económica e financeira para a instalação de um CIRVER e para assumir a qualidade de gestor de um CIRVER.

2 - A capacidade económica e financeira a que se refere o número anterior é avaliada em função dos seguintes factores: 
a) Declarações abonatórias adequadas emitidas por entidades bancárias;

b) Volume de negócios;

C) Valores do capital próprio;

d) Equilíbrio financeiro tendo em conta, nomeadamente, o conjunto dos indicadores de liquidez geral, autonomia financeira e grau de cobertura do imobilizado.

3 - Os critérios de ponderação dos factores de avaliação referidos no número anterior serão definidos no programa do concurso.

4 - Considera-se que possui a capacidade técnica a que se alude no n. ${ }^{\circ} 1$ o facto de o candidato ou alguma das empresas que o integrem ter sido responsável, durante os últimos cinco anos, pelo tratamento de, pelo menos, $50000 \mathrm{t}$ de resíduos perigosos.

5 - No caso de agrupamentos de empresas, é necessária a declaração de responsabilidade da empresa que preenche o requisito consagrado no número anterior de que não abandona a operação técnica do CIRVER.

6 - A comissão de abertura elabora, após a apreciação das candidaturas, um relatório provisório de selecção dos candidatos composto por:

a) Lista provisória dos candidatos seleccionados e não seleccionados;

b) Fundamentação da selecção de candidatos proposta.

7 - O relatório provisório é notificado aos candidatos, devendo constar da notificação o prazo para a apresentação de pronúncia sobre o teor do mesmo, em sede de audiência prévia, o qual é o previsto no $n .^{\circ} 2$ do artigo $20 .^{\circ}$

8 - Após a pronúncia dos candidatos, a comissão de abertura pondera as observações realizadas e elabora o relatório final, que é constituído por:

a) Lista final dos candidatos seleccionados e não seleccionados;

b) Fundamentação da selecção de candidatos proposta;

c) Fundamentação do não acatamento das observações realizadas pelos candidatos, se as houver.

9 - O relatório final é objecto de homologação pela entidade licenciadora e posteriormente notificado aos candidatos. 
SECÇÃO III

Apreciação dos projectos

SUBSECÇÃO I

Comissão de análise

Artigo $44 .^{\circ}$

Constituição da comissão de análise

1 - A fase de apreciação e selecção dos projectos é conduzida pela comissão de análise, composta por cinco membros efectivos e igual número de suplentes, designados pela entidade licenciadora mediante despacho.

2 - O despacho constitutivo da comissão de análise refere obrigatoriamente:

a) A identificação dos membros efectivos e suplentes;

b) A identificação do seu presidente;

c) A identificação do vogal que substitui o presidente nas suas faltas e impedimentos.

3 - A comissão de análise pode agregar peritos, sem direito de voto, para a emissão de pareceres em áreas especializadas.

4 - A comissão de análise não pode, salvo casos de manifesta impossibilidade, devidamente fundamentados, ser constituída em mais de um terço pelos elementos que tenham feito parte da comissão de abertura das candidaturas.

5 - Em caso de impedimento temporário ou permanente dos membros efectivos da comissão, a sua substituição é assegurada por membro suplente de acordo com a ordem da respectiva lista, o qual tem a obrigação de assumir todos os actos praticados e as decisões tomadas anteriormente pela comissão.

\section{Artigo 45. ${ }^{\circ}$}

Funcionamento da comissão de análise

1 - A comissão de análise entra em exercício de funções no dia útil subsequente à formulação do convite aos candidatos seleccionados pela entidade coordenadora.

2 - A comissão de análise apenas pode reunir quando estiverem presentes mais de dois terços dos seus membros em efectividade de funções.

3 - A comissão de análise será coadjuvada por um secretário por ela escolhido de entre os seus membros ou de entre o pessoal dos serviços da entidade 
coordenadora, neste caso com anuência do respectivo dirigente, a quem compete, designadamente, lavrar as actas.

4 - As deliberações são aprovadas por maioria de votos, não sendo admitidas abstenções, devendo a fundamentação constar da respectiva acta.

5 - Em caso de empate na votação, o presidente tem voto de qualidade. 6 - Os membros da comissão de análise que relativamente a qualquer deliberação votem vencidos devem ditar para a acta as razões da sua discordância com o sentido da deliberação.

\section{Artigo 46.}

\section{Competência da comissão de análise}

1 - Compete à comissão de análise a instrução de toda a fase de apresentação e apreciação dos projectos do procedimento concursal, podendo, para o efeito, solicitar o apoio de outras entidades.

2 - Compete ainda à comissão de análise:

a) Conduzir o acto público de análise dos projectos;

b) Proceder à apreciação dos projectos;

c) Propor à entidade licenciadora o licenciamento dos projectos seleccionados.

3 - A comissão de análise tem o dever de deliberar sobre a exclusão de candidatos do concurso quando tenha conhecimento da existência de factos susceptíveis de constituírem justa causa de exclusão nos termos do disposto no artigo $15 .^{\circ}$

4 - Tanto a comissão de análise como os seus membros, individualmente considerados, podem solicitar, através do seu presidente, esclarecimentos aos candidatos nos termos do disposto no artigo $24 .^{\circ}$

\section{SUBSECÇÃO II}

\section{Apresentação dos projectos}

\section{Artigo 47. ${ }^{\circ}$}

\section{Convite}

1 - Terminada a fase de pré-qualificação, a entidade coordenadora formula, simultaneamente, convite aos candidatos seleccionados, por qualquer meio escrito, para apresentarem um projecto nos termos das peças concursais. 
2 - Do convite devem constar, designadamente, os seguintes elementos:
a) Referência ao anúncio;
b) Hora e data limites da recepção de projectos;
c) Elementos que devem ser indicados nos projectos;
d) Modo de apresentação dos projectos;
e) Local de entrega dos projectos e respectivo horário de funcionamento;
f) Data, hora e local do acto público de análise dos projectos;
g) Critérios de selecção dos projectos a licenciar;
h) Prazo durante o qual os candidatos ficam vinculados a manter os projectos.

\section{Artigo $48 .^{\circ}$}

\section{Caducidade do direito de apresentação do projecto}

A não apresentação dos projectos no prazo a fixar nos termos do disposto na alínea

b) do . $^{\circ} 2$ do artigo anterior faz precludir o direito do candidato a apresentar 0 projecto.

\section{Artigo 49.}

\section{Modo de apresentação do projecto}

1 - O projecto e os documentos que o acompanham devem ser apresentados em invólucros separados, opacos e fechados, em cujos rostos devem escrever-se as palavras «Projecto» e «Documentos», respectivamente, os quais devem ser guardados num outro invólucro opaco e fechado, constando a identificação do concurso e do candidato em todos eles.

2 - O projecto terá, obrigatoriamente, de ser instruído com os seguintes documentos:

a) Autorização municipal da localização, com respeito pelas regras da concorrência, devidamente identificada em planta cadastral, a qual fica condicionada a posterior emissão de declaração de impacte ambiental favorável ou condicionalmente favorável;

b) Declaração municipal de não sujeição do projecto a licenciamento de operação de loteamento. 
3 - Os projectos, bem como os documentos que os acompanham, devem ser redigidos em língua portuguesa ou, não o sendo, devem ser acompanhados de tradução devidamente legalizada e em relação à qual o candidato declara aceitar a prevalência, para todos os efeitos, sobre os respectivos originais.

\section{Artigo $500^{\circ}$}

\section{Prazo de manutenção dos projectos}

1 - A entrega do projecto nos termos do presente procedimento implica a assunção do dever de o manter durante um prazo de três anos a contar a partir da data da entrega.

2 - Se os candidatos não se opuserem à prorrogação dentro dos oito dias anteriores ao termo do prazo previsto no número anterior ou da sua prorrogação, considerarse-á o mesmo prorrogado por mais seis meses.

\section{SUBSECÇÃO III}

\section{Análise dos projectos}

\section{Artigo 51. ${ }^{\circ}$}

\section{Acto público de apresentação dos projectos}

1 - Em sessão pública, a comissão de análise faz rubricar, pela maioria dos seus membros, os documentos inseridos no invólucro referido no n. ${ }^{\circ} 1$ do artigo $49 .^{\circ}$, podendo as rubricas ser substituídas por chancela.

2 - Só podem intervir no acto público do concurso os representantes dos candidatos, até ao máximo de três elementos por candidato, desde que devidamente credenciados para os representarem no acto.

3 - Analisados os documentos, a comissão de análise delibera sobre a admissão, admissão condicional e exclusão dos projectos.

4 - São excluídos os projectos:

a) Que não sejam recebidos no prazo fixado;

b) Que não cumpram o estabelecido no artigo $49 .^{\circ}$

5 - São admitidos condicionalmente os projectos que não contenham todos os documentos ou dados essenciais à sua apreciação, devendo os elementos em falta ser apresentados em prazo a estipular pela comissão de análise, não superior a 15 
dias, sob pena de exclusão do procedimento, suspendendo-se o acto público por esse prazo.

6 - A comissão de análise, imediatamente ou após o decurso do prazo concedido para a regularização dos projectos admitidos condicionalmente, reinicia o acto público e procede à leitura da lista dos projectos admitidos, elaborada de acordo com a ordem de entrada, e identifica os projectos a excluir, com a indicação dos respectivos motivos.

7 - A decisão prevista no número anterior apenas pode ser objecto de reclamação no próprio acto público, devendo a comissão de análise suspender tal acto pelo tempo necessário à sua apreciação.

8 - Cumpridas as formalidades previstas nos números anteriores e decididas as eventuais reclamações apresentadas pelos candidatos relativamente a esta fase do acto público, o presidente da comissão de análise encerra o mesmo.

\section{Artigo 52. ${ }^{\circ}$}

\section{Critérios de apreciação dos projectos}

1 - A comissão de análise procede à apreciação dos projectos admitidos a concurso, em sessão privada, tendo por base os seguintes critérios:

a) Qualidade técnica do projecto;

b) Adequação aos objectivos consagrados no artigo $2 .^{\circ}$ do presente diploma;

c) Prazo de construção;

d) Sustentabilidade financeira do projecto, na qual deverão ser ponderados o montante do investimento, a rentabilidade do projecto do CIRVER e o regime de preços;

e) Garantias prestadas relativamente aos riscos da actividade licenciada, nos termos do artigo $62 .^{\circ}$ do presente diploma.

2 - Os factores de avaliação de cada um dos critérios referidos no número anterior, bem como a respectiva ponderação, serão definidos no programa do concurso.

\section{Artigo 53. ${ }^{\circ}$}

\section{Instalações já licenciadas}

Os candidatos poderão integrar nos projectos que apresentem instalações que se encontrem já licenciadas e que sejam da sua propriedade. 


\section{Artigo 54. ${ }^{\circ}$}

\section{Relatório provisório}

1 - Após a apreciação dos projectos, a comissão de análise elabora um relatório provisório de classificação dos projectos composto por:

a) Lista classificativa provisória dos projectos e respectiva fundamentação;

b) Indicação dos projectos cujo licenciamento se pretende propor e dos projectos que se pretende propor que sejam preteridos.

2 - O relatório provisório é notificado aos candidatos cujos projectos tenham sido apreciados, devendo constar da notificação o prazo de apresentação de pronúncia, em sede de audiência prévia, sobre o teor do mesmo.

\section{Artigo 55.}

\section{Relatório final}

1 - Após a pronúncia dos candidatos nos termos do disposto no n. 2 do artigo anterior, a comissão de análise pondera as observações realizadas pelos candidatos e elabora o relatório final.

2 - 0 relatório final é constituído por:

a) Lista classificativa final dos projectos e respectiva classificação;

b) Indicação dos projectos cujo licenciamento propõe e dos projectos preteridos;

c) Fundamentação do não acatamento das observações realizadas pelos candidatos, se as houver.

3 - O relatório final é enviado à entidade licenciadora para homologação da lista de classificação final.

\section{SECÇÃO IV}

\section{Licenciamento}

\section{Artigo 56. ${ }^{\circ}$}

\section{Competência}

1 - A entidade licenciadora procede, mediante despacho, à homologação da lista de classificação final e ao licenciamento do CIRVER.

2 - O licenciamento mencionado no número anterior fica, contudo, condicionado à obtenção dos documentos necessários à emissão do alvará. 


\section{Artigo 57. ${ }^{\circ}$}

\section{Causas de não licenciamento}

Não haverá lugar a licenciamento quando todos os projectos apresentados sejam preteridos.

\section{Artigo 58.}

\section{Anulação do procedimento}

1 - A entidade competente para o licenciamento pode anular o procedimento quando:

a) Por circunstância imprevisível, seja necessário alterar os elementos fundamentais dos documentos que servem de base ao procedimento;

b) Outras razões supervenientes e de manifesto interesse público o justifiquem.

2 - A decisão de anulação do procedimento deve ser fundamentada e publicitada nos mesmos termos em que foi publicitada a sua abertura.

3 - Os candidatos que, entretanto, tenham apresentado a sua candidatura ou o projecto, consoante a fase em que ocorrer a anulação, devem ser notificados dos fundamentos da decisão de anulação do procedimento.

\section{SECÇÃO V}

\section{Diligências complementares}

\section{Artigo 59.}

\section{Enumeração}

Após a decisão de licenciamento, e anteriormente à emissão do alvará de licença de instalação, haverá lugar às seguintes diligências complementares, de acordo com o disposto nos artigos subsequentes:
a) Prestação de caução relativa à instalação;
b) Prestação de caução definitiva relativa à exploração;
C) Apresentação de garantias relativas a riscos de actividade, nos termos do projecto apresentado e seleccionado;
d) Liquidação das taxas de licenciamento;
e) Obtenção dos pareceres, autorizações e licenciamentos enumerados no artigo $65 .^{\circ}$ 


\section{Artigo 60.}

\section{Caução relativa à instalação}

1 - Antes da emissão do alvará de licença de instalação, o candidato que viu o seu projecto licenciado deverá prestar caução que assegure o exacto e pontual cumprimento das obrigações resultantes da licença.

2 - A caução referida no número anterior é condição da emissão do alvará de licença de instalação.

3 - O montante da caução é de $10 \%$ do valor global da instalação constante do orçamento apresentado pelo candidato com o respectivo projecto.

4 - A caução é prestada através de depósito, em dinheiro ou em títulos emitidos ou garantidos pelo Estado, à ordem da entidade coordenadora.

5 - O depósito referido no número anterior pode ser substituído por garantia bancária ou seguro-caução que ofereça garantias equivalentes àquele, à ordem do INR, e em qualquer dos casos devidamente documentados.

6 - Quando o depósito for efectuado em títulos, estes são avaliados pelo seu respectivo valor nominal, salvo se nos últimos três meses a média da cotação na Bolsa de Valores de Lisboa ficar abaixo do par, caso em que a avaliação será feita por $90 \%$ dessa média.

7 - Implica a perda da caução:

a) A caducidade do licenciamento;

b) A cassação do alvará de licença.

8 - A caução poderá ser levantada após a vistoria referida no n. ${ }^{\circ} 10$ do artigo $65 .^{\circ} \mathrm{e}$ desde que do respectivo relatório não conste qualquer condição ou reserva.

\section{Artigo 61.}

\section{Caução definitiva relativa à exploração}

1 - Antes da emissão do alvará de licença de exploração, o candidato que viu o seu projecto licenciado deverá prestar caução definitiva que assegure o exacto e pontual cumprimento das obrigações resultantes da licença.

2 - A caução referida no número anterior é condição da emissão do alvará de licença de exploração. 
3 - 0 montante da caução é de $3 \%$ do valor médio anual da facturação no período a que se reporta o licenciamento, constante do estudo de viabilidade apresentado pelo candidato com o respectivo projecto.

4 - A caução poderá ser levantada no termo do prazo da licença ou das respectivas prorrogações desde que tenham sido cumpridas todas as obrigações fixadas no alvará de licença de exploração.

5 - Caso não se mostrem cumpridas todas as obrigações fixadas no alvará de licença de exploração, a entidade coordenadora utilizará a caução para suprir, directa ou indirectamente, as omissões ou erros do gestor do CIRVER, devolvendo posteriormente a parte da caução que não foi necessário utilizar.

6 - É aplicável à caução prevista no presente artigo o disposto nos n.os 4 a 6 do artigo anterior.

\section{Artigo 62..$^{\circ}$}

\section{Garantia relativa a riscos da actividade}

1 - Os riscos decorrentes da actividade licenciada, de acordo com o estabelecido no caderno de encargos, deverão estar garantidos por uma das seguintes modalidades:

a) Seguro de responsabilidade civil;

b) Declaração de responsabilidade do candidato ou das empresas que integram o candidato, com menção do património que fica afecto.

2 - Excluem-se do património mencionado na alínea b) do número anterior os activos adstritos à actividade técnica da empresa ou que a ela se encontrem geograficamente adjacentes.

\section{Artigo $63 .^{\circ}$}

\section{Caducidade do licenciamento}

1 - O licenciamento caduca se:

a) As taxas referidas no artigo $96 .^{\circ}$ não forem pagas no prazo estabelecido;

b) Não forem obtidas as autorizações e os licenciamentos referidos no artigo $65 .^{\circ}$ no prazo de três anos;

c) Caducar o licenciamento ou autorização municipal da edificação. 2 - Sempre que caduque o licenciamento, a entidade licenciadora, por proposta da entidade coordenadora, devolve à comissão de análise a lista classificativa, 
determinando que the seja submetida, no prazo de 10 dias úteis, nova proposta de licenciamento.

3 - Na situação prevista no número anterior, os candidatos que apresentaram projecto são convidados a, no prazo de 30 dias, conformarem os respectivos projectos às exigências que eventualmente constem de legislação que tenha entrado em vigor em momento posterior à respectiva apresentação.

4 - Para além das alteraçõos previstas no número anterior, a introdução de alterações ao projecto inicialmente apresentado implica a respectiva exclusão.

\section{SECÇÃO VI}

\section{Impugnações no procedimento tendente ao licenciamento}

\section{Artigo $64 .^{\circ}$}

\section{Actos recorríveis}

Todos os actos materialmente definitivos que sejam lesivos dos candidatos são contenciosamente impugnáveis, nos termos do regime especial consagrado para o contencioso dos actos relativos à formação de contratos administrativos de empreitada e concessão de obras públicas, de prestação de serviços e de fornecimento de bens.

\section{CAPÍTULO III}

\section{Licença}

\section{SECÇÃO I}

\section{Alvarás de licença}

\section{Artigo 65.}

\section{Alvarás de licença}

1 - O licenciamento de um CIRVER é titulado por dois alvarás, emitidos pelo INR, um relativo à sua instalação e outro relativo à respectiva exploração.

2 - Para além de outras menções que sejam julgadas convenientes, do alvará de licença de instalação devem constar obrigatoriamente:
a) A identificação do respectivo titular;
b) O prazo de execução das obras constantes do projecto licenciado;
c) As características essenciais do projecto; 
d) As condições impostas no licenciamento do CIRVER ou por entidades terceiras que nele tiveram intervenção.

3 - Para além de outras menções que sejam julgadas convenientes, do alvará de licença de exploração devem constar obrigatoriamente:

a) A identificação do respectivo titular;

b) 0 prazo de validade da licença e o respectivo termo inicial;

c) As características essenciais do projecto;

d) As condições impostas no licenciamento do CIRVER ou por entidades terceiras que nele tiveram intervenção.

4 - O licenciamento de um CIRVER não afasta a necessidade de licenciamento ou autorização municipal das edificações, nos termos do disposto no Regime Jurídico da Urbanização e da Edificação, cuja responsabilidade de obtenção é das entidades licenciadas.

5 - O licenciamento de um CIRVER não está sujeito a licenciamento industrial, mas a direcção regional da economia territorialmente competente emite parecer sobre os projectos licenciados, num prazo de 30 dias a contar a partir da data da recepção do pedido de parecer, formulado pela entidade coordenadora, o qual é vinculativo nas questões incluídas no âmbito das atribuições do Ministério da Economia, desde que digam respeito à legalidade do projecto licenciado.

6 - Incumbe, ainda, à entidade coordenadora remeter às entidades competentes de avaliação de impacte ambiental e de licença ambiental toda a documentação apresentada pela entidade a licenciar para os efeitos dos respectivos procedimentos, bem como solicitar os pareceres do Instituto de Desenvolvimento e Inspecção das Condições do Trabalho e da autoridade de saúde competente.

7 - O prazo para a emissão da declaração de impacte ambiental é de 80 dias.

8 - 0 prazo para a emissão de licença ambiental é de 60 dias.

9 - O alvará de licença de instalação apenas pode ser emitido após a recepção pela entidade coordenadora de todos os pareceres das entidades por ela consultadas, bem como de:

a) Declaração de impacte ambiental favorável, emitida nos termos do Decreto-Lei n. ${ }^{\circ} 69 / 2000$, de 3 de Maio, ou de documento comprovativo de se encontrar decorrido o prazo para a produção do respectivo deferimento tácito, nos termos previstos no mesmo diploma; 
b) Licença ambiental emitida nos termos do Decreto-Lei n. ${ }^{\circ} 194 / 2000$, de 21 de Agosto;

c) Notificação ou relatório de segurança, de acordo com o disposto no Decreto-Lei

n. ${ }^{\circ} 164 / 2001$, de 23 de Maio, quando aplicável; e

d) Alvará de licença municipal de edificação.

10 - O alvará de licença de exploração apenas pode ser emitido após a realização de vistoria conjunta de todas as entidades que legalmente nela devam intervir e desde que do respectivo relatório não conste nenhuma condição ou reserva.

11 - Sem prejuízo do disposto no número anterior, a unidade ou as unidades em causa podem ser autorizadas a funcionar provisoriamente, por prazo a fixar pela entidade licenciadora, desde que as falhas detectadas sejam de pormenor e não ponham em causa a segurança ambiental e dos trabalhadores e não constituam perigo para a saúde pública.

12 - Findo o prazo previsto no número anterior, há obrigatoriamente lugar à realização de uma vistoria.

13 - Podem ser emitidos alvarás parciais quer de instalação quer de exploração relativamente a cada uma das unidades que compõem os CIRVER.

14 - Em caso de licenciamento de projecto apresentado por agrupamento de empresas, a constituição da entidade jurídica referida na candidatura é condição da emissão do alvará de licença de instalação.

\section{Artigo 66.}

\section{Conteúdo}

Consideram-se parte integrante do conteúdo da licença:

a) As obrigações emergentes dos termos do concurso;

b) As obrigações assumidas pelo gestor de um CIRVER no projecto objecto do licenciamento;

c) Os termos, os modos e as condições da licença definidos nos termos do disposto na presente secção;

d) As obrigações do gestor de um CIRVER previstas no capítulo IV do presente diploma. 


\section{Artigo 67.}

\section{Termo inicial de vigência da licença}

Constitui termo inicial do prazo de validade da licença:

a) Relativamente à instalação do CIRVER, a data da emissão do alvará da licença de instalação;

b) Relativamente à exploração do CIRVER, a data da emissão do alvará da licença de exploração.

\section{Artigo 68.}

\section{Prazo da licença}

1 - Os alvarás da licença são emitidos pelos seguintes prazos: a) O alvará da licença de instalação, pelo prazo constante do projecto objecto de licenciamento;

b) 0 alvará da licença de exploração, pelo prazo de 10 anos. 2 - 0 prazo fixado na alínea a) do número anterior apenas pode ser prorrogado por uma única vez e por prazo não superior a um ano, mediante requerimento da entidade licenciada.

3 - O prazo fixado na alínea b) do n. ${ }^{\circ} 1$ pode ser objecto de prorrogação por períodos de cinco anos quando se reúnam cumulativamente as seguintes condições:

a) Não ter ocorrido nenhuma situação de suspensão da licença;

b) $O$ gestor do CIRVER apresentar à entidade coordenadora, com uma antecedência mínima de seis meses em relação ao termo do prazo do licenciamento, um plano de adaptação tecnológica.

4 - A prorrogação do prazo da licença obedece ao procedimento previsto no artigo seguinte.

\section{Artigo 69..$^{\circ}$}

\section{Prorrogação da vigência da licença}

1 - A requerimento do gestor de um CIRVER apresentado com a antecedência mínima de um ano em relação ao termo do prazo de vigência do alvará da licença de exploração, pode o prazo desta ser prorrogado, sem limite de vezes, mediante despacho da entidade competente para a sua emissão, por período não superior a metade do prazo fixado no $n .^{\circ} 1$ do artigo anterior desde que o gestor de um 
CIRVER tenha cumprido cabalmente as obrigações a cujo cumprimento estava adstrito por efeito da atribuição da licença.

2 - 0 acto que decide a prorrogação ou não da licença deve ser emitido no prazo de três meses a contar a partir da recepção do plano de adaptação tecnológica.

3 - O acto que negue a prorrogação do prazo da licença deve ser fundamentado, explicitando as razões de facto e de direito que obstam à prorrogação.

4 - A entidade licenciadora pode condicionar o deferimento do pedido de prorrogação da licença à inclusão de alterações às condições de licenciamento vigentes, sempre que o entenda necessário, no sentido de assegurar o adequado funcionamento das instalações e das operações de gestão, a melhoria dos níveis dos serviços assegurados aos utentes, a protecção do ambiente e da saúde pública ou a segurança das pessoas e bens.

5 - As alterações introduzidas na licença em consequência da aplicação do disposto no número anterior são eficazes desde o seu averbamento no alvará.

\section{Artigo $709^{\circ}$}

Área de actuação

A licença pode ser de âmbito nacional ou regional, conforme o que for definido nas peças concursais para a atribuição das licenças.

\section{SECÇÃO II}

\section{Alterações da licença}

Artigo 71.

\section{Modificação da personalidade jurídica do gestor de um CIRVER}

1 - Toda a alteração subjectiva do licenciamento depende de prévia autorização da entidade licenciadora.

2 - Sempre que houver modificação da personalidade jurídica do gestor de um CIRVER, designadamente através de fusão ou cisão, deve o facto ser comunicado à entidade licenciadora de modo que se proceda ao averbamento no alvará da mudança de titularidade da licença e à verificação da manutenção dos requisitos necessários à titularidade da qualidade de gestor de um CIRVER.

3 - Deve ainda ser comunicada à entidade licenciadora qualquer modificação que não se repercuta na personalidade jurídica do gestor de um CIRVER, mas 
susceptível de alterar o objecto dos critérios de avaliação da capacidade técnica e financeira do gestor de um CIRVER realizados no âmbito do concurso ou de colocar o gestor de um CIRVER em situação de impedimento.

4 - A comunicação referida nos números anteriores deve ser acompanhada dos documentos necessários à verificação da manutenção da capacidade técnica e financeira do gestor de um CIRVER ou da pessoa jurídica que pretender suceder-lhe nessa qualidade.

5 - A entidade licenciadora pode intimar o gestor de um CIRVER a prestar informações sobre a matéria referida nos n.os 2 e 3 e solicitar a entrega dos documentos referidos no n. ${ }^{\circ} 4$ quando tenha suspeita fundada da ocorrência de modificação da personalidade do gestor de um CIRVER nos termos do disposto no presente artigo, abrindo oficiosamente o procedimento tendente à emissão da declaração de conformidade.

6 - A entidade licenciadora deve emitir, no prazo de 30 dias a contar a partir da recepção da comunicação e dos respectivos documentos, acto de autorização de manutenção da licença ou dos actos necessários à sua emissão, devendo, neste caso, proceder a audiência prévia do gestor de um CIRVER e estabelecer um prazo para a sua execução.

7 - No caso de a não autorização se dever a presumida falta de capacidade financeira, pode esta ser concedida após reforço da caução.

8 - 0 procedimento de autorização implica a apreciação da manutenção dos requisitos necessários à titularidade da qualidade de gestor de um CIRVER previstos no presente diploma e deve ser promovido pelo gestor de um CIRVER em fase anterior à consolidação jurídica da modificação, sendo o projecto de modificação o seu objecto.

\section{Artigo $72 .^{\circ}$}

\section{Cessão da posição de gestor de um CIRVER}

1 - O alvará de licença apenas é transmissível mediante prévia autorização da entidade licenciadora.

2 - A autorização deve ser acompanhada de relatório justificativo da verificação dos requisitos exigidos na fase de pré-qualificação e não pode implicar qualquer alteração ao projecto licenciado. 
3 - O incumprimento dos deveres previstos no presente artigo implica a nulidade da transmissão da licença.

\section{Artigo 73.}

\section{Impedimento superveniente}

1 - A superveniência de facto susceptível de colocar o gestor de um CIRVER em situação de impedimento deve ser imediatamente comunicada por este à entidade coordenadora.

2 - A entidade coordenadora deve propor à entidade licenciadora, quando seja notória a situação de impedimento do gestor de um CIRVER, em acto devidamente fundamentado, a suspensão da licença, nos termos do disposto no artigo 87. ${ }^{\circ}$

3 - O acto de suspensão da licença por situação de impedimento superveniente caduca com o desaparecimento dessa situação ou com a demonstração de que a mesma não se verifica, desde que tal demonstração ocorra antes de decorrido o prazo consagrado na alínea b) do n. ${ }^{\circ} 1$ do artigo $88 .^{\circ}$

\section{Artigo $74 .^{\circ}$}

\section{Alterações ao projecto licenciado}

1 - Apenas são admitidas alterações ao projecto objecto de licenciamento decorridos que estejam dois anos, contados a partir do termo inicial do alvará da licença de exploração da unidade em causa, e sempre com fundamento em factos supervenientes, designadamente os decorrentes de evoluções tecnológicas, que sejam reconhecidos como justificativos pela entidade licenciadora.

2 - Não dependem do decurso do prazo referido no número anterior as alterações ao projecto decorrentes de imposição legal.

3 - As alterações ao projecto licenciado carecem de autorização expressa da entidade licenciadora, sem prejuízo do disposto no artigo seguinte.

4 - 0 pedido de alteração do projecto deve ser instruído com os documentos necessários à avaliação do mérito das alterações propostas, devendo ainda o gestor de um CIRVER entregar os documentos solicitados pela entidade licenciadora. 5 - No prazo de 60 dias a contar a partir da entrega do pedido ou dos documentos posteriormente solicitados, deve a entidade licenciadora aprovar a proposta de alteração ao projecto ou recusá-la. 
6 - A aprovação da alteração ao projecto deve ser averbada no alvará da licença.

7 - 0 acto de recusa deve ser fundamentado e indicar, caso seja possível, os termos que possibilitem a aprovação da alteração.

8 - A autorização da alteração ao projecto não preclude a necessidade de promoção de outros procedimentos autorizativos legalmente devidos, nomeadamente os relativos a licenciamento ou autorização municipal regulados pelo Regime Jurídico da Urbanização e da Edificação.

\section{Artigo $75 .^{\circ}$}

\section{Ajustamentos}

1 - Carecem de simples comunicação prévia, acompanhada dos documentos imprescindíveis à compreensão do teor da alteração proposta, as alterações ao projecto que consubstanciem meros ajustamentos destinados ao seu aperfeiçoamento.

2 - No prazo de 30 dias a contar a partir da recepção da comunicação referida no n. ${ }^{\circ} 1$, deve a entidade licenciadora, quando seja o caso, sujeitar a alteração ao projecto ao procedimento de autorização previsto no artigo anterior.

3 - A comunicação prévia é eficaz e título suficiente para a promoção da alteração ao projecto 45 dias depois da sua recepção pela entidade licenciadora, salvo no caso de ser exercida a prerrogativa consagrada no número anterior.

\section{Artigo $76 .^{\circ}$}

Alterações à licença imputáveis à entidade licenciadora

A entidade licenciadora apenas pode proceder à alteração das condições da licença quando esteja em causa a respectiva adequação a novas normas legais ou regulamentares, nacionais ou comunitárias.

\section{SECÇÃO III}

\section{Caducidade da licença}

Artigo $77 .^{\circ}$

\section{Caducidade}

1 - As licenças caducam: 
a) Por decurso do prazo nelas fixado ou da sua prorrogação;

b) Pela não execução das obras necessárias à instalação do CIRVER no prazo previsto no projecto objecto de licenciamento;

c) Pelo não início do funcionamento do CIRVER no prazo previsto no projecto objecto de licenciamento;

d) Pela extinção do titular da licença.

2 - No caso de caducidade da licença o respectivo alvará deve ser cassado nos termos definidos no artigo $88 .^{\circ}$

\section{CAPÍTULO IV}

\section{Execução}

\section{SECÇÃO I}

\section{Direitos e obrigações do gestor de um CIRVER em relação à entidade} licenciadora

\section{Artigo $78 .^{\circ}$}

\section{Direitos do gestor de um CIRVER}

1 - Constituem direitos do gestor de um CIRVER:

a) Desenvolver a actividade nos termos definidos no alvará da licença;

b) Exigir que a actividade seja exercida pelo número de gestores de um CIRVER definidos no respectivo concurso enquanto vigorarem as licenças emitidas ao abrigo do mesmo, sem prejuízo do disposto no $n .^{\circ} 2$.

2 - 0 número de licenças poderá, no entanto, ser aumentado no caso de se verificar um aumento da produção de resíduos perigosos no território nacional e as entidades licenciadas não pretenderem aumentar a capacidade das instalações licenciadas.

3 - No caso previsto no número anterior, as entidades licenciadas dispõem de um prazo de 15 dias, contados a partir da notificação para o efeito, para manifestarem a sua intenção de adequar as instalações licenciadas às novas necessidades.

4 - Caso as entidades licenciadas manifestem essa intenção, dispõem de um prazo de dois meses para apresentarem o respectivo projecto de ampliação.

5 - A entidade coordenadora dispõe de um prazo de dois meses para apreciar o projecto apresentado e propor à entidade licenciadora a alteração da licença do 
CIRVER, ou a opção pelo aumento do número de licenças, caso considere o projecto inaceitável.

Artigo 79. ${ }^{\circ}$

Obrigações do gestor do CIRVER em relação à entidade licenciadora Constituem obrigações do gestor do CIRVER:

a) Respeitar as condições e os limites constantes do alvará da licença, bem como as que lhe são inerentes;

b) Cumprir as disposições legais e regulamentares, nacionais ou comunitárias, relativas à actividade de recuperação, valorização e eliminação de resíduos perigosos;

c) Cumprir as normas técnicas de exploração aplicáveis;

d) Utilizar equipamentos devidamente aprovados pelas entidades competentes, quando for o caso;

e) Apresentar à entidade coordenadora até ao fim do $3 .^{\circ}$ trimestre de cada ano o orçamento de receitas e despesas para o ano seguinte, com a explicitação dos custos de investimento e da respectiva justificação;

f) Facultar a verificação das instalações e dos equipamentos do CIRVER aos funcionários e agentes da entidade coordenadora devidamente credenciados para o efeito;

g) Fornecer a informação necessária à verificação e fiscalização das obrigações e das condições decorrentes do licenciamento, bem como da informação destinada a tratamento estatístico, permitindo o acesso à documentação de suporte;

h) Proceder às correcções necessárias tendo em vista o regular funcionamento das instalações e dos equipamentos e o adequado exercício da actividade licenciada;

i) Garantir, em termos de igualdade, o acesso aos serviços prestados mediante os preços aplicáveis, nos termos definidos no presente diploma

\section{SECÇÃO II}

Direitos e obrigações do gestor do CIRVER perante os detentores e transportadores de resíduos

Artigo 80.

Igualdade de acesso aos serviços prestados 
1 - Constitui obrigação do gestor do CIRVER garantir a igualdade de acesso à actividade exercida relativamente a todos os produtores de resíduos perigosos.

2 - Caso o gestor constate a existência de sobrecarga do CIRVER, tem a obrigação de referenciar o produtor para outro CIRVER e comunicar o facto à entidade coordenadora.

3 - Ao gestor do CIRVER fica expressamente vedada a suspensão da actividade sem aviso prévio, salvo por motivo de força maior, sem prejuízo do disposto no artigo seguinte.

\section{Artigo 81. ${ }^{\circ}$}

\section{Suspensão da prestação individual do serviço}

1 - Em caso de mora do utente relativamente aos pagamentos devidos ao gestor do CIRVER em virtude da actividade regulada no presente diploma superior a 90 dias, goza o gestor do CIRVER do direito de suspender a sua actividade relativamente a esse utente, devendo, no entanto, comunicar tal facto à entidade coordenadora.

2 - A comunicação prevista no número anterior é feita num prazo de 10 dias, contados a partir da recusa do recebimento dos resíduos, por carta registada com aviso de recepção ou mediante requerimento entregue na entidade coordenadora.

\section{SECÇÃO III}

\section{Regime de preços}

\section{Artigo 82. ${ }^{\circ}$}

\section{Preços}

1 - Os gestores dos CIRVER estão obrigados a anunciar e divulgar regularmente, de forma detalhada, os vários componentes dos preços aplicáveis, devendo fornecer aos utentes uma factura que especifique devidamente os valores que apresenta.

2 - Os gestores dos CIRVER têm a obrigação de comunicar à entidade coordenadora os preços dos serviços que prestam, bem como as alterações aos mesmos, até 30 dias antes da sua prática.

3 - Por portaria do membro do Governo responsável pela área do ambiente, poderão ser fixados preços máximos relativos a cada tipo de serviço prestado.

Artigo

Prescrição 
Os créditos das entidades licenciadas relativos à actividade dos CIRVER prescrevem decorridos que estejam dois anos sobre a respectiva facturação ou três anos sobre o serviço prestado.

\section{CAPÍTULO V}

Fiscalização e sanções

\section{SECÇÃO I}

\section{Fiscalização}

Artigo 84.

\section{Competência}

1 - A fiscalização dos CIRVER é assegurada pela Inspecção-Geral do Ambiente e pela comissão de coordenação e desenvolvimento regional territorialmente competente, sem prejuízo dos poderes de fiscalização atribuídos por lei a outras entidades.

2 - Todas as entidades públicas que se apercebam da existência de infracções contra-ordenacionais ou do mero desrespeito pelas condições do licenciamento têm o dever de participar esse facto à Inspecção-Geral do Ambiente e à comissão de coordenação e desenvolvimento regional territorialmente competente.

\section{Artigo 85.}

\section{Conteúdo}

1 - O poder de fiscalização consiste no controlo do cumprimento das leis e dos regulamentos aplicáveis, das cláusulas do alvará da licença e, bem assim, das normas que fazem parte integrante da licença, nos termos do disposto no artigo 66. ${ }^{\circ}$, onde quer que o gestor do CIRVER exerça a sua actividade, podendo, para tanto, exigir-lhe as informações e os documentos que considerar necessários.

2 - 0 pessoal de fiscalização dispõe de livre acesso, no exercício das suas funções, a todas as infra-estruturas e aos equipamentos do gestor do CIRVER afectos ao centro e a todas as instalações do gestor do CIRVER.

\section{Artigo 86.}

\section{Relatório anual}

1 - O gestor do CIRVER é responsável pela monitorização do funcionamento do centro. 
2 - 0 gestor do CIRVER enviará, todos os anos, à entidade coordenadora, até ao termo do $1 .^{\circ}$ trimestre do ano seguinte àquele a que diz respeito, o relatório final, donde constem obrigatoriamente:

a) A quantidade e a classificação dos resíduos recebidos, identificando a origem/produtor dos mesmos, bem como o tipo de tratamento a que foram submetidos;

b) A quantidade e a classificação dos resíduos resultantes da laboração de cada componente do CIRVER, bem como o destino dado aos mesmos;

c) Relatório da actividade donde conste toda a informação relativa à monitotização efectuada aos parâmetros ambientais;

d) 0 orçamento de receitas e despesas, com explicitação e justificação dos custos de investimento.

3 - O gestor do CIRVER enviará ainda anualmente à entidade coordenadora, até ao termo do $1 .^{\circ}$ semestre do ano seguinte a que respeita o exercício considerado, os documentos de prestação de contas, devidamente certificados por um revisor oficial de contas.

\section{SECÇÃO II}

\section{Sanções administrativas}

\section{Artigo 87.}

\section{Suspensão da licença}

1 - Constitui fundamento para a suspensão da licença a violação, de reduzida gravidade, de normas legais ou regulamentares, nacionais ou comunitárias, que regulam a actividade e que não constitua fundamento para a cassação definitiva do alvará da licença.

2 - A decisão de suspensão da licença é da competência da entidade licenciadora e tanto pode dizer respeito à globalidade do CIRVER como a qualquer uma das suas unidades.

3 - Em caso de suspensão da licença de um CIRVER, a entidade coordenadora tem a obrigação de desenvolver todos os esforços no sentido de minimizar os danos ambientais que a suspensão possa acarretar. 


\section{Artigo 88. ${ }^{\circ}$}

\section{Cassação da licença}

1 - Constituem fundamento para a cassação do alvará da licença:

a) A violação grave de normas legais ou regulamentares, nacionais ou comunitárias, que regulam a actividade;

b) A manutenção dos fundamentos que determinaram a suspensão por um período superior a dois meses;

c) A verificação de fundamentos para determinar uma segunda suspensão da licença;

d) A transmissão da licença sem prévia autorização da entidade licenciadora;

e) A instauração de processo especial de recuperação de empresa ou falência relativo ao gestor do CIRVER;

f) A interrupção da actividade, salvo por motivo de força maior, por período superior a um mês;

g) A modificação subjectiva do gestor do CIRVER sem autorização prévia da entidade licenciadora;

h) A modificação objectiva no titular da licença que obste ao desenvolvimento da actividade nos termos licenciados;

i) $O$ incumprimento pelo gestor do CIRVER de forma reiterada das obrigações resultantes do licenciamento;

j) A suspensão da actividade por um período superior a um mês. 2 - A decisão de cassação do alvará é da competência da entidade licenciadora, abrangendo, sempre, a globalidade do CIRVER.

3 - A cassação do alvará da licença faz-se mediante notificação ao gestor do CIRVER de decisão fundamentada, na qual se determine o prazo para a entrega do respectivo alvará.

4 - A audiência prévia do gestor do CIRVER pode ser dispensada quando a urgência na cessação da actividade por parte do gestor do CIRVER, fundada na gravidade dos fundamentos, seja significativa.

5 - No caso de cassação da licença e para além da perda da caução e de outras sanções que lhe sejam aplicáveis, o gestor do CIRVER é responsável pelos danos ambientais provocados pela sua conduta. 
6 - No caso de cassação da licença, a entidade licenciadora pode declarar a utilidade pública da expropriação dos imóveis afectos ao CIRVER.

7 - A indemnização devida pela expropriação reporta-se ao valor dos imóveis expropriados, devendo ser calculada de acordo com os critérios consagrados no Código das Expropriações.

8 - Dado o interesse público em causa, fica, nesse caso, autorizada a negociação para a celebração de contrato de concessão do CIRVER.

\section{SECÇÃO III}

\section{Sanções contra-ordenacionais}

\section{Artigo 89.}

\section{Contra-ordenações}

1 - Sem prejuízo da responsabilidade civil, criminal ou disciplinar, são puníveis como contra-ordenação:

a) A violação do disposto no artigo $4 .^{\circ}$ do presente diploma;

b) A execução de obras sem licença ou em desconformidade com a mesma;

c) A exploração do CIRVER em desconformidade com os termos da licença;

d) A violação do disposto no artigo $71 .^{\circ}$ do presente diploma;

e) A violação do disposto no artigo $74 .{ }^{\circ}$ do presente diploma;

f) A violação do disposto no artigo $79 .{ }^{\circ}$ do presente diploma;

g) A violação do disposto no artigo $81 .^{\circ}$ do presente diploma;

h) A violação do disposto no artigo $82 .{ }^{\circ}$ do presente diploma;

i) A violação do disposto no artigo $86 .^{\circ}$ do presente diploma.

2 - A contra-ordenação prevista nas alíneas a), b), d) e e) do número anterior é punível com coima graduada de (euro) 500 e até ao máximo de (euro) 3700, no caso de pessoa singular, ou até (euro) 44800 , no caso de pessoa colectiva.

3 - A contra-ordenação prevista nas alíneas c), f) e h) do $n .{ }^{\circ} 1$ é punível com coima graduada de (euro) 250 até ao máximo de (euro) 1900, no caso de pessoa singular, ou até (euro) 25000, no caso de pessoa colectiva.

4 - A contra-ordenação prevista nas alíneas g) e i) do n. ${ }^{\circ} 1$ é punível com coima graduada de (euro) 125 até ao máximo de (euro) 800, no caso de pessoa singular, ou até (euro) 12500, no caso de pessoa colectiva. 
5 - Os montantes fixados nos números anteriores serão revistos sempre que sejam alterados os limites das coimas fixadas no regime geral.

\section{Artigo $900^{\circ}$}

Instrução e decisão dos processos

1 - É competente para a instrução do processo de contra-ordenação a entidade que tenha procedido ao levantamento do auto de notícia, excepto no caso de o auto de notícia ter sido levantado pelas autoridades policiais, nomeadamente a Guarda Nacional Republicana e a Polícia de Segurança Pública, em que a autoridade competente para a instrução do processo é a Inspecção-Geral do Ambiente.

2 - A aplicação das coimas e das sanções acessórias cabe ao inspector-geral do Ambiente, sem prejuízo das competências próprias das demais entidades intervenientes no processo.

\section{Artigo 91.}

\section{Afectação do produto das coimas}

0 produto das coimas é distribuído da forma seguinte:
a) $10 \%$ para a entidade que levantou o auto;
b) $30 \%$ para a entidade que aplica a coima;
c) $60 \%$ para os cofres do Estado.

\section{CAPÍTULO VI}

Observatório

Artigo $92 .^{\circ}$

\section{Criação}

1 - É criado o Observatório Nacional dos CIRVER, adiante designado abreviadamente por Observatório.

2 - O Observatório é composto pelos seguintes membros:

a) Um representante nomeado pelo membro do Governo responsável pela área do ambiente, que preside;

b) Dois representantes do INR;

c) Um representante de cada comissão de coordenação e desenvolvimento regional com jurisdição na área em que o CIRVER esteja instalado; 
d) Um representante de cada direcção regional da economia com jurisdição na área em que o CIRVER esteja instalado;

e) Um representante da Autoridade da Concorrência;

f) Um representante da Associação Nacional de Municípios Portugueses;

g) Um representante da cada um dos municípios em cujo território estiver instalado um CIRVER;

h) Um representante de cada administração regional de saúde em cuja circunscrição territorial esteja instalado um CIRVER;

i) Um representante das organizações não governamentais da área do ambiente;

j) Um representante das associações industriais.

\section{Artigo 93.}

\section{Funções}

1 - A actividade do Observatório compreende:

a) Proceder à recolha de todas as informações relativas à qualidade do serviço prestado, compilando e harmonizando essa informação de modo a torná-la acessível à população em geral;

b) Elaborar e publicitar listagens comparativas entre os CIRVER e sobre os elementos referidos na alínea anterior;

c) Recomendar à entidade coordenadora a realização de auditorias às entidades licenciadas, divulgando as matérias com influência nos níveis de qualidade do serviço prestado;

d) Emitir recomendações dirigidas às entidades licenciadas sobre aspectos relacionados com a gestão dos CIRVER;

e) Emitir recomendações dirigidas às entidades licenciadora e coordenadora, bem como às entidades licenciadas, sobre aspectos relativos à actividade licenciada;

f) Alertar o Governo e as autarquias locais para a verificação de situações anómalas no sector e propor a adopção de medidas tendentes à sua correcção.

2 - Os gestores dos CIRVER devem enviar ao Observatório, até ao final do $1 .^{\circ}$ trimestre de cada ano, cópia de todos os documentos enviados à entidade coordenadora. 
3 - O Observatório será apoiado no desenvolvimento da sua actividade por um secretariado permanente, designado pela entidade coordenadora, e por consultores externos.

4 - Os encargos resultantes do funcionamento do Observatório serão custeados pela entidade coordenadora.

5 - As contas do Observatório, depois de auditadas, serão aprovadas pela entidade licenciadora e publicadas.

\section{CAPÍTULO VII}

\section{Disposições transitórias e finais}

\section{Artigo 94. ${ }^{\circ}$}

\section{Medidas cautelares}

1 - Sempre que seja detectada uma situação de perigo para a saúde pública ou para o ambiente, o presidente do INR e o inspector-geral do Ambiente podem adoptar as medidas cautelares que, em cada caso, se justifiquem para prevenir ou eliminar a situação de perigo, nomeadamente a suspensão da laboração, o encerramento, no todo ou em parte, da instalação ou a apreensão, de todo ou parte, do equipamento mediante selagem.

2 - A cessação das medidas cautelares previstas no número anterior é determinada, a requerimento do operador, por despacho do inspector-geral do Ambiente, após a verificação de que a situação de perigo cessou.

3 - A adopção de medidas cautelares ao abrigo do presente artigo, bem como a sua cessação, são comunicadas de imediato à entidade coordenadora.

\section{Artigo 95. ${ }^{\circ}$}

\section{Liquidação e pagamento de taxas}

1 - A emissão dos alvarás de licença está dependente do pagamento das taxas mencionadas nas alíneas a), b) e c) ou d), consoante o caso, do n. ${ }^{\circ} 4$ do presente artigo.

2 - As taxas previstas nas alíneas e) e f) do $n .{ }^{\circ} 4$ do presente artigo deverão ser pagas em momento anterior à prática do acto ou da formalidade a que se referem. 3 - As taxas previstas nas alíneas a) e b) do n. ${ }^{\circ} 4$ do presente artigo deverão ser cobradas após o termo do prazo para a apresentação de candidaturas ou de 
projectos, consoante o caso, implicando o seu não pagamento a exclusão do procedimento.

a) - São as seguintes as taxas do procedimento de licenciamento e de fiscalização:

a) Fase de pré-qualificação - (euro) 3750;

b) Fase de apreciação e selecção de projectos - (euro) 5000;

c) Emissão do alvará de instalação do CIRVER - (euro) 5000;

d) Emissão do alvará de exploração do CIRVER - (euro) 5000;

e) Emissão de autorização provisória - (euro) 5000;

f) Vistoria - (euro) 2500.

5 - É ainda devida uma taxa pela actividade da entidade coordenadora e de funcionamento do Observatório no valor mínimo de entre um dos seguintes:

a) $0,5 \%$ da respectiva facturação;

b) (euro) 0,50 por cada tonelada de resíduo recebido.

6 - No $1 .^{\circ}$ ano de exploração do CIRVER, a liquidação da taxa é feita por referência aos elementos apresentados pelo titular do alvará da licença de exploração no projecto licenciado.

7 - No $2 .^{\circ}$ ano de exploração e nos subsequentes, a taxa é liquidada por referências aos valores relativos ao ano imediatamente anterior.

8 - 0 prazo do pagamento das taxas à entidade coordenadora é de 15 dias, contados a partir da notificação da respectiva liquidação.

9 - Da liquidação das taxas cabe impugnação graciosa ou judicial, nos termos gerais aplicáveis.

10 - O pagamento das taxas previstas no presente preceito não dispensa o pagamento daquelas que forem legalmente devidas pela intervenção de terceiras entidades.

\section{Artigo $96 .^{\circ}$}

\section{Falsidade de documentos e de declarações}

Sem prejuízo da participação à entidade competente para os efeitos de procedimento penal, a falsificação de documentos ou a prestação culposa de falsas declarações nas candidaturas, nos projectos e nas informações que devem ser prestadas no exercício da actividade de gestor do CIRVER determina, consoante o 
caso, a respectiva exclusão do concurso, a invalidade do licenciamento e dos actos subsequentes ou a cassação do alvará de licença.

\section{Artigo $97 .^{\circ}$}

\section{Novos licenciamentos}

1 - Todos os licenciamentos de novas unidades do tipo das que integram necessariamente os CIRVER, nos termos do $n .^{\circ} 3$ do artigo $1 .^{\circ}$, ou de centros integrados no âmbito da aplicação objectiva do presente diploma estão sujeitos ao regime nele fixado, com excepção daqueles que se destinem à resolução de um passivo ambiental localizado.

2 - 0 disposto no número anterior não se aplica aos projectos de licenciamento ou autorização que deram entrada nos serviços competentes em momento anterior à entrada em vigor do presente diploma.

\section{Artigo $98 .^{\circ}$}

\section{Entrada em vigor}

O presente diploma entra em vigor no dia seguinte ao da sua publicação. Visto e aprovado em Conselho de Ministros de 2 de Outubro de 2003. - José Manuel Durão Barroso - Maria Manuela Dias Ferreira Leite - Maria Celeste Ferreira Lopes Cardona - Carlos Manuel Tavares da Silva - Luís Filipe Pereira - António José de Castro Bagão Félix - Amílcar Augusto Contel Martins Theias.

Promulgado em 5 de Dezembro de 2003.

Publique-se.

O Presidente da República, JORGE SAMPAIO.

Referendado em 16 de Dezembro de 2003.

O Primeiro-Ministro, José Manuel Durão Barroso. 
Anexo C - Sínteses de Planos Internacionais

Síntese do plano de gestão de resíduos da Holanda, 2002-2012

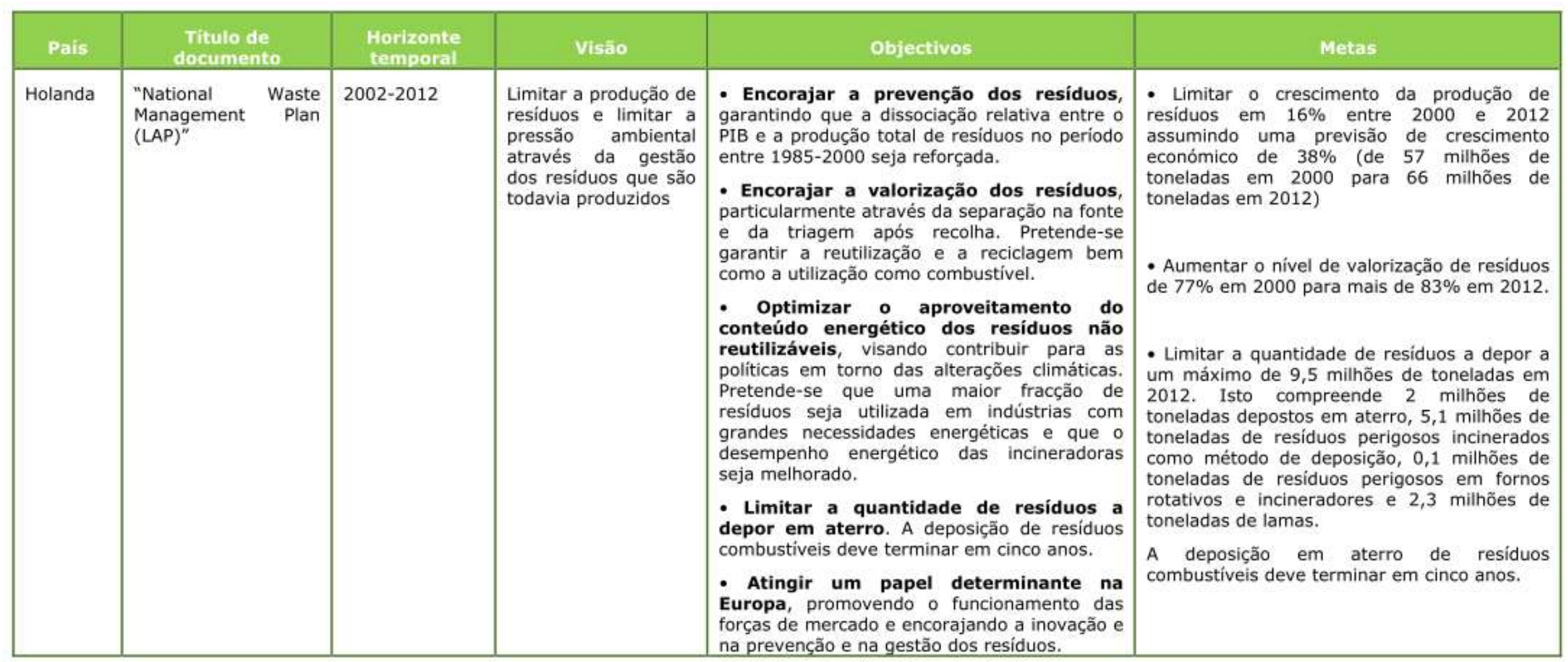

Fonte: PERSU II, 2011 
Síntese do plano de gestão de resíduos da Finlândia, 2008-2016

\begin{tabular}{|c|c|c|c|c|c|}
\hline Pais & $\begin{array}{l}\text { Título de } \\
\text { documento }\end{array}$ & $\begin{array}{l}\text { Horizonte } \\
\text { temporal }\end{array}$ & Vistâo & Objectivos & Metas \\
\hline Finlândia & $\begin{array}{l}\text { "Kohti } \\
\text { kierrätysyhteiskuntaa } \\
-\quad \text { Valtakunnallinen } \\
\text { jätesuunnitelma } \\
\text { vuoteen } 2016 \\
\\
\text { [Towards a recycling } \\
\text { society - National } \\
\text { waste plan until } \\
2016]^{\prime} \text {. }\end{array}$ & $2008-2016$ & $\begin{array}{l}\text { Uma sociedade para } \\
\text { a reciclagem }\end{array}$ & $\begin{array}{l}\text { - Aumentar a eficiência da produção e } \\
\text { consumo de materiais; } \\
\text { - Promover a reciclagem; } \\
\text { - Diminuir os químicos tóxicos nos } \\
\text { resíduos; } \\
\text { - Reduzir os efeitos danosos no clima } \\
\text { resultantes da gestão de resíduos; } \\
\text { - Reduzir os riscos para a saúde e para } \\
\text { o ambiente resultantes da gestão dos } \\
\text { resíduos; } \\
\text { - Desenvolver e clarificar a gestão de } \\
\text { resíduos; } \\
\text { - Aumentar o know-how associado à } \\
\text { gestão de resíduos; } \\
\text { - Gerir de modo seguro a transferência } \\
\text { de resíduos. }\end{array}$ & $\begin{array}{l}\text { Metas principais: } \\
\text { 1. Estabilizar o volume de produção resíduos } \\
\text { sólidos urbanos ao nivel a que estava no } \\
\text { início de } 2000 \text {. Após essa estabilização, o } \\
\text { volume de produção deve decrescer a partir } \\
\text { de } 2016 ; \\
\text { 2. Atingir um nivel de reciclagem de } 50 \% \text { dos } \\
\text { RU. Da fracção restante, valorizar } \\
\text { energeticamente cerca de } 30 \% \text { e garantir } \\
\text { que serão depostos em aterro apenas cerca } \\
\text { de } 20 \% \text { ou menos dos RU produzidos; } \\
\text { Metas adicionais: } \\
\text { - Valorizar a totalidade do estrume resultante } \\
\text { das actividades agrícolas. } \\
\text { - Garantir o tratamento de cerca de } 90 \% \text { das } \\
\text { águas residuais destas áreas em estações de } \\
\text { tratamento e } 10 \% \text { em produção de biogás } \\
\text { nas instalações agricolas; } \\
\text { - itorias técnicoos RCD reciclando materiais ou } \\
\text { através de valorização energética; } \\
\text { - Substituir } 5 \% \text { dos agregados naturais usados } \\
\text { na construção por resíduos industriais e de } \\
\text { mineração; } \\
\text { Valorizar } 100 \% \text { das águas residuais } \\
\text { domésticas; } \\
\text { Promover acordos voluntários sectoriais para } \\
\text { a eficiência na utilização dos materiais que } \\
\text { estabeleçam metas para a prevenção e } \\
\text { reciclagem. }\end{array}$ \\
\hline
\end{tabular}

Fonte: PERSU II, 2011 
Síntese do plano de gestão de resíduos da Inglaterra, 2007-2020

\begin{tabular}{|c|c|c|c|c|c|}
\hline Pais & $\begin{array}{l}\text { Titulo de } \\
\text { documento }\end{array}$ & $\begin{array}{l}\text { Horizonte } \\
\text { temporal }\end{array}$ & Vistão & Objectivos & Metas \\
\hline Inglaterra & $\begin{array}{l}\text { "Waste Strategy for } \\
\text { England } 2007^{\prime \prime}\end{array}$ & $2007-2020$ & $\begin{array}{l}\text { Responsabilidade do } \\
\text { produtor e do } \\
\text { consumidor - todos } \\
\text { os actores da } \\
\text { sociedade têm que } \\
\text { partilhar } \\
\text { responsabilidades na } \\
\text { gestão de resíduos }\end{array}$ & $\begin{array}{l}\text { - Dissociar o crescimento económico da } \\
\text { produção de resíduos (de todos os } \\
\text { sectores) e colocar maior ênfase na prevençăo } \\
\text { e reutilização; } \\
\text { - Atingir e exceder as metas da Directiva } \\
\text { Aterros para os resíduos urbanos } \\
\text { biodegradáveis em 2010, } 2013 \text { e } 2020 \text {; } \\
\text { - Aumentar a fracção de resíduos não } \\
\text { urbanos desviados da deposição em } \\
\text { aterro e assegurar uma melhor integração do } \\
\text { tratamento de resíduos urbanos e não } \\
\text { urbanos; } \\
\text { - Assegurar o investimento em infra- } \\
\text { estruturas essenciais para desviar os } \\
\text { residuos da deposição e para a gestão de } \\
\text { residuos perigosos; e, } \\
\text { - Garantir o maior benefício ambiental } \\
\text { desse investimento através do aumento da } \\
\text { reciclagem e da valorização energética dos } \\
\text { resíduos remanescentes através de um mix de } \\
\text { tecnologias. }\end{array}$ & $\begin{array}{l}\text { - Redução anual liquida das emissões de } \\
\text { gases de efeito de estufa, resultantes da } \\
\text { gestão dos resíduos, em pelo menos } 9,3 \\
\text { milhões de toneladas de CO2 equivalente, } \\
\text { em comparação com o valor de } 2006 \\
\text { (equivalente à retirada de circulação de } \\
\text { cerca de } 3 \text { milhões de automóveis) } \\
\text { - Reduzir a quantidade de residuos } \\
\text { domésticos não reutilizados, reciclados ou } \\
\text { compostados de } 22,2 \text { milhões de toneladas } \\
\text { em } 2000 \text { para } 15,8 \text { milhões de toneladas } \\
\text { ( } 29 \% \text { em } 2010 \text { e para } 12,2 \text { milhões de } \\
\text { toneladas em } 2020 \text { - redução de } 45 \% \text {. } \\
\text { Este decréscimo equivale a uma diminuição } \\
\text { de cerca de } 50 \% \text { por habitante (de } \\
450 k g / h a b \text { em } 200 \text { para } 225 \mathrm{~kg} / \text { hab em } \\
2020 \text { ); } \\
\text { - Reciclagem e compostagem de residuos } \\
\text { domésticos - pelo menos } 40 \% \text { em } 2010 \text {, } \\
45 \% \text { em } 2015 \text { e } 50 \% \text { em } 2020 \text {; e } \\
\text { - Valorização de resíduos urbanos - } 53 \% \\
\text { em } 2010,67 \% \text { em } 2015 \text { e } 75 \% \text { em } 2020 ; \\
\text { - Decréscimo da deposição em aterro de } \\
\text { residuos comerciais e industriais em } 20 \% \\
\text { até } 2010 \text { por comparação com os valores } \\
\text { de } 2004 \text {; } \\
\text { - Até } 2012 \text {, diminuir para metade a } \\
\text { quantidade de RCD que são depostos em } \\
\text { aterro através da redução, reutilização } \\
\text { reciclagem. }\end{array}$ \\
\hline
\end{tabular}

Fonte: PERSU II, 2011 
Síntese do plano de gestão de resíduos da Escócia, 2003-2020

\begin{tabular}{|c|c|c|c|c|c|}
\hline Pais & $\begin{array}{l}\text { Titulo de } \\
\text { documento }\end{array}$ & $\begin{array}{l}\text { Horizonte } \\
\text { temporal }\end{array}$ & Vișẩo & Objectivos & Metas \\
\hline Escócia & $\begin{array}{l}\text { "National Waste Plan } \\
2003^{\prime \prime}\end{array}$ & $2003-2020$ & $\begin{array}{l}\text { Dissociar a utilização } \\
\text { dos recursos do } \\
\text { crescimento } \\
\text { económico }\end{array}$ & $\begin{array}{l}\text { - Minimizar o impacte dos resíduos no } \\
\text { ambiente, localmente e globalmente; } \\
\text { - Aumentar a eficiência da utilização dos } \\
\text { recursos; } \\
\text { - Compensar as injustiças ambientais } \\
\text { sofridas por aqueles que têm que viver com as } \\
\text { consequências de uma sociedade de consumo }\end{array}$ & $\begin{array}{l}\text { - Garantir uma abrangência de recolha } \\
\text { selectiva para mais de } 90 \% \text { das habitações } \\
\text { em } 2020 \text {; } \\
\text { - Cessar o crescimento da produção de } \\
\text { residuos urbanos em } 2010 \text {; } \\
\text { - Atingir um nivel de reciclagem e de } \\
\text { compostagem de } 25 \% \text { em } 2006 \text { e } 55 \% \text { em } \\
2020 \text { ( } 35 \% \text { de reciclagem e } 20 \% \text { de } \\
\text { compostagem) } \\
\text { - Valorizar energeticamente } 14 \% \text { dos } \\
\text { resíduos urbanos; } \\
\text { - Reduzir a deposição em aterro dos } \\
\text { resíduos urbanos de } 90 \% \text { para } 30 \% \text {; } \\
\text { - Apoiar as empresas relativamente a } \\
\text { estratégias de minimização de resíduos; e } \\
\text { - Desenvolver mercados de materiais } \\
\text { reciclados tornando a reciclagem mais } \\
\text { viável e reduzindo os seus custos. }\end{array}$ \\
\hline
\end{tabular}

Fonte: PERSU II, 2011 
